\title{
Reformy ekonomiczne i polityczne a rozwój gospodarczy Indii (1991-2012)
}


盗 


\section{Reformy ekonomiczne i polityczne a rozwój gospodarczy Indii (1991-2012)}

Grzegorz Bywalec

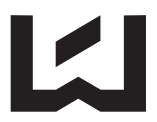

WYDAWNICTWO

UNIWERSYTETU

ŁÓDZKIEGO

ŁÓDŹ 2015 


\title{
Grzegorz Bywalec - Uniwersytet Łódzki
}

Wydział Studiów Międzynarodowych i Politologicznych, Instytut Studiów Międzynarodowych Zakład Azji Wschodniej, 90-131 Łódź, ul. Narutowicza 59a e-mail: gbywalec@o2.pl

\author{
RECENZENT \\ Bogustawa Drelich-Skulska \\ REDAKTOR WYDAWNICTWA UŁ \\ Dorota Stepień
}

SKŁAD I ŁAMANIE

MUNDA - Maciej Torz

PROJEKT OKŁADKI

Łukasz Orzechowski

Zdjęcie wykorzystane na okładce: (C) Depositphotos.com/tom.griger

(C) Copyright by Grzegorz Bywalec, 2015

(C) Copyright for this edition by Uniwersytet Łódzki, Łódź 2015

\author{
Wydane przez Wydawnictwo Uniwersytetu Łódzkiego \\ Wydanie I. W.06922.15.0.M
}

Ark. wyd. 18,8; ark. druk. 18,375

ISBN 978-83-7969-697-0

e-ISBN 978-83-7969-698-7

Wydawnictwo Uniwersytetu Łódzkiego

90-131 Łódź, ul. Lindleya 8

www.wydawnictwo.uni.lodz.pl

e-mail: ksiegarnia@uni.lodz.pl

tel. (42) 6655863 


\section{SPIS TREŚCI}

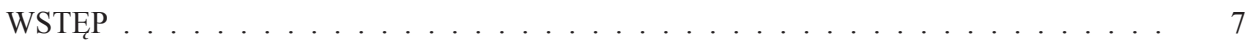

I. GOSPODARKI KRAJÓW ROZWIJAJĄCYCH SIĘ W ŚWIETLE EKONOMII

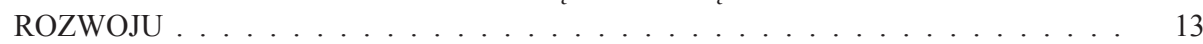

1.1. Ekonomia rozwoju i jej miejsce w teorii ekonomii . . . . . . . . . . . . . . . 13

1.1.1. Geneza, powstanie i przedmiot ekonomii rozwoju . . . . . . . . . . . . . 13

1.1.2. Ewolucja ekonomii rozwoju . . . . . . . . . . . . . . . . 18

1.2. Problemy startu i rozwoju gospodarczego krajów zacofanych (ze szczególnym uwzględnieniem postkolonialnej Azji) . . . . . . . . . . . . . . . . 29

1.3. Indie - istota i przesłanki wyboru modelu rozwoju gospodarczego . . . . . . . . . 37

II. INDIE W LATACH 1947-1991. USTRÓJ POLITYCZNY, SPOŁECZEŃSTWO I GO-

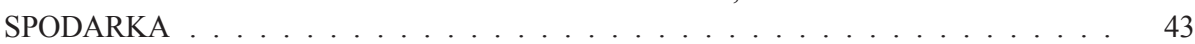

2.1. Powstanie niepodległego państwa oraz jego ustrój polityczny i terytorialny . . . . . 43

2.2. Kierunki i determinanty przemian ustroju politycznego . . . . . . . . . . . 48

2.2.1. Lata 1950-1984-monopolizacja i centralizacja życia politycznego . . . . . 50

2.2.2. Lata 1985-1991 - polaryzacja i próby decentralizacji życia politycznego . . 57

2.3. Demografia i problemy społeczno-kulturowe . . . . . . . . . . . . . . . 60

2.3.1. Przemiany demograficzne . . . . . . . . . . . . . . . . 60

2.3.2. Problemy etniczne i religijne . . . . . . . . . . . . . . . . . 66

2.3.3. Stratyfikacja społeczna i kulturowa . . . . . . . . . . . . . . . 70

2.4. Rozwój gospodarczy . . . . . . . . . . . . . . . . . . . . . . . . . . . 77

2.4.1. Podstawy prawne, dynamika gospodarki i zmiany w jej strukturze . . . . . . 77

2.4.2. Problem ubóstwa . . . . . . . . . . . . . . . . . . . . . . 87

2.4.3. Dynamika i poziom rozwoju gospodarczego stanów . . . . . . . . . . . . . . . 90

2.4.4. Gospodarka Indii na tle Azji . . . . . . . . . . . . . . . . . . . . 93

III. REFORMY EKONOMICZNE PO 1991 ROKU. PRZESŁANKI, ISTOTA, WDRAŻANIE. . 97

3.1. Geneza i przyczyny reform ekonomicznych . . . . . . . . . . . . . . . . 97

3.2. Nowa polityka ekonomiczna - istota i narzędzia . . . . . . . . . . . . . . . . 105

3.3. Pierwsze lata wdrażania reform - doświadczenia, dylematy i efekty . . . . . . . . . 112

IV. REFORMY USTROJU POLITYCZNEGO PO 1991 ROKU. DECENTRALIZACJA

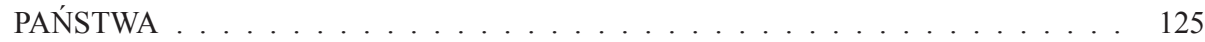

4.1. Problemy i uwarunkowania decentralizacji . . . . . . . . . . . . . . . . 125

4.2. Próby reformowania ustroju lokalnego w latach 1947-1991 . . . . . . . . . . . . . 136

4.3. Istota i organizacja samorządowego ustroju lokalnego ustanowionego w latach 1992-1993 . . . . . . . . . . . . . . . . . . . . . 144

4.4. Funkcjonowanie samorządności lokalnej po 1993 roku . . . . . . . . . . . . . . 163

V. ROZWÓJ GOSPODARCZY PO 1991 ROKU. EFEKTY MAKROEKONOMICZNE . . 169

5.1. Dynamika wzrostu gospodarczego … . . . . . . . . . . . . . . . . . . . 169

5.2. Zmiany w strukturze gospodarki . . . . . . . . . . . . . . . . . . . . 173

5.2.1. Rolnictwo . . . . . . . . . . . . . . . . . . . . . . . 175

5.2.2. Przemysł . . . . . . . . . . . . . . . . . . . . . 178

5.2 .3 . Usługi . . . . . . . . . . . . . . . . . . . . . . . . . . 181 
5.3. Stosunki gospodarcze z zagranicą - inwestycje i handel . . . . . . . . . . . . . . 185

5.4. Zatrudnienie . . . . . . . . . . . . . . . . . . . . . . . . . . . . . . . . . 194

5.5. Gospodarka Indii na tle Azji i świata . . . . . . . . . . . . . . . . . 200

VI. REGIONALNY I SPOŁECZNY WYMIAR ROZWOJU GOSPODARCZEGO

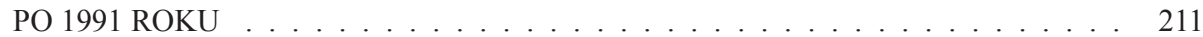

6.1. Regionalne zróżnicowanie wzrostu gospodarczego . . . . . . . . . . . . . . . 211

6.1.1. Dynamika wzrostu gospodarczego stanów . . . . . . . . . . . . . . . 211

6.1.2. Struktura wytwarzania produktu społecznego według stanów . . . . . . . . . 223

6.2. Regionalne zróżnicowanie poziomu rozwoju gospodarczego . . . . . . . . . . . . . 228

6.3. Społeczne aspekty rozwoju gospodarczego - ujęcie regionalne . . . . . . . . . . . 239

6.3.1. Przemiany demograficzne . . . . . . . . . . . . . . . . . . 240

6.3.2. Warunki życia w świetle wybranych wskaźników społecznych . . . . . . . . 247

6.3.3. Dynamika i struktura ubóstwa . . . . . . . . . . . . . . . . . . 264

PODSUMOWANIE I UWAGI KOŃCOWE . . . . . . . . . . . . . . . . . . . . . . . . 271

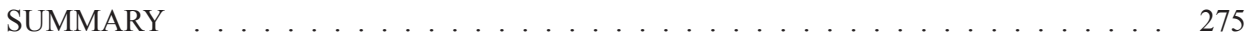

BIBLIOGRAFIA . . . . . . . . . . . . . . . . . . . . . . . . 279

SPIS TABEL I RYSUNKÓW _. . . . . . . . . . . . . . . . . . . . . . . . . 291

OD REDAKCJI . . . . . . . . . . . . . . . . . . . . . . . . . 295 


\section{WSTEP}

Jedną z najważniejszych kwestii teoretycznych ekonomii oraz polityki gospodarczej po II wojnie światowej stał się rozwój ponad 100 krajów, które wyzwoliły się spod kolonialnego panowania i/lub innego rodzaju uzależnienia od wysoko rozwiniętych krajów kapitalistycznych i rozpoczęły samodzielny byt państwowy. Na ich obszarze zamieszkiwało niemal 70 proc. ludności świata. Były to - poza wyjątkami - kraje bardzo zacofane gospodarczo. Ich głównym problemem w pierwszych latach niepodległości i formalnego uniezależnienia stało się wejście na drogę rozwoju gospodarczego, który pozwoliłby na zmniejszanie ogromnej skali ubóstwa oraz dystansu do najbardziej rozwiniętych państw świata.

Do kraju, gdzie problemy wyboru modelu gospodarczego i odpowiedniej drogi rozwojowej nabrały szczególnej wagi i miały nie tylko wewnętrzny, ale i zewnętrzny - regionalny, a nawet światowy wymiar, należały Indie. Były one ze względu na swoją odmienność trudno porównywalne z innymi państwami postkolonialnymi. Ich nietypowość wynikała przede wszystkim z ogromnej liczby mieszkańców, jej dużej dynamiki wzrostowej, zróżnicowania etnicznego, religijnego, językowego oraz specyficznej, utrwalanej przez tysiąclecia struktury społecznej i systemu wartości.

Przed władzami niepodległych Indii stanęły ogromne wyzwania. Najważniejszym było skonstruowanie odpowiedniego modelu gospodarki, czyli takiego, który zapewniałby szybką poprawę sytuacji ekonomicznej kraju i przekładał się na systematyczną poprawę warunków życia ludności.

Po długoletnich sporach $\mathrm{w}$ gronie indyjskich intelektualistów, zarówno w okresie kolonialnym, jak i - przede wszystkim - bezpośrednio po uzyskaniu niepodległości, przyjęto, że ustrój gospodarczy Indii będzie próbą tzw. ustroju dualnego, czyli - mieszanką kapitalizmu i socjalizmu. Miał on łączyć to, co dobre w gospodarce kapitalistycznej (efektywność) z tym, co dobre w gospodarce socjalistycznej (sprawiedliwość, równość).

Niestety, po niespełna czterech dekadach, w latach 80 . XX wieku, można było stwierdzić, że w indyjskich warunkach ekonomicznych, społecznych i etnicznych próba pójścia „trzecią drogą" nie dała satysfakcjonujących wyników, przynajmniej takich jak wcześniej oczekiwali „ojcowie-założyciele” niepodległego państwa. Sytuacja gospodarcza co prawda poprawiała się, ale inne, startujące z podobnego poziomu kraje, uzyskiwały znacznie wyższą dynamikę rozwojową.

Pod koniec lat 80., po czterech dekadach powolnego rozwoju gospodarczego i fiaska podejmowanych prób jego przyspieszenia, w sytuacji, gdy Indie były wyprzedzane przez wiele krajów z pobliskiego geograficznie i kulturowo otoczenia, zarówno kapitalistycznych jak i socjalistycznych, konieczną stała się przebudowa 
założeń ideowych gospodarowania i podjęcie radykalnych działań reformatorskich. Reformy takie zostały przygotowane przez rząd i w latach 1991-1992 rozpoczęto ich wdrażanie. Składały się one z dwóch elementów: jeden dotyczył gospodarki, a drugi - państwa.

Od rozpoczęcia reform minęło ponad dwadzieścia lat. W tym czasie bardzo korzystnie zmienił się krajobraz gospodarczy i społeczny Indii. Dzięki wysokiej dynamice rozwojowej kraj ten na początku drugiej dekady XXI wieku zalicza się już do czołówki światowych potęg ekonomicznych.

Problematyka rozwoju gospodarczego Indii po reformach z lat 1991-1992 nie znalazła jednak - jak dotąd - szerszego zainteresowania w środowisku polskich ekonomistów. W naszej literaturze naukowej nie pojawiły się obszerniejsze prace na ten temat. Istnieją co najwyżej opracowania cząstkowe w postaci artykułów i przyczynków publikowane na łamach czasopism lub jako fragmenty zbiorczych monografii. Jest to tym bardziej zastanawiające, że wcześniej, a więc w latach 50., 60. i 70. minionego wieku, gospodarka indyjska była często przedmiotem analiz i publikacji polskich ekonomistów, o czym mogą świadczyć przypisy i bibliografia w niniejszej pracy.

Prezentowana rozprawa jest próbą zmniejszenia tej luki w polskim piśmiennictwie ekonomicznym. Jej celem jest przedstawienie i ocena rozwoju gospodarczego Indii po podjętych na początku lat 90 . ubiegłego stulecia gruntownych reformach gospodarki i ustroju politycznego państwa. Przedmiotem analizy są przyczyny, środki, sposoby i efekty realizacji tych reform. Badaniem objęto lata 1991-2012.

W pracy weryfikowana jest następująca hipoteza główna: liberalizacja oraz deregulacja wysoce upaństwowionej i scentralizowanej gospodarki oraz ustroju politycznego owocują znaczącym przyspieszeniem rozwoju gospodarczego kraju i poprawą warunków życia społeczeństwa. Hipotezę tę można będzie uznać za udowodnioną wówczas, gdy zostaną empirycznie potwierdzone następujące hipotezy cząstkowe:

1. Liberalizacja oraz deregulacja gospodarki wyraźnie zwiększają tempo wzrostu produktu krajowego brutto i powodują istotne zmiany w strukturze jego wytwarzania.

2. Liberalizacja oraz deregulacja gospodarki przyspieszają wzrost gospodarczy regionów i jednocześnie powodują zwiększenie przestrzennego zróżnicowania poziomu rozwoju gospodarczego.

3. Liberalizacja oraz deregulacja gospodarki powodują poprawę warunków życia ludności i jednocześnie zwiększają przestrzenne oraz - w wielu przypadkach - społeczne dysproporcje w tej dziedzinie.

Badania przeprowadzono w trzech wymiarach:

1. Makroekonomicznym, czyli w odniesieniu do całej indyjskiej gospodarki.

2. Przestrzennym - krajowym i międzynarodowym, tj. według podziałów regionalnych (stanów) oraz na tle innych krajów. 
3. Społecznym, tzn. z uwzględnieniem demograficznego i społecznego zróżnicowania indyjskiego społeczeństwa.

Cel i hipotezy badawcze określiły konstrukcję rozprawy. Składa się ona z sześciu rozdziałów.

Rozdział I zawiera teoretyczne wprowadzenie do późniejszych analiz empirycznych rozwoju gospodarczego i przemian politycznych w Indiach. Problematyka ta mieści się w nowo powstałej po II wojnie światowej subdyscyplinie nauk ekonomicznych, tj. ekonomii rozwoju - zajmującej się zagadnieniami startu i rozwoju gospodarczego krajów zacofanych, najczęściej byłych kolonii. Ekonomia rozwoju stanowi bezpośrednie zaplecze naukowe dla polityki gospodarczej tej grupy krajów. Z tych powodów przedstawiono genezę i ewolucję jej teorii oraz wynikające z tego dylematy wyboru dróg rozwojowych krajów nierozwiniętych. W tym kontekście wskazano także na teoretyczne aspekty i przesłanki wyboru modelu gospodarki niepodległych Indii zarówno bezpośrednio po odzyskaniu przez ten kraj niepodległości, jak i później, tzn. po reformach z lat 1991-1992.

Rozdział II rozpoczyna część empiryczną rozprawy i dotyczy spraw społecznych oraz gospodarczych Indii w okresie 1947-1991. W pierwszym jego fragmencie wyeksponowano genezę, organizację i problemy realizacyjne przyjętego u zarania niepodległości modelu ustrojowego państwa. W drugiej części rozdziału scharakteryzowano dynamikę oraz przekształcenia strukturalne w życiu społecznym i gospodarczym. W celu obiektywizacji oceny tych przemian dokonano porównań Indii z ówczesnym rozwojem gospodarczym innych, dużych państw Azji. Rozdział ten jest wstępem i tłem do dalszych - tj. po wprowadzeniu reform w latach 1991-1992 - analiz indyjskiej gospodarki i życia społecznego.

W rozdziale III podjęto próbę dokładniejszej charakterystyki reform indyjskiej gospodarki rozpoczętych w 1991 roku. Wskazano ich bezpośrednie przesłanki i przyczyny oraz główne elementy ,nowej polityki ekonomicznej” - bo tak zostały nazwane te reformy. $\mathrm{W}$ ostatnim fragmencie rozdziału uwagę skupiono na praktycznych problemach, dylematach oraz pierwszych efektach wdrażania nowych reguł gospodarowania i to nie tylko w wymiarze ekonomicznym, lecz także politycznym i społecznym.

W rozdziale IV przedstawiono drugi element indyjskich reform, tj. przekształcenia ustroju politycznego państwa. Ich istotą było utworzenie w 1992 roku na najniższym, terytorialnym szczeblu organizacji administracji publicznej, obligatoryjnego, demokratycznego samorządu lokalnego. W Indiach istniał co prawda od prawieków samorząd, ale nie miał charakteru demokratycznego, był częścią niezwykle zhierarchizowanego, opartego na nierównościach, systemu organizacji społeczeństwa. Zasadniczy problem wdrożenia nowego ustroju lokalnego po 1992 roku polegał więc na tym, aby dotychczasowy system samorządu przekształcić w nowy - oparty na zasadach równości społecznej, wolności i demokracji. Druga część rozdziału poświęcona jest szczegółowej prezentacji reformy decentralizacyjnej, jej podstawom prawnym, nowym strukturom i instytucjom, 
ich kompetencjom, a także praktycznym problemom i dylematom wdrażania demokratycznych samorządów w indyjskich wsiach i miastach.

W rozdziale $\mathrm{V}$ poddano analizie makroekonomiczne efekty indyjskich reform gospodarki i państwa z pierwszych lat 90 . Obejmuje ona dwudziestoletni okres, a więc na tyle długi przedział czasowy, aby móc dostrzec, pomierzyć i ocenić cały proces modernizacji indyjskiej gospodarki. Analizę skupiono przede wszystkim na dynamice podstawowych makrowskaźników gospodarczych oraz przekształceniach w strukturze gospodarki. W celu obiektywizacji i relatywizacji indyjskich przemian gospodarczych w ostatnim fragmencie rozdziału dokonano ich porównań z dynamiką innych, wielkich i szybko rozwijających się gospodarek świata.

W rozdziale VI scharakteryzowano zmiany przestrzenne w indyjskiej gospodarce. Szybki rozwój gospodarczy kraju zazwyczaj niesie ze sobą pogłębianie się terytorialnych różnic $\mathrm{w}$ tej dziedzinie. O skali tych procesów informuje analiza w pierwszych dwóch podrozdziałach. W trzecim podrozdziale podjęto natomiast próbę zbadania regionalnych dysproporcji w kształtowaniu się warunków życia ludności, traktowanych jako społeczny efekt reform gospodarki i państwa. Szczególną uwagę skoncentrowano na zmianach w przestrzennym oraz demograficzno-społecznym rozkładzie ubóstwa, gdyż jego skala była i nadal pozostaje podstawowym wyznacznikiem postępu gospodarczego i społecznego w Indiach.

Rozprawę oparto na studiach naukowej i fachowej literatury, głównie autorów indyjskich. Także materiał liczbowy i faktograficzny, stanowiący podstawę analiz empirycznych, zaczerpnięto - poza wyjątkami - bezpośrednio z oryginalnych, indyjskich źródeł statystycznych.

Przydatne okazały się również wielokrotne pobyty autora w Indiach i wędrówki po tym kraju. Takie skojarzenie dwóch źródeł poznania indyjskiej rzeczywistości gospodarczej i społecznej, tj. analizy danych statystycznych i fachowej literatury z naoczną obserwacją, pozwoliło m.in. na ich wzajemną weryfikację i wyrobienie sobie bardziej obiektywnej opinii o tym kraju i dokonujących się w nim przemianach.

Na koniec kilka uwag natury formalnej. Sprawa pierwsza to pisownia nazwisk, imion oraz nazw stanów. W polskim piśmiennictwie jest ona bardzo zróżnicowana, co może czasem prowadzić do nieporozumień. W niniejszej pracy używa się imion, nazwisk oraz nazw stanów w transkrypcji angielskiej, czyli w takiej, jaka jest powszechnie stosowana w indyjskiej - anglojęzycznej literaturze, aktach prawnych oraz źródłach statystycznych. Niekiedy jedynie - w części tekstowej - posłużono się utrwalonymi już nazwami spolszczonymi, jak np. Bengal Zachodni (zamiast West Bengal), Bombaj, Kaszmir, Hajdarabad, Andamany, Nikobary itp. Nazwy miast i stanów podawane są w starej, anglojęzycznej wersji językowej, a nie w nowej, którą zaczęto wprowadzać w latach 90. XX wieku, czyli w językach regionalnych, np. Madras (od 2000 roku - Chennai), Bombay (od 1995 roku - Mumbai), Orissa (od 2011 roku - Odisha), West Bengal (od 2011 roku - Paschim Banga), Bangalore (od 2006 roku Bengalūru) itp. 
Kontrowersje mogą budzić również niektóre zapisy dat, a odnosi się to do fragmentów rozprawy dotyczących gospodarki. Są one inne niż w polskiej i w ogóle europejskiej, literaturze ekonomicznej. Wynika to $z$ faktu, że indyjska statystyka gospodarcza, a w ślad za nią literatura fachowa i naukowa, posługują się powszechnie pojęciem „rok gospodarczy”, który trwa od 1 kwietnia do 31 marca roku następnego, a więc nie pokrywa się z rokiem kalendarzowym. W indyjskich źródłach statystycznych oraz publikacjach ekonomicznych zapisuje się go na dwa sposoby: z półpauzą (np. 1991-92) albo z ukośnikiem (np. 1991/92). W niniejszej pracy w celu uniknięcia nieścisłości i nieporozumień, dla oznaczenia roku gospodarczego przyjęto zapis drugi (z ukośnikiem).

W polskim piśmiennictwie kwestią sporną jest niekiedy nazwa mieszkańców, czyli obywateli Indii. Spotykamy się z określeniami „Hindus” lub „Indus”. W pracy przyjęto drugą, coraz częściej stosowaną wersję, czyli Indus (ang. Indian, niem. Inder). Natomiast słowo „hindus” (pisane małą literą) odnosi się do wyznawców hinduizmu (ang. Hindu, niem. Hindu) i używane jest tylko w tym znaczeniu.

Serdecznie dziękuję recenzentce rozprawy p. prof. dr hab. Bogusławie Drelich-Skulskiej z Katedry Międzynarodowych Stosunków Gospodarczych Uniwersytetu Ekonomicznego we Wrocławiu za trud lektury, zgłoszone uwagi oraz wskazówki, które istotnie wpłynęły na ostateczny kształt merytoryczny i formalny pracy.

Podziękowania kieruję również do p. prof. dr hab. Małgorzaty Pietrasiak oraz wszystkich Pracowników i Doktorantów Zakładu Azji Wschodniej na Uniwersytecie Łódzkim za okazaną mi pomoc naukową i organizacyjną w trakcie przygotowywania rozprawy. 



\section{GOSPODARKI KRAJÓW ROZWIJAJĄCYCH SIE W ŚWIETLE EKONOMII ROZWOJU}

Chcąc wyjaśnić i ocenić realizowany przez Indie model rozwoju gospodarczego przyjęty bezpośrednio po powstaniu niepodległego państwa w 1947 roku, jak i ten nowy - po reformach lat 1991-1992, najwłaściwsze wydaje się odwołanie do aparatu pojęciowego i narzędzi badawczych wypracowanych przez ekonomię rozwoju (development economics) - nową, powstałą po 1945 roku, subdyscyplinę ekonomii, zajmującą się głównie problemami krajów zacofanych i startujących do rozwoju gospodarczego. Dlatego pierwszą partię rozdziału poświęcono genezie, istocie i ewolucji ekonomii rozwoju, a następnie odniesiono jej główne wątki teoretyczne do praktycznych zagadnień rozwoju gospodarczego postkolonialnych krajów Azji, ze szczególnym uwzględnieniem Indii jako przedmiotu niniejszych badań.

\subsection{Ekonomia rozwoju i jej miejsce w teorii ekonomii}

\subsubsection{Geneza, powstanie i przedmiot ekonomii rozwoju}

Jedną z ważnych kwestii teoretycznych ekonomii jako samodzielnej dyscypliny badawczej, czyli od początków XVII wieku, a w ślad za tym także praktyki gospodarczej, były zagadnienia źródeł, narzędzi, sposobów oraz kierunków i dynamiki rozwoju gospodarczego. Ekonomiści próbowali wyjaśnić kwestię, dlaczego gospodarki jednych krajów rozwijały się szybko i osiągały wysoki poziom dobrobytu społecznego, natomiast w innych krajach działo się to wolniej i popadały one we względny, a czasem bezwzględny niedorozwój. Jakie były przyczyny i mechanizmy procesów powodujących, że niektóre kraje szybko wychodziły $\mathrm{z}$ zacofania, a inne się w nim pogrążały? Co stało u podstaw gwałtownego załamania się stosunkowo dobrze rozwiniętych gospodarek i ich zejścia do poziomu zacofanych? Tego typu pytań i problemów można by wymienić więcej, literatura poruszająca te tematy jest obszerna, a formułowane diagnozy i zalecane terapie są bardzo zróżnicowane [Matera, 2014].

Powstanie po II wojnie światowej kilkudziesięciu nowych państw w Azji i Afryce oraz chęć ich uniezależnienia się od byłych kolonizatorów, a także podobne zachowania licznych, wcześniej powstałych państw pokolonialnych 
(gł. Ameryki Łacińskiej) odcisnęły piętno na teorii ekonomii oraz polityce gospodarczej. Skala problemu była wielka i miała globalny wymiar, bowiem ok. 70 proc. ludności ówczesnego świata zamieszkiwało właśnie w krajach zacofanych. Procesy dekolonizacyjne, zarówno te z pierwszej połowy XX wie$\mathrm{ku}$, jak i te z pierwszych dwóch dekad po II wojnie światowej oraz narastające współzawodnictwo pomiędzy systemem kapitalistycznym a socjalistycznym sprawiły, że na warsztatach ekonomistów poczesne miejsce zajęła problematyka rozwoju gospodarczego nowo powstałych państw w wymiarze normatywnym i pozytywnym [Clunies-Ross i in., 2009, s. 7-9]. Nastąpiło - jak pisał G. Myrdal [1958, s. 27-28] - „wielkie przebudzenie” ekonomistów, także tych z krajów rozwiniętych. Dotyczyło to szczególnie młodej generacji badaczy, którym nie odpowiadały już tradycyjne ujęcia teoretyczne i stawiane diagnozy względem nowego i to o niespotykanej skali problemu, jakim były gospodarki nowo powstających państw Azji i Afryki oraz od niemal wieku zaniedbane sprawy Ameryki Łacińskiej ${ }^{1}$. Według dominującej do tej pory teorii ekonomii, a głównie jej nurtu neoklasycznego, rozwój nowych krajów winien odbywać się w podobny sposób jak dotychczas. Oznaczało to, że kraje nierozwinięte, chcąc przezwyciężyć swe zacofanie, powinny przebyć podobną drogę, jaką szły wcześniej kraje Europy Zachodniej i Ameryki Północnej. Takie podejście zwalniało teorię ekonomiczną od podejmowania nowych, odrębnych badań krajów słabo rozwiniętych i zastosowania wobec nich nowych kategorii i narzędzi badawczych [Kleer, 1962, s. 20-23].

W tych właśnie procesach i powstałej atmosferze intelektualnej lat 40. i 50. należy upatrywać podstawowych przesłanek wyodrębnienia się w nauce o gospodarce nowego i dynamicznie rozszerzającego się nurtu badawczego, tj. ekonomii rozwoju. W nowej powojennej rzeczywistości nie można już było - jak zazwyczaj czyniono dotychczas - zawężać rozumienia rozwoju gospodarczego do kategorii wzrostu gospodarczego [Zadroga, 2012]. Takie postępowanie nie rokowało wielkich szans na wyjaśnienie i opisanie zachodzących zjawisk oraz procesów, szczególnie w odniesieniu do gospodarek nowo powstających państw i - co najważniejsze - sformułowanie jakichś zaleceń pod adresem ich polityki gospodarczej. Należało w tej sytuacji wyjść poza tradycyjne schematy i ujęcia neoklasycznej ekonomii, w których dominowała problematyka wzrostu gospo-

${ }^{1}$ Gunnar Myrdal [1958, s. 137] pisał w tej sprawie m.in.: „W epoce «Wielkiego Przebudzenia» tragiczne by było, gdyby młodzi ekonomiści w krajach nierozwiniętych dali się zwieść tendencyjności myśli ekonomicznej krajów rozwiniętych; tendencyjność ta, utrudniająca logiczne rozumowanie uczonym krajów bogatych, wpłynąć by musiała niemal fatalnie na poczynania uczonych krajów nierozwiniętych. Życzyłbym im natomiast, by mieli odwagę odrzucić obszerne wywody teoretyczne i doktryny nie mające znaczenia, nieistotne, a czasem jaskrawo nieadekwatne, i by zaczęli myśleć od nowa - by zaczęli od badania swych własnych potrzeb i zagadnień. Zaprowadzi ich to daleko poza przestarzałą liberalistyczną ekonomię Zachodu i ekonomię marksizmu". 
darczego, czyli uwagę skupić na szerszej kategorii - rozwoju gospodarczym w całej jego złożoności².

Zalążki ekonomii rozwoju pojawiły się pod koniec lat 40. XX wieku wraz $\mathrm{z}$ niepodległością pierwszych państw postkolonialnych (Filipin, Indii, Pakistanu, Birmy, Cejlonu, Indonezji), a wyraźny kształt zaczęła ona przybierać na początku lat 50. Była odzewem - jak wyżej wspomniano - na powstanie i wejście na drogę niepodległego rozwoju kilkudziesięciu nowych postkolonialnych krajów Azji i Afryki. Jej głównym zadaniem stało się sformułowanie strategii rozwoju gospodarczego i przemian strukturalnych w tych krajach oraz sposobu włączenia ich do światowego systemu gospodarczego [Meier, 2001, s. 13-14].

W sensie merytorycznym bezpośrednio u źródeł narodzin ekonomii rozwoju, jako odrębnej dyscypliny ekonomii, w ramach której zostałyby formułowane i poddawane praktycznej weryfikacji nowe ujęcia teoretyczne, leżały następujące przesłanki [Piasecki, 2007, s. 15-17; 2003b]:

1. Dotychczasowe, tradycyjne teorie wzrostu i rozwoju gospodarczego krajów biednych i chcących wyjść z zacofania nie przynosiły pozytywnych skutków, gdyż były oparte na niewłaściwych, nieadekwatnych do nowej rzeczywistości przesłankach.

2. Dostrzeżenie, że nowo powstałe, z reguły słabo rozwinięte gospodarczo kraje są ze swej natury zupełnie innymi podmiotami niż kraje wysoko - czy nawet - średnio rozwinięte i wymagają zupełnie nowego podejścia badawczego, a w praktyce nowych rozwiązań instytucjonalnych oraz innych narzędzi polityki gospodarczej.

3. Powstanie państw socjalistycznych, które do problemów wychodzenia z zacofania podeszły $\mathrm{w}$ zupełnie odmienny niż dotychczasowy - kapitalistyczny sposób i zaczęły na tym polu osiągać wyjątkowo dobre, wręcz spektakularne

${ }^{2}$ Ernst F. Schumacher [1981, s. 229], jeden z ważnych przedstawicieli ekonomii rozwoju, tak uzasadniał to nowe podejście metodyczne ekonomii do spraw powojennego, szczególnie postkolonialnego świata: „Zjawiska rozwoju gospodarczego obejmują sferę szerszą i głębszą niż opisywana przez ekonomię [tj. wzrost gospodarczy - przyp. G.B.], a tym bardziej przez ekonometrię. Źródła rozwoju tkwią poza sferą gospodarki, na polu oświaty, organizacji, dyscypliny oraz ponad nią, w niepodległości politycznej i świadomości niezależności narodowej. Zręczne przeszczepy dokonywane przez zagranicznych specjalistów lub tubylczą elitę, która straciła kontakt z mieszkańcami własnego kraju, nie mają wiele wspólnego z rozwojem”. Podobne, to znaczy bardzo szerokie podejście do kategorii „rozwój gospodarczy” i potrzebę odejścia od badania wzrostu gospodarczego prezentuje Amartya K. Sen w pracy Pojęcie rozwoju (The Concept of Development) [2008, s. 53] pisząc m.in.: „Było całkowicie naturalne, że wczesne publikacje z zakresu ekonomii rozwoju, gdy pojawiła się jako samodzielna dyscyplina po II wojnie światowej, koncentrowały się na sposobach osiągania wzrostu gospodarczego, a w szczególności powiększaniu produktu narodowego oraz zatrudnienia [...]. Proces rozwoju ekonomicznego nie może abstrahować od zwiększania podaży żywności, odzieży, mieszkań, usług medycznych, obiektów dydaktycznych itp. oraz od przekształcania struktury produkcji, i te zmiany mają bez wątpienia duże znaczenie dla wzrostu gospodarczego". 
rezultaty. Należało im przeciwstawić jakąś równie atrakcyjną i „niesocjalistyczną" alternatywę przyspieszonego nadrabiania zaległości.

Początkowo przedmiotem zainteresowań ekonomii rozwoju były - jak wyżej stwierdzono - gospodarki kilkunastu państw Azji, które najwcześniej, bo już w latach 40. i 50. XX wieku przestawały być koloniami. Do tej grupy doszły następnie liczne kraje Afryki, gdzie apogeum dekolonizacji przypadło na lata 60. [Bartkowiak, 2013, s. 78]. Na warsztaty ekonomistów rozwoju trafily także niemal wszystkie kraje Ameryki Łacińskiej, z których co prawda większość już od wielu dziesięcioleci funkcjonowała jako samodzielne państwa, ale jednak ich życie polityczne, a szczególnie gospodarki, były mocno eksploatowane przez obcy kapitał i - poza wyjątkami - w swych strukturach ekonomicznych i społecznych niewiele się różniły od krajów Azji i Afryki. Ostatecznie przedmiotem ekonomii rozwoju stały się gospodarki ok. 130 państw określanych w różnych okresach jako: kraje zacofane, kraje Trzeciego Świata, kraje słabo rozwinięte się czy rozwijające się ${ }^{3}$. Ich wspólną cechą był niski poziom rozwoju gospodarczego wyrażany wielkością PKB na 1 mieszkańca, który powstawał przede wszystkim w sektorze agrarnym. Ponadto były to kraje z reguły przeludnione i o wysokim przyroście naturalnym, niskim poziomie edukacji oraz ochrony zdrowia, a głód oraz wysoka i przedwczesna śmiertelność były zjawiskami masowymi. Stosunki społeczne, zwłaszcza na wsiach, gdzie mieszkała większość ludności, miały charakter feudalny. Ustrój

${ }^{3}$ Przez wiele lat najbardziej popularnym i najczęściej używanym terminem na oznaczenie krajów zacofanych był „Trzeci Świat”. Jego autorstwo przypisywane jest francuskiemu demografowi i ekonomiście Alfredowi Sauvy. Użył go w 1952 roku, na oznaczenie krajów zacofanych, przez analogię do stanu trzeciego w przedrewolucyjnej Francji. Termin ten odnosił się do grupy krajów, które nie zaliczały się ani do wysoko rozwiniętych krajów kapitalistycznych (pierwszy świat), ani do krajów socjalistycznych (drugi świat). Były to na ogół kraje niedawno wyzwolone spod kolonialnego panowania i gospodarczo zacofane. Stał się on bardzo popularny nie tylko w publicystyce i życiu politycznym, ale też w literaturze naukowej, szczególnie po konferencji Ruchu Państw Niezaangażowanych w Bandungu w 1955 roku. Z biegiem czasu określenie „Trzeci Świat” nabierało pejoratywnego wydźwięku i stawało się stygmatyzujące oraz obraźliwe dla krajów rozwijających się, tym bardziej, że niektóre z nich wykazywały wysoką dynamikę rozwojową i postępowe zmiany społeczne. W latach 80. zaczęło wychodzić z użycia i utraciło sens w latach 90. po likwidacji dwubiegunowego podziału świata (kapitalizm-socjalizm); stało się pojęciem historycznym, stosowanym zazwyczaj wówczas, gdy rozważania dotyczą kształtu i rozwoju gospodarczego świata w pierwszych dekadach po II wojnie światowej, dlatego też posługujemy się nim w niniejszej pracy. Nie oznacza to oczywiście, że sam problem zacofania i wyjścia z tego stanu znacznej części świata przestał być aktualnym. Nie, problem pozostał, a w wielu przypadkach uległ nawet zaostrzeniu, zmienił się tylko język jego opisu. Szerzej na ten temat w: Solarz [2009]. Niektórzy autorzy na określenie ogółu krajów Azji, Afryki i Ameryki Łacińskiej niebędących rozwiniętymi krajami kapitalistycznymi ani socjalistycznymi używali terminu „Pośredni Świat” [Sachs, 1959]. Niekiedy wyróżnia się jeszcze „Czwarty Świat”, a nawet „Piąty Świat”. Do „Czwartego Świata” zalicza się te kraje, które nie posiadają wprawdzie zasobów naturalnych, ale podejmują działania w celu realizacji procesów rozwojowych. Natomiast „Piąty Świat”, to te kraje, które nie dysponują surowcami ani innymi czynnikami rozwoju, które umożliwiałyby wzrost i rozwój gospodarczy [Rynarzewski, 2006, s. 403]. 
polityczny tych państw, jeżeli nawet nadano mu status demokratycznego, to były to najczęściej demokracje fasadowe, a w rzeczywistości dominowały nadal stare układy społeczne i tradycyjne systemy wartości, w tym niemal powszechna korupcja, która paraliżowała wszelkie reformy ${ }^{4}$.

Ekonomia rozwoju jako odrębna subdyscyplina ekonomii nie posiada $\mathrm{w}$ istocie samodzielnego, autonomicznego tworzywa badawczego ani też własnego aparatu metodycznego. Przedmiotem jej badań są - jak już wyżej sygnalizowano - wybrane i odpowiednio scalone te wątki ekonomii, które dotyczyły i nadal dotyczą, przede wszystkim rozwoju gospodarek krajów nie tak dawno zacofanych, a obecnie zwanych rozwijającymi się (lub niedorozwiniętymi), jak również tych, które w okresie niespełna kilku dekad potrafiły - wychodząc z głębokiego zacofania - przebić się do światowej czołówki (np. Korea Południowa, Singapur czy Tajwan). Ekonomii rozwoju nie można jednak utożsamiać z teoriami rozwoju gospodarczego w ich wąskim sensie. Te ostatnie są tylko jednym z dwóch jej elementów. Drugim składnikiem ekonomii rozwoju jest socjologia rozwoju (sociology of development), w szerokim rozumieniu tego terminu [Kozak, 2001, s. 8]. W ekonomii rozwoju wątki stricte ekonomiczne są poszerzane i przeplatane z zagadnieniami społecznymi, kulturowymi, politycznymi i demograficznymi (por. przyp. 2).

W kontekście wyjaśniania istoty i celu ekonomii rozwoju wspomnieć trzeba o drugiej, pokrewnej dziedzinie ekonomii, tj. ekonomii wzrostu, z której się zresztą ta pierwsza - jak wyżej wspomniano - wywodzi. Przy bliższej analizie obu tych kategorii (ekonomii wzrostu i ekonomii rozwoju) okazuje się, że w drugiej połowie $\mathrm{XX}$ wieku nie powinno się już traktować ich jako swoistych sióstr, ale jako odrębne, chociaż spokrewnione subdyscypliny ekonomii. Pozostało przede wszystkim podobieństwo semantyczne (tzn. wzrost i rozwój), natomiast różnią się one co do istoty i zakresu przedmiotowego badań. W dodatku różnice te powiększają się. Najkrócej ujmując, termin ,ekonomia wzrostu” odnosi się współcześnie przede wszystkim do rozważań na temat wzrostu gospodarczego krajów rozwiniętych, zaś ekonomia rozwoju to - jak wyżej stwierdzono - teoria polityki gospodarczej krajów rozwijających się, w dodatku mocno poszerzona o wspomniane wątki społeczno-kulturowe ${ }^{5}$. W praktyce badawczej, szczególnie analizach empirycznych, nie zawsze jednak da się dochować wierności semantyce i klasyfikacjom teoretycznym, gdyż problemy

${ }^{4}$ Niektórzy autorzy, badając problematykę startu i rozwoju krajów słabo rozwiniętych, nie traktowali jednak takich pojęć, jak ,gospodarka zacofana”, „gospodarka słabo rozwinięta” oraz „gospodarka rozwijająca się" za synonimiczne. Są to - dowodzili - zupełnie odmienne pojęcia, chociażby z tego względu, że pierwsza (gospodarka zacofana) ma charakter statyczny, druga (gospodarka słabo rozwinięta) znajduje się na pograniczu statyki i dynamiki, a trzecia (gospodarka rozwijająca się) jest kategorią dynamiczną. Szeroko kwestie te wyjaśniał Kleer [1962, s. 29-41].

5 R. Barro i X. Sala i Martin pisali w pracy Economic Growth (1995), że: „Obszary zainteresowań ekonomii rozwoju i ekonomii wzrostu rozeszły się, tak że te dwie sfery stały się całkowicie odseparowane od siebie" [za: Bartkowiak, 2003, s. 271]. 
wzrostu i rozwoju wzajemnie się przeplatają i/lub nakładają na siebie, są na ogół względem siebie synergiczne. Ponadto istnieją nadal znaczące zróżnicowania poglądów co do istoty i metody ekonomii rozwoju. Używanie tych samych terminów na gruncie obu tych subdyscyplin nie zawsze oznacza tę samą treść. Dynamiczna, chociaż tylko półwieczna, historia ekonomii rozwoju - co niżej przedstawiamy - bynajmniej nie sprzyjała porządkowaniu jej terminologii i metodyki badań, a to znacząco utrudnia studia teoretyczne i prace empiryczne.

\subsubsection{Ewolucja ekonomii rozwoju}

Jak wcześniej stwierdzono, ekonomia rozwoju, jako subdyscyplina ekonomii, ugruntowała się w latach 50. ubiegłego wieku. Apogeum jej rozkwitu przypada jednak na lata 60 . i pierwszą połowę lat 70 . Wyrazem tego są liczne rozprawy teoretyczne i empiryczne na temat Trzeciego Świata autorstwa wybitnych ekonomistów, w tym kilku późniejszych laureatów Nagrody Nobla ${ }^{6}$. W rezultacie bardzo ożywionych dyskusji świata nauki oraz praktycznych doświadczeń polityki gospodarczej, zarówno w krajach nierozwiniętych jak i rozwiniętych, zaczęły się tworzyć odrębne podejścia teoretyczne i metodyczne do badań nad problematyką rozwoju krajów zacofanych, a na ich fundamentach powstawały różnorakie programy rozwojowe dla poszczególnych państw i/lub całych regionów świata. Spróbujmy przedstawić ważniejsze z nich ${ }^{7}$. Zastosujemy metodę retrospekcji, czyli próbę odtworzenia historii ekonomii rozwoju.

${ }^{6}$ Problem „przypisania” wybitnych ekonomistów do ekonomii rozwoju nie jest bynajmniej prosty, co potwierdzają studia literatury przedmiotu. Jest to uzależnione od podejścia do tego proble$\mathrm{mu}$, to znaczy czy do „ekonomistów rozwoju” zaliczymy szerokie grono badaczy zajmujących się w ogóle badaniami rozwoju gospodarczego i piszących na te tematy, czyli „ekonomistów rozwoju sensu largo" czy też „ekonomistów rozwoju sensu stricto”, to znaczy takich, którzy w jakimś okresie pracy naukowej skoncentrowali się na zagadnieniach ekonomii rozwoju (zgodnie z definicją tej subdyscypliny) i wnieśli do niej istotny wkład. W naszym przypadku chodzi oczywiście o to drugie podejście („,ekonomiści rozwoju sensu stricto”). Za prekursorską pracę z zakresu ekonomii rozwoju uznaje się zazwyczaj artykuł austriackiego ekonomisty (polskiego pochodzenia, ur. w 1905 roku w Krakowie, po II wojnie światowej pracował w USA) Paula N. Rosensteina-Rodana pt: Problems of Industrialization of Eastern and South-Eastern Europe, opublikowany w 1943 roku w "Economic Journal". Natomiast za swoistego guru ekonomii rozwoju uchodzi pochodzący z Indii Amartya K. Sen (Nagroda Nobla 1998). Inni wybitni, o światowej renomie ekonomiści, których można zaliczyć do głównego nurtu ekonomii rozwoju, to - oprócz obu wyżej wymienionych: Raul Prebisch, Ragnar Nurkse, Celso M. Furtado, Walt W. Rostow, Hans W. Singer, Gerald M.H. Meier, William A. Lewis, Gunnar Myrdal, Theodore W. Schultz i Joseph E. Stiglitz. Czterej ostatni są laureatami Nagrody Nobla w dziedzinie ekonomii.

7 Charakterystykę ewolucji ekonomii rozwoju oparto - oprócz prac bezpośrednio cytowanych - na lekturze publikacji takich autorów, jak: Piasecki [2003a; 2003b; 2007], Bartkowiak [2003; 2013], Kozak [2001], Nawrot [2014], Zadroga [2012], Durth i in. [2002], Jabłoński [2008; 2011], Telep [2010], Bąkiewicz, Żuławska [2010]. 
Periodyzując historię ekonomii rozwoju, można wyróżnić jej kilka faz:

1. Lata 50. i 60. - okres tworzenia zrębów i „dojrzewania” ekonomii rozwoju.

2. Lata 70. - okres konfrontacji teorii rozwoju Trzeciego Świata z rzeczywistością i próby modyfikacji ekonomii rozwoju.

3. Lata 80. i pierwsza połowa lat 90. - okres kryzysu ekonomii rozwoju i jej znaczące przewartościowania - w kierunku teorii liberalnych opartych na prawach globalnego rynku kapitału i towarów.

4. Przełom wieków i pierwsze lata XXI wieku - „otrzeźwienie” po latach nadmiernej liberalizacji i deregulacji gospodarek, renesans ekonomii rozwoju i ewolucja w kierunku propagowania zrównoważonego rozwoju (sustainable development) oraz mocne akcentowanie społecznych czynników rozwoju w krajach rozwijających się, tj. kapitału ludzkiego i społecznego.

Za najważniejszy problem ekonomii rozwoju na samym jej początku, tj. w latach 40. i 50. minionego wieku, uznano powstrzymanie pogrążania się w zacofaniu krajów biednych na wszystkich kontynentach i zapoczątkowanie ich rozwoju. Ranga i zarazem złożoność sytuacji gospodarczej, politycznej oraz kulturowej, a także wzajemne uwarunkowania tych trzech sfer były wielką przeszkodą w tym względzie. Należało podjąć jakieś nadzwyczajne kroki, aby przezwyciężyć istniejący zastój, a nawet regres, potęgowany dodatkowo tworzeniem się nowych państw i - bezpośrednio lub pośrednio - skutkami wojny światowej. Koniecznym było uczynienie czegoś nadzwyczajnego, co można by nazwać „wielkim pchnięciem" (big push), jak to uczynił w latach 50. wspomniany Rosenstein-Rodan ${ }^{8}$. Formułowane w tym celu teorie startu do rozwoju nazywa się czasem, z perspektywy kilku dziesięcioleci „teoriami pierwszej generacji”. Jedną z najważniejszych jest propozycja W.W. Rostowa wyrażona w rozprawie The Process of Economic Growth (1952) ${ }^{9}$. Kluczem do zapoczątkowania modernizacji postkolonialnych krajów - jak postulował Rostow - miała być rosnąca stopa akumulacji kapitału fizycznego, która zwiększałaby tempo wzrostu gospodarczego (a tym samym przyszłą akumulację) i w ten sposób generowała modernizację gospodarki, a w ślad za tym

${ }^{8} \mathrm{~W}$ artykule opublikowanym w polskim periodyku naukowym „Ekonomista” (Uwagi o teorii „,wielkiego pchnięcia” 1959, nr 2) P. Rosenstein-Rodan tak pisze m.in.: „Niezbędnym (choć niewystarczającym) warunkiem powodzenia [tj. zapoczątkowania rozwoju - przyp. G.B.] jest minimum rozmiarów inwestycji. Oto w największym skrócie, istotna część teorii «wielkiego pchnięcia»". Metaforycznie owe inwestycje powodujące ,wielkie pchnięcie” przyrównuje on do siły, która jest niezbędna do osiągnięcia pewnej krytycznej szybkości przez samolot, aby uniósł się w powietrze.

9 Za najważniejszy element teorii Rostowa w odniesieniu do rozwoju gospodarczego uznaje się jego teorię stadiów wzrostu. Została ona pierwotnie opublikowana w postaci artykułu i później nieco modyfikowana. Rostow [1959] wyróżnił sześć stadiów wzrostu (rozwoju): społeczeństwo tradycyjne (the traditional society), okres poprzedzający start i tworzący warunki rozwoju (the preconditions for take-off), okres startu (the take-off), okres osiągania dojrzałości gospodarczej (the drive to maturity), okres wysokiej i masowej konsumpcji (the age of high mass-consumption), okres pokonsumpcyjny (beyond consumption). 
oddziaływała pozytywnie na warunki życia społeczeństw. Uruchomiony zostałby samonapędzający się spiralny mechanizm wzrostu i rozwoju gospodarczego. Barierą takiego scenariusza był jednak niemal we wszystkich krajach zacofanych - co już wcześniej podkreślał Rosenstein-Rodan w cytowanych artykułach - niedostatek kapitału fizycznego ${ }^{10}$. Według Rostowa źródłem początkowego kapitału fizycznego winny być krajowe oraz międzynarodowe oszczędności; w tym ostatnim przypadku byłyby to zagraniczne pożyczki oraz akcje pomocowe w postaci wspomagania inwestycji infrastrukturalnych czy też bezpośrednio zwiększających potencjał wytwórczy (np. budowa fabryk, szkolenie załóg itp.). Scenariusz taki był oczywiście możliwy, a może nawet jedyny, ale jego skala nie mogła być duża z uwagi na ogromne potrzeby inwestycyjne Trzeciego Świata przy równocześnie niewielkiej podaży kapitału ze strony państw zachodnich, które musiały odbudowywać i modernizować swoje gospodarki po zniszczeniach wojennych. Ponadto wielką barierą startu oraz rozwoju gospodarczego krajów zacofanych były struktury społeczne, podziały polityczne, systemy wartości kulturowych, a bardzo często także obawa przed ponownym uzależnieniem się od byłych kolonizatorów.

Problemom kapitału jako warunkowi startu i rozwoju gospodarczego wiele uwagi poświęcił Ragnar Nurkse, ekonomista (pochodzący z Estonii) zaliczany do „ojców” ekonomii rozwoju. Twierdził m.in., że ważnym problemem jest nie tylko podaż kapitału, krajowa czy zagraniczna, ale także - a często przede wszystkim - popyt na ten kapitał, czyli wielkość, struktura rynku kapitałowego oraz bodźce do inwestowania ${ }^{11}$. Główną barierą rozwoju w krajach Trzeciego Świata - według

10 Jednym z ważnych, aczkolwiek trudnym do skwantyfikowania, warunków ,,wielkiego pchnięcia” jest według Rosensteina-Rodana - ,zjawisko niepodzielności woli i energii” (chodzi o władze państwowe i elity społeczne). Pisał on [1959]: „Odosobnione, rozdrobnione wysiłki mogą w całości «nie złożyć się» na dostatecznie silny bodziec rozwoju, a także swoista «atmosfera» rozwoju, klimat ożywienia, wytworzyć się może dopiero przy pewnym minimalnym tempie i rozmiarach inwestycji. Nasza znajomość psychologii jest zbyt skromna, aby pozwoliła na jakiekolwiek próby teoretycznego ujęcia tych zjawisk. Jednakże czynnik ten ma swoją wagę. Niejednokrotnie on właśnie zadecydować może o całej różnicy pomiędzy koniecznymi, a wystarczającymi warunkami powodzenia". W wymiarze praktycznym ,niepodzielność” ta miałaby się wyrażać w niemal jednoczesnym podejmowaniu inwestycji w wielu działach gospodarki. Wywołany zostałby w ten sposób efekt komplementarności oraz synergii pomiędzy tymi przedsięwzięciami, co dałoby skumulowany efekt w postaci owego „wielkiego pchnięcia” gospodarki i uruchomienia spirali wzrostu oraz rozwoju społecznego.

${ }^{11}$ W głównej rozprawie Nurksego stanowiącej - jak można czasem przeczytać - ,standardowe dzieło klasycznej ekonomii rozwoju" pt.: Problemy tworzenia kapitatu w krajach gospodarczo słabo rozwiniętych pisał on m.in.: „Pierwsze zagadnienie, którym się zajmujemy, wiąże się z bodźcami do inwestowania, rozumianymi tak, jak je widzi pojedynczy inwestor czy przedsiębiorca. Innymi słowy, dotyczy ono warunków określających popyt na kapitał, który ma być zastosowany w procesie produkcji. Dychotomiczny związek pomiędzy popytem a podażą, tak bliski sercu ekonomistów, może być w pełni zastosowany do sił rządzących akumulacją kapitału. Tworzenie kapitału nie jest wyłącznie sprawą podaży kapitału, chociaż podaż stanowi niewątpliwie najważniejszą część problemu" [Nurkse, 1953, wyd. pol. 1962, s. 25]. 
Nurksego - była jednak materialna bieda i kulturowe zacofanie, które nie pozwalają na wytworzenie nadwyżek (oszczędności) w celach inwestowania. Powstaje tzw. błędne koło ubóstwa (vicious circle of poverty - tłumaczone także jako zaklęty albo diabelski krąg biedy), z którego trudno się wyrwać ${ }^{2}$. Jego schemat pokazano na rys. 1.1.

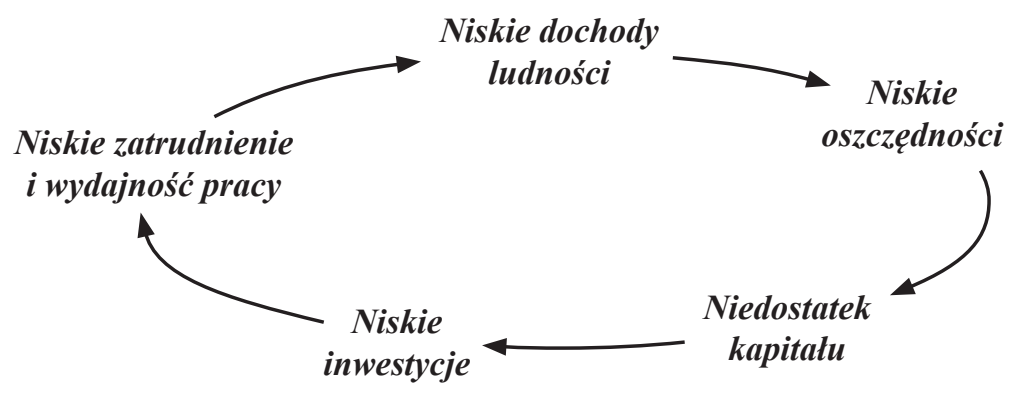

Rysunek 1.1. Schemat błędnego koła ubóstwa R. Nurksego

Źródło: opracowanie własne.

Nurkse zdawał sobie sprawę, że kraje zacofane nie są w stanie samodzielnie zapoczątkować wychodzenia z biedy i zacofania, czyli przerwać „błędnego koła ubóstwa" i pozostawione same sobie ugrzęzną na długie lata w stagnacji, czyli w „równowadze niedorozwoju”. Wobec takiej perspektywy warunkiem zapoczątkowania rozwoju, czyli „wielkiego pchnięcia”, jest zaangażowanie zagranicznego kapitału, a więc uruchomienie na większą skalę napływu do kraju obcego kapitału w postaci kredytów oraz pomocy rzeczowej lub finansowej, ale przy ograniczoności napływu konsumpcyjnych towarów luksusowych ${ }^{13}$. Takie zewnętrzne

${ }^{12}$ R. Nurkse nie jest bynajmniej autorem sformułowania „błędne koło ubóstwa”, on jedynie szczególnie uwypuklił ten problem. Używało go wcześniej w odniesieniu do krajów zacofanych wielu ekonomistów. Dużo uwagi „błędnemu kołu” poświęcał już na początku lat 50. (przed Nurksem) m.in. - i to w różnych odniesieniach - G. Myrdal [1958, s. 30-43]. Szczególnym dziełem Myrdala o problemach rozwoju postkolonialnej Azji, w tym owego „błędnego koła”, jest jego monumentalna, trzytomowa (prawie 2300 s.), wydana w 1968 roku, praca pt.: Dramat Azji. Badania nad nędza narodów (Asian Drama: An Inquiry into the Poverty of Nations). Z uwagi na inny cel rozważań i ograniczoność miejsca (względem ogromnej rozległości problematyki), kwestiom tym - poza wyjątkami - nie poświęcamy więcej uwagi.

${ }^{13} \mathrm{~W}$ warunkach ograniczoności pozyskiwania krajowego kapitału (czyli niedostatku oszczędności) zmorą wielu krajów, szczególnie ich elit (z reguły wielce skorumpowanych), było przeznaczanie oszczędności na import luksusowych dóbr. Nie poprawiały one warunków życia większości społeczeństwa, a w dodatku negatywnie oddziaływały na jego wzorce spożycia poprzez wywoływanie tzw. efektu demonstracyjnej konsumpcji. Takie systemy wartości i zachowania zamożniejszych warstw społecznych uniemożliwiały przeznaczenie nadwyżek na cele inwestycyjne, czy zapoczątkowanie spirali rozwoju gospodarczego. Dlatego też wiele krajów wprowadzało bariery przeciwko 
wsparcie pozwoliłoby zapoczątkować wychodzenie ze stanu „równowagi niedorozwoju” i wejście na ścieżkę ,zrównoważonego rozwoju”.

„Zrównoważony rozwój” rozumiał Nurkse - podobnie jak Rosenstein-Rodan - jako wzrost inwestycji i produkcji nie tylko w wybranych działach gospodarki, lecz w możliwie dużej ich liczbie, co pozwoliłoby uniknąć wąskich gardeł w gospodarce, czyli ukształtowanie takich proporcji i mechanizmów, aby gospodarka mogła się rozwijać w sposób zrównoważony (proporcjonalny) ${ }^{14}$. Problematyka startu do rozwoju, a następnie , proporcjonalnego wzrostu” (balanced growth) zajmowała wiodące miejsce w badaniach ekonomistów zaliczanych do ekonomii rozwoju w latach 50. i 60. ubiegłego wieku ${ }^{15}$.

Do ważniejszych wątków ekonomii rozwoju lat 50. i 60. należała kwestia wyboru ścieżki rozwoju gospodarczego przez zacofane, z reguły postkolonialne gospodarki, zwłaszcza krajów Azji i Afryki. Jak już wcześniej wspomniano, dylemat był następujący: czy startujące do samodzielnego życia państwa powinny przyjąć konwencję rozwoju taką, jak wcześniej czyniły to kraje wysoko rozwinięte (czyli przez naśladownictwo), czy też wytyczać nowe, własne szlaki rozwojowe [Sachs, 1959].

Analizy pierwszych lat powojennych wskazują, że dystans pomiędzy krajami rozwiniętymi a Trzecim Światem nie tylko nie maleje, lecz wzrasta. Nie sprawdza się więc hipoteza wystąpienia - poza wyjątkami - tzw. efektu doganiania, to znaczy różnice w poziomie rozwoju zwiększają się. Ewentualna próba pójścia drogą krajów wysoko rozwiniętych, na ogół byłych kolonizatorów (np. Wielkiej Brytanii, Francji czy Holandii), stawała się z upływem lat mało prawdopodobna z tego przede wszystkim powodu, że taki rozwój musiałby trwać bardzo długo i mieć gruntowne podstawy materialne (kapitał), zaś na to nowych państw nie było stać, a ponadto „nie miały czasu”, ponieważ presja społeczna na szybką poprawę warunków bytu była bardzo duża. Dodatkowym czynnikiem komplikującym sprawę były - jakkolwiek by tego nie oceniać z późniejszej perspektywy - sukcesy krajów socjalistycznych, których gospodarkę oparto na wła-

importowi artykułów luksusowych, chociaż nie oznaczało to automatycznego skierowania uzyskanych tą drogą oszczędności do sektora krajowych inwestycji i pobudzania w ten sposób wzrostu gospodarczego [Nurkse, 1962, s. 180-182].

${ }^{14}$ Nurkse [1962, s. 35] uzasadniając rozszerzanie rynku (podaży i popytu) kapitałowego i przez to zwiększenie produkcji dóbr inwestycyjnych i konsumpcyjnych pisał m.in.: „Ludzie, którzy posługują się zwiększoną ilością i to ulepszonych narzędzi w szeregu uzupełniających się przedsięwzięć, stają się dla siebie wzajemnie klientami. Większość gałęzi produkcji dostarczających artykułów masowego spożycia jest względem siebie komplementarna w tym znaczeniu, że przemysły te tworzą dla siebie wzajemnie rynek, a tym samym podtrzymują się. Ta podstawowa komplementarność wypływa w gruncie rzeczy z różnorodności ludzkich potrzeb. Argumenty na rzecz «zrównoważonego wzrostu» opierają się na potrzebie «zrównoważonej diety»".

15 Por. przykładowo rozważania na ten temat w pracach: G. Myrdala [1958], I. Sachsa [1959], P.N. Rosensteina-Rodana [1943; 1959] i G.M. Meiera [1971]. 
sności państwowej, centralnym planowaniu i zarządzaniu przy równoczesnym ograniczeniu wolności obywatelskich. Pierwsze efekty gospodarek socjalistycznych stały się bardzo „zaraźliwe” dla Trzeciego Świata, wskazywały, że istnieje jakaś inna, krótsza droga dla państw zacofanych niż powtarzanie historii byłych kolonizatorów [Sachs, 1959].

W pierwszych latach 70. następuje istotne przewartościowanie w ekonomii rozwoju. Ekonomiści tego nurtu odchodzą od wąskiego, tylko ekonomicznego traktowania rozwoju gospodarczego i poszerzają jego problematykę o czynniki jakościowe, takie jak kulturowe, edukacyjne, ekologiczne, kapitał ludzki i społeczny itp., a więc traktują rozwój gospodarczy w takim ujęciu, jak to jest w zawarte $\mathrm{w}$ definicjach Schumachera i Sena podanych na początku tego rozdziału (por. przypis 2). Na plan dalszy zeszły problemy rozwoju gospodarczego, w takim jak do niedawna ujęciu, czyli traktowanie go tylko jako ilościowego wzrostu produkcji. Oczywiście, że wzrost produkcji (PKB) jest bardzo ważny, ale nie jest bynajmniej warunkiem wystarczającym dla rozwoju - i w ogóle - postępu ekonomicznego. Ogromną i coraz bardziej istotną rolę odgrywają podziały dochodów z tytułu wzrostu gospodarczego, to znaczy jak się one rozkładają w społeczeństwie, jak wygląda ich zróżnicowanie przestrzenne, czy dysproporcje narastają, czy też się zmniejszają? Reasumując, w latach 70. ekonomia rozwoju zaczęła powoli wychodzić - jak pisał E.J. Mishan [1986, s. 23-27] - „z niewoli wzrostu gospodarczego" $"$.

Istotne przewartościowania ekonomii rozwoju w latach 70. nie uchroniły jej przed popadnięciem w kryzys, który trwał przez całą dekadę lat 80 . i przeciągnął się na lata 90. [Piasecki, 2007, s. 18-24].

Pierwsze po wojnie większe kryzysy gospodarcze, tj. naftowe (1973-1974, 1979-1981) oraz kryzys zadłużeniowy w Ameryce Łacińskiej (1982-1983) odbiły się piętnem na teorii ekonomii oraz polityce gospodarczej. Tym bardziej, że nie były spodziewane, zaskoczyły teoretyków. Wobec załamania gospodarczego, $\mathrm{w}$ teorii ekonomii i w polityce gospodarczej na plan pierwszy wysunęły się kwestie makroekonomicznej stabilizacji i zmian strukturalnych, szczególnie w krajach rozwijających się. Zagadnienia będące dotąd przedmiotem ekonomii rozwoju stały się mniej ważne. Mówiło się nawet o bezwzględnej porażce całego nurtu, przynajmniej w odniesieniu do niektórych regionów świata. Zakwestionowano m.in. niemal powszechną opinię o niezbędności interwencjonizmu państwa w życie gospodarcze. Pomimo bezpośredniego zaangażowania gospodarczego państwa nie odnotowano (poza nietypowymi wyjątkami, jak Tajwan, Korea Południowa,

${ }^{16}$ E. Mishan [1986, s. 24], traktując o utrwalonym przez pierwsze powojenne dziesięciolecia fetyszu wzrostu gospodarczego, pisał: „Doszło do tego, że do lat sześćdziesiątych XX wieku wiara w postęp ekonomiczny tak zawładnęła naszymi umysłami, iż stała się milczącym założeniem istnienia opatrzności”. 
Hongkong i Singapur) poważniejszych sukcesów ani w wymiarze gospodarczym, ani społecznym. Do wymiernych porażek ekonomii rozwoju w odniesieniu do krajów rozwijających się należy zaliczyć w szczególności [Piasecki, 2007, s. 19]:

- niedostateczny przyrost nowych miejsc pracy i wzrost bezrobocia;

- wzrost nierówności dochodowych i powiększanie się obszarów ubóstwa;

- utratę tożsamości kulturowej niektórych krajów rozwijających się;

- pogłębianie się uzależnienia gospodarczego krajów rozwijających się od krajów wysoko rozwiniętych.

Ta nowa sytuacja w gospodarce światowej po 1980 roku sprawiła, że w połowie dekady doszło do ponownego i wyraźnego ożywienia dyskusji pomiędzy zwolennikami neoklasycznego podejścia do rozwoju gospodarczego, określanymi mianem „Grupy Banku Światowego" a ekonomistami zaliczanymi do innych nurtów ekonomii, nazwanymi „Resztą” [Piasecki, 2007, s. 20]. Najważniejsza różnica pomiędzy stronami sporu dotyczyła roli państwa w gospodarce oraz kwestii cen. W systemie, w którym państwo odgrywa dużą rolę - uznawała Grupa Banku Światowego - następuje na ogół zniekształcenie systemu cen, co deformuje całą gospodarkę i w konsekwencji dynamikę jej rozwoju. Najprawdopodobniej rozwój Trzeciego Świata byłby szybszy, gdyby odbywał się w warunkach zderegulowanego i liberalnego systemu gospodarczego. Ten pogląd urósł w latach 80 . niemal do rangi paradygmatu, tym bardziej, że w wymiarze praktycznym był wspierany przez liberalną politykę ekonomiczną prezydenta USA Ronalda Reagana oraz deregulacyjne reformy gospodarcze rządu Wielkiej Brytanii podjęte przez premier Margareth Thatcher, a także dynamiczny rozwój niektórych krajów do niedawna zacofanych - głównie tzw. azjatyckich tygrysów. Natomiast gospodarki, w których udział państwa był znaczny, rozwijały się co prawda, ale w wolniejszym tempie. W tej sytuacji ekonomia rozwoju, będąc pod presją faktów, musiała zmodyfikować swoje dotychczasowe kanony i opowiedziała się także za zwiększeniem roli rynku i tym samym ograniczeniem interwencjonizmu państwa [Piasecki, 2007, s. 21]. Zmiany te określa się niekiedy mianem „neoliberalnej kontrrewolucji” [Payne, Phillips, 2011, s. 109] ${ }^{17}$.

${ }^{17}$ Anthony Payne i Nicola Phillips [2011, s. 112] tak charakteryzują argumenty „liberalnych kontrrewolucjonistów” przeciw ekonomii rozwoju: „Pierwsi orędownicy rewolucji neoliberalnej ubolewali nad sposobem, w jaki ekonomia rozwoju zbudowała swoje intelektualne podstawy na hipotetycznym i w dużej mierze fałszywym rozróżnieniu pomiędzy krajami «rozwiniętymi»a «rozwijającymi się», i opowiadali się za powrotem do pewnej formy «monoekonomii» zbudowanej na «uniwersalnych» zasadach racjonalności, które stanowiły rdzeń neoklasycznej teorii ekonomicznej (a także przedmiot krytyki ze strony «pierwszego pokolenia» ekonomistów rozwoju). Po drugie, wpływ myśli Keynesa na ekonomię rozwoju spowodował, że nadmierną uwagę skupiono na tworzeniu kapitału na szeroką skalę, czego konsekwencją było zaburzone rozumienie oraz diagnoza wymogów wzrostu i rozwoju. Po trzecie, twierdzono, że interwencja państwa w gospodarkę niesie ze sobą niedopuszczalne konsekwencje w formie bezładu gospodarczego i politycznego". 
„Neoliberalna kontrrewolucja" rehabilitująca wolny rynek, i to w skali globalnej (międzynarodowej), doprowadziła także do przeorientowania polityki gospodarczej dużej liczby krajów, szczególnie rozwijających się. Jej „sztandarem” stał się tzw. Konsensus Waszyngtoński (Washington Consensus). Był on syntezą reform proponowanych przez Bank Światowy (BŚ), Międzynarodowy Fundusz Walutowy (MFW) oraz rząd USA. Przedstawiony został w 1989 roku na konferencji w Waszyngtonie przez Johna Williamsona (angielskiego ekonomistę pracującego głównie w USA $)^{18}$. Proponowane przez niego rekomendacje dla realizacji nowej polityki gospodarczej odnosiły się w swej pierwotnej wersji do krajów Ameryki Łacińskiej, przeżywających w latach 80. duże trudności gospodarcze (kryzys zadłużeniowy). Nieco później zostały uogólnione i podniesione do rangi programów restrukturyzacyjnych dla wszystkich gospodarek rozwijających się.

Według sformułowań Williamsona zawartych w pracy podanej w przypisie 18 Konsensus Waszyngtoński (tzw. pierwsza wersja konsensusu) dotyczył modyfikacji polityki w takich obszarach gospodarki, jak:

1. Deficyt fiskalny. Utrzymanie dyscypliny fiskalnej i unikanie dużego deficytu budżetu państwa w stosunku do PKB.

2. Priorytety w wydatkach publicznych. Reorientacja polityki wydatków publicznych i preferowanie wydatków prorozwojowych, kierowanych na edukację, ochronę zdrowia oraz infrastrukturę.

3. Reforma podatkowa. Poszerzanie bazy podatkowej, poprawa ściągalności podatków, obniżanie krańcowych stóp podatkowych (zwłaszcza podatków bezpośrednich).

4. Stopy procentowe. Utrzymanie pozytywnych, lecz umiarkowanych realnych stóp procentowych.

5. Kurs walutowy. Utrzymanie jednolitego kursu walutowego na poziomie zapewniającym konkurencyjność eksportu i równowagę bilansu płatniczego.

6. Polityka handlowa. Liberalizacja handlu, w tym likwidacja różnych ograniczeń ilościowych (licencji), obniżanie taryf celnych i dążenie do ich uniformizacji.

7. Bezpośrednie inwestycje zagraniczne. Liberalizacja przepływów bezpośrednich inwestycji zagranicznych, znoszenie barier ich wejścia na krajowe rynki oraz równorzędne ich traktowanie w porównaniu do inwestycji przedsiębiorstw krajowych.

8. Prywatyzacja. Prywatyzowanie przedsiębiorstw państwowych w celu zwiększenia ich efektywności i dopuszczenie do tego procesu kapitału zagranicznego.

9. Deregulacja. Zmniejszenie roli państwa w funkcjonowaniu rynków, wspieranie konkurencyjności jego uczestników. Regulacje państwowe winny

18 Pierwsza wersja Konsensusu Waszyngtońskiego została opublikowana przez J. Williamsona pod tytułem What Washington Means by Policy Reform jako drugi rozdział pracy pod jego redakcją pt.: Latin American Adjustment. How Much Has Happened?, Peterson Institute for International Economics, Washington, D.C., 1990. 
koncentrować się na sprawach związanych z bezpieczeństwem narodowym, ochroną środowiska, ochroną konsumenta oraz nadzorem nad instytucjami finansowymi.

10. Prawa własności. Państwo winno zapewniać ochronę własności we wszystkich jej postaciach (materialnych, prawnych i intelektualnych).

Konsensus Waszyngtoński był modyfikowany w latach późniejszych, aczkolwiek nie były to zmiany istotne ${ }^{19}$. Zachowane zostało jego podstawowe przesłanie teoretyczno-ideowe oraz zalecenia dla polityki gospodarczej. Bazujący na podstawach liberalnej teorii, czyli tzw. fundamentalizmie rynkowym MFW - jak pisał J.E. Stiglitz [2004, s. 46-47] - Konsensus Waszyngtoński miał być w ostatniej dekadzie XX wieku i pierwszych latach XXI wieku swoistym dekalogiem dla polityki gospodarczej zarówno w krajach rozwijających się, jak i wysoko rozwiniętych. Przemawiały za nim już nie tylko argumenty teoretyczne, lecz także spektakularne sukcesy gospodarek wysoko rozwiniętych (np. USA, Wielkiej Brytanii) czy też niektórych państw Ameryki Łacińskiej (głównie tzw. cud chilijski) oraz krajów Azji Wschodniej i Południowej ${ }^{20}$. Stał się także - co znamienne - podstawą reform kilku gospodarek europejskich krajów postsocjalistycznych, które w latach 90. przekształcały się z państwowych (socjalistycznych) w wolnorynkowe [Jabłoński, 2011]. Trzeba jednak zaznaczyć, że stopień jego wykorzystania był różny w poszczególnych krajach Europy Środkowo-wschodniej ${ }^{21}$. Konsensus Waszyngtoński pomimo intelektualnej atrakcyjności nie zyskał jednak w dłuższym czasie - jak to się początkowo zapowiadało - powszechnej aprobaty, spotkał się ze sporą krytyką i jej fala systematycznie narastała, szczególnie w pierwszej dekadzie lat XXI wieku ${ }^{22}$. Proponowana w Konsensusie Waszyngtońskim oraz innych zaleceniach MFW i Banku Światowego polityka gospodarcza oparta na tzw. złotych zasadach kapitalizmu, czyli szybkiej liberalizacji, deregulacji, prywatyzacji i otwarciu na świat, przy równocześnie restrykcyjnej polityce pieniężnej i fiskal-

${ }^{19} \mathrm{~W}$ modyfikacjach tych zalecano $\mathrm{m}$ in.: wprowadzenie proekologicznych podatków, tworzenie niezależnych banków centralnych i silnego nadzoru bankowego oraz sprawnego aparatu fiskalnego, poprawę sądownictwa gospodarczego.

${ }^{20}$ Należy dodać, że koronnym argumentem „neoliberalnej kontrrewolucji” przeciw ekonomii rozwoju były sukcesy gospodarcze krajów Azji Południowo-Wschodniej w latach 90., które propagatorzy Konsensusu Waszyngtońskiego przypisywali sobie. Ale podobnie czynili ekonomiści rozwoju, którzy twierdzili, że bez dużego udziału państwa w gospodarce, sam rynek nie zapewniłby tym krajom „cudu gospodarczego” [Payne, Phillips, 2011, s. 121-122].

${ }^{21}$ W Polsce udana transformacja gospodarcza była efektem nie implementacji zaleceń Konsensusu Waszyngtońskiego, lecz - przeciwnie - odrzucenia głównych wątków tej doktryny. Podobnie postąpiły Chiny. Natomiast przyjęcie dużej części reformatorskiego pakietu Konsensusu Waszyngtońskiego przez Czechy i Rosję skończyło się poważnym załamaniem ich gospodarek już pod koniec lat 90. (m.in. głęboki kryzys rosyjski w 1998 roku). Szerzej na ten temat pisze Stiglitz [2004, s. 164-170].

${ }^{22} \mathrm{Z}$ opiniami krytycznymi można się dokładniej zapoznać m.in. w artykułach Z.J. Stańczyka [2004] oraz Ł. Jabłońskiego [2011]. 
nej, nie uchroniła gospodarek większości krajów Azji oraz Ameryki Łacińskiej od załamań. Przeciwnie - istotnie przyczyniła się do ogólnoświatowych kryzysów finansowych lat 90. XX wieku [Stiglitz, 2004, s. 66; Jabłoński, 2011]. Na początku XXI wieku coraz częściej pojawiały się zarzuty, że Konsensus Waszyngtoński był programem działającym niemal wyłącznie na korzyść krajów bogatych i przyczynił się do wzrostu zróżnicowania ekonomicznego świata, tj. dalszego oddalania się krajów tzw. centrum od krajów peryferyjnych [Jabłoński, 2011].

Wspomniana wcześniej opozycja wobec „Grupy Banku Światowego”, czyli „Reszta”, przystąpiła do kontrataku, którego bodaj najmocniejszym elementem był Konsensus z Santiago de Chile, przyjęty w kwietniu 1998 roku przez głowy państw i rządów uczestniczących w drugim szczycie Ameryk. Przywracał on częściowo znaczenie ingerencji państwa w gospodarkę, szczególnie tam, gdzie zawodziły mechanizmy wolnego rynku. Nowe, nieznane dotąd, wyzwania postawiła przed krajami rozwijającymi się globalizacja, która nie była na ogół korzystna dla rozwijającego się świata. Wielu krajom rozwijającym się - twierdził w tym kontekście m.in. J. Stiglitz - potrzebne są nie globalne wzorce, ale rozwiązania wynikające z ich regionalnej i lokalnej specyfiki gospodarczej, demograficznej oraz społeczno-kulturowej [Bąkiewicz, Żuławska, 2010, s. 83].

Na przełomie stuleci XX i XXI, w wyniku ścierania się poglądów autorów należących do wymienionych wyżej, przeciwstawnych sobie grup oraz różnych doświadczeń praktycznych, wykształcił się nowy, będący ich syntezą paradygmat rozwojowy wdrażany w pierwszych latach XXI wieku. Nazywa się go niekiedy Konsensusem Postwaszyngtońskim. Podstawowymi jego elementami są następujące twierdzenia [za: Piasecki, 2003a, s. 64-65; 2007, s. 30-31]:

1. Sektor prywatny ma podstawowe znaczenie dla gospodarki i jej rozwoju. Gospodarka winna charakteryzować się dużą wrażliwością na parametry rynkowe, takie jak ceny, stopy procentowe itp.

2. Wszędzie tam, gdzie ujawnią się niedoskonałości rynku, winno interweniować państwo, jednakże jego działania muszą być przyjazne rynkowi.

3. Zasadniczą rolę w rozwoju gospodarczym odgrywają inwestycje w kapitał ludzki i społeczny, które muszą w odpowiednich proporcjach uzupełniać kapitał fizyczny (na zasadzie substytucji i/lub komplementarności).

4. Polityka gospodarcza winna sprzyjać w długim okresie inwestycjom krajowym i zagranicznym i czynić gospodarkę otwartą.

5. Na większą niż dotychczas skalę należy zwracać uwagę na otoczenie kulturowe gospodarki, tj. systemy wartości, tradycje, podziały etniczne itp.

6. Gospodarka musi mieć zdolność wysokiej absorpcji informacji z otoczenia zewnętrznego i sprawne kanały jej wewnętrznych przepływów.

7. Infrastruktura prawno-instytucjonalna gospodarki (prawo gospodarcze i cywilne, sądownictwo, instytucje państwa, organizacje gospodarcze itp.) powinna być bardziej niż dotychczas dostosowana do reguł rynkowych, aby rynek mógł sprawnie funkcjonować. 
Powyższy wykaz podstawowych tez Konsensusu Postwaszyngtońskiego wskazuje pośrednio, że na przełomie XX i XXI wieku następuje odrodzenie ekonomii rozwoju, aczkolwiek w zmodyfikowanej wersji. Kryzys ekonomii rozwoju w latach 80. i 90. nie był - jak sądzili niektórzy ekonomiści i politycy - jej klęską i zamknięciem rozdziału w podręcznikach historii myśli ekonomicznej. Oczywiście doświadczenia tamtych dwóch dekad przewartościowały wiele wątków ekonomii rozwoju, niektóre z nich zostały odrzucone, gdyż nie miałyby racji bytu w warunkach gospodarczych i politycznych XXI wieku. Inne jednak pomyślnie przeszły próbę czasu i ożyły, wzbogacając najnowszą myśl ekonomiczną. W drugiej dekadzie XXI wieku można mówić zatem o „nowej ekonomii rozwoju"23.

Reasumując, do nowych, wcześniej niedostrzeganych lub mało eksponowanych wątków ekonomii rozwoju zaliczyć należy przede wszystkim:

1. Analizę roli instytucji w dynamizowaniu rozwoju gospodarczego, czyli instytucjonalizm i jego prymat w teorii nowej ekonomii rozwoju [Nawrot, 2014, s. $31-36]^{24}$.

2. Rozwój badań empirycznych nad poziomem i jakością życia (w szerokim ich rozumieniu) w skali nie tylko lokalnej, lecz także globalnej oraz uznanie tych kategorii za główny cel rozwoju gospodarczego [Zadroga, 2012]. Wyraża się to obliczaniem i systematycznym publikowaniem różnych wskaźników i rankingów warunków życia w skali kontynentów oraz świata. Są one pomocne w badaniach nad rozwojem gospodarczym i społecznym różnych krajów i regionów.

3. Koncepcje wzrostu zrównoważonego społecznie, ekologicznie oraz ekonomicznie (sustainable development) i to w długim okresie [Bąkiewicz, Żuławska, 2010, s. 84-85].

4. Rozwój badań empirycznych ze szczególnym uwzględnieniem badań terenowych (field studies) oraz diagnoz wzrostu (growth diagnostics), pozwalających głębiej poznać regionalne oraz lokalne problemy funkcjonowania życia gospodarczego i społecznego i na tej podstawie formułować teorie i zalecenia praktyczne [Nawrot, 2014, s. 36-39].

5. Uwzględnianie w badaniach nad rozwojem, zwłaszcza dużych krajów rozwijających się (np. Indii, Brazylii, Meksyku, Indonezji), problematyki tzw.

${ }^{23}$ Można się jednak spotkać z opiniami kwestionującymi uznawanie już ekonomii rozwoju jako odrębnej dyscypliny ekonomii i sugestie włączenia jej do „generalnej teorii rozwoju gospodarki światowej" [Piasecki, 2003b, s. 231-232].

${ }^{24}$ Chodzi o instytucje w bardzo szerokim ich rozumieniu: a) instytucje sfery prawnej i gospodarczej (np. prawa własności, prawa obrotu towarowego), b) instytucje sfery regulacyjnej (np. prawo gospodarcze, sądownictwo), c) instytucje stabilizujące rynek (polityka pieniężna i fiskalna), d) instytucje osłonowe (np. polityka społeczna, system ubezpieczeń), e) instytucje systemu kulturowego (style życia, systemy wartości, wzorce kulturowe, edukacja) [Piasecki, 2007, s. 28-29; Nawrot, 2014, s. 31-36]. 
globalnych dóbr publicznych (np. atmosfery, przyrody, wody, krajobrazu) i tworzenia dla nich swoistej infrastruktury globalnej (global governance) [Nawrot, 2014, s. 44].

\subsection{Problemy startu i rozwoju gospodarczego krajów zacofanych (ze szczególnym uwzględnieniem postkolonialnej Azji)}

W niniejszym fragmencie rozprawy - z racji jej głównego celu - skupimy się na teoretycznych problemach wyboru i aplikacji modeli rozwoju gospodarczego w zacofanych, z reguły postkolonialnych, krajach Azji, oczywiście w kontekście przedstawionych $\mathrm{w}$ poprzednim podrozdziale problemów ekonomii rozwoju. Analiza ma charakter retrospektywny, to znaczy m.in., że termin „kraje zacofane" (bądź pojęcia pokrewne) odnosi się do stanu ich gospodarek w okresie bezpośrednio powojennym, a omawiane problemy widziane są oczami ówczesnych ekonomistów i polityków, a nie postrzegane z perspektywy pierwszych lat XXI w.

Postkolonialne kraje azjatyckie stanowiły podobną zbiorowość pod względem społecznym, kulturowym, religijnym, historycznym, geograficznym oraz demograficznym. Startowały również z podobnego poziomu swych gospodarek. Ta właśnie suma i charakter podobieństw odróżnia je, i to dość wyraźnie, od pozostałych - jak wcześniej stwierdzono - krajów zaliczanych do Trzeciego Świata (Afryki i Ameryki Łacińskiej).

Traktując o problemach startu i początków rozwoju krajów zacofanych, z reguły odzyskujących niepodległość i wychodzących z uzależnienia od byłych metropolii kolonialnych (Wielkiej Brytanii, Francji, Holandii, Portugalii i in.), nie sposób nie zwrócić uwagi na rolę, jaką te metropolie odgrywają w gospodarce swoich byłych kolonii. W jaki sposób ich wcześniejsza, kolonialna polityka oraz zachowania po uzyskaniu przez te kraje niepodległości wpływają na warunki startu i rozwój gospodarczy w pierwszych latach istnienia nowych państw?

W literaturze przedmiotu traktującej o początkach rozwoju gospodarczego świata postkolonialnego po II wojnie światowej wyróżnia się zazwyczaj trzy teorie. Są to [Budnikowski, 2003, s. 376-379; Rynarzewski, 2006, s. 402-406; Świerkocki, 2004, s. 71]:

1. Teoria zależności (dependency theory). Trudno jednoznacznie określić jej autorów, a należą do nich m.in. tacy ekonomiści, jak: Raul Prebisch, Hans W. Singer, Andre G. Frank oraz Paul A. Baran. Zręby teorii zależności powstały pod koniec lat 40., a została ona rozwinięta w latach 50. i 60. XX wieku. Według jej twórców oraz ich zwolenników, zacofanie krajów postkolonialnych jest następstwem ich uzależnienia politycznego oraz gospodarczego od byłych metropolii i to w różnych okresach historycznych. Proces tego uzależniania miał różny charakter, od aktywnego - tj. niszczenia jakichś rodzajów gospodarki (np. początkującego 
przemysłu, upraw rolnych i zastępowanie ich innymi, korzystnymi dla kolonizatorów) - do biernego - tj. nierozwijania jakichś rodzajów działalności, pomimo że były po temu bardzo korzystne lokalne warunki, ale nie odpowiadało to kolonizatorom. Jednym słowem byli kolonizatorzy narzucili krajom postkolonialnym model gospodarczy korzystny dla metropolii (tzw. centrum), a z reguły niekorzystny dla byłych kolonii i innych krajów gospodarczo zacofanych (tzw. peryferii).

2. Teoria wzrostu zubożającego (immiserizing growth). Jej autorem jest Jagdish N. Bhagwati (ekonomista amerykański indyjskiego pochodzenia). Podstawowe założenie tej teorii $\mathrm{w}$ stosunku do krajów zacofanych sprowadza się do tego, że te z nich, które posiadają dużo surowców (np. ropy naftowej, herbaty, kawy, kauczuku, metali kolorowych), chcąc osiągnąć wyższy produkt krajowy (czyli wzrost gospodarczy), starają się zwiększać ich produkcję i w ślad za tym eksport. Wzrost eksportu (podaży) obniży zazwyczaj ceny surowców na rynkach światowych, co może sprawić, że pomimo zwiększenia wydobycia i wywozu (a więc wzrostu PKB) łączne wpływy finansowe $\mathrm{z}$ tego tytułu nie zwiększą się, a przeciwnie - mogą zmaleć i być nawet niższe niż przed obniżką cen, co oznacza pogorszenie sytuacji gospodarczej kraju, a więc jego ubożenie.

3. Hipoteza sekularnego pogarszania się terms of trade krajów nierozwiniętych (Prebisch-Singer thesis). Została sformułowana niemal jednocześnie pod koniec lat 40. przez Raula Prebischa (ekonomistę argentyńskiego) i Hansa W. Singera (ekonomistę niemiecko-angielskiego) i jest „spokrewniona” z teorią zależności. Według hipotezy Prebischa-Singera, dokumentowanej wynikami badań eksportu krajów wywożących surowce i produkty nisko przetworzone, czyli na ogół krajów zacofanych, w okresie długim następuje pogorszenie się terms of trade eksporterów tych towarów, co staje się niekorzystne dla tych krajów i przyczynia się do ich uzależnienia od importerów, z reguły krajów przemysłowych (często byłych kolonizatorów). Uzyskane z eksportu dochody ze sprzedaży surowców (z reguły o niskiej elastyczności dochodowej popytu) są wydawane na produkty wysoko przetworzone (o wyższej elastyczności dochodowej popytu), co pogarsza bilans handlowy krajów nierozwiniętych i niejednokrotnie może prowadzić do dalszego ich ubożenia. W celu zmiany tej sytuacji Prebisch oraz Singer zalecają krajom eksportującym przesunięcie czynników produkcji z wytwarzania oraz wywozu surowców na ich przetwarzanie w kraju i wysyłanie już jako towarów przemysłowych (przynajmniej częściowo przetworzonych). Autorzy sugerowali ponadto eksporterom surowców oraz produktów nisko przetworzonych organizowanie się w porozumienia kartelowe i zwiększanie w ten sposób swej siły przetargowej. Postulowano też wywieranie presji politycznej na kraje rozwinięte w celu zwiększenia przez nie pomocy gospodarczej i szerszego otwarcia swoich rynków dla towarów z krajów zacofanych.

Jak wcześniej wskazano, inną, często najważniejszą kwestią w okresie startu, czyli zapoczątkowania rozwoju gospodarczego w krajach zacofanych było pozyskanie źródeł kapitału. Jeden z podstawowych dylematów w tej dziedzinie sprowadzał się do wyznaczenia wielkości oraz proporcji pomiędzy wewnętrznymi a ze- 
wnętrznymi źródłami kapitału. Oczywiście - w sensie teoretycznym - dominować winny źródła krajowe, a import kapitału miał mieć charakter uzupełniający, zazwyczaj komplementarny do zasobu krajowego. Z reguły w całym Trzecim Świecie jednak tak nie było i konieczne stawało się sięgnięcie po zagraniczne kapitały.

We wszystkich postkolonialnych krajach Azji zasoby kapitału własnego nie były wystarczające i dodatkowo istotnie zróżnicowane w poszczególnych państwach. O nadwyżkach kapitału możemy mówić jedynie w odniesieniu do państw Azji Zachodniej (arabskich), które nie były wcześniej koloniami, lecz jedynie krajami uzależnionymi od państw europejskich, głównie Wielkiej Brytanii i Francji. Źródło kapitału stanowiły tam zazwyczaj zyski z wydobycia oraz eksportu gazu i ropy naftowej, których ich właściciele nie chcieli jednak zamieniać w inwestycje produkcyjne w innych częściach azjatyckiego kontynentu i najczęściej lokowali w europejskich lub amerykańskich instytucjach finansowych.

Zapoczątkowanie rozwoju gospodarczego po uzyskaniu niepodległości oraz jego kontynuacja zależały w dużym stopniu od istniejącej, oddziedziczonej po kolonizatorach struktury gospodarczej i społecznej. Zazwyczaj gospodarki większości państw Azji, które usamodzielniły się w latach 40. i 50. ubiegłego wieku, składały się z trzech elementów [Sachs, 1959; 1961, s. 48-55]:

1. Sektora wysoce kapitalistycznego, na ogół prywatnego (często powiązanego z byłymi kolonizatorami), niekompatybilnego (lub tylko w nieznacznym stopniu) z resztą gospodarki.

2. Przedkapitalistycznego, feudalnego i bardzo dużego sektora rolnego, wytwarzającego zazwyczaj ponad połowę krajowego produktu społecznego. Jest to najczęściej sektor o długotrwałej stagnacji, pozbawiony bodźców rozwojowych i nie występuje w nim reprodukcja rozszerzona.

3. Nowo powstającego sektora gospodarki, głównie przemysłu, na który składają się z reguły przedsiębiorstwa prywatne (kapitalistyczne), ale też przedsiębiorstwa państwowe - nowo utworzone lub powstałe w drodze nacjonalizacji przedsiębiorstw byłych kolonizatorów.

Taka niejednolita, wielosektorowa struktura gospodarek, aczkolwiek różna w poszczególnych regionach i krajach kontynentu azjatyckiego, jest dużym, instytucjonalnym utrudnieniem już na starcie do rozwoju i następnie komplikuje utrzymanie jego względnie wysokiego tempa, szczególnie wówczas, gdy chcemy - jak wcześniej stwierdzono - aby był to rozwój równomierny. Natura tych sektorów jest różna i najczęściej sprzeczne są ich interesy, a także preferencje rozwojowe. Ich koordynacja nie może się odbywać poprzez rynek, to znaczy z wykorzystaniem jego podstawowych sił i mechanizmów, ingerencja państwa jest niezbędna. Bez bezpośredniego udziału państwa w działalności gospodarczej trudno będzie - tak sądziła większość ekonomistów i polityków w latach 50. i 60. - zapewnić zacofanym gospodarkom „wielkie pchnięcie”, a następnie rozwój, który przełożyłby się w niedługiej perspektywie na odczuwalną poprawę warunków życia ludności. 
Oprócz wyboru ścieżek rozwoju gospodarczego i sposobu pozyskiwania kapitału w celu wspomnianego ,wielkiego pchnięcia”, do najważniejszych wątków teoretycznych tworzącej się ekonomii rozwoju, a w ślad za tym polityki gospodarczej, zalicza się problem wyboru technik wytwarzania przez kraje zacofane. Zagadnienie to miało szczególny wymiar w odniesieniu do krajów azjatyckich, które bardziej różniły się pomiędzy sobą poziomem technik produkcji, wielkością kapitałów, strukturą gospodarek, liczbą ludności niż było to w innych regionach świata. Generalnie dylemat sprowadzał się do określenia racjonalnych proporcji, zaś w praktyce wyboru pomiędzy technikami o niskiej kapitałochłonności (pracochłonnymi) a technikami o wysokiej kapitałochłonności, czyli wykorzystującymi nowoczesne urządzenia i technologie. Problematyka ta nabrała szczególnie dużego znaczenia w tych krajach nierozwiniętych, które do swej polityki gospodarczej wprowadziły elementy planowania i centralnego zarządzania gospodarką. Budziła ona dużo kontrowersji, czego dowodem są różnorakie podejścia teoretyczne, w dodatku szybko zmieniające się z upływem czasu. Podstawowy podział poglądów przebiegał pomiędzy zwolennikami technik pracochłonnych a technik kapitałochłonnych. Za R. Piaseckim [2003a, s. 22-35] można wyróżnić sześć faz rozwoju poglądów (dyskusji) w sprawie wyboru technik wytwarzania ${ }^{25}$. W skróconej wersji periodyzacja ta przedstawia się następująco:

1. Do połowy lat 50. XX wieku - dominacja poglądów o potrzebie stosowania technik o niskim poziomie kapitałochłonności (pracochłonnych).

2. Od połowy lat 50. do połowy lat 60 . - ożywiona dyskusja pomiędzy zwolennikami technik pracochłonnych a kapitałochłonnych, bez wyraźnej przewagi którejś opcji.

3. Druga połowa lat 60. i pierwsza połowa lat 70. - dyskusja wokół koncepcji technik pośrednich (intermediate technologies) E.F. Schumachera i duża jej popularność zarówno w teorii, jak i praktyce (m.in. z uwagi na uwzględnianie wśród czynników rozwoju m.in. takich zmiennych, jak poziom oświaty, organizacja i kultura pracy, dyscyplina społeczna).

4. Druga połowa lat 70. i lata 80. - nowe wątki w odniesieniu do technik wytwarzania (m.in. problem ekorozwoju i wykorzystania teorii gier). Uwzględnianie nowych czynników w wyborze technik wytwarzania, np. instytucjonalnych i kulturowych.

5. Przełom lat 80. i 90. - dyskusja wokół technik dostosowanych (appropriate technologies), będących rozwinięciem technik pośrednich. Chodziło m.in. o różnicowanie technik wytwarzania i dostosowywanie ich do warunków technicznych, gospodarczych, demograficznych, ekologicznych i kulturowych poszczególnych krajów.

${ }^{25} \mathrm{~W}$ polskiej literaturze ekonomicznej na temat wyboru technik wytwarzania w krajach nierozwiniętych należy wyróżnić w szczególności prace Zofii Dobrskiej [1963] i Adama Rybarskiego [1968]. 
6. Lata 90. i początek XXI wieku - osłabienie dyskusji na temat technik wytwarzania w krajach słabo rozwiniętych na skutek rozpowszechnienia się neoliberalnego modelu rozwoju i ograniczenia roli państwa w gospodarce. Na plan pierwszy wysunęły się sprawy deregulacji, liberalizacji i prywatyzacji, czyli prymatu rynku nad państwem, rozpoczęło się tym samym stopniowe eliminowanie planowania gospodarczego z zarządzania rozwijającymi się gospodarkami.

Dylematy wyboru technik wytwarzania dotyczyły przede wszystkim sektora przemysłowego, który miał być wiodący i stanowić o dynamice, a także poziomie rozwoju gospodarczego kraju. W dodatku problem ten dotyczył głównie przemysłu państwowego, gdyż tu można było liczyć na zgromadzenie pokaźniejszego kapitału, który umożliwiałby zastosowanie nowoczesnego aparatu produkcyjnego i wydajnych technologii. Prywatne przedsiębiorstwa nie miały w tym względzie większego wyboru, gdyż zazwyczaj nie dysponowały odpowiednim kapitałem. Pozostawały im więc techniki pracochłonne i tylko powolne ich modernizowanie.

Eksponując przyspieszoną industrializację, początkująca ekonomia rozwoju „zapomniała” o rolnictwie, głównym przecież sektorze zacofanych gospodarek Azji. Było ono uznawane na ogół jako źródło zacofania, przysłowiowy „kamień młyński” u szyi gospodarki i nie próbowano w nim dostrzec źródła modernizującego gospodarkę. Uzyskanie w krótkim czasie postępu w sektorze rolnictwa wydawało się praktycznie niemożliwe i to nie tyle z powodu niedostatku kapitału, ile głównie z przyczyn społeczno-kulturowych. Dla wzrostu produkcji w rolnictwie konieczne były - oprócz kapitałów (głównie na infrastrukturę, taką jak drogi, urządzenia irygacyjne, handel i przetwórstwo) - ogromne, na skalę historyczną, zmiany w ustroju rolnym, przede wszystkim radykalne reformy stosunków własnościowych, czyli nadanie chłopom ziemi, podniesienie kultury rolnej, edukację ludności wiejskiej itp. [Rudowicz, 1973, s. 103]. Takie przedsięwzięcia wymagałyby bardzo długiego czasu i nawet po ich formalnym wdrożeniu nie gwarantowałyby dobrych wyników. Dowiodła tego późniejsza praktyka i nie tylko na obszarze Azji, w Afryce, Ameryce Łacińskiej, lecz także w europejskich krajach socjalistycznych $^{26}$. Realnie biorąc, źródłem rozwoju rolnictwa przez długi czas

${ }^{26}$ Bertrand Schneider, francuski ekonomista, autor jednego z raportów dla Klubu Rzymskiego (Rewolucja bosych, pierwsze wydanie francuskie 1985, wydanie polskie 1989) tak oceniał powojenną politykę rozwojową względem Trzeciego Świata [1989, s. 15]: „Eksperci od spraw rozwoju i ekonomiści na całym świecie w większości potępiają zastosowane w ostatnim dwudziestoleciu w krajach Trzeciego Świata metody polityki rozwojowej, jako źle zaplanowane i nieskuteczne. Krytykują programowe niemal opieranie się krajów rozwijających się na wielkich przedsięwzięciach przemysłowych, wzorowanych na modelach zachodnich, z gruntu obcych, zupełnie nie dostosowanych do miejscowych potrzeb i wymagań. W większości przypadków olbrzymie kapitały zainwestowane w te przedsięwzięcia przynoszą korzyści małej grupie ludności, a na obszarach rolniczych tego typu polityka rozwojowa wchodzi często w konflikt z lokalną kulturą, wprowadza zamęt w obyczajach i tradycjach, w końcu zostaje odrzucona przez tych, którym miała pomóc". 
musiały być techniki pracochłonne. Modernizacyjną rolę reform rolnych i inwestycji w tym sektorze dostrzeżono dopiero w latach 60 . i to nie tyle z przyczyn stricte gospodarczych, ile może przede wszystkim z powodów społeczno-kulturowych (głównie zatrudnienia i bezrobocia) [Nawrot, 2014, s. 24].

W sektorze usług, które co prawda w latach 40. i 50. dawały przeciętnie ok. 30 proc. krajowego produktu brutto, też niewielkie były szanse na zastosowanie technik kapitałochłonnych. Większość usług była oparta na prostej, fizycznej pracy osób je świadczących (służba domowa i hotelowa, transport miejski, handel uliczny, usługi naprawcze), a więc dużym zatrudnieniu pracowników o niskich kwalifikacjach. Nie było zresztą wówczas popytu na usługi o wyższym poziomie uzbrojenia technicznego czy kwalifikacji pracowniczych. Aby sektor ten mógł inaczej funkcjonować i unowocześniać się, konieczne są wcześniejsze gruntowne zmiany w sektorze przemysłowym oraz - ale w znacznie mniejszym stopniu - w rolnictwie i w ogóle w gospodarce wiejskiej.

Klucz do pomyślnego startu i dalszego rozwoju ówczesnych, postkolonialnych gospodarek azjatyckich, znajdował się więc w zmianach ustroju sektora przemysłowego. Dylemat pierwszy, jaki musiały rozstrzygnąć zarówno teoria ekonomii, a w ślad za nią polityka gospodarcza, to ,ile państwa w przemyśle”? Następne kwestie to: źródła finansowania industrializacji i docelowa struktura gospodarki - rzeczowa oraz własnościowa.

Jak wcześniej zaznaczono, większość ekonomistów zajmujących się krajami zacofanymi, zaliczanych do ekonomii rozwoju, uznawała, że bezpośredni udział państwa w gospodarce, szczególnie w jej ówczesnej lokomotywie, czyli przemyśle, jest konieczny. Potwierdzały to również statystyki gospodarcze z pierwszych kilkunastu lat powojennych. Nierzadkie były zatem opinie, że interwencjonizm państwowy stał się w krajach nierozwiniętych ,podstawowym narzędziem wzrostu gospodarczego" [Rudowicz, 1973, s. 100]. Dyskusyjną była tylko skala i sposób zaangażowania państwa ${ }^{27}$. Miał to być tzw. interwencjonizm akumulacyjny (tj. przede wszystkim dostarczanie kapitału) w przeciwieństwie do interwencjonizmu w krajach wysoko rozwiniętych, którego celem było podtrzymywanie koniunktury, czyli zapobieganie kryzysom [Sachs, 1961, s. 85]. Kwestie te były

${ }^{27}$ I. Sachs [1959] tak pisał w tej kwestii: „W praktyce we wszystkich krajach «świata pośredniego» jest obecnie [lata 50. XX wieku - przyp. G.B.] powszechnie uznawana konieczność bezpośredniego udziału państwa w działalności gospodarczej. Wobec braku dostatecznych nadwyżek, które mogą być użyte na inwestycje, wobec ogromu pilnych zadań wynikających z konieczności znalezienia krótszej drogi rozwoju gospodarczego - niewielu ma przeciwników koncepcja planującej roli państwa, zdolnego do zmobilizowania środków i do zainwestowania ich we właściwy sposób; faktu tego nie może zmienić krytyczne stanowisko wielu ekonomistów, którzy podnoszą zarzut braku elastyczności państwa jako czynnika zarządzającego gospodarką. Jednakże - mimo dość powszechnej zgody co do konieczności istnienia sektora publicznego w gospodarce krajów nierozwiniętych - poglądy co do roli i zasięgu tego sektora różnią się bardzo". 
rozmaicie rozwiązywane w poszczególnych krajach postkolonialnych, wyłączając oczywiście kraje socjalistyczne. Tego ostatniego, socjalistycznego rozwiązania nie akceptowała jednak większość krajów zacofanych i pozostawała nadal w obrębie gospodarki kapitalistycznej, dopuszczając państwo jedynie jako ważny podmiot gospodarczy, a nie jako bezwzględnego hegemona.

Wraz z zagadnieniem skali interwencjonizmu państwa w gospodarce postkolonialnych krajów Azji niezwykle ważną kwestią był - o czym wspomniano w podrozdziale 1.1 - wybór ścieżki rozwoju. Problem sprowadzał się do tego, czy ma to być „powtórka” z historii gospodarczej krajów wysoko rozwiniętych, czy też właściwszy byłby inny wariant, jakaś droga „,na skróty”, która pozwoliłaby krajom zacofanym wcześniej odrobić dystans i zbliżyć się do rozwiniętej części świata. Generalnie zdecydowana większość ówczesnych ekonomistów (w latach 40. i 50.) opowiadała się za drugim wariantem, czyli szukaniem nowych dróg. Jednym z powodów takiego podejścia był fakt, że ówczesna, bezpośrednio postkolonialna sytuacja krajów azjatyckich była gorsza od warunków, w jakich w XIX wieku rozpoczynały start kraje rozwinięte (np. Wielka Brytania, Francja, Holandia). W tych ostatnich rozwój gospodarczy odbywał się w oparciu o długotrwały proces wewnętrznej akumulacji, jego siłą motoryczną była rodzima burżuazja handlowa i przemysłowa. W krajach postkolonialnych nie ma takiej warstwy, można mówić co najwyżej o nielicznych przypadkach. W dodatku te istniejące, prywatne przedsiębiorstwa były w większości własnością kapitału zagranicznego [Sachs, 1961, s. 26-30]. Realną alternatywą do „klasycznej” ścieżki rozwoju i odrabiania wielkich, historycznych zaległości stawało się właśnie znaczące zaangażowanie państwa w gospodarkę ${ }^{28}$. Praktyczny problem sprowadzał się zatem do ustalenia rozmiarów państwowego interwencjonizmu i konkretnych rozwiązań organizacyjno-technicznych w tej dziedzinie. Na tych właśnie problemach koncentrowała się teoria ekonomii i polityka gospodarcza wszystkich krajów Trzeciego Świata odzyskujących niepodległość29.

Wspomniany wcześniej I. Sachs, analizując rolę państwa w gospodarkach krajów nierozwiniętych pierwszych kilkunastu lat powojennych, zwłaszcza azjatyckich, wyróżnia dwa krańcowe wzorce (modele) ich ustroju: japoński oraz

28 „Teza o możliwości powtórzenia «klasycznego», wolnokonkurencyjnego rozwoju kapitalistycznego w dzisiejszych krajach zacofanych [lata 50. - przyp. G.B.] - pisał I. Sachs [1961, s. 26] - liczy jednak niewielu zdeklarowanych i jawnie występujących w tej sprawie obrońców w kołach uniwersyteckich ekonomistów nawet na Zachodzie".

${ }_{29}$ Dokładniej problemy interwencjonizmu państwa w gospodarkę krajów startujących do rozwoju i rozwijających się z punktu widzenia ekonomii i polityki gospodarczej krajów zacofanych w pierwszych dwóch powojennych dekadach przedstawiają m.in. I. Sachs [1961], J. Kleer [1962] oraz B. Rudowicz [1973]. Z uwagi na ograniczone rozmiary rozdziału nie omawiamy szerzej tych spraw, jedynie w podrozdziale 1.3 oraz w rozdziałach 2, 3 i 5 nawiążemy do wybranych, szczegółowych wątków tych zagadnień w odniesieniu do Indii. 
indyjski ${ }^{30}$. Dla ułatwienia takiej analizy w odniesieniu do modelu ustrojowego konkretnego państwa proponuje on wykorzystanie układu współrzędnych, w którym jedna oś byłaby wytyczona przez „,czysty” wzorzec japoński, a druga wyrażałaby „czysty” wzorzec indyjski. Naniesione na taki układ cechy gospodarki jakiegoś badanego kraju pozwoliłyby lepiej zdefiniować jego ustrój gospodarczy, a przeprowadzając dodatkowo analizę w czasie, można by określić jego ewolucję, to znaczy czy podąża on w „kierunku” modelu japońskiego czy indyjskiego. $\mathrm{Z}$ analizy wyłączone zostały azjatyckie kraje socjalistyczne (Chiny, Korea Północna, Mongolia oraz Wietnam Północny).

Głównymi cechami polityki gospodarczej państwa w „modelu japońskim” są [Sachs, 1964, s. 117]:

1. Trwały i dominujący charakter sektora publicznego jedynie w zakresie infrastruktury oraz systemu bankowego, finansującego sektor prywatny. Takie rozwiązanie ma być alternatywą dla rozwijania sektora publicznego w działach bezpośrednio produkcyjnych.

2. Tworzenie przez państwo nowych przedsiębiorstw produkcyjnych, ale na okres krótki. Po osiągnięciu przez nich dojrzałości produkcyjnej i odpowiedniego poziomu rentowności winny zostać sprywatyzowane.

3. Popieranie i umacnianie przez państwo klasy kapitalistów oraz tworzenia przez nich grup monopolistycznych.

4. Otwarta polityka państwa w stosunku do kapitału zagranicznego oraz wymiany międzynarodowej.

5. Słabo rozwinięte planowanie gospodarcze $\mathrm{i}-\mathrm{z}$ reguły - ograniczające się do programowania bazującego głównie na kategoriach finansowych.

Z kolei w ,indyjskim modelu” polityki gospodarczej państwa dominują następujące cechy [Sachs, 1964, s. 117-118]:

1. Trwałość sektora publicznego w sferze produkcyjnej i jego szybszy rozwój niż sektora prywatnego, co ma doprowadzić do jego dominującej pozycji.

2. Zarezerwowanie dla państwa niektórych kluczowych gałęzi gospodarki (głównie przemysłu) i szybkie osiąganie w nich dominującej pozycji.

3. Ograniczanie rozwoju prywatnego kapitału w wyniku realizacji polityki przedstawionej w punktach 1 i 2 .

4. Priorytet dla planowej industrializacji opierającej się na prymacie sektora państwowego, ze szczególnym uwzględnieniem przemysłu ciężkiego; winno to zdynamizować w niedługim czasie wzrost produkcji i istotnie przyczynić się do umocnienia niezawisłości gospodarczej i politycznej kraju.

${ }^{30}$ Powołując się często na prace Ignacego Sachsa, należy wyjaśnić, że był to w latach 50 . i 60. polski ekonomista (ur. w 1927 roku w Warszawie). W 1968 roku wyjechał na stałe za granicę i pracował głównie w Brazylii i we Francji. Znany jest $m$ in. jako jeden z twórców ekosocjoekonomii (ecosocioeconomics). Jego duża znajomość powojennej Azji wynikała m.in. z tego, że w latach 1957-1960 pracował w polskiej ambasadzie w Indiach i prowadził badania gospodarki tego kraju. 
5. Powszechne i zinstytucjonalizowane planowanie gospodarcze w wymiarze nie tylko finansowym, lecz także rzeczowym (fizycznym).

Powyższe modele gospodarki, jak nietrudno dostrzec, znacząco różnią się od siebie. Ten pierwszy (japoński) jest bliski tradycyjnemu, neoklasycznemu modelowi gospodarki kapitalistycznej. Natomiast model drugi (indyjski) zawiera w sobie znaczące wątki gospodarki socjalistycznej (głównie takie jak planowanie i dominująca rola sektora publicznego), aczkolwiek nie eliminuje sektora kapitalistycznego opierającego się na prywatnej własności kapitału, jak to czyniono w większości krajów socjalistycznych. Oba te modele - co podkreślał Sachs [1959; 1964, s. 118] - nie występują w czystej postaci w żadnym kraju, są mniej lub bardziej zbliżone do jednego z nich i w kierunku któregoś ewoluują. Nawet sama gospodarka indyjska odchylała się czasem w kierunku „modelu japońskiego", zaś gospodarka trzeciego pod względem liczby ludności kraju Azji, czyli Indonezji miała wówczas (w latach 50. i na początku lat 60.) tendencję do upodabniania się do „modelu indyjskiego”. Znamienne jest, że powstałe w 1947 roku z Indii Brytyjskich drugie - obok Indii - państwo, tj. Pakistan, wdrażało model japoński [Sachs, 1961, s. 114]. Pozostałe zacofane kraje ówczesnej Azji Południowej i Wschodniej nie odgrywały w pierwszych dwóch powojennych dekadach istotnej roli gospodarczej. Ich znaczenie zaczęło rosnąć dopiero w latach 70. i prawie we wszystkich działo się to za sprawą dużego udziału państwa.

\subsection{Indie - istota i przesłanki wyboru modelu rozwoju gospodarczego}

W poprzednich podrozdziałach przedstawiono podstawowe problemy wyboru ścieżek rozwoju gospodarczego krajów azjatyckich. Mają one być tłem do poniższej prezentacji dylematów wyboru modelu gospodarczego przez Indie w pierwszych dekadach niepodległości tego kraju, tj. do czasu radykalnych reform gospodarki i państwa w latach 1991-1992.

Studiując literaturę polityczną oraz ekonomiczną lat 40. i 50. dotyczącą gospodarki indyjskiej, nie sposób doszukać się jednego źródła modelu gospodarczego tego kraju. Jest on bez wątpienia owocem syntezy różnych teorii oraz obserwacji wcześniejszych doświadczeń innych krajów - rozwiniętych i rozwijających się. Na kształt tego modelu istotnie wpływała - co podkreślali zarówno indyjscy, jak i zagraniczni politycy oraz ekonomiści - wielkość tego kraju, jego złożoność etniczna, religijna i specyficzne, oparte na długiej tradycji - stosunki społeczne. Poza Chinami, które obrały zupełnie inną drogę rozwoju, nie ma drugiego na świecie państwa, z którym można by porównać Indie. W takiej sytuacji trudno byłoby szukać wzorców i prostych odniesień, należało zatem podjąć próby skonstruowania własnego, oryginalnego modelu rozwoju gospodarki i ustroju politycznego. 
Model gospodarki niepodległych Indii był przedmiotem ożywionych dyskusji już w latach 30. XX wieku, a więc jeszcze w czasach kolonialnych. Szczególnie dużo miejsca poświęcał tej problematyce Indyjski Kongres Narodowy (IKN), partia skupiająca indyjskie elity intelektualne - główna orędowniczka utworzenia wolnego państwa i jego architektka.

Nie wnikając w szczegóły wieloletnich dyskusji programowych oraz nowe, specyficzne uwarunkowania wewnętrzne i zewnętrzne bezpośrednio po uzyskaniu niepodległości, można stwierdzić, że u podstaw modelu gospodarczego ówczesnych Indii legły [Chandra i in., 1999, s. 341; Tendulkar, Bhavani, 2007, s. 18-31]:

1. W sensie teoretycznym:

- teoria Johna M. Keynesa zaprezentowana w jego Ogólnej teorii zatrudnienia, procentu i pieniadza;

- teoria ekonomii rozwoju lat 40. i 50., głównie prace Nurksego, Prebischa i Singera;

- programy brytyjskiej Partii Pracy (Labour Party) z pierwszych lat powojennych (m.in. program częściowej nacjonalizacji przemysłu prowadzonej przez rząd C. Attleégo oraz reformy socjalne W. Beveridge'a).

2. W sensie praktycznym:

- doświadczenia amerykańskiego New Dealu prezydenta F.D. Roosevelta;

- doświadczenia radzieckiego planowania i industrializacji w latach 30. $\mathrm{XX}$ wieku.

Pierwsze lata niepodległych Indii (1947-1950) upłynęły na integrowaniu bardzo zróżnicowanych organizmów gospodarczych byłej kolonii brytyjskiej oraz ponad $550 \mathrm{księstw.}$

Wraz z procesami scalania gospodarki prowadzono prace nad jej przyszłym modelem. Gospodarka Indii miała być - w świetle przytoczonych wyżej źródeł - gospodarką mieszaną (dual-economy, mixed-economy), to znaczy połączeniem gospodarki wolnorynkowej z rozbudowanym sektorem publicznym oraz dużymi kompetencjami regulacyjnymi państwa ${ }^{31}$. Głównym promotorem takiego modelu był pierwszy premier niepodległych Indii - Jawaharlal Nehru, który w 1948 roku stanął na czele Komisji programu gospodarczego Indyjskiego Kongresu Narodowego. Miała to być gospodarka wolnorynkowa, ale z dużym udziałem państwa,

31 Zarys modelu gospodarczego niepodległych Indii powstał w 1944 roku w ramach tzw. Planu Bombajskiego (Bombay Plan - A Brief Memorandum Outlining a Plan of Economic Development for India), tj. dokumentu zredagowanego przez osiem ważnych indyjskich osobistości życia gospodarczego (przedsiębiorców, dyrektorów, technokratów). Głównym promotorem Planu był Jehangir R.D. Tata - jeden z pionierów indyjskiego uprzemysłowienia. Ten dokument został wykorzystany przy konstrukcji pierwszego planu pięcioletniego 1951/52-1955/56. Oprócz Planu Bombajskiego istniały jeszcze opracowane w ostatnich latach kolonialnych dwa plany przyszłego ustroju gospodarczego Indii, tj.: Plan Ludowy (Poeple's Plan) - postulujący wprowadzenie gospodarki komunistycznej oraz Plan Gandyjski (Gandhian Plan) - zakładający oparcie gospodarki na samorządnych i samowystarczalnych wsiach [Iwanek, Burakowski, 2013, s. 208]. 
zwłaszcza w przemyśle i wspomagana centralnym planowaniem ${ }^{32}$. Pięcioletnie plany gospodarcze stawały się głównym narzędziem polityki gospodarczej kra$\mathrm{ju}^{33}$. W celu przygotowania i nadzoru nad realizacją planów powołano w marcu 1950 roku Komisję Planowania, której przewodniczącym został premier J. Nehru i ta zasada łączenia stanowisk obowiązywała w późniejszych latach. J. Nehru był wielkim zwolennikiem planowania gospodarczego. Pozostawał pod wrażeniem sukcesów centralnego planowania radzieckiego, które pragnął zaimplementować w strukturach gospodarki indyjskiej. Sądził, że da się je połączyć z demokratycznym ustrojem nowo powstałego państwa i będzie ono akceleratorem rozwoju jego gospodarki [Ramachandran, 2013, s. 77]. Planowaniem miał być objęty przede wszystkim sektor publiczny, a szczególnie państwowy przemysł. Znacznie utrudnione było natomiast wykorzystanie planowania w sektorze prywatnym, a przede wszystkim w rolnictwie, które było bardzo rozdrobnione, a w dodatku jego wyniki zależały w dużym stopniu od czynników klimatycznych.

Model indyjski miał być wersją tzw. trzeciej drogi rozwoju, czyli rozwiązaniem pośrednim pomiędzy kapitalizmem a socjalizmem. W tym względzie zgadzała się większość polityków i ekonomistów. Nie wchodził w rachubę wybór ani klasycznej drogi kapitalistycznej, ani też drogi komunistycznej - jak w ZSRR czy w Chinach po 1949 roku $^{34}$. W późniejszej literaturze przedmiotu przyjęło się nazywać model gospodarczy Indii ,indyjskim socjalizmem” albo „,nehruizmem”35.

${ }^{32}$ Paul A. Baran [1963, s. 217] - amerykański ekonomista, badacz wzrostu i rozwoju gospodarczego krajów zacofanych, reasumując analizę problematyki startu gospodarki indyjskiej pisał m.in.: „Dlatego też w Indiach, podobnie jak w innych krajach nierozwiniętych tylko państwo może mobilizować potencjalnie istniejącą w systemie ekonomicznym nadwyżkę i wykorzystać ją do rozwoju produkcyjnych urządzeń narodu”.

33 Główną rolę w konstrukcji indyjskich planów gospodarczych odegrał wybitny, o światowej renomie, statystyk (założyciel Indyjskiego Instytutu Statystycznego) - Prasanta Chandra Mahalanobis, pełniący równocześnie funkcję wiceprzewodniczącego Komisji Planowania (zastępcy premiera J. Nehru). Był on wiodącym współautorem Rezolucji Przemystowej z 1956 roku, która zostanie przedstawiona w rozdziale II. Szczególnie duży wpływ wywarł Mahalanobis na kształt drugiego planu gospodarczego (1955/56-1960/61). W planie tym uwagę skoncentrowano na industrializacji kraju, a przede wszystkim rozbudowie przemysłu ciężkiego. Dla jego budowy zastosował Mahalanobis m.in. zmodyfikowaną wersję modelu input-output W. Leontiewa. Ta właśnie konstrukcja II planu gospodarczego nazywana bywa niekiedy „modelem Mahalanobisa” [Burange, Yamini, 2011, s. 6; Datt, Mahajan, 2014, s. 193-194].

${ }^{34}$ W przemówieniu do Indyjskiego Kongresu Narodowego J. Nehru powiedział: „Nie możemy porównywać naszych problemów z problemami Ameryki, Anglii czy Europy Zachodniej, które to kraje mają dwieście lat doświadczeń wzrostu przemysłowego. Porównania takie mogą być czasami przydatne, lecz zawodzą. Musimy zrozumieć nasze problemy w Indiach takimi, jakie są, niewątpliwie ucząc się z doświadczeń Ameryki, Anglii, Jugosławii, Rosji czy Chin, jednakże mając w pamięci, że warunki Indii są szczególne" [Mukherjee (ed.), 2007, s. 230].

${ }^{35}$ Istotną rolę w kształtowaniu indyjskiej polityki gospodarczej drugiej połowy lat 50 . odegrali dwaj wybitni i uznani w świecie polscy ekonomiści, którzy przez pewien czas byli doradcami 
Głównym celem „ojców” indyjskiego państwa było stworzenie „socjalistycznego modelu społeczeństwa” („Socialist Pattern of Society”) opierającego się na wolności gospodarczej i demokracji. „Indyjski socjalizm” miał być jednak daleki od modelu gospodarki komunistycznej wdrażanej w Związku Radzieckim, aczkolwiek na grunt indyjski przetransponowano niektóre rozwiązania radzieckie bądź się na nich wzorowano. Rząd premiera J. Nehru nie zdecydował się jednak na gruntowną, rewolucyjną - jak w Chinach czy ZSRR - przebudowę struktury własnościowej środków produkcji, czyli całkowite przejęcie ich przez państwo.

Do rangi jednego z najważniejszych kanonów indyjskiej gospodarki urosło - wywodzące się jeszcze ze sformułowanej w czasach walki o niepodległość ,zasady samodzielności" (self-reliance) - założenie, że będzie ona samowystarczalna, czyli bazująca przede wszystkim na własnych zasobach kapitałowych i jako niezorientowana na eksport nie stanie się zależna od zewnętrznego popytu i tym samym fluktuacji na rynkach światowych [Singh, 1966, s. 581]. Takie podejście wynikało w decydującej mierze z wielkości zasobów naturalnych Indii - materialnych i ludzkich. Wybór determinowała dodatkowo sytuacja geopolityczna kraju, tj. sąsiedztwo dwóch dużych i wrogich państw, czyli Pakistanu i Chin, a także nasilająca się w skali światowej „zimna wojna”, utrudniająca rozwój wymiany handlowej i przepływy kapitałów. Indie skazane więc były - przynajmniej w pierwszych latach niepodległości - na gospodarkę wysoce autarkiczną, mocno zorientowaną „do wewnątrz”, a więc odgraniczoną od innych gospodarek systemem zakazów i ceł ${ }^{36}$. Podkreślić trzeba, że indyjskie elity polityczne i gospodarcze obawiały się otwarcia gospodarki i ewentualnego powrotu - pod płaszczem inwestorów - zachodniego kapitału, a zwłaszcza byłych brytyjskich kolonialistów i swoistej ekonomicznej rekolonizacji kraju [Wolpert, 2010, s. 433]. Niepodległość kraju rozumiano szeroko, to znaczy włączono w to pojęcie także niezależność gospodarki od zagranicznych inwestorów oraz dostawców środków produkcji i towarów konsumpcyjnych ${ }^{37}$. Nie chciano dopuścić, aby tak wielki de-

rządu indyjskiego, tj. Oskar Lange (w latach 1955-1956) i Michał Kalecki (w latach 1959-1960). Wyrazem tego są m.in. ich polskie publikacje na temat gospodarki indyjskiej [Kalecki, 1960; Lange, 1961].

${ }^{36} \mathrm{~W}$ czterostopniowej skali oceny strategii uczestnictwa gospodarki w handlu międzynarodowym w latach 1966-1985 przez 41 krajów rozwijających się (uczestnictwo: 1) ,mocno zorientowane na zewnątrz”, 2) ,umiarkowanie zorientowane na zewnątrz”, 3) ,umiarkowanie zorientowane do wewnątrz”, 4) „mocno zorientowane do wewnątrz”), Indie znalazły się - wśród krajów Azji - w ostatniej (czwartej) grupie państw (m.in. za Hongkongiem, Koreą Płd., Singapurem, Malezją, Tajlandią, Turcją, Filipinami, Indonezją, Pakistanem i Sri Lanką [za: Budnikowski, 2003, s. 384].

37 Jak już wcześniej wspominano, podobne rozwiązania przyjęto w większości nowo powstałych, dużych i średnich państw w Azji i to bez względu na to, czy wdrażały model ,japoński” czy „,indyjski”. Uznawano m.in., że kluczem do szybkiego rozwoju i uzyskania niezależności ekonomicznej oraz politycznej kraju jest rozwój rodzimego przemysłu. Była to tzw. strategia „uprzemysłowienia antyimportowego". Rozbudowany protekcjonizm miał być czynnikiem pobudzającym 
mograficznie i surowcowo zamożny kraj mógł ponownie uzależnić się od innych krajów, jak to było w niedalekiej przeszłości. Indusi mieli w świadomości ogromne straty, jakie poniósł ich kraj w wyniku ponadtrzystuletniego uzależnienia się i grabieży ze strony Brytyjczyków ${ }^{38}$.

Głównie z powyższych powodów za priorytet w rozwoju gospodarczym i środek do osiągnięcia celów społecznych uznano rozwój przemysłu państwowego. W rękach państwa miał znaleźć się przede wszystkim przemysł ciężki, natomiast przemysł lekki i konsumpcyjny mogły pozostawać w rękach prywatnych, lecz podlegały ścisłej kontroli organów państwa.

Niektóre problemy modelu ustrojowego indyjskiej gospodarki, zarówno przed, jak i po 1991 roku, zostaną dokładniej przedstawione w następnych rozdziałach rozprawy jako uzupełnienie i/lub rozszerzenie analiz empirycznych.

rozwój gospodarczy i substytutem importu, w którym dostrzegano możliwość ponownego uzależnienia się od obcego kapitału. Tylko dzięki rozbudowanej pomocy państwa i polityce antyimportowej - sądzono - można rozwijać przemysł, szczególnie jego nowe gałęzie (tzw. infant industry), które w warunkach wolnego rynku międzynarodowego nie byłyby w stanie sprostać konkurencji krajów wysoko rozwiniętych. Takie podejście wywodzi się m.in. z teorii tzw. cła wychowawczego. W krajach rozwijających się, zadaniem czasowego wprowadzenia „cła wychowawczego” (i ewentualnie jeszcze innych barier antyimportowych) jest ułatwienie startu, a następnie zdynamizowanie rozwoju własnego przemysłu i w ten sposób zapoczątkowanie wychodzenia kraju z gospodarczego zacofania. Szerzej na te tematy piszą m.in.: T. Rynarzewski [2003; 2006, s. 284-285], R. Piasecki [2003b], P.R. Krugman i M. Obstfeld [2007, s. 364-370].

${ }_{38}$ Paul A. Baran [1963, s. 134-135] - pisał w latach 50. XX wieku: ,[...] gdyby ta masa nadwyżki, którą Anglia wydarła Indiom, została zainwestowana w Indiach, ekonomiczny rozwój Indii do dnia dzisiejszego nie wykazywałby dużego podobieństwa ze swym obecnym, ponurym obrazem. Byłoby rzeczą bezpłodną zastanawiać się, czy Indie osiągnęłyby do dziś poziom rozwoju ekonomicznego odpowiadający ich bogactwom naturalnym i możliwościom ich ludności. W każdym bądź razie los kolejnych pokoleń Hindusów nie przypominałby, nawet w przybliżeniu, chronicznej katastrofy ostatnich dwóch stuleci”. 



\section{INDIE W LATACH 1947-1991 USTRÓJ POLITYCZNY, SPOLECZEŃSTWO I GOSPODARKA}

\subsection{Powstanie niepodległego państwa oraz jego ustrój polityczny i terytorialny}

W dniu 15 sierpnia 1947 roku Indie przestały być kolonią, a stały się dominium w ramach Brytyjskiej Wspólnoty Narodów (od 1949 roku - Wspólnoty Narodów). Pełną suwerenność uzyskały 26 stycznia 1950 roku - w dniu wejścia w życie konstytucji ${ }^{1}$. Na mapie świata pojawiło się nowe państwo - republika parlamentarna o strukturze federacji.

Najpilniejszym zadaniem indyjskich władz stało się scalenie w jeden organizm państwowy ogromnych obszarów Półwyspu Indyjskiego, zamieszkałych przez ludzi bardzo zróżnicowanych etnicznie, kulturowo i religijnie. W skład Indii weszła część Indii Brytyjskich (British India) - kolonii podległej bezpośrednio władzy brytyjskiej oraz $554 \mathrm{księstw} \mathrm{(princely} \mathrm{states)} \mathrm{[Boivin,} \mathrm{2011,} \mathrm{s.} \mathrm{92].}$ Księstwa te były pozostałością ustroju przedkolonialnego, istniejącego na obszarze subkontynentu indyjskiego. Brytyjczycy nie rościli sobie praw suwerenności w stosunku do tych księstw i przetrwały one cały okres kolonialny. Różniły się obszarem, liczbą ludności, zasobami materialnymi i kulturowymi oraz poziomem rozwoju gospodarczego. Po ustanowieniu niepodległości Indii zdecydowana większość księstw przystąpiła dobrowolnie do zjednoczonego państwa indyjskiego, a niektóre zostały do tego zmuszone [Panikkar, 1967, s. 233-234]2. Pozostała część Indii Brytyjskich oraz kilkadziesiąt księstw weszło w skład Pakistanu,

${ }^{1}$ Podstawą powołań na konstytucję Indii - jeśli nie zaznaczono inaczej - są: Konstytucja Republiki Indii [1976] i /lub The Constitution of India [2000].

${ }^{2}$ Najmocniej inkorporacji do państwa indyjskiego opierał się nizam największego księstwa, tj. Hajdarabadu, co spowodowało akcję zbrojną rządu federalnego i księstwo to zostało w 1948 roku przemocą włączone do Indii. Na podstawie konstytucji władze federalne zostały zobowiązane do świadczenia na rzecz byłych władców księstw i ich następców tzw. prywatnej szkatuły, czyli wysokich uposażeń pieniężnych oraz zapewnienia im wielu przywilejów, takich jak np.: bezpłatna opieka lekarska, zwolnienia od podatków i ceł, nietykalność sądowa czy zachowanie tytułów feudalnych. Wszystkie te przywileje cofnięto w 1971 roku na mocy 26 poprawki do konstytucji. 
zamieszkałego głównie przez muzułmanów, który proklamował niepodległość dzień wcześniej niż Indie, czyli 14 sierpnia 1947 roku³$^{3}$.

Ustrój państwa indyjskiego został określony przez konstytucję uchwaloną w dniu 26 listopada 1949 roku. Jest to jedna z najobszerniejszych konstytucji na świecie, szczegółowo regulująca strukturę, funkcjonowanie oraz kompetencje głównych instytucji państwa indyjskiego, w tym także ustrój terytorialny kraju. Składa się ona z preambuły, części głównej oraz 12 załączników ${ }^{4}$. Tekst konstytucji liczy 395 artykułów (niektóre z nich składają się z kilku części) $)^{5}$. Podstawową formą modyfikacji i uzupełniania konstytucji są poprawki; według stanu na styczeń 2013 roku było ich $98^{6}$.

Taka wyjątkowo szczegółowa i skomplikowana konstrukcja konstytucji wynika przede wszystkim ze specyfiki organizacji i funkcjonowania społeczeństwa indyjskiego, to znaczy jego ogromnego - nieporównywalnego z żadnym innym krajem świata - zróżnicowania etnicznego, językowego, religijnego oraz stratyfikacji społecznej. Stworzenie z takiego konglomeratu ludzi jednego społeczeństwa i jednego bytu państwowego wymaga z natury rzeczy precyzyjnego prawa $\mathrm{i}$ to przede wszystkim na szczeblu najwyższym - ogólnokrajowym.

Podstawowymi podmiotami władzy ustawodawczej i wykonawczej Indii na szczeblu centralnym (federalnym) są: parlament, prezydent oraz rząd federalny (rada ministrów). Szczebel pośredni, zwany powszechnie stanowym, tworzą: sta-

${ }^{3}$ Bezpośrednio po podziale Indii Brytyjskich w 1947 roku i powstaniu Indii oraz Pakistanu na terenach przygranicznych doszło do - jak się szacuje - największych w historii świata przesiedleń ludności. Procesom tym towarzyszyły krwawe pogromy, a także intensywne działania wojenne, głównie na obszarze Kaszmiru (1947-1948). Z obszaru Indii do Pakistanu wyemigrowało ok. 7 mln muzułmanów, natomiast z Pakistanu do Indii przeszło ok. $10 \mathrm{mln}$ hindusów oraz sikhów. W walkach zbrojnych zginęło ok. 1 mln ludzi [Wolpert, 2010, s. 416].

${ }^{4} \mathrm{~W}$ preambule konstytucji stwierdza się, że Indie są „suwerenną, socjalistyczną, świecką i demokratyczną republiką”. Należy dodać, że słów „socjalistyczna” oraz ,świecka” nie było w preambule tekstu konstytucji uchwalonej w 1949, wprowadzono je dopiero w 1976 roku na mocy 42 poprawki.

${ }^{5} \mathrm{~W}$ literaturze prawniczej istnieją kontrowersje co do numeracji artykułów w indyjskiej konstytucji. Sprawa jest - wbrew pozorom - skomplikowana. W niektórych publikacjach podawana jest większa liczba artykułów (np. 446, 450). Formalnie rzecz ujmując, dokument ten zawiera niezmiennie 395 artykułów. Niemniej jednak na mocy wielu poprawek do konstytucji pojawiają się w niej nowe zapisy, które niektórzy autorzy uznają za osobne artykuły, a inni nazywają je paragrafami. Przykładowo, po wprowadzeniu poprawek 73 i 74 do konstytucji, artykuł 243 (traktowany przez niektórych badaczy jako jeden artykuł) składa się z dwóch części - dotyczących samorządów wiejskich i miejskich. Pierwsza z nich zawiera paragrafy od 243 A do O (15 paragrafów), druga od 243 P do 243 ZG (18 paragrafów). Można więc spotkać publikacje, w których zamiast jednego artykułu 243, podaje się 33 oddzielne artykuły. Podobnie jest w wielu innych przypadkach [Baba, 2009].

${ }^{6}$ Pierwszą poprawkę wprowadzono już w maju 1951 roku (weszła w życie w czerwcu 1951), a więc kilkanaście miesięcy po uchwaleniu konstytucji, ostatnią (98) w 2012 roku (weszła w życie od 1 stycznia 2013 roku) [The Constitution (Amendment) Acts, 2013]. 
ny, terytoria unijne oraz - od 1991 roku - Narodowe Terytorium Stołeczne Delhi (Delhi NCT). Strukturę organizacyjną władzy publicznej na obu szczeblach państwa indyjskiego przedstawia rys. 2.1.

\section{Szczebel federalny}

Wladza ustawodawcza:

PARLAMENT INDII

Izba Ludowa (niższa)

Izba Stanów (wyższa)

Wladza wykonawcza: Prezydent Republiki

Rada Ministrów

Ministerstwa

\section{Szczebel stanowy}

ORGAN USTAWODAWCZY STANU

W stanach Assam, Andhra Pradesh, Bihar, Jammu \& Kashmir, Karnataka, Maharashtra, Uttar Pradesh - 2 izby: Zgromadzenie Ustawodawcze oraz Rada Ustawodawcza, w pozostałych - 1 izba: Zgromadzenie Ustawodawcze

\section{Gubernator Stanu}

Rada Ministrów

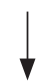

Ministerstwa

Rysunek 2.1. Organizacja władzy publicznej w Indiach na szczeblu federalnym i stanowym

Źródło: opracowanie własne na podstawie [The Constitution of India, 2000].

Władzą ustawodawczą Indii jest parlament składający się z prezydenta i dwóch izb: Izby Ludowej (Lok Sabha) oraz Rady Stanów (Rajya Sabha). Izba Ludowa składa się łącznie z nie więcej niż 552 członków. Z tej liczby 530 reprezentują okręgi wyborcze stanów oraz nie więcej niż 20 członków wybranych $\mathrm{w}$ terytoriach unijnych zgodnie z procedurą określoną przez parlament ${ }^{7}$. Ponadto prezydent republiki może dokooptować do składu Izby Ludowej nie więcej niż dwóch przedstawicieli tzw. społeczności anglo-indyjskiej, jeśli uzna, że nie jest ona odpowiednio reprezentowana w parlamencie. Kadencja Izby Ludowej trwa pięć lat, ale decyzją prezydenta Izba może być wcześniej rozwiązana.

${ }^{7}$ Faktyczna liczba członków Izby Ludowej jest zmienna i nie taka sama po każdych wyborach, dotyczy to szczególnie pierwszych kilku kadencji indyjskiego parlamentu. Procedury ustalania liczby mandatów w okręgach wyborczych poszczególnych stanów są bardzo skomplikowane i nie zawsze jest ona proporcjonalna do liczby ludności stanu lub okręgu wyborczego. Istnieją bowiem często preferencje dla wyodrębnionych kast oraz plemion - mają one m.in. zarezerwowane mandaty zarówno w Izbie Ludowej, jak i zgromadzeniach ustawodawczych stanów. Dotyczy to w szczególności tzw. obszarów i plemion wyodrębnionych. Konstytucja określa tylko górne granice liczby członków Izby Ludowej. 
Izba wyższa, czyli Rada Stanów, składa się maksymalnie z 250 członków, z czego 12 pochodzi z nominacji prezydenta republiki (uznani za wkład do sztuki, literatury, nauki i działalności społecznej) oraz nie więcej niż 238 osób wybranych przez zgromadzenia ustawodawcze stanów oraz terytoria unijne. Kadencja Rady Stanów trwa 6 lat. Rada Stanów nie podlega rozwiązaniu, ale co dwa lata następuje wymiana jednej trzeciej jej składu.

Najwyższym organem władzy wykonawczej, czyli głową państwa jest prezydent republiki (President of India), wybierany na pięć lat przez kolegium składające się z członków obu izb parlamentu oraz zgromadzeń ustawodawczych stanów. Drugą osobą w państwie jest wiceprezydent (Vice-President of India) wybierany przez obie izby parlamentu. Wiceprezydent jest jednocześnie z urzędu przewodniczącym Rady Stanów i jego kadencja trwa również 5 lat.

Niższym organem federalnej władzy wykonawczej jest Rada Ministrów (Council of Ministers) powoływana do pomocy prezydentowi w wykonywaniu jego konstytucyjnych funkcji. Premiera mianuje prezydent; pozostali ministrowie też są powoływani przez prezydenta, ale z rekomendacji premiera. Rada Ministrów ponosi zbiorową odpowiedzialność przed Izbą Ludową. Na stanowiska premierów rządu federalnego powoływane są z reguły osoby wskazane przez partie dysponujące większością w Izbie Ludowej.

W stanach władzę ustawodawczą pełni gubernator (Governor of a State) oraz stanowe organy ustawodawcze, składające się w stanach: Andhra Pradesh, Bihar, Maharashtra, Karnataka, Uttar Pradesh, Jammu \& Kashmir i Assam (od grudnia 2013) - z dwóch izb, niższej - Zgromadzenia Ustawodawczego (Vidan Sabha) oraz wyższej - Rady Ustawodawczej (Vidan Parishad), a w pozostałych stanach $-\mathrm{z}$ jednej izby (Zgromadzenie Ustawodawcze). Procedura wyboru kolegialnych organów ustawodawczych stanów jest skomplikowana i odmienna dla stanów dwu- i jednoizbowych; w tych pierwszych - część deputowanych pochodzi z wyborów, część zaś jest powoływana przez gubernatora, w drugich - członkowie zgromadzenia stanowego pochodzą z bezpośrednich wyborów. Poza tym zasady wyborcze ulegają ciągłym zmianom. Liczba członków stanowych zgromadzeń ustawodawczych zawiera się w granicach 60-500 i jest zależna od liczby ludności stanu. Liczba członków stanowych rad ustawodawczych nie może być (z wyjątkiem Jammu \& Kashmir) większa niż jedna trzecia liczby członków zgromadzeń ustawodawczych, ale nie mniejsza niż 40 osób.

Oprócz kompetencji członka władzy ustawodawczej, gubernator posiada przede wszystkim władzę wykonawczą - jest jej najwyższym organem na szczeblu stanowym; władzę tę sprawuje za pośrednictwem stanowej rady ministrów. Jest on mianowany przez prezydenta republiki i piastuje urząd przez pięć lat, ale pod warunkiem aprobaty prezydenta, który może odwołać go w każdej chwili. Ponadto prezydent republiki jest uprawniony do wydawania gubernatorowi bezpośrednich poleceń. W świetle tych uprawnień prezydenta kraju, status stanów nie jest więc jednoznaczny, posiadają one - jak przystało na państwo federal- 
ne - dużą samodzielność w ramach określonego przez konstytucję prawa, ale fakt, że gubernator jest mianowany przez prezydenta i może być w każdej chwili przez niego odwołany, w praktyce samodzielność tę istotnie ogranicza. Na szczeblu stanowym tworzona jest również Rada Ministrów, na czele której stoi premier; jej zadaniem jest - podobnie jak w przypadku rządu federalnego - służenie pomocą i radą gubernatorowi w pełnieniu jego władzy wykonawczej. Premiera rządu stanowego powołuje gubernator, ministrowie są powoływani również przez gubernatora, ale na wniosek premiera. Stanowe rady ministrów ponoszą zbiorową odpowiedzialność przed zgromadzeniami ustawodawczymi stanów.

Oprócz stanów istnieją jeszcze tzw. terytoria unijne (zwane także związkowymi). Są to bardzo małe jednostki administracyjne podległe bezpośrednio władzom federalnym. Terytoriami unijnymi administruje prezydent republiki poprzez mianowanego przez siebie zarządcę. Decyzją parlamentu federalnego mogą jednak zostać utworzone na terytoriach unijnych organy ustawodawcze oraz rada ministrów bądź tylko jedna z tych instytucji.

Podział kompetencji pomiędzy władzą centralną a stanową nie jest zawsze rozłączny. Niektóre kompetencje leżą jednocześnie w gestii centrum oraz stanów. Do podstawowych zadań władzy centralnej (federalnej) należą: obrona narodowa, federalny wymiar sprawiedliwości, ustawodawstwo federalne, dyplomacja, organizacja statystyki gospodarczej i społecznej, szczególnie ważne badania naukowe, utrzymanie dróg federalnych, kolei, portów morskich i lotniczych, regulacja przemysłu i handlu, ochrona środowiska oraz turystyka.

Większość zadań publicznych realizowana jest natomiast przez władze stanowe. Do ich kompetencji zaliczyć należy przede wszystkim: utrzymanie policji, obronę cywilną, stanowy wymiar sprawiedliwości, szkolnictwo średnie i wyższe, edukację dorosłych, pomoc społeczną, opiekę zdrowotną i lecznictwo szpitalne, publiczną gospodarkę mieszkaniową, planowanie regionalne oraz miejskie, utrzymanie dróg stanowych i niektórych ponadlokalnych, ochronę środowiska oraz ochronę konsumentów, kulturę (teatry, muzea, biblioteki, sport i turystyka), ponadlokalne usługi użyteczności publicznej (gazownictwo, dostawa wody i energii elektrycznej) oraz niektóre sprawy dotyczące rolnictwa.

Terytorialna organizacja państwa indyjskiego, a w szczególności drugiego szczebla administracji, czyli liczby i granic stanów, należały do najtrudniejszych kwestii politycznych w pierwszych latach niepodległych Indii. Budziły wiele emocji, które wielokrotnie doprowadzały do konfliktów społecznych, często krwawych.

Pierwotną, ustanowioną w 1950 roku, strukturą terytorialną Indii był podział kraju według granic prowincji brytyjskich oraz księstw. Wyodrębniono 4 kategorie jednostek drugiego szczebla administracji, tj. 27 stanów i terytorium unijne. Stany miały jednakże różny status: A ( 9 stanów - Assam, Bihar, Bombay, Madhya Pradesh, Madras, Orissa, Punjab, Uttar Pradesh oraz West Bengal), B (8 stanów - Hyderabad, Jammu \& Kashmir, Madhya Bharat, Mysore, Patiala and East Punjab 
States Union, Rajasthan, Saurashtra oraz Travancore-Cochin), C (10 stanów - Ajmer, Bhopal, Bilaspur, Coorg, Delhi, Himachal Pradesh, Kutch, Manipur, Tripura oraz Vindhya Pradesh), D (terytorium unijne, tj. Andaman and Nicobar Islands).

Podział ten okazał się jednak nieadekwatny do nowej rzeczywistości i już w 1956 roku, na podstawie Ustawy o reorganizacji stanów (The States Reorganization Act 1956), stanowiącej 7 poprawkę do konstytucji, dokonano istotnych zmian w strukturze administracyjnej kraju. W miejsce istniejących dotąd 27 stanów o różnym statusie, utworzono 14 równorzędnych stanów i 6 terytoriów unijnych zarządzanych centralnie [Boivin, 2011, s. 93-94]. Były to następujące stany: Andhra Pradesh, Assam, Bihar, Bombay, Jammu \& Kashmir, Kerala, Madhya Pradesh, Madras (w 1968 roku zmienił nazwę na Tamil Nadu), Mysore, Orissa, Punjab, Rajasthan, Uttar Pradesh oraz West Bengal. Status terytoriów unijnych uzyskały: 1. Andamany i Nikobary, 2. Delhi, 3. Himachal, 4. Lakshadiwy, Minikoj i Amindiwy, 5. Manipur, 6. Tripura.

Takie rozwiązanie - jak pokazał czas - również nie zapewniło stabilności kraju. W latach następnych pod wpływem silnych oddolnych ruchów etnicznych i religijnych, w drodze podziału lub łączenia istniejących stanów, powstały nowe stany. Jedną z najbardziej spornych kwestii przy delimitacji stanów było kryterium językowe, chodziło o to, aby w miarę możliwości nie rozdzielać obszarów, na których mieszkańcy posługują się tym samym językiem [Das, 2009, s. 341-345].

W 1960 roku stan Bombay - powstały z połączenia Maharashtry i Gujaratu - został ponownie podzielony na Maharashtrę oraz Gujarat. W 1963 roku ze stanu Assam wyłączono niewielki stan Nagaland. W 1966 roku podzielony został Punjab na dwa stany - Haryanę (zamieszkały głównie przez hindusów) i Punjab (zamieszkały głównie przez sikhów). W 1969 roku ze stanu Assam wydzielono Meghalayę, który uzyskał status stanu w 1971 roku. W 1971 roku terytorium unijne Himachal przekształcono w stan, w 1972 roku tak samo stało się z terytoriami Manipuru oraz Tripury. W 1973 roku powstała Karnataka. W 1975 roku utworzono Sikkim, a w 1987 roku stanami zostały: Mizoram, Arunachal oraz Goa. W 2000 roku wyodrębniono jeszcze trzy stany: Uttaranchal (od 2007 roku - Uttarkhand), Jharkhand, Chhattisgarh. W 2014 roku utworzono nowy stan Telangana.

\subsection{Kierunki i determinanty przemian ustroju politycznego}

Podstawowym problemem twórców państwa indyjskiego, zarówno w okresie walki o niepodległość, jak i w pierwszych latach po jej uzyskaniu, był kształt jego ustroju politycznego. Trudności wynikały przede wszystkim z ogromnego zróżnicowania etnicznego, religijnego i ekonomicznego ludności zamieszkującej subkontynent indyjski. Jak z takiego konglomeratu narodowości, wyznawców różnych religii, posługujących się odrębnymi językami, w większości analfabe- 
tów, żyjących dotąd w różnych księstwach lub też na terenach brytyjskiej kolonii, utworzyć jedno społeczeństwo i jeden organizm państwowy i jaką nadać mu formę ustrojową?

Indyjskie elity, z reguły wykształcone i ukształtowane mentalnie na uniwersytetach angielskich, które przewodziły ruchowi niepodległościowemu, zdecydowały się na utworzenie państwa demokratycznego na wzór amerykańsko-europejski. Uznano, że w tak wielce skomplikowanej sytuacji etnicznej istnienie Indii jako jednolitego państwa jest możliwe tylko w warunkach demokracji, tj. zapewnienia wszystkim mieszkańcom subkontynentu jednakowych praw i możliwości aktywnego uczestniczenia w życiu publicznym. Struktura państwa winna mieć charakter federacji, co przez zachowanie autonomii większych grup narodowościowych, religijnych oraz regionów geograficznych łagodziłoby ewentualne konflikty społeczne i polityczne.

Jeżeli w ruchu niepodległościowym, a szczególnie w jego awangardowej partii politycznej - Indyjskim Kongresie Narodowym - istniała niemal zgodność co do demokratycznej i federalnej formy ustroju niepodległych Indii, to spierano się o jego konkretne rozwiązania, a szczególnie o sposób wdrażania. Istniały w tej materii dwie grupy poglądów:

1. Według zwolenników pierwszej grupy, indyjska demokracja ma być budowana „od góry”, tzn. od władz centralnych, poprzez szczebel pośredni, czyli stany i następnie objąć szczebel lokalny. Indie powinny być przede wszystkim silnym, demokratycznym państwem ponadnarodowym. Za takim rozwiązaniem opowiadał się m.in. Jawaharlal Nehru i większość przywódców Indyjskiego Kongresu Narodowego.

2. Druga grupa optowała za odwrotnym rozwiązaniem, tj. tworzeniem demokratycznego systemu „od dołu”, czyli od demokratyzacji tradycyjnych wspólnot wiejskich (panczajatów), następnie stanów i na końcu szczebla centralnego. Tej grupie przewodził „ojciec” niepodległych Indii - Mahatma Gandhi, który postulował m.in., aby fundamentem państwa stały się tradycyjne społeczności wiejskie, ale o odnowionym systemie wartości, to znaczy pozbawione dotychczasowej nierówności, gwałtu i przemocy, a oparte na równości i współpracy. W myśl tej doktryny (zwanej „socjalizmem gandhystowskim”), wieś i jej produkcja rolna oraz rzemieślnicza miała być główną dziedziną działalności gospodarczej w kraju i wzorem stosunków społecznych [Gerlach, 1988, s. 89-90; Mrozek, 1974, s. 302-303] ${ }^{8}$.

${ }^{8}$ Niestety wiele koncepcji M. Gandhiego nie znalazło zrozumienia u innych przywódców Indyjskiego Kongresu Narodowego, zarówno tych o geograficznym kształcie państwa (tzn. Indie razem z Pakistanem), jak i jego ustroju politycznym. Rzeczywistość potoczyła się w innym kierunku niż chciał Gandhi. Był tym bardzo zawiedziony i rozgoryczony, do tego stopnia, że pomimo zaproszeń nie wziął udziału w uroczystej proklamacji niepodległości Indii w Delhi w dniu 15 sierpnia 1947 roku i przebywał w tym czasie w Kalkucie. Dzień wcześniej korespondent ogólnoindyjskiego radia na zapytanie o przesłanie na Dzień Niepodległości miał usłyszeć od Gandhiego: „wypłakałem już wszystkie łzy” [za: Das, 2009, s. 256]. 
W wyniku wieloletnich dyskusji i sporów zwyciężyła opcja pierwsza, co oznacza tworzenie indyjskiej demokracji „od góry”. Wyrazem tego jest konstytucja Indii, która weszła w życie w dniu 26 stycznia 1950 roku. Konstytucja ta - jak wspomniano - dekretująca w swej preambule demokratyczny charakter ustroju i bardzo szczegółowo regulująca jego struktury oraz zasady funkcjonowania, stała się swoistą konstrukcją nośną - szkieletem ustroju państwa indyjskiego.

Wydaje się, że w istniejących warunkach politycznych i społecznych Indii pierwszych lat niepodległości, tylko odgórne, powolne wprowadzanie demokratycznego ustroju było jedynym, racjonalnym działaniem. Zastosowanie tej strategii spowodowało jednak, że przez cztery pierwsze dekady niepodległości, a więc do lat 90., Indie były właściwie na wpół demokratycznym państwem, to znaczy demokratyczny porządek obowiązywał na szczeblu centralnym i stanowym, natomiast szczebel lokalny - poza wyjątkami - praktycznie nie ulegał zmianie. Zalecane przez art. 40 konstytucji tworzenie demokratycznych samorządów lokalnych (panczajatów) miało charakter epizodyczny i dotyczyło tylko niektórych regionów; sprawy te zostaną szerzej omówione w rozdziale IV.

Na szczeblach stanowych oraz w administracji lokalnej wytworzyła się szczególna sytuacja, będąca mieszaniną formalnej, dekretowanej przez akty prawne demokracji i starego systemu opartego na tradycyjnych wartościach i regułach zachowań publicznych. Aparat administracyjny nowego państwa - zarówno na poziomie federalnym, jak i stanowym - został zdominowany przez oddziedziczoną po Brytyjczykach warstwę urzędników. Tworzenie nowej służby administracyjnej było procesem trudnym i bardzo powolnym. Trudności te wynikały nie tylko z ogromnej skali potrzeb, niedostatku odpowiednich szkół, nauczycieli itp., lecz także utrwalonych przez wieki systemów wartości i hierarchii społecznych, dla których system demokratyczny był wręcz wrogi, gdyż burzył odwieczne układy oraz reguły życia prywatnego i publicznego.

\subsubsection{Lata 1950-1984 - monopolizacja i centralizacja życia politycznego}

Dominującą cechą ewolucji ustroju państwa indyjskiego w pierwszych czterech dekadach jego istnienia była powolna, ale systematyczna centralizacja. Nie był to jednak okres jednolity. Można wyróżnić w nim trzy podokresy:

1. Lata 1950-1960. W życiu politycznym dominują sprawy wewnętrzne, a szczególnie tworzenie podstawowych, demokratycznych struktur państwa na szczeblu stanowym.

2. Lata 1961-1972. Życie polityczne i funkcjonowanie państwa jest mocno zdeterminowane przez czynniki zewnętrzne, tj. przede wszystkim przez zagrożenie wynikające z konfliktów zbrojnych z Portugalią (1961), Chinami (1962) i Pakistanem (1964/65 oraz 1971/72). 
3. Lata 1973-1984. Następuje kulminacja konfliktów wewnętrznych na tle politycznym, religijnym oraz gospodarczym (bieda), czego wyrazem jest m.in. wprowadzenie w 1975 roku stanu wyjątkowego i nasilenie centralnej regulacji życia publicznego. Symboliczną datą końcową narastającej centralizacji i biurokratyzacji państwa jest zabójstwo premiera rządu federalnego - Indiry Gandhi (październik 1984).

Pierwszym, bardzo ważnym wydarzeniem w historii indyjskiej demokracji były powszechne i bezpośrednie wybory do parlamentu krajowego (Izby Ludowej) w 1952 roku. Zwyciężył w nich Indyjski Kongres Narodowy, uzyskując 74 proc. miejsc w parlamencie. Partia ta, będąca architektem i budowniczym niepodległych Indii, skupiająca większość elit tego kraju, była do połowy lat 70. ubiegłego wieku jedyną, znaczącą siłą na indyjskiej scenie politycznej. W pierwszych pięciu wyborach parlamentarnych (1952-1971) uzyskiwała ona po 54-75 proc. mandatów poselskich. Nie jest wielką przesadą opinia, że w praktyce ustrój polityczny Indii był przez pierwsze trzy dekady niepodległości niemal monopartyjny. O dominującej roli IKN świadczy to, że na drugiej pozycji we wspomnianych wyborach lokowały się partie, które uzyskiwały po 3-8 proc. mandatów [Brass, 1999, s. 144].

System demokratyczny Indii powoli się utrwalał, kraj ten rzeczywiście stawał się ,największą demokracją świata". Była to jednakże demokracja specyficzna, wysoce scentralizowana, czemu przez wiele lat sprzyjała wspomniana, prawie monopolistyczna pozycja Indyjskiego Kongresu Narodowego, ale - podkreślmy - legitymizowana demokratycznymi wyborami. Władze centralne pochodzące z nominacji tej partii miały wyjątkowo wielkie kompetencje. Rola stanów, formalnie samorządnych, posiadających samodzielnie wybierane władze, była dość ograniczona. Władze lokalne (dystryktów, bloków, wsi) pochodziły - poza wyjątkami - z nominacji stanowych i rekrutowały się z warstw uprzywilejowanych.

Wdrażanie demokratycznego porządku społecznego w Indiach w pierwszym z wyróżnionych wyżej podokresów (lata 50.) przebiegało w wyjątkowo niesprzyjających warunkach politycznych i gospodarczych.

Tworzenie jednolitego państwa, tj. łączenie w większe jednostki administracyjne (stany, terytoria unijne i dystrykty) obszarów bezpośrednio podległych władzom brytyjskim ze strukturami byłych ok. 560 państw-księstw (w tym niektórych dużych) było procesem bardzo trudnym i znaczonym wieloma, nawet krwawymi konfliktami. Podobny skutek wywołał podział Indii Brytyjskich na dwa państwa - Indie i Pakistan, którego głównym powodem były względy

\footnotetext{
${ }^{9}$ Można spotkać się z poglądami, że Indie muszą być państwem demokratycznym. Tak liczne i ogromnie zróżnicowane społeczeństwo - pod względem ekonomicznym, etnicznym, kulturowym, edukacyjnym i in. - może funkcjonować w jednym państwie tylko wówczas, gdy będzie ono demokratyczne. Żadna niedemokratyczna, autorytarna władza nie byłaby w stanie na dłuższą metę zapewnić stabilności takiego państwa i skutecznie nim zarządzać [Minkner, 2010, s. 117].
} 
religijne i wielowiekowe konflikty komunalistyczne - pomiędzy hindusami, muzułmanami oraz sikhami ${ }^{10}$. Systematycznie przybierały na sile konflikty pomiędzy grupami etnicznymi, w wyniku czego krajowi groził chaos, a nawet rozpad już u zarania niepodległości. Zadaniem nowego, demokratycznego państwa było likwidowanie tych zagrożeń, co nie zawsze mogło się odbywać w sposób pokojowy i przy zastosowaniu tylko demokratycznych instrumentów ${ }^{11}$.

$\mathrm{Na}$ kształt indyjskiej demokracji negatywnie wpływał także spór programowy w łonie Indyjskiego Kongresu Narodowego. Przyjęty na początku lat 50. kurs na tworzenie tzw. socjalizmu indyjskiego budził liczne kontrowersje w kręgach liberalnie nastawionych członków partii. Narastająca opozycja wobec ,indyjskiego socjalizmu" przybierała z czasem na sile, co odbijało się ujemnie na funkcjonowaniu państwa, szczególnie na jego niższych poziomach organizacyjnych [Mrozek, 1976, s. 92-96].

Konsolidację państwa indyjskiego i rozwój jego demokratycznego ustroju w latach 50. bardzo utrudniała sytuacja ekonomiczna, dodatkowo pogłębiana tzw. eksplozją demograficzną, tj. wyjątkowo dużym przyrostem demograficznym - ok. 2 proc. rocznie, co szerzej przedstawiono w następnym podrozdziale 2.3.

W drugim z wyróżnionych podokresów, tj. w latach 60., bardzo duży wpływ na sytuację wewnętrzną Indii miały czynniki zewnętrze, a konkretnie konflikty zbrojne z Portugalią, Pakistanem oraz Chinami. Można nawet postawić tezę, że prawie cała dekada lat 60 . upłynęła w Indiach pod znakiem tych wojen.

Pierwszym z tych konfliktów był zatarg Indii z Portugalią o jej kolonialne posiadłości na Półwyspie Indyjskim, tj. Goa, Daman i Diu. Zakończył się on w grudniu 1961 roku interwencją wojsk indyjskich i okupacją tych trzech enklaw, a w 1962 roku przyłączeniem ich do Indii (w 1987 roku Goa stał się stanem Indii).

Drugi konflikt zbrojny Indii lat 60. to spór z Chinami o tereny graniczne w Himalajach. Przerodził się on w otwartą - i przegraną przez Indie - wojnę. Fakt ten niekorzystnie wpłynął na nastroje społeczne oraz sytuację polityczną w kraju i był odczuwany przez wiele lat.

Wykorzystując wewnętrzne trudności gospodarcze i polityczne oraz przegraną wojnę z Chinami, w 1964 roku wojska pakistańskie zaatakowały Indie. Duża skala działań zbrojnych pomiędzy armiami Pakistanu i Indii nie przyniosła jednak militarnego rozstrzygnięcia. Wojnę zakończyło zawarcie traktatu pokojowego w Taszkiencie w styczniu 1966 roku.

${ }^{10}$ Komunalizm jest to nadmierne eksponowanie i wykorzystywanie religii i - tym samym - różnic religijnych dla osiągnięcia celów politycznych. Termin ten odnosi się tylko do sytuacji na Półwyspie Indyjskim, a dotyczy szczególnie stosunków pomiędzy hindusami, muzułmanami oraz sikhami. Wyróżnia się komunalizm hinduski, muzułmański oraz sikhijski. Premier J. Nehru nazwał to zjawisko indyjską wersją faszyzmu i obawiał się, że komunalizm może doprowadzić do rozpadu Indii [Chandra $\mathrm{i}$ in., 1999, s. 78].

${ }^{11}$ Procesy te omawia szeroko K. Dębnicki [2000]. 
Problemy wewnętrzne Indii połowy lat 60. dodatkowo skomplikowała śmierć Jawaharlala Nehru (maj 1964), a także jego następcy Lala B. Shastriego (styczeń 1966). Nowym premierem Indii została córka J. Nehru - Indira Gandhi. Do tego doszły jeszcze skutki niekorzystnych warunków atmosferycznych, a szczególnie największe dotąd w XX wieku susze w kolejnych latach 1965 i 1966, które doprowadziły do znacznych niedoborów żywności i pojawienia się masowego głodu.

Pokój między Indiami a Pakistanem nie trwał jednak długo. W latach 19711972 doszło do kolejnej, trzeciej wojny między tymi państwami, z której Indie wyszły zwycięsko. Wojnę tę zakończono traktatem w Shimli w lipcu 1972 roku. Dodatkowym, korzystnym dla Indii skutkiem tej wojny był rozpad Pakistanu i powstanie Bangladeszu.

Wszystkie te wewnętrzne oraz zewnętrzne wydarzenia i okoliczności negatywnie wpłynęły na rozwój demokracji indyjskiej. Zamiast jej pogłębiania, tj. m.in. decentralizowania struktur i systemu funkcjonowania państwa, następował proces jego centralizacji. Politycznym wyrazem narastającego kryzysu politycznego były wyniki wyborów do parlamentu krajowego oraz organów ustawodawczych stanów w latach 1967 i 1969. Czwarte w historii niepodległych Indii powszechne wybory w lutym 1967 roku były niepomyślne dla Indyjskiego Kongresu Narodowego, aczkolwiek udało mu się jeszcze utrzymać większość w Izbie Ludowej ${ }^{12}$. IKN w wyniku tych wyborów roku obsadził zaledwie 54 proc. miejsc w parlamencie [De Ruijter, 1998, s. 10-16]. Znacząco zyskały natomiast radykalizujące się partie prawicy i lewicy; spektakularny sukces odniosły obie partie komunistyczne, uzyskując łącznie 8 proc. mandatów poselskich oraz dużą liczbę mandatów w parlamentach niektórych stanów, a szczególnie w Kerali i Bengalu Zachodnim. Partie komunistyczne stały się wówczas główną siłą opozycyjną wobec $\mathrm{IKN}^{13}$.

Dotkliwsze - niż na szczeblu krajowym - straty poniósł Indyjski Kongres Narodowy w wyborach stanowych. W istniejących wówczas 17 stanach, na ogólną liczbę ok. 3,5 tys. miejsc w organach ustawodawczych, IKN uzyskał ok. 1,7 tys. mandatów. Utracił więc władzę w 6 największych stanach północno-zachodnich

${ }^{12}$ Indyjski Kongres Narodowy wszedł po śmierci J. Nehru (1964) oraz L.B. Shastriego (1966) w fazę ostrych walk frakcyjnych. Jak nigdy dotąd zarysowały się w nim wyraźnie trzy nurty: lewicowy, centrowy i prawicowy. Doprowadziło to jesienią 1969 roku do rozłamu w partii i wyjścia z niego skrajnie prawicowego skrzydła, zwanego Syndykatem.

${ }^{13}$ Komunistyczna Partia Indii (KPI) została założona w 1925 roku (zdelegalizowana w latach 1934-1942). W 1964 roku wystąpiła z niej frakcja lewacka, zakładając Komunistyczną Partię IndiiMarksistowską (KPI-M). Głównym powodem odejścia z KPI części działaczy był sprzeciw wobec jej współpracy z IKN. Od 1964 roku istnieją więc w Indiach dwie partie komunistyczne. Partie te odgrywały często znaczącą rolę na scenie politycznej niektórych stanów. W 1957 roku w Kerali został utworzony - po raz pierwszy w historii Indii - stanowy rząd komunistyczny. Ponadto w latach następnych partie komunistyczne dominowały w rządzie Bengalu Zachodniego. Uczestniczyły także w rządach stanowych Tamil Nadu, Tripury oraz Manipuru. W latach 90., a także na początku bieżącego stulecia ich znaczenie istotnie zmalało zarówno na scenie krajowej, jak i w stanach. 
zamieszkałych przez 50 proc. ludności kraju [Mrozek, 1971, s. 115]. Objęcie rządów w najważniejszych stanach Indii przez partie opozycyjne do IKN, zaostrzyło konflikty na linii centrum-stany; niejednokrotnie centrum starało się ograniczać kompetencje administracyjne i samodzielność finansową tych stanów.

Centralizacji zarządzania państwem w ostatnich latach 60. i na początku lat 70. towarzyszyła zmiana orientacji politycznej Indyjskiego Kongresu Narodowego, a więc także wyłonionego przez tę partię rządu centralnego. Nastąpił tzw. zwrot $\mathrm{w}$ lewo, co odpowiadało oczekiwaniom większości społeczeństwa oraz uczestników sceny politycznej, a szczególnie rosnących w siłę obu partii komunistycznych. Wyrazem tego było przyspieszenie reform gospodarczych i społecznych, a szczególnie podjęcie intensywnej kampanii politycznej pod hasłem „Usunąć nędzę”, która spotkała się z przychylnością biedniejszych warstw społeczeństwa. Program „Usunąć nędzę” stał się podstawą efektownego zwycięstwa Indyjskiego Kongresu Narodowego w przedterminowych wyborach parlamentarnych w marcu 1971 roku. „Oczyszczony” z prawicowych polityków IKN odzyskał utraconą w 1967 roku pozycję uzyskując 68 proc. mandatów poselskich [Brass, 1999, s. 144]. Sukcesem Indyjskiego Kongresu Narodowego, kierowanego przez I. Gandhi, zakończyła się też w marcu 1972 roku seria wyborów do parlamentów stanowych. Tak więc po kilkuletnim kryzysie politycznym sytuacja powróciła „do normy”, to znaczy IKN ponownie i to wyraźnie dominował na scenie politycznej. Taki rozwój wypadków stwarzał możliwości realizacji zapowiadanych prospołecznych programów gospodarczych i politycznych. Tak się jednak nie stało.

Trzeci z wyróżnionych wyżej podokresów to lata 1973-1984. Rok 1972, w którym zwycięsko dla Indii zakończyła się największa wojna z Pakistanem, nie stał się jednak początkiem oczekiwanych przez społeczeństwo reform i poprawy warunków życia. Po niedługiej euforii z odniesionego zwycięstwa rozpoczął się kolejny i znacznie głębszy kryzys niż ten z połowy lat 60 . Jego wyrazem był ponowny wzrost niezadowolenia i radykalizacji społeczeństwa, co wzmacniało i konsolidowało siły polityczne opozycyjne do Indyjskiego Kongresu Narodowego. Doszło do wielu akcji nieposłuszeństwa społecznego, a nawet aktów terroru.

W połowie 1975 roku wydarzenia społeczno-polityczne przybrały dramatyczny obrót. W dniu 25 czerwca 1975 roku przywódcy opozycji utworzyli Ludowy Komitet Walki, który miał kierować całą kampanią zwalczania rządu i zmuszenia go do ustąpienia. Główne działania prowadzące do tego celu miały się rozpocząć 28 czerwca. Jeśli to nie przyniosłoby oczekiwanych rezultatów, to w dniu 9 lipca zamierzano podjąć czynną akcję obywatelskiego nieposłuszeństwa, co najprawdopodobniej doprowadziłoby do wojny domowej i zamachu stanu, a więc obalenia legalnego, demokratycznie wybranego rządu.

W sytuacji gwałtownie narastającej anarchizacji życia społecznego i zamachów terrorystycznych, rząd I. Gandhi zwrócił się do prezydenta republiki z wnioskiem, aby na podstawie art. 352 konstytucji Indii ogłosił na terenie ca- 
łego kraju stan wyjątkowy. W dniu 26 czerwca prezydent Indii wprowadził stan wyjątkowy, zawieszając tym samym konstytucyjne prawa obywateli [Chandra i in.,1999, s. 254].

Po wprowadzeniu stanu wyjątkowego zahamowała się anarchizacja życia społecznego oraz pogłębianie się kryzysu gospodarczego. Istotnie ograniczone zostały jednak swobody obywatelskie. Dokonano licznych aresztowań, do więzień trafiło ok. 100 tys. ludzi. Wprowadzono cenzurę w środkach masowego przekazu. Odwołano także ze stanowisk rządowych oraz stanowych - i niekiedy aresztowano - wielu nieudolnych lub skorumpowanych funkcjonariuszy państwowych. Zdelegalizowane zostały najbardziej ekstremistyczne - lewicowe i prawicowe oraz komunalistyczne partie i ugrupowania społeczne. Większość społeczeństwa Indii przyjęła wprowadzenie stanu wyjątkowego z zadowoleniem. Zmniejszyła się w wyniku niego uciążliwość życia, zmalała korupcja i biurokracja, ograniczona została spekulacja, spadła inflacja i poprawił się stan bezpieczeństwa publicznego [Kalmar, 1989, s. 218].

Wprowadzenie stanu wyjątkowego zmieniło kalendarz polityczny. Przypadające na 1976 rok wybory zostały przesunięte na marzec 1977 roku, a tym samym przedłużyła się kadencja rządu I. Gandhi. W ramach przygotowań do wyborów złagodzono restrykcje stanu wyjątkowego, w styczniu 1977 roku zwolniono więźniów politycznych. Formalne zniesienie stanu wyjątkowego zapowiedziano na 21 marca 1977 roku, a więc w następny dzień po zakończeniu wyborów. Indyjski Kongres Narodowy spodziewał się kolejnego zwycięstwa, które miało być „nagrodą" za zduszenie inflacji, poprawę sytuacji żywieniowej i bezpieczeństwa publicznego oraz ograniczenie wszechwładzy lokalnej i stanowej biurokracji. Tak się jednak nie stało.

W styczniu 1976 roku powstał blok partii pod nazwą Front Janata (Front Ludowy). Jego głównym celem było stawienie czoła Indyjskiemu Kongresowi Narodowemu i odsunięcie go od władzy.

Przesunięte, szóste wybory parlamentarne w dniach 16-20 marca 1977 roku zakończyły się klęską Indyjskiego Kongresu Narodowego, który na 542 miejsca w Izbie Ludowej obsadził tylko 152. Front Janata i sprzymierzony z nim Kongres dla Demokracji uzyskały 241 mandatów [De Ruijter, 1998, s. 28]. Resztą mandatów podzieliły się inne ugrupowania polityczne, na ogół opozycyjne w stosunku do IKN. Indyjski Kongres Narodowy utracił więc przewagę w parlamencie i został po raz pierwszy w historii Indii odsunięty od władzy ${ }^{14}$.

${ }^{14}$ Za główne przyczyny klęski wyborczej Indyjskiego Kongresu Narodowego w 1977 roku uznaje się: niezrealizowanie programu „Usunąć nędzę” ogłoszonego w 1970 roku, podobnie złą realizację „Programu 20 punktów” z lipca 1975 roku, nadużywanie władzy przez syna I. Gandhi - Sanjaya (szczególnie za kierowaną przez niego przymusową sterylizację ludzi w celu zmniejszenia przyrostu naturalnego) oraz ograniczenie swobód demokratycznych poprzez wprowadzenie licznych zmian w prawodawstwie. 
Front Janata wraz ze sprzymierzonymi małymi partiami utworzył pierwszy w historii Indii „niekongresowy” rząd, aczkolwiek jego premierem został były długoletni działacz Indyjskiego Kongresu Narodowego i wicepremier w rządzie I. Gandhi (1967-1969), a później jej opozycjonista - Morarji Desai.

Reformatorski impet, z jakim rozpoczął działalność nowy rząd M. Desaia, nie trwał długo, właściwie wyczerpał się już w 1977 roku. W gronie rządzącej koalicji pojawiały się konflikty na tle zróżnicowanego podejścia do sposobu rządzenia. Front Janata nie mógł poradzić sobie z narastającymi konfliktami na wsi, szczególnie wśród warstw najuboższych oraz najniżej stojących w kastowej hierarchii. Grupy te były niezadowolone z perspektywy niespełnienia obietnic zawartych w ogłoszonych wcześniej programach społecznych „Usunąć nędzę” (1970) oraz „Programie 20 punktów" (1975); ten ostatni został odrzucony przez Front Janata [Gudowski, 1990, s. 87]. Zamożni posiadacze ziemscy, mając poparcie w nowych władzach federalnych oraz stanowych, zaczęli odzyskiwać prawa utracone w ramach reform rolnych wdrażanych przez rząd I. Gandhi, np. odbierali ziemię ubogim rolnikom, żądali zwrotu udzielonych im pożyczek, a umorzonych w okresie stanu wyjątkowego itp. Takie praktyki miały miejsce szczególnie w rolniczych stanach północnych Indii, gdzie Janata Front miał duże wpływy i odniósł największy sukces wyborczy.

Nasilające się w rządzącej koalicji konflikty doprowadziły w niedługim czasie do upadku dwóch rządów Frontu Janata, wskutek czego w sierpniu 1979 prezydent Indii rozwiązał parlament i wyznaczył na styczeń 1980 roku nowe, przedterminowe wybory.

Po krótkiej, intensywnej kampanii w styczniu 1980 roku odbyły się wybory parlamentarne. Wysokie zwycięstwo odniósł Indyjski Kongres Narodowy, na którego głosowało 43 proc. wyborców, co dawało mu 353 mandaty w Izbie Ludowej (67 proc.). Wybory styczniowe w 1980 roku były wielkim sukcesem Indyjskiego Kongresu Narodowego. Indira Gandhi, podobnie jak w 1971 roku, triumfalnie powróciła na scenę polityczną.

Głównym problemem Indii lat 80 . stały się ponownie konflikty społeczne, spotęgowane nieudolnymi rządami Frontu Janata. Przybierały one coraz częściej skrajną postać, tj. walk partyzanckich oraz krwawego terroru. Groziło to nawet rozpadem państwa. Niektóre regionalne ruchy społeczno-polityczne domagały się suwerenności, argumentując swe żądania odrębnością etniczną i/bądź religijną [Hasan, 1999, s. 168].

Najdotkliwiej na sytuacji politycznej Indii pierwszych lat 80. odcisnął się tzw. konflikt sikhijski w Punjabie, który kosztował życie 40-50 tys. ludzi ${ }^{15}$. W fazę

15 Konflikt sikhijski ma długą historię, a u jego podłoża tkwi religia oraz ekonomia. Otóż społeczność sikhijska, stanowiąca ok. 60 proc. mieszkańców stanu Punjab i zaledwie niespełna 2 proc. mieszkańców Indii znacząco odróżnia się od reszty społeczeństwa indyjskiego nie tylko religią i kulturą, ale także poziomem zamożności. Sikhowie, zwani niekiedy arystokratami Indii, chcieli utworzenia własnego państwa - Sikhistanu lub Khalistanu [Wolpert, 2010, s. 495]. 
krytyczną wszedł on na początku lata 1984 roku, a apogeum osiągnął jesienią, kiedy to z rąk sikhów zginęła premier Indii - I. Gandhi. Wtedy konflikt z regionalnego przerodził się w ogólnokrajowy, czego wyrazem było swoiste polowanie na sikhów jako odwet za zabicie I. Gandhi. Sytuacja zaczęła się normalizować $\mathrm{w}$ drugiej połowie lat 80 .

W tym samym okresie doszło do zaburzeń społecznych w północno-wschodnich regionach kraju, w tzw. Trójkącie Assamskim. Przyczyną konfliktu były waśnie pomiędzy licznymi grupami etnicznymi zamieszkującymi tę część Indii. O złożoności sytuacji etnicznej w tym regionie może świadczyć fakt, że podział terytorialny oraz sposób administrowania w tej części kraju jest przedmiotem specjalnej regulacji konstytucyjnej ${ }^{16}$. W latach 60 ., 70. i 80. ubiegłego stulecia w Trójkącie Assamskim powstało aż 7 stanów. Są to najmniejsze (oprócz Goa) stany Indii. Konflikty w północno-wschodnich Indiach zostały zakończone negocjacjami politycznymi w 1985 roku $^{17}$. Ich skutkiem były wybory stanowe w Assamie w grudniu 1985 roku, w wyniku których władzę przejęła lokalna partia - Rada Ludowa Assamu [Solski, 1989, s. 318-319].

Do otwartych konfliktów na tle etnicznym i religijnym w latach 80 ., szczególnie pomiędzy hindusami a muzułmanami, doszło jeszcze w kilku innych stanach, takich jak: Jammu \& Kashmir, Bihar, Maharashtra i Gujarat. Na południu kraju zaczął tlić się konflikt tamilski.

Reasumując prezentację przemian politycznych w latach 1950-1984, można stwierdzić, że w rezultacie zaistniałych wydarzeń oraz zmian politycznych w tym okresie systematycznie postępowała centralizacja życia politycznego. Wzrastały kompetencje władzy centralnej, a relatywnie obniżała się rola stanów. Sektor lokalny, który nie miał charakteru samorządowego, praktycznie nie odgrywał żadnej roli w życiu politycznym i społecznym kraju.

\subsubsection{Lata 1985-1991 - polaryzacja i próby decentralizacji życia politycznego}

Zabójstwo I. Gandhi w dniu 31 października 1984 roku i objęcie teki premiera rządu federalnego przez jej syna Rajiva Gandhiego jest ważną cezurą w historii niepodległych Indii. Następują przede wszystkim znaczące zmiany w życiu politycznym, a w ślad za tym podejmowane są próby radykalnych reform gospodarczych.

${ }^{16}$ Regulacje te są zawarte w 6 załączniku do Konstytucji Indii jako „Postanowienia w sprawie administracji obszarami plemiennymi w stanach Assam, Meghalaya, Tripura i Mizoram” [The Constitution of India, 2000, Sixth Schedule].

17 Głównym powodem konfliktu assamskiego był duży napływ ludności z Bengalu Wschodniego w okresie III wojny indyjsko-pakistańskiej i utworzenia Bangladeszu (1971-1972). W 1983 roku doszło do krwawych walk pomiędzy przybyszami bengalskimi a tubylcami assamskimi. 
W grudniu 1984 roku - zgodnie z kalendarzem wyborczym - odbyły się ósme wybory parlamentarne. W wyborach tych ponownie zwyciężył Indyjski Kongres Narodowy, odnosząc wielki sukces w postaci 76 proc. miejsc w parlamencie (415 na 543 obsadzone mandaty) [De Ruijter, 1998, s. 10, 32]. Desygnowany przez IKN rząd R. Gandhiego, mając wielką przewagę w Izbie Ludowej, mógł podjąć realizację programu modernizacji życia politycznego i gospodarczego. Tak też się stało, chociaż sytuację bardzo komplikowały wspomniane wydarzenia, tj. nasilone konflikty etniczne i religijne (pendżabski, tamilski i assamski), a także tragedia w mieście Bhopal (stan Madhya Pradesh), która spotkała się z wielkim oburzeniem opinii społecznej. W dniu 3 grudnia $1984 \mathrm{w}$ wyniku awarii instalacji gazowych w amerykańskiej fabryce chemikaliów śmiertelnie zatruło się ponad 2 tys. okolicznych mieszkańców, a setki tysięcy osób doznały poważnego uszczerbku na zdrowiu [Wolpert, 2010, s. 502-503].

Wraz z R. Gandhim do władzy doszła nowa generacja polityków - pokolenie czterdziestolatków, ludzi wykształconych, często na amerykańskich i angielskich uczelniach, technokratów, nazywanych przez media computer boys [Kohli, 2012, s. 33-34]. Oni właśnie zapoczątkowali technologiczną modernizację Indii, która przybrała w latach późniejszych niezwykle wysoką dynamikę i sprawiła, że kraj ten stał się światową potęgą w dziedzinie przemysłu i usług komputerowych ${ }^{18}$.

Na szczególną uwagę zasługują podjęte przez rząd R. Gandhiego reformy ekonomiczne, prowadzące do liberalizacji i deregulacji gospodarki oraz otwierania jej na świat. Kontynuowano również prace nad decentralizacją państwa poprzez upowszechnienie demokratycznych samorządów na poziomie wsi i miast; problemy te są dokładniej opisane w następnych dwóch rozdziałach.

Sytuacja polityczna i nastroje społeczne w kraju nie ulegały jednak poprawie, pomimo załagodzenia konfliktu pendżabskiego oraz assamskiego. Pod koniec dekady na południu Indii - wolnym dotychczas od większych zaburzeń społecznych - zaczął narastać nowy konflikt etniczny - tamilski. Był on pośrednio efektem sytuacji politycznej na Sri Lance, a mianowicie aktywizacji separatystycznego ruchu Tygrysów Tamilskich, dążącego do utworzenia na tej wyspie państwa tamilskiego. Ruch ten spotkał się z aprobatą ludności tamilskiej zamieszkującej południowe Indie, a szczególnie stan Tamil Nadu. Oficjalne stanowisko rządu Indii było jednak w tej sprawie odmienne. W ruchu tamilskim na Sri Lance upatrywano zagrożenie dla jedności Indiii ${ }^{19}$. Prewencyjna interwencja zbrojna Indii na

18 Wyrazem tego było m.in. utworzenie 1988 roku Centre for Development of Advanced Computing (C-DAC), którego zadaniem było organizowanie i koordynowanie rozwoju tego sektora. Zaczęto budować parki technologiczne, centra badawcze oraz systemy kształcenia kadr informatyków [Tokarski, Bhutani, 2007, s. 110-112].

19 W 1987 roku rząd Sri Lanki zwrócił się do rządu indyjskiego o pomoc wojskową w zwalczaniu terroryzmu Tamilskich Tygrysów. Rząd R. Gandhiego wysłał na wyspę tzw. Indyjski Korpus Pokojowy, który jednak nie spełnił swego zadania, a dodatkowo przyczynił się do zaognienia sytu- 
Sri Lance (do 1972 roku Cejlon) spotkała się z protestami indyjskich Tamilów i doprowadziła do aktów terrorystycznych, których ofiarą padł w 1991 roku sam R. Gandhi, ginąc z rąk tamilskiej terrorystki.

W 1989 roku odbyły się kolejne wybory parlamentarne. Rządowe reformy liberalizujące gospodarkę i próbujące decentralizować państwo nie spotkały się z akceptacją większości społeczeństwa. Partia premiera R. Gandhiego - Indyjski Kongres Narodowy uzyskał w nich zaledwie 195 mandatów, a więc ponaddwukrotnie mniej niż w wyborach w 1984 roku. Największy sukces odniosła głosząca nacjonalistyczne, hinduistyczne hasła Indyjska Partia Ludowa (BJP), uzyskując 85 miejsc w parlamencie, podczas gdy w poprzednich wyborach musiała się zadowolić zaledwie 2 mandatami [De Ruijter, 1998, s. 35].

Wyjściem z zaistniałej sytuacji mogło być utworzenie rządu koalicyjnego lub mniejszościowego, a więc niejednorodnego politycznie i tym samym słabego. Nie chcąc dopuścić do ponownego rządu z udziałem Indyjskiego Kongresu Narodowego, pozostałe dwa bloki polityczne utworzyły w Izbie Ludowej „egzotyczny” sojusz, tzn. BJP poparła mniejszościowy rząd Frontu Narodowego, na czele którego stanął Vishwanath P. Singh. Ten wysoce niejednorodny i - jak się okazało - skłócony rząd przetrwał rok. W tym czasie zaostrzały się konflikty religijne pomiędzy hindusami a muzułmanami (szczególnie o budowę hinduskiej świątyni w Ajodhii), narastały ruchy separatystyczne w Kaszmirze i Tamil Nadu.

Indyjska Partia Ludowa, mocno wspierająca wielkohinduski szowinizm, była niezadowolona z ugodowej polityki rządu Frontu Narodowego V.P. Singha i wycofała mu parlamentarne poparcie. W listopadzie 1990 roku nastąpiła więc zmiana rządu. Powołany został nowy rząd pod kierunkiem Chandry Shekhara, b. przewodniczącego Janata Dal, któremu wsparcia udzielił tym razem Indyjski Kongres Narodowy. Sytuacja rządu Ch. Shekhara była wyjątkowo trudna, stał się on bowiem swoistym zakładnikiem Indyjskiego Kongresu Narodowego i miał ograniczone pole manewru. W marcu 1991 roku Shekhar złożył rezygnację z zajmowanego stanowiska i w tej sytuacji ogłoszone zostały przedterminowe wybory parlamentarne.

Kampania wyborcza była krótka, ale bardzo intensywna i zakończyła się dramatem. Otóż w drugim dniu wyborów parlamentarnych, tj. 21 maja, tamilska terrorystka - samobójczyni zabiła byłego premiera i przewodniczącego Indyjskiego Kongresu Narodowego - R. Gandhiego. Wybory zostały przerwane i dokończono je 15 czerwca 1991 roku.

Wybory majowo-czerwcowe również nie przyniosły zdecydowanego rozstrzygnięcia, żadne z ugrupowań politycznych nie uzyskało większości. Zszedł właściwie ze sceny rządzący w latach 1989-1991 Front Narodowy, jego główna

acji w tym kraju. Interwencja wojskowa w Sri Lance spotkała się w kraju z ostrą krytyką opozycji politycznej R. Gandhiego oraz doprowadziła do publicznych, często zbrojnych wystąpień rodzimych Tamilów oraz licznej grupy imigrantów ze Sri Lanki. W 1989 roku wojska indyjskie zaczęły się wycofywać ze Sri Lanki [Chandra i in., 1999, s. 280-281]. 
siła polityczna - Janata Dal - musiała zadowolić się zaledwie 55 miejscami w parlamencie - wobec $143 \mathrm{w}$ poprzednich wyborach. Znaczący przyrost elektoratu i mandatów zanotowała Indyjska Partia Ludowa (BJP) - z 85 do 119. Na pozycji lidera umocnił się IKN, który powiększył swą frakcję parlamentarną z 195 do 245 posłów, ale to oczywiście nie dawało jeszcze bezwzględnej większości w parlamencie [De Ruijter, 1998, s. 35].

$\mathrm{Z}$ uwagi na różnice programowe oraz zadawnione konflikty personalne nie było możliwe utworzenie rządu większościowego. W tej sytuacji Indyjski Kongres Narodowy zdecydował się na utworzenie rządu mniejszościowego, którego wspierać miały małe ugrupowania polityczne, głównie regionalne i lokalne, a także w niektórych przypadkach takie partie, jak Komunistyczna Partia Indii-Markistowska czy Janata Dal. Premierem rządu mniejszościowego został nowy (po R. Gandhim) przewodniczący IKN - P.V. Narashima Rao, były minister spraw zagranicznych w rządach I. Gandhi oraz R. Gandhiego. W grudniu 1993 roku do IKN dołączyli dysydenci z Janata Dal i w ten sposób zapewnili rządowi N. Rao przetrwanie całej kadencji, a więc do 1996 roku.

\subsection{Demografia i problemy społeczno-kulturowe}

\subsubsection{Przemiany demograficzne}

Dokładnych danych o sytuacji demograficznej Indii dostarczają przeprowadzane co dziesięć lat spisy powszechne. Według pierwszego w historii niepodległych Indii spisu powszechnego w 1951 roku kraj ten zamieszkiwało 361 mln ludzi, a w 1991 roku liczba mieszkańców wyniosła $846 \mathrm{mln}$ (przyrost o 134,3 proc). Przeciętnie w ciągu dekady liczba mieszkańców Indii powiększała się o 22-25 proc., przy czym wskaźniki wzrostu były nieco wyższe przed rokiem 1971 [Bose, 2001, s. 17, 19]. Po 1971 roku mamy do czynienia z nieznacznym obniżaniem się dynamiki wzrostowej. Dokładniej liczbę, dynamikę oraz strukturę ludności Indii w podziale na mieszkańców miast oraz wsi przedstawiono w tab. 2.1.

Z tab. 2.1 wynika, że w latach 1951-1991 szybciej zwiększała się liczba ludności miejskiej, w wyniku czego zmieniły się relacje pomiędzy liczebnością mieszkańców wsi oraz miast. W 1951 roku w miastach mieszkało 17,2 proc. Indusów, a 1991 roku było to już 25,7 proc. Jest to w głównej mierze efektem wysokiej migracji ludności wiejskiej do miast oraz rozwoju miast, tj. powstawania nowych miast i powiększania się już istniejących. Stopa urodzeń jest bowiem znacznie większa na wsi niż w mieście. Pomimo wzrostu, stopień urbanizacji demograficznej w Indiach jest w dalszym ciągu niski, co sprawia, że znane hasło M. Gandhiego „Indie żyją na wsi” jest i długo będzie jeszcze aktualne [za: Mishra, 2001, s. 140]. 
Tabela 2.1. Liczba oraz dynamika i struktura ludności Indii w latach 1971-1991 według spisów powszechnych

\begin{tabular}{|c|c|c|c|c|c|c|c|}
\hline \multicolumn{3}{|c|}{ Lata } & 1951 & 1961 & 1971 & 1981 & 1991 \\
\hline \multirow{3}{*}{$\begin{array}{l}\text { Ludnośćc } \\
\text { ogółem } \\
\text { w tym: }\end{array}$} & \multicolumn{2}{|r|}{$\mathrm{mln}$} & 361 & 439 & 548 & 683 & 846 \\
\hline & \multirow{2}{*}{$\begin{array}{l}\text { wskaźniki } \\
\text { dynamiki }\end{array}$} & spis $1951=100,0$ & 100,0 & 121,6 & 151,8 & 189,2 & 234,3 \\
\hline & & spis poprzedni $=100,0$ & 100,0 & 121,6 & 124,8 & 124,6 & 126,5 \\
\hline \multirow{4}{*}{$\begin{array}{l}\text { Ludność } \\
\text { wiejska }\end{array}$} & \multicolumn{2}{|r|}{ mln } & 299 & 360 & 439 & 524 & 629 \\
\hline & \multirow{2}{*}{$\begin{array}{l}\text { wskaźniki } \\
\text { dynamiki }\end{array}$} & spis $1951=100,0$ & 100,0 & 120,4 & 146,8 & 174,7 & 210,4 \\
\hline & & spis poprzedni $=100,0$ & 100,0 & 120,4 & 121,9 & 119,4 & 120,0 \\
\hline & \multicolumn{2}{|c|}{ udział w ludności ogółem, w proc. } & 82,8 & 82,0 & 80,1 & 76,7 & 74,3 \\
\hline \multirow{4}{*}{$\begin{array}{l}\text { Ludność } \\
\text { miejska }\end{array}$} & & $\mathrm{mln}$ & 62 & 79 & 109 & 159 & 217 \\
\hline & \multirow{2}{*}{$\begin{array}{l}\text { wskaźniki } \\
\text { dynamiki }\end{array}$} & spis $1951=100,0$ & 100,0 & 127,4 & 175,8 & 256,5 & 350,0 \\
\hline & & spis poprzedni $=100,0$ & 100,0 & 127,4 & 138,0 & 145,9 & 136,5 \\
\hline & \multicolumn{2}{|c|}{ udział w ludności ogółem, w proc. } & 17,2 & 18,0 & 19,9 & 23,3 & 25,7 \\
\hline
\end{tabular}

Źródło: opracowanie i część obliczeń własnych na podstawie: [India 2003. Observer Statistical Handbook, 2003, s. D-01], [Dev (ed.), 2013, tab. A-11.2].

Zróżnicowanie terytorialne urbanizacji demograficznej przedstawiono - wraz $\mathrm{z}$ innymi danymi o ludności - $\mathrm{w}$ tab. 2.6. Najwyższymi wskaźnikami tego typu urbanizacji, na poziomie 30 i więcej procent, legitymują się stany północno-zachodnie (Goa, Haryana, Punjab, Gujarat, Maharashtra) i południowe (Karnataka, Kerala, Tamil Nadu), najmniejszymi zaś stany północne i północno-wschodnie (Bihar, Orissa i stany Trójkąta Assamskiego).

Zmienia się również struktura ludności według płci i wieku. Znamienną dla stosunków ludnościowych Indii jest - w porównaniu z większością krajów świata - znacząca przewaga liczby mężczyzn nad liczbą kobiet i przewaga ta nieznacznie zwiększa się: z 941 kobiet na 1 tys. mężczyzn $(+59)$ w 1951 roku do 933 na 1 tys. mężczyzn $(+67)$ w 1991 roku. Jest to zresztą tendencja utrzymująca się od początku XX wieku, a więc procesy maskulinizacji struktury demograficznej istniały już w czasach kolonialnych.

Różnica w strukturze ludności według płci jest bardziej widoczna wśród dzieci. W 1951 roku na 1 tys. chłopców w wieku 0-6 lat przypadało 976 dziewczynek (-24), a w 1991 było ich już 945 (-55) [Bose, 2001, s. 20]. Relacje te są w głównej mierze efektem specyficznych stosunków społecznych i kulturowych w Indiach, co zostanie przedstawione w podrozdziale 2.3.3.

W latach 80. i 90. obserwuje się m.in. systematyczny spadek udziału dzieci (do 14 lat) w populacji globalnej, zwiększa się natomiast odsetek osób w wieku produkcyjnym (15-59 lat) oraz poprodukcyjnym. Jest to efektem spadku stopy urodzeń i wydłużania się życia Indusów, co obrazują statystyki zestawione w tab. 2.2-2.4. 
Jak widać w tab. 2.2, przyrost naturalny w Indiach jest bardzo duży. Stanowi on wypadkową wysokiej liczby urodzeń i równie wysokiej śmiertelności. Różnica pomiędzy stopą urodzeń a stopą zgonów obniża się od lat 60 ., co oznacza niewielki spadek przyrostu naturalnego, a więc zmniejszenie tempa wzrostu demograficznego.

Tabela 2.2. Stopa urodzeń i zgonów oraz przyrost naturalny w latach 1951-1991, na 1 tys. mieszkańców (rocznie)

\begin{tabular}{|c|c|c|c|}
\hline Lata & Urodzenia & Zgony & Przyrost naturalny \\
\hline $1951-61$ & 41,7 & 22,8 & 18,9 \\
\hline $1961-71$ & 41,1 & 19,0 & 22,1 \\
\hline $1971-81$ & 37,2 & 15,0 & 22,2 \\
\hline 1985 & 32,9 & 11,8 & 21,1 \\
\hline 1991 & 29,5 & 9,8 & 19,7 \\
\hline
\end{tabular}

Źródło: [Gedam, 1999, s. 159].

W pierwszych czterech dekadach niepodległych Indii dokonały się duże zmiany w trwaniu życia Indusów. Na początku lat 50. - statystycznie ujmując - mieszkaniec tego kraju - zarówno mężczyzna, jak i kobieta - żył ok. 32 lat. W ciągu kolejnych czterech dziesięcioleci przeciętna długość życia Indusa niemal się podwoiła i na początku lat 90., wyniosła prawie 60 lat. Uznać to należy za duży sukces indyjskiej polityki gospodarczej i społecznej, bowiem zmiany te były bez wątpienia skumulowanym efektem przemian gospodarczych oraz demograficzno-społecznych, takich jak rozwój oświaty i medycyny, likwidacja masowego głodu._Do końca lat 70. przeciętne trwanie życia mężczyzn było dłuższe niż kobiet, statystycznie mężczyźni żyli ok. 1 rok dłużej. Sytuacja zmieniła się w latach 80., co uznać należy wręcz za przełom w rozwoju demograficzno-społecznym Indii. Przeciętne trwanie życia indyjskich kobiet jest już - podobnie jak w większości krajów świata - dłuższe niż mężczyzn i różnica ta powoli się zwiększa.

Tabela 2.3. Przeciętne dalsze trwanie życia ludności (e ${ }^{\circ}-\mathrm{w}$ latach) w okresie 1951-1991

\begin{tabular}{|c|c|c|c|}
\hline Lata & Mężczyźni & Kobiety & Różnica mężczyźni - kobiety \\
\hline 1951 & 32,5 & 31,7 & $+0,8$ \\
\hline 1961 & 41,9 & 40,6 & $+1,3$ \\
\hline 1971 & 46,4 & 44,7 & $+1,7$ \\
\hline 1981 & 54,1 & 54,7 & $-0,6$ \\
\hline 1991 & 59,0 & 59,7 & $-0,7$ \\
\hline
\end{tabular}

Źródło: [Acharya i in., 2006, s. 137], część obliczeń własnych. 
Interesujące są zmiany przeciętnej długości życia w przekroju miasto-wieś. Jak wynika $\mathrm{z}$ danych $\mathrm{w}$ tab. 2.4, w okresie 1981-1991 przeciętne trwanie życia ludzkiego w miastach jest dłuższe niż na wsi i dotyczy to w jednakowym stopniu mężczyzn oraz kobiet, przy czym różnice są znacznie wyższe w przypadku kobiet ${ }^{20}$. W ciągu dekady nastąpiła jednak zmiana w tej dziedzinie, to znaczy różnice zmniejszyły się. Znamienne jest, że w miastach przeciętne trwanie życia kobiet jest w całym badanym okresie dłuższe niż mężczyzn, natomiast na wsi sytuacja jest odwrotna - dłużej żyją mężczyźni, aczkolwiek na początku lat 90. nastąpiło zrównanie tych wskaźników. Oznacza to poprawę materialnych warunków bytu, podnoszenie poziomu edukacji oraz opieki medycznej indyjskiego społeczeństwa i zmniejszanie się zróżnicowania pod tym względem.

Tabela 2.4. Zróżnicowanie przeciętnego dalszego trwania życia ludności ( $\mathrm{e}^{\mathrm{o}}-\mathrm{w}$ latach) pomiędzy miastem a wsią w okresie 1981-1991

\begin{tabular}{|c|l|c|c|c|}
\hline \multicolumn{2}{|c|}{ Lata* } & Mężczyźni & Kobiety & $\begin{array}{c}\text { Różnica } \\
\text { mężczyźni - kobiety }\end{array}$ \\
\hline \multirow{4}{*}{$1981-1985$} & miasta & 64,9 & 67,3 & $-2,4$ \\
\cline { 2 - 5 } & wsie & 59,8 & 59,4 & $+0,4$ \\
\cline { 2 - 5 } & różnica miasto-wieś & 5,1 & 7,9 & - \\
\hline \multirow{3}{*}{$1988-1992$} & miasta & 65,5 & 68,0 & $-2,5$ \\
\cline { 2 - 5 } & wsie & 61,9 & 62,0 & $-0,1$ \\
\cline { 2 - 5 } & różnica miasto-wieś & 3,6 & 6,0 & - \\
\hline
\end{tabular}

* wielkości średnioroczne dla podanych okresów.

Źródło: [Gedam, 1999, s. 241], część obliczeń własnych.

Przeciętne trwanie życia ludzkiego jest jednak znacząco zróżnicowane regionalnie, co obrazują wskaźniki zamieszczone w tab. 2.6. Najwyższymi wartościami wskaźników trwania życia legitymują się północno-zachodnie oraz południowe stany Indii, a szczególnie Haryana, Maharashtra, Karnataka, Kerala, Punjab oraz Tamil Nadu. Najbardziej niekorzystne wartości przybierają te wskaźniki w czterech środkowych i północno-wschodnich stanach Indii (Uttar Pradesh, Bihar, Madhya Pradesh, Assam oraz Orissa). Po raz kolejny potwierdza się teza o znacznych dysproporcjach w rozwoju ekonomicznym oraz społecznym pomiędzy południowo-zachodnią a środkowo-wschodnią częścią Indii; do spraw tych powrócimy w podrozdziale 2.4.3.

${ }^{20}$ Należy wyjaśnić, że w zależności od źródła, dane statystyczne nieco różnią się od siebie. Nie są to jednak na tyle istotne różnice, aby uniemożliwiały porównania i prowadziły do odmiennych konkluzji. 
Inną ważną charakterystyką demograficzną i zarazem społeczną jest wielkość i różnorakie struktury poziomu edukacji społeczeństwa. Jego najwłaściwszą miarą dla krajów słabo rozwiniętych jest stopa alfabetyzacji, tzn. odsetek ludności umiejącej czytać i pisać. Wielkości tych wskaźników dla Indii w latach 19511991 zestawiono $\mathrm{w}$ tab. 2.5, a ich rozkład przestrzenny obrazują dane w tab. 2.6.

Tabela 2.5. Stopa alfabetyzacji społeczeństwa w latach 1951-1991

\begin{tabular}{|c|c|c|c|c|}
\hline \multirow{2}{*}{ Lata } & \multirow{2}{*}{$\begin{array}{l}\text { Ludność } \\
\text { ogółem* }\end{array}$} & \multicolumn{2}{|c|}{ W tym: } & \multirow{2}{*}{$\begin{array}{c}\text { Różnica } \\
\text { mężczyźni- kobiety }\end{array}$} \\
\hline & & Mężczyźni & Kobiety & \\
\hline 1951 & 18,3 & 27,2 & 8,9 & 18,3 \\
\hline 1961 & 28,3 & 40,4 & 15,4 & 25,1 \\
\hline 1971 & 34,5 & 46,0 & 22,0 & 24,0 \\
\hline 1981, w tym: & 43,7 & 56,4 & 29,8 & 26,6 \\
\hline miasta & 67,3 & 76,8 & 56,4 & 21,4 \\
\hline wsie & 36,1 & 49,7 & 21,8 & 27,9 \\
\hline $\begin{array}{l}\text { Różnica } \\
\text { miasto-wieś }\end{array}$ & 31,2 & 27,1 & 34,6 & - \\
\hline 1991, w tym: & 52,2 & 64,1 & 39,3 & 24,8 \\
\hline miasta & 73,1 & 81,1 & 64,1 & 17,0 \\
\hline wsie & 44,7 & 57,9 & 30,6 & 27,3 \\
\hline $\begin{array}{l}\text { Różnica } \\
\text { miasto-wieś }\end{array}$ & 28,4 & 23,2 & 33,5 & - \\
\hline
\end{tabular}

* odsetek ludności w wieku 7 i więcej lat umiejącej czytać i pisać.

Źródło: [Bose, 2001, s. 22], [Gedam, 1999, s. 244] oraz część obliczeń własnych.

Jak można dostrzec w tab. 2.5, w pierwszych czterech dekadach po uzyskaniu niepodległości w Indiach dokonał się znaczący wzrost odsetka ludności umiejącej czytać - z 18,3 proc. w 1951 roku do 52,2 proc. w 1991 roku. Jest to bez wątpienia duże osiągnięcie społeczne tego okresu. Istotne są jednak pod tym względem różnice pomiędzy kobietami a mężczyznami, aczkolwiek systematycznie się zmniejszają. Na początku lat 50 . czytać i pisać potrafił co czwarty indyjski mężczyzna i zaledwie co 11 kobieta, a na początku lat 90 . sztukę tę opanowało blisko 65 proc. mężczyzn i 40 proc. kobiet. Oczywiście odmiennie kształtuje się skala zróżnicowania umiejętności czytania i pisania w przekroju miasto-wieś. Jak wynika z tab. 2.5, w 1981 roku 67 proc., a w 1991 roku 73 proc. mieszkańców miast potrafiło czytać i pisać, natomiast na wsi odsetki te wynosiły odpowiednio 36 i 45 proc. Dystans między miastami a wsiami nieco się zmniejszył - z 31,2 do 28,4 punktów procentowych. Pomimo obniżania się, nadal istotne są jednak różnice pomiędzy alfabetyzacją kobiet i mężczyzn zarówno w miastach, jak i na wsiach. 
Tabela 2.6. Przestrzenne zróżnicowanie wybranych wskaźników rozwoju społeczno-kulturowego na początku lat 90 . XX wieku

\begin{tabular}{|c|c|c|c|}
\hline Stany & $\begin{array}{c}\text { Stopa } \\
\text { urbanizacji } \\
\text { demograficznej* }\end{array}$ & $\begin{array}{c}\text { Przeciętne dalsze } \\
\text { trwanie życia ludności } \\
\left(\mathrm{e}^{\mathrm{o}}-\mathrm{w} \text { latach }\right)^{* *}\end{array}$ & $\begin{array}{c}\text { Stopa } \\
\text { alfabetyzacji*** }\end{array}$ \\
\hline & 1991 & 1993-1997 & 1991 \\
\hline Indie ogółem & 25,7 & 61,1 & 52,2 \\
\hline Andhra Pradesh & 23,3 & 62,4 & 44,1 \\
\hline Assam & 11,1 & 56,7 & 52,9 \\
\hline Bihar & 13,1 & 59,6 & 37,5 \\
\hline Goa & 41,0 & - & 75,5 \\
\hline Gujarat & 34,5 & 61,9 & 61,6 \\
\hline Haryana & 24,6 & 64,1 & 55,9 \\
\hline Himachal Pradesh & 8,7 & - & 63,9 \\
\hline Jammu \& Kashmir & 23,8 & - & - \\
\hline Karnataka & 30,9 & 63,3 & 56,0 \\
\hline Kerala & 26,4 & 73,3 & 89,9 \\
\hline Madhya Pradesh & 23,2 & 55,5 & 44,7 \\
\hline Maharashtra & 38,7 & 65,5 & 64,9 \\
\hline Manipur & 27,5 & - & 59,9 \\
\hline Meghalaya & 18,6 & - & 49,1 \\
\hline Nagaland & 17,2 & - & 61,7 \\
\hline Orissa & 13,4 & 57,2 & 49,1 \\
\hline Punjab & 29,5 & 67,7 & 58,5 \\
\hline Rajasthan & 22,9 & 60,0 & 38,6 \\
\hline Sikkim & - & - & 56,9 \\
\hline Tamil Nadu & 34,2 & 64,1 & 62,7 \\
\hline Tripura & 15,3 & - & 60,4 \\
\hline Uttar Pradesh & 19,8 & 57,6 & 40,7 \\
\hline West Bengal & 27,5 & 62,8 & 57,7 \\
\hline
\end{tabular}

* odsetek ludności mieszkającej w miastach, ** wielkości średnioroczne, *** odsetek ludności powyżej 7 lat umiejącej czytać i pisać.

Źródło: [India 2003. Observer Statistical Handbook, 2003, s. M-01, M-07, M-08, Q-02, Q-04], [Bose, 2001, s. 115], [Statistical Outline of India 1999-2000, 1999, s. 40, 210, 212]. 
Wszystkie te statystyki wskazują, że jakkolwiek skala analfabetyzmu była w pierwszych latach niepodległości Indii bardzo duża, to w badanym okresie zmniejszała się i to we wszystkich przekrojach, co świadczy o systematycznym, chociaż powolnym rozwoju i demokratyzacji edukacji w Indiach.

Powyższe statystyki uzupełnia prezentacja stopnia analfabetyzmu w przekroju przestrzennym, czyli według stanów. Danych do analizy dostarcza tab. 2.6. Otóż w 1991 roku najmniejszymi odsetkami analfabetów legitymują się stany północno-zachodnie i południowe (Goa, Maharashtra, Kerala, Himachal Pradesh, Gujarat, Punjab i Tamil Nadu). Stosunkowo wysokimi wskaźnikami alfabetyzacji charakteryzują się także stany zaliczające się zazwyczaj do najbardziej zacofanych, tj. leżące w północno-wschodniej części kraju (Bengal Zachodni, Assam, Nagaland, Tripura, Sikkim i Manipur). Zjawisko to wytłumaczyć można przede wszystkim podejmowanymi w tych stanach w latach 80. i 90. akcjami edukacyjnymi wynikającymi m.in. z programów partii rządzących w tych regionach, tj. partii regionalnych oraz lewicowych (takich jak np. Komunistyczna Partia Indii w Bengalu Zachodnim, Kerali). Wyłonione przez te partie rządy stanowe uznawały, że pierwszym krokiem do wyjścia z zacofania jest likwidacja analfabetyzmu i podnoszenie poziomu wykształcenia społeczeństwa.

Konkludując analizę podstawowych parametrów demograficznych, można stwierdzić, że ewolucja struktury ludności Indii według wieku, a także tendencje najważniejszych miar rozwoju społecznego (edukacji, trwania życia i umieralności), wskazują, że w pierwszych czterech dekadach nastąpiły korzystne zmiany jakości społeczeństwa, systematycznie stawało się ono bardziej wykształcone i zdrowsze. Procesy te przekładają się na wzrost kapitału ludzkiego Indusów, co będzie oddziaływać stymulująco na procesy gospodarowania, demokratyzacji systemu zarządzania państwem oraz aktywizacji społeczności lokalnych w następnych dekadach.

\subsubsection{Problemy etniczne i religijne}

Półwysep Indyjski był od tysiącleci - jak chyba żaden inny obszar na świecie - bardzo zróżnicowany etnicznie, językowo, religijnie oraz obyczajowo. Do tego dochodziła jeszcze specyficzna, wyjątkowo zhierarchizowana struktura społeczna, czyli podział na kasty. W tak zdywersyfikowanym społeczeństwie istotną rolę we wszystkich wymiarach jego życia publicznego, a więc także w gospodarce, odgrywają właśnie czynniki natury etnicznej. Indii nie da się zrozumieć i opisać bez klucza etnicznego [Tokarski, 2011].

Struktura etniczna mieszkańców niepodległych Indii jest spuścizną kilku tysięcy lat burzliwej historii subkontynentu. Politycy przejmujący władzę w 1947 roku stanęli przed następującym zadaniem: w jaki sposób z tak wielkiego konglomeratu narodów i grup etnicznych stworzyć jedno społeczeństwo i utrzymać zjednoczone 
państwo? Patrząc z niemal siedmiodekadowej perspektywy można stwierdzić, że ta sztuka się im udała, pomimo wielu kłopotów i trudnych chwil ${ }^{21}$.

Podstawowym i stosunkowo łatwym w kwantyfikacji kryterium zróżnicowania etnicznego jest zazwyczaj język. Otóż w 1967 roku w VIII załączniku do konstytucji Indii (poprawka 21) wyróżniono 14 języków, które mogą być regionalnie lub lokalnie uznane za urzędowe. W 1992 roku - na mocy poprawki 71 - ich liczbę zwiększono do $18^{22}$. Oprócz tych języków istnieją setki języków lokalnych, plemiennych, narzeczy itp. Informacje statystyczne z tego zakresu są niejednoznaczne i trudno porównywalne. Według spisu ludności w 1951 roku, istniało w Indiach 845 języków, względnie narzeczy [Desai, 1960, s. 50].

Oficjalnie - zgodnie z art. 343 konstytucji Indii - językiem urzędowym tego kraju jest język hindi w pisowni devanagari, a używane cyfry to cyfry indyjskie $\mathrm{w}$ transkrypcji międzynarodowej [The Constitution of India, 2000] $]^{23}$. Drugim językiem urzędowym - oficjalnie zwanym pomocniczym - jest język angielski.

Na szczeblach stanowych i lokalnych, oprócz języka hindi, konstytucja dopuszcza - jako języki urzędowe - 17 języków regionalnych (por. tab. 2.7). Organy ustawodawcze stanów mogą zatwierdzić jeden lub więcej języków używanych na ich terenie za języki urzędowe. Integrację językową zasadniczo utrudnia różnorodność alfabetów poszczególnych języków, tylko niektóre z nich (np. hindi i marathi) mają identyczne liternictwo.

Strukturę społeczeństwa indyjskiego według języków zaprezentowano w tab. 2.7. Nietrudno dostrzec, że dominującym jest język hindi, którym posługuje się ok. 40 proc. mieszkańców Indii, szczególnie Indii środkowych i północno-zachodnich. Kolejne miejsca zajmują, ale ze wskaźnikami w granicach 5-9 proc., języki; bengali (głównie Bengal Zachodni), telugu (Andhra Pradesh), marathi (Maharashtra), tamilski (Tamil Nadu) i gudżaracki (Gujarat).

${ }^{21}$ Octavio Paz - meksykański pisarz, laureat literackiej Nagrody Nobla w 1990 roku, wieloletni ambasador Meksyku w Indiach (1962-1968) tak charakteryzował fenomen tego kraju: „Indie są etnograficznym i historycznym muzeum, ale jest to muzeum żywe, w którym najnowocześniejsza nowoczesność miesza się z archaicznością pamiętającą całe tysiąclecia. Właśnie dlatego Indie są tym rodzajem rzeczywistości, który łatwiej opisać kawałek po kawałku, niż jakoś ogólniej zdefiniować. Wobec tej różnorodności można się nie bez racji zapytać: czy Indie są naprawdę narodem? Odpowiedź jest jednoznaczna. $Z$ jednej strony Indie są konglomeratem rozmaitych ludów, kultur, języków i religii, z drugiej zaś są jednym terytorium pod jedną władzą państwową i rządzącym się jedną narodową konstytucją" [Paz, 1997, s. 66].

${ }^{22}$ W 2003 roku na mocy 92 poprawki do konstytucji (weszła w życie w styczniu 2004 roku) status języków urzędowych nadano 4 językom regionalnym. Obecnie (2014) istnieją w Indiach 22 języki urzędowe [Constitution of India 2007, s. 330, http://lawmin.nic.in/coi/coiason29july08. pdf (dostęp: 23.07.2014)].

${ }^{23}$ W Europie cyfry indyjskie oraz dziesiętny system pozycyjny zwane są arabskimi, ponieważ dotarły na nasz kontynent za pośrednictwem Arabów. Był to efekt dotarcia do Indii w VII wieku kupców arabskich, a później - w X wieku - podboju i islamizacji znacznych obszarów subkontynentu oraz utworzenia Sułtanatu Delhijskiego. 
Tabela 2.7. Struktura ludności według języków wyszczególnionych w VIII załączniku do konstytucji w 1991 roku

\begin{tabular}{|l|c|c|}
\hline \multirow{2}{*}{ Nazwa języka } & \multicolumn{2}{|c|}{ Osoby mówiące danym językiem } \\
\cline { 2 - 3 } & liczba osób, w mln & w proc. ogółu ludności \\
\hline assamski & 13,08 & 1,55 \\
\hline bengalski & 69,60 & 8,22 \\
\hline gudżaracki & 40,67 & 4,81 \\
\hline hindi & 337,27 & 39,86 \\
\hline kannada & 32,75 & 3,87 \\
\hline konkani & 1,76 & 0,21 \\
\hline malajalam & 30,18 & 3,56 \\
\hline manipurski & 1,27 & 0,15 \\
\hline marathi & 62,48 & 7,38 \\
\hline nepalski & 2,08 & 0,25 \\
\hline orija & 28,06 & 3,32 \\
\hline pendżabski & 32,75 & 3,87 \\
\hline sindhi & 2,12 & 2,51 \\
\hline tamilski & 53,01 & 6,26 \\
\hline telugu & 66,12 & 7,81 \\
\hline urdu & 43,41 & 5,82 \\
\hline pozostałe & 5,56 & 0,52 \\
\hline
\end{tabular}

Źródło: opracowanie i część obliczeń własnych na podstawie [Mallikarjun, 2001].

Analizując rozmieszczenie geograficzne języków w Indiach, nietrudno dostrzec podobieństwo przestrzenne stanów do obszarów językowych. Potwierdza się w ten sposób teza o dominacji kryterium etniczno-językowego przy ustalaniu obszaru i granic stanów. Nie oznacza to oczywiście jednolitości językowej stanów, bowiem w większości z nich, oprócz języka dominującego, istnieją setki lokalnych języków i narzeczy.

Duża liczba języków bardzo utrudnia organizację i funkcjonowanie życia publicznego. Różnorodność językowa staje się często barierą kontaktów, porozumienia i współpracy między mieszkańcami nawet jednej wsi czy regionu. Nastręcza wiele kłopotów administracji publicznej w jej komunikowaniu się z petentami, obniża efektywność edukacji, zmniejsza mobilność przestrzenną ludzi, zwiększa skłonność do konfliktów itp. Wszystko to - kumulując się - hamuje procesy unifikacji i modernizacji państwa.

Inną, niezwykle ważną determinantą życia publicznego Indii jest system religijny. Podziały religijne często nakładają się na struktury etniczne i językowe. Taki skumulowany rezultat działania czynników - etnicznego i religijnego - jest 
bardzo silny i może być groźny dla porządku publicznego, czego Indie doświadczyły wielokrotnie w postaci wielkich i często bardzo krwawych konfliktów etniczno-religijnych.

W administrowaniu tak wielkim i zróżnicowanym religijnie krajem, jakim są Indie, konieczne jest uwzględnianie podziałów religijnych i to we wszystkich niemal dziedzinach życia publicznego. Podziały te, podobnie jak czynnik etniczno-językowy, istotnie determinują przede wszystkim strukturę terytorialną nie tylko na poziomie stanów, lecz jeszcze bardziej na poziomie lokalnych jednostek administracyjnych. Historia pierwszych czterech dekad niepodległych Indii dowodzi, że najbardziej burzliwe są te konflikty, zwane komunalistycznymi, które mają u swych podstaw lokalne źródło religijne. Zresztą nawet - jak wskazują fakty - konflikty o niereligijnym początku z czasem mogą nabrać wymiaru religijnego. Przykładem takich sytuacji są: w latach 80. - konflikt sikhijski (w Punjabie) oraz w latach 90. - konflikt hindusko-muzułmański na tle budowy świątyni w Ajodhii (w Uttar Pradesh). Podłoże religijne ma też konflikt kaszmirski (pomiędzy muzułmanami a hindusami), który leży u podstaw nieustannego sporu Indii z Pakistanem i w każdej chwili może się przekształcić w wojnę.

Liczba religii, podobnie jak grup etnicznych i języków, jest w Indiach niezwykle duża, nieporównywalnie większa niż w jakimkolwiek innym kraju świata, i - co za tym idzie - nie do końca znana. Rejestracji statystycznej poddaje się co najwyżej kilka najważniejszych wyznań religijnych, co obrazują dane w tab. 2.8 .

Dominującą religią w Indiach jest hinduizm, którego wyznawcy stanowią ok. 80 proc. mieszkańców kraju. Drugą religią jest islam - ok. 13 proc. indyjskiej populacji. Innymi znaczącymi religiami są: chrześcijaństwo, sikhizm oraz buddyzm, których liczba wyznawców zawiera się w przedziale 1-2,5 proc. społeczeństwa indyjskiego. Wyznawcy pozostałych religii, a jest ich bardzo dużo, stanowią niespełna 2 proc. mieszkańców Indii.

Tabela 2.8. Struktura ludności według wyznań religijnych według spisów powszechnych

\begin{tabular}{|l|c|c|c|}
\hline \multicolumn{1}{|c|}{ Wyznawcy religii } & 1971 & 1981 & 1991 \\
\hline buddyści & 0,7 & 0,8 & 0,8 \\
\hline chrześcijanie & 2,6 & 2,4 & 2,3 \\
\hline hindusi & 82,7 & 82,6 & 82,0 \\
\hline dżiniści & 0,5 & 0,5 & 0,4 \\
\hline muzułmanie & 11,2 & 11,4 & 12,1 \\
\hline sikhowie & 1,9 & 2,0 & 1,9 \\
\hline pozostali & 0,4 & 0,3 & 0,5 \\
\hline
\end{tabular}

Źródło: [Statistical Outline of India 1999-2000, 1999, s. 47]. 
Z tab. 2.8 wynika, że w okresie czterech dziesięcioleci niepodległych Indii struktura religijna ich społeczeństwa jest właściwie niezmienna. Obserwuje się niewielki spadek odsetka hindusów, a wzrost odsetka muzułmanów, udział wyznawców pozostałych religii pozostaje niemal na tym samym poziomie.

Znamienne jest duże zróżnicowanie społeczności religijnych pod względem wykształcenia. Najwyższymi wskaźnikami alfabetyzacji legitymują się dżiniści (94,1 proc.), a kolejne miejsca zajmują: chrześcijanie ( 80,3 proc.), buddyści (72,7 proc.), sikhowie $(69,4$ proc.), hindusi $(65,1$ proc.) oraz muzułmanie (59,1 proc.) [Satyanarayanan, 2004].

Jeżeli idzie o przestrzenne rozmieszczenie religii, to w większości stanów dominuje hinduizm; jego wyznawcy stanowią 70-95 proc. ogólu ich ludności. Hindusi są mniejszością religijną jedynie w stanie Jammu \& Kashmir, gdzie przeważają muzułmanie. W małych północno-wschodnich stanach, takich jak Nagaland, Mizoram oraz Meghalaya, większością są zazwyczaj chrześcijanie.

Podsumowując, wieloetniczność, wielojęzyczność i zróżnicowanie religijne społeczeństwa Indii są z jednej strony wielkim bogactwem kulturowym kraju, ale z drugiej - komplikują organizację terytorialną oraz zarządzanie publiczne i gospodarkę, szczególnie na szczeblu lokalnym.

\subsubsection{Stratyfikacja społeczna i kulturowa}

Społeczeństwo indyjskie jest - oprócz wyżej przedstawionych podziałów etniczno-religijnych - bardzo zróżnicowane wertykalnie, czyli zhierarchizowane. Wynika to głównie z wielowiekowej historii i kultury mieszkańców Półwyspu Indyjskiego. Wiele $\mathrm{z}$ tych podziałów stoi nawet $\mathrm{w}$ sprzeczności z indyjską konstytucją, głoszącą równość ludzi i demokratyczny porządek. Pomimo to nie można tych nieformalnych społeczno-kulturowych stratyfikacji pomijać w analizie funkcjonowania państwa oraz gospodarki. Znaczenie tradycji, przyzwyczajeń, utrwalonych przez wieki, a nawet tysiąclecia relacji społecznych jest tak duże, iż pomimo zakazów prawnych nadal istotnie determinują one wszystkie poziomy i dziedziny funkcjonowania państwa indyjskiego.

Główne elementy tradycyjnej stratyfikacji społecznej w Indiach dotyczą przede wszystkim mieszkańców wyznających religię hinduską, czyli około 80 proc. ludności. Nie oznacza to, że nie występują one także w społecznościach wyznających inne religie, które - często nieświadomie - przyjęły niektóre wartości i zachowania wyznawców hinduizmu [Gupta, 1984, s. 84]. W tej sytuacji możemy więc mówić o dominacji w Indiach systemu wartości hinduistycznych. Należy dodać, że część wyznawców pozostałych religii to konwertyci z hinduizmu w pierwszym lub kolejnym pokoleniu. Ludzie ci, zmieniając wyznanie, nie zawsze zmieniali sposób życia, a więc pozostali w większym lub mniejszym stopniu w kręgu hinduskiego obyczaju. 
Podstawowym problemem życia publicznego pierwszych dekad niepodległych Indii jest istnienie obok siebie dwóch różnych, przeciwnych i w praktyce wykluczających się systemów społeczno-kulturowych, tj.:

- nowoczesnego, oficjalnie przyjętego w konstytucji z 1950 roku, ale nieznanego wcześniej na Półwyspie Indyjskim - czyli przed przybyciem Brytyjczyków - opartego na zachodnich wartościach kulturowych, takich jak m.in. egalitaryzm, demokracja i indywidualizm;

- tradycyjnego, rozpowszechnionego od tysiącleci systemu społecznego - ale w dużej mierze zniesionego w konstytucji Indii z 1950 roku - opierającego się na wartościach przeciwnych do tych pierwszych, tj. hierarchiczności i holizmie. Niektórzy autorzy określają go mianem „systemu zinstytucjonalizowanej nierówności” [Gupta, 1984, s. 29].

Tradycyjny, czyli ten drugi, system społeczny nie funkcjonuje na obszarze całego kraju w sposób jednakowy. W miastach rozwija się, wyedukowana na sposób zachodni, indyjska klasa średnia, której członkowie w większości odrzucili tradycyjny sposób życia i system wartości. Indyjskie miasta stanowią mieszankę kulturową, zlepek różnych języków, religii, zawodów itp., gdzie dotychczasowe więzy kulturowe zanikają. Pisząc o tradycyjnym systemie społecznym Indii, mamy na myśli przede wszystkim wieś, zamieszkałą przez ponad 70 proc. obywateli tego kraju.

Zasadniczym elementem starego systemu społecznego, istniejącego niemal w niezmienionej postaci przez całe pierwsze czterdziestolecie niepodległych Indii jest podział ludności na grupy społeczne. Można wyróżnić trzy rodzaje grup kształtujących świadomość oraz określających miejsce Indusa w społeczeństwie. Są to [Gaikwad, 1999, s. 68]: kasta, rodzina, autonomiczna wspólnota wiejska.

W społeczeństwie indyjskim, w przeciwieństwie do zachodniego indywidualizmu, nie liczy się samodzielna jednostka, liczy się przede wszystkim grupa. Tożsamość człowieka to tożsamość grupy, do której on należy [Nehru, 1957, s. 245]. Wykluczenie z grupy wiąże się z utratą tożsamości. Indus rodzi się jako członek grupy, żyje w zgodzie z zasadami narzuconymi przez grupę, a jego indywidualizm i działanie nie wychodzi zazwyczaj poza jej obręb. Taka struktura oraz system wartości czynią daną zbiorowość statyczną, o bardzo ograniczonych zdolnościach rozwoju [Nehru, 1957, s. 290]. Jest to swoista odmiana endogamii. Rozwój społeczny w systemie ograniczonym przez grupę może następować przede wszystkim w jej obrębie, czyli być ukierunkowany do wewnątrz, a nie na zewnątrz.

Kastowość, czyli hierarchiczny system organizacji ok. 80 proc. społeczeństwa indyjskiego, tj. przede wszystkim wyznawców hinduizmu, wyraża się w postaci warn i dżati [Gerlach, 1988, s. 4-12] $]^{24}$. Warny, czyli stany, są podstawową

${ }^{24}$ Warna - dosł. kolor, oznacza także „kategorię”, „stan”, „pochodzenie społeczne”, „miejsce w hierarchicznym porządku”. Dżati to „rodzaj”, ,gatunek”, a gdyby stworzyć słownikową definicję, dżati znaczyłoby: „grupa istot żywych o jednakowych cechach” [Paz, 1997, s. 52]. 
jednostką podziału rytualno-funkcjonalnego społeczeństwa. Istnieją cztery hierarchiczne warny. Są to (od najwyższej do najniższej):

1. Bramini - sprawują funkcje kapłańskie, zajmują się także religijnym nauczaniem, stanowią religijną elitę intelektualną.

2. Kszatrijowie - pełnią funkcje rządzących, zajmują się polityką, a w dawnych czasach stanowili trzon dowódców armii.

3. Wajśjowie - jest to warstwa wytwórców, a więc rolników, rzemieślników, kupców, bankowców itp.

4. Śudrowie - służący; we współczesnej nomenklaturze byłaby to najemna siła robocza.

Przynależność do poszczególnych warn jest zdeterminowana tylko przez urodzenie i niemożliwe jest jej zmienienie. Oprócz czterech warn, istnieją jeszcze osoby nienależące do żadnej z nich, czyli tzw. niedotykalni (albo bezkastowcy, pariasi, dalici) ${ }^{25}$.

Warna składa się z tysięcy dżati. Dżati oznacza w istocie grupę kastową, do której przynależy każdy hindus, a jedynym kryterium przynależności jest urodzenie. Każda dżati wyróżnia się specyficznymi cechami, jak np.: własnymi tradycjami, rytuałami, wykonywanym zawodem, odpowiednią dietą, sposobem ubierania się, zasadami zawierania małżeństw itp. Konfiguracja dżati we wsi stanowi o podziale pracy [Adams, 2001, s. 161]. Istnieje także nieformalny kodeks wzajemnych relacji poszczególnych dżati we wsi i w regionie. Hindus nie może istnieć poza dżati. Nie będzie mógł wówczas ożenić się, posiadać potomstwa, nie będzie wiedział, jakimi regułami postępowania ma się kierować w stosunkach z innymi ludźmi itp. Dżati odgrywają więc zasadniczą rolę w życiu każdego hindusa.

System kastowy jest tak silnie zakorzeniony w indyjskim społeczeństwie, że determinuje on wszystkie wymiary i aspekty życia. Ma on także istotny wpływ na gospodarkę, życie polityczne oraz funkcjonowanie administracji publicznej. Sytuacja ta nie zmienia się pomimo upływu czasu i konstytucyjnych zakazów oraz propagowania przez media i instytucje edukacyjne równościowych i demokratycznych zasad współżycia społecznego ${ }^{26}$. Kampanie wyborcze, zarówno do

${ }^{25}$ Terminy: niedotykalni, bezkastowcy, dalici, pariasi, harijanie stosuje się w literaturze (także w niniejszej pracy) zamiennie, na określenie tej części społeczeństwa, która według tradycyjnego systemu społecznego nie należy do żadnej kasty. Według religii hinduskiej niedotykalni to ludzie całkowicie wykluczeni z życia społecznego. H. Ellinger [1997, s. 69-70] pisze w tej kwestii m.in.: „Bez cienia przesady można powiedzieć, że hinduska ortodoksja uważa pariasów za istoty pomiędzy człowiekiem i zwierzęciem - a może nawet za niższe od zwierząt”.

${ }^{26}$ K.W. Kapp [1963, s. 64-65] pisze, iż: „nie ulega wątpliwości, że kultura hinduska - a w szczególności takie jej elementy jak religijne i przedtechnologiczne instytucje oraz takie wartości jak hierarchiczny system kastowy, ograniczone lub statyczne poziomy aspiracji, moralna powściągliwość etc. - spowalnia wzrost ekonomiczny”. Z kolei J. Nehru [1957, s. 255] tak ocenia 
parlamentu, jak i ciał lokalnych, każdorazowo potwierdzają, iż podziały kastowe nadal odgrywają największą rolę w zachowaniach wyborczych i w ogóle w trybie życia Indusów, a szczególnie mieszkańców wsi ${ }^{27}$.

Drugim rodzajem grupy, która określa świadomość oraz zachowania prywatne i publiczne Indusów, jest ród, czyli rodzina. W Indiach dominuje wielopokoleniowy model rodziny. W skład takiej rodziny wchodzą seniorzy rodu, ich dzieci - tj. synowie (samotni lub z żonami) i niezamężne córki oraz wnuki. Członkowie rodzin posiadają wspólny majątek, solidarnie uczestniczą w zdobywaniu środków do życia, razem spożywają posiłki itp. Pomimo wielu zalet tego systemu, takich jak poczucie rodzinnej tożsamości czy bezpieczeństwo socjalne, model ten kształtuje postawy, które z nowoczesnego - zachodniego punktu widzenia - należy ocenić negatywne. Podobnie jak w przypadku kast, system rodowy zabija indywidualizm oraz utrudnia rozwój jednostki. Przez całe cztery dekady niepodległych Indii był on istotnym hamulcem postępu i modernizacji społecznej.

Trzecią grupą, w której funkcjonuje Indus, jest wspólnota wiejska. Według M. Gandhiego - jak wspomniano - każda indyjska wieś powinna być małą republiką posiadającą pełnię władzy oraz być samowystarczalna. Dla Indusa pojęcie wsi charakteryzuje najszerszą wspólnotę, do której należy i tylko w jej obrębie odnajduje on swoją tożsamość. Jest ona wspólnotą ziemi i kast. Ziemia określa obszar wspólnoty, zaś wzajemne relacje i zależności pomiędzy kastami tworzą sieć bardzo skomplikowanych stosunków społecznych, które różnią się w zależności od wsi i regionu [Gerlach, 1988, s. 11]. Określają one miejsce poszczególnych kast, rodzin i płci w społecznościach wiejskich. Determinują życie wieśniaków i sprawiają, iż - podobnie jak to miało miejsce w dwóch poprzednich przypadkach - nie byliby oni w stanie żyć poza tą wspólnotą.

Obserwując indyjską rzeczywistość społeczno-kulturową, nietrudno zauważyć, iż jej niemal stałym elementem jest konflikt, rozwiązywany najczęściej drogą przemocy. Przez cały okres niepodległości Indii życie publiczne - jak rzadko którego kraju na świecie - wyróżnia się wyjątkowo dużą liczbą sporów oraz przemocy i to w różnych układach społecznych [Dębnicki, 2000, s. 21-77]. Przyjmując

tę sytuację: „W warunkach dzisiejszego społeczeństwa ustrój kastowy, ze wszystkimi swymi następstwami, jest czymś nieznośnym, reakcyjnym, stanowi balast i sprzeciwia się postępowi. W jego ramach nie może być mowy ani o równości i możliwości rozwoju, ani o demokracji politycznej, a tym bardziej ekonomicznej. Między tymi dwiema koncepcjami konflikt jest nieunikniony i tylko jedna z nich może się ostać".

${ }^{27}$ L. Dumont, wybitny francuski antropolog - znawca indyjskiego systemu kastowego, tak m.in. pisze w tej kwestii: „Jednej rzeczy możemy być pewni, a mianowicie, że społeczeństwo w swoich ogólnych ramach nie uległo zmianom. Kasty wciąż istnieją, a niedotykalność, mimo że została zdelegalizowana, nadal utrzymuje swoją moc. Pod tym względem są zgodni wszyscy specjaliści. Zatem ogólnie rzecz biorąc, nastąpiły zmiany w społeczeństwie, a nie zmiana społeczeństwa” [Dumont, 2009, s. 310-311]. 
za kryterium rodzaj i źródła konfliktów w Indiach, można wyróżnić cztery ich główne płaszczyzny:

- kastową (kastowcy - bezkastowcy, konflikty pomiędzy kastami);

- płci (różna rola społeczna kobiety i mężczyzny);

- religijną (konflikty między wyznawcami różnych religii);

- administracyjną (stosunki władza-obywatel; problem biurokracji i korupcji).

Jak już wspomniano, jednym z kluczowych - w kontekście budowania nowoczesnego i demokratycznego społeczeństwa - elementów indyjskiej konstytucji stało się zniesienie kastowości i tym samym niedotykalności. Artykuł 17 konstytucji głosi: „Znosi się «nietykalność», a jej praktykowanie w jakiejkolwiek formie jest zakazane. Stosowanie jakichkolwiek ograniczeń w prawie wynikających $\mathrm{z}$ «nietykalności» stanowi przestępstwo karane zgodnie z prawem”. Pomimo zakazu konstytucyjnego niedotykalność nie zniknęła z krajobrazu społecznego wolnych Indii. Należy zatem zgodzić się z opinią M. Gandhiego, który twierdził, że dopóki nie zmieni się system wartości hindusów z wyższych kast, dopóty też - pomimo zapisów prawnych - status niedotykalnych nie ulegnie zmianie ${ }^{28}$. Utrwalony przez wieki system wartości oraz olbrzymie korzyści dla członków kast wyższych, wynikające z istnienia licznej społeczności niedotykalnych, powodują, że odwrót od tych praktyk jest bardzo trudny oraz powolny. Ponadto, aby zniknięcie niedotykalnych stało się faktem, potrzebna jest także zmiana świadomości samych zainteresowanych i nabycie wiedzy o przysługujących im prawach. A to też - wbrew pozorom - nie jest łatwe, więc proces ten zachodzi w bardzo wolnym tempie.

Kolejnym problemem, który zaostrza konflikty międzyludzkie oraz istotnie hamuje procesy modernizacji społecznej, jest sytuacja indyjskich kobiet. Struktura społeczeństwa, jak również indyjskiej rodziny, ma ciągle charakter patriarchalny. Wyróżnia się trzy rodzaje czynników, które ograniczają rolę kobiet w Indiach [Gleason, 2001, s. 110-111]:

1. Ograniczenia kulturowe, czyli tradycyjna rola kobiety jako gospodyni domowej oraz osoby całkowicie podporządkowanej mężczyźnie ${ }^{29}$.

2. Ograniczenia ekonomiczne, czyli praktycznie całkowite uzależnienie finansowe kobiety od mężczyzny.

3. Ograniczenia polityczne wynikające $\mathrm{z}$ systemu wartości kulturowych - polegające na niechęci do obsadzania kobiet na wysokich stanowiskach w strukturach partyjnych i administracyjnych.

${ }^{28}$ M. Gandhi nazywał niedotykalnych „dziećmi bożymi” (harijanami) i na łamach utworzonego przez siebie na początku lat 30. pisma „Harijan” prowadził intensywną kampanię o prawa dla tej grupy ludzi.

${ }^{29}$ Istotę tradycyjnych relacji pomiędzy kobietami a mężczyznami w Indiach trafnie oddaje M. Gandhi w swej autobiografii: „Dla żony hindusa bezwzględne posłuszeństwo wobec swego małżonka jest niemal religią. Hindus - małżonek uważa siebie za pana i władcę swojej żony, która winna okazywać mu na każdym kroku uległość” [Gandhi, 1958, s. 221]. 
Podobnie jak to miało miejsce w przypadku kast, kobiety mają zagwarantowane określone prawa w konstytucji. Zabrania ona m.in. dziecięcych małżeństw, praktyk sati, poligamii, tradycyjnej instytucji posagu itp. Regulacje te mają jednak niewielki wpływ na praktykę życia codziennego.

W tradycyjnym systemie życia publicznego występują asymetryczne oczekiwania względem płci [Gosh, 2004, s. 95-96]. Cechy, które powinny charakteryzować polityka, takie jak: chęć władzy, dynamizm, inicjatywa, niezależność, odwaga, zdolności organizacyjne, są uznawane jako atrybuty typowo męskie i tym samym wykluczają kobiety z odgrywania ról publicznych.

Głównym elementem tradycji, który czyni narodziny córki w rodzinie wydarzeniem negatywnym, a często tragicznym, jest funkcjonująca od tysiącleci instytucja posagu. Podobnie jak hindus nie może istnieć poza kastą, tak hinduska nie może funkcjonować poza małżeństwem; małżeństwo jest dla niej wręcz kulturowym przymusem. Według tradycji, rodzina panny młodej musi obdarować rodzinę pana młodego posagiem. Jego wysokość jest ustalana przez rodziców, którzy prawie zawsze aranżują małżeństwa. Można więc uznać, iż kobieta stanowi koszt, a mężczyzna zysk dla rodziny; wartość kobiety jest mierzona wysokością posagu $[\text { Gosh, 2004, s. 104] }]^{30}$. Tylko matka, która rodzi synów, jest społecznie wartościowa. Synowie są bardziej pożądani przez indyjskie rodziny nie tylko ze względu na posag, lecz także z powodu przedłużenia istnienia rodziny (nazwisko rodowe), a także $\mathrm{z}$ tego powodu, iż to oni odprawiają rytuały żałobne po śmierci swoich rodziców.

Trzecią płaszczyzną konfliktów społecznych w Indiach jest religia. W tym kraju mieszkają wyznawcy wszystkich większych systemów religijno-filozoficznych świata. Niektóre z nich (hinduizm, sikhizm, dżinizm) wywodzą się bezpośrednio z obszaru dzisiejszych Indii, część (islam, zaratusztrianizm) mają swe źródła w innych kulturach azjatyckich, lecz zdołały trwale zakorzenić się w tym kraju, a pozostałe (głównie chrześcijaństwo) dotarły do Indii wraz z europejskimi kolonizatorami. Główny konflikt, wywołujący największe społeczne reperkusje, rozgrywa się na linii hinduizm-islam.

Wyznawców obu największych indyjskich religii, oprócz kwestii natury fundamentalnej, różni bardzo wiele, począwszy od nawyków żywieniowych, skończywszy na wyznawanych doktrynach politycznych. Nasilenie konfliktów

${ }^{30}$ Kulturowe i materialne upośledzenie indyjskiej kobiety, niechęć do rodzenia oraz wychowywania dziewczynek są przyczyną wielu morderstw niemowląt płci żeńskiej, a także częstych aborcji płodów żeńskich. Praktyki takie ułatwia wprowadzenie w 1975 roku badań prenatalnych w celu wykrywania wad rozwojowych płodów. Pod tym właśnie pretekstem identyfikowana jest płeć przyszłego dziecka, a taka wiedza niejednokrotnie sprzyja decyzjom aborcyjnym. Nierzadkie są również tzw. mordy posagowe, to znaczy mąż pozbawia życia swą żonę z powodu niewniesienia przez nią posagu lub jego niepełnej wartości. Z tych głównie powodów biorą się nietypowe relacje pomiędzy liczbą kobiet a liczbą mężczyzn, tzn. większość stanowią ci ostatni. Statystyczna egzemplifikacja tego problemu znajduje się w podrozdziałach 2.3.1 oraz 6.3.1. 
religijnych miało miejsce - jak stwierdzono w podrozdziale 2.2.1 - w latach 80. i 90. ubiegłego stulecia, wraz z rozpowszechnieniem przez nacjonalistów hinduskich ideologii hindutvy. Głosi ona, iż prawdziwym Indusem może być tylko osoba wyznająca hinduizm. Wyznawcy innych religii są na obszarze Indii - według hindutvy - tylko imigrantami [Kinnvall, 2002].

Czwartą płaszczyzną konfliktów społecznych jest praktyka funkcjonowania administracji publicznej w Indiach, a konkretniej relacje pomiędzy instytucjami publicznymi a obywatelami. Idzie tu szczególnie o zjawiska korupcji, której wyjątkowo wysoka skala występuje na poziomie lokalnym, na styku obywatel-władza, gdzie wiele ważnych spraw ludzi zależy od woli urzędników. Na tych właśnie lokalnych poziomach życia publicznego korupcja jest nagminna, jest wręcz normą polityczno-obyczajową i to bez względu na rządzącą partię czy wyznawaną religię. Pomimo solidnych, demokratycznych podstaw państwa indyjskiego, tak bardzo rozpowszechniona korupcja powoduje jego erozję, czyni to państwo „miękkim”. Jest to zjawisko niezwykle szkodliwe w specyficznej sytuacji niepodległych Indii, będących przecież w stadium konsolidacji setek narodowości, religii, kast i tym samym tworzących nową jakość społeczną na subkontynencie ${ }^{31}$. Podejmowane wielokrotnie przeciwdziałania praktykom korupcyjnym, często bardzo spektakularne (jak np. w okresie stanu wyjątkowego w połowie lat 70.), nie przynosiły jednak istotnego efektu.

Oprócz ogólnoindyjskich konfliktów kastowych, religijnych, etnicznych mamy również do czynienia z konfliktami regionalnym i lokalnymi. Problemy zaczynają się często - szczególnie na prowincji - już w szkołach, lecznicach, sklepach, a także w lokalach wyborczych, do których nie chcą uczęszczać członkowie wyższych kast, szczególnie wówczas, gdy przebywają w nich niedotykalni. Takie same są kłopoty z organizowaniem zebrań rad samorządowych, podejmowaniem uchwał, podziałem obciążeń lub przyznawaniem środków finansowych itp. Ponadto bardzo często indywidualne, prywatne nieporozumienia pomiędzy urzędnikami lub urzędnikami a petentami z różnych kast czy grup religijno-etnicznych przenoszą się na szersze forum i stają zaczynem konfliktów rasowych lub religijnych na większą skalę.

Fakt, że żyjące w wolnym, nominalnie demokratycznym państwie społeczeństwo pozostaje nadal bardzo zróżnicowane etnicznie, religijnie i kulturowo sprawia, iż trudno jest określić je mianem społeczeństwa globalnego, jest ono wciąż wielkim zbiorem społeczności lokalnych. Silna sieć prastarych, niedemokratycznych, tradycyjnych układów i uzależnień przeszkadza, a często uniemożliwia wprowadzanie nowoczesnego zarządzania, szczególnie, gdy ma ono bazować na

${ }^{31}$ G. Myrdal [1975, s. 301] - charakteryzując indyjską rzeczywistość społeczno-polityczną - pisał m.in.: ,[...] korupcja i szeroko rozpowszechniona świadomość korupcji przeciwdziałają dążeniom do konsolidacji narodu, a przede wszystkim zmniejszają szacunek i lojalność wobec rządu". 
samorządności i indywidualnej przedsiębiorczości. W tej sytuacji szerokie i głębokie reformy gospodarcze, otwarcie na świat oraz decentralizacja po 1991 roku wydają się szansą na szybszą i powszechnie odczuwalną poprawę warunków materialnych bytu i modernizację społeczno-kulturową na indyjskim subkontynencie.

\subsection{Rozwój gospodarczy}

Podobnie jak w życiu politycznym, tak i w gospodarce Indii w pierwszych dekadach niepodległości kraju można wyróżnić dwie fazy:

1. Okres socjalizmu indyjskiego (1947-1984).

2. Okres rewizji socjalizmu indyjskiego (1985-1991) ${ }^{32}$.

Najwłaściwszym kryterium periodyzacji „,socjalizmu indyjskiego” są okresy planów gospodarczych - zazwyczaj pięcioletnich i według ich sekwencji zostanie przeprowadzona analiza.

\subsubsection{Podstawy prawne, dynamika gospodarki i zmiany w jej strukturze}

W rozdziale I przedstawiono przesłanki i założenia ustrojowe indyjskiej gospodarki. W niniejszym podrozdziale zostanie dokonana prezentacja podstaw prawnych tegoż ustroju i analiza empiryczna podstawowych wskaźników wzrostu i rozwoju gospodarczego Indii.

Najważniejszym elementem gospodarki Indii od zarania niepodległości tego kraju był-jak we wszystkich krajach postkolonialnych Azji - sektor przemysłowy, ze szczególnym uwzględnieniem przemysły ciężkiego. Dla J. Nehru rozbudowa przemysłu ciężkiego była - jak już wspomniano w rozdziale I - wręcz synonimem uprzemysłowienia [Datt, Mahajan, 2014, s. 193]. Skala i tempo uprzemysławiania decydowały o dynamice gospodarki i zmianach warunków życia społeczeństwa. Dlatego też tej problematyce poświęcimy szczególną uwagę.

Założenia i główne kierunki uprzemysłowienia Indii zostały sformułowane w 1948 roku w rezolucji w sprawie polityki przemysłowej (The Industrial Policy Resolution 1948). Położyła one podwaliny pod ustrój gospodarczy niepodległego państwa. Rezolucja ta wyróżniła cztery subsektory działalności przemysłowej [Burange, Yamini, 2011, s. 7; Datt, Mahajan, 2014, s. 204]:

32 Niektórzy badacze rozwoju gospodarczego Indii podają inne cezury faz, a mianowicie 1950/51-1980/81 oraz 1980/81-1991/92 [Burange, Yamini, 2011, s. 21]. Wydaje się jednak, a potwierdzają to statystyki, że rzeczywista modernizacja gospodarki rozpoczęła się dopiero po 1984 roku, a więc po objęciu stanowiska premiera rządu Indii przez R. Gandhiego. Dlatego za początek drugiej fazy uznajemy rok 1985. 
1. Branże będące monopolem państwa (przemysł zbrojeniowy, energii atomowej, przemysł i transport kolejowy).

2. Sześć branż, w których nowe przedsiębiorstwa muszą być państwowymi, natomiast już istniejące mogą funkcjonować jako prywatne, ale po 10 latach zostaną przejęte za odszkodowaniem przez państwo (przemysł węglowy, hutniczy, lotniczy, okrętowy, paliwowy oraz telekomunikacyjny).

3. Branże będące pod kontrolą rządu i konsultowane z rządami stanowymi, ale niepodlegające centralnemu planowaniu (m.in. przemysł samochodowy, budowlany, nawozowy, cukierniczy, papierowy, włókienniczy oraz ciężka chemia);

4. Subsektor przedsiębiorstw prywatnych oraz spółdzielczych mogących się rozwijać bez ingerencji państwa.

W 1951 roku weszła w życie, w ramach przygotowania pierwszego pięcioletniego planu gospodarczego, ustawa o rozwoju i regulacji działalności gospodarczej (The Industries Development an Regulations Act 1951). Na jej mocy m.in. podjęcie działalności w formie spółki kapitałowej oraz jej rozszerzenie wymaga zgody (licencji) władz państwowych. Oznacza to w istocie ustanowienie zasady, że co nie jest dozwolone, jest zakazane [Bossak, 2008, s. 262].

W kwietniu 1956 roku parlament indyjski uchwalił nową ustawę o polityce przemysłowej kraju; nazwano ją rezolucją przemysłową (The Industrial Policy Resolution 1956). Wprowadzała ona m.in. nową klasyfikację przemysłu modyfikującą tę ustanowioną przez rezolucję z 1948 roku [Kapila, 2005, s. 224-226]. Rezolucja z 1956 roku rozszerzała kompetencje sektora publicznego w gospodarce, aczkolwiek równocześnie zakazywała dyskryminacji sektora prywatnego, np. poprzez politykę podatkową, ograniczenie dostępu do źródeł energii, surowców czy środków transportu. Państwo wspierać winno - m.in. przez subsydiowanie i ulgi podatkowe - rozwój działalności gospodarczej na wsi, przede wszystkim małych przedsiębiorstw (produkcyjnych i przetwórczych) oraz zwiększanie ich konkurencyjności w stosunku do dużych przedsiębiorstw. Rezolucja zalecała ponadto wydłużenie horyzontów planowania oraz przyspieszenie industrializacji obszarów słabo rozwiniętych. Jednym z najważniejszych zadań państwa było zmniejszanie nierówności międzyregionalnych w poziomie rozwoju przemysłu oraz infrastruktury (głównie transportu i irygacji) oraz w ogóle poprawianie warunków życia ludności, przede wszystkim poprzez zmniejszanie rozmiarów ubóstwa, a szczególnie głodu, który był wówczas stałym elementem krajobrazu społecznego w większości regionów kraju.

Taka, mocno scentralizowana polityka gospodarcza wynikała przede wszystkim z konieczności optymalizacji wykorzystania ograniczonych krajowych zasobów kapitałowych, tzn. kierowania ich do tych działów oraz regionów, w których przyniosą najwyższe wskaźniki dynamiki przemysłowej i najkorzystniej przełożą się na rozwój społeczny. Bardziej zdecentralizowany model polityki ekonomicznej prowadziłby do rozproszenia nakładów kapitałowych i zmniejszenia tempa rozwoju gospodarczego. Rezolucja przemysłowa z 1956 roku znacząco zmodyfikowała istniejący od 1948 roku podział przemysłu na sektory. Wyróżnia ona trzy 
kategorie (sektory) przemysłu [Burange, Yamini, 2011, s. 8; Kapila, 2005, s. 225; Datt, Mahajan, 2014, s. 205]:

1. Kategoria A - 17 branż będących w wyłącznej kompetencji państwa, m.in. koleje, transport, przemysły: lotniczy, broni i amunicji, żelaza i stali, energii atomowej, przetwórstwa ropy naftowej, kablowy i telefoniczny, wytwarzania oraz dystrybucji energii elektrycznej.

2. Kategoria B - 12 branż, w których istnieje sektor prywatny, ale państwo przejmuje ster poprzez ich wykupywanie oraz zakładanie nowych przedsiębiorstw.

3. Kategoria $\mathrm{C}$ - pozostałe branże, w których władze państwowe dopuszczają istnienie prywatnych przedsiębiorstw i będą wspierać ich działalność poprzez rozwój infrastruktury oraz ułatwienie kooperacji z sektorem publicznym.

Szczególnie preferowanymi inwestycjami w sektorze przemysłowym były: hutnictwo, metalurgia, kopalnictwo węgla i innych surowców oraz przetwórstwo ropy naftowej. Wiele inwestycji przemysłowych wznoszono przy udziale Związku Radzieckiego, który stał się wówczas największym partnerem gospodarczym Indii. Zaniedbany został natomiast rozwój średniego i drobnego przemysłu, zazwyczaj komplementarnego dla dużego przemysłu; obniżało to efektywność całego sektora [Boivin, 2011, s. 99].

Jeżeli polityka przemysłowa była wysoce scentralizowana, czyli podlegała władzom federalnym, to większość kompetencji w odniesieniu do rolnictwa, wytwarzającego wówczas ponad połowę produktu krajowego brutto, została powierzona stanom. Wynikało to z bardzo zróżnicowanego poziomu rozwoju kultury rolnej, odmiennych stosunków własnościowych i społecznych w różnych regionach kraju oraz orientacji politycznej władz stanowych. Jak pokazała późniejsza historia, w tych stanach, w których władze sprawowały partie lewicowe (np. w Kerali) sprawniej realizowano reformy rolne i miał miejsce szybszy rozwój rolnictwa oraz obszarów wiejskich [Boivin, 2011, s. 97-98]. W drugiej połowie lat 60. w indyjskim rolnictwie dokonała się istotna zmiana, a była nią ,zielona rewolucja”, czyli wprowadzenie, a następnie upowszechnienie w niektórych regionach uprawy nowych odmian zbóż (głównie pszenicy i ryżu). Dzięki temu w niedługim czasie Indie stały się samowystarczalne pod względem żywnościowym, klęski głodowe na masową skalę przeszły do historii.

Okres „socjalizmu indyjskiego" rozpoczyna się wraz z wdrożeniem pierwszego planu pięcioletniego. Plan ten realizowano w latach 1951/52-1955/56. Główną uwagę w tym planie, jak i kilku następnych ,pięciolatkach”, skoncentrowano na rozbudowie przemysłu (głównie ciężkiego) i infrastruktury (irygacja, energetyka i transport). Taka strategia rozwoju wynikała nie tylko z konkretnej sytuacji gospodarczej Indii, lecz także była - jak już stwierdzono w rozdziale I - odbiciem panującej w pierwszych latach po II wojnie światowej doktryny teoretycznej, zgodnie z którą uznawano, że decydującą rolę w procesie wychodzenia z głębokiego zacofania ekonomicznego i kulturowego odgrywa właśnie industrializacja, a zwłaszcza rozwój przemysłu ciężkiego. 
Wyniki realizacji zarówno pierwszego, jak i następnych planów pięcioletnich, nie były imponujące. Obrazują to wskaźniki wzrostu dochodu narodowego przedstawione w tab. 2.9.

Tabela 2.9. Tempo wzrostu produktu krajowego netto (PKN) Indii w latach 1951-1990

\begin{tabular}{|l|c|c|c|}
\hline \multirow{2}{*}{\multicolumn{1}{|c|}{ Plany gospodarcze }} & \multirow{2}{*}{ Okresy planów } & \multicolumn{2}{c|}{$\begin{array}{c}\text { Przeciętne roczne tempo wzrostu, } \\
\text { ceny stałe, w proc. }\end{array}$} \\
\cline { 3 - 4 } & & Globalnie & per capita \\
\hline I plan 5-letni & $1951 / 52-1955 / 56$ & 3,6 & 1,7 \\
\hline II plan 5-letni & $1956 / 57-1960 / 61$ & 4,1 & 2,1 \\
\hline III plan 5-letni & $1961 / 62-1965 / 66$ & 2,7 & 0,3 \\
\hline Trzy plany roczne & $1966 / 67-1968 / 69$ & 3,7 & 1,5 \\
\hline IV plan 5-letni & $1969 / 70-1973 / 74$ & 3,3 & 1,0 \\
\hline V plan 5-letni & $1974 / 75-1978 / 79$ & 5,0 & 2,7 \\
\hline Plan roczny & $1979 / 80$ & $-6,0$ & $-8,2$ \\
\hline VI plan 5-letni & $1980 / 81-1984 / 85$ & 5,4 & 3,2 \\
\hline VII plan 5-letni & $1985 / 86-1989 / 90$ & 5,8 & 3,6 \\
\hline
\end{tabular}

Źródło: opracowanie własne na podstawie: [Gedam, 1999, s. 86], [Economic Survey 20022003, 2003, tab. 1.2].

Dane statystyczne w tab. 2.9 wskazują, że w okresie realizacji pierwszych czterech planów gospodarczych (1951-1974) przeciętne tempo wzrostu dochodu narodowego nie przekraczało 4 proc., a w ujęciu per capita -2 proc. Są to wskaźniki niewysokie, świadczące o umiarkowanym tempie wzrostu gospodarczego ${ }^{33}$. Należy zaznaczyć, że sekwencja planów pięcioletnich była czasem przerywana $^{34}$. Zdarzyło się to trzy razy: w latach 1966/67-1968/69, 1979/80 oraz w latach 1990/91-1991/92. Sytuacja ta była zazwyczaj wyrazem trudności gospodarczych, klęsk żywiołowych, różnorakich zaburzeń społecznych, a także zmian politycznych, tj. przejęcia władzy przez partie opozycyjne do Indyjskiego Kongresu Narodowego, które zwykle były przeciwne pięcioletniemu, centralnemu planowaniu - tak działo się właśnie w ostatnich latach 70. i 80. minionego wieku. Należy zaznaczyć, że w latach 50. i 60 . osiągane wyniki gospo-

${ }^{33} \mathrm{~W}$ literaturze indyjskiej i źródłach statystycznych - szczególnie starszej daty - dla charakterystyki wzrostu gospodarczego podaje się najczęściej wskaźniki wzrostu produktu krajowego netto (PKN). Wskaźniki wzrostu produktu krajowego brutto (PKB) zaczęto na szerszą skalę stosować dopiero w latach 80 . minionego stulecia. Są one albo identyczne, albo różnią się między sobą nieistotnie $(0,1-0,3$ proc.), co pozwala - bez obaw popełnienia większego błędu - na zamienne posługiwanie się nimi w analizie dynamiki wzrostu gospodarczego Indii.

${ }^{34}$ Okresy, kiedy nie realizowano planów pięcioletnich, nazywa się często w literaturze indyjskiej „wakacjami planowymi” [Prasad, 1993, s. 369-370]. 
darcze znacząco odbiegały od ustaleń planowych. Wynikało to przede wszystkim z faktu dużego udziału w gospodarce sektora prywatnokapitalistycznego (głównie w rolnictwie), który z natury rzeczy trudno poddaje się planowaniu [Rudowicz, 1973, s. 76].

Głównym nośnikiem wzrostu gospodarczego w latach 1947-1974 był przemysł, czego dowodzi jego wysoka dynamika oraz szybki wzrost udziału w produkcie krajowym (por. tab. 2.10 i 2.11). Tempo rozwoju przemysłu było rzeczywiście wysokie, szczególnie w okresie realizacji pierwszych planów gospodarczych. W latach 1945-1952 przeciętna, roczna stopa wzrostu przemysłu wynosiła 4,7 proc. w latach 1951-1956 - 7,4 proc., w latach 1956-1961 - 6,8 proc., w latach 1961-1965 - 8,9 proc. Jednak w okresie 1965-1974 nastąpiło osłabienie dynamiki rozwojowej przemysłu i jego roczne przyrosty kształtowały się na poziomie ok. 3 proc., podobnie wyglądała sytuacja w drugiej połowie lat 70. i na początku lat 80 . Ponowne, i to duże przyspieszenie industrializacji, następuje dopiero $\mathrm{w}$ drugiej połowie lat 80 ., kiedy to roczne przyrosty produkcji przemysłowej wynoszą przeciętnie 8-9 proc. [Majumdar, 2012, s. 163, 304].

Na niskie tempo wzrostu gospodarczego w pierwszej połowie lat 60 . istotny wpływ wywarły dwie wojny Indii z sąsiadami tj. z Chinami (1962) oraz z Pakistanem (1965-1966). Spowodowały one m.in. konieczność nagłej rewizji planów gospodarczych i wygospodarowania dodatkowych środków finansowych na cele wojenne, a więc głównie na rozbudowę przemysłu zbrojeniowego, co - jak wyżej wykazano - zaowocowało wysokimi przyrostami produkcji, ale zadecydował o tym duży udział produkcji militarnej ${ }^{35}$.

Szczególnie niekorzystny był rok gospodarczy 1965/66, kiedy to produkt krajowy brutto obniżył się o niemal 4 proc. a w roku 1966/67 zwiększył się tylko o 1 proc. [Panda, 2013, s. 18]. Przyczynami tego załamania były intensywne działania wojenne na granicy indyjsko-pakistańskiej oraz klęski nieurodzaju w następstwie katastrofalnych susz w latach 1965-1966. W roku gospodarczym 1965/66 produkcja rolna (wraz z leśnictwem i rybołówstwem) zmniejszyła się o 9,9 proc., a w roku 1966/67 o następne 1,7 proc. [Economic Survey 2013-14. Statistical Appendix, s. 7]. W wyniku tego pojawiło się widmo masowego głodu na dużych obszarach kraju ${ }^{36}$. Zmusiło to rząd do zaciągnięcia kredytów zagranicz-

35 Wydatki na zbrojenia Indii zwiększyły się z 2,8 mld rupii w roku gospodarczym 1961/62 do 7 mld rupii w roku 1963/64 i 10 mld rupii w roku 1969/70. Udział wydatków na obronę narodową w dochodzie narodowym Indii wzrósł z niespełna 2 proc. w roku 1961/62 do 4 proc. w drugiej połowie dekady [Mrozek, 1971, s. 163-164].

${ }^{36} \mathrm{~W}$ celu zmniejszenia skutków klęsk pogodowych inwestowano w rozbudowę urządzeń irygacyjnych, umożliwiających sztuczne nawadnianie ziemi, a gdzie indziej - retencję wielkich mas wody. Sytuacja żywnościowa zaczęła się poprawiać także pod wpływem wspomnianej wcześniej „zielonej rewolucji”, a więc wprowadzenia do uprawy wysokoplennych odmian zbóż - pszenicy w północnych Indiach i ryżu na południu kraju, a także zwiększenie zużycia nawozów mineralnych, 
nych i znaczącego importu zboża ${ }^{37}$. Z tych właśnie powodów w budżecie państwa pojawił się rekordowy deficyt (7,4 proc. PKB) [Acharya i in., 2006, s. 155].

Inną przyczyną słabej dynamiki gospodarczej była narastająca biurokracja, a w ślad za nią korupcja i wszelkiego rodzaju przestępczość polegająca na transferze środków publicznych w prywatne ręce. W okresie rządów J. Nehru oraz I. Gandhi nastąpiło swoiste skumulowanie się dwóch źródeł biurokratyzacji gospodarki i życia publicznego. Stara, oddziedziczona po systemie feudalnym i kolonializmie biurokracja została wzmocniona biurokracją wykreowaną przez centralistyczny system zarządzania gospodarką (przyznawanie licencji, dotacji, limitów produkcyjnych, polityki kadrowej itp.). Efektem tego było monstrualne zbiurokratyzowanie i skorumpowanie życia gospodarczego, co z natury rzeczy musiało spowalniać rozwój gospodarczy.

W kontekście korupcji i biurokratyzacji wspomnieć należy o sytuacji w sektorze finansowym. System ubezpieczeń oraz bankowość podlegały również ścisłej regulacji państwa. W 1949 roku znacjonalizowano za odszkodowaniem Reserve Bank of India, który stał się bankiem centralnym z prawem emisji pieniądza i papierów wartościowych oraz kredytowania innych banków, a także prawem do kontroli nad działalnością banków prywatnych [Rudowicz, 1973, s. 110]. W 1969 roku znacjonalizowano 14 największych banków komercyjnych Indii, a w następnych latach miano czynić to z pozostałymi bankami oraz towarzystwami ubezpieczeniowymi [Bhagwati, Panagariya, 2013, s. 8]. Prywatnymi pozostały tylko średnie i małe banki, które z braku kapitałów oraz w obawie przed prywatyzacją nie podejmowały intensywnej ekspansji kredytowej. Towarzystwa ubezpieczeń na życie, w których duże udziały miał kapitał zagraniczny, głównie brytyjski, zostały upaństwowione w latach 50. W 1956 roku została powołana państwowa korporacja ubezpieczeń na życie, której znaczne zyski zasilały budżet państwa. Zarówno przy przejęciu przez państwo banków, spółek ubezpieczeniowych, jak i przedsiębiorstw z innych działów gospodarki, każdorazowo ich byli właściciele otrzymali odszkodowanie.

Nacjonalizacja dużej części sektora bankowego sprawiła m.in., że w polityce kredytowej uprzywilejowane były duże przedsiębiorstwa publiczne. Jednakże

środków ochrony roślin itp. W wyniku tego nastąpił znaczący wzrost zbiorów zbóż i po kilku latach Indiom nie groził już masowy głód, aczkolwiek poziom wyżywienia był nadal bardzo niski [Rozłucki, 1980, s. 53-68]. Pod koniec lat 70. Indie stały się nawet eksporterem zboża.

${ }^{37} \mathrm{Na}$ prośbę I. Gandhi znaczącą pomoc okazały Indiom w tym okresie Stany Zjednoczone Ameryki. Złożyły się na to dostawy ok. $12 \mathrm{mln}$ ton zboża oraz kredyty i pożyczki na sumę $435 \mathrm{mln}$ dolarów. Trudna sytuacja gospodarcza oraz uległość wobec USA wywołały w kręgach opozycyjnych i w ogóle w społeczeństwie ostrą krytykę rządu I. Gandhi, co przełożyło się na wyniki wyborów parlamentarnych i stanowych w 1967 roku. Indyjski Kongres Narodowy wygrał co prawda wybory parlamentarne, ale jego przewaga była już bardzo mała. Przegrał natomiast wybory w wielu ważnych stanach i tam władzę przejęła opozycja [Wolpert, 2010, s. 451-455]. 
część tych kredytów nie była spłacana, lecz częściowo lub całkowicie umarzana, a więc - ostatecznie - przybierała postać dotacji. Nie starczało natomiast pomocy finansowej dla przedsiębiorstw prywatnych, co najczęściej prowadziło do ich likwidacji lub ograniczania produkcji. Taka właśnie sytuacja na rynku finansowym była również pożywką dla rozwoju korupcji oraz akceleratorem dalszej biurokratyzacji gospodarki.

Reformy gospodarcze w połowie lat 60 ., polegające $\mathrm{z}$ reguły na dalszej centralizacji i nacjonalizacji życia gospodarczego, przyniosły jednak krótkotrwałe pozytywne efekty. Na początku lat 70 . sytuacja ponownie się pogorszyła, co było efektem wojny z Pakistanem, a m.in. koniecznością wyżywienia ok. $10 \mathrm{mln}$ uciekinierów z Bangladeszu. Sytuację pogorszyła wielka susza w latach 1972-1973 oraz duży wzrost cen ropy na skutek wojny izraelsko-arabskiej w 1973 roku. Wyrazem tego był znaczący wzrost inflacji i bezrobocia oraz zamrożenie płac. Przełamanie kryzysu i ponowne ożywienie nastąpiło w drugiej połowie lat 70 ., a było ono w głównej mierze skutkiem zaostrzenia kursu politycznego (m.in. wprowadzenie stanu wyjątkowego) i zwiększenia dyscypliny realizacji planów przez rządzący Indyjski Kongres Narodowy. Po tej poprawie koniunktury, w drugiej połowie lat 70. i na przełomie dekad nastąpiło jednak głębokie załamanie gospodarcze. W roku 1979/80 dochód narodowy obniżył się aż o 6 proc. w stosunku do roku poprzedniego i był to największy spadek w całym okresie niepodległego państwa [Panda, 2013, s. 18]. Główną przyczyną tego załamania była oczywiście nasilona centralizacja i nacjonalizacja gospodarki, natomiast metaforyczną „kroplą przepełniającą czarę” stał się ponowny, skokowy i wysoki wzrost cen ropy naftowej na rynkach światowych w okresie tzw. drugiego kryzysu naftowego (1979-1982). Źródłem tego kryzysu była rewolucja w Iranie, tj. obalenie monarchii i przekształcenie kraju w republikę islamską oraz rozpoczęcie wojny iracko-irańskiej (1980-1988).

Narastająca centralizacja i etatyzacja życia gospodarczego w latach 60. i 70 . nie przynosiły jednak oczekiwanych rezultatów. Nadmierne preferowanie rozwoju przemysłu państwowego, szczególnie ciężkiego, nie zaowocowało przyspieszeniem wzrostu gospodarczego, ani - tym bardziej - poprawą warunków życia ludności, czego dowodem były m.in. opisane w podrozdziale 2.2.1 zaburzenia społeczne i konieczność wprowadzenia stanu wyjątkowego. W gospodarce narastała dysharmonia, coraz bardziej dokuczliwe stawały się tzw. wąskie gardła, szczególnie w dziedzinach wytwarzających środki konsumpcji. Zaczęto dotkliwie odczuwać niedorozwój sektora prywatnego, tj. małych oraz średnich przedsiębiorstw i kurczenie się indywidualnej przedsiębiorczości. Stało się to podstawą do rewizji niektórych elementów polityki gospodarczej przez koalicyjny rząd Frontu Janata, który - jak wspomniano - wygrał wybory parlamentarne w marcu 1977 roku. Zmiany te wyrażono w Deklaracji w sprawie polityki przemysłowej z grudnia 1977 (The Industrial Policy Statement 1977) [Datt, Mahajan, 2014, s. 205-206]. Deklaracja ta zwracała przede wszystkim uwagę na potrzebę 
przyspieszenia rozwoju małych, rodzinnych przedsiębiorstw, szczególnie na obszarach wiejskich, które tworzyły nowe miejsca pracy (samozatrudnienie).

Po ponownym przejęciu władzy przez Indyjski Kongres Narodowy w styczniu 1980 roku nastąpiła modyfikacja polityki gospodarczej ustanowionej przez Front Janata. Wyraziła się ona w Deklaracji w sprawie polityki przemysłowej $\mathrm{z}$ lipca 1980 roku (The Industrial Policy Statement 1980). Odwołano się w niej ponownie do podstawowych założeń Rezolucji przemysłowej w 1956 roku. Oprócz dalszego rozwijania wielkiego przemysłu państwowego, podkreślono - podobnie jak w deklaracji z 1977 roku - potrzebę rozwoju rolnictwa i drobnego przemysłu rolno-spożywczego, rzemiosła, zwiększenie zatrudnienia i ograniczenie bezrobocia, na co duży wpływ mógłby mieć rozwój lokalnej przedsiębiorczości publicznej i prywatnej. Deklaracja ta zalecała też zwiększanie wymiany międzynarodowej na poziomie przedsiębiorstw, reorganizację powiązań, tj. ściślejszą kooperację między wielkimi przedsiębiorstwami publicznymi a przedsiębiorstwami małymi (tzw. federalizm gospodarczy), lepsze wykorzystanie czynników produkcji (surowców, energii, a szczególnie zasobów pracy). Zwrócono też uwagę na potrzebę nadzoru nad jakością dóbr konsumpcyjnych oraz kontroli ich cen, aby zapobiegać niewłaściwym zachowaniom producentów oraz kupców.

Proliberalne i deregulacyjne zmiany w polityce i praktyce gospodarczej zaowocowały w latach 80., szczególnie w drugiej połowie tego dziesięciolecia, przyspieszeniem tempa wzrostu indyjskiej gospodarki. W całej dekadzie lat 80 . przyrosty produktu krajowego przekraczały średnio 5 proc. rocznie, co - jak na warunki ,indyjskiego socjalizmu" - było rezultatem rekordowym, a motorem tego przyspieszenia był $\mathrm{w}$ dalszym ciągu przemysł, aczkolwiek zbliżoną (ok. 7 proc.) dynamikę wzrostu wykazują też usługi (por. tab. 2.9 i 2.10).

$\mathrm{O}$ zasadniczych zmianach $\mathrm{w}$ gospodarce możemy jednak mówić dopiero po śmierci I. Gandhi (1984) i objęciu urzędu premiera federalnego przez R. Gandhiego, który - jak stwierdzono w podrozdziale 2.2.2 - zapoczątkował reformy modernizacyjne. Stały się one wstępem do wielkich zmian dokonanych po 1990 roku, co będzie przedmiotem analizy w rozdziale III.

Wraz ze wzrostem indyjskiej gospodarki następowały zmiany w jej strukturze. Stojący u podstaw ustroju gospodarczego przyspieszony rozwój sektora publicznego (państwowego i spółdzielczego) zaowocował zwiększeniem się jego udziału w wytwarzaniu produktu krajowego brutto. Wzrósł on z ok. 10 proc. na przełomie lat 50. i 60. do niemal 30 proc. w 1990 roku. Udział sektora prywatnego poza rolnictwem utrzymywał się stale na poziomie ok. 40 proc. PKB. Malał natomiast udział sektora rolniczego (prywatnego) z ok. 50 proc. PKB na początku lat 60. do blisko 30 proc. w 1990 roku [Kohli, 2012, s. 43]. Dokładniej o zmianach w sektorowej strukturze wytwarzania produktu krajowego brutto Indii informują wskaźniki zestawione w tab. 2.10 i 2.11 .

W tab. 2.10 zawarto wskaźniki tempa wzrostu wyróżnionych trzech sektorów indyjskiej gospodarki. W całym okresie badanego czterdziestolecia najniższymi 
indeksami wzrostu legitymuje się sektor I (rolnictwo, leśnictwo i rybołówstwo). W okresie pierwszych 10 lat produkcja rolna (i pokrewnych działów) zwiększa się o niespełna 3 proc. rocznie. Połowa lat 60 . to okres wielkiego kryzysu indyjskiego rolnictwa. Przeciętne tempo wzrostu produkcji rolnej w tym czasie jest ujemne (ok. -0,2 proc.), a w roku gospodarczym 1966/67 - na skutek wielkiej suszy - produkcja ta zmniejszyła się o ponad 1 proc., co przy wysokim wzroście demograficznym oznaczało pogorszenie poziomu wyżywienia indyjskiego społeczeństwa, a nawet nawroty klęsk głodowych. Ta sytuacja przyczyniła się w zasadniczym stopniu do podjęcia radykalnych działań w celu poprawy sytuacji w dziedzinie rolnictwa oraz wyżywienia. Przy znacznej pomocy międzynarodowej udało się w Indiach przeprowadzić tzw. zieloną rewolucję, która - jak już wspomniano - zlikwidowała głód jako zjawisko chroniczne i masowe. W latach 70. i 80. nastąpiła więc poprawa sytuacji w rolnictwie i w ogóle w gospodarce żywnościowej kraju - średnioroczne tempo wzrostu produkcji czystej rolnictwa przekroczyło 3 proc.

Niskie tempo wzrostu produkcji rolnej w pierwszych czterech dekadach niepodległości Indii sprawiło, że - przy wyższej dynamice rozwojowej sektora przemysłowego i usługowego - udział sektora I w tworzeniu PKB systematycznie obniżał się - z niespełna 57 proc. w roku 1951/52 do 33 proc. w roku 1990/91. Ale do połowy lat 80 ., rolnictwo było sektorem wiodącym, co świadczy o bardzo wolnym wychodzeniu indyjskiej gospodarki z wielowiekowego zacofania, znacznie wolniejszym niż w największym, a podobnym pod względem poziomu rozwoju i struktury gospodarczej, kraju Azji, tj. Chinach, gdzie w 1990 roku udział sektora I w tworzeniu PKB wyniósł 27 proc. [Rocznik Statystyczny RP 2000, 2000, s. 705].

Tabela 2.10. Tempo wzrostu PKB Indii w podziale na sektory

\begin{tabular}{|l|c|c|c|c|}
\hline \multirow{2}{*}{ Lata } & \multirow{2}{*}{$\begin{array}{c}\text { Tempo wzrostu } \\
\text { PKB* }\end{array}$} & \multicolumn{3}{|c|}{ Sektory gospodarki } \\
\cline { 3 - 5 } & & $\begin{array}{c}\text { I - rolnictwo } \\
\text { i działy pokrewne }\end{array}$ & $\begin{array}{c}\text { II - przemysł } \\
\text { i działy pokrewne }\end{array}$ & III - usługi \\
\hline $1951 / 52-1955 / 56$ & 3,6 & 2,9 & 6,0 & 3,8 \\
\hline $1956 / 57-1960 / 61$ & 4,3 & 3,3 & 6,6 & 6,1 \\
\hline $1961 / 62-1965 / 66$ & 2,8 & $-0,2$ & 6,9 & 4,8 \\
\hline $1966 / 67$ & 1,0 & $-1,3$ & 3,3 & 3,0 \\
\hline $1951 / 52-1966 / 67$ & 3,4 & 1,8 & 6,3 & 4,4 \\
\hline $1967 / 68-1980 / 81$ & 3,8 & 3,3 & 4,1 & 4,3 \\
\hline $1981 / 82-1990 / 91$ & 5,6 & 3,5 & 7,1 & 6,8 \\
\hline
\end{tabular}

* przyrosty średnioroczne, ceny stałe.

Źródło: [Acharya i in., 2006, s. 128, 148]. 
Okres realizacji pierwszych trzech planów pięcioletnich cechuje się - jak wcześniej wykazano - dużą dynamiką industrializacji, co wyrażają wysokie wskaźniki wzrostu produkcji sektora II (przemysł przetwórczy, wydobywczy, górnictwo, budownictwo), zawierające się w granicach 6-7 proc. rocznie. $\mathrm{W}$ ostatnich latach 60. i prawie całej następnej dekadzie tempo rozwoju sektora przemysłowego obniżało się (do ok. 4 proc.), aby znów - pod wpływem reform - znacząco zwiększyć się w latach 80. (powyżej 7 proc.). Te wysokie indeksy wzrostu sprawiły, że jego udział w tworzeniu indyjskiego PKB wzrósł z 15 proc. na początku lat 50., do niemal 23 proc. w połowie lat 60 . W następnych 15 latach udział ten utrzymuje się na poziomie $22-23$ proc. PKB, a w latach 80 ., szczególnie w drugiej połowie tej dekady, zwiększył się do blisko 28 proc.

Pomimo tej względnie dużej dynamiki wzrostowej, sektor przemysłowy ma spośród trzech sektorów najniższy udział w tworzeniu indyjskiego PKB. Nie wywarł więc takiego wpływu na gospodarkę, jak to było w innych, szybko rozwijających się krajach azjatyckich, np. w Chinach, Japonii czy Korei Południowej, gdzie na przełomie lat 80. i 90. udział sektora II kształtował się na poziomie 40-50 proc. PKB [Rocznik Statystyczny RP 1999, 1999, s. 708].

Tabela 2.11. Struktura wytwarzania PKB Indii według sektorów

\begin{tabular}{|c|c|c|c|}
\hline \multirow{2}{*}{ Lata } & \multicolumn{3}{|c|}{ PKB ogółem = 100,0 } \\
& \multicolumn{3}{|c|}{ w tym wytworzony w*: } \\
\cline { 2 - 4 } & sektor I & sektor II & sektor III \\
\hline $1950 / 51$ & 56,5 & 15,1 & 28,4 \\
\hline $1955 / 56$ & 54,5 & 16,9 & 28,6 \\
\hline $1960 / 61$ & 52,1 & 18,7 & 29,2 \\
\hline $1965 / 66$ & 44,8 & 22,8 & 32,4 \\
\hline $1970 / 71$ & 45,8 & 22,4 & 31,8 \\
\hline $1975 / 76$ & 44,0 & 22,4 & 33,6 \\
\hline $1980 / 81$ & 39,6 & 24,4 & 36,0 \\
\hline $1985 / 86$ & 36,3 & 26,0 & 37,7 \\
\hline $1990 / 91$ & 32,9 & 28,0 & 39,1 \\
\hline
\end{tabular}

* w proc., ceny stałe.

Źródło: [Gedam, 1999, s. 98].

Tempo rozwoju usług było - jak widać w tab. 2.10 i 2.11 - niższe niż przemysłu. Niemniej jednak w połowie lat 80 . sektor usług stał się wiodącym w gospodarce Indii; jego udział w tworzeniu produktu krajowego przewyższył sektor rolny. Można więc twierdzić, że indyjska gospodarka wyszła w tym okresie z fazy agrarno-usługowej, a stała się usługowo-agrarną. W świetle tej makroekonomicznej statystyki widać, że sektor przemysłowy, pomimo dynamicznego rozwoju 
w pierwszych dekadach, nie stał się dominujący w gospodarce Indii. Oznacza to, że nie wywarł jednak tak istotnego piętna na rozwoju gospodarczym, jak było to w większości innych krajów azjatyckich wychodzących z głębokiego zacofania - zarówno kapitalistycznych, jak i socjalistycznych.

Wysoki udział sektora usług w tworzeniu indyjskiego PKB nie może być jednoznacznie interpretowany, to znaczy tylko jako wyraz jej unowocześnienia, czyli serwicyzacji. Wskaźniki te można uznać nawet za wyraz zacofania gospodarczego i w ogóle społecznego. W pierwszych trzech dekadach niepodległości, $\mathrm{w}$ indyjskim sektorze usług nie dominują jeszcze nowoczesne rodzaje usług, lecz - jak we wszystkich prawie krajach nierozwiniętych - do absurdu czasem rozbudowane usługi proste $w$ tradycyjnych działach gospodarki, tj. np. duża skala handlu ulicznego i bazarowego, ulicznej gastronomii, transportu miejskiego (riksze), służby hotelowej i domowej, usług naprawczych itp.

\subsubsection{Problem ubóstwa}

W koncepcjach twórców i pierwszych sterników niepodległych Indii - jak stwierdzono w rozdziale I - za główny, społeczny cel przyspieszonej industrializacji i w ogóle rozwoju gospodarczego, uznano stworzenie „socjalistycznego modelu społeczeństwa”. Podstawowym wyznacznikiem postępu w tej dziedzinie miało być zmniejszanie się ogromnych nierówności społecznych, a w tym przede wszystkim ograniczanie ubóstwa.

Przez dziesiątki lat życie gospodarcze i społeczne Indii kojarzone było z ogromną biedą dotykającą zdecydowaną większość społeczeństwa, biedą często trudną do wyobrażenia dla mieszkańców zachodniej półkuli. Indyjskie społeczeństwo uchodziło niemal za klasyczny przypadek społeczeństwa masowego ubóstwa ${ }^{38}$.

Statystycznym wyrazem ubóstwa są odsetki ludności żyjącej poniżej linii ubóstwa, tj. wymiernej w jednostkach pieniężnych lub naturalnych (np. kalorii) granicy, poniżej której następuje wykluczenie społeczne, a w kategoriach biologicznych - poważne zagrożenie życia [Sen, 2008, s. 124]. Linia ubóstwa (zwana też progiem albo granicą ubóstwa) dzieli badaną populację na ubogich oraz nieubogich. Oczywiście granica ta nie jest kategorią w pełni obiektywną, niezmienną

${ }^{38}$ Nędza i poniżenie człowieka stały się wręcz jednym ze znaków firmowych Indii. J.K. Galbraith w swej książce pod tytułem Istota masowego ubóstwa [1987], napisanej pod wpływem dłuższego pobytu w Indiach i osobistego rozpoznania tego problemu (jako ambasador USA na początku lat 60. ubiegłego wieku) wyróżnia dwie formy ubóstwa. Pisze on [1987, s. 9]: „W pewnych społeczeństwach ofiarą ubóstwa pada bardzo nieznaczna liczba, a w każdym razie mniejszość jego członków, natomiast w innych dotyka ono wszystkich z wyjątkiem bardzo niewielu". Ta druga sytuacja odpowiadała ówczesnemu społecznemu krajobrazowi Indii. 
W czasie i przestrzeni. W jej ustalaniu uwzględnia się nie tylko sytuację ekonomiczną jednostek, rodzin czy grup ludności, lecz także trudne do kwantyfikacji ich stany społeczne i kulturowe (np. dostęp do edukacji, ochrony zdrowia, wody pitnej, prawa obywatelskie). Linia ubóstwa ustalana jest zazwyczaj tzw. metodą ekspertów, a więc czynią to specjaliści z różnych dziedzin - ekonomii, demografii, medycyny, kultury oraz prawa. W następnej kolejności przeprowadza się badania statystyczne i na ich podstawie są obliczane wskaźniki (stopa) ubóstwa.

W tab. 2.12 zestawiono wskaźniki ubóstwa społeczeństwa indyjskiego dla pierwszych czterech dekad po uzyskaniu niepodległości. Z danych tych wynika, że w pierwszym ćwierćwieczu niepodległości, a więc do połowy lat 70., poziom ubóstwa społeczeństwa indyjskiego nie tylko się nie zmniejszał, ale nastąpił nawet jego znaczący wzrost. W latach 1951/52-1973/74 odsetek ludności znajdującej się w strefie nędzy (poniżej linii ubóstwa) zwiększył się o 9,6 punktu procentowego, co należy uznać za bardzo wysoki wzrost. Proces ten był w głównej mierze efektem wysokiego przyrostu naturalnego ludności, a na ten ostatni wpływała wysoka i w dodatku rosnąca stopa urodzeń oraz wydłużanie się długości życia Indusów, co zmniejszało ich śmiertelność (por. tab. 2.2-2.3). Drugi zespół przyczyn to wspomniane $\mathrm{w}$ podrozdziale 2.4.1 trudności gospodarcze $\mathrm{w}$ połowie lat 60 . wynikłe z wojen z Chinami i Pakistanem oraz klęsk pogodowych w latach 1965-1966.

Tabela 2.12. Wskaźniki ubóstwa ludności Indii

\begin{tabular}{|c|c|c|c|c|}
\hline \multirow{2}{*}{ Lata } & \multicolumn{4}{|c|}{ Odsetek ludności poniżej linii ubóstwa } \\
\cline { 2 - 4 } & \multirow{2}{*}{ ogółem } & \multicolumn{2}{|c|}{ w tym: } & \multirow{2}{*}{$\begin{array}{c}\text { różnica } \\
\text { miasta-wsie }\end{array}$} \\
\cline { 3 - 4 } & & miasta & wsie & \\
\hline $1951-52$ & 45,3 & 35,5 & 47,4 & $-11,9$ \\
\hline $1961-62$ & 46,5 & 43,6 & 47,2 & $-3,6$ \\
\hline $1970-71$ & 52,9 & 45,0 & 54,8 & $-9,8$ \\
\hline $1973-74$ & 54,9 & 49,0 & 56,4 & $-7,4$ \\
\hline $1977-78$ & 51,3 & 45,2 & 53,1 & $-7,9$ \\
\hline 1983 & 44,5 & 40,8 & 45,7 & $-4,9$ \\
\hline $1987-88$ & 38,9 & 38,2 & 39,1 & $-0,9$ \\
\hline $1993-94$ & 36,0 & 32,4 & 37,3 & $-4,9$ \\
\hline
\end{tabular}

Źródło: [Acharya i in., 2006, s. 136], część obliczeń własnych.

Znacznie szybciej rosła stopa ubóstwa w miastach niż na wsiach, co tłumaczyć należy przede wszystkim dużymi migracjami do miast i rosnącym tam bezrobociem. Na te migracje w decydującym stopniu wpływał zaś rozwój przemysłu oraz przeludnienie, pogarszanie się warunków pracy i życia na wsi, przynajmniej w niektórych regionach kraju. Wspomniana wcześniej „zielona rewolucja” w latach 60 . przyniosła - chociaż z pewnym opóźnieniem - wzrost plonów i poprawę 
poziomu życia ludności wiejskiej, ale nie dotyczyło to wszystkich jej warstw ani też całego kraju ${ }^{39}$.

Pomimo wyższej dynamiki wzrostu ubóstwa w miastach w pierwszym ćwierćwieczu niepodległości, było ono - jak wynika z tab. 2.12 - znacznie niższe niż na obszarach wiejskich. Jednakże w miarę upływu czasu różnice systematycznie się zmniejszały.

Obniżenie się pod koniec lat 80 . stopy ubóstwa poniżej 40 proc., zarówno na obszarach miejskich, jak i wiejskich, uznać można - w konkretnych indyjskich warunkach - za istotne osiągnięcie społeczne. Jest to bez wątpienia efekt powolnego co prawda, ale systematycznego wzrostu gospodarczego oraz postępowych przemian społeczno-kulturowych. W niektórych regionach kraju wielce pozytywną rolę w ograniczaniu ubóstwa odegrała prospołeczna, nakierowana na rozwijanie lokalnej przedsiębiorczości, polityka władz stanowych (głównie lewicowych rządów w Kerali i Bengalu Zachodnim) [Kohli, Mullen, 2003, s. 217-220].

Istotne obniżenie rozmiarów ubóstwa stało się jednym z najważniejszych celów społecznych siódmego planu gospodarczego (1985/86-1989/90), będącego - jak wspomniano - głównym narzędziem nowej polityki rządu R. Gandhiego. Zamierzano zmniejszyć zasięg ubóstwa do poziomu 25 proc. ludności kraju. Zrealizowanie jednak tak ambitnego zadania w krótkim przedziale czasu i wobec szybko narastającego kryzysu energetycznego oraz wzrostu zadłużenia publicznego, okazało się niemożliwe. Odnotowano jednak znaczący - jak nigdy dotąd - postęp w poprawie warunków życia najbiedniejszych grup społecznych.

39 „Zielona rewolucja” nie objęła całego obszaru rolnego Indii. Wyodrębnić można dwa rejony jej koncentracji, tj. północno-zachodni, gdzie rozwinęła się uprawa nowych odmian pszenicy (Punjab, Haryana, Uttar Pradesh) oraz rejon południowy, gdzie wprowadzano nowe odmiany ryżu (Tamil Nadu, Andhra Pradesh oraz Kerala). Wielką przeszkodą we wdrażaniu i znaczącym postępie reform indyjskiego rolnictwa były specyficzne, niemal jeszcze feudalne stosunki społeczne na wsi, a więc małe gospodarstwa, często dzierżawiące ziemię od latyfundystów, stare techniki uprawy, niski poziom kultury rolnej itp. W świetle tego unowocześnienie rolnictwa wymagało nie tylko „zielonej rewolucji”, ale równocześnie - jak metaforycznie piszą niektórzy indyjscy ekonomiści - „,czerwonej rewolucji”, czyli radykalnych reform rolnych polegających na nadaniu chłopom na własność dzierżawionej dotąd ziemi lub też tworzenie wielkich, państwowych albo spółdzielczych gospodarstw na wzór chiński lub radziecki [Chandra i in., 1999, s. 416]. Do tak radykalnych zmian jednak nie doszło, uchwalane wielokrotnie reformy rolne były z reguły bojkotowane przez latyfundystów i realizowane tylko częściowo, struktura własnościowa oraz obszarowa nie uległa istotniejszym zmianom. W wyniku ,zielonej rewolucji” wzrosły dochody części rolników, szczególnie tych, którzy posiadali lub dzierżawili większe połacie ziemi. Pogłębiło się jednak zróżnicowanie materialne ludności wiejskiej, zmniejszać zaczęła się - tak do tej pory rozpowszechniona - dzierżawa ziemi, gdyż latyfundyści - wobec perspektyw większego zysku - sami zaczęli ją uprawiać. W tej sytuacji wielu dzierżawców utraciwszy ziemię stawało się robotnikami rolnymi, zatrudnianymi jako najemna, z reguły sezonowa siła robocza. Rodziło to konflikty społeczne nie tylko na obszarach wiejskich, ale także w miastach, dokąd często udawali się pozbawieni ziemi rolnicy i tym samym zwiększali liczbę bezrobotnych oraz biedoty miejskiej. „Zielona rewolucja” zwiększyła - co jest paradoksem - dysproporcje regionalne w poziomie rozwoju gospodarczego. 


\subsubsection{Dynamika i poziom rozwoju gospodarczego stanów}

Analiza przestrzennego zróżnicowania wzrostu gospodarczego w Indiach zostanie przeprowadzona w oparciu o podział kraju na stany. Nie zostały jednak uwzględnione wszystkie stany. Osiem niewielkich obszarowo oraz ludnościowo stanów leżących w północno-wschodniej części kraju (w pobliżu granic z Chinami, Birmą, Bangladeszem, Bhutanem i Nepalem) ujęto łącznie pod nazwą Trójkąta Assamskiego (Arunachal Pradesh, Assam, Manipur, Meghalaya, Mizoram, Nagaland, Sikkim i Tripura ${ }^{40}$. Z uwagi na bardzo małe znaczenie dla gospodarki indyjskiej pominięto także - z jednym wyjątkiem Delhi (od 1991 roku Delhi NCT) - terytoria unijne ${ }^{41}$. Podstawowe wskaźniki do tej analizy zestawiono w tab. 2.13.

Analizując tab. 2.13, nietrudno dostrzec, że dynamika gospodarcza indyjskich stanów w latach 80 . była istotnie zróżnicowana. Najwyższymi wskaźnikami wzrostu produktu społecznego netto (PSN) legitymują się Rajasthan oraz Delhi - w obu tych jednostkach nastąpiło jego podwojenie (wskaźniki wzrostu powyżej 200 proc.). Do drugiej grupy zaliczają się te stany, w których tempo wzrostu gospodarczego przekracza średni przyrost PSN dla całych Indii $(67,2$ proc.). Są to według kolejności stóp wzrostu: Haryana $(88,6)$, Andhra Pradesh $(85,4)$, Goa (80,3), Maharashtra (79,5), Tamil Nadu $(72,1)$ i Punjab $(68,7)$. Trzecią grupę tworzą stany, których tempo wzrostu PSN kształtuje się na poziomie nieco niższym niż średnie krajowe, ale przewyższa 60 proc. Są to: Gujarat $(65,6)$, Karnataka $(63,1)$, Uttar Pradesh $(62,6)$ oraz Bihar $(61,1)$. Najniższymi przyrostami PSN legitymują się natomiast: Himachal Pradesh $(59,2)$, stany Trójkąta Assamskiego $(58,6)$, Madhya Pradesh $(53,4)$, West Bengal $(50,7)$, Kerala $(37,6)$, Jammu \& Kashmir $(29,5)$ oraz Orissa $(26,2)$.

$\mathrm{Z}$ analizy wskaźników dynamiki PSN w tab. 2.13 wynika, że znacznie szybciej rozwijały się północno-zachodnie i południowo-wschodnie stany Indii. Stany wykazujące szybszy niż średni krajowy wzrost gospodarczy zwiększyły swój udział w gospodarce Indii (produkcie krajowym). Należą do nich przede wszystkim takie stany, jak: Maharashtra (przyrost o 1,0 punkt procentowy), Rajasthan $(0,9)$, Andhra Pradesh $(0,8)$, Haryana i Delhi (po 0,3$)$, Tamil Nadu $(0,2)$ oraz Punjab $(0,1)$. Są to głównie stany leżące w północno-zachodniej części kraju. W przypadku pozostałych stanów mamy do czynienia albo z utrzymaniem dotychczasowego udziału $\mathrm{w}$ tworzeniu produktu krajowego, albo też z jego obniżeniem

${ }^{40}$ Nazwa „Trójkąt Assamski” jest często używana w ekonomicznej i geograficznej literaturze indyjskiej na oznaczenie tych właśnie 8 małych stanów. Są bardzo często wyłączane z regionalnej analizy indyjskiej gospodarki z uwagi na ich nietypowość dla struktury terytorialnej Indii: administracyjną (specjalne regulacje), małą powierzchnię i liczbę ludności oraz niewielkie gospodarki.

${ }^{41} \mathrm{Z}$ uwagi na wielokrotną reorganizację stanowego szczebla administracji państwa w latach wcześniejszych i częste zmiany granic stanów i terytoriów unijnych - co opisano w podrozdziale 2.1 - analizą objęto tylko lata 80 . 
się. Dotyczy to w szczególności Uttar Pradesh, Orissy, Kerali, Biharu, Madhya Pradesh oraz Trójkąta Assamskiego. Są to (poza Keralą) stany leżące w środkowo-wschodniej części kraju.

Powyższa analiza wskazuje, że w latach 80 . nastąpiło pogłębienie się regionalnego zróżnicowania indyjskiej gospodarki. W wytwarzaniu produktu krajowego zwiększył się udział stanów północno-zachodnich, a zmniejszył stanów środkowych i północno-wschodnich.

Tabela 2.13. Wybrane wskaźniki zróżnicowania regionalnego indyjskiej gospodarki

\begin{tabular}{|c|c|c|c|c|c|c|}
\hline \multirow{3}{*}{ Stany } & \multicolumn{3}{|c|}{$\begin{array}{l}\text { Produkt społeczny netto stanów } \\
\text { (PSN), ceny stałe }\end{array}$} & \multicolumn{3}{|c|}{$\begin{array}{c}\text { Produkt społeczny netto stanów } \\
\text { (PSN) per capita, w rupiach, } \\
\text { ceny stałe }\end{array}$} \\
\hline & \multirow{2}{*}{$\begin{array}{l}\text { wzrost } \\
\text { 1980/81 } \\
-1990 / 91 \\
\text { w proc. }\end{array}$} & \multicolumn{2}{|c|}{\begin{tabular}{|c|} 
udział w produkcie \\
krajowym netto \\
$(\mathrm{PKN})$ Indii, w proc. $*$ \\
\end{tabular}} & \multirow[t]{2}{*}{$1980 / 81$} & \multirow[t]{2}{*}{ 1990/91 } & \multirow{2}{*}{$\begin{array}{c}\text { wzrost } \\
1980 / 81 \\
-1990 / 91 \\
\text { w proc. }\end{array}$} \\
\hline & & $1980 / 81$ & $1990 / 91$ & & & \\
\hline Andhra Pradesh & 185,4 & 6,9 & 7,7 & 1380 & 2060 & 149,2 \\
\hline Bihar & 161,1 & 6,0 & 5,8 & 917 & 1197 & 130,5 \\
\hline Delhi & 205,5 & 2,3 & 2,6 & 4030 & 5447 & 135,2 \\
\hline Goa & 180,3 & 0,3 & 0,3 & 3145 & 4883 & 155,3 \\
\hline Gujarat & 165,6 & 6,2 & 6,1 & 1940 & 2641 & 136,1 \\
\hline Haryana & 188,6 & 2,9 & 3,2 & 2370 & 3509 & 148,1 \\
\hline Himachal Pradesh & 159,2 & 0,7 & 0,7 & 1704 & 2241 & 131,5 \\
\hline Jammu \& Kashmir & 129,5 & 1,0 & 0,8 & 1776 & 1784 & 100,5 \\
\hline Karnataka & 163,1 & 5,3 & 5,2 & 1520 & 2039 & 134,1 \\
\hline Kerala & 137,6 & 3,6 & 3,1 & 1508 & 1815 & 120,4 \\
\hline Madhya Pradesh & 153,4 & 6,7 & 6,3 & 1358 & 1696 & 124,9 \\
\hline Maharashtra & 179,5 & 14,4 & 15,4 & 2435 & 3483 & 143,0 \\
\hline Orissa & 126,2 & 3,3 & 2,5 & 1314 & 1383 & 105,3 \\
\hline Punjab & 168,7 & 4,2 & 4,3 & 2674 & 3730 & 139,5 \\
\hline Rajasthan & 205,4 & 3,9 & 4,8 & 1222 & 1942 & 158,9 \\
\hline Tamil Nadu & 172,1 & 6,8 & 7,0 & 1498 & 2237 & 149,3 \\
\hline Uttar Pradesh & 162,6 & 13,3 & 12,9 & 1278 & 1652 & 129,3 \\
\hline West Bengal & 150,7 & 9,1 & 8,3 & 1773 & 2145 & 121,0 \\
\hline Trójkąt Assamski & 158,6 & 3,1 & 3,0 & $1284 *$ & $1544 *$ & 120,2 \\
\hline Indie - ogółem** & 167,2 & 100,0 & 100,0 & 1543 & 2091 & 135,5 \\
\hline
\end{tabular}

* uwzględniono tylko stan Assam, ** w obliczeniach PSN pominięto terytoria związkowe (unijne), na obszarze których wytwarza się ok. 0,5 proc. PKN Indii.

Źródło: opracowanie i część obliczeń własnych na podstawie [Indian Public Finance Statistics 1999-2000, 2000, s. 85, 87]. 
Analiza dynamiki wzrostu gospodarczego stanów oraz wynikające z tego zmiany udziału stanów w PKN Indii umożliwiają poznanie miejsca i znaczenia danego stanu w indyjskiej gospodarce. Nie daje to jednak jeszcze podstaw do pełnej oceny sytuacji gospodarczej stanów ani relacji pomiędzy nimi pod tym względem. Taką wiedzę można uzyskać dopiero po analizie poziomu rozwoju gospodarczego i jego dynamiki, którego najlepszym, agregatowym miernikiem jest wielkość produktu społecznego na 1 mieszkańca [Bhattacharya, Sakthivel, 2004; Kohli, 2012, s. 317]. Wynika to z faktu, że tak mierzony poziom rozwoju gospodarczego jest wypadkową nie tylko rozmiarów i tempa wzrostu globalnego produktu społecznego w danym stanie, lecz także dynamiki zmian demograficznych. Poziom rozwoju gospodarczego podnosi się wówczas, gdy tempo wzrostu produktu społecznego przewyższa tempo zmian demograficznych. W przeciwnym razie mamy do czynienia z regresem ekonomicznym, czyli obniżaniem się poziomu rozwoju gospodarczego.

W ostatnich trzech kolumnach tab. 2.13 zestawiono wielkości produktu społecznego netto stanów (PSN) per capita. Na tej podstawie można dokonywać porównań poziomu rozwoju gospodarczego oraz jego zmian w latach 80 .

Dane liczbowe w tab. 2.13 wskazują, że poziom rozwoju gospodarczego poszczególnych stanów Indii był w obu badanych latach znacząco zróżnicowany. W roku gospodarczym 1980/81 regionem o najwyższym produkcie społecznym netto per capita było Delhi (4030 rupii) i wartość ta przekraczała 3,1-krotnie średnią krajową oraz 4,4-krotnie produkt społeczny netto w stanie najbardziej zacofanym - Biharze (917 rupii). W ciągu dekady, czyli do roku 1990/91, różnica w stosunku do średniej krajowej zwiększyła się do 3,5-krotności, a w odniesieniu do Biharu była 4,5-krotna (Delhi - 5447 rupii, a Bihar 1197 rupii).

Wielkości produktu społecznego netto poszczególnych stanów w obu badanych latach oraz wskaźniki ich zmian wskazują, że w latach 80. postępował w Indiach proces terytorialnego różnicowania się (dywergencji) poziomu rozwoju gospodarczego. Najwyższe przyrosty PSN per capita miały miejsce w zachodnich (Rajasthan, Goa, Haryana, Maharashtra, Punjab, Gujarat i Karnataka) oraz południowych (Tamil Nadu i Andhra Pradesh) stanach Indii.

Jakkolwiek dane w tab. 2.13 umożliwiają porównywanie poziomu rozwoju gospodarczego poszczególnych stanów - co wyżej uczyniono, to jednak postępując w ten sposób, trudno byłoby sformułować generalną konkluzję o zmienności poziomu rozwoju w skali całego kraju. Aby móc to uczynić, należy wykorzystać niektóre statystyczne metody analizy zmienności struktur. W tym właśnie celu posłużono się takimi miarami, jak rozstęp oraz współczynnik zmienności. Wyliczeń dokonano na podstawie danych $\mathrm{z}$ tab. $2.13^{42}$.

${ }^{42}$ Rozstęp jest - w naszym przypadku - różnicą pomiędzy najwyższą a najniższą wartością produktu społecznego netto per capita $\mathrm{w}$ badanych stanach $\mathrm{w}$ danym roku. W zapisie matematycznym ma on postać $\mathrm{R}_{\mathrm{x}}=\mathrm{x}_{\max }-\mathrm{x}_{\min }$. Natomiast współczynnik zmienności określony jest wzorem 
Rozstęp, czyli odległość pomiędzy najwyższą a najniższą stanową wartością produktu społecznego netto per capita, tj. pomiędzy Delhi a Biharem wyniósł w roku gospodarczym 1980/91 3113 rupii, a w roku 1990/91 było to już 4250 rupii. Jeżeli uwzględnilibyśmy nie krańcowe stany (o najwyższej i najniższej wartości PSN per capita), ale zajmujące w tej klasyfikacji miejsca drugie od początku i drugie od końca (czyli przedostatnie), tj. w 1980/81 roku Goa oraz Rajasthan, a w 1990/91 - Goa i Orissa, to - jak widać w tab. 2.13 - różnice wynosiły odpowiednio 1923 rupie oraz 3500 rupii. Dyspersja jest więc bardzo wyraźna.

Ostatecznym weryfikatorem hipotezy o przestrzennym różnicowaniu się poziomu rozwoju gospodarczego Indii w latach 80. są rosnące wartości współczynnika zmienności. Wyniosły one: w 1980/81 roku - 32,3 proc., a w 1990/91 $-36,7$ proc. Oznacza to, że tezę o narastającej w latach 80 . dywergencji regionalnej poziomu rozwoju gospodarczego Indii można uznać za udowodnioną.

\subsubsection{Gospodarka Indii na tle Azji}

Studia historycznie wskazują, że gospodarka zlokalizowana na obszarze zbliżonym do dzisiejszych Indii należała niemal zawsze do największych w świecie. Szacuje się, że około 1000 roku nowej ery ówczesne Indie wytwarzały niemal 30 proc. światowego PKB i były największą gospodarką globu ziemskiego. Przewyższały o ok. 25 proc. gospodarkę chińską, niemal 11-krotnie japońską oraz 3,3-krotnie zachodnioeuropejską. Pozycję tę utrzymywały do końca XV wieku, kiedy na czoło wyszły Chiny. W XVIII wieku Indie zostały zdystansowane przez Europę Zachodnią, a pod koniec XIX wieku przez Stany Zjednoczone Ameryki [Majumdar, 2012, s. 127-128 oraz tab. A 6].

Gospodarka niepodległych Indii na przełomie lat 40. i 50. była największą w Azji - od Nowej Gwinei po Bosfor. W 1950 roku 22,6 proc. azjatyckiego PKB powstało w Indiach [Bywalec, 2010]. W pierwszych latach po II wojnie światowej Indie były w lepszej sytuacji niż pozostałe państwa tego regionu. Najbardziej zaludniona i rozwinięta gospodarczo południowo-wschodnia część Azji była mocno zniszczona przez działania wojenne i okupację japońską. Indie odzyskały wolność w sposób pokojowy i nie doszło tam, jak w Indonezji, Indochinach (Laos, Kambodża, Wietnam) czy Malezji, do zbrojnych, wyniszczających gospodarkę konfliktów z kolonizatorami (Holandią, Wielką Brytanią i Francją) ani też wieloletnich wojen domowych oraz podziału państw na socjalistyczne i kapitalistyczne (Chiny, Korea, Wietnam).

$\mathrm{V}_{\mathrm{dx}}=\mathrm{d}_{\mathrm{x}} / \mathrm{M}_{\mathrm{x}}$, gdzie $\mathrm{d}_{\mathrm{x}}$ - odchylenie przeciętne wartości produktu stanowego netto per capita od średniej arytmetycznej w stanach w poszczególnych latach, $\mathrm{M}_{\mathrm{x}}$ - średnia arytmetyczna wartości produktu stanowego netto per capita dla badanych stanów w danym roku). Wartości współczynnika zmienności podano w procentach. Wzory i procedurę wyliczeń przyjęto za: [Domański (red.), 2001, s. 48-50]. 
Sytuacja zmieniła się w pierwszej połowie lat 50. Po przejściu przez Azję „dekolonizacyjnego tsunami” i ukształtowaniu się nowych państw oraz stabilizacji stosunków międzynarodowych rozpoczęła się odbudowa i intensywna rozbudowa ich gospodarek. Tempo wzrostu gospodarczego wielu południowo-wschodnich gospodarek było imponujące. Dokładniej dynamikę wzrostu gospodarczego całej Azji oraz wyróżnionych 10 państw przedstawiono w tab. 2.14.

Tabela 2.14. Dynamika PKB Indii na tle innych krajów Azji, rok $1950=100,0 *$

\begin{tabular}{|l|r|r|r|r|r|r|r|r|r|}
\hline Kraje & 1955 & 1960 & 1965 & 1970 & 1975 & 1980 & 1985 & 1990 & $1990 / 80$ \\
\hline Indie & 119,5 & 147,1 & 168,2 & 211,3 & 245,1 & 286,7 & 366,5 & 494,1 & 172,3 \\
\hline Chiny & 145,9 & 187,0 & 210,5 & 267,2 & 333,8 & 436,3 & 666,6 & 879,3 & 201,5 \\
\hline Indonezja & 129,0 & 146,3 & 156,8 & 208,9 & 295,9 & 415,6 & 487,4 & 679,5 & 163,5 \\
\hline Japonia & 154,6 & 233,0 & 364,5 & 629,7 & 786,3 & 974,4 & 1150,1 & 1436,0 & 164,2 \\
\hline Korea Płd. & 141,5 & 170,8 & 231,6 & 392,6 & 695,2 & 977,5 & 1442,1 & 2325,6 & 237,9 \\
\hline Tajlandia & 135,3 & 181,2 & 256,1 & 383,8 & 505,6 & 733,5 & 956,3 & 1561,7 & 212,9 \\
\hline Tajwan & 160,7 & 226,7 & 361,7 & 589,7 & 865,0 & 1419,8 & 2126,3 & 2717,2 & 191,4 \\
\hline Pakistan & 111,3 & 128,6 & 174,7 & 246,5 & 288,0 & 389,9 & 546,5 & 717,6 & 184,0 \\
\hline Iran & 100,1 & 165,2 & 244,2 & 429,7 & 695,7 & 556,9 & 736,8 & 710,4 & 127,6 \\
\hline Turcja & 147,4 & 185,0 & 233,4 & 321,1 & 460,5 & 528,5 & 667,3 & 890,9 & 168,6 \\
\hline Azja** & 135,2 & 176,5 & 226,9 & 325,5 & 421,2 & 533,6 & 678,7 & 877,0 & 164,4 \\
\hline $\begin{array}{l}\text { Udział } \\
\text { Indii } \\
\text { w PKB Azji }\end{array}$ & 20,0 & 18,8 & 16,7 & 14,7 & 13,1 & 12,1 & 12,2 & 12,7 & - \\
\hline
\end{tabular}

* ceny stałe, w proc., ** uwzględniono 57 krajów.

Źródło: [Bywalec, 2010].

Z tab. 2.14 wynika, że już w pierwszej połowie lat 50. dynamika wzrostu gospodarczego Indii była niższa od średniej dla całej Azji. W następnych trzech dekadach - do 1980 roku - różnice w tempie wzrostu gospodarczego powiększały $\mathrm{się}^{43}$. Efektem tego było systematyczne zmniejszanie się udziału indyjskiej gospo-

${ }^{43} \mathrm{~W}$ naukowej literaturze oraz publicystyce ekonomicznej - głównie indyjskiej - na określenie tempa wzrostu gospodarczego Indii w pierwszych trzech dekadach niepodległości kraju (do 1980 roku) używano często pojęcia „indyjskie tempo wzrostu”. Większość krajów azjatyckich rozwijała się - jak wykazuje przeprowadzona analiza - w tempie wyższym i zmiennym w czasie, a wzrost PKB Indii był niemal jednostajny $i$ - poza wyjątkowymi latami - zamykał się w przedziale 3-4 proc. Sformułowanie ,indyjskie tempo wzrostu” nabrało z biegiem czasu znaczenia metaforycznego. Kojarzyło się m.in. z wolnym, monotonnym chodem słonia - symbolu Indii, w przeciwieństwie do dynamicznego poruszania się smoka - symbolu Chin, czy tygrysa - symbolu kilku krajów Azji Południowo-Wschodniej. 
darki w gospodarce kontynentu azjatyckiego (57 państw). Jej udział w tworzeniu PKB Azji zmalał z 22,6 proc. w 1950 roku, do 16,7 proc. w 1965 roku oraz 12,1 proc. w 1980 roku. W okresie 1950-1980 tempo wzrostu indyjskiego PKB było niemal dwukrotnie niższe niż średnie dla całego kontynentu i blisko trzyipółkrotnie niższe niż w Japonii czy Korei Południowej, a w odniesieniu do Tajwanu różnica była niemal pięciokrotna. Nawet Pakistan, powstały w 1947 roku - podobnie jak Indie $-\mathrm{z}$ byłej kolonii brytyjskiej, notował znacznie wyższe przyrosty PKB. Wskaźniki te obiektywizują formułowane wcześniej opinie o wolnym tempie rozwoju gospodarczego Indii w pierwszych dekadach niepodległości i niepowodzeniu doktryny ,indyjskiego socjalizmu”. Indyjski model rozwoju nie wytrzymał konkurencji ani z krajami kapitalistycznymi, ani też z socjalistycznymi Chinami.

Istotne zmiany i odwrócenie tendencji nastąpiło - jak wcześniej wykazano - w latach 80., a szczególnie w drugiej połowie tej dekady. Poczynione przez rząd R. Gandhiego reformy liberalizujące gospodarkę zaowocowały wysoką dynamiką jej rozwoju. W latach 1980-1990, jak wynika z tab. 2.14, tempo wzrostu indyjskiej gospodarki przewyższyło już średnią dla całej Azji i nie odbiegało istotnie od najszybciej rozwijających się wówczas gospodarek tego kontynentu. Dzięki temu zaczął się powwoli zwiększać udział gospodarki indyjskiej w gospodarce Azji. Oznacza to, że zaczęła ona odrabiać straty z poprzednich trzech dziesięcioleci. Przełom lat 80. i 90. zaowocował jednak nagłym pogorszeniem koniunktury gospodarczej. Na progu lat 90. XX stulecia Indie znalazły się w największym od zarania niepodległości kryzysie gospodarczym; zostanie to przedstawione w następnych rozdziałach pracy. 



\section{REFORMY EKONOMICZNE PO 1991 ROKU PRZESŁANKI, ISTOTA, WDRAŻANIE}

W poprzednich rozdziałach przedstawiono teoretyczne i praktyczne problemy gospodarki Indii w pierwszych czterech dekadach niepodległości kraju. $\mathrm{W}$ przyjętym modelu gospodarki, a w ślad za tym w jej strukturze, mechanizmach i dynamice rozwojowej tkwią oczywiście przesłanki zapoczątkowanych w 1991 roku reform. Zaprezentowany obraz jest jednak - poza niektórymi elementami - zbyt ogólny. W celu jego przybliżenia w niniejszym rozdziale wyodrębniono, usystematyzowano i szerzej przedstawiono te czynniki, które legły bezpośrednio u podstaw rewizji dotychczasowego modelu ,indyjskiego socjalizmu”. Następnie zostały scharakteryzowane główne kierunki i składniki „,nowej polityki ekonomicznej”, a więc programu reform gospodarki wdrażanego po 1991 roku.

\subsection{Geneza i przyczyny reform ekonomicznych}

Przyczyny reform indyjskiej gospodarki w ostatnich latach 80. i na początku lat 90. minionego wieku można ująć w następujące grupy:

1. Niewłaściwy model rozwoju gospodarki przyjęty w pierwszych latach niepodległości kraju. Model ten - zaprezentowany w podrozdziale 1.3 - pomimo swoich teoretycznych i ideowych zalet, zgodnych z ówczesnymi poglądami większości ekonomistów i polityków, w praktyce jednak się nie sprawdził. Co więcej, na dłuższą metę stał się wręcz hamulcem rozwojowym indyjskiej gospodarki. Dominował w nim szeroko rozbudowany sektor państwowy na czele z przemysłem ciężkim i wydobywczym, który pochłaniał wielkie środki publiczne, a nie przynosił efektów adekwatnych do tych nakładów. Sytuację pogarszała nadmierna centralizacja życia gospodarczego oraz politycznego, w tym także - z natury swej usztywniające gospodarkę - centralne planowanie. Przedstawione poniżej czynniki są pochodną realizacji tegoż właśnie modelu.

2. Nadmierna i systematycznie narastająca do połowy lat 80. regulacja administracyjna gospodarki. Dotyczyła ona szczególnie przemysłu i handlu zagranicznego, a wyrażała się licencjonowaniem i licznymi, często absurdalnymi, ograniczeniami biurokratycznymi. Licencje stały się jednym z głównych narzędzi regulacji gospodarki. Skala licencjonowania była tak duża, że Indie nazywano 
żartobliwie „państwem licencji” (Licence Raj). Obywatel, który chciał prowadzić działalność gospodarczą na własny rachunek, musiał uzyskać na to pozwolenie władzy państwowej. W okresie największego nasilenia licencjonowania należało uzyskać aprobatę ok. 80 agend urzędowych. $\mathrm{O}$ wielkości i strukturze produkcji nie decydowały argumenty rynkowe (popyt, podaż, cena), lecz ustalenia zawarte w licencjach i planach. Także import towarów był obłożony licznymi licencjami oraz wysokimi cłami. Działalność przedsiębiorstw była nieustannie kontrolowana przez funkcjonariuszy państwa, co rodziło m.in. dużą skalę korupcji; szerzej na te tematy w dalszej części rozdziału. Licencjonowanie hamowało inicjatywę gospodarczą i racjonalne zachowania się przedsiębiorców w sektorze publicznym oraz - przede wszystkim - właścicieli przedsiębiorstw prywatnych. Regulacja państwowa miała w swej intencji chronić krajową gospodarkę, a szczególnie początkujące gałęzie przemysłu. Ochrona ta była skierowana „do wewnątrz”, bez dostatecznego uwzględniania roli sytuacji „zewnętrznej”. Władze indyjskie ulegały złudzeniu, że tak wielka gospodarka, w dużym i zasobnym w bogactwa kraju, z ogromnym rezerwuarem pracy (w tym ludzi dobrze wykształconych), przyniosą korzystne rezultaty i to bez istotniejszego zasilania zewnętrznego.

3. Prymat polityki nad ekonomią, który wyrażał się podporząd kowaniem zarządzania przedsiębiorstwami państwowymi celom politycznym i społecznym. Efektem tego było nieprzywiązywanie należytej wagi do parametrów efektywnościowych albo wręcz ich pomijanie w ocenie przedsiębiorstwa, ustalanie cen wielu towarów poniżej kosztów produkcji (głównie dóbr konsumpcyjnych i środków do produkcji rolnej). Takie właśnie zachowania państwa stały się główną przyczyną obfitego dotowania dużej części przedsiębiorstw publicznych. Działało to demobilizująco na zachowania kierownictw przedsiębiorstw oraz postawy pracowników. Mając niemal pewność wsparcia ze strony władz państwowych, przedsiębiorstwa nie troszczyły się o modernizację produkcji, racjonalizację kosztów, optymalizację swoich struktur, wzrost wydajności, dyscyplinę pracy itp. Profesjonalny rachunek ekonomiczny nie odgrywał praktycznie żadnej roli w działalności przedsiębiorstw państwowych.

4. Przerosty zatrudnienia i przesadne w stosunku do możliwości przedsiębiorstw uprawnienia socjalne i prawne ich pracowników. Prowadziło to do nieefektywnego gospodarowania zasobami pracy i wysokich kosztów produkcji. Szczególnie uciążliwe i komplikujące jakiekolwiek zmiany w przedsiębiorstwach było prawo pracy i duża rola w zarządzaniu związków zawodowych. W większych firmach, zatrudniających ponad 100 osób, pracownicy nabywali gwarancję długoletniego zatrudnienia. Utrudniało to zasadniczo tak ważny proces, jakim winna być prywatyzacja przedsiębiorstw państwowych oraz restrukturyzacja firm prywatnych, a także zatrudnianie nowych, wyżej kwalifikowanych pracowników.

5. Dominacja i uprzywilejowanie w sektorze przemyslowym przedsiębiorstw państwowych. Przedsiębiorstwa prywatne mogły oczywiście funkcjonować. Jednakże, gdy ich aktywa przekraczały określoną kwotę podporządkowy- 
wano je specjalnej, wysoce restrykcyjnej ustawie z 1969 roku - The Monopolies and Restrictive Trade Practices Act (MRTP), która miała zapobiegać nadmiernej koncentracji produkcji i nieuczciwym praktykom handlowym, a przez to chronić konsumentów (weszła w życie w czerwcu 1970 roku, ale nie obowiązywała w stanie Jammu \& Kashmir). Takie było oficjalne uzasadnienie uchwalenia ustawy, natomiast w rzeczywistości chodziło o ścisłą kontrolę sektora prywatnego i hamowanie jego rozwoju. Do realizacji tych zadań została powołana mocą powyższej ustawy specjalna Komisja ds. monopoli i ograniczania praktyk handlowych (The Monopolies and Restrictive Trade Practices Commission - MRTP Commission) funkcjonująca jako wydział ds. przedsiębiorstw (Department of Company Affairs) w Ministerstwie Przedsiębiorstw (Ministry of Company Affairs). Ustawa o MRTP z 1969 roku została zliberalizowana w 1984 roku. Początkowo do przedsiębiorstw prywatnych objętych regulacją MRTP zaliczane były te, których aktywa przekraczały 25 krorów rupii, w 1980 roku dolną wartość aktywów podniesiono do 50 krorów rupii, w 1985 roku do 100 krorów rupii, a w 1991 roku limity te zniesiono ${ }^{1}$. Za sytuację monopolistyczną w świetle tej ostatniej poprawki uznaje się taką, gdy udział firmy w rynku przekracza 25 proc. Od 1973 roku kapitał zagraniczny nie mógł przekraczać 40 proc. kapitału spółek. W pierwszej połowie lat 70. nasilono - na niespotykaną dotąd skalę - nacjonalizację przemysłu ciężkiego.

6. Powszechna biurokratyzacja i podążająca za nią korupcja na każdym poziomie organizacji gospodarki i państwa. Wynikały one w głównej mierze - jak wcześniej wspominano - z nadmiernych kompetencji organów państwowych w stosunku do przedsiębiorstw. Była to zazwyczaj tzw. duża korupcja, w odróżnieniu od tej małej - dominującej na poziomie społeczności lokalnych i na ogół drobnych, codziennych spraw. W „dużej” korupcji uczestniczyli zazwyczaj funkcjonariusze (urzędnicy) państwowi z jednej strony - jako korumpowani i wymuszający zachowania korupcyjne, a z drugiej - korumpujący, czyli członkowie kierownictw przedsiębiorstw, szczególnie prywatnych. Skala oraz kształt praktyk korupcyjnych na styku państwa i gospodarki była zróżnicowana i zależna od szczebla władzy oraz rodzaju spraw, których dotyczyła. Mogło to być - przykładowo - wymuszanie uchwalania odpowiednich aktów prawnych, pozyskiwania koncesji, wygrywania przetargów, wyłudzania dotacji czy przydziału surowców, obsadzania ważnych stanowisk itp. Pomimo oficjalnego zwalczania korupcji, patologia ta bynajmniej nie tylko nie malała, ale systematycznie powiększała się i to bez względu na to, jaka partia była przy władzy - czy to na szczeblu krajowym, czy stanowym. Do większych afer korupcyjnych z udziałem najwyższych

${ }^{1}$ Kror (crore - cr) jest liczebnikiem stosowanym w niektórych krajach Azji Południowej, $1 \mathrm{kror}=10 \mathrm{mln}$. Używanie tej jednostki jest $\mathrm{z}$ reguły praktyczniejsze niż posługiwanie się milionami czy miliardami. 
urzędników państwowych doszło w 1981 roku, kiedy to Indie zakupiły od niemieckiej stoczni okręty podwodne. Największy jednak skandal korupcyjny w Indiach związany był z zakupem w 1986 roku przez ten kraj broni (410 dział przeciwlotniczych) od szwedzkiego koncernu Bofors AB za kwotę ok. 1,4 mld USD. Udział w nim brali m.in. bliscy współpracownicy premiera R. Gandhiego. Stał się on jedną z ważniejszych przyczyn upadku jego reformatorskiego rządu i przegranych wyborów przez Indyjski Kongres Narodowy w 1989 roku [Iwanek, Burakowski, 2013, s. 336, 338].

7. Monopolistyczna, czyli bardzo restrykcyjna polityka państwa w zakresie importu. Była to tzw. polityka substytucji importu. Jej narzędzia stanowiły licencje, zakazy, wysokie - często „zaporowe” - cła. Zasady substytucji importu zostały wprowadzone już w pierwszych latach po uzyskaniu niepodległości i w miarę upływu czasu ich skala narastała. Polityka ta doprowadziła niemal do całkowitego odcięcia gospodarki indyjskiej od rynku światowego. Równocześnie nie powstał przemysł antyimportowy, który kompensowałby niedobór dóbr zagranicznych. Stosunkowo niewielkie kontyngenty towarów importowanych zostały podzielone na trzy grupy: 1) towary konsumpcyjne, 2) towary kapitałowe, 3) towary pośrednie [Gutowski, 2002, s. 172-174; Förstmann, Gregosz, 2010]. Praktycznie całkowicie zakazane było sprowadzanie dóbr konsumpcyjnych, z wyjątkiem niewielu najbardziej niezbędnych produktów wytwarzanych w kraju w niedostatecznej ilości; kompetencje w tym zakresie posiadały nieliczne państwowe agencje. Dobra kapitałowe oraz pośrednie zostały objęte systemem licencji. Podzielono je na dwie części - objęte ograniczonymi licencjami (restricted) oraz objęte listą Open General Licensing $(O G L)$. Te drugie mogły być sprowadzane bez licencji. Natomiast zaliczane do trzeciej grupy dobra pośrednie podzielone zostały na 4 podgrupy: a) zabronione (banned), b) ograniczone - objęte licencjami (restricted), c) dozwolone, ale objęte limitowaniem (limited permissible), d) towary pozostałe - objęte OGL. Oprócz licencjonowania stosowano często tzw. ograniczenia pozataryfowe (np. można było sprowadzić maszynę, ale tylko dla potrzeb własnych i nie mogła być ona odsprzedana w ciągu 5 lat), albo też import był możliwy tylko w sytuacji, gdy firma miała licencję produkcyjną.

W latach 80., w ramach reform liberalizacyjnych rządu R. Gandhiego, rozpoczęto łagodzenie restrykcji importowych, ale w to miejsce podwyższano stawki celne, co w istocie nie zmniejszało skali państwowego protekcjonizmu. Pomimo tych zmian, jeszcze w 1990 roku 93 proc. krajowej produkcji przemysłowej było chronione antyimportowymi restrykcjami.

Liberalizacja i deregulacja handlu zagranicznego w okresie rządów R. Gandhiego wyrażała się m.in. w rozszerzaniu listy towarów importowanych objętych listą OGL - dopuszczającą ich wwóz na podstawie ogólnych (otwartych) pozwoleń lub w ogóle nieograniczony. Oznacza to zmniejszanie się liczby towarów, których import był zakazany lub ograniczony, czyli wymagał indywidualnych licencji. Na liście OGL znajdowały się przede wszystkim dobra kapitałowe i nie- 
które tzw. dobra pośrednie, które nie posiadały krajowych substytutów. Lista dóbr kapitałowych objętych OGL zwiększyła się z niespełna $80 \mathrm{w}$ roku 1977 do ponad 1300 w 1990 roku. Jednakże import towarów konsumpcyjnych był nadal bardzo ograniczony i mogły go prowadzić tylko specjalne agencje państwowe [Chand, Sen, 2002].

Głównym hamulcem rozwoju indyjskiego importu były wysokie cła. Jeszcze w drugiej połowie lat 80. należały one do najwyższych na świecie [Gutowski, 2002, s. 175-177]. Przykładowo w 1986 roku importowe stawki celne wynosiły przeciętnie dla dóbr konsumpcyjnych $-128,5$ proc. wartości przywozu, dóbr kapitałowych $-114,5$ proc., dóbr pośrednich - 123 proc., przetworzonych produktów przemysłowych - 121,7 proc. Były one - dla przykładu - wyższe niż w Chinach średnio o 1/3, a 3-5-krotnie przewyższały cła nakładane przez Tajlandię. Stawki celne na niektóre towary dochodziły nawet do 400 proc. W dodatku indyjski system celny był bardzo skomplikowany i nieprzejrzysty, dużo było w nim wyjątków. Znamienny dla indyjskiego handlu zagranicznego był niemal stały wzrost stawek celnych, podczas gdy w większości krajów rozwijających się cła obniżano.

8. Podobna do polityki importu, ściśle kontrolowana przez państwo, polityka eksportowa. Nadrzędnym celem tej polityki było oczywiście zapewnienie dostatecznej podaży dóbr konsumpcyjnych i kapitałowych na krajowym rynku. Drogą do tego miało być wspieranie wysokowartościowego eksportu i pozyskiwanie w ten sposób środków zarówno dla budżetu państwa, jak i na rozwój konkretnych gałęzi i przedsiębiorstw (np. na zakup surowców czy niezbędnych maszyn) [Gutowski, 2002, s. 177-180]. Narzędziami państwa w tej dziedzinie były - podobnie jak w przypadku importu - licencje oraz cła. Rozmiary licencjonowania eksportu były jednak mniejsze niż w przypadku importu. Dominowało natomiast wyznaczanie kontyngentów eksportowych oraz kontrola wywozu zarówno towarów żywnościowych (w których Indie posiadały komparatywną przewagę na rynkach zagranicznych), jak i produktów przetworzonych. Stosowano różnego rodzaju narzędzia wspierające eksport bądź to w postaci bezpośrednich dopłat, albo też poprzez politykę licencji, przyznawanie ulg importowych w sytuacji, gdy towary były sprowadzane dla celów produkcji eksportowej, zwroty podatku importowego (lub jego części) w przypadku reeskportu, wyznaczanie specjalnych stref gospodarki, których zadaniem jest produkcja na eksport (tzw. EPZ - export processing zones), ulgi w podatku dochodowym itp. Pomimo tych działań nie następowały znaczące zmiany w strukturze eksportu, dominowały $\mathrm{w}$ nim nadal produkty nisko przetworzone, z reguły pochodzenia rolniczego. Były to zazwyczaj towary o niewysokiej jakości i cenowo niekonkurencyjne na rynkach światowych, a konkurencja w tej dziedzinie - i to ze strony krajów nierozwiniętych - była szczególnie duża. W efekcie wpływy z eksportu do budżetu państwa, jak i zyski przedsiębiorstw eksportujących były małe i w dodatku obniżały się. 
9. Niesprawny i nieadekwatny do potrzeb gospodarki system bankowy. Do końca lat 80 . był on - jak wykazano w rozdziale II - wysoce znacjonalizowany i scentralizowany. Banki bardziej przypominały agendy państwa, zasilane środkami finansowymi z budżetu centralnego lub stanowego i sterowane przez urzędników państwowych, niż - jak to powinno wynikać z ich istoty - niezależne instytucje gospodarcze zajmujące się przyjmowaniem depozytów i udzielaniem kredytów, czyli gospodarowaniem pieniądzem na zasadach rynkowych. Polityka kredytowa banków wynikała najczęściej nie z ich rachunku ekonomicznego, ale była funkcją preferencji i zaleceń państwa w stosunku do takiego czy innego sektora gospodarki lub konkretnego przedsiębiorstwa. Zaciągane przez przedsiębiorstwa kredyty były często niespłacane i stawały się w istocie bezzwrotnymi zapomogami. Większość publicznych podmiotów gospodarczych, a także niektórych prywatnych, nie mogłaby samodzielnie istnieć bez owego „quasikredytowego" zasilania. Taka sytuacja w sektorze bankowym dodatkowo deformowała cały system finansowy państwa i była jednym z głównych źródeł biurokratyzacji i korupcji życia gospodarczego i całej sfery publicznej. Negatywnie odbijała się także na budżecie państwa oraz budżetach stanowych, kreując m.in. wysokie deficyty i dług publiczny.

10. Upaństwowiony sektor ubezpieczeniowy. Szybki rozwój prywatnego sektora ubezpieczeniowego po odzyskaniu niepodległości oraz narastająca w nim patologia, szczególnie korupcja, stały się pretekstem do jego nacjonalizacji. W 1956 roku - jak już wspomniano w rozdziale II - państwo przejęło 245 krajowych i zagranicznych zakładów ubezpieczeń na życie i towarzystw wzajemnych ubezpieczeń. W ich miejsce utworzono jedną, państwową Korporację Ubezpieczeń na Życie (Life Insurance Corporation). W 1972 roku na mocy General Insurance Business (Nationalisation) Act znacjonalizowano sektor ubezpieczeń powszechnych. Ustawa weszła w życie 1 stycznia 1973 roku. W miejsce 107 dotychczasowych ubezpieczycieli utworzono cztery spółki ubezpieczeń powszechnych, które stały się podmiotami zależnymi General Insurance Corporation of India.

Do przedstawionego wyżej zestawu stricte ekonomicznych przyczyn podjęcia reform gospodarczych dodać trzeba bardzo ważny czynnik natury polityczno-psychologicznej, o dużym znaczeniu prestiżowym. Chodzi konkretnie o wyniki rywalizacji gospodarczej Indii z dwoma dużymi i w dodatku wrogimi sąsiadami, tj. Chinami oraz Pakistanem, nie wspominając już o tzw. tygrysach z Azji Południowo-Wschodniej. Przez cztery powojenne dekady oba te graniczące z Indiami kraje, a szczególnie Chiny, osiągały wyższe tempo wzrostu gospodarczego (por. tab. 2.14). Taka sytuacja znacząco obniżała prestiż władz indyjskich i w ogóle dyskredytowała model ,indyjskiego socjalizmu" i to nie tylko w kraju, ale przede wszystkim na arenie międzynarodowej ${ }^{2}$. Sprawa nabrała dodatkowej

2 S. Bhutani [2006] pisał w tej kwestii m.in. „Azjatyckie tygrysy i Chiny prześcignęły Indie w czasie trwania jednego pokolenia. W porównaniu z nimi, Indie są zaspanym słoniem”. 
wagi, kiedy pod koniec latach 70 . Chiny zapoczątkowały reformy polegające na liberalizacji gospodarki i otwarciu jej na świat (głównie poprzez znaczący import bezpośrednich inwestycji zagranicznych oraz wymianę handlową). Reformy te zaowocowały dużym przyspieszeniem rozwoju gospodarki Chin i to we wszystkich jej sektorach. Powiększało to dodatkowo dystans pomiędzy Chinami a Indiami. W latach 1979-1993 przeciętne roczne tempo rozwoju produkcji sektora rolnego wynosiło w Chinach 5,2 proc., a w Indiach 2,7 proc. Odpowiednie wskaźniki dla przemysłu kształtowały się w tym okresie na poziomie 9,3 proc. i 5,4 proc., a w sektorze usług było to 11,3 proc. i 5,9 proc. Różnice dynamiki wzrostu są więc ogromne, co oznacza, że pomiędzy tymi największymi ludnościowo krajami świata powiększał się dystans rozwojowy, oczywiście na niekorzyść Indii [Bardhan, 2010, s. 21-25].

Jak już napisano w rozdziale II, próbę zmiany istniejącej sytuacji gospodarczej podjęto w połowie lat 80 ., po objęciu funkcji premiera rządu federalnego przez R. Gandhiego. Wyrazem tego była konstrukcja przedstawionego w końcu 1985 roku projektu VII planu pięcioletniego (1985/86-1989/90). Dodać należy, że był on traktowany jako pierwszy etap piętnastoletniego planu perspektywicznego na lata 1985-2000, planu nakreślającego strategię i podstawowe parametry rozwoju gospodarczego i społecznego Indii do końca wieku.

Zadania VII planu pięcioletniego wykonano z nadwyżką. Produkt narodowy netto - jak podano w rozdziale II (tab. 2.9) - zwiększał się przeciętnie o 5,8 proc. w skali roku, a w ujęciu per capita były to przyrosty o 3,6 proc. Są to najwyższe wskaźniki wzrostu gospodarczego w 40-letniej historii Indii.

Niestety cieniem na pomyślnych wynikach gospodarczych drugiej połowy lat 80. kładzie się ogromny - nienotowany do tej pory - wzrost zadłużenia państwa; sytuacja przypomina w dużej mierze Polskę oraz niektóre kraje Ameryki Łacińskiej w latach 70. Deficyt budżetu państwa zwiększył się z 6 proc. w roku gospodarczym 1980/81 do 8,4 proc. w roku 1990/91 [Gutowski, 2002, s. 181]. Był on finansowany głównie poprzez zadłużanie się rządu w banku centralnym, czyli Banku Rezerw Indii (RBI). Wewnętrzny, skumulowany dług publiczny (rządu i stanów) wzrósł z 45,7 proc. w roku 1984/85 do 54,6 proc. PKB w roku 1989/90. Szybko powiększało się także zadłużenie zagraniczne; w 1980/81 roku wynosiło 23,5 mld. USD, a w 1990/91 roku - 83,3 mld USD. Rezerwy dewizowe zmniejszyły się z 5,8 mld USD w roku 1980/81 do 3,1 mld USD w sierpniu 1990 roku i tylko 896 mln USD w styczniu 1991 [Chandra i in., 1999, s. 363-364; Gutowski, 2002, s. 182]. Do tego doszedł duży, wywołany wojną amerykańsko-iracką, spadek napływu walut od Indusów pracujących w krajach Zatoki Perskiej, szczególnie w Kuwejcie i Iraku. Wpływy te szacowano na ok. 2,5 mld USD rocznie. Ponadto Indie utraciły ważnych partnerów handlowych, jakimi były Irak oraz Iran. Wojna w Zatoce Perskiej spowodowała także nagły i wysoki wzrost cen ropy naftowej, co miało ogromne znaczenie dla bilansu handlowego Indii - import pokrywał wówczas ok. 70 proc. zapotrzebowania kraju na ten surowiec. Z kolei 
w wyniku upadku europejskiego systemu socjalistycznego, a szczególnie rozpadu Związku Radzieckiego, załamał się eksport do tego obszaru i spadły dochody walutowe. W latach 80. ok. 40 proc. indyjskiego eksportu szło na te właśnie rynki, a saldo obrotów było dodatnie. Sytuację budżetu państwa pogarszały też znaczące wydatki związane z zaangażowaniem się Indii w konflikt syngalesko-tamilski na Sri Lance, a szczególnie koszty ekspedycji zbrojnej Indyjskiego Korpusu Pokojowego na tę wyspę w latach 1987-1990.

Trudności ze zrównoważeniem budżetu państwa i szybkie narastanie długu publicznego zagroziło upadłością państwa. Drastyczne obniżanie się ratingu kredytowego sprawiało, że Indiom było coraz trudniej pozyskać krótkoterminowe pożyczki na międzynarodowym rynku kapitałowym. Rosnący nacisk na dewaluację rupii sprawił, że Bank Rezerw Indii postanowił usztywnić jej kurs. W czerwcu 1991 roku indyjskie rezerwy walutowe stopniały do wartości dwutygodniowego importu. Nie mogąc regulować bieżących zobowiązań, kraj stanął na krawędzi bankructwa [Gutowski, 2002, s. 182]. Ta właśnie dramatyczna sytuacja finansowa oraz korzystne dla Indyjskiego Kongresu Narodowego wybory parlamentarne (maj-czerwiec 1991) - o czym poniżej - stały się bezpośrednim impulsem do natychmiastowego i gruntownego naprawiania gospodarki oraz państwa. Dodać trzeba, że nigdy wcześniej Indie nie były krajem mocno zadłużonym, taka sytuacja wydarzyła się po raz pierwszy. Znaczącą rolę w tych trudnych dla indyjskich finansów publicznych chwilach odegrała pożyczka stabilizacyjna Międzynarodowego Funduszu Walutowego (MFW) zabezpieczona indyjskim złotem. Pomoc MFW obwarowana była jednakże nakazami podjęcia przez indyjski rząd radykalnych reform gospodarczych w duchu przyjętego w latach 1989-1990 Konsensusu Waszyngtońskiego (por. podrozdział 1.2).

Sprawy ekonomiczne nie były jedynym źródłem indyjskiego kryzysu. Na sytuację gospodarczą i nastroje społeczne drugiej połowy lat 80 . i pierwszych lat 90. ubiegłego wieku ogromny wpływ wywarły - jak nigdy dotąd - zaostrzające się konflikty etniczne oraz religijne i to równocześnie w wielu regionach kraju, których ofiarą padł m.in. były premier R. Gandhi. Podjęte przez rząd Gandhiego reformy liberalizujące gospodarkę i życie polityczne nie spotkały się - wbrew oczekiwaniom - z powszechną aprobatą społeczeństwa indyjskiego, a szczególnie niektórych elit. Liberalizacja gospodarki znacząco zmniejszała wpływy jakże licznej i zbiurokratyzowanej oraz niewiarygodnie skorumpowanej administracji wszystkich szczebli, gdyż odbierała im część władzy gospodarczej (np. udzielanie różnorakich licencji, kontrolę, przydzielanie dotacji itp.) i związane z tym dodatkowe dochody. Pogarszała się również sytuacja pracowników państwowych zakładów, bowiem wiele z nich pozbawiono dotacji, przez co zostały zmuszane do restrukturyzacji, a niekiedy nawet likwidacji. Liberalizacji nie aprobowały również niektóre kręgi prywatnego biznesu, które przystosowały się przez lata do licencjonowania działalności gospodarczej i całego systemu kontroli oraz wynikającej z tego korupcji. Zagrożeniem dla nich stawało się dopuszczenie na ry- 
nek obcego kapitału i towarów, gdyż oznaczałoby to zwiększenie konkurencji i trudności ze zbytem swych produktów. Lewa strona sceny politycznej (głównie partie komunistyczne) uznawała liberalizację gospodarki za zdradę ,indyjskiego socjalizmu" uderzającą w biedną, lecz liczną, bo stanowiącą większą część społeczeństwa i równoczesne bogacenie się warstw zamożnych. Partie prawicowe, a szczególnie rosnące w siłę ugrupowania hinduistyczne, w liberalizacji i otwarciu gospodarki dopatrywały się z kolei zagrożenia interesów indyjskich i nowej wersji kolonializmu [Bywalec, 2003].

Duża skala konfliktów etnicznych i religijnych (głównie w Punjabie, Assamie, Tamil Nadu, Gujaracie) oraz narastające niezadowolenie części społeczeństwa z reform gospodarczych i wielkich skandali korupcyjnych przełożyły się na głosy wyborcze. Wybory parlamentarne w listopadzie 1989 roku wygrała koalicja partii centroprawicowych, a przegrał rządzący Indyjski Kongres Narodowy. Przewodniczący IKN i główny animator odnowy gospodarczej R. Gandhi przestał być premierem.

$\mathrm{Z}$ uwagi na dużą liczbę partii w zwycięskiej koalicji, nie była ona w stanie sformułować spójnego programu gospodarczego. W niektórych dziedzinach kontynuowano politykę reform zapoczątkowanych przez R. Gandhiego, ale na ogół zostały one zaniechane. Wypadkową tego zamieszania było pogłębienie się chaosu w funkcjonowaniu państwa i drastyczne pogorszenie sytuacji gospodarczej, co po niespełna półtora roku - jak opisano w rozdziale II - doprowadziło do kryzysu politycznego i przedterminowych wyborów parlamentarnych (w maju-czerwcu 1991 roku). Najwięcej głosów uzyskał teraz Indyjski Kongres Narodowy, ale nie wystarczały one do stworzenia rządu większościowego. Powstał więc rząd mniejszościowy IKN wspomagany przez niektóre małe ugrupowania polityczne (głównie regionalne), a na jego czele stanął P.V. Narashima Rao. Rząd N. Rao pomimo braku parlamentarnej większości przetrwał jednak całą kadencję, a więc do roku 1996; jego atutem stał się program reform gospodarczych i ich pierwsze, często spektakularne, efekty.

\subsection{Nowa polityka ekonomiczna - istota i narzędzia}

Lata 1991-1992 są przełomowe dla indyjskiej gospodarki i w ogóle dla historii niepodległych Indii. W wyniku podjętych przez rząd N. Rao reform ustrojowych państwa i gospodarki, nazwanych „,nową polityką ekonomiczną”, kraj ten wszedł w nową fazę rozwojową. Funkcję lokomotywy rozwoju miał pełnić od tej pory - nie jak dotychczas - sektor państwowy, lecz prywatny, którego głównym regulatorem jest rynek, a nie założenia planów ogólnokrajowych czy stanowych. Gospodarka miałaby zostać mocno zliberalizowana i zderegulowana [Kar, Sakthivel, 2006]. W fachowej literaturze indyjskiej zapoczątkowanie przez rząd N. Rao 
przełomowych reform określa się czasem metaforycznie „big bangiem” [Kohli, 2012, s. 38-39] $]^{3}$.

Analizując główne elementy ,nowej polityki ekonomicznej” Indii, nie sposób nie dostrzec jej znaczącego podobieństwa do większości zaleceń - o czym już wspominano - Konsensusu Waszyngtońskiego. Można nawet stwierdzić, że reformy indyjskie były swoistym poligonem doświadczalnym dla tegoż programu. Indyjscy politycy i ekonomiści zwolennicy reform - głównie z Indyjskiego Kongresu Narodowego - niechętnie się jednak do tego przyznawali w obawie przed krytyką opozycji - zarówno prawicowej (z reguły nacjonalistycznej), jak i lewicowej (socjalistycznej oraz komunistycznej). Chodziło przede wszystkim o ewentualny zarzut o uległość wobec międzynarodowych instytucji finansowych (MFW i Bank Światowy) oraz USA; do wątków tych będziemy jeszcze nawiązywać w podrozdziale 3.3 oraz $\mathrm{w}$ rozdziale $\mathrm{V}$.

Pakiet programowy „nowej polityki ekonomicznej” rządu N. Rao składał się z dwóch części. Część pierwsza zawierała wątki stabilizujące gospodarkę, druga - projekcje rozwojowe na dłuższy okres. Jego ważnym, może nawet najbardziej znaczącym przesłaniem, były nowe wskazania dla polityki gospodarczej państwa. Od tej pory miałaby ona polegać nie na bezpośrednim sterowaniu gospodarką, lecz na selektywnym wspieraniu tych działów, które pozwalały na szybkie unowocześnianie gospodarki i uczynienie jej otwartą na procesy globalizacyjne, czyli m.in. zwiększające jej konkurencyjność międzynarodową. Dotyczy to przede wszystkim nowoczesnych gałęzi wysokich technologii. Priorytetem stał się rozwój przemysłu i usług informatycznych oraz telekomunikacyjnych i finansowych, w rozwoju których można wykorzystać bogate zasoby rodzimego kapitału ludzkiego i w ten sposób uzyskiwać w tych dziedzinach przewagi konkurencyjne w skali międzynarodowej. Dokładniej rzecz ujmując, w pakiecie „nowej polityki ekonomicznej” wyróżnić należy następujące elementy [Bywalec, 2003; Mohanty, 2011; Tandon, 2012 oraz bezpośrednio powoływane akty prawne]:

1. Znaczące ograniczenie roli sektora państwowego w gospodarce. W praktyce wyrażało się to $\mathrm{w}$ zmniejszeniu liczby gałęzi przemysłu zarezerwowanych dla państwa - na mocy przedstawionej w rozdziale II Rezolucji w sprawie polityki przemysłowej z 30 kwietnia 1956 roku. Liczbę tych gałęzi zmniejszono z 17 do 8 w roku 1991, a w latach 1993-1998 o kolejne 4; w kompetencji państwa

3 Podkreśla się niejednokrotnie, że „nowa polityka ekonomiczna” zapoczątkowana przez rząd N. Rao jest także momentem przełomowym w myśleniu indyjskich elit $i$ to bez względu na ich konotacje polityczne. Oznacza ona wręcz odejście od dotychczasowych schematów i zakwestionowanie obowiązującego paradygmatu gospodarczego, swoistą rewolucję mentalnościową. Okazało się, że alternatywą dla "socjalizmu indyjskiego" nie musi być tylko faszyzm, jak argumentowali niektórzy politycy [Wolpert, 2010, s. 524]. Zmiana ta powinna oczywiście oddziaływać na postawy i zachowania polityków wszystkich szczebli oraz kadr zarządzających gospodarką i życiem społecznym. Nabyta przez kilka dekad rutyna i konieczność pospiesznego „uczenia się” nowych reguł gospodarowania rodziły opór i przez to spowalniały wdrażanie reform. 
pozostały nadal: przemysł zbrojeniowy, energii atomowej, wydobywania i przeróbki minerałów przydatnych $\mathrm{w}$ energetyce jądrowej oraz przemysł środków transportu kolejowego. Ostatecznie po 2000 roku tylko dwie gałęzie podlegają bezpośredniemu nadzorowi państwa, tj. przemysł związany $\mathrm{z}$ energią atomową i transportem kolejowym.

2. Radykalne zmniejszenie licencjonowania działalności przemysłowej. W 1991 roku zniesiono obowiązek uzyskiwania państwowych licencji w przemyśle $\mathrm{z}$ wyłączeniem 18 gałęzi dotyczących spraw bezpieczeństwa wewnętrznego i obrony narodowej, spraw strategicznych, społecznych, ochrony środowiska, wytwarzania produktów niebezpiecznych i artykułów konsumpcji luksusowej. W latach następnych liczba gałęzi objętych licencjami systematycznie malała - do pięciu. Powodem utrzymania tych licencji były względy zdrowotne, bezpieczeństwa oraz ochrony środowiska naturalnego.

3. Rozpoczęcie prywatyzacji. Do prywatyzacji przystąpiono ze znacznym opóźnieniem, bo dopiero w 1998 roku. Miało jej być poddane wiele, zazwyczaj do tej pory nieefektywnych przedsiębiorstw i dopuszczenie do tych przedsięwzięć kapitału zagranicznego, który mógł nabywać bez państwowych zezwoleń, czyli na warunkach rynkowych, większościowe pakiety akcji w wyłączonych spod licencjonowania firmach. Od 1992 roku fundusze zagraniczne mogły inwestować na indyjskich giełdach papierów wartościowych, w tym celu m.in. obniżono podatek od zysków kapitałowych z 65 do 30 proc. Zakres inwestycji zagranicznych był systematycznie zwiększany w latach 90 . Szeroko otwartą dla kapitału zagranicznego stała się infrastruktura. Zagraniczni inwestorzy mogli w przedsiębiorstwach budujących autostrady, ulice, mosty, tunele i porty obejmować pakiety akcji do 100 proc. Z dużą zwłoką, bo dopiero po uchwaleniu Electricity Bill 2003, rozszerzony został dostęp kapitału zagranicznego do sektora energetycznego, co przyczyniło się do jego wyjścia z głębokiej zapaści i umożliwiło rozwój innych segmentów gospodarki. Wprowadzono i wydłużano „wakacje podatkowe” dla inwestorów bez względu na ich pochodzenie. Dopuszczono do działalności także instytucje oparte na partnerstwie publiczno-prywatnym, szczególnie w sektorze usług.

4. Zmianę sposobu regulowania swobody dzialalności gospodarczej i zapobiegania praktykom monopolistycznym. W tym celu zliberalizowano - jak wcześniej wspomniano - ustawę o MRTP, dopuszczając duże przedsiębiorstwa prywatne do inwestowania w dowolnych ,zdelicencjonowanych" gałęziach przemysłu. W 2003 roku Ustawa o MRTP została zastąpiona Ustawą o konkurencji (The Competition Act 2002). W 2003 roku powołano Indyjską Komisję ds. Konkurencji (Competition Commission of India), której zadaniem jest nadzorowanie funkcjonowania systemu ochrony konkurencji na obszarze całego kraju. Wielokrotnie modyfikowano także Ustawę o ochronie konsumentów (The Consumer Protection Act 1986) z 1986 roku. W 1996 roku uchwalono Ustawę o arbitrażu i polubownym rozstrzyganiu sporów krajowych oraz międzynarodowych (The Arbitration and Conciliation Act 1996). 
5. Rozpoczęcie decentralizacji administracyjnej państwa. Istotą tej reformy było utworzenie lokalnego, samorządowego szczebla administracji; sprawy te są przedstawione w rozdziale IV.

6. Podjęcie - w ślad za zmianami ustroju administracyjnego państwa - reform systemu finansów publicznych oraz ich decentralizacji. Polegały one na zwiększeniu roli stanów oraz jednostek administracyjnych niższych szczebli w gospodarowaniu środkami publicznymi. Pospiesznie podjęto prace nad przebudową budżetu państwa, a szczególnie systemu dochodów podatkowych. Głównym architektem tych reform był Raja J. Chelliah, wybitny, o renomie międzynarodowej, finansista. Podstawą nowego ustroju podatkowego stały się trzy raporty powołanego w 1991 roku Komitetu ds. reform podatkowych pod kierunkiem R.J. Chelliaha (Chelliah Tax Reforms Committee), których zalecenia zaczęły być wdrażane w 1993 roku. Komitet zajmował się przede wszystkim podatkami bezpośrednimi i jego propozycje dotyczyły zarówno zmian doraźnych, jak i modelu polityki podatkowej w dłuższym okresie. Zalecił on m.in. zwiększanie udziału w dochodach państwa podatków konsumpcyjnych oraz bezpośrednich. Podatki od ludności (osób fizycznych) winny wynosić 10, 20 i 30 proc. dochodów, a podatek od osób prawnych należy docelowo zredukować do poziomu 30 proc. zysków. Zaproponowano także - celem zwiększenia wpływów budżetowych - wprowadzenie opodatkowania dochodów z rolnictwa powyżej 25 tys. rupii. Zmiany te powodowały wzrost udziału podatków bezpośrednich w dochodach budżetu państwa.

Natomiast nad reformą podatków pośrednich pracował Komitet pod kierunkiem K.L. Rekhiego. W 1993 roku opublikował założenia reform podatkowych. Komitet zalecał systematyczne integrowanie, harmonizowanie i upraszczanie podatków pośrednich m.in. poprzez zastępowanie zróżnicowanych regionalnie podatków obrotowych przez podatki od wartości dodanej (VAT) ${ }^{4}$.

7. Zniesienie administracyjnej regulacji cen. W 2002 roku odstąpiono od tzw. mechanizmu cen administracyjnych (Administered Price Mechanism), co pozwoliło na rynkowe, a więc pośrednie regulowanie obrotu i konsumpcji wielu ważnych, zarówno dla inwestorów, jak i konsumentów, towarów. Szczególną uwagę skoncentrowano na rynku energetycznym, w tym cenach ropy naftowej, gazu i ich pochodnych. Ceny tych produktów silnie oddziałują bowiem na ceny towarów i usług na wszystkich prawie rynkach. Systematycznie delicencjonowano

${ }^{4}$ Historia wdrażania jednolitego podatku od wartości dodanej jest bardzo długa. Pierwsze próby podjęto jeszcze w latach 80 . W 1986 roku wprowadzono jego zmodyfikowaną postać tj. MODVAT. Ostatecznie po długoletnich próbach VAT wprowadzony został dopiero 1 kwietnia 2005 roku. Podstawową jego stawkę ustalono na 12,5 proc. W praktyce stawki VAT są zróżnicowane w poszczególnych stanach oraz grupach towarowych. Pomimo wdrożenia VAT-u niemal powszechne w Indiach jest uskarżanie się na duże skomplikowanie i nieczytelność podatków od działalności gospodarczej oraz ich częste zmiany. 
i prywatyzowano przemysł energetyczny, a przede wszystkim wytwarzanie i dystrybucję energii elektrycznej. W 1998 roku została uchwalona w tym celu Electricity Regulatory Commissions Act - ustawa m.in. powołująca Centralną Komisję ds. spraw regulacji gospodarki energią elektryczną (Central Electricity Regulatory Commission). Na podstawie przygotowanego przez tę Komisję projektu uchwalono i wdrożono w życie w 2003 roku Ustawę o gospodarowaniu elektrycznością (The Electricity Bill 2003) - modyfikowaną jeszcze w latach 2004 i 2007. Harmonizowała ona dotychczasowe przepisy o wytwarzaniu, przesyłaniu, dystrybucji, użytkowaniu oraz cenach energii elektrycznej. Ustawa nakazuje m.in. rozwijanie produkcji i sprzedaż indywidualnym konsumentom odpowiedniego odsetka energii elektrycznej uzyskanej ze źródeł odnawialnych i niekonwencjonalnych.

8. Zdewaluowanie rupii i doprowadzenie do jej wymienialności. Stymulowało to napływ obcych kapitałów i indyjski eksport, a hamowało import. Najpierw wprowadzono częściową wymienialność na rachunkach handlowych polegającą na tym, że 60 proc. wpływów dewizowych eksporterów mogło być wymieniane po kursie wolnorynkowym, zaś 40 proc. musiało być wymieniane w banku emisyjnym po kursie ustalonym przez Bank Rezerw Indii. Jednym z ważnych elementów „nowej polityki ekonomicznej” było dewaluowanie rupii. W okresie od marca 1992 roku do marca 2000 roku kurs wymiany zmienił się z 25,9 rupii do 43,3 rupii za 1 USD [Datt, Mahajan, 2014, s. 865].

9. Stopniowe ograniczanie bezpośrednich regulacji administracyjnych w wymianie gospodarczej z zagranicą. Dotyczy to szybkiego - jak już wspominano - odchodzenia od licencji oraz kontyngentów - eksportowych i importowych, czyli zaniechanie polityki substytucji importu. Szczególną rolę odgrywała jednak systematyczna redukcja stawek celnych i uczynienie ich porównywalnymi ze stawkami celnymi innych państw, a także zaleceniami Światowej Organizacji Handlu (WTO); zagadnienia te są szerzej opisane w podrozdziale $5.3^{5}$.

10. Rozwijanie rynku kapitałowego. Istnienie rynku kapitałowego jest warunkiem koniecznym dla prawidłowego funkcjonowania i rozwoju całej realnej sfery gospodarki. W 1991 roku powołany został Komitet ds. sektora finansowego pod kierunkiem M. Narasimhama, którego ustalenia stały się podstawą reform indyjskiego systemu finansowego. Szczególną uwagę zwrócono na potrzebę rozwoju instytucji oraz takiej regulacji prawnej rynku finansowego, aby stymulowała napływ kapitału. Indyjski rynek finansowy został otwarty dla zagranicznych inwestorów. W 1992 roku uchylone zostały kontrole cenowe przy emisji akcji, które prowadziły często do niedoszacowania przedsiębiorstw (tzw. underpricing). Rynki kapitałowe zostały poddane nadzorowi Security and Exchange Board of

${ }^{5}$ Efektem redukcji ceł były istotne zmiany w strukturze dochodów państwa. W roku 1990/91 wpływy z ceł stanowiły niemal 36 proc. dochodów podatkowych budżetu centralnego, natomiast w roku 2000/01 było to już 25 proc. [Sury (ed.), 2003, s. 719]. Spadek dochodów z ceł był kompensowany wzrostem wpływów z tytułu podatków bezpośrednich (PIT i CIT). 
India (SEBI - powstała w 1988 roku). Jej kompetencje w nowych warunkach gospodarowania uregulowała ustawa z 1992 roku (The Securities and Exchange Board of India Act 1992). W wyniku tego emisje akcji stały się atrakcyjniejsze dla przedsiębiorstw i szybko zwiększała się ich liczba. Od 1992 roku indyjskie przedsiębiorstwa mogły występować na giełdach zagranicznych. Na indyjskim rynku kapitałowym pojawiły się także - po wdrożeniu ustawy o SEBI - renomowane zagraniczne instytucje finansowe. To wszystko spowodowało wzrost kursów akcji i uczyniło indyjskie giełdy, tj. głównie Bombay Stock Exchange (BSE) oraz powstałą w 1992 roku (działalność rozpoczęła od kwietnia 1993 roku) - także w Bombaju - National Stock Exchange of India (NSE) atrakcyjnym rynkiem wschodzącym. Działalność obu tych giełd stała się znaczącym katalizatorem rozwoju indyjskiego rynku kapitałowego w latach następnych.

11. Liberalizacja systemu bankowego. To właśnie w sektorze bankowym najwcześniej rozpoczęto reformy. Były one bezwzględnym warunkiem zmian w innych sektorach gospodarki. Reformy miały gruntowanie zmienić wysoce scentralizowany i zbiurokratyzowany do tej pory system bankowy. Przede wszystkim zmniejszano i modyfikowano nadmierne uprzywilejowanie banku centralnego - Banku Rezerw Indii. Sektor bankowy, zgodnie z duchem reform, został poddany przyspieszonej deregulacji, decentralizacji i prywatyzacji. Rynek pieniądza oparto na regułach wolnej i uczciwej konkurencji. W tym kontekście istotnym zmianom zaczęła ulegać sama polityka kredytowa, a podstawowe jej parametry (głównie stopy procentowe) ustalały się już na rynku pieniężnym, a nie - jak dotąd - arbitralnie. Państwowe banki nie były już przymuszane do zasilania pożyczkami bankrutujących przedsiębiorstw. Stopniowo restrukturyzowano ich aktywa i wzmacniano kapitałowo. Przystąpiono do rozbudowy sieci bankowej, tak by kredyty, zarówno produkcyjne, jak i konsumpcyjne, stały się dostępne dla małych przedsiębiorstw oraz większej liczby gospodarstw domowych, szczególnie na wsi. W tym celu m.in. dopuszczono do tworzenia regionalnych, lokalnych i branżowych banków prywatnych. Dla zwiększenia konkurencyjności w systemie bankowym i podwyższenia aktywów bankowych, umożliwiono dostęp do indyjskiego rynku bankom zagranicznym. Odzew na liberalizację i deregulację w sektorze bankowym był duży, banki szybko zaczęły dostosować się do bazylejskich standardów kapitałowych; do 1996 roku wymogi bazylejskie spełniało ok. 2/3 banków indyjskich państwowych.

12. Prywatyzacja i deregulacja działalności ubezpieczeniowej. Wyjątkowo długo, bo do końca lat 90., utrzymywał się monopol państwa w sektorze ubezpieczeń. W 1993 roku powołano Komitet ds. reformy ubezpieczeń pod kierunkiem R.N. Malhorty, który w 1994 roku ogłosił raport w tej sprawie. Efekty raportu ujawniły się dopiero kilka lat później. Opierając się na raporcie Komitetu Malhorty, w 1999 roku uchwalono Ustawę o urzędzie regulacji i rozwoju ubezpieczen (The Insurance Regulatory and Development Authority Act 1999). Na jej mocy zaczęto tworzyć prywatne instytucje ubezpieczeniowe, w tym także z udziałem kapitału zagranicznego. 
13. Racjonalizacja dzialalności przedsiębiorstw państwowych. Publiczny sektor gospodarki został objęty jurysdykcją Rady ds. Rekonstrukcji Przemysłowej i Finansowej (Board for Industrial and Financial Reconstruction - BIFR działa od 1987 roku jako departament w Ministerstwie Finansów). W kompetencji tej instytucji pozostawały decyzje odnośnie do likwidacji lub sanacji jednostek sektora publicznego. Miałoby się to odbywać poprzez ich restrukturyzację oraz prywatyzację, tj. sprzedaż częściowego lub większościowego pakietu akcji. BIFR prowadził również likwidację niektórych, wysoce deficytowych, a mało ważnych dla gospodarki przedsiębiorstw.

Powyższe założenia „nowej polityki ekonomicznej” mogą sugerować całkowite odejście od idei i praktyki socjalizmu, jak to miało miejsce w Europie Środkowo-Wschodniej. Tak się jednak nie stało. Utrzymany został m.in. jeden z podstawowych atrybutów gospodarki socjalistycznej, czyli centralne planowanie, aczkolwiek zmieniła się jego formuła i cel. Nie ma ono już charakteru dyrektywnego sensu stricto, a upodobniło się do planowania indykatywnego. Nie jest już tak zbiurokratyzowane, jak w poprzednich okresach, a plany przybrały charakter zestawu prognoz i zaleceń dla naczelnych oraz stanowych organów gospodarki i życia społecznego. Zresztą - argumentowano - żaden z szybko rozwijających się krajów Azji Wschodniej i Południowo-Wschodniej nie zrezygnował z planowania. Co więcej, to państwowemu planowaniu umiejętnie połączonemu $\mathrm{z}$ rynkiem kraje tego regionu zawdzięczają wielkie sukcesy gospodarcze i społeczne ${ }^{6}$.

$\mathrm{Z}$ uwagi na sytuację polityczną, tj. zmiany rządu federalnego w wyniku wyborów parlamentarnych w roku 1989 i 1991 (a także zabójstwa b. premiera R. Gandhiego) oraz wspomniany kryzys finansowy, nie wprowadzono w latach 1990/91-1991/92 nowego - VIII planu pięcioletniego, chociaż istniał już jego projekt. Te dwa lata są kolejnymi, trzecimi w historii gospodarki indyjskiej, ,,wakacjami planowymi". Cechuje je wyraźnie obniżenie dynamiki gospodarczej; w roku 1990/91 produkt krajowy netto zwiększył się o 5,4 proc., a w krytycznym roku 1991/92 zaledwie o 0,5 proc. [Economic Survey 2002-2003, tab. 1.2].

Skorygowany VIII plan pięcioletni zaczęto realizować dopiero w kwietniu 1992 roku, a więc na początku roku gospodarczego 1992/93. Jego realizację zakończono w marcu 1997 roku. Przedstawione wyżej najważniejsze wątki „nowej polityki ekonomicznej” stały się przesłaniem ideowym i trzonem tego planu.

${ }^{6} \mathrm{~W}$ sierpniu 2014 roku nowo powołany przez zwycięską w wyborach parlamentarnych (w maju-czerwcu tego roku) koalicję Narodowego Sojuszu Demokratycznego (zdominowaną przez Indyjską Partię Ludową) rząd Narendy Modiego zapowiedział likwidację Komisji Planowania i dalsze modyfikacje planowania gospodarczego. Oznacza to, jak pisali niektórzy obserwatorzy indyjskiej gospodarki i życia politycznego, formalny koniec ,,indyjskiego socjalizmu”, chociaż trudno wyobrazić sobie tak wielką gospodarkę bez systemu centralnego planowania. W czasie kończenia niniejszej pracy nie były znane dokładniejsze propozycje tych zmian. 


\subsection{Pierwsze lata wdrażania reform - doświadczenia, dylematy i efekty}

Sytuacja wewnętrzna Indii na początku lat 90. XX wieku, czyli po głębokiej zapaści gospodarczej i kryzysie politycznym była - o czym już wspominano - bardzo trudna. Opinia publiczna podzieliła się co do oceny istoty i sposobu działań reformatorskich rządu Narashimy Rao. Z jednej strony widziano nikłe efekty „socjalizmu indyjskiego" i wynikające z tego potrzeby głębokich reform. Z drugiej strony dostrzegano jednak ogromne koszty społeczne i polityczne, jakie będą związane z ich wdrażaniem. Reformy te niosły ze sobą - jak każde duże zmiany - nie tylko głębokie przekształcenia w systemie gospodarczym, ale w ślad za tym znaczące przemodelowanie struktury społecznej zarówno w aspekcie wertykalnym, jak i przestrzennym. Oznaczało to, że część społeczeństwa, względnie dobrze usytuowana i ustabilizowana w dotychczasowym systemie może pogorszyć swą sytuację materialną oraz status społeczny, jeśli nie bezwzględnie to przynajmniej względnie. Natomiast w wyniku działań reformatorskich poprawi się sytuacja innej części społeczeństwa, aczkolwiek efekty nie przyjdą szybko i będą wymagały dużego wysiłku i wyrzeczeń. Tak też się stało.

Zapoczątkowanie w 1991 roku reform i przedstawienie ich scenariusza na następne lata bynajmniej nie zjednoczyło społeczeństwa. Przeciwnie - dodatkowo go zdestabilizowało i podzieliło. Oprócz oczywistych pozytywnych, nigdy wcześniej nieosiąganych, wyników makroekonomicznych (o czym w rozdziale V), reformy niosły ze sobą niezadowolenie części środowisk gospodarczych oraz politycznych, to znaczy tych ich odłamów, które traciły swoje uprzywilejowane w okresie ,socjalizmu indyjskiego” pozycje. Ponadto - co najistotniejsze - reformy nie poprawily warunków życia ok. $300 \mathrm{mln}$ biednych ludzi, tj. głównie nieposiadających ziemi chłopów oraz mieszkańców szybko rozrastających się wielkomiejskich slumsów. Pogłębiły się dystanse między nimi a beneficjentami reform [Wolpert, 2010, s. 529-530]. W efekcie tego w kraju ponownie narasta chaos i dramatycznie nasilają się - jak nigdy dotąd - konflikty etniczno-religijne, szczególnie pomiędzy muzułmanami a hindusami [Boivin, 2011, s. 118-119]. $\mathrm{W}$ tej sytuacji zaczęły rosnąć w siłę partie opozycyjne, czyli prawicowe, nacjonalistyczne, które kontestowały wiele elementów polityki ekonomicznej centrolewicowego rządu Narashimy Rao.

Rosnąca rozbieżność interesów różnych grup społecznych przekładała się na zachowania partii politycznych. Reformy były krytykowane zarówno przez partie prawicowe - głównie Indyjską Partię Ludową, jak i partie lewicowe, z Komunistyczną Partią Indii (Marksistowską) na czele. Zarzucały one rządowi m.in. uległość wobec Międzynarodowego Funduszu Walutowego realizującego wówczas program Konsensusu Waszyngtońskiego (por. rozdział I). W wymiarze behawioralnym wyrazem stosunku Indusów do reform było wstępowanie (lub występo- 
wanie) do (z) odpowiednich partii i/lub głosowanie w wyborach parlamentarnych oraz regionalnych na tę lub inną partię, w zależności od tego, czy jej program odpowiadał interesom danej grupy społecznej. Istną plagą indyjskiego parlamentaryzmu stały się częste zmiany przynależności partyjnej przez posłów już w czasie trwania kadencji ${ }^{7}$. Ponadto w latach 80 . i 90 . ubiegłego wieku na indyjskiej scenie politycznej pojawia się wiele nowych partii, a szczególnie partii bazujących na klasach i kastach upośledzonych oraz najniższych kastach rolniczych. Coraz częściej partie te osiągają sukcesy wyborcze i ich przedstawiciele zaczynają zajmować wyższe stanowiska we władzach publicznych stanów i jednostek lokalnych. Zjawisko to obserwuje się przede wszystkim w północnych i środkowych stanach Indii [Brass, 1999, s. 138-139].

W sceptycznym lub nawet wrogim stosunku społeczeństwa indyjskiego do reform i ich pierwszych wyników należy upatrywać istotnych zmian w krajobrazie politycznym Indii ostatnich lat XX wieku i w pierwszej dekadzie bieżącego stulecia. Najbardziej wymiernym wyrazem tych nastrojów są wybory parlamentarne w 1996 roku i klęska Indyjskiego Kongresu Narodowego, głównego animatora radykalnych przemian gospodarczych. IKN poniósł największą klęskę w swej historii, uzyskując zaledwie 140 mandatów, czyli o 104 mniej niż w wyborach w 1991 roku. Wybory nie wyłoniły jednak zdecydowanego zwycięzcy, posiadającego większość parlamentarną. Najwięcej foteli w niższej izbie parlamentu obsadziła Indyjska Partia Ludowa (BJP), bo aż 161, co oznacza przyrost w stosunku do wyborów w 1991 roku o 41 mandatów, a w 1989 roku uzyskała 85 mandatów; awans tej partii jest więc oszałamiający. Trzecią siłą polityczną po wyborach w 1996 roku był blok partii lewicowych, który zdobył 52 mandaty, w tym Komunistyczna Partia Indii (M) - 32 mandaty. Relatywnie, w stosunku do innych demokratycznych państw Azji, duże wpływy stronnictw lewicowych, a zwłaszcza obu partii komunistycznych, działały hamująco na procesy liberalizacji i deregulacji gospodarki, przede wszystkim blokowały prywatyzację dużych przedsiębiorstw oraz banków i towarzystw ubezpieczeniowych. Partie te, podobnie jak niektóre grupy biznesu, obawiając się utraty dotychczasowych pozycji w gospodarce i administracji, prowadziły antyreformatorskie kampanie ostrzegające m.in. przed powrotem kolonializmu, „wyprzedażą Indii” itp. Dodać jednak trzeba, że do porażki Indyjskiego Kongresu Narodowego znacząco przyczyniła się też - podobnie jak w drugiej połowie lat 80. (rząd R. Gandhiego) - seria skandali korupcyjnych z udziałem członków rządu federalnego oraz ważnych urzędników stanowych. Skandale te dezawuowały moralnie reformatorów z Indyjskiego Kongresu Narodowego, odbierały im mandat do propagowania idei reform oraz ich realizacji. Tę sytuację skwapliwie wykorzystała opozycja polityczna.

7 W 1985 roku, na mocy 52 poprawki do konstytucji radykalnie ograniczono „międzypartyjne migracje". Wprowadzono zasadę, że poseł opuszczający partię traci mandat, z wyjątkiem sytuacji, gdy z partii odchodzi co najmniej $1 / 3$ posłów. 
Lata 1996-1999, podobnie jak okres 1989-1991, cechują się wysoką niestabilnością polityczną, czego wyrazem są częste zmiany rządów na szczeblu federalnym i w wielu stanach. Reasumując, w ostatnich latach XX wieku sympatie polityczne społeczeństwa indyjskiego przesunęły się zdecydowanie na prawo, czego dowodzą wyniki kolejnych wyborów zarówno parlamentarnych, jak i stanowych. Te zachowania wyborcze Indusów są bez wątpienia votum nieufności do całego pakietu reform oraz ich realizatorów, wywodzących się w większości z szeregów Indyjskiego Kongresu Narodowego.

Wysokie zwycięstwo wyborcze partii prawicowych z Indyjską Partią Ludową na czele i odsunięcie od władzy Indyjskiego Kongresu Narodowego nie przyniosło jednak - podobnie jak w latach 1989-1991 - stabilizacji sceny politycznej. Utworzone przez ogólnoindyjskie partie prawicowe oraz partie regionalne i lokalne sojusze okazały się nietrwałe i szybko się rozpadły ${ }^{8}$. Efektem licznych konfliktów i przetasowań w szeregach rządzącej koalicji i w partiach opozycyjnych były dwukrotne przedterminowe wybory parlamentarne - w roku 1998 oraz w roku 1999. Dopiero po wyborach w 1999 roku wytworzyła się pod przewodnictwem Indyjskiej Partii Ludowej (182 mandaty) trwała koalicja zwana Aliansem Narodowo-Demokratycznym (złożona z 28 partii). W październiku 1999 roku koalicja ta powołała rząd federalny, na czele którego stanął Atal B. Vajpayee. Tym razem rząd prawicowy okazał się - pomimo zróżnicowanego zaplecza - trwały, gdyż sprawował władzę przez pięć lat, tj. do wyborów w 2004 roku. Indyjski Kongres Narodowy uzyskał zaledwie 114 mandatów [Iwanek, Burakowski, 2013, s. 388].

Zdominowany przez Indyjską Partię Ludową rząd nie odstąpił co prawda od podstaw programowych ,nowej polityki ekonomicznej”, ale też ich wdrażanie nie było jego priorytetem. Zbyt dużo uwagi poświęcono natomiast sprawom stricte politycznym, a szczególnie realizacji programu hindutvy („hinduskości” - nacjonalizmu hinduskiego), czyli umacniania w systemie państwa tożsamości hinduskiej i organizacji życia publicznego według reguł hinduizmu [Zajączkowski, 2007]. Próbowano to czynić m.in. poprzez nadawanie hinduizmowi statusu religii uprzywilejowanej i obsadzanie ważnych stanowisk publicznych tylko przez osoby ją wyznające, co oznaczało dyskryminację obywateli innych grup etnicznych

${ }^{8}$ Zjawiskiem charakterystycznym dla indyjskiej sceny politycznej lat 90 . był dynamiczny wzrost popularności regionalnych i lokalnych partii politycznych. Wyrazem tego jest coraz większa liczba mandatów w Izbie Ludowej uzyskiwana przez te partie - w 1984 roku było ich 30, a w następnych wyborach: 1989 - 49, 1991 - 57, 1996 - 122, 1998 - 174 [Khan, 1998, s. 187-188]. Rosnąca rola partii regionalnych i lokalnych oznacza istotne zmiany jakościowe na indyjskiej scenie politycznej i państwowej. Konsekwencją tego jest wzrost żądań dotyczących zwiększenia autonomii regionów i lokalnych jednostek administracyjnych. Partii regionalnych i lokalnych nie można już lekceważyć, gdyż stają się ważnymi elementami koalicji rządowych. Niejednokrotnie koalicje te stają się nawet swoistymi zakładnikami takiej, czy innej partii regionalnej [Tokarski, 2006]. 
oraz innych wyznań, a dodatkowo generowało konflikty społeczne'. Takie postępowanie władz centralnych nasilało w wielu regionach konflikty komunalistyczne i destabilizowało życie społeczne.

Ważną proreformatorską decyzją podjętą przez rząd prawicowy było jednak znaczące obniżenie podatków w 1996 roku. Maksymalna stawka podatkowa dla przedsiębiorstw została obniżona do 35 proc., a podatku dla osób fizycznych do 30 proc. ${ }^{10}$ Jednakże w 1999 roku - po ukształtowaniu się nowej koalicji prawicowej - podatki te zostały ponownie podniesione $\mathrm{z}$ uwagi na potrzebę zmniejszenia deficytu budżetowego państwa. Podwyżki wyniosły 10 proc. i podatek dla przedsiębiorstw wzrósł do 38,5 proc., a podatek od dochodów osobistych do 33 proc. dochodów ${ }^{11}$. Wzrosły także niektóre podatki pośrednie oraz cła. Sytuację po 1998 roku pogorszyło też wprowadzenie przez USA - największego partnera handlowego Indii - sankcji gospodarczych w odpowiedzi na przeprowadzenie przez ten kraj prób z bronią nuklearną. Restrykcje miały też dobrą stronę, gdyż przyspieszyły liberalizację handlu zagranicznego poprzez cofnięcie niektórych licencji na przywóz towarów, m.in. dóbr konsumpcyjnych.

Pomimo oporu ze strony części elektoratu Indyjskiej Partii Ludowej - o czym w dalszej części rozdziału - rządy prawicowe włączały stopniowo gospodarkę w proces globalizacji i próbowały uczynić z Indii docelowo światowe, a na krótką metę przynajmniej kontynentalne mocarstwo. Takie podejście wynikało nie tylko z rangi demograficznej Indii i tkwiącego w ponadmiliardowym społeczeństwie

${ }^{9}$ Francuski historyk, badacz dziejów Indii M. Boivin [2011, s. 122] tak charakteryzuje okres rządów partii prawicowych (1996-2004): „Istotne wyzwania dla rozwoju Indii, a mianowicie gospodarka wodna, niedostatki infrastruktury, klęski głodu w wielu regionach, poważne różnice w rozwoju ekonomicznym pomiędzy północą a południem kraju - nie były tematem obrad. Nie powzięto żadnych konkretnych środków, ażeby przyspieszyć aktywność w dziedzinie gospodarki”.

${ }^{10}$ Nie bez wpływu na kontynuowanie polityki reform po 1996 roku jest fakt, że w latach 1996-1998 funkcję ministra finansów w rządach prawicowych sprawował Palaniappan Chidambaram, który wcześniej - należąc do Indyjskiego Kongresu Narodowego - był członkiem gabinetów R. Gandhiego oraz N. Rao i współpracował z M. Singhiem przy konstrukcji programu „nowej polityki ekonomicznej”. P. Chidambaram został ponownie powołany na stanowisko ministra finansów w roku 2004 przez premiera M. Singha i pozostawał nim do 2008 roku. Jego pierwszą ważną decyzją w 1996 roku - jako ministra finansów - była wspomniana właśnie reforma podatków, znacznie je obniżająca.

11 Trzeba jednakże pamiętać, że udział podatków bezpośrednich w ogólnej sumie podatków wpływających do budżetu centralnego jest niewielki, aczkolwiek w latach 90. systematycznie zwiększał się, kompensując spadek dochodów z tytułu ceł. W roku 1990/91 podatki bezpośrednie (PIT i CIT) stanowiły 18,6 proc., a w roku 2000/01 - 35,7 proc. podatków centralnych. Pod koniec lat 90., na ok. 1 mld mieszkańców Indii, podatek od dochodów osobistych płaciło zaledwie 14,2 mln osób, co jest i tak wielkością czterokrotnie większą niż w roku 1990/91 (ok. 3,5 mln) [Bywalec, 2005]. Oczywiście przyczyną tego stanu rzeczy są bardzo niskie dochody ogromnej części społeczeństwa, wysokie koszty poboru podatków oraz wyjątkowa mała i nieudolna ich ściągalność. Ponadto w tej dziedzinie występuje bodaj największa skala korupcji i przestępczości gospodarczej. 
potencjału gospodarczego, ale też z przyczyn politycznych, tj. wysokiej dozy indyjskiego nacjonalizmu, jakim były przesiąknięte programy partii prawicowych. Przysłowiowy sen z oczu spędzał indyjskim przywódcom dynamiczny rozwój Chin oraz innych krajów Azji Południowo-Wschodniej. Ich ambicją było dotrzymanie im kroku, a w przyszłości nawet osiągnięcie wyższego tempa wzrostu gospodarczego, co pozwoliłoby Indiom awansować do grona potęg światowych. Wyrazem mocarstwowych ambicji było też wspomniane wcześniej przeprowadzenie w 1998 roku testów z bronią jądrową i włączenie Indii do grupy państw atomowych.

Reasumując, z uwagi na niestabilną sytuację polityczną w kraju i załamanie gospodarcze w Azji Wschodniej, w latach 1996-1999 nie wdrożono jednak żadnych nowych, istotnych rozwiązań, przez co - ogólnie ujmując - proces modernizacji gospodarki i ustroju państwa został wyraźnie spowolniony. Stosunkowo wysokie wskaźniki wzrostu indyjskiej gospodarki w tym okresie były przesuniętym w czasie efektem decyzji podjętych w latach 1991-1996 przez rząd Indyjskiego Kongresu Narodowego [Zajączkowski, 2012, s. 635]. Rozwiązania te opierały się przede wszystkim - jak już wykazano - na wykorzystaniu ekstensywnych, czyli prostych rezerw, będących bezpośrednim efektem uwalniania gospodarki indyjskiej z gorsetu nadmiernych ograniczeń, takich jak: licencje, zakazy importu, wysokie cła, polityka kursu walutowego itp.

Argumenty ekonomiczne, ale także charakterystyczne dla rządów prawicowych mocarstwowe aspiracje Indii, legły u podstaw otwarcia indyjskiej gospodarki na inwestycje zagraniczne. Do takiego postępowania zmuszał w głównej mierze niedostatek krajowego kapitału. Rzeczywiście w drugiej połowie lat 90. (z wyjątkiem lat 1997-1998, czyli okresu kryzysu wschodnioazjatyckiego i amerykańskich sankcji) do indyjskiej gospodarki zaczęły napływać pokaźne strumienie kapitałowe $\mathrm{z}$ zagranicy $\mathrm{i}$ to $\mathrm{w}$ dziedzinie nowoczesnego przemysłu i usług. Głównymi argumentami dla zagranicznych inwestorów była obfita podaż pracy, wielki krajowy rynek zbytu oraz prorynkowa orientacja reform.

Jeżeli chodzi o indyjski rynek pracy, to na uwagę zasługują liczne zasoby wysoko kwalifikowanej i - co również godne uwagi - relatywnie taniej pracy. Jest to efektem rozwoju wyższej edukacji. Indyjskie kształcenie akademickie - wzorowane na systemie angielskim i amerykańskim - pozostało nadal na dobrym poziomie; do kwestii tych powrócimy w dalszej części rozdziału.

Drugi aspekt atrakcyjności inwestycyjnej Indii wynikał z ogromnego i głębokiego rynku zbytu finalnych produktów konsumpcyjnych, głównie artykułów przemysłowych i to w dłuższym horyzoncie czasowym. U źródeł popytu wewnętrznego tkwi duża liczba ludności, a szczególnie dynamicznie powiększająca się klasa średnia i niski dotąd stopień zaspokojenia jej aspiracji konsumpcyjnych. Do middle class zalicza się ludzi relatywnie dobrze wykształconych, ambitnych, przedsiębiorczych i pracowitych. Są to przede wszystkim posiadacze ziemscy, przedsiębiorcy, politycy, wyżsi urzędnicy, managerowie, twórcy oraz 
nauczyciele. Jakkolwiek grupy te są - pomimo na ogół młodego wieku - w sensie systemu wartości mocno zakotwiczone w tradycjach i kulturze indyjskiej, to w swoich aspiracjach i zachowaniach konsumpcyjnych orientują się na ogół na zachodnie wzorce. Na przełomie XX i XXI stulecia liczebność indyjskiej klasy średniej była szacowana na blisko $300 \mathrm{mln}$ osób [Bhutani, 2006] ${ }^{12}$. Wzrost aspiracji konsumpcyjnych znacznej części społeczeństwa istotnie stymulował rozwój handlu, rzemiosła, transportu, bankowości itp. Wewnętrzny popyt konsumpcyjny był systematycznie zasilany z zewnątrz przez transfery pieniężne od pracujących za granicą Indusów, szacowane na początku XXI wieku na 16 mld USD rocznie [Bhutani, 2006]. Aby podołać szybko rosnącemu popytowi, musiały powstawać nowe przedsiębiorstwa, szczególnie małe i średnie, najszybciej dostosowujące się do potrzeb rynkowych. Pobudzało to znacząco rodzimą przedsiębiorczość i sprzyjało szybszemu rozwojowi całej gospodarki.

W kontekście zmian w aspiracjach i zachowaniach konsumpcyjnych dużej części indyjskiego społeczeństwa wspomnieć trzeba o istotnych przemianach w zakresie organizacji i funkcjonowania handlu oraz problemach z tym związanych. Otwarcie gospodarki na import kapitału i towarów konsumpcyjnych, a zwłaszcza obniżenie ceł wwozowych, sprawiło, że na rynku pojawiły się nowe podmioty gospodarcze, będące zazwyczaj filiami zagranicznych sieci produkcyjnych i handlowych. Tym samym pogorszyła się sytuacja rodzimych wytwórców i kupców, którzy do tej pory byli niejednokrotnie monopolistami na swoich rynkach. W tej nowej sytuacji bardzo często nie wytrzymywali oni nie tylko zagranicznej konkurencji, lecz także konkurencji między sobą, której wcześniej nie było. Taka sytuacja zmuszała część z nich do zwiększania aktywności, obniżania cen oraz poprawienia jakości swych produktów. Przedsiębiorstwa, które tego nie czyniły i nie sprostały konkurencji, musiały po prostu zbankrutować. Rodziło to znaczący opór części sfer biznesowych przeciwko napływowi obcego kapitału oraz towarów, przestrzegano m.in. przed wyprzedażą indyjskiego majątku, wywozem zysków itp. [Gutowski, 2002, s. 191]. Takie nastroje legły u podstaw wzrostu sympatii i udzielania wsparcia partiom i ruchom politycznym o zabarwieniu nacjonalistycznym. Ponownie odżyła idea swadeshi, czyli samowystarczalności indyjskiej gospodarki, popularna w okresie walk o niepodległość Indii. W tym właśnie sprzeciwie wobec szybkiego otwierania na świat tkwi też jedna z przyczyn politycznych sukcesów partii prawicowych w latach 90., a przede wszystkim Indyjskiej Partii Ludowej.

Dużą rolę w ożywieniu i modernizacji indyjskiej gospodarki odegrał - jak już wspomniano - napływ zagranicznego kapitału i czynione przez niego inwestycje na obszarze Indii, zarówno inwestycje bezpośrednie (zakupy maszyn, części

12 Według szacunków Indyjskiej Izby Kupieckiej (Indian Merchants' Chamber), w połowie lat 90. liczba bardzo bogatych Indusów wynosiła ok. $6 \mathrm{mln}$, do klasy konsumpcyjnej zaliczano ok. $150 \mathrm{mln}$, do tzw. klasy wspinającej się (climbers) - ok. $275 \mathrm{mln}$, a do klasy aspirującej dalsze 275 mln osób [za: Gutowski, 2002, s. 188-189]. 
lub całości przedsiębiorstw), jak i portfelowe (zakup papierów wartościowych, np. akcji, obligacji i in.). Bezpośrednio po wdrożeniu programu „,nowej polityki ekonomicznej" obowiązywały jeszcze ograniczenia będące pozostałością okresu poprzedniego oraz bieżącego oporu ze strony przedsiębiorstw indyjskich. Dotyczyło to zwłaszcza tych zagranicznych inwestorów, którzy chcieli pozyskać więcej niż 49 proc. udziału w kapitale indyjskiego przedsiębiorstwa. Wówczas musieli uzyskać zezwolenie Urzędu Promocji Inwestycji Zagranicznych (Foreign Investment Promotion Board - FIPB). Preferowane były inwestycje przedsiębiorstw, których właścicielami byli mieszkający za granicą Indusi (gdy posiadali co najmniej 60 proc. kapitału przedsiębiorstwa). Mogli oni nabywać nawet 100 proc. kapitału (akcji, udziałów) krajowych przedsiębiorstw [Gutowski, 2002, s. 193-194]. W pierwszych latach po reformie obserwuje się coroczne, znaczące przyrosty inwestycji bezpośrednich ${ }^{13}$. Głównymi inwestorami były przedsiębiorstwa amerykańskie oraz brytyjskie, japońskie, holenderskie i niemieckie; dokładniej zagadnienia te są przedstawione $\mathrm{w}$ rozdziale $\mathrm{V}$.

Jedną z najważniejszych oznak wdrażania nowej polityki ekonomicznej, a szczególnie tak mocno eksponowanego jej otwarcia na świat, były korzystne zmiany w handlu zagranicznym. Zaczęły zwiększać się wpływy z eksportu, aczkolwiek nie było to tylko efektem wzrostu ilości wywożonych towarów, lecz - jak wcześniej wykazano - przede wszystkim prowadzonej przez Bank Rezerw Indii polityki dewaluacji indyjskiej rupii względem obcych walut. Taka polityka kursowa sprawiała, że wzrastała opłacalność eksportu, co było istotnym stymulatorem zwiększania produkcji na eksport i prowadziło do jej unowocześnienia, zmniejszania kosztochłonności itp. Ważną przyczyną obniżenia się fizycznych rozmiarów eksportu w pierwszych dwóch latach transformacji był rozpad Związku Radzieckiego, największego do tej pory partnera handlowego Indii i głównego odbiorcy jej towarów.

Znaczące ożywienie w eksporcie następuje po 1993 roku. W latach 19931996 roczna stopa wzrostu eksportu wyniosła ok. 20 proc., co jest dużym osiągnięciem wobec wspomnianego spadku wywozu do ZSSR i europejskich krajów

13 Napływ bezpośrednich inwestycji zagranicznych oraz często związane z tym tworzenie specjalnych stref ekonomicznych ma, oprócz ewidentnych zalet, także wady. Lokalizacje nowych inwestycji, szczególnie typu greenfield, powodują niejednokrotnie wielkie problemy techniczne, ekonomiczne i - co najważniejsze - społeczne i kulturowe. Te ostatnie wynikają - przykładowo - z wywłaszczeń i przesiedleń ludności z obszarów inwestowania do innych regionów, czyli istotnych zmian w sieci osiedleńczej i związanej z tym utraty miejsc pracy (gospodarstwa rolnego, warsztatu), zmian otoczenia społecznego oraz kulturowego itp. Skala tych zjawisk i wynikających z nich konfliktów - często krwawych - jest w Indiach wyjątkowo duża, co przekłada się m.in. na sympatie polityczne i zachowania wyborcze części społeczeństwa [Levien, 2011]. Miały one zapewne wpływ na wyniki wyborów parlamentarnych w 2014 roku, czyli wielką przegraną rządzącego w latach 2004-2014 reformatorskiego Indyjskiego Kongresu Narodowego. 
socjalistycznych. Oznacza to istotną reorientację geograficzną indyjskiego handlu zagranicznego. Eksport stał się w tych latach jednym z motorów napędowych gospodarki Indii. Oprócz wspomnianej dewaluacji rupii, istotną rolę w stymulacji eksportu zaczęły wywierać znaczące obniżki ceł wywozowych, co - obniżając ceny - zwiększało konkurencyjność indyjskich towarów, poprawiała się także ich jakość. Ponadto coraz szybciej zwiększał się eksport usług, który w następnych latach stał się lokomotywą rozwoju indyjskiego handlu zagranicznego.

Wzrost eksportu i chęć jego dalszego intensyfikowania pociągnęły za sobą potrzebę zwiększania importu, szczególnie tych dóbr, których w Indiach brakowało, a były one niezbędnymi komponentami towarów wywożonych. Ale początkowo, do 1994 roku, nie obserwuje się, pomimo obniżenia ceł i kontyngentów wwozowych, wyraźnego wzrostu importu. Dotyczy to w szczególności przetworzonych artykułów konsumpcyjnych oraz rolniczych, dla przywozu których ostatnie restrykcje zniesiono jeszcze później, bo dopiero w 2001 roku [Förstmann, Gregosz, 2010]. Jest to skutkiem, po pierwsze - trudności budżetowych, a po drugie - podrożenia importu na skutek dewaluacji rupii. Ożywienie nastąpiło w połowie dekady, ale od 1997 roku ma miejsce ponowny spadek tempa wzrostu indyjskiego importu, na co wpłynęło okresowe (do 2001 roku) podniesienie ceł. Dotyczyło to szczególnie produktów rolnych, na wwóz których zamierzano cofnąć ograniczenia ilościowe, a podwyżka opłat celnych miała hamować ich napływ na indyjski rynek. Należy dodać, że znaczący wpływ na politykę handlu zagranicznego Indii lat 90. wywierał fakt, że były one członkiem Światowej Organizacji Handlu (WTO) od samego jej początku, tj. 1 stycznia 1995 roku (powstała z przekształcenia się dotychczasowego GATT - General Agreement on Tariffs and Trade). Dokładniej rozwój i problemy inwestycji zagranicznych oraz wymiany handlowej przedstawione zostaną $\mathrm{w}$ rozdziale $\mathrm{V}$.

Dostęp do rynków zagranicznych i korzystne zmiany w wymianie międzynarodowej powoli zaczęły oddziaływać m.in. na wzrost efektywności i konkurencyjności wielu gałęzi indyjskiego przemysłu. W wyniku tego wzrosła rentowność produkcji indyjskich przedsiębiorstw, niejednokrotnie do tej pory deficytowych. Poprawiła się także jakość wytwarzanych dóbr, czego dowodem była m.in. liczba pozyskanych certyfikatów jakości ISO 9000. W styczniu 1993 roku certyfikaty takie uzyskało zaledwie 8 przedsiębiorstw, a w maju 1996 roku było ich już ok. 1200 [Gutowski, 2002, s. 200].

Indyjskie reformy gospodarcze rozpoczęte w 1991 roku realizowały - jak już wspominano - dwa cele, nie w pełni jednak ze sobą kompatybilne. Po pierwsze, były kołem ratunkowym dla pogrążonej w głębokiej zapaści gospodarce. Po drugie - stały się kluczem, swoistą mapą drogową Indii w ostatnich latach XX wieku i na początku XXI wieku. Osiągnięcie jednocześnie obu tych celów jest - wbrew pozorom - bardzo trudne, zazwyczaj bowiem to, co jest skuteczne w krótkim czasie, w dłuższym okresie może okazać się nieracjonalne i na odwrót. Takie dylematy musiano niejednokrotnie rozstrzygać. 
Inspirowane Konsensusem Waszyngtońskim reformy indyjskie nie miały jednak - poza wyjątkowymi zagadnieniami - charakteru terapii szokowej, lecz były to na ogół przekształcenia wolne, gradualne. Taka strategia wynikała nie tyle $\mathrm{z}$ racji ekonomicznych, ile - a może przede wszystkim - z uwarunkowań społeczno-politycznych oraz etniczno-kulturowych. W tak specyficznym kraju, gdzie skala tyranii status quo jest wyjątkowo duża, gdzie od wieków wszystko dzieje się powoli, szybkie zmiany gospodarcze doprowadziłyby: w wariancie „pokojowym” - do istotnych przetasowań na indyjskiej scenie politycznej, czyli w strukturach władzy, co miało miejsce w drugiej połowie lat 90., a w wariancie gorszym - „konfliktowym” - do poważnych zaburzeń w życiu publicznym (otwartych protestów społecznych, strajków, demonstracji ulicznych itp.), których - jak wskazuje obserwacja codziennego życia indyjskich miast i wsi - nie brakuje. Podsumowując, te właśnie czynniki polityczne i społeczno-kulturowe odgrywały - jak w rzadko którym kraju - bardzo ważną rolę w pierwszych latach transformowania indyjskiej gospodarki. Bez ich uwzględnienia nie sposób wyjaśnić wielu decyzji ekonomicznych i zachowań władz krajowych oraz stanowych, a także lokalnych - szczególnie po 1993 roku, czyli w warunkach tak dużej reformy politycznej, jaką była decentralizacja, to znaczy tworzenie demokratycznego samorządu terytorialnego.

Nakładanie się problemów politycznych i społeczno-kulturowych na sprawy ekonomiczne jest bodaj najwyraźniej widoczne w odniesieniu do prywatyzacji przedsiębiorstw państwowych. Pomimo niewątpliwej potrzeby i świadomości władz co do konieczności przekształceń własnościowych, proces ten przebiegał od samego początku w bardzo wolnym tempie i był spóźniony w stosunku do innych reform. Jak już wspomniano, w sektorze ubezpieczeń prywatyzację rozpoczęto dopiero pod koniec lat 90 . Na przeszkodzie prywatyzacji stał m.in. nieuregulowany system podatków obrotowych (głównie VAT), szczególnie w dynamicznie rozwijającym się sektorze usług. Ponadto sądzono, że prywatyzacji poddane zostaną w pierwszej kolejności rentowne przedsiębiorstwa państwowe, a nie te gorsze, dotowane przez państwo, które wymagają intensywnej sanacji. Innym - bodaj najważniejszym - hamulcem prywatyzacji były obawy o masowe zwolnienia pracowników i zwiększenie bezrobocia, na co dowodem była sytuacja w postsocjalistycznych krajach Europy Środkowo-Wschodniej. Kwestie prywatyzacji stały się w Indiach - podobnie jak w innych krajach transformujących swe gospodarki - przedmiotem burzliwych sporów politycznych. Szczególnie budziły opór ze strony partii lewicowych, głównie obu partii komunistycznych, które jakkolwiek nie stanowiły wielkiej siły politycznej, to często na forum parlamentu pełniły rolę tzw. języczka u wagi, to znaczy bez ich akceptacji nie było możliwe podjęcie decyzji [Förstmann, Gregosz, 2010]. Nie chciano również dopuszczać do konfrontacji z nadmiernie skłonnymi do strajków związkami zawodowymi. $\mathrm{Z}$ tych to powodów w krajobrazie gospodarczym Indii w dalszym ciągu, pomimo upływu lat, utrzymywały się duże, wielce zbiurokratyzowane i o przestarzałym 
parku maszynowym, przedsiębiorstwa i to nie tylko państwowe, ale też prywatne, zatrudniające nadmiar pracowników i „produkujące” najczęściej straty. Firmy prywatne, jeśli stawały się bankrutami, to też nie zawsze je likwidowano, lecz przechodzily pod zarządy państwowe, byle tylko nie zwalniały pracowników. Oba te rodzaje dużych przedsiębiorstw były w takich sytuacjach dotowane przez państwo. Chociaż takie postępowanie było ekonomicznie nieracjonalne i niezgodne z duchem reform, to za utrzymaniem status quo przemawiały właśnie względy społeczne i polityczne. Obawiano się nie tylko prywatyzacji dużych przedsiębiorstw, ale nawet ich modernizacji, jeśli skutkami ubocznymi tych działań byłyby duże zwolnienia pracowników.

Przykładem racjonalnego postępowania rządu indyjskiego w latach 1991-1993 była natomiast szybka poprawa indyjskiego bilansu płatniczego, ograniczenie inflacji i deficytu budżetowego państwa. Sprawiło to, że deficyt zmniejszył się z 7 proc. w 1991 roku do 4,8 proc. PKB w 1993 roku. Osiągnięto to w wyniku restrykcyjnej polityki pieniężnej oraz fiskalnej, a konkretniej - zmian kursu rupii oraz ograniczenia publicznych wydatków, głównie inwestycyjnych (w tym wydatków zbrojeniowych), a także zwiększenia podatków. Kontynuacja takiej polityki na dłuższą metę jest nieracjonalna i - najprawdopodobniej - niemożliwa. Konsolidacja finansów państwa poprzez dalsze redukowanie wydatków wpływa negatywnie na aktywność gospodarczą, zmniejsza produkcję i hamuje inwestycje, a co za tym idzie - maleje m.in. strumień podatków zarówno pośrednich, jak i bezpośrednich. Troska o niski bieżący deficyt budżetowy ogranicza też zmniejszanie ceł, dalej jeszcze wysokich i stanowiących pokaźny udział w dochodach państwa, pomimo ich znaczących redukcji po 1991 roku. To wszystko zaś spowalnia liberalizację indyjskiego handlu zagranicznego, który w warunkach otwarcia gospodarki na świat i globalizacji mógłby być ważnym stymulatorem wewnętrznej produkcji oraz konsumpcji, a przez to $\mathrm{w}$ niedalekiej przyszłości korzystnie oddziaływać na bilans płatniczy oraz budżet państwa i w ogóle podnosić konkurencyjność indyjskiej gospodarki [Gutowski, 2002, s. 203-204]. W sytuacji takich zachowań państwa mamy poniekąd do czynienia z dylematem przysłowiowego błędnego koła, które nie wiadomo, gdzie i kiedy przerwać.

Do najważniejszych determinant indyjskiej transformacji gospodarczej należą problemy demograficzne, rozpatrywane - w tym przypadku - w aspekcie rynku pracy oraz zatrudnienia. $Z$ racji dużej i szybko rosnącej liczby ludności nieustannie powiększa się podaż pracy i to zarówno pod względem ilościowym, jak i jakościowym. Indie są jednym z najmłodszych społeczeństw świata. $\mathrm{Na}$ przełomie pierwszej i drugiej dekady bieżącego wieku ponad 50 proc ludności Indii stanowiły osoby poniżej 25 . roku życia. Ponadto struktura wiekowa ludności Indii jest znacznie korzystniejsza niż w kraju ich głównego konkurenta - w Chinach oraz - przede wszystkim - w większości krajów wysoko rozwiniętych, gdzie szybko postępują procesy starzenia się społeczeństw. Prognozy demograficzne dobrze więc rokują dla Indii w nasilającym się współzawodnictwie światowym. 
Ten znaczący atut demograficzny, zwany czasem demograficzna dywidenda, wynika z faktu, że ogromną część mieszkańców tego kraju stanowią osoby we wczesnym wieku produkcyjnym i wchodzące dopiero na rynek pracy.

Wraz z liczbą oraz wiekiem pracujących dynamicznie zmienia się również struktura podaży pracy pod względem kwalifikacji. Indyjskie szkoły corocznie opuszczają miliony wykwalifikowanych młodych ludzi (inżynierów, informatyków, techników, rzemieślników itp.) zdolnych do pracy w nowoczesnych działach gospodarki. Na początku XXI wieku funkcjonowało w Indiach ponad 250 uniwersytetów i ok. 13 tys. innych szkół wyższych. Każdego roku z indyjskich uczelni wychodzi prawie 2,5 mln absolwentów, w tym ok. 350 tys. inżynierów i niemal wszyscy znają język angielski [Zajączkowski, 2012, s. 649-650]. Ponadto po 2000 roku obserwuje się znaczną skalę reemigracji, głównie z Bliskiego Wschodu i Afryki Wschodniej. Do kraju coraz częściej powracają osoby dobrze wykształcone i zawodowo doświadczone za granicą. Są to wykwalifikowani robotnicy, inżynierowie, a często także zamożni przedsiębiorcy, którzy zakładając w ojczyźnie firmy lub filie posiadanych zagranicą, tworzą nie tylko nowe produkty, ale - co najważniejsze - miejsca pracy.

W powyższym kontekście nie sposób pominąć takiego waloru indyjskiego społeczeństwa, jak pracowitość, przedsiębiorczość i innowacyjność. Niejednokrotnie zwraca się uwagę na niemal tradycyjne, jakby genetyczne uzdolnienia Indusów do przedmiotów ścisłych, co w wyrazie zawodowym przekłada się zazwyczaj na wysokie kwalifikacje takich pracowników, jak: informatycy, finansiści, inżynierowie, lekarze, chemicy, farmaceuci itp. Istotne znaczenie mają też, szczególnie w warunkach szybko postępującej w latach 90. globalizacji gospodarki, relatywnie niskie koszty pracy, wynikające generalnie z niższych niż w krajach rozwiniętych kosztów utrzymania oraz aspiracji społecznych. Te właśnie cechy podażowej strony rynku pracy zwiększają międzynarodową konkurencyjność indyjskich przedsiębiorstw, stymulują eksport oraz przyciągają inwestycje zagraniczne. Do spraw tych powrócimy w rozdziale $\mathrm{V}$, w kontekście analizy rozwoju usług, a szczególnie offshoringu.

Nie można jednakże zapominać o istnieniu drugiej, „,iemniejszej” strony indyjskiej demografii i rynku pracy, czyli o dziesiątkach milionów młodych ludzi, którzy nie mają jeszcze możliwości nauczenia się pisania i czytania, nie wspominając już o szansach na zdobycie wyższych kwalifikacji zawodowych. Jest to wielki problem, a perspektywa jego rozwiązania nie jest bynajmniej bliska, nawet przy założeniu realizacji najbardziej korzystnych scenariuszy rozwojowych.

Reformy liberalizacyjno-deregulacyjne po 1991 roku spowodowały zmniejszenie roli państwa - rozumianego jako władza centralna - w indyjskiej gospodarce. Ale nie zawsze było to ograniczenie państwa w ogóle. Często regulacyjne kompetencje centrum przejął średni szczebel struktury państwa, czyli stany. W niektórych dziedzinach gospodarki i życia publicznego można nawet mówić o wzroście roli władz stanowych i to pomimo utworzenia w 1993 roku ich prze- 
ciwwagi w postaci samorządu lokalnego oraz wyposażenia go w znaczne kompetencje i środki finansowe. Dotyczy to, przykładowo, uprawnień stanów w zakresie przyjmowania inwestycji zagranicznych oraz tworzenia specjalnych stref ekonomicznych, instytucji tak ważnych dla modernizacji wielu regionów i w ogóle przyspieszania rozwoju całej gospodarki.

Wzrost kompetencji gospodarczych stanów, szczególnie tych dużych i zamożniejszych, dysponujących lepszą infrastrukturą i bardziej kwalifikowanymi zasobami pracy, może prowadzić do pogłębienia dysproporcji w przestrzeni gospodarczej kraju pomiędzy stanami, a czasem także w obrębie stanów. Rosnąca ranga stanów, czyli regionalnego szczebla organizacji indyjskiego państwa - będąca wyrazem jego liberalizacji i demokratyzacji - niesie więc z sobą nie tylko szanse, ale i zagrożenia. Te ostatnie są w przypadku Indii dość poważne. Zbyt duże, a w dodatku pogłębiające się, zróżnicowanie gospodarcze stanów, skojarzone z ich odrębnością etniczną i religijną, może w pewnych okolicznościach rodzić nastroje separatystyczne i godzić w jedność państwa. Niebezpieczeństwa takie wielokrotnie pojawiały się w niedługiej przecież historii tego kraju.

Wszystkie te sprawy dotyczące ekonomicznych i społecznych skutków indyjskich reform gospodarki i państwa, w tym także jej zróżnicowania terytorialnego, są przedmiotem dokładniejszej, bo opartej na statystyce, analizy w rozdziałach $\mathrm{V}$ oraz VI i to ze znacznie dłuższej, bo dwudekadowej perspektywy. 



\section{ROZDZIAŁ IV}

\section{REFORMY USTROJU POLITYCZNEGO PO 1991 ROKU. DECENTRALIZACJA PAŃSTWA}

Niemal równolegle z rozpoczęciem reform indyjskiej gospodarki, przystąpiono do reformowania ustroju politycznego państwa. Był on - jako pokazano w rozdziale II - demokratyczny, ale tylko na szczeblu centralnym i regionalnym (stanowym). Niedemokratyczny pozostawał nadal - pomimo czynionych prób - szczebel lokalny. W pierwszych latach 90. nastąpiło więc „dopełnienie” indyjskiej demokracji, czyli decentralizacja, w wyniku której utworzony został demokratyczny samorząd lokalny. Reforma decentralizacyjna była największą modyfikacją ustroju politycznego Indii od początku niepodległego państwa. Ma ona ogromne znaczenie dla przyszłego rozwoju kraju i to we wszystkich jego wymiarach. W wyniku demokratyzacji lokalnego szczebla struktury państwa rozpoczęly się istotne przeobrażenia w sposobach funkcjonowania, kulturze, relacjach międzyludzkich i systemach wartości indyjskiego społeczeństwa. Zwiększenie samodzielności lokalnych władz wpływa także korzystnie na indywidualną przedsiębiorczość, a ta skumulowana w skali kraju będzie przyspieszać jego rozwój gospodarczy. Niniejszy rozdział poświęcamy prezentacji indyjskiej decentralizacji, traktując ją jako drugi człon wielkich reform w tym kraju.

\subsection{Problemy i uwarunkowania decentralizacji}

Decentralizacja pojmowana jest jako proces przekazywania władzy i środków finansowych na niższe szczeble struktury państwa. Uważa się ją na ogół za zjawisko korzystne ekonomicznie, społecznie i politycznie. Najogólniej ujmując, celem decentralizacji jest podniesienie ekonomicznej oraz społecznej efektywności funkcjonowania państwa, a w ślad za tym osiąganie wyższych wskaźników wzrostu gospodarczego, które z kolei winny przyczyniać się do poprawy poziomu życia społeczeństwa. Ale nie zawsze tak musi być, a priori nie da się zazwyczaj jednoznacznie ocenić decentralizacji1 ${ }^{1}$.

${ }^{1}$ Wybitny francuski badacz decentralizacji R. Prud'homme [1994, s. 1] tak m.in. pisał w tej kwestii: ,Z decentralizacją jest podobnie jak z lekarstwem. Trzeba ją stosować we właściwym czasie, we właściwej dawce i na odpowiednią chorobę. Stosowana niewłaściwie jest bardziej szkodliwa niż pożyteczna". 
Po II wojnie światowej można wyróżnić trzy okresy nasilania się procesów decentralizacyjnych na całym niemal świecie, a w szczególności w państwach, które powstały po rozpadzie systemu kolonialnego. Indie mogą uchodzić w tej dziedzinie za niemal wzorcowe studium przypadku².

Okres pierwszy to lata 50. XX wieku, kiedy większość nowo powstałych państw organizowała swój ustrój na zasadach demokracji i decentralizacji kompetencji oraz struktur terytorialnych. Jednakże w miarę upływu czasu oraz pojawiania się trudnych i często nieprzewidzianych problemów rozwojowych, w tym także potrzeby umacniania, a niejednokrotnie wręcz utrzymania państwowości oraz intensyfikacji procesów industrializacji, rządzące siły polityczne w wielu krajach uznawały, że model państwa zdecentralizowanego jest mało wydajny w osiąganiu makroekonomicznych i makrospołecznych celów. Na okres wychodzenia z zacofania $\mathrm{i}$ budowy nowych struktur państwa oraz gospodarki bardziej efektywnym wydawał się model scentralizowany, wsparty dodatkowo planowaniem gospodarczym. Dlatego też, pomimo wcześniejszych zamiarów i politycznych deklaracji, w praktyce nie podejmowano reform decentralizacyjnych, a jeśli nawet zostały formalnie uchwalone, to nie były w pełni realizowane lub w ogóle zostały zaniechane. Na okres kilkunastu lat problematyka reform decentralizacyjnych zeszła na dalszy plan, a nasiliły się procesy centralizacyjne [Bywalec, 2012].

Odrodzenie decentralizacji nastąpiło pod koniec lat 70. Było w dużej mierze efektem rozczarowania centralizacją (głównie gospodarki), która też nie przynosiła oczekiwanych efektów, a dodatkowo stawała się przyczyną wielu patologii gospodarczych i społeczno-politycznych. Powrót do reform decentralizacyjnych nie trwał jednak długo. Pojawiające się coraz częściej, po niemal trzech powojennych dekadach trwałego rozwoju gospodarki światowej, kryzysy gospodarcze znacząco skomplikowały przemiany ustrojowe zarówno w krajach rozwijających się, jak i rozwiniętych. Decentralizacja ponownie zeszła na dalszy plan.

Dopiero pod koniec lat 80 . i w całej dekadzie lat 90 . minionego wieku, a nawet jeszcze w pierwszych latach XXI stulecia, mamy do czynienia ze swoistą eksplozją reform decentralizacyjnych. Dotyczy to przede wszystkim słabo rozwiniętych państw Azji, Afryki oraz Ameryki Łacińskiej. Podobne zjawiska wystąpiły także w krajach wysoko rozwiniętych (tzw. decentralizacja korekcyjna) ${ }^{3}$.

${ }^{2}$ Dokładniej kwestie zalet i wad oraz metody badań decentralizacji przedstawia autor niniejszej pracy w artykułach opublikowanych na łamach „Samorządu Terytorialnego” oraz „Gospodarki Narodowej” [Bywalec, 2007; 2008; 2012]. Tam też podana jest obszerna literatura z tego zakresu. $\mathrm{Z}$ tych powodów w niniejszej pracy ograniczono się tylko do zwięzłego opisu decentralizacji, ze szczególnym uwzględnieniem jej specyfiki i uwarunkowań w Indiach.

3 J. Manor [2006] pisze wręcz o swoistej modzie na decentralizację w latach 90. i na początku XXI wieku: „Nie licząc krajów rozwiniętych, ponad 60 krajów Azji, Afryki i Ameryki Południowej doświadczyło w ostatnich latach - w różny sposób - reform decentralizacyjnych, a międzynarodowe organizacje rozwoju zalecają kolejnym krajom, aby poszły ich śladem". 
Mocnym impulsem dla reform decentralizacyjnych w całym niemal świecie - w tym także i w Indiach - był kryzys i następnie rozpad systemu socjalistycznego w ZSRR i Europie Środkowo-Wschodniej, z natury swej wysoce scentralizowanego i niedemokratycznego. Jednym z najważniejszych elementów przebudowy ustroju tych państw była decentralizacja i tworzenie demokratycznych struktur terytorialnych.

Istotnym czynnikiem sprzyjającym procesom decentralizacji było zakończenie „zimnej wojny” i procesy przyspieszonej integracji gospodarczej państw, obserwowane prawie na wszystkich kontynentach ${ }^{4}$. Nie bez znaczenia jest także triumf w ostatnich dwóch dekadach $\mathrm{XX}$ wieku liberalnego modelu gospodarki opartego na kanonach teorii M. Friedmana i odwrót od ekonomii keynesowskiej. Decentralizacja mieści się w programie reform liberalizujących i deregulujących gospodarkę oraz życie społeczne. Ponadto jest ona implicite zawarta $\mathrm{w}$ - opisanym w rozdziale I - Konsensusie Waszyngtońskim, który był inspiracją dla wielu reform w ostatniej dekadzie XX wieku, w tym także - jak zaznaczono - reform indyjskich. Decentralizacja bywa wykorzystywana również jako narzędzie łagodzenia konfliktów społecznych, szczególnie wówczas, gdy mają one także kontekst terytorialny. Niejednokrotnie dzięki decentralizacji zapobiega się tendencjom dezintegracyjnym i rozpadom państw.

Decentralizacji sprzyjała nasilająca się pod koniec XX wieku globalizacja. Okazało się, że decentralizacja jest najskuteczniejszym antidotum na negatywne skutki tego procesu. Ponadto, jak dowodzi praktyka, systemy zdecentralizowane potrafią najlepiej wykorzystać i zaadoptować do lokalnych społeczności to, co jest w globalizacji najlepsze.

Dokładniejsza analiza decentralizacji pozwala dostrzec jej zalety i wady. Są one przedmiotem wielu analiz oraz sporów zarówno na niwie teoretycznej, jak i praktycznej. $Z$ tego dyskursu oraz doświadczeń wynika m.in., że decentralizacji nie powinno się a priori traktować ani jako kategorii jednoznacznie pozytywnej, ani też negatywnej - trzeba ją niemal zawsze odnosić do konkretnego kraju oraz czasu.

Wykorzystując ogólną wiedzę o problemach decentralizacji i odnosząc ją do kształtu i uwarunkowań indyjskiej gospodarki, życia społecznego, politycznego, demografii oraz kultury, do potencjalnych zalet, czyli korzyści z decentralizacji w tym kraju, zaliczyć można:

1. Zastosowanie zasady subsydiarności, czyli odpowiedniego rozłożenia w pionowym układzie władzy (centrum - stany - samorządy lokalne) kompetencji w zakresie realizacji poszczególnych funkcji państwa, czyli funkcji stabilizacyjnej, redystrybucyjnej oraz alokacyjnej. Każda z tych funkcji (lub jej elementów) może mieć swoje optimum efektywności na innym szczeblu struktury państwa.

${ }^{4}$ Przykładem tego procesu może być przede wszystkim postępująca integracja na obszarze Unii Europejskiej, której ważnym elementem jest decentralizacja (regionalizacja). 
Kompetencje te należy tak usytuować, aby ich łączny, skumulowany w skali państwa efekt był najkorzystniejszy, czyli w danych warunkach optymalny.

2. Upodmiotowienie społeczności lokalnych oraz aktywizowanie ich, szczególnie warstw biednych, upośledzonych kulturowo oraz edukacyjnie, do działań na rzecz swojego najbliższego otoczenia. $\mathrm{W}$ ten sposób podnosić się będzie poziom ich świadomości politycznej i odpowiedzialności za rozwój swoich „małych ojczyzn”. Wszystko to - kumulując się - powinno sprzyjać rozwojowi gospodarczemu oraz społecznemu w wymiarze regionalnym i krajowym.

3. Dzięki wzrostowi autonomii samorządów lokalnych szybciej zwiększa się innowacyjność najniższych jednostek terytorialnych, a w następstwie tego ich konkurencyjność. Władze lokalne, mogąc swobodnie działać i posiadając lepsze rozpoznanie (niż np. władze stanowe) zasobów materialnych i ludzkich oraz potrzeb na swoich terytoriach, będą starały się efektywniej je wykorzystać i tą drogą osiągać przewagi konkurencyjne. Przyczyni się to do ich szybszego rozwoju gospodarczego i społeczno-kulturowego, a ostatecznie korzystnie przełoży na rozwój stanów i całego kraju. Badania rozwoju gospodarczego wskazują, że w dłuższych okresach kraje zdecentralizowane rozwijają się szybciej niż kraje o znacznej skali centralizacji, aczkolwiek nie zawsze tak musi byćs.

4. Łagodzenie i zmniejszanie tak licznych w społecznościach lokalnych Indii konfliktów na tle religijnym i etnicznym (komunalizm). Demokratyczne wybory i współuczestniczenie obywateli w zarządzaniu swoimi miejscowościami daje szansę na stopniowe ograniczanie różnorakich patologii, takich jak: korupcja, biurokracja, różnego rodzaju praktyki dyskryminacyjne, a także - pośrednio - ubóstwo.

Z kolei do wad i zagrożeń niesionych przez decentralizację indyjskiego państwa należy zaliczyć:

1. Trudności w prowadzeniu polityki gospodarczej na szczeblu krajowym, a także na poziomach stanowych, szczególnie w okresach intensywnych reform. Interesy gospodarcze samorządów terytorialnych - zarówno lokalnych, jak i stanowych - często nie są zgodne z interesem kraju jako całości. W warunkach systemu zdecentralizowanego, i to $\mathrm{w}$ kraju bardzo biednym, znacznie trudniej jest realizować np. planową politykę uprzemysłowienia kraju, rozbudowy infrastruktury transportowej itp.

2. W kraju o nieutrwalonej świadomości państwowej, jakim były Indie w pierwszych dekadach niepodległości, znaczące przesuwanie kompetencji oraz

${ }^{5}$ A. Iimi [2005] pisze w tej sprawie: „W teorii nie ma wątpliwości, że decentralizacja prowadzi do wydajnego dostarczania usług publicznych i tym samym powoduje szybki wzrost gospodarczy. Z empirycznego punktu widzenia jednak jest wciąż kontrowersyjne, czy zachodzi jakaś relacja pomiędzy decentralizacją a wzrostem". Niektórzy badacze związków pomiędzy decentralizacją a wzrostem gospodarczym uważają, że to właśnie procesy decentralizacji są jednym z głównych przyczyn szybkiego wzrostu gospodarczego Chin i Indii w ostatnich dekadach [Bardhan, 2002]. 
środków finansowych na niższe szczeble organizacji państwa mogłoby rodzić nastroje separatystyczne i zagrażać jego integralności. Ta ostatnia jest naczelną wartością w każdym nowo powstałym państwie.

3. Decentralizacja wcale nie musiałaby zmniejszać wspomnianych wcześniej patologii, takich jak korupcja, biurokratyzacja czy praktyki dyskryminacyjne. Wręcz odwrotnie, mogłaby je nawet zwiększać - o czym w dalszej części rozdziału.

W świetle powyższych argumentów całkiem zasadna wydaje się polityka indyjskich władz w pierwszych latach niepodległości. Przyjęty - jak wcześniej przedstawiono - kurs na przyspieszoną industrializację i wiodącą rolę sektora publicznego oraz utrzymanie integralności państwa były wartościami nadrzędnymi i warunkiem wyjścia z głębokiego zacofania kolonialnego. Trudno wyobrazić sobie inną drogę. Tymi to głównie argumentami tłumaczyć należy ograniczoną autonomię stanów i zatrzymanie się demokracji na drugim szczeblu struktury państwa (stanowym). Decentralizację odłożono po prostu na dalszą przyszłość, tym bardziej, że jej pierwsze próby - zarówno w latach 50., jak i 70. - nie zapowiadały sukcesów.

W przedstawiony wcześniej „kalendarz” oraz problemy reform decentralizacyjnych na świecie po II wojnie światowej wpisuje się historia decentralizacji w Indiach. O jej kształcie i sekwencji czasowej decydowały trzy grupy czynników: gospodarcze, demograficzne oraz społeczno-kulturowe. $Z$ uwagi na przejrzystość wykładu opisane są one osobno, ale w rzeczywistości działają jednocześnie i wzajemnie się uzupełniają, znoszą, stymulują lub ograniczają. Ostateczny, realny kształt przemian indyjskiego ustroju lokalnego jest ich wypadkową.

Aspekt gospodarczy decentralizacji w warunkach indyjskich to przede wszystkim aktywizacja ekonomiczna jednostek terytorialnych wszystkich szczebli, co w wymiarze poszczególnych stanów i całego kraju winno się przełożyć na szybszy wzrost gospodarczy. Niskie tempo rozwoju gospodarki Indii w pierwszych czterech dekadach było w pewnym stopniu rezultatem wysokiej centralizacji zarządzania gospodarką i niedostatkiem oddolnych inicjatyw w tej dziedzinie, czyli stagnacji rozwoju lokalnego, a okresami nawet jego regresu. Przekazanie samorządnym jednostkom lokalnym znacznej części kompetencji gospodarczych, np. praw do pozyskiwania własnych dochodów, możliwości ich samodzielnego rozdysponowania, prowadzenia działalności gospodarczej na własny rachunek itp., najprawdopodobniej korzystnie wpłynęłoby na kształt i dynamikę ich gospodarki.

W rozwoju gospodarczym Indii, na wszystkich szczeblach gospodarki, szczególnie istotną, a czasem decydującą, rolę odgrywają - jak rzadko gdzie indziej na świecie - czynniki natury przestrzennej, demograficznej oraz społeczno-kulturowej, dlatego poświęcimy im więcej uwagi. Dotyczy to w pełni także procesu decentralizacji państwa.

Traktując o przestrzennych i demograficznych uwarunkowaniach decentralizacji w Indiach, przede wszystkim trzeba uwagę zwrócić na problem efektywności gospodarowania dobrami publicznymi na poziomie najniższych, samorządowych 
jednostek terytorialnych. Konkretnie chodzi o to, aby minimalizować koszty udostępniania dóbr publicznych lokalnym społecznościom. W tym celu należy podejmować próby optymalizacji geograficzno-demograficznej najniższych szczebli struktury przestrzennej państwa, czyli tworzenia jednostek terytorialnych o takiej powierzchni i liczbie mieszkańców, w których średnie, a także krańcowe koszty dostarczania dóbr publicznych na jedną osobę będą zbliżone do siebie i będą maleć w miarę wzrostu liczby mieszkańców (tzw. efekt skali).

Jednym z ważniejszych problemów reform indyjskiego ustroju terytorialnego jest ustalenie tzw. optymalnego obszaru decentralizacji, czyli takich wielkości stanów i jednostek lokalnych (panczajatów i rad miejskich), w ramach których najkorzystniej dla ich mieszkańców będą realizowane publiczne zadania gospodarcze i społeczne. Problem ten ma w Indiach szczególny wymiar z uwagi na wyją̧tkowo duże zróżnicowanie drugiego poziomu organizacji terytorialnej państwa, czyli stanów i to nie tylko pod względem powierzchni, ukształtowania terenu, klimatu, liczby ludności, ale - co najważniejsze - ich ogromnej różnorodności etnicznej i religijnej. Tak duże i wielowymiarowe dysproporcje deformują, a czasem wręcz uniemożliwiają konkurencję międzyterytorialną, preferując jedne obszary a dyskryminując inne. Wywołuje to zazwyczaj negatywne skutki gospodarcze oraz polityczno-społeczne, jak - przykładowo - konieczność stosowania znaczących dotacji wyrównawczych, przyspieszone przemieszczanie się kapitałów, różnicowanie warunków życia ludności oraz jej migracje na inne obszary (tzw. głosowanie nogami). W praktyce zarządzania rodzi to zazwyczaj różnorakie konflikty, zarówno w układzie pionowym, tj. pomiędzy władzą centralną a rządami stanowymi oraz samorządami lokalnymi, a także poziomym - pomiędzy władzami tych samych szczebli struktury państwa.

Nie bez znaczenia dla efektywności indyjskiej decentralizacji jest również przestrzenne rozmieszczenie ludności na obszarze jednostek terytorialnych, czyli sieć osiedleńcza. Chodzi tu przede wszystkim o stopień urbanizacji, a więc odsetek ludności miejskiej, wielkość miast, liczbę ludności wiejskiej i zabudowę wsi, to znaczy, czy jest to zabudowa skoncentrowana (np. w postaci osad, osiedli, wzdłuż drogi) czy też zabudowa rozproszona (np. pojedyncze domy lub ich niewielkie skupiska znacznie oddalone od siebie). Wszystkie te parametry są bardzo istotne, decydują o możliwościach i kosztach wytwarzania, dostarczenia dóbr publicznych oraz wielkości popytu na te dobra. Stopień urbanizacji jest ważny jeszcze z tego względu, że istnieją duże różnice w poziomie zamożności, sposobie życia, systemach wartości mieszkańców miast i wsi. Takie same lub podobne instytucje samorządu lokalnego inaczej funkcjonują w mieście niż na wsi. Ranga powyższych problemów jest w Indiach wyjątkowo duża, co wynika z wielkiego obszaru kraju, bardzo zróżnicowanego ukształtowania terenu, warunków klimatycznych, infrastruktury transportowej, gęstości zaludnienia itp. Te właśnie czynniki w znacznym stopniu utrudniały podejmowane w latach 50., 60. i 70. próby wprowadzania demokratycznego samorządu lokalnego, sprawiały, że w niektó- 
rych regionach (np. Kerali, Karnatace i Bengalu Zachodnim) przedsięwzięcia te przynosiły dobre efekty, a w większości stanów - kończyły się niepowodzeniem lub przybierały jakieś patologiczne formy.

W organizacji ustroju terytorialnego Indii wielką rolę odgrywają też uwarunkowania historyczne. Determinują one m.in. sieć osiedleńczą i stosunki społeczne. Niejednokrotnie to właśnie argumenty historyczne, czyli tzw. ciężar dziedzictwa - często wielowiekowego - przesądzają o granicach i wielkości jednostek terytorialnych, nawet jeśli to nie jest zgodne ze współczesnymi wymogami racjonalnej organizacji terytorialnej państwa. Tak przecież było - jak wykazano w rozdziale II - z kształtowaniem drugiego szczebla organizacji państwa indyjskiego, czyli wielkości i granic stanów. Analiza podziału administracyjnego Indii wyraźnie wskazuje, że czynnik historyczny odgrywa w nim istotną rolę i ona wcale nie maleje.

Gwoli ścisłości, argumentów historycznych na ogół nie powinno się przedkładać nad wymogi współczesnej ekonomii, polityki czy kultury. Jeżeli jednak nie stoją one z nimi w rażącej sprzeczności, to nie ma powodów by uciekać od historii. Nawiązywanie do przeszłości wywołuje na ogół pozytywne stany emocjonalne, przez co staje się dodatkowym spoiwem społeczności lokalnych. Razem wziąwszy, te właśnie aspekty geohistoryczne znacząco podnoszą wartość lokalnego kapitału społecznego, tak istotnego dla pomyślnej realizacji programów decentralizacyjnych.

Delegowanie władzy, czyli kompetencji administracyjnych oraz środków finansowych na szczebel lokalny rodzi wiele problemów, których zazwyczaj nie było wówczas, gdy takie decyzje zapadały na poziomie regionu czy państwa. Nie idzie tu tylko o stronę organizacyjną i logistyczną tych procesów, ale przede wszystkim o ich aspekt społeczno-kulturowy, czyli rolę takich czynników, jak zróżnicowanie etniczne, polityczne, wyznaniowe, edukacyjne, systemy wartości czy stratyfikację społeczną.

Jak wskazują obserwacje i badania decentralizacji, zwłaszcza w krajach Azji, Afryki czy Ameryki Łacińskiej, te właśnie kwestie społeczno-kulturowe nastręczały najwięcej problemów w realizacji programów decentralizacyjnych [Jütting i in., 2004]. W całej rozciągłości sprawy te ujawniają się, i to ze szczególną ostrością, w Indiach. Tworzenie na poziomie wsi i miast samorządów znacznie - wbrew pozorom - komplikuje życie ich mieszkańców. Dotyczy to przede wszystkim tych jednostek, których mieszkańcy są zróżnicowani etnicznie, religijnie i należą do różnych kast (pomimo ich formalnej likwidacji). Do dotychczasowych, tradycyjnych przyczyn konfliktów dochodzą nowe, wynikające z reguł demokratycznych, takich jak problem wyboru i podziału władzy, nakładania obowiązków (np. podatków, opłat, robót publicznych), rozdziału środków finansowych itp.

Wprowadzenie demokratycznych procedur wyłaniania władz lokalnych rodzi zazwyczaj nowe elity i nowe reguły ich funkcjonowania, które są najczęściej opozycyjne do starych i ukształtowanych niedemokratycznie elit. Można więc twierdzić, że demokracja, burząc istniejące od stuleci struktury i porządki społeczne, 
nie tworzy automatycznie nowego systemu wartości i nowych reguł zachowań ludzkich. W tym właśnie okresie przejściowym otwierają się zazwyczaj nowe fronty konfliktów lokalnych, zwłaszcza, gdy społeczność danego terytorium jest mocno zróżnicowana. Ich częstość i natężenie może być czasem tak duże, że sparaliżuje, a przynajmniej mocno zdeformuje lokalną gospodarkę i życie społeczne. $\mathrm{W}$ takich sytuacjach niejednokrotnie racjonalne argumenty natury technicznej lub ekonomicznej schodzą na dalszy plan, a górę biorą emocje uwarunkowane klasowo, etniczne lub religijne. Historia Indii - i to nawet ta najnowsza - dostarcza na to tysięcy przykładów. Pamiętać jednakże trzeba, że w ciągu kilku dziesięcioleci rola starych elit w życiu lokalnym indyjskich wsi i miast powoli, ale systematycznie obniża się. W drugiej dekadzie XXI wieku ich znaczenie jest niepomiernie mniejsze niż w pierwszych latach po uzyskaniu przez ten kraj niepodległości. Wynika to oczywiście z faktu naturalnej, biologicznej wymiany pokoleń. Stare, ukształtowane jeszcze w czasach kolonialnych elity są zastępowane przez nowe, bardziej wykształcone i otwarte na świat grupy ludzi, których system wartości i sposoby zachowań różnią się od tych, jakie obowiązywały w pokoleniu ojców czy dziadków.

Do hamulców indyjskiej decentralizacji należy - pomimo stałego postępu - niski poziom edukacji ludzi, szczególnie na wsi. Osoby słabo wykształcone, a jakże często jeszcze analfabeci, o poglądach ukształtowanych przez tradycyjne wartości, przyzwyczajone do życia w systemie niedemokratycznym, nie dostrzegają po prostu potrzeby jakichkolwiek zmian w swym otoczeniu i są im przeciwne. Taką sytuację wykorzystują z reguły dotychczasowe elity i one - tym razem w sposób demokratyczny - przejmują lokalną władzę, ale na ogół nie po to, aby coś rzeczywiście modernizować i polepszać, lecz przede wszystkim - nawet pod pozorem zmian - zachować poprzednie porządki, w tym szczególnie swoje uprzywilejowane pozycje.

W efekcie takich postaw i zachowań mamy często do czynienia z dualizmem ustrojowym na poziomach lokalnych. W wyniku decentralizacji, w społecznościach lokalnych obok starego, niedemokratycznego i wysoce zhierarchizowanego systemu zaczyna funkcjonować nowy - demokratyczny porządek. Oba te porządki, pomimo ideowych oraz strukturalnych przeciwieństw, żyją jednak na co dzień w symbiozie - nowy nie wyparł jeszcze starego, ale stary nie jest już w stanie zablokować nowego. Indyjski przypadek nie jest jedynym na świecie, podobnie jest $\mathrm{w}$ wielu krajach postkolonialnych i rozwijających się. Jednakże skala owej dualności ustroju lokalnego w Indiach po reformach decentralizacyjnych z lat 1992-1993, czyli koegzystencji „starego” z „nowym”, nie ma chyba równej.

Jak już sygnalizowano, niezwykle ważnym problemem indyjskiego życia publicznego, skorelowanym zresztą z poprzednimi zjawiskami, jest niski status kobiet, stanowiących prawie połowę społeczeństwa. Większość kobiet, szczególnie na obszarach wiejskich, była dotąd praktycznie wyłączona z życia publicznego. Struktura i funkcjonowanie społeczności lokalnych, w tym także rodzin, miała i nadal ma 
charakter patriarchalny. Przestrzeń aktywności kobiety ogranicza się z reguły do obejścia domowego, w którym jednakże dominuje mężczyzna (mąż, ojciec), a żona (córka) jest jego podwładną. Stanowi to istotną barierę w budowaniu egalitarnych i demokratycznych społeczności lokalnych. Nie można mówić o poprawnym, skutecznym funkcjonowaniu samorządów dopóki kobietom nie zagwarantuje się dostępu do działalności publicznej oraz uczestnictwa we władzy. Postulaty te do lat 90. XX stulecia nie znajdowały jednak odbicia w rzeczywistości.

Jedną z ważniejszych przesłanek indyjskiej decentralizacji była chęć zmniejszenia skali ubóstwa oraz korupcji, zjawisk w dużym stopniu powiązanych ze sobą, występujących na ogół równolegle. Decentralizacja miała być narzędziem i sposobem na upodmiotowienie, aktywizację ekonomiczną i polityczną dużych, bo liczących kilkaset milionów osób, grup społecznych żyjących w ubóstwie i zmarginalizowanych, a przez to poprawienie ich warunków bytu.

Niewielkie co prawda doświadczenia indyjskie oraz przeprowadzone badania empiryczne w tych krajach rozwijających się, gdzie podjęto reformy decentralizacyjne, nie dają jednakże przekonujących dowodów na pozytywny wpływ decentralizacji na zmniejszanie rozmiarów ubóstwa, przynajmniej w krótkim okresie, a więc na ogół w fazie początkowej wdrażania demokracji na poziomie lokalnym. Korzystnych efektów można oczekiwać dopiero w okresach dłuższych [Crook, Sverrisson, 2001].

Nikła skuteczność reform decentralizacyjnych w ograniczaniu ubóstwa wynika $\mathrm{w}$ zasadniczym stopniu $\mathrm{z}$ tego, że jest ono mocno sprzężone $\mathrm{z}$ innymi negatywnymi cechami indyjskiego społeczeństwa, takimi jak niski poziom wykształcenia oraz stanu zdrowia, szczególnie na obszarach wiejskich. Wysoki poziom analfabetyzmu oraz niezadawalające zdrowie zasadniczo ograniczają aktywność publiczną, w tym zawodową, ludności, hamują wprowadzanie postępu technicznego i organizacyjnego w tradycyjnie wykonywanych zawodach i tworzenie miejsc pracy w nowych sektorach gospodarki. A dopiero takie postępowanie może doprowadzić do poprawy materialnych warunków bytu i wychodzenie z biedy.

Istotną przeszkodą w realizacji programów zmniejszania ubóstwa i marginalizacji ekonomicznej oraz kulturowej znacznej części mieszkańców kraju są też nieprzychylne tym procesom postawy i zachowania starych, tradycyjnych elit i lokalnych grup interesów, które w poprawie warunków życia warstw najuboższych zaczynają dostrzegać nie szanse, ale zagrożenie dla swych pozycji ekonomicznych i miejsca w hierarchii lokalnych społeczności. Bardzo często w takich sytuacjach stare elity próbują bojkotować reformy decentralizacyjne, deformować oraz opóźniać je i to pomimo werbalnej akceptacji nowych reguł życia społecznego. Nierzadkie jest także pozorowanie aktywności publicznej i wchodzenie do nowych, demokratycznych struktur władzy lokalnej, bądź też różnego rodzaju ukryte szantaże w stosunku do ubogich i zależnych od nich grup ludności, konfliktowanie ich itp. [Bywalec, 2012]. 
Działalność władz i innych instytucji funkcjonujących na poziomie lokalnym (np. organizacji charytatywnych) na rzecz ograniczania biedy jest też często utrudniona różnorakimi podziałami społeczności lokalnych, wynikającymi z religii, rasy, przynależności do określonej grupy społecznej, sympatii politycznych itp. Rola tych czynników jest szczególnie istotna wówczas, gdy działania na rzecz dobra wspólnego wymagają zaangażowania i zgodnej współpracy większej liczby osób, a staje się to praktycznie niemożliwe ze względu na głębokie podziały społeczne czy religijne itp. W Indiach szczególnie dotkliwy jest podział na kasty, głęboko zakorzeniony w społecznościach wiejskich i to pomimo jego konstytucyjnego zakazu od 1950 roku'.

Innym, niezwykle dokuczliwym problemem społecznym w Indiach jest korupcja, szczególnie rozpowszechniona na poziomach lokalnych. Ma ona w tradycji indyjskiej, jak i w ogóle azjatyckiej, bardzo długą historię, bo sięgającą starożytności ${ }^{7}$.

Wbrew pozorom, nie zawsze korupcja jest uznawana za wartość negatywną. Można spotkać się przykładowo z poglądami, że w niektórych krajach rozwijających się, takich właśnie jak Indie, w warunkach słabej władzy państwowej, przy ułomnych instytucjach publicznych, niejednoznacznych i zmieniających się przepisach oraz chaosie organizacyjnym, korupcja może - paradoksalnie - na swój sposób porządkować ten system i przyczyniać się do poprawy jego sprawności i efektywności gospodarowania ${ }^{8}$. Bardzo często ta właśnie niedoskonałość państwa, czyli nieodpowiednia struktura i funkcjonowanie jego organów, może wręcz stymulować, czyli wymuszać zachowania korupcyjne przedsiębiorstw i jednostek ludzkich.

Oprócz ułomności państwa, czynnikiem istotnie sprzyjającym powszechności korupcji w Indiach są religie, w tym szczególnie hinduizm i oparty na nim system wartości oraz zachowań zarówno w sferze prywatnej, jak i publicznej. W hinduskim systemie wartości mocno eksponuje się więzi rodzinne, wyznaniowe, kastowe oraz plemienne. Wszystkie więc czynności i zachowania człowieka na forum publicznym są podporządkowane zwiększaniu korzyści nie tylko swoich, lecz także ludzi z najbliższego otoczenia, co rodzi nepotyzm, klikowość, klientelizm itp. ${ }^{9}$

6 „Jest oczywistym - pisze indyjski badacz kastowości A.R. Gupta [1984, s. 167] - że system kastowy manifestuje się w całym systemie zachowań, zarówno w rodzinie, w społeczeństwie, jak również w administracji i polityce".

${ }^{7} \mathrm{O}$ swoistej randze i rozpowszechnieniu korupcji świadczy m.in. to, że ma wiele znaczeń oraz form. Niektórzy autorzy wyróżniają ok. 40 sposobów (odmian) tego zjawiska w zależności od przyczyny, sytuacji i kontekstu [Bardhan, 1997, s. 15-16].

8 P. Bardhan [1997, s. 17] pisze m.in.: „Korupcja jest bardzo potrzebnym smarem do skrzypiących kół sztywnej administracji”.

9 W kontekście korupcji w Indiach, należy zauważyć, że system gospodarek azjatyckich od czasu kryzysu lat 1997-1998 określa się niekiedy mianem kapitalizmu kumpelskiego (crony capitalism). Trudno jest jednoznacznie wyjaśnić ten termin, ale w przybliżeniu crony capitalism można rozumieć jako sposób prowadzenia działalności gospodarczej tworzący i wykorzystujący w nad- 
W badaniach korupcji oraz jej odniesień do gospodarki i życia publicznego uwzględnia się zazwyczaj tzw. korupcję małą (niskiego szczebla) i korupcję dużą (wysokiego szczebla). Granica między nimi jest płynna, umowna. Ta pierwsza (mała) występuje niemal na każdym kroku, przejawia się w codziennych relacjach międzyludzkich, szczególnie na linii urzędnik (funkcjonariusz)-petent, a więc przykładowo - w lokalu administracyjnym, szkole, szpitalu, aptece, miejscu pracy, urzędzie podatkowym, środkach transportu itp. Drugi rodzaj korupcji (duża) to niezgodne z prawem i/lub etyką zachowania ludzi na wyższym szczeblu hierarchii społeczno-politycznej, a więc między politykami, wysokimi urzędnikami oraz - najczęściej - na pograniczu dużego biznesu i polityki. Oba te rodzaje korupcji są wyraźnie widoczne w Indiach i wzajemnie się zazębiają, można mówić wręcz o synergii między nimi. Skoro lokalni politycy dostrzegają i są uczestnikami częstych oraz na ogół bezkarnych praktyk korupcyjnych na wysokich (stanowych i centralnych) szczeblach władzy, to dochodzą do wniosku, że i oni mogą w swoim otoczeniu postępować w podobny sposób ${ }^{10}$.

Decentralizacja oddziałuje w zróżnicowany sposób na oba te rodzaje korupcji. W Indiach, podobnie jak w większości państw rozwijających się, wychodzących w drugiej połowie XX wieku z głębokiego, postkolonialnego zacofania gospodarczego i społecznego, korupcja jest - jak już wspominano - zjawiskiem powszechnym, codziennym, elementarnym składnikiem mentalności ludzi, szczególnie na niższych szczeblach hierarchii społecznej. Korumpowanie kogoś i bycie korumpowanym jest wręcz standardem codziennych zachowań, niesprzecznym z tradycyjnymi normami etycznymi. Umiejętność korumpowania nie jest bynajmniej wadą, przeciwnie - jest zaletą człowieka, gdyż oznacza, że może on być bardziej skutecznym w realizacji interesów - swoich i /lub swej grupy (rodziny, kasty itp.).

miarze nieformalne (koleżeńskie, przyjacielskie, rodzinne) więzi pomiędzy podmiotami gospodarczymi, a szczególnie między nimi a instytucjami władzy publicznej, oczywiście dla osiągania partykularnych interesów tych pierwszych [Pęciak, 2013, s. 186-188].

${ }^{10}$ K. Dębnicki [2000, s. 122-123] tak opisuje to zjawisko: „Wprowadzając skomplikowany system licencjonowania na zakładanie zakładów przemysłowych, import towarów i komponentów potrzebnych do produkcji, a także na eksport (do końca lat 80.), władze dały centralnej i lokalnej biurokracji potężną broń w postaci możliwości wywierania wpływu na życie gospodarcze oraz szansę korumpowania się. Skorumpowana administracja z kolei, szczególnie szczebla lokalnego, zaczęła zawierać, nieformalnie najczęściej, sojusze z lokalnie dominującymi kastami, partiami politycznymi oraz, mniej lub bardziej sporadycznie, bandami przestępców, wynajmowanymi w razie potrzeby dla załatwiania porachunków z przeciwnikami politycznymi, albo gwarantowania «właściwych wyników» lokalnych, a nierzadko i powszechnych wyborów. W taki sposób odtwarzały się nieformalne, tradycyjne struktury władzy. Ich najważniejszymi elementami była przynależność do lokalnej, dominującej kasty, bardzo często więzi typu rodzinnego, powstające przez utrzymującą się wciąż dużą rodzinę oraz odwoływanie się do przemocy, szczególnie częste wobec prób emancypacji tradycyjnie upośledzonych grup społecznych". 
Przy takim jak powyższe, i niemal w Indiach powszechnym, mentalnym podejściu do korupcji i tego typu praktykach, demokratyczna decentralizacja niewiele zmieni. Na początku może nawet przyczynić się do eskalacji korupcji i jej swoistej decentralizacji (tzw. zdecentralizowana korupcja) oraz demokratyzacji. Przesuwanie przez rząd centralny oraz władze regionalne na poziom lokalny wielu uprawnień i środków finansowych zwiększa bazę podmiotową i przedmiotową dla korupcyjnych praktyk. W ten sposób decentralizacja sprzyja tworzeniu się nowych, lokalnych sieci powiązań, ale nie tylko tych pozytywnych, lecz także negatywnych, w których ważnym, a często podstawowym spoiwem są znajomości, pokrewieństwo, sąsiedztwo, solidarność etniczna i/lub religijna. Zbudowany w takich warunkach i na takich wartościach lokalny kapitał społeczny ma wymiar patologiczny, jest wartością negatywną. Trudno zatem oczekiwać od społeczności lokalnej pełnienia przez nią funkcji kontrolnych, ograniczających korupcję [Bywalec, 2012].

Ważnym czynnikiem natury politycznej, który miał wpływ na zapoczątkowanie w 1992 roku tworzenia lokalnej samorządności w Indiach, były częste konflikty na linii władze federalne-władze stanowe. Posiadające znaczną samodzielność rządy stanowe - szczególnie te duże - zachowywały się nieraz jak przysłowiowe „państwa w państwie”. Nie chciały realizować na swoim terytorium polityki rządu, bądź ją deformowały i podporządkowywały partykularnym interesom polityków stanowych, co negatywnie odbijało się na wskaźnikach ekonomicznych zarówno stanów, jak i całej gospodarki. Duża autonomia stanów, a nierzadko ich samowola, połączona z podziałami etnicznymi i religijnymi, anarchizowała państwo, sprzyjała narastaniu konfliktów społecznych i nastrojów separatystycznych, które - kumulując się - niejednokrotnie zagrażały nawet integralności państwa indyjskiego.

Widząc rosnącą siłę polityczną stanów i ich anarchizującą rolę, rząd centralny próbował je w różny sposób osłabiać. Jednym ze skutecznych i zarazem trwałych narzędzi realizacji tego celu miała stać się właśnie decentralizacja, czyli nadanie znacznej samodzielności i demokratyzowanie lokalnego szczebla struktury państwa. Sprawiłoby to, że kompetencje władz stanowych zostałyby niemal automatycznie ograniczone $\mathrm{i}$ to nie tylko - jak do tej pory - od góry, tj. przez rząd centralny, lecz także od dołu - przez demokratyczne samorządy wsi i miast. Zmniejszyłoby się w ten sposób pole władztwa stanowych rządów. Taka struktura organizacyjna i podział kompetencji sprzyjałyby - zgodnie z zasadą subsydiarności - racjonalizacji funkcji państwa i to we wszystkich ich wymiarach.

\subsection{Próby reformowania ustroju lokalnego w latach 1947-1991}

W rozdziale II przedstawiono kształt i ewolucję ustroju terytorialnego Indii w latach 1947-1991 w odniesieniu do jego centralnego oraz drugiego - regionalnego (stanowego) szczebla. W niniejszym rozdziale skupiono się na trzecim elemencie struktury państwa, czyli ustroju lokalnym. 
W historii ustroju lokalnego niepodległych Indii wyróżnić można trzy fazy:

1. Lata 1947-1949, tj. okres po uzyskaniu niepodległości, a przed wejściem w życie konstytucji (26.01.1950 roku).

2. Lata 1950-1992, tj. okres obowiązywania konstytucji z dnia 26.11. 1949 roku.

3. Okres po 1992 roku, tj. od daty uchwalenia przez parlament indyjski dwóch poprawek do konstytucji nr 73 i 74 o utworzeniu demokratycznego samorządu lokalnego.

Regulacja konstytucyjna ustroju Indii z 1949 roku - pomimo swojej szczegółowości - ,zatrzymała się” jednak na poziomie stanów. Analizując tekst konstytucji, nie sposób dostrzec uregulowań prawnych struktur organizacyjnych państwa poniżej stanów, czyli na szczeblu lokalnym.

Pomimo faktu, że system panczajatów, jako podstawowych jednostek administracyjnych na Półwyspie Indyjskim, ma tysiącletnie tradycje, pierwszy projekt konstytucji niepodległych Indii lakonicznie tylko wspominał o organizacji życia publicznego na poziomie lokalnym. Gdy Mahatma Gandhi - twórca i propagator idei gram swaraj (samorządności wiejskiej) - zapoznał się z projektem konstytucji, uznał, że pominięcie spraw lokalnych jest wynikiem przeoczenia. Gandhi uważał wspólnoty wiejskie za najważniejszy składnik, wręcz fundament ustroju nowego, demokratycznego przecież państwa. Twierdził - o czym już wspominano w rozdziale II - że każda wieś, oprócz tego, że ma być demokratyczna, winna być swoistą „małą republiką", z własną władzą ustawodawczą, wykonawczą i sądowniczą [za: Myrdal, 1968, s. 857]. Ten pogląd nie znalazł jednak licznego grona zwolenników wśród młodszej generacji intelektualistów i polityków wywodzących się z Indyjskiego Kongresu Narodowego, która zdominowała indyjskie życie publiczne oraz scenę polityczną w pierwszych latach nowego państwa.

Na czele przeciwników zamieszczania w konstytucji zapisów dotyczących panczajatów i ich miejsca w systemie państwa stał Bhimrao R. Ambedkar, jeden z głównych twórców indyjskiej ustawy zasadniczej (przewodniczący komisji redakcyjnej konstytucji), późniejszy minister sprawiedliwości i pierwszy niedotykalny (dalita), który uzyskał w Indiach wyższe wykształcenie. Ambedkar twierdził, że owe „małe republiki” - z panującym w nich przez wieki archaicznym systemem kastowym - doprowadziły Indie do ruiny. Podczas obrad Zgromadzenia Konstytucyjnego w dniu 4 listopada 1948 roku mówił o wspólnotach wiejskich, że ,zatapiają lokalizm, są siedliskiem ignorancji, ograniczonego myślenia i komunalizmu" [za: Malaviya, 1956, s. 258]. Przestrzegał przed próbami idealizowania i, co z tym idzie, powrotu do systemu organizacyjnego społeczności wiejskich podobnego do tego, który panował w wiekach wcześniejszych. Inni politycy, o zbliżonych do Ambedkara poglądach, podnosili, że panczajaty przetrwały tylko w sensie semantycznym, a - jako instytucje struktury społecznej $-\mathrm{w}$ istocie nigdy nie działały na rzecz rozwiązywania ani indywidualnych, ani też 
zbiorowych problemów mieszkańców wsi, służyły tylko warstwom uprzywilejowanym. Według Ambedkara i jego zwolenników mechanizmy funkcjonowania tradycyjnych panczajatów nie dadzą się pogodzić z duchem postępowej konstytucji opartej na ideach równości i demokracji. Indyjska wieś pozostawała nadal siedliskiem nietolerancji, przemocy i wyzysku.

Autorzy konstytucji stanęli przed trudnym wyborem odpowiedniego modelu ustroju indyjskiej wsi, na której żyło wówczas ponad 80 proc. obywateli nowo powstałego państwa, a perspektywa istotnych zmian proporcji ludnościowych między miastem a wsią była wówczas bardzo odległa, liczona nie dekadami, ale wręcz setkami lat ${ }^{11}$. Czy w tej sytuacji jest możliwe pogodzenie systemu tradycyjnych wiejskich panczajatów ze strukturami i atrybutami nowoczesnego państwa i społeczeństwa, takimi jak równość ludzi oraz demokratyczny system wyłaniania władz i funkcjonowania instytucji lokalnej administracji publicznej?

W wyniku dyskusji nad kształtem indyjskiej konstytucji przyjęto ostatecznie kompromisowe rozwiązanie o ustroju lokalnym wsi. W artykule 40 ustawy konstytucyjnej znalazł się zapis o panczajatach, jednak bez określania zasad ich organizacji oraz funkcjonowania. Zapis ten ma następującą treść: „Państwo podejmuje kroki w celu zorganizowania panczajatów wiejskich i wyposażenia ich w takie uprawnienia i taką władzę, które mogą być niezbędne do umożliwienia im działania w charakterze jednostek samorządowych".

W dosłownej interpretacji artykuł 40 nie ma charakteru obligatoryjnego, lecz fakultatywny. Jednak gdyby uwzględnić inne zapisy konstytucji, np. o zniesieniu kastowości, równych prawach kobiet i mężczyzn, to daje on możliwości tworzenia nowoczesnych, w pełni demokratycznych samorządów.

Pomimo braku jednoznacznej regulacji konstytucyjnej statusu panczajatów, mogły one jednak odegrać dużą rolę w społecznej transformacji Indii oraz być akceleratorem różnorakich programów rozwojowych na wsi. Tak się jednak nie stało głównie za sprawą oporu starych elit i ich politycznych przedstawicieli, którzy w istocie pogardzali wizją demokratycznych panczajatów i widzieli w nich zagrożenie dla swoich interesów oraz pozycji społecznych. Do rozwoju terytorialnej samorządności nie przywiązywały wagi - poza wyjątkami - wysoce zbiurokratyzowane i skorumpowane rządy stanowe. Zmianom nie sprzyjała również bierna postawa mieszkańców wsi wynikająca $\mathrm{z}$ wysokiego analfabetyzmu, przywiązania do tradycji oraz zróżnicowania społeczno-kulturowego [Mathew, 2000, s. 5-6].

${ }^{11}$ Hipotezę tę potwierdzają statystyki demograficzne. Według wyników pierwszego w XXI stuleciu spisu ludności Indii (2001) na wsi zamieszkiwało prawie 72 proc. Indusów, a więc w ciągu pięćdziesięciolecia odsetek ludności wiejskiej niewiele się zmniejszył [Manpower Profile India Yearbook, 2008, s. 13]. Jest zatem wielce prawdopodobne, że do końca XXI wieku w strukturze ludności Indii będą jeszcze przeważać mieszkańcy wsi i nadal aktualna będzie konstatacja M. Gandhiego, że „Indie żyją na wsi” (por. podrozdział 2.3.1). 
Wobec braku centralnej regulacji, większość kompetencji w odniesieniu do samorządu lokalnego - jak to wynika z innych artykułów indyjskiej konstytucji - przejęły stany. To właśnie władze stanowe uzyskały pośrednio uprawnienia w zakresie szczegółowej organizacji instytucji lokalnych na swoim terytorium. Takie rozwiązanie ma logiczne uzasadnienie, gdyż na poziomie stanów jest najłatwiej skonstruować właściwe struktury administracji lokalnej. Podejście to ma też wadę, którą są - jak pokazały następne dekady - silne stanowe partykularyzmy uwzględniające w głównej mierze interesy rządzących partii oraz polityków itp., co prowadzić może do dezintegracji kraju i sprzyja narastaniu różnorakich konfliktów społecznych, a w ostateczności nawet separatyzmów regionalnych i lokalnych.

Gandhyjska koncepcja gram swaraj nie znalazła więc miejsca w realiach politycznych pierwszych lat niepodległości Indii. Dość szybko jednak politycy uświadomili sobie błąd. Aby poprawić sytuację na wsi, w 1952 roku podjęto realizację ambitnego programu rozwoju wspólnot wiejskich. Nie przynosił on jednak oczekiwanych efektów. W celu wyjaśnienia tego stanu rzeczy i w ogóle głębszego rozpoznania problemów wsi, w styczniu 1957 roku pod przewodnictwem Balawantraja R. Mehty powołano specjalny Komitet (B.R. Mehta Committee). Zalecenia i wnioski wynikające $\mathrm{z}$ raportu tego Komitetu, opublikowane w listopadzie 1957 roku, stały się sygnałem powrotu do gram swaraj, czyli tworzenia demokratycznych samorządów wiejskich ${ }^{12}$.

Komitet B.R. Mehty stwierdzał m.in., że programy rozwojowe dla wsi, a więc głównie rozbudowa infrastruktury technicznej (drogi, kanały, studnie, telefony, elektryczność) i podnoszenie poziomu edukacji oraz ochrony zdrowia nie mają większych szans powodzenia, jeśli nie istnieją kompetentne i wiarygodne instytucje władzy lokalnej, pośredniczące w realizacji projektów i potrafiące angażować w te przedsięwzięcia mieszkańców. Zalecano również tzw. demokratyczną decentralizację, czyli obowiązkowe tworzenie na obszarach wiejskich ciał samorządowych i wyposażenie ich w odpowiednie uprawnienia oraz środki finansowe [Joshi, Narwani, 2002, s. 30-32]. Komitet proponował utworzenie trójszczeblowego systemu samorządowego, to znaczy na poziomie wsi byłyby to gram panchayats, na poziomie zespołu wsi (bloku) - panchayats samitis, a na poziomie

12 Znamienną cechą funkcjonowania życia politycznego w Indiach, i to na różnych szczeblach państwa, jest częste powoływanie różnorakich komisji (komitetów). Zauważa to m.in. G. Myrdal [1975, s. 449-450) pisząc: „W Indiach, gdzie prowadzi się dyskusję publiczną na te tematy [polityczne, gospodarcze itp. - przyp. G.B.] stojącą na najwyższym poziomie w Azji Południowej i chyba w całym Trzecim Świecie, na porządku dziennym jest wyznaczanie specjalnych komisji, których zadaniem jest konkretne formułowanie i pilne domaganie się radykalnych reform. Zawartych w raportach tych komisji propozycji dotyczących ogólnej linii postępowania następnie się nie realizuje i szybko się o nich zapomina". Zasada ta odnosi się w pełni do dyskusji na temat lokalnej samorządności i obowiązywała - jak to wykazuje przeprowadzona analiza - przez niemal cztery dekady, tj. od lat 50. do lat 90. 
dystryktu - zilla parishads. Główną rolę w tym systemie odgrywać winny jednostki szczebla pośredniego, czyli panchayats samitis. W skład rad wiejskich (gram panchayats) wchodziłyby osoby wybrane w równych, demokratycznych i bezpośrednich wyborach.

Źródłami dochodów demokratycznych panczajatów winny być - według raportu Komitetu B.R. Mehty - środki z podatków od własności (w tym domu), podatek targowy, podatek od pojazdów mechanicznych, podatki z tytułu dochodów ze sprzedaży zwierząt oraz dotacje państwowe (z budżetu centralnego lub stanowego). Do zadań panczajatów należałoby przede wszystkim: zaopatrzenie wsi w wodę, utrzymanie higieny, oświetlenie, utrzymanie dróg, gospodarka gruntami, elementarna edukacja i ochrona zdrowia oraz pomoc społeczna.

W 1958 roku Narodowa Rada Rozwoju (National Development Council) zaakceptowała większość zaleceń Komitetu B.R. Mehty. Ich realizacją miały się zająć rządy stanowe, które otrzymały prawo zakładania jednostek szczebla lokalnego oraz decydowania o szczegółach ich struktur i kompetencji.

Ustalenia Komitetu B.R. Mehty, jakkolwiek zyskały aprobatę w kręgach wiodących sił politycznych, czyli głównie Indyjskiego Kongresu Narodowego, to jednak nie brakowało też ich oponentów. Kwestionowano w szczególności uczynienie głównym ogniwem samorządu lokalnego jego średniego szczebla, czyli panchayats samitis, a nie szczebla dystryktowego, czyli zilla parishads [Joshi, Narwani, 2002, s. 32].

Pierwszym stanem, który wprowadził system demokratycznych panczajatów był Rajasthan. W dniu 2 października 1959 roku (w 90. rocznicę urodzin M. Gandhiego) premier Indii J. Nehru zainaugurował w miejscowości Nagaur działalność pierwszego panczajatu powstałego i mającego funkcjonować według zaleceń Komisji Mehty. Nehru uznał inaugurację panczajatu nowego typu za najbardziej rewolucyjny i historyczny krok nowych Indii. Ale - zgodnie z przysłowiem - pierwsza jaskółka wiosny nie czyni. Wywołała ona jednak falę entuzjazmu i oczekiwania na historyczną zmianę skostniałych przez wieki panczajatów. Do połowy lat 60. system zdemokratyzowanych panczajatów został formalnie wprowadzony prawie na całym obszarze kraju i objął ok. 90 proc. ludności wiejskiej [Mathew, 2000, s. 6-8]. Jednak - jak już niejednokrotnie wcześniej i później bywało - większość mądrych diagnoz i zaleceń Komitetu B.R. Mehty pozostało na papierze. Indyjska wieś, scementowana odwieczną tradycją kast, silną religijnością oraz niskim poziomem edukacji okazała się i tym razem materiałem wyjątkowo twardym i opornym na zmiany. Pomimo intensywnego promowania idei gram swaraj, system demokratycznych panczajatów rozwijał się bardzo wolno i nie przynosił spodziewanych efektów. Niejednokrotnie te nowe panczajaty stawały się żywą karykaturą samorządności lokalnej.

Główną barierą w realizacji ambitnego programu demokratyzacji wsi była - o czym wspominano w rozdziale II - postępująca centralizacja życia gospodarczego i politycznego. Drugi zespół przeszkód na drodze decentralizacji to stosunki 
społeczne na indyjskiej prowincji, a szczególnie zachowawcza postawa lokalnych elit, a więc grup dominujących ekonomicznie, społecznie i kulturowo. Ten ostatni zespół przyczyn wskazuje, że postępowych reform nie da się wdrażać tylko mocą administracyjnych decyzji, że trzeba najpierw dokonać istotnych zmian w świadomości społeczności lokalnych poprzez rozwój edukacji. Równolegle z edukacją polityczną winno się wprowadzić obowiązkowe wybory do samorządów lokalnych odbywające się w regularnych odstępach czasu; takie postępowanie powoli co prawda, ale stopniowo przyzwyczajałoby wiejskie społeczności do nowego, demokratycznego rytuału.

$\mathrm{Na}$ zalecaną odgórnie autonomizację i demokratyzację lokalnego szczebla administracji publicznej zazwyczaj niechętnie patrzyły rządy stanowe. Tworzenie się samorządnej władzy lokalnej ograniczało kompetencje urzędników stanowych i w ogóle zmniejszało pole rządzenia, a w ślad za tym kurczyły się różnorakie profity, szczególnie łapownictwo. Istnieją dowody, że lokalne elity wraz ze swoimi stronnikami w rządach stanowych, a nawet władzach centralnych, celowo sabotowały program wdrażania demokracji lokalnej ${ }^{13}$.

Istotnym hamulcem rozwoju samorządności na indyjskiej wsi są niemal nieustanne konflikty komunalistyczne, niejednokrotnie bardzo krwawe. Ogromne zróżnicowanie ludności pod względem etnicznym, religijnym i językowym utrudnia, a często wręcz uniemożliwia integrację społeczności lokalnych. Cechą tych konfliktów jest długotrwałość, przenoszą się one z pokolenia na pokolenie i tkwią w ludzkiej świadomości w postaci urazów, uprzedzeń, chęci odwetu i z tych powodów łatwo się odnawiają.

$\mathrm{W}$ drugiej połowie lat 60 . i latach 70 . ubiegłego wieku - jak przedstawiono w rozdziale II - na sytuacji wewnętrznej Indii cień kładą wojny z Chinami i Pakistanem, śmierć J. Nehru oraz nasilenie się konfliktów społecznych z powodu narastającej biedy, a także spory polityczne, których apogeum był stan wyjątkowy w latach 1975-1977. Sprawy decentralizacji zeszły w tej sytuacji na dalszy plan. Proces demokratyzacji lokalnego szczebla struktury państwa został właściwie zatrzymany, a górę wzięły tendencje centralistyczne.

Do spraw reform ustroju lokalnego powrócono w 1977 roku, po pierwszych od zniesienia stanu wyjątkowego wyborach parlamentarnych, przegranych przez Indyjski Kongres Narodowy i zwycięstwie Frontu Janaty (por. rozdział II). W grudniu tego roku utworzony przez Front Janaty pierwszy „niekongresowy” rząd Indii powołał Komitet, którego zadaniem było sporządzenie raportu o stanie

${ }^{13}$ B.S. Gupta pisał w tej kwestii m.in.: „Demokrację indyjską poniżej szczebla stanowego cechuje zupełna pustka. Lokalne ciała samorządowe obumarły. [...] Tak, jak centrum niechętnie przekazywało władzę i środki na potrzeby stanów, tak stany niechętnie dzieliły się środkami i władzą z lokalnymi ciałami samorządowymi. Samorządy miejskie wegetowały z braku funduszów i szalejącej korupcji, podczas gdy system panczajatów służył głównie ustabilizowaniu władzy starej elity dominującej na wsi” [za: Dębnicki, 2000, s. 115]. 
ustroju lokalnego i sformułowanie rekomendacji odnośnie do dalszych reform. Na czele Komitetu stanął Ashok Mehta (A. Mehta Committee).

Od sierpnia 1978 roku - daty ogłoszenia raportu Komitetu A. Mehty - mówi się o drugiej generacji panczajatów. Zawierający 132 rekomendacje raport A. Mehty znacząco modyfikował funkcje panczajatów. Według dotychczasowego ujęcia (wynikającego z raportu B.R. Mehty w 1957 roku), ich głównym zadaniem było wspomaganie i koordynacja programów rozwojowych wsi. Natomiast według raportu A. Mehty z 1978 roku panczajaty miały się stać instytucjami stricte politycznymi, trwałymi składnikami ustroju Indii. Wśród zaleceń Komitetu A. Mehty na uwagę zasługują następujące postulaty [Joshi, Narwani, 2002, s. 36-37]:

- najważniejszym szczeblem panczajatów winny być panczajaty dystryktowe (zilla parishads), a nie - jak wcześniej - panczajaty blokowe (panchayats samitis);

- panczajaty na poziomie wsi (gram panchayats) powinny być zastąpione przez mandal panchayats, obejmujące obszar większy niż panczajat wiejski, ale mniejszy niż obszar bloku (panchayat samiti) - populacja mieszkańców mandal panchayats winna wynosić 15-20 tys.;

- wśród pracowników wszystkich szczebli panczajatów winna dominować wykwalifikowana służba cywilna;

- partie polityczne powinny brać udział w wyborach do panczajatów;

- winny zostać utworzone na szczeblu centralnym i stanowym komisje finansowe do spraw panczajatów;

- oprócz dotacji, panczajaty winny mieć możliwość uzyskiwania dochodów własnych;

- na szczeblu dystryktowym (zilla parishads) należy sporządzać plany rozwojowe, które byłyby wprowadzane za pośrednictwem mandal panchayats.

Pierwszym stanem, który w 1978 roku wprowadził ustrój panczajatów zgodnie z rekomendacjami Komitetu A. Mehty, był Bengal Zachodni, a następnie uczyniły to Karnataka, Andhra Pradesh oraz Jammu \& Kashmir.

$\mathrm{Za}$ jedną z przyczyn trudności rozwoju lokalnej demokracji w pierwszych czterech dekadach niepodległych Indii, a szczególnie kryzysu samorządowego w latach 60. i 70., uznaje się brak precyzyjnego zapisu konstytucyjnego dotyczącego instytucji władzy publicznej poniżej szczebla stanowego. Dlatego też władze stanowe nie traktują z należytą powagą procesu autonomizacji i demokratyzacji lokalnych struktur państwa. Co więcej, taki niedookreślony ich status jest im na rękę. Coraz częściej pojawiają się więc głosy, aby wprowadzić do konstytucji odpowiednie poprawki nadające wyborom do samorządów lokalnych taką rangę, jaką mają wybory do parlamentu federalnego oraz parlamentów stanowych. Powszechne i demokratyczne wybory winny być jedynym sposobem ustalania składów władz lokalnych.

Zainteresowanie lokalnym szczeblem administracji państwa odradza się w połowie lat 80., po objęciu urzędu premiera przez R. Gandhiego. Aktywizacja lokalnych instytucji i poprawa warunków bytu mieszkańców wsi (likwidacja klęsk 
głodowych) stały się jednymi z ważniejszych elementów jego reform. Bodźcem do tego miałyby być dobre doświadczenia funkcjonujących już demokratycznych panczajatów w Bengalu Zachodnim i Karnatace.

W 1985 roku powołany został Komitet pod przewodnictwem G.V.K. Rao (G.V.K. Rao Committee), który przygotował raport o rozwoju obszarów wiejskich. W raporcie tym zalecano m.in. dalsze przekazywanie kompetencji samorządom wiejskim i ograniczanie tym samym centralnego i stanowego sterowania problemami lokalnymi. To samorządy powinny stać się - w duchu gram swaraj - prawdziwymi, niezależnymi gospodarzami na swoich terenach. Szczególną uwagę zwrócono na zadania władz lokalnych w ograniczaniu ubóstwa, którego skala na indyjskiej wsi - jak dotąd - nie zmniejszała się. Komitet Rao uznał m.in., że przewodnią rolę w organizacji i realizacji programów rozwoju obszarów wiejskich winny odgrywać panczajaty dystryktowe (zilla parishads), które należy wyposażyć w nowe, przekazane z poziomu rządów stanowych, kompetencje, szczególnie w zakresie planowania lokalnego oraz gospodarki finansowej. To na nich spoczywałby ciężar koordynacji i odpowiedzialności za rozwój lokalny. W stanach, gdzie nie istniał poziom dystryktowy administracji lokalnej, funkcje koordynatorów powinny przejąć samorządy niższego szczebla (samitis, blocs). Tym samym rządy stanowe zostałyby odciążone od zarządzania lokalnego, co racjonalizowałoby cały system funkcjonowania państwa (w duchu zasady subsydiarności), a jednocześnie zmniejszałaby się rola polityczna stanów i wynikające $\mathrm{z}$ tego różnorakiego rodzaju patologie (korupcja, klientelizm itp.).

Raport Komitetu D.V.K Rao stał się podstawą żywej dyskusji i budził liczne kontrowersje, szczególnie w odniesieniu do zbyt dużych kompetencji przyznanych samorządom lokalnym i tym samym ograniczaniu roli stanów. W celu rozstrzygnięcia spornych kwestii, w 1986 roku utworzony został nowy Komitet pod kierownictwem Laxmi M. Singhviego (L.M. Singhvi Committee). Generalnie zaakceptowane zostały jednak najważniejsze punkty raportu Komitetu Rao. Dodatkowo Komitet Singhviego postulował m.in., aby rady wiejskie - ze względów ekonomicznych - nie były obowiązkowo tworzone w każdej wsi, lecz mogłyby obejmować 2-3 wsie. Ponadto warunkiem powodzenia reform ustroju lokalnego byłoby -zdaniem Komitetu - umocowanie jego kształtu w konstytucji. Należałoby także odpolitycznić proces wyboru władz samorządowych poprzez ograniczenie angażowania się partii politycznych w tę dziedzinę życia lokalnych społeczności.

Ustalenia Komitetu Singhviego stały się podstawą projektu konstytucyjnej regulacji ustroju lokalnego przedstawionego w 1989 roku. W ten sposób rząd R. Gandhiego chciał położyć kres trwającym niemal trzy dekady dyskusjom kończącym się na ogół rekomendacjami różnych komitetów (komisji), w wyniku których jednak niewiele lub nic się nie zmieniało, gdyż brakowało jednoznacznej, konstytucyjnej regulacji prawnej samorządności lokalnej. Projekt Komitetu Singhviego miał w swej ostatecznej wersji zamienić się w 64 poprawkę do konstytucji. W październiku 1989 roku został on zaaprobowany przez Izbę Ludową, 
ale odrzuciła go reprezentująca stany izba wyższa, czyli Rada Stanów. Głównym argumentem za nieprzyjęciem nowelizacji ustroju lokalnego była propozycja nadania samorządom lokalnym daleko idących uprawnień i tym samym ograniczenie roli stanów. Obawiano się m.in. anarchizacji życia publicznego.

Jeżeli chodzi o ustrój terytorialny miast, to problem ten nie wywoływał tylu kłopotów i kontrowersji, co w przypadku obszarów wiejskich, chociażby z uwagi na fakt, że mieszkańcy miast stanowili tylko 1/4 ludności kraju. Zresztą system wiejski - jak wcześniej wspomniano - był dla nich niemal zawsze punktem odniesienia. Przyjęte więc rozwiązania prawne dla wiejskich panczajatów były po niezbędnych modyfikacjach przyjmowane przez lokalne struktury władz miejskich. W miastach, w zależności od ich wielkości i charakteru zabudowy, wyodrębniły się trzy rodzaje samorządu, tj.: panczajaty miejskie (nagar panchayats), zarządy (rady) miejskie (municipalities) oraz korporacje miejskie (municipal corporations).

Reasumując analizę ustroju terytorialnego Indii w pierwszych czterech dekadach ich niepodległości (do 1991 roku), można stwierdzić, że pomimo kilkukrotnych prób jego decentralizacji i po spektakularnych, krótkotrwałych sukcesach w niektórych regionach, w rzeczywistości - w skali kraju - nie miała ona miejsca. Wręcz przeciwnie, przeważały tendencje centralizacyjne ${ }^{14}$. Samorząd lokalny w pełnym tego słowa znaczeniu nie wkomponował się jeszcze - poza wyjątkami $-\mathrm{w}$ indyjski system polityczny.

\subsection{Istota i organizacja samorządowego ustroju lokalnego ustanowionego w latach 1992-1993}

Jak przedstawiono $\mathrm{w}$ poprzednim podrozdziale, po kilku nieudanych lub - w niektórych stanach - połowicznych próbach ustanowienia lokalnej samorządności, po raz kolejny zadania tego podjął się rząd R. Gandhiego pod koniec lat 80. Proponowane poprawki do konstytucji zostały w 1989 roku zaaprobowane przez Izbę Ludową, ale odrzucone przez Radę Stanów.

$\mathrm{W}$ niedługim czasie sprawa powróciła jednak na forum ustawodawcze. Kwestię decentralizacji państwa podjęto niemal natychmiast po wyborach parlamentarnych w 1991 roku, kończących politycznie burzliwy okres rządów partii opozy-

\footnotetext{
${ }^{14}$ Analizując te zagadnienia, K. Dębnicki pisze m.in.: „Tendencja do centralizacji [...] zaczęła jednak ponownie rosnąć po uzyskaniu niepodległości w 1947 roku. Było to dość naturalne zjawisko - nasilenie kontroli państwa, centralizacja procesu decyzyjnego w obliczu trudności wewnętrznych i zagrożenia zewnętrznego, z jednoczesnym uświadomieniem sobie (choć z różnych względów niewyartykułowanych), że ani władza, ani poddani z przyczyn kulturowych nie są gotowi do przyjęcia nowoczesnego modelu zdecentralizowanej zachodniej demokracji” [Dębnicki, 2000, s. 82].
} 
cyjnych do Indyjskiego Kongresu Narodowego. Utworzony w czerwcu tego roku przez powracający do władzy Indyjski Kongres Narodowy rząd P.V. Narashimy Rao uznał decentralizację za - obok liberalizacji i deregulacji - najważniejszy element swoich reform. Pomiędzy decentralizacją oraz liberalizacją i deregulacją gospodarki dostrzegano silny synergizm. Podobna zresztą była konwencja reform ustrojowych w wielu innych państwach, modyfikujących swoje systemy polityczne i gospodarki, a szczególnie w odchodzących od socjalizmu krajach Europy Środkowo-Wschodniej. Niewątpliwie rząd indyjski wzorował się na tych właśnie reformach. Ponadto zalecenia równoczesnego przeprowadzenia reform ekonomicznych i politycznych formułowały międzynarodowe instytucje gospodarcze - zasilające finansowo Indie - takie jak Bank Światowy i Międzynarodowy Fundusz Walutowy, a także niektóre agendy Organizacji Narodów Zjednoczonych.

Konstytucyjny status samorządom lokalnym, czyli panczajatom wiejskim i radom miejskim, nadany został przez wprowadzenie do konstytucji Indii w grudniu 1992 roku dwóch poprawek - 73 i 74. Weszły one w życie: 24 kwietnia 1993 roku - poprawka 73, a 1 czerwca 1993 - poprawka 74 [Kashyap, 2008, s. 239-242]. Wdrożenie to nie miało jednak charakteru bezpośredniego, lecz pośredni - poprzez ustawodawstwo stanowe ${ }^{15}$. W ciągu roku od daty uchwalenia poprawek przez parlament federalny musiały je ratyfikować organy ustawodawcze stanów i wydać własne ustawy dostosowawcze (tzw. Conformity Acts), uwzględniające specyfikę stanową. Do kwietnia 1995 roku miały się odbyć wybory do rad lokalnych. Ogólny schemat organizacyjny ustroju lokalnego Indii po wprowadzeniu poprawek do konstytucji nr 73 i 74 przedstawia rys. 4.1 .

Poprawki do konstytucji 73 i 74 uporządkowały i ujednoliciły status prawny samorządów lokalnych w Indiach i zasadniczo ograniczyły w tej dziedzinie rolę władz stanowych ${ }^{16}$. Według poprawki 73, w każdym stanie muszą być utworzone wiejskie samorządy lokalne - panczajaty:

- na poziomie wsi (gram panchayat);

- na poziomie pośrednim (subdystryktu), tj. zespołu wsi (taluka, block, samiti), w stanach, których liczba ludności przewyższa $2 \mathrm{mln}$, w mniejszych nie muszą być tworzone;

- na poziomie dystryktu (zilla parishad).

15 Poprawki do konstytucji 73 i 74 nie obejmowały początkowo takich stanów, jak: Nagaland, Meghalaya oraz Mizoram, Delhi NCT oraz - do grudnia 1996 roku - tzw. obszarów plemiennych w siedmiu stanach (Andhra Pradesh, Gujarat, Himachal Pradesh, Maharashtra, Madhya Pradesh, Orissa i Rajasthan).

${ }_{16}$ Poprawki 73 i 74 wprowadzone zostały do tekstu konstytucji. Poprawka 73 - dotycząca wsi - stanowi część IX konstytucji (artykuł 243 i artykuły 243A do 243O). Poprawka 74 - została włączona jako część IX A konstytucji (artykuły 243P do 243ZG) i dotyczy organizacji oraz funkcjonowania lokalnych samorządów miejskich [The Constitution of India, 2000, part IX, s. 208-214 oraz part IX A, s. 214-220]. 


\section{Obszary wiejskie}

(Panchayats Raj Institutions)

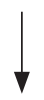

Panczajaty dystryktowe

(Zilla Parishads i in.)

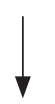

Panczajaty pośrednie

(Block-, Samiti, Taluka Panchayats)
Obszary miejskie

(Urban Local Bodies)

Korporacje miejskie (Municipal corporations)

Rady miejskie (Municipalities)

Panczajaty miejskie (Nagar Panchayats)

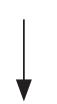

Panczajaty wiejskie

(Gram-, Village Panchayats)

Rysunek 4.1. Organizacja lokalnego szczebla administracji publicznej w Indiach*

* nazwy jednostek administracyjnych są różne w poszczególnych stanach (języki regionalne), w nawiasach podano tylko najczęściej używane.

Źródło: opracowanie własne na podstawie [Report of the Eleventh Finance Commission for 2000-2005, 2000, s. 264-268].

Panczajaty wiejskie (gram panchyats) są to samorządy jednej lub kilku sąsiednich wsi o łącznej liczbie mieszkańców w granicach $1,5-8,0$ tys. ${ }^{17}$ Liczba ludności panczajatów szczebla pośredniego (talukas, bloks, samitis) zawiera się z reguły w przedziale 80-200 tys., zaś na obszarze panczajatów dystryktowych (zilla parishads) zamieszkuje zazwyczaj 1-2 mln; wielkości te są różne w poszczególnych stanach $\mathrm{i}-\mathrm{z}$ uwagi na przyrost demograficzny i migracje - ulegają zmianom.

W skład rady samorządu na poziomie gminy wiejskiej (gram panchayat) wchodzi 7-20 osób wybranych w demokratycznych wyborach, którzy powołują spośród siebie przewodniczącego (sarpanch). W radach samorządów stopnia drugiego-pośredniego (w różnych stanach: taluka, taluk, taluq, tehsil, mandal, mudigere, block i in.) składających się z 10-20 panczajatów, zasiada 15-51 osób,

17 Jeżeli gram panchayat (wiejska gmina) składa się z kilku wsi (zazwyczaj małych), to w niektórych stanach - np. Kerali, Madhya Pradesh i Orissie - tworzone są dodatkowo na poziomie wchodzących w jej skład wsi instytucje zebrań wiejskich (gram sabha). Sprawy te nie są regulowane przez poprawki do konstytucji 73 i 74, lecz fakultatywnie przez ustawodawstwa stanowe. W tym kontekście mówi się czasem o czwartym szczeblu indyjskiej decentralizacji. W latach 90. ubiegłego wieku ponad 40 proc. ludności wiejskiej mieszkało we wsiach (osiedlach) małych, bo liczących mniej niż 500 obywateli, a 25 proc. żyło we wsiach (osiedlach) o liczbie 500-1000 mieszkańców [Rürup, 1999, s. 70, 73, 76]. 
którzy wybierają przewodniczącego (nazywają się oni z reguły: tehsildar, talukdar). Na poziomie dystryktu (zilla parishad) obejmującego 4-10 jednostek drugiego szczebla (blok, taluka) rady samorządu składają się z 31-51 członków, a na ich czele stoją prezydenci (zwani w różnych stanach: president, chairperson, adhyaksha, sabhadhipati $)^{18}$.

Poprawka do konstytucji nr 74 określa rodzaje i zasady tworzenia jednostek samorządu lokalnego na terenach zurbanizowanych. Nie mają one - w przeciwieństwie do samorządu wiejskiego - szczebli, lecz ich charakter jest uzależniony - jak wspomniano - od wielkości miasta. Są to następujące rodzaje samorządów miejskich:

- panczajaty miejskie (nagar panchayats) na obszarach „przejściowych”, czyli tych, które są w trakcie zmieniania swojego charakteru z wiejskiego na miejski (osiedla, małe miasta, przedmieścia metropolii itp.);

- rady miejskie (municipalities, municipal councils) na niewielkich obszarach miejskich (15-500 tys. mieszkańców);

- rady korporacji miejskich (municipal corporations) w dużych miastach - metropoliach (powyżej 500 tys. mieszkańców, aczkolwiek granica nie zawsze jest przestrzegana) $)^{19}$.

Konstytucja reguluje czas trwania kadencji organów przedstawicielskich panczajatów wiejskich i rad miejskich, która wynosi pięć lat. W radach samorządowych rezerwuje się miejsca dla tzw. plemion tubylczych (scheduled tribes) i osób bezkastowych (scheduled castes) - proporcjonalnie do ich udziału w ludności danego rejonu.

Specjalnie potraktowane są w obu poprawkach do konstytucji kobiety, których liczba nie może być mniejsza niż $1 / 3$ ogólnej liczby wybranych przedstawicieli rad lokalnych ${ }^{20}$. Nietrudno dostrzec, że nowa procedura wyłaniania władz lokalnych znacząco odbiega od dotychczasowych, tradycyjnych, kiedy to nie były one demokratycznie wybierane, czas pełnienia funkcji nie był sztywno regulowany, o wyborze decydowała przynależność kastowa i religijna, a kobiety i bezkastowcy nie mogli być w ogóle wybierani.

${ }^{18}$ Liczby członków samorządów lokalnych nie są stałe w poszczególnych stanach i okresach, ulegają zmianom w zależności od różnych czynników m.in. wielkości danej jednostki lokalnej. Dlatego też w literaturze oraz statystykach można się często spotkać z odmiennymi danymi, zależnymi głównie od daty badania.

19 Szczegółowo strukturę i organizację władzy lokalnej na obszarach miejskich przedstawia Sachdeva [2011]. Z uwagi na inny cel niniejszej pracy oraz mniejszą - niż w przypadku wsi - rangę lokalnego ustroju miast w Indiach, zagadnieniom tym nie poświęcamy więcej miejsca.

${ }^{20}$ Wcześniej, tzn. przed uchwaleniem poprawek 73 i 74, tylko w dwóch wiodących pod względem decentralizacji stanach, tj. Karnatace i Bengalu Zachodnim, w lokalnych radach samorządowych zarezerwowane było 25 proc. miejsc dla kobiet. Ale w praktyce udział ten był niekiedy przekraczany i dochodził do 40 proc. [Rürup, 1999, s. 80]. 
Legislatury poszczególnych stanów mogą - na podstawie poprawek 73 i 74 - nadać panczajatom wiejskim określone uprawnienia, niezbędne do realizacji ich funkcji jako samorządów lokalnych. Załącznik XI do konstytucji wylicza listę zadań, które mogą być przesunięte ze szczebla stanowego na szczebel panczajatów. Wyszczególniono w nim 29 dziedzin, za które odpowiedzialność może być przekazana przez legislaturę stanu panczajatom wiejskim. Sytuacja samorządów miejskich jest $\mathrm{w}$ tej kwestii bardzo podobna. W załączniku XII do konstytucji wymienia się 18 zadań, które mogą być przekazane samorządom miast.

Zadania, które mogą być przekazywane przez stany samorządom wiejskim, to [The Constitution of India, 2000, Eleventh Schedule - art. 243G, s. 392]:

1) wspomaganie rolnictwa;

2) ochrona i poprawa jakości gleb, reformy rolne, komasacja gruntów rolnych;

3) „mała” irygacja, gospodarka zasobami wodnymi;

4) hodowla zwierząt, mleczarstwo, drobiarstwo;

5) rybołówstwo;

6) uprawa i zarządzanie lasami publicznymi;

7) „mała” produkcja leśna;

8) przemysł drobny wraz z przetwórstwem żywności;

9) tkactwo i chałupnictwo;

10) mieszkalnictwo wiejskie;

11) zaopatrzenie w wodę pitną;

12) zaopatrzenie w paliwa i pasze;

13) utrzymanie i rozbudowa dróg, urządzeń odwadniających, mostów, promów, dróg wodnych i innych środków transportu lokalnego;

14) elektryfikacja wsi oraz dystrybucja energii elektrycznej;

15) gospodarka niekonwencjonalnymi źródłami energii;

16) programy łagodzenia ubóstwa;

17) szkolnictwo podstawowe i średnie;

18) kształcenie specjalistyczne (edukacja zawodowa);

19) kształcenie dorosłych oraz edukacja nieformalna;

20) biblioteki;

21) działalność kulturalna;

22) organizacja targów i jarmarków;

23) ochrona zdrowia i higiena (szpitale, ośrodki pierwszej pomocy oraz ambulatoria);

24) organizacja pomocy rodzinnej;

25) poprawa sytuacji kobiet i dzieci;

26) opieka społeczna (wraz z opieką nad osobami niepełnosprawnymi);

27) pomoc dla grup społecznie upośledzonych (w tym kast i plemion wyszczególnionych);

28) organizacja dystrybucji lokalnych dóbr publicznych;

29) gospodarowanie majątkiem komunalnym. 
Do zadań publicznych, które mogą być przekazywane przez władze stanowe samorządom miejskim należą [The Constitution of India, 2000, Twelfth Schedule - art. 243W, s. 393]:

1) planowanie zagospodarowania przestrzeni miejskiej;

2) gospodarka gruntami miejskimi oraz regulacja budownictwa;

3) planowanie rozwoju gospodarczego i społecznego miasta;

4) gospodarka drogowa i mostowa;

5) zaopatrzenie w wodę gospodarstw domowych oraz instytucji komunalnych i gospodarczych;

6) ochrona zdrowia oraz utrzymanie higieny i czystości;

7) ochrona przeciwpożarowa i usługi pożarnicze;

8) gospodarka miejskimi zasobami leśnymi, ochrona środowiska i działalność proekologiczna;

9) ochrona interesów grup społecznie upośledzonych oraz osób niepełnosprawnych;

10) poprawa warunków życia w slumsach;

11) łagodzenie ubóstwa miejskiego;

12) utrzymanie miejskich obiektów komunalnych (parki, ogrody, boiska);

13) promowanie właściwych zachowań w zakresie kultury, edukacji oraz estetyki;

14) organizacja pochówków i kremacji zmarłych oraz zarządzanie obiektami kremacji i pochówków;

15) organizacja schronisk dla zwierząt oraz ich ochrona przed okrucieństwem;

16) organizacja statystyki ruchu ludności wraz ze statystyką urodzeń i zgonów;

17) organizacja urządzeń użyteczności publicznej, w tym: oświetlenia ulic, parkingów, przystanków komunikacji miejskiej, szaletów publicznych;

18) regulowanie działalności rzeźni oraz garbarni.

Przedstawiony wykaz zadań publicznych dla samorządów lokalnych ma charakter fakultatywny, co oznacza, że stany mogą, ale nie muszą, przekazywać niektóre kompetencje poszczególnym szczeblom i rodzajom samorządów lokalnych. Dokładniej zadania te wyszczególniono w tzw. ustawach dostosowawczych (Conformity Acts), które - zgodnie z poprawkami 73 i 74 - zostały uchwalone przez legislatury stanowe w latach 1993-1994.

Liczba i zakres delegacji do wykonywania zadań publicznych przez samorządy lokalne zależy od konkretnej sytuacji w poszczególnych stanach, która jest uwarunkowana lokalnymi czynnikami historycznymi i bieżącymi - natury ekonomicznej, społecznej, kulturowej i politycznej. Dopuszcza się również takie sytuacje, że stany mogą - oprócz wyżej wymienionych prerogatyw konstytucyjnych - zalecić samorządom lokalnym realizację innych, dodatkowych zadań, jeśli nie 
jest to sprzeczne z tzw. listami kompetencyjnymi, czyli Lista Unii, Lista Stanów oraz Lista Wspólnq ${ }^{21}$.

Wprowadzenie w 1992 roku dwóch poprawek do konstytucji dotyczących lokalnego szczebla organizacji terytorialnej dopełnia jakby indyjską demokrację, która do tej pory nie miała gruntownych fundamentów, czyli nie była osadzona w społecznościach lokalnych.

Według danych spisu powszechnego w lutym 2001 roku, a więc pierwszego po wdrożeniu poprawek do konstytucji $\mathrm{nr} 73$ i 74, na obszarze Indii istniały: 593 dystrykty (zilla parishads i in.), 5564 jednostek pośrednich - subdystryktów (blocs, talukas i in.), 640 tys. wsi oraz 5161 osiedli i miast różnej wielkości [Bose, 2001, s. 3]. Z danych tych wynika, że utworzenie samorządu lokalnego w Indiach jest największym przedsięwzięciem decentralizacyjnym na świecie.

Zgodnie z poprawką do konstytucji nr 73, po 1992 roku legislatury stanowe uzyskały prawo nadawania organom wiejskiej administracji uprawnień niezbędnych do uczynienia $z$ nich instytucji samorządu lokalnego. Uprawnienia te winny sprzyjać realizacji zasad sprawiedliwości społecznej, przygotowaniu i wykonywaniu planów rozwoju gospodarczego, a także realizacji zadań wyszczególnionych w XI załączniku do konstytucji.

Spośród trzech szczebli samorządu wiejskiego, jednostką podstawową jest szczebel najniższy tj. panczajat wiejski (gram panchayat). Posiada on największe kompetencje do samodzielnego regulowania spraw lokalnych. Znacznie mniejszy jest zakres samodzielności samorządów wiejskich dwóch wyższych szczebli - pośredniego (blokowego) i dystryktowego. Pełnią one w przeważającym stopniu funkcje administracyjno-koordynacyjne, to znaczy uczestniczą w realizacji zadań zleconych przez stany, a obejmujących obszary większe niż jeden panczajat. Zadania te formułowane są głównie w postaci tzw. planów rozwojowych, co wynika z planowego charakteru indyjskiej gospodarki. Plany te obejmują w szczególności: programy edukacyjne, ochronę zdrowia, warunki bytu oraz irygację - najważniejszą kwestię gospodarczą na indyjskiej wsi [Decentralisation in India, 2000, s. 50-51]. Podobnie wygląda sytuacja w odniesieniu do nakładania i pobierania podatków. W większości stanów dwa najwyższe szczeble samorządów wiejskich nie posiadają uprawnień w tym zakresie [Rai $\mathrm{i}$ in., 2001, s. 162].

Praktyka pierwszych lat indyjskiej decentralizacji pokazała, że władze stanów dość często i to w znacznym stopniu czyniły użytek z nadanych im uprawnień regulacyjnych w stosunku do samorządów lokalnych, to znaczy przekazywały samorządom wykonywanie określonych zadań. Niejednokrotnie jednak stosowano też zakazy podejmowania przez samorządy realizacji takich czy innych zadań

${ }^{21}$ W siódmym załączniku do konstytucji Indii (art. 246) wyodrębnione są tzw. listy kompetencyjne określające uprawnienia władz federalnych i stanowych, w tym także do pozyskiwania dochodów. Są to Lista Unii, Lista Stanów oraz Lista Wspólna [The Constitution of India, 2000, Seventh Schedule, art. 246, s. 363-373]. 
publicznych. Taka arbitralna - aczkolwiek mieszcząca się w granicach konstytucyjnej regulacji - reglamentacja kompetencji i zadań ogranicza oczywiście autonomię samorządów lokalnych i kłóci się z naczelnym przesłaniem decentralizacji. Jednakże, z drugiej strony - ma ona też zalety, gdyż m.in. zapobiega podejmowaniu przez samorządy zadań ponad ich realne możliwości bądź też partykularnych i nieracjonalnych z szerszego punktu widzenia, co pociąga wysokie wydatki i z reguły zadłużanie się sektora lokalnego.

Samorządy mogą wykonywać przekazane przez stany zadania samodzielnie lub też łączyć się w ich realizacji $\mathrm{z}$ innymi samorządami, tworząc w tym celu odpowiednie, poziome porozumienia i związki organizacyjne [The Local Government System in India, 2004, s. 80].

Jak wspomniano, liczba wykonywanych przez samorządy lokalne zadań publicznych jest w poszczególnych stanach zróżnicowana i zmienna w czasie. Istnieją jednak zadania wspólne, szczególnie ważne dla życia społecznego, których lista jest identyczna w większości stanów. Rozkład tych kompetencji pomiędzy szczeblami administracji publicznej informuje m.in. o skali oraz strukturze decentralizacji.

W tab. 4.1 zawarto wykaz kompetencji władz poszczególnych szczebli struktury administracyjnej państwa indyjskiego w zakresie realizacji publicznych zadań cywilnych, to znaczy wyłączających zadania z zakresu obrony narodowej, utrzymania stosunków międzynarodowych (dyplomacja) czy niektórych rodzajów badań, np. kosmicznych, badań nad energią atomową itp., które z natury swej pozostają $\mathrm{w}$ gestii rządu federalnego.

Spośród wyróżnionych w tab. 4.1 dziesięciu grup zadań publicznych, do najbardziej zdecentralizowanych, czyli realizowanych przez samorządy lokalne, należą: wspieranie rozwoju gospodarczego, ochrona środowiska wraz z ochroną sanitarną, edukacja, ochrona zdrowia oraz infrastruktura ekonomiczna (techniczna).

Świadczenie podstawowych usług administracji ogólnej (rejestracja ludności, bezpieczeństwo publiczne, sądownictwo) leży z reguły w kompetencji rządów stanowych oraz samorządów miejskich (każdego rodzaju), a w przypadku wsi - tylko samorządów najwyższego szczebla, czyli dystryktowych.

Najbardziej zdecentralizowanym zadaniem publicznym jest edukacja - wychowanie przedszkolne oraz szkolnictwo podstawowe. Te zadania realizowane są wyłącznie przez samorządy miejskie, a na wsi - samorządy podstawowego szczebla, czyli panczajaty. Organizacją szkolnictwa średniego zajmują się - w zależności od jego typu - rządy stanowe oraz samorządy miast, a na wsi - samorządy pośrednie (blok, taluka, samiti). Organizacja szkolnictwa wyższego oraz edukacji dorosłych leżą w gestii władz stanowych.

Stosunkowo wysoce zdecentralizowany jest także system opieki zdrowotnej. Organizacją podstawowej opieki medycznej zajmują się - oprócz władz stanowych - samorządy miejskie, a w środowisku wiejskim samorządy drugiego 
szczebla. Opieka specjalistyczna, w tym utrzymanie szpitali, a także działania profilaktyczne (np. szczepienia, badania prewencyjne, zapobieganie epidemiom) leży - w zależności od ich rodzaju - w kompetencji rządów stanowych, w miastach - samorządów miejskich, a na wsiach - samorządów dystryktowych.

Tabela 4.1. Struktura kompetencji administracji publicznej w Indiach

\begin{tabular}{|c|c|c|c|c|c|c|}
\hline \multirow{4}{*}{ Rodzaj zadania publicznego } & \multicolumn{6}{|c|}{ Uprawnienia w zakresie wykonywania zadań publicznych } \\
\hline & \multirow[b]{3}{*}{$\begin{array}{l}\text { Władze } \\
\text { federalne }\end{array}$} & \multirow[b]{3}{*}{$\begin{array}{l}\text { Władze } \\
\text { stanowe }\end{array}$} & \multicolumn{4}{|c|}{ Władze lokalne } \\
\hline & & & \multirow{2}{*}{$\begin{array}{l}\text { Samo- } \\
\text { rządy } \\
\text { miejskie } \\
\text { (Urban } \\
\text { Local } \\
\text { Bodies) }\end{array}$} & \multicolumn{3}{|c|}{$\begin{array}{c}\text { Samorządy wiejskie } \\
\text { (Panchayats Raj Institutions) }\end{array}$} \\
\hline & & & & $\begin{array}{l}\text { dystryk- } \\
\text { towe } \\
\text { (zilla } \\
\text { parishad) }\end{array}$ & $\begin{array}{c}\text { po- } \\
\text { średnie } \\
\text { (block, } \\
\text { taluka, } \\
\text { samiti) }\end{array}$ & $\begin{array}{l}\text { wiejskie } \\
\text { (gram } \\
\text { pan- } \\
\text { chayat) }\end{array}$ \\
\hline 1 & 2 & 3 & 4 & 5 & 6 & 7 \\
\hline \multicolumn{7}{|c|}{ Administracja ogólna } \\
\hline Policja & & $\mathrm{X}$ & & & & \\
\hline Ochrona przeciwpożarowa & & $\mathrm{X}$ & $\mathrm{X}$ & $\mathrm{X}$ & & \\
\hline Ochrona cywilna & & $\mathrm{X}$ & $\mathrm{X}$ & $\mathrm{X}$ & & \\
\hline Wymiar sprawiedliwości & $\mathrm{X}$ & $\mathrm{X}$ & & & & \\
\hline Rejestracja ludności & & & $\mathrm{X}$ & $\mathrm{X}$ & & \\
\hline Statystyka (sprawozdawczość) & $\mathrm{X}$ & $\mathrm{X}$ & $\mathrm{X}$ & $\mathrm{X}$ & & \\
\hline \multicolumn{7}{|c|}{ Edukacja } \\
\hline Oświata przedszkolna & & & $\mathrm{X}$ & & & $\mathrm{X}$ \\
\hline Szkolnictwo podstawowe & & & $\mathrm{X}$ & & & $\mathrm{X}$ \\
\hline Szkolnictwo średnie & & $\mathrm{X}$ & $\mathrm{X}$ & & $\mathrm{X}$ & \\
\hline Szkolnictwo zawodowe & & $\mathrm{X}$ & & & & \\
\hline Szkolnictwo wyższe & & $X$ & & & & \\
\hline Edukacja dorosłych & & $\mathrm{X}$ & & & & \\
\hline \multicolumn{7}{|c|}{ Opieka społeczna } \\
\hline Żłobki i przedszkola & & & $\mathrm{X}$ & & & $\mathrm{X}$ \\
\hline Pomoc rodzinna & & $\mathrm{X}$ & & & & \\
\hline Domy opieki społecznej & & $X$ & & & & \\
\hline \multicolumn{7}{|c|}{ Zdrowie publiczne } \\
\hline Opieka podstawowa & & $\mathrm{X}$ & $\mathrm{X}$ & & $X$ & \\
\hline Szpitale & & $\mathrm{X}$ & $\mathrm{X}$ & $\mathrm{X}$ & & \\
\hline Profilaktyka & & $\mathrm{X}$ & $\mathrm{X}$ & $\mathrm{X}$ & & \\
\hline
\end{tabular}




\begin{tabular}{|c|c|c|c|c|c|c|}
\hline 1 & 2 & 3 & 4 & 5 & 6 & 7 \\
\hline \multicolumn{7}{|c|}{ Mieszkalnictwo i planowanie społeczne } \\
\hline Mieszkalnictwo & & $\mathrm{X}$ & & & & \\
\hline Planowanie miejskie & & $\mathrm{X}$ & $\mathrm{X}$ & & $\mathrm{X}$ & \\
\hline Planowanie regionalne & & $\mathrm{X}$ & & $\mathrm{X}$ & & \\
\hline \multicolumn{7}{|c|}{ Transport } \\
\hline Drogi & $\mathrm{X}$ & $\mathrm{X}$ & $\mathrm{X}$ & $\mathrm{X}$ & & \\
\hline Drogi miejskie & & $\mathrm{X}$ & $\mathrm{X}$ & & & \\
\hline Koleje & $\mathrm{X}$ & & & & & \\
\hline Porty & $\mathrm{X}$ & & & & & \\
\hline Lotniska & $\mathrm{X}$ & & & & & \\
\hline \multicolumn{7}{|c|}{ Środowisko i sytuacja sanitarna } \\
\hline Oczyszczanie wody & & $\mathrm{X}$ & $\mathrm{X}$ & & $\mathrm{X}$ & \\
\hline Wywóz i utylizacja śmieci & & & $\mathrm{X}$ & & $\mathrm{X}$ & \\
\hline Cmentarze i krematoria & & & $\mathrm{X}$ & & $\mathrm{X}$ & \\
\hline Ochrona środowiska & $\mathrm{X}$ & $\mathrm{X}$ & $\mathrm{X}$ & $\mathrm{X}$ & $\mathrm{X}$ & \\
\hline Ochrona konsumentów & & $\mathrm{X}$ & & & & \\
\hline \multicolumn{7}{|c|}{ Kultura, czas wolny i sport } \\
\hline Teatry i koncerty & & $\mathrm{X}$ & & & & \\
\hline Muzea i biblioteki & & $\mathrm{X}$ & & & & \\
\hline Parki i place publiczne & & & $\mathrm{X}$ & & & \\
\hline Sport i czas wolny & & $\mathrm{X}$ & & & & \\
\hline Turystyka & $\mathrm{X}$ & $\mathrm{X}$ & & & & \\
\hline \multicolumn{7}{|c|}{ Usługi użyteczności publicznej } \\
\hline Gazownictwo & & $\mathrm{X}$ & $\mathrm{X}$ & & & \\
\hline Dostawa wody & & $\mathrm{X}$ & $\mathrm{X}$ & & $\mathrm{X}$ & \\
\hline Elektryczność & & $\mathrm{X}$ & $\mathrm{X}$ & $\mathrm{X}$ & & \\
\hline \multicolumn{7}{|c|}{ Wspieranie rozwoju gospodarczego } \\
\hline $\begin{array}{l}\text { Rolnictwo, leśnictwo, } \\
\text { rybołówstwo }\end{array}$ & & $\mathrm{X}$ & $\mathrm{X}$ & $\mathrm{X}$ & $\mathrm{X}$ & $\mathrm{X}$ \\
\hline Pobudzanie gospodarki & & $\mathrm{X}$ & $\mathrm{X}$ & $\mathrm{X}$ & $\mathrm{X}$ & $\mathrm{X}$ \\
\hline Handel i przemysł & $\mathrm{X}$ & $\mathrm{X}$ & $\mathrm{X}$ & & & \\
\hline
\end{tabular}

Źródło: opracowanie własne na podstawie [The Local Government System in India, 2004, s. $80-81]$. 
Realizacją zadań w zakresie publicznej gospodarki mieszkaniowej zajmują się na ogół władze stanowe. W niektórych przypadkach (np. planowania przestrzennego) mogą one jednak przekazywać kompetencje samorządom miast, a na obszarach wiejskich - samorządom dystryktów lub bloków.

Zadania w dziedzinie transportu publicznego są stosunkowo mało zdecentralizowane. Zarządzanie kolejami, portami morskimi oraz lotnictwem cywilnym leży w kompetencji rządu federalnego, zaś zarządzanie drogami lądowymi oraz miejskimi ulicami podlega władzom stanów oraz samorządów miejskich i - w niektórych przypadkach - samorządów dystryktowych.

Niski jest również stopień decentralizacji sfery kultury oraz sportu i rekreacji (w tym turystyki). Te zadania leżą zazwyczaj w gestii rządów stanowych i - niekiedy - samorządów miejskich.

Jeżeli chodzi o zaspokojenie elementarnych potrzeb zbiorowych z zakresu infrastruktury, czyli dostarczanie takich dóbr, jak: woda, energia elektryczna, gaz czy też oczyszczanie miejsc publicznych oraz wywóz śmieci, a także utrzymanie terenów kremacyjnych, to zadania w tym zakresie są zdecentralizowane. $Z$ uwagi na specyfikę tych dóbr, niektóre rodzaje ich produkcji i dystrybucji znajdują się w kompetencji stanów, natomiast większość jest przedmiotem działalności samorządów lokalnych, a więc wszystkich rodzajów rad miejskich oraz - w przypadku wsi - samorządów dystryktowych i pośrednich (blokowych).

Rządy stanowe oraz wszystkie szczeble i rodzaje samorządu lokalnego zobowiązane są do pomocy i promowania działalności gospodarczej na swoim terenie. Szczególnie dotyczy to samorządów wiejskich, których ważną misją jest wspieranie lokalnego rolnictwa i innych rodzajów gospodarki wiejskiej. Idzie tu nie tylko o pomoc organizacyjną czy szkoleniową, ale także wsparcie materialne i finansowe, szczególnie w dziedzinie budowy i konserwacji urządzeń irygacyjnych, zaopatrzenia rolników w nawozy czy też zbytu produktów rolnych. Samorządy lokalne muszą wspierać także ludność w sytuacji zagrożeń, czyli - jakże częstych w Indiach - kataklizmów wynikających z kaprysów natury (susze, powodzie czy trzęsienia ziemi).

W badaniach nad decentralizacją najwięcej uwagi poświęca się zagadnieniom finansowym, czyli uprawnieniom samorządów do pozyskiwania dochodów oraz samodzielności w ich wydatkowaniu. Decentralizację finansów publicznych uznaje się zazwyczaj za rdzeń procesów decentralizacyjnych ${ }^{22}$. Tak też jest w przypadku Indii. W poprawkach 73 i 74 szczególne miejsce przypada właśnie regulacjom finansów samorządów lokalnych i dlatego tym sprawom poświęcona zostanie większa uwaga.

${ }^{22}$ Francuscy badacze samorządności lokalnej Gaudemet i Molinier [2000, s. 131] piszą w tej kwestii m.in.: „Decentralizacja jest rzeczywista, gdy podmioty lokalnej władzy są naprawdę panami swoich finansów [...] decentralizacja będzie czysto pozorna, jeżeli wspólnota lokalna nie ma rzeczywistej wolności finansowej, mimo iż ma nawet rozlegle kompetencje prawne". 
Jeżeli idzie o sposoby i źródła pozyskiwania dochodów przez wiejskie samorządy lokalne, to - w oparciu o poprawkę 73 - władze stanów mogą w drodze ustawy [Maheshwari, 2003, s. 173]

- nadać uprawnienia samorządom wiejskim do nakładania, pobierania określonych podatków, ceł i opłat oraz dysponowania dochodami z tych tytułów;

- przekazywać samorządom wiejskim dochody z podatków, ceł i opłat nakładanych oraz pobieranych przez stany;

- ustalać i przekazywać dotacje dla samorządów wiejskich ze Skonsolidowanego Funduszu Stanu;

- tworzyć specjalne fundusze dla kredytowania niektórych rodzajów działalności gospodarczej samorządów wiejskich.

Bezpośrednio regulacją finansów lokalnych zajmują się powołane na mocy poprawek 73 i 74 Stanowe Komisje Finansowe ${ }^{24}$. Zgodnie z tymi poprawkami, gubernatorzy stanów mają obowiązek powoływania co pięć lat Stanowych Komisji Finansowych, których celem jest:

1. Przegląd i ocena sytuacji finansowej samorządów lokalnych.

2. Formułowanie zaleceń dla gubernatorów stanów odnośnie do:

- zasad dystrybucji dochodów netto z podatków, ceł i opłat pobieranych przez stany, które mogą być dzielone pomiędzy stany a samorządy wiejskie (dystrybucja pionowa) oraz podziału tych środków pomiędzy samorządami (dystrybucja pozioma);

${ }^{23}$ Reguluje to artykuł 243H konstytucji Indii, będący częścią poprawki 73.

${ }^{24}$ Kompetencje Stanowych Komisji Finansowych reguluje artykuł 243 I konstytucji Indii wchodzący w skład poprawki 73. Należy wyjaśnić, że na szczeblu federalnym istnieje od 1951 roku Komisja Finansowa, która jest organem konstytucyjnym powołanym na mocy art. 280. Jest to najważniejsza instytucja $\mathrm{w}$ indyjskim systemie finansowym powoływana przez prezydenta republiki na 5 lat. Do jej obowiązków należy m.in. przygotowanie i przedstawianie prezydentowi - a ten z kolei obu izbom parlamentu - zaleceń odnośnie do kształtu polityki finansowej w okresie realizacji kolejnego pięcioletniego planu gospodarczego. Zalecenia te dotyczą w szczególności [Bywalec, 2005]:

- ustalania struktury podziału pomiędzy centrum a stanami dochodów netto z opłat i podatków nakładanych i ściąganych przez rząd Indii (zgodnie z art. 269 i 270 konstytucji);

- ustalania kryteriów i zasad podziału pomiędzy poszczególne stany tej części dochodów podatkowych, która została przeznaczona dla stanów;

- ustalania wysokości oraz metody podziału pomiędzy stany dotacji przewidzianych w art. 275 konstytucji;

- określania dotacji dla tzw. obszarów i plemion wyodrębnionych (wyszczególnionych w 5 i 6 załączniku do konstytucji);

- proponowania specjalnych dotacji dla stanów z uwagi na klęski żywiołowe czy inne ważne okoliczności; nakładania nowych podatków oraz wszelkich zmian w systemie finansów publicznych;

- formułowanie zaleceń odnośnie do środków, które powinny być przekazane stanom na uzupełnienie budżetów lokalnych: XI Komisja Finansowa (2000-2005) wydała po raz pierwszy takie zalecenia w duchu reform decentralizacyjnych z 1992 roku, tj. poprawek do konstytucji nr 73 i 74 . 
- rodzajów podatków i opłat, które mogą być ustalane, pobierane oraz rozdysponowywane przez samorządy wiejskie;

- zasad i wielkości dotacji dla samorządów wiejskich ze Skonsolidowanego Funduszu Stanu;

- tworzenia środków specjalnych potrzebnych samorządom wiejskim do poprawy ich sytuacji finansowej;

- wszystkich innych spraw związanych z publiczną gospodarką finansową na poziomie lokalnym.

W ramach poprawki nr 73 dokonano również rozszerzenia artykułu 280 konstytucji, traktującego o działającej na szczeblu federalnym Komisji Finansowej (subklauzula 280.3.bb). Zgodnie z tą modyfikacją Komisja Finansowa została zobligowana do formułowania zaleceń prezydentowi państwa odnośnie do wyodrębnienia w budżecie centralnym środków finansowych na uzupełnienie dochodów samorządów wiejskich. Środki te przekazywane są do Skonsolidowanych Funduszów Stanów, a o ich konkretnym przeznaczeniu decydują Stanowe Komisje Finansowe [Oommen, Datta, 1995, s. 3].

W poprawce 74 zawarte są - jak wspomniano - zalecenia dotyczące zasad finansowania samorządów miejskich (rad municypalnych). Treść większości z nich jest analogiczna lub podobna do przedstawionych wyżej artykułów dotyczących finansów samorządów wiejskich; z tego właśnie względu pominiemy ich prezentację ${ }^{25}$.

Do roku 1993, czyli przed wejściem w życie poprawek do konstytucji nr 73 i 74, w każdym stanie obowiązywały oddzielne ustawy regulujące kwestie wiejskich i miejskich organów władzy lokalnej (tylko w niektórych stanach miały one status samorządów), w tym kwestie dochodów tych jednostek. Ponieważ nie istniały żadne konstytucyjne dyrektywy co do lokalnych finansów, stany miały praktycznie całkowitą dowolność w decydowaniu o ich kształcie. Po roku 1993 na skutek obowiązku uchwalenia przez stany ustaw dostosowawczych (Conformity Acts), dopasowano tym samym istniejące wcześniej akty prawne do obowiązujących zaleceń konstytucyjnych zawartych w poprawkach 73 i 74 [Oommen, Datta, 1995, s. 18].

Z zapisu skorygowanej o poprawki 73 i 74 konstytucji Indii wynika, że o kształcie samorządności lokalnej, czyli o obowiązkach i uprawnieniach jednostek lokalnych decydują ciała ustawodawcze poszczególnych stanów. Większość uprawnień samorządów jest im nadawana przez stany i one tym samym ponoszą odpowiedzialność za ich realizację [Decentralisation in India, 2000, s. 50-51].

Powyższe, wynikające bezpośrednio z konstytucji, regulacje stanowią podstawę prawną dla gospodarki finansowej na poziomie lokalnym, a więc systemu pozyskiwania oraz rozdysponowania środków finansowych.

${ }^{25}$ Zasady finansów samorządów miejskich po 1992 roku regulują następujące artykuły konstytucji, wprowadzone w ramach poprawki $\mathrm{nr} 74$ : 243W, 243X oraz $243 \mathrm{Y}$. 
W zmodyfikowanym po 1992 roku systemie finansów lokalnych Indii można wyróżnić pięć rodzajów dochodów [Cauvery i in., 2000, s. 281]:

1) podatki własne;

2) niepodatkowe dochody własne;

3) udziały w podatkach nakładanych i pobieranych przez rządy stanowe;

4) dotacje;

5) pożyczki i darowizny.

Zgodnie ze wskazaniami konstytucyjnymi, władze stanów mogą przekazywać samorządom lokalnym uprawnienia do nakładania i pobierania niektórych podatków oraz dysponowania wpływami z tego tytułu. Taka regulacja sprawia m.in., że podatki lokalne są zróżnicowane w poszczególnych stanach. Zaznaczyć należy, iż wszystkie te podatki, które mogą być przekazywane na poziom lokalny są wymienione w Liście Stanów. W kompetencji samorządów lokalnych znajdują się z reguły następujące podatki [Cauvery i in., 2000, s. 277-283]:

- podatki od własności, w szczególności od gruntów i budynków;

- oktroja i podatek graniczny ${ }^{26}$

- podatki od zwierząt i łodzi;

- podatki od pojazdów;

- podatki od wykonywania zawodu, handlu i pracy najemnej;

- podatki od ogłoszeń;

- inne podatki, takie jak np.: od widowisk, od transferu własności, od pasażerów przewożonych drogami wodnymi i lądowymi.

W tab. 4.2 zestawiono - w układzie stanowym - rozkład uprawnień samorządów wiejskich do nakładania i pobierania podatków lokalnych.

$\mathrm{Z}$ tab. 4.2 wynika, że w zakresie kompetencji finansowych, w pierwszych latach po wprowadzeniu decentralizacji Indii wyróżnić można trzy sytuacje ${ }^{27}$ :

1. Samorządy określonego szczebla są zobligowane przez władze stanowe do ustalania oraz pobierania określonych rodzajów podatków (podatki obligatoryjne).

2. Samorządy określonego szczebla mają prawo do ustalania oraz pobierania określonych rodzajów podatków (podatki fakultatywne, opcjonalne).

3. Samorządy określonego szczebla nie posiadają żadnych uprawnień do nakładania i pobierania podatków.

${ }^{26}$ Oktroja - podatek nakładany na towary wwożone na terytoria lokalne w celu ich konsumpcji. Był ważnym podatkiem w wiekach średnich, w okresie istnienia dużej liczby samodzielnych państw-księstw i samorządnych miast. Aktualnie jest stosowany tylko w niektórych krajach.

${ }^{27}$ Oczywiście po 2000 roku następowały dalsze zmiany w zakresie regulacji kompetencji finansowych samorządów w poszczególnych stanach. Z uwagi na ich liczbę oraz daty zmian trudno byłoby je wszystkie uwzględnić. Ponadto nie miały one jakiegoś istotnego charakteru. Wszystkie ważne regulacje dokonane zostały w pierwszych latach po wejściu w życie poprawek 73 i 74 . 
Tabela 4.2. Kompetencje do nakładania i pobierania podatków lokalnych przez samorządy wiejskie po przyjęciu Conformity Acts (zgodnie z poprawką do konstytucji nr 73)

\begin{tabular}{|c|c|c|c|c|}
\hline $\begin{array}{c}\text { Szczebel } \\
\text { samorządu } \\
\text { wiejskiego } \\
\text { (panczajaty) }\end{array}$ & $\begin{array}{c}\text { Stany, } \\
\text { w których } \\
\text { nie istnieją } \\
\text { panczajaty } \\
\text { danego szczebla }\end{array}$ & $\begin{array}{c}\text { Podatki } \\
\text { obligatoryjne } \\
\text { i fakultatywne }\end{array}$ & $\begin{array}{l}\text { Wszystkie } \\
\text { podatki są } \\
\text { fakultatywne }\end{array}$ & $\begin{array}{l}\text { Brak uprawnień } \\
\text { do nakładania } \\
\text { i/lub pobierania } \\
\text { podatków }\end{array}$ \\
\hline $\begin{array}{l}\text { Panczajaty } \\
\text { wiejskie } \\
\text { (gram } \\
\text { panchayats) }\end{array}$ & - & $\begin{array}{l}\text { Andhra Pradesh, } \\
\text { Assam, Goa, } \\
\text { Haryana, } \\
\text { Karnataka, } \\
\text { Kerala, Madhya } \\
\text { Pradesh, } \\
\text { Maharashtra, } \\
\text { Manipur, Punjab, } \\
\text { Tamil Nadu, } \\
\text { West Bengal }\end{array}$ & $\begin{array}{l}\text { Arunachal } \\
\text { Pradesh, Bihar, } \\
\text { Himachal } \\
\text { Pradesh, Orissa, } \\
\text { Rajasthan, } \\
\text { Tripura, Uttar } \\
\text { Pradesh, Jammu } \\
\text { \& Kashmir }\end{array}$ & - \\
\hline $\begin{array}{l}\text { Panczajaty } \\
\text { pośrednie } \\
\text { (blocks, talukas } \\
\text { i in.) }\end{array}$ & $\begin{array}{l}\text { Goa, Manipur, } \\
\text { Sikkim }\end{array}$ & $\begin{array}{l}\text { Madhya Pradesh, } \\
\text { Punjab }\end{array}$ & $\begin{array}{l}\text { Andhra Pradesh, } \\
\text { Assam, Bihar, } \\
\text { Gujarat, } \\
\text { Rajasthan, Tamil } \\
\text { Nadu, Tripura, } \\
\text { Uttar Pradesh, } \\
\text { West Bengal }\end{array}$ & $\begin{array}{l}\text { Arunachal } \\
\text { Pradesh, Haryana, } \\
\text { Himachal } \\
\text { Pradesh, } \\
\text { Karnataka, } \\
\text { Kerala, } \\
\text { Maharashtra, } \\
\text { Orissa, Jammu } \\
\text { \& Kashmir }\end{array}$ \\
\hline $\begin{array}{l}\text { Panczjaty } \\
\text { dystryktowe } \\
\text { (zilla parishads) }\end{array}$ & $\begin{array}{l}\text { Jammu } \\
\text { \& Kashmir }\end{array}$ & - & $\begin{array}{l}\text { Assam, Bihar, } \\
\text { Gujarat, } \\
\text { Maharashtra, } \\
\text { Rajasthan, Tamil } \\
\text { Nadu, Uttar } \\
\text { Pradesh, West } \\
\text { Bengal }\end{array}$ & $\begin{array}{l}\text { Andhra Pradesh, } \\
\text { Arunachal } \\
\text { Pradesh, Goa, } \\
\text { Haryana, } \\
\text { Himachal } \\
\text { Pradesh, } \\
\text { Karnataka, } \\
\text { Kerala, Madhya } \\
\text { Pradesh, } \\
\text { Manipur, Orissa, } \\
\text { Punjab, Tripura, } \\
\text { Sikkim }\end{array}$ \\
\hline
\end{tabular}

* brak danych dla: Nagalandu, Meghalayi i Mizoramu oraz stanów utworzonych w 2000 roku (Jharkhand, Chattisgarh i Uttarakhand).

Źródło: [Mukherjee, 2001, s. 55].

We wszystkich stanach samorządy wiejskie najniższego szczebla (gram panchayats) mogą uzyskiwać dochody z podatków własnych. Nakładanie i pobieranie tych podatków może im być przez rządy stanowe nakazane (podatki własne obligatoryjne) bądź jedynie zalecone (podatki własne fakultatywne). 
Na poziomie pośrednim (blokowym) tylko rządy stanów Madhya Pradesh i Punjab nakazują władzom lokalnym pobieranie określonych podatków. W 9 stanach większość podatków lokalnych na tym szczeblu może być ustalana i pobierana przez samorządy w sposób fakultatywny, natomiast w 8 stanach samorządy szczebla pośredniego nie posiadają uprawnień do pozyskiwania własnych podatków.

W żadnym stanie nie przekazano uprawnień do obligatoryjnego nakładania i pobierania podatków władzom najwyższego szczebla samorządu wiejskiego - dystryktowym. W 8 stanach uprawnienia te mają charakter fakultatywny, a w 13 stanach samorządy dystryktowe nie posiadają w ogóle prawa do nakładania podatków.

Reasumując powyższą analizę, stwierdzamy, że najszerszy zakres kompetencji w zakresie pozyskiwania własnych dochodów podatkowych uzyskały w wyniku poprawki 73 samorządy najniższego szczebla - samorządy wiejskie, znacznie mniejszy - samorządowe pośrednie (blokowe), a najmniejszy - samorządy dystryktowe. Oznacza to równocześnie, że samorządy wiejskie winny legitymować się najwyższą samodzielnością finansową. W przypadku sektora miejskiego, wszystkie rodzaje samorządów mają uprawnienia do nakładania i pobierania podatków; dokładniej sprawy te reguluje ustawodawstwo stanowe.

Na uwagę zasługuje fakt, że pierwotnie Stanowe Komisje Finansowe rekomendowały na ogół rządom stanów utrzymanie na szczeblu lokalnym ,podatkowego status quo", czyli takiego systemu, jaki istniał przed 1992 rokiem. Nie zalecały tym samym istotnego rozszerzenia uprawnień do nakładania i pobierania podatków przez samorządy i przez to zwiększenia ich samodzielności dochodowej. Wynikało to głównie z niskiej kultury podatkowej na indyjskiej wsi. Lokalna administracja podatkowa była jeszcze bardzo słabo zorganizowana, mało kompetentna i w dodatku wielce skorumpowana, a same samorządy bardzo często niewłaściwie gospodarowały pozyskanymi dochodami podatkowymi. Nie bez znaczenia są tu także wysokie - bezwzględnie i względnie (do dochodów) - koszty poboru podatków. Ponadto, zwiększenie wpływów podatkowych - jak wynika z raportów wielu Stanowych Komisji Finansowych - prowadziłoby niejednokrotnie do mniej efektywnego ich wykorzystania niż w sytuacji, gdy najważniejsze decyzje o wydatkowaniu podejmowane są na szczeblu stanowym, po ewentualnej konsultacji z władzami lokalnymi [Mathur, 2000, s. 369].

Drugim - po podatkach - źródłem zasilania finansowego samorządów lokalnych są niepodatkowe dochody własne. Dochody te mają marginalne znaczenie w budżetach wiejskich panczajatów, natomiast w przypadku samorządów miejskich odgrywają często istotną rolę. W skład tych dochodów wchodzą [Joshi, Narwani, 2002, s. 101-103]:

- opłaty lokalne i grzywny;

- dochody z działalności przedsiębiorstw lokalnego sektora publicznego;

- pożyczki i darowizny. 
Rodzaje, wysokość i wpływy z tytułu opłat lokalnych są bardzo zróżnicowane nie tylko pomiędzy stanami, ale także w obrębie stanów, szczególnie tych większych. Wyszczególnienie wszystkich opłat lokalnych na terenie Indii jest zadaniem wyjątkowo trudnym, tym bardziej, że opłaty te nieustannie się zmieniają. Z tych względów ograniczymy się tylko do wykazu najczęściej pobieranych opłat, występujących we wszystkich stanach. Opłatami tymi są:

- opłaty targowe;

- opłaty rejestracyjne (opłaty od rejestracji urodzin i zgonów, zawierania związków małżeńskich, opłaty od nabycia zwierząt, nowych budynków itp.);

- opłaty za zezwolenia (lokalne pozwolenia i koncesje itp.);

- inne opłaty wynikające ze specyfiki lokalnego życia gospodarczego i społecznego.

Do dochodów budżetów samorządowych z działalności lokalnych przedsiębiorstw publicznych zalicza się przede wszystkim dochody z tytułu sprzedaży przez te przedsiębiorstwa takich dóbr i usług publicznych, jak: woda, elektryczność, oczyszczanie miast i wsi, usług konserwacyjno-remontowych, wypożyczanie maszyn rolniczych, korzystanie z młynów, urządzeń irygacyjnych, usług rozrywkowych i turystycznych itp.

Innym niepodatkowym źródłem zasilania finansowego samorządów lokalnych są pożyczki i darowizny. Wyróżnia się pożyczki: krótkoterminowe - na pokrycie bieżącej płynności finansowej samorządów oraz pożyczki długoterminowe - na pokrycie potrzeb inwestycyjnych. Pożyczki te mogą być zaciągane u rządów stanowych lub - jeśli samorząd mieści się na terytorium unijnym - u rządu centralnego. Innym źródłem pożyczek są rynki finansowe. Jeżeli idzie o dochody $\mathrm{z}$ darowizn, to występują one sporadycznie i ich rola w kształtowaniu dochodów lokalnych jest znikoma.

W zdecydowanej większości indyjskich samorządów lokalnych dochody z podatków i opłat lokalnych nie są w stanie pokryć wydatków. Dlatego też muszą one korzystać z innych, zewnętrznych źródeł zasilania finansowego, którymi są najczęściej transfery $\mathrm{z}$ budżetów stanowych w postaci udziałów w podatkach stanowych lub dotacje.

Rodzaj i wielkość dochodów samorządów lokalnych z tytułu udziału w podatkach stanowych są bardzo zróżnicowane terytorialnie. We wszystkich stanach samorządy otrzymują udziały z dochodów podatkowych od pojazdów mechanicznych. W niektórych stanach podobnie dzielony jest podatek gruntowy, a także podatek od organizacji imprez rozrywkowych.

Zróżnicowane są także kryteria podziału podatków pomiędzy samorządy lokalne a administracje stanowe. Podział ten dokonuje się albo na bazie poboru podatków, czyli proporcjonalnie do ilości środków finansowych ściągniętych przez rządy stanowe na obszarze danego samorządu lokalnego, albo według specjalnie skonstruowanych, stanowych algorytmów, lub też stosowane są systemy mieszane. Dochody podatkowe stanów mogą być dzielone - w przypadku samorządów 
wiejskich - pomiędzy stan a poszczególne szczeble samorządów [Rao, Sarojini, 1998, s. 20]. W stanach Punjab i Kerala następuje podział określonych podatków tylko pomiędzy stanami a najniższym szczeblem samorządów wiejskich - gram panchayats, w stanach Andhra Pradesh i Tamil Nadu w podziale partycypują szczeble pośrednie (bloki), a w Biharze i Bengalu Zachodnim uczestniczą w tym rozdziale zarówno szczeble pośrednie, jak i dystryktowe. Są także stany, w których samorządy lokalne wszystkich szczebli są beneficjentami podziału niektórych dochodów podatkowych (Gujarat, Madhya Pradesh, Maharashtra, Rajasthan) [Mukherjee, 2001, s. 57-58]. Regulacje te są bardzo zróżnicowane w poszczególnych stanach i nieustannie się zmieniają.

Oprócz własnych podatków, udziałów w podatkach stanowych oraz własnych dochodów niepodatkowych, znaczącym źródłem dochodów indyjskich samorządów lokalnych są dotacje. Wyróżnia się dotacje ogólne oraz dotacje celowe [Bhatia, 1999, s. 613].

Dotacje ogólne mają zazwyczaj charakter wyrównawczy, służą równoważeniu lokalnych budżetów. Natomiast dotacje celowe są to środki stanowe przekazywane na finansowanie konkretnych zadań publicznych, własnych lub zleconych. Oba te rodzaje dotacji mogą występować w dwóch formach: względnej (procentowej) i kwotowej. W pierwszym przypadku rządy stanowe przekazują samorządom lokalnym pewną sumę środków, równą np. określonej w procentach części planowanego deficytu lub - w przypadku dotacji celowych - wartości realizowanego zadania publicznego. Dotacje kwotowe są natomiast ustalonymi w określonej wysokości strumieniami środków pieniężnych na pokrycie (zmniejszenie) deficytu budżetowego lub sfinansowanie określonych zadań. Dotacje, zarówno ogólne, jak i celowe, przyznawane są częściej samorządom biednym, o obiektywnie ograniczonych możliwościach pozyskiwania dochodów własnych. Rządy stanowe poprzez politykę dotacji chcą przyczynić się do zmniejszania dystansu gospodarczego między poszczególnymi jednostkami terytorialnymi.

W indyjskim systemie finansów stanowych i lokalnych dominują dotacje celowe, a więc przeznaczone na finansowanie konkretnych zadań publicznych na terytorium danej jednostki samorządowej. W niektórych stanach stanowią one nawet główne źródło zasilania samorządów wiejskich. Największym udziałem dotacji w dochodach legitymują się zazwyczaj samorządy dystryktowe, co wynika ze specyfiki ich zadań oraz niskich uprawnień do pozyskiwania własnych dochodów. Samorządy dystryktowe działają na dużych obszarach wiejskich, zamieszkałych przeważnie przez 1-2 mln osób. Wśród ich zadań publicznych przeważają z natury rzeczy - jak wyżej wspomniano - zadania zlecone o ponadlokalnej skali, wynikające najczęściej z realizacji centralnych lub stanowych planów rozwoju gospodarczo-społecznego. Zadania te są z natury rzeczy finansowane w decydującym stopniu ze środków centralnych i/lub stanowych, przekazywanych w postaci dotacji. 
Dotacje dla wiejskich samorządów pochodzą z reguły od rządów stanowych. W niektórych jednakże przypadkach ich źródłem może być rząd federalny. Ta ostatnia sytuacja ma zazwyczaj miejsce wówczas, gdy panczajaty podejmują się realizacji specjalnych zadań, organizowanych lub wspieranych przez rząd federalny. Mają one więc w większości przypadków charakter dotacji celowych. Samorządy wiejskie mogą także w szczególnych sytuacjach pozyskiwać dotacje od samorządów szczebla pośredniego (blokowego) oraz dystryktowego [Joshi, Narwani, 2002, s. 101].

Powyższa charakterystyka źródeł i sposobów pozyskiwania dochodów przez samorządy lokalne po reformie decentralizacyjnej lat 1992-1993 nie wyczerpuje oczywiście całości tego zagadnienia. Przedstawione regulacje stanowią jedynie konstrukcję szkieletową całego systemu dochodów lokalnego szczebla administracji publicznej w Indiach. Na jego sprawność funkcjonalną oraz efektywność ekonomiczną i społeczną silnie oddziałuje - jak już wskazywano - wiele czynników natury politycznej, religijnej, kulturowej, a nawet położenie geograficzne. Wszystkie one odgrywają w warunkach indyjskich wyjątkowo dużą rolę.

Analizując wdrażanie systemu demokratycznej samorządności w Indiach, szczególnie na obszarach wiejskich, daje się dostrzec, że jedną z największych bolączek gospodarki lokalnej jest znacznie wolniejsze tempo wzrostu dochodów samorządów w stosunku do tempa wzrostu ich zadań publicznych. Następuje swoiste rozwieranie się nożyc pomiędzy zadaniami publicznymi samorządów a ich możliwościami finansowymi. Jest ono - uogólniając - następstwem [Cauvery $\mathrm{i}$ in., 2000, s. 282]:

1. Wprowadzenia do konstytucji poprawek 73 i 74 i wynikającego z tego obowiązku przekształcania istniejących jednostek terytorialnych w samorządy lokalne i tym samym znacznego - regulowanego konstytucyjnie - rozszerzenia zakresu ich działalności.

2. Dużego przyrostu populacji, szybkiego tempa rozwoju gospodarczego kraju i wynikających z tego wzrostu potrzeb oraz poziomu życia znacznej części indyjskiego społeczeństwa, co przekłada się także na zwiększenie oczekiwań lokalnych społeczności względem samorządów terytorialnych.

Prowadzone przez indyjskich ekonomistów analizy pierwszych lat decentralizacji wskazują, że jedną z najważniejszych barier pozyskiwania dochodów przez samorządy lokalne jest niska wydajność własnych źródeł dochodów, szczególnie na terenach wiejskich. Przede wszystkim niewystarczające są sumy pobieranych podatków, co wynika - generalnie - z dużej biedy i zacofania gospodarczego na znacznych obszarach Indii, niskiej kultury podatkowej i oczywiście wielu patologii społecznych, z korupcją na czele.

Dużą przeszkodą w poprawie lokalnej gospodarki finansowej jest niska sprawność władz samorządowych w zakresie pozyskiwania podatków. Dotyczy to w szczególności podatków od własności - najbardziej wydajnego źródła dochodów lokalnych w niektórych stanach. Wysokość wpływów budżetowych 
z tego tytułu nie zwiększa się jednak adekwatnie do wzrostu liczby i wartości przedmiotów opodatkowania. Odnosi się to głównie do tych obszarów, na których w ciągu dwóch dekad funkcjonowania nowego ustroju lokalnego, dokonał się znaczący postęp gospodarczy, wzrósł dobrobyt materialny dużej części społeczeństwa, podniósł się poziom edukacji itp. Wraz z tym nie zwiększały się jednak odpowiednio wpływy podatkowe samorządów lokalnych.

Ważnym, ale zazwyczaj wielce spornym, jest problem uniformizacji systemu dochodów samorządów lokalnych na terenie całego kraju. Istniejący system dochodów lokalnych jest bardzo zróżnicowany w poszczególnych stanach. Takie rozwiązanie ma oczywiście duże zalety, ale ma też wady. Podstawową wadą jest utrudnienie prowadzenia jednolitej, spójnej polityki fiskalnej na obszarze całego kraju, co przyczynia się do obniżenia globalnej efektywności gospodarki publicznej. Ogromna różnorodność źródeł i sposobów pozyskiwania dochodów w poszczególnych stanach komplikuje - a niekiedy wręcz uniemożliwia - analizy finansowe, a w ślad za tym kontrolę i nadzór nad lokalnymi finansami publicznymi. Zróżnicowane systemy podatkowe w stanach oddziałują ponadto na zachowania niektórych podatników, szczególnie przedsiębiorstw oraz zamożniejszych osób fizycznych, przyczyniając się m.in. do tzw. głosowania nogami, tj. migracji do obszarów o korzystniejszych systemach podatkowych, lepszej infrastrukturze lokalnej itp. Zjawiska te nasiliły się po 2000 roku w wyniku znacznego przyspieszenia rozwoju gospodarczego w niektórych stanach, napływu kapitału zagranicznego, powstawania specjalnych stref ekonomicznych i wzrostu liczebnego klasy średniej - sprawy te są szerzej przedstawione w następnych rozdziałach.

\subsection{Funkcjonowanie samorządności lokalnej po 1993 roku}

W pierwszych latach po uchwaleniu poprawek do konstytucji 73 i 74 oraz ustanowieniu samorządów lokalnych, główną przeszkodą implementacji nowego ustawodawstwa były zachowawcze postawy rządów stanowych. Wynikający z litery i ducha obu poprawek konstytucyjnych obowiązek przekazywania przez władze stanów kompetencji i środków finansowych do samorządów niższych szczebli realizowany był bardzo wolno i z wielkimi oporami. Podstawowa zasada pionowego podziału władzy publicznej, która przyświecała całej reformie decentralizacyjnej, czyli zasada subsydiarności, nie była w pełni przestrzegana [Rürup, 1999, s. 77]. Ponadto samorządy lokalne uskarżały się na nadmierną, często samowolną ingerencję stanowych organów władzy w ich plany, decyzje oraz przede wszystkim - budżety. Sprzyjały temu wspomniane wcześniej trudności z pozyskiwaniem własnych dochodów, wskutek czego działalność gospodarcza wielu samorządów lokalnych opierała się w przeważającej mierze na pomocy rządów stanowych. Miało to miejsce przede wszystkim w odniesieniu do wielu 
samorządów wiejskich w biednych oraz małych stanach, w których zdecydowana większość dochodów pochodzi od rządów stanowych. W przypadku samorządów miejskich stopień uzależnienia od stanów jest na ogół mniejszy, głównie dlatego, że dysponują one większymi dochodami własnymi.

Wysokie wsparcie finansowe ze strony stanów jest oczywiście w większości przypadków konieczne, ale sprawa ma też drugą stronę. Duża ilość środków pieniężnych przekazywana bezpośrednio ze stanów działa demobilizująco na władze lokalne, gdyż nie podejmują one działań w celu zwiększenia dochodów własnych, a w ślad z tym nie rozszerza się zakresu realizowanych zadań publicznych. Ma to również wpływ na stosunki społeczne i polityczne zarówno na poziomie stanowym, jak i lokalnym. Działalność lokalnych polityków i urzędników koncentruje się w takich sytuacjach na zabiegach o pozyskiwanie względów polityków stanowych. Ci ostatni zaś wykorzystują istniejące możliwości do poszerzania własnych wpływów politycznych, czyli rozbudowy swojej bazy wyborczej, a to m.in. rodzi klientelizm i sprzyja wzrostowi korupcji.

Racjonalizację samorządności lokalnej utrudnia bardzo skomplikowany i niejednorodny podział administracyjny kraju. Szczególnie uciążliwa jest niejednorodność, to znaczy występowanie obok stanów dużych obszarowo i zamieszkałych przez kilkadziesiąt milionów ludzi (a nawet ponad $200 \mathrm{mln}$ jak w Uttar Pradesh), stanów małych o liczbie ludności nieprzekraczającej $3 \mathrm{mln}$. Do tego dochodzą jeszcze inne podziały, jak np. według wyodrębnionych obszarów i plemion. Podobnie niejednorodna jest struktura obszarowa i ludnościowa samorządów na szczeblach lokalnych. W związku z tym coraz częściej postuluje się reorganizację struktury państwa w celu jego racjonalizacji przestrzenno-gospodarczej [Joshi, Narwani, 2002, s. 116]. Przeprowadzenie takich zmian jest jednak bardzo trudne z uwagi na ogromne zróżnicowanie etniczne i kulturowe indyjskiego społeczeństwa. Dowodzi tego zresztą historia zmian struktury administracyjnej państwa w pierwszych dekadach po odzyskaniu niepodległości.

Jak wcześniej stwierdzono, niezwykle ważną rolę w praktyce funkcjonowania indyjskich samorządów lokalnych odgrywają czynniki społeczno-polityczne. Bardzo często stanowi oraz lokalni politycy nie są zainteresowani rozwojem samorządności. Powszechne, demokratyczne wybory członków władz lokalnych oraz demokratyczna ich kontrola determinują zachowania polityków. Podejmują oni chętnie te decyzje, które przynoszą im łatwe profity, a unikają takich, które - choć racjonalne - mogą być politycznie nieopłacalne, to znaczy prowadzić do zmniejszenia ich władzy i znaczenia politycznego lub też całkowitej eliminacji z życia publicznego. Przykładowo, znani przecież lokalnym społecznościom politycy - obawiając się o reelekcję - rzadko kiedy decydują się na wprowadzenie nowych podatków czy podniesienie stawek podatków już istniejących. Niechęć władz stanowych i lokalnych do wprowadzania zmian, i tym samym utrzymanie status quo, spowodowana jest także bardzo wysokim stopniem korupcji wśród lokalnych i stanowych polityków oraz urzędników. Wyjątkowo dużym polem ko- 
rupcji są właśnie lokalne systemy finansowe, w tym szczególnie funkcjonowanie instytucji poboru podatków i innych świadczeń na wspólne cele, a także rozdział pomocy socjalnej. Jest to najbardziej widoczne na indyjskiej wsi i stanowi jedną z ważniejszych przyczyn niskich dochodów własnych wiejskich samorządów $\mathrm{i}$ to w regionach o względnie dobrze rozwiniętym, a więc także dochodowym, rolnictwie czy rzemiośle. Duża jest również skala nieformalnych powiązań przy podejmowaniu decyzji o lokalnych inwestycjach infrastrukturalnych.

Niezwykle ważnym elementem reform samorządu terytorialnego jest konstytucyjny obowiązek wprowadzenia do rad lokalnych kobiet i to w znacznej liczbie, bo wynoszącej minimum $1 / 3$ ich składu.

W latach 1995-1996 odbyły się stanach - poza Biharem - pierwsze wybory do rad wszystkich trzech szczebli samorządu lokalnego. Wybrano w nich ok. $3 \mathrm{mln}$ radnych, z tego ok. 1 mln stanowiły kobiety. Wyjście tak dużej liczby kobiet na forum publiczne, czyli poza obręb swojej rodziny i domostwa, ma ogromne konsekwencje nie tylko dla samego funkcjonowania władz lokalnych, szczególnie na wsi, ale istotnie oddziałuje na całokształt życia społecznego. Czynne, a zwłaszcza bierne prawo wyborcze kobiet oznacza podniesienie ich świadomości politycznej oraz poziomu edukacji, a w ślad za tym - reorientację w systemach wartości. To zaś pociąga za sobą zmiany w preferencjach politycznych, a więc także w zachowaniach wyborczych i to na wszystkich poziomach organizacji politycznej państwa. Dekompozycji ulega cały, dotychczas zmaskulinizowany krajobraz polityczny Indii. Przyspiesza się tym samym obumieranie starego, niedemokratycznego i przesadnie zhierarchizowanego systemu wartości oraz wynikających z niego podziału ról i zachowań ludzi. Nadanie praw i aktywizację publiczną setek milionów kobiet w Indiach w wyniku reform decentralizacyjnych uznaje się niekiedy za największy eksperyment społeczny naszych czasów. Jest on zwiastunem i zarazem kluczem do lepszej przyszłości mieszkańców indyjskiego subkontynentu, a także wzorcem do naśladowania w innych regionach Azji.

Jednym z najbardziej kłopotliwych problemów pierwszych lat realizacji reformy decentralizacyjnej było przezwyciężenie oporu kobiet (ich wstydu, poczucia niekompetencji itp.) przed podjęciem się publicznej aktywności na forum samorządowym. Ponadto mniej wykształcone kobiety, bez doświadczeń w działalności publicznej, były niejednokrotnie manipulowane przez mężczyzn - zarówno członków swoich rodzin, jak i członków rad samorządowych oraz partie polityczne - $\mathrm{i}$ traktowane jako przysłowiowe „maszynki do głosowania”. W związku z tym pojawiła się potrzeba organizowania całego systemu edukacji i doradztwa dla kobiet podejmujących działalność publiczną [Rürup, 1999, s. 75-76].

Jakkolwiek emancypacja i aktywizacja polityczna kobiet jest - jak wskazuje praktyka - procesem bardzo wolnym i ma różną dynamikę w poszczególnych stanach czy grupach etnicznych, to jednak odnotowuje się postęp, co wcześniej czy później zaowocuje wielką zmianą kulturową w Indiach. W ślad za tym nastąpią istotne przeobrażenia $\mathrm{w}$ materialnych warunkach bytu, $\mathrm{w}$ tym przede wszystkim 
przyspieszone wychodzenie ze sfery ubóstwa i wykluczenia materialnego oraz społecznego. Dowodem na to mogą być doświadczenia demokratycznych panczajatów w stanach o niskim poziomie analfabetyzmu kobiet (np. Karnataka, Kerala). Odsetek kobiet w radach samorządowych tych stanów już w latach 90. przekraczał $1 / 3$ i co więcej - kobiety stawały się bardzo aktywnymi działaczkami samorządowymi, istotnie przyczyniającymi się do korzystnych zmian w życiu swoich lokalnych społeczności [Rürup, 1999, s. 80-81]. W 2008 roku w wyborach do rad wiejskich (gram panchayats) na ogólną liczbę 2645883 radnych, 975057 stanowiły kobiety (36,9 proc.), w samorządach szczebla pośredniego (blocks, talucas) spośród 156794 wybranych było 58191 kobiet (37,1 proc.), natomiast na trzecim szczeblu samorządu lokalnego - dystryktowym (zilla parishads) wśród 15613 radnych, kobietami było 5810 (37,2 proc.) [India Country Report 2013, 2013, s. 55].

Podobne, pozytywne efekty na polu demokratyzacji i równouprawnienia ludzi wnoszą do indyjskiego systemu politycznego i społecznego te fragmenty poprawek 73 i 74, które dotyczą z reguły mało liczebnych plemion tubylczych oraz niedotykalnych (dalitów). Te grupy społeczne pozostawały wcześniej - pomimo konstytucyjnych zapisów - poza nawiasem oficjalnego życia politycznego.

Poważnym i trudnym do jednoznacznej regulacji problemem są relacje pomiędzy parlamentami stanowymi a trzystopniowymi radami samorządowymi. Szczególnie kontrowersyjna jest rola partii politycznych, które są często „pasem transmisyjnym" pomiędzy legislatywami poszczególnych szczebli. Ma to zalety, ale także nie jest wolne od wad. Do tych ostatnich należy przede wszystkim widmo nadmiernej polityzacji życia lokalnego, podporządkowania go partiom politycznym, poszczególnym politykom, a nie interesom mieszkańców danego terytorium. Dlatego też nieustannie podnoszone są głosy odpolitycznienia demokracji lokalnej. Nie ma jednak konkretnych pomysłów na realizację tego zadania. Jeśliby się odsunęło partie polityczne, to rodzi się pytanie, czym winny być one zastąpione? Musiałyby się tworzyć jakieś inne, lokalne instytucje obywatelskie, co jest jednak bardzo trudne, szczególnie na obszarach mocno zróżnicowanych etnicznie, religijnie oraz ekonomicznie. Ponadto jest wielce prawdopodobne, że te nowe instytucje obywatelskie też mogłyby się w niedługim czasie upolitycznić oraz ulec różnego rodzaju patologizacji, a szczególnie korupcji i nepotyzmowi, co jest - jak już wielokrotnie wspominano - tak częste i charakterystyczne dla życia społecznego Indii, zwłaszcza na szczeblach lokalnych.

Czynnikami utrudniającymi codzienne funkcjonowanie wiejskich panczajatów są nie tylko sprawy personalne, a więc zaangażowanie i kompetencje lokalnych polityków i urzędników. W latach 90. na wielu obszarach, szczególnie tych biedniejszych, praktyczną, codzienną przeszkodą w działalności wiejskich samorządów była niedostateczna baza materialna, to znaczy niedobór lub całkowity brak publicznych pomieszczeń i ich odpowiedniego wyposażenia dla pracy służb samorządowych. Zebrania rad wiejskich odbywały się niejednokrotnie pod gołym 
niebem, w cieniu drzewa. Ogromnym utrudnieniem była zła łączność między siedzibami wiejskiej administracji a jednostkami wyższych szczebli czy też innymi instytucjami życia publicznego. Chodzi przede wszystkim o niedostateczne wyposażenie w sieć komputerową, brak Internetu itp. Pod koniec lat 90. tylko niespełna 20 proc. wiejskich samorządów dysponowało komputerami i miało dostęp do Internetu, co nie oznacza jeszcze, że efektywnie z tych urządzeń korzystano. Sytuacja istotnie poprawia się w po 2000 roku, a jest to m.in. efektem rozwoju indyjskiego przemysłu i usług informatycznych. Nadal jednak system łączności i komunikowania się na poziomie lokalnych instytucji trudno uznać za satysfakcjonujący, a dotyczy to w szczególności zaniedbanych gospodarczo regionów Indii środkowych i całej niemal północno-wschodniej części kraju.

Doświadczenia pierwszych lat funkcjonowania lokalnej samorząaności wskazują, że w większości stanów relacje pomiędzy władzami stanowymi (parlamentami i rządami stanowymi) a ich lokalnymi odpowiednikami (radami i zarządami jednostek lokalnych) nie kształtują się dobrze. Często mamy do czynienia z otwartymi konfliktami wynikającymi głównie z odmienności interesów, wzajemnego nierozumienia się itp. Trudności te są szczególnie odczuwalne w tych stanach, gdzie występuje trójszczeblowa struktura samorządu lokalnego.

Pomimo dwóch dekad reformowania ustroju lokalnego, nie wykształciły się jeszcze trwałe i efektywne instytucje powiązań poziomych samorządów, które mogłyby stanowić forum ich współpracy oraz być silnym partnerem dla stanów oraz rządu federalnego. Jakkolwiek od 1958 roku istnieje po temu odpowiednia instytucja, tj. All India Panchayat Parishad, mająca koordynować działalność samorządów wiejskich, to jednak efekty jej pracy są mizerne. O pewnym ożywieniu w tej dziedzinie możemy mówić dopiero po 2000 roku.

Zasada subsydiarności, która tkwi u źródeł decentralizacji również nie jest w pełni przestrzegana. Samorządom lokalnym dość często nie są przekazywane ani kompetencje, ani środki finansowe, albo też tylko kompetencje, ale bez dostatecznych środków. A jeśli nawet takie delegowanie ma formalnie miejsce, to niejednokrotnie fakt ten pozostaje na papierze; szczególnie dotyczy to programów socjalnych i zatrudnieniowych. Powołane mocą poprawki 73 stanowe komisje finansowe mające regulować gospodarkę finansową samorządów działają niezwykle opieszale i do końca lat 90 . tylko niektóre z nich przygotowały programy lokalnej polityki finansowej [Rürup, 1999, s. 76-77].

Poprawki do konstytucji nr 73 i 74 z 1992 roku ustanowiły ogólne zasady procesu decentralizacji oraz konstrukcję docelowego modelu indyjskiego ustroju lokalnego. Konkretny, praktyczny kształt samorządności lokalnej nadają jednak władze stanów ${ }^{28}$. Tu właśnie tkwi poważny problem oraz niepewność, czy

${ }^{28}$ Wielu badaczy indyjskiego ustroju lokalnego uznaje, że najwłaściwszym postępowaniem badawczym winny być analizy ustroju lokalnego prowadzone odrębnie dla poszczególnych stanów. 
będą one skutecznie i wytrwałe wdrażać paragrafy wspomnianych poprawek. Doświadczenia $\mathrm{z}$ opisanych wcześniej pierwszych prób decentralizacji w latach 50. i 70. wskazują, że nie są to obawy bezpodstawne. Politycy stanowi nie są zwolennikami głębokiej decentralizacji, bowiem ta oznacza ograniczenie ich władzy i wynikających z tego tytułu przywilejów oraz gratyfikacji. Aby ograniczyć takie zachowania, potrzebne jest również - oprócz silnej presji odgórnej (rządowej) - wytworzenie na szczeblu stanowym i lokalnym silnego, oddolnego lobby prodecentralizacyjnego, w skład którego wchodziłyby oczywiście organizowane poziomo samorządy lokalne, organizacje cywilne i różne ruchy społeczne, media itp. Tego typu postawy i zachowania społeczne zaczynają się z wielkim trudem rodzić, ale jest to proces powolny i wymagający długiego czasu, a więc wymiany pokoleń.

Po ponownym przejęciu władzy przez Indyjski Kongres Narodowy w 2004 roku władze federalne, widząc - pomimo początkowych, często spektakularnych sukcesów - mierne wyniki pierwszej dekady wdrażania lokalnej samorządności, zdecydowały się m.in. na utworzenie w 2004 roku Ministerstwa Samorządu Wiejskiego (Ministry of Panchayati Raj). Zadaniem tego ministerstwa jest - najogólniej ujmując - monitorowanie oraz przede wszystkim przyspieszenie realizacji 73 poprawki do konstytucji Indii z 1992 roku. Do najważniejszych zadań ministerstwa należy m.in. koordynowanie prac całego systemu organizacji samorządu wiejskiego, tj. terminowości wyborów, ich prawidłowego przebiegu, właściwej organizacji i funkcjonowania urzędów lokalnych itp. Ministerstwo ściśle nadzoruje działalność stanowych komisji finansowych oraz dystryktowych komitetów planowania. Chodzi w szczególności o to, aby stany przekazywały terminowo i w odpowiedniej ilości środki finansowe do samorządów lokalnych i by były one wydawane zgodnie z przyjętymi celami oraz nie dochodziło tu do patologii, a głównie korupcji. Duża waga przywiązywana jest także do edukacji wiejskich samorządowców, ich permanentnego dokształcania. Wiele miejsca zajmuje też popularyzacja idei samorządności, która, pomimo upływu lat, nie dotarła jeszcze do świadomości wielu mieszkańców indyjskiego subkontynentu. 


\section{ROZDZIAL V}

\section{ROZWÓJ GOSPODARCZY PO 1991 ROKU EFEKTY MAKROEKONOMICZNE}

Podstawowymi kategoriami makroekonomii są: wzrost gospodarczy oraz rozwój gospodarczy. W sensie semantycznym są to terminy bliskoznaczne, ale w ujęciu merytorycznym tak nie jest. Wzrost gospodarczy definiowany jest zazwyczaj jako proces tworzenia i powiększania się podstawowych wielkości w gospodarce, tj. ilości produkowanych w danym okresie dóbr materialnych i usług. Sformułowanie to nie wyjaśnia jednak innych, bardzo ważnych cech procesów gospodarczych, takich szczególnie, jak zmiany w strukturze i jakości produkcji badanego podmiotu (kraju, regionu, świata). Tym drugim pojęciem, zawierającym w sobie zarówno aspekty ilościowe, jak i strukturalno-jakościowe zmian gospodarczych, jest rozwój gospodarczy ${ }^{1}$. Wzrost gospodarczy jest elementem - aczkolwiek najważniejszym - rozwoju gospodarczego. W takim to właśnie rozumieniu rozwoju gospodarczego, będzie on - w odniesieniu do Indii - przedmiotem analizy w dalszej części pracy.

Rozwoju gospodarczego nie da się mierzyć bezpośrednio, to znaczy przy pomocy jednego wskaźnika. Wyraża się go zazwyczaj w sposób pośredni, złożony, tzn. poprzez analizę wzrostu gospodarczego, czyli tempa zmian produktu krajowego brutto lub netto (PKB/PKN) oraz przekształceń w strukturze jego wytwarzania według sektorów gospodarki lub w ujęciu przestrzennym. Taką też metodę przyjęto $\mathrm{w}$ poniższej analizie ${ }^{2}$.

\subsection{Dynamika wzrostu gospodarczego}

Wielkości wskaźników dynamiki wzrostu PKB/PKN Indii w latach 1991/922011/12, a więc po reformach liberalizujących gospodarkę i decentralizujących państwo, zestawiono w tab. 5.13.

${ }^{1}$ Tak właśnie obie te kategorie - wzrost oraz rozwój gospodarczy - wyjaśniane są w podręcznikach ekonomii [por. m.in.: Kwiatkowski, 2005, s. 280; Klamut, 2006, s. 195].

${ }^{2}$ Por. wyjaśnienia na temat stosowania w indyjskiej statystyce gospodarczej wskaźników wzrostu produktu krajowego brutto (PKB) oraz produktu krajowego netto (PKN) zawarte w podrozdziale 2.4 (przyp. 33).

${ }^{3} \mathrm{~W}$ tab. 5.1 i wszystkich następnych, jak również w tekście, zastosowano zasadę, że w przypadku istnienia różnych danych statystycznych dla tych samych lat, dla obliczeń przyjmowano 
Analizując tab. 5.1 nietrudno dostrzec, że w porównaniu z dynamiką wzrostu w poprzednich dekadach (por. rozdział II) po 1991 roku nastąpiło znaczące przyspieszenie wzrostu gospodarczego Indii. Głębokie załamanie w 1991 roku zostało względnie szybko przezwyciężone, bo już w roku gospodarczym 1992/93 odnotowano przyrost PKB o ponad 5 proc. Nie było to jednak jeszcze efektem „nowej polityki ekonomicznej", którą zaczęto wdrażać w 1992 roku, lecz rezultatem nadzwyczajnych działań, a głównie zagranicznej pomocy kredytowej. Rok gospodarczy 1992/93 to w istocie czas pośpiesznego porządkowania indyjskiej gospodarki i przestawiania jej na nowe tory.

Pierwsze rzeczywiste, makroekonomiczne efekty reform liberalizujących gospodarkę i decentralizujących państwo indyjskie pojawiają się dopiero w 1993/94 roku, dlatego ten właśnie rok przyjmuje się najczęściej jako początkową, wyjściową datę „nowej ery” w historii gospodarczej niepodległych Indii i do niej będzie odnoszona większość wskaźników w tym i następnym rozdziale.

W badanym okresie indyjskiej transformacji ustrojowej można wyróżnić trzy fazy rozwoju gospodarczego ${ }^{4}$ :

1. Lata 1993/94-1996/97.

2. Lata $1997 / 98-2002 / 03$.

3. Lata 2003/04-2011/12.

Sekwencja faz gospodarczych jest zbliżona do cyklu przemian politycznych i nie jest to bynajmniej podobieństwo przypadkowe. Oba te procesy, tj. cykl gospodarczy oraz polityczny, są wzajemnie przez siebie - $\mathrm{i}$ to bardzo mocno - determinowane, co już było widoczne w poprzednich dekadach.

Fazę pierwszą, czyli okres bezpośrednio po podjęciu reform (1993/941996/97) cechuje wysoki i progresywny wzrost PKB - od 5,7 do 8,0 proc. rocznie, co - po dekadach niskiego tempa wzrostu - określa się czasem ,indyjskim cudem gospodarczym" [Wolpert, 2010, s. 528]. Reformy są wdrażane z dużą, niespotykaną dotąd determinacją.

Jednakże - jak wyjaśniono w rozdziale III - w wyniku wyborów parlamentarnych w 1996 roku zupełnie zmieniła się scena polityczna Indii. Druzgocącą porażkę poniósł reformujący gospodarkę i państwo Indyjski Kongres Narodowy, a do władzy doszły partie prawicowe z Indyjską Partią Ludową na czele, które sprawowały ją aż do wyborów na wiosnę 2004 roku.

wielkości pochodzące z nowszych wydań podawanych źródeł. Należy stwierdzić, że sytuacje takie są w praktyce statystyki indyjskiej dość częste, co wynika z wielkości gospodarki i długiego okresu spływu informacji oraz ich agregacji w centralnych instytucjach statystyki gospodarczej. Niejednokrotnie najpierw instytucje te podają wstępne, szacunkowe dane, a później - w kolejnych edycjach źródeł - publikowane są dane ostateczne, które - chociaż zazwyczaj nieznacznie - różnią się od siebie.

${ }^{4} \mathrm{~W}$ rozdziale V i VI - podobnie jak w rozdziale II - stosujemy konsekwentnie zapis lat gospodarczych z ukośnikiem, np. 1992/93 (por. uwagi we Wstępie). 
Tabela 5.1. Wzrost gospodarczy Indii - przyrosty produktu krajowego brutto/netto (PKB/PKN)

\begin{tabular}{|c|c|c|c|c|c|c|}
\hline \multirow[b]{2}{*}{ Lata } & \multicolumn{2}{|c|}{ Wzrost PKB* } & \multicolumn{2}{|c|}{ Wzrost PKN } & \multicolumn{2}{|c|}{$\begin{array}{c}\text { Wzrost PKN } \\
\text { per capita }\end{array}$} \\
\hline & $\begin{array}{c}\text { Rok } \\
\text { poprzedni } \\
=100,0\end{array}$ & $\begin{array}{c}\text { Rok } \\
1993 / 94 \\
=100,0\end{array}$ & $\begin{array}{c}\text { Rok } \\
\text { poprzedni } \\
=100,0\end{array}$ & $\begin{array}{c}\text { Rok } \\
1993 / 94 \\
=100,0\end{array}$ & $\begin{array}{c}\text { Rok } \\
\text { poprzedni } \\
=100,0\end{array}$ & $\begin{array}{c}\text { Rok } \\
1993 / 94 \\
=100,0\end{array}$ \\
\hline 1991/92 & 1,4 & 93,6 & 0,8 & 94,1 & $-1,2$ & 97,9 \\
\hline $1992 / 93$ & 5,4 & 94,9 & 5,4 & 94,9 & 3,4 & 96,7 \\
\hline $1993 / 94$ & 5,7 & 100,0 & 6,1 & 100,0 & 3,7 & 100,0 \\
\hline $1994 / 95$ & 6,4 & 106,4 & 6,4 & 106,4 & 4,3 & 104,3 \\
\hline $1995 / 96$ & 7,3 & 114,2 & 7,4 & 114,3 & 5,3 & 109,8 \\
\hline 1996/97 & 8,0 & 123,3 & 8,3 & 123,8 & 6,2 & 116,6 \\
\hline $1997 / 98$ & 4,3 & 128,6 & 4,1 & 128,9 & 2,2 & 119,2 \\
\hline 1998/99 & 6,7 & 137,2 & 6,7 & 137,6 & 4,6 & 124,7 \\
\hline $1999 / 00$ & 7,6 & 147,6 & 7,5 & 147,9 & 5,6 & 131,7 \\
\hline $2000 / 01$ & 4,3 & 153,9 & 3,7 & 153,4 & 1,8 & 134,1 \\
\hline $2001 / 02$ & 5.5 & 162,4 & 5,6 & 162,0 & 3,5 & 138,8 \\
\hline $2002 / 03$ & 4,0 & 168,9 & 4,0 & 168,5 & 2,4 & 142,1 \\
\hline $2003 / 04$ & 8,1 & 182,6 & 8,0 & 182,0 & 6,6 & 151,5 \\
\hline $2004 / 05$ & 7,0 & 195,4 & 7,0 & 194,7 & 4,9 & 158,9 \\
\hline $2005 / 06$ & 9,5 & 214,0 & 9,5 & 213,2 & 7,8 & 171,3 \\
\hline $2006 / 07$ & 9,6 & 234,9 & 9,5 & 233,5 & 7,9 & 184,8 \\
\hline $2007 / 08$ & 9,3 & 256,7 & 9,7 & 256,1 & 8,1 & 199,8 \\
\hline 2008/09 & 6,7 & 273,9 & 6,5 & 272,7 & 4,7 & 209,2 \\
\hline $2009 / 10$ & 8,6 & 297,5 & 8,6 & 296,2 & 6,8 & 223,4 \\
\hline 2010/11 & 8,9 & 324,0 & 8,4 & 321,1 & 6,8 & 238,6 \\
\hline $2011 / 12$ & 6,7 & 345,7 & 6,9 & 343,3 & 5,1 & 250,8 \\
\hline
\end{tabular}

* według cen czynników produkcji, w proc., ceny stałe z 2004/05 roku.

Źródło: opracowanie i część obliczeń własnych na podstawie: [Economic Survey 2012-13. Statistical Appendix, 2013, s. A-4, A-7], [Economic Survey 2013-14. Statistical Appendix, 2014, s. 3, 7].

Druga faza rozwoju gospodarczego, czyli okres rządów koalicji prawicowych pod dominacją Indyjskiej Partii Ludowej (1996-2004), cechuje się zwolnieniem procesów reformatorskich, co w skali makro wyraziło się znaczącym osłabieniem tempa wzrostu gospodarczego; spadło ono z przeciętnego poziomu bliskiego 7 proc. w latach 1993/94-1996/97 do około 5 proc. w latach 1997/98 2002/03. Gwoli ścisłości - oprócz czynnika politycznego - nie bez wpływu na spadek impetu rozwojowego indyjskiej gospodarki miały uwarunkowania zewnętrzne, a szczególnie głęboki kryzys gospodarczy w latach 1997-1998, który 
dotknął bliskie Indiom kraje Azji Południowo-Wschodniej, a także amerykańskie sankcje ekonomiczne w odpowiedzi na indyjskie próby z bombą atomową [Rothermund, 2008, s. 110]. Natomiast na drugie załamanie wysokiego wzrostu (2000/01-2002/03) istotnie wpłynęły wyjątkowo niekorzystne warunki pogodowe - susze na przemian z powodziami. W styczniu 2001 roku w Gujaracie nastąpiło trzęsienie ziemi o bardzo dużej sile, wskutek którego zginęło około 20 tys. ludzi i zniszczone zostały setki tysięcy domów i mieszkań. Wspomnieć trzeba jeszcze o wyjątkowo krwawym konflikcie religijnym muzułmańsko-hinduskim w Gujaracie w 2002 roku. W wyniku pogromu muzułmanów życie straciło wówczas ponad 2 tys. osób, a około 100 tys. ludzi musiało - ze strachu przed hindusami - opuścić swoje domy i przenieść się do obozowisk poza miastami [Wolpert, 2010, s. 552-554] $]^{5}$. Pewną rolę w osłabieniu dynamiki rozwojowej odegrało także podniesienie w 1999 roku podatków bezpośrednich oraz pośrednich. Negatywnie na indyjskiej gospodarce odbiła się też sytuacja w Zatoce Perskiej i na Bliskim Wschodzie po zamachu na nowojorskie wieże we wrześniu 2001 roku, a konkretniej tzw. II wojna iracka i wkroczenie wojsk NATO do Afganistanu, co wpłynęło, podobnie jak na początku lat 90., na wzrost cen ropy naftowej oraz zmniejszyło transfery pieniężne od Indusów pracujących w tych regionach. Obniżyły się także obroty handlowe z regionem Bliskiego Wschodu. Skumulowanym efektem tych niemal równoczesnych i niesprzyjających wydarzeń był m.in. nieznaczny tylko (o 2,7 proc.) wzrost produkcji przemysłowej w 2001/02 roku oraz spadek (o około 5 proc.) produkcji rolnej w roku następnym (por. tab. 5.4).

Wybory parlamentarne na wiosnę 2004 roku przynoszą niespodziewaną przebudowę indyjskiej sceny politycznej. Wygrywa je Indyjski Kongres Narodowy - po 8 latach przebywania w opozycji. Na czele rządu federalnego staje „ojciec indyjskich reform", czyli były minister finansów w rządzie N. Rao - Manmohan Singh. Sytuacja powtórzyła się w 2009 roku, z nadania Indyjskiego Kongresu Narodowego w dalszym ciągu u steru rządu pozostał M. Singh.

Trzecia, najbardziej dynamiczna faza rozwoju indyjskiej gospodarki przypada na okres rządu M. Singha, a więc zaczyna się w 2004 roku. Przeciętne tempo wzrostu PKB w latach 2003/04-2009/10 wynosi niemal 9 proc. i Indie są drugim po Chinach najszybciej rozwijającym się dużym krajem świata. Bardzo wysoka

${ }^{5}$ Również niekorzystne zjawiska geograficzno-klimatyczne wpłynęły na zmniejszenie przyrostu PKB w roku 2004/05 (szczególnie w produkcji rolnej - por. tab. 5.4). Chodzi tu o skutki wielkiego tsunami w 2004 roku, które zniszczyło część wybrzeża południowo-wschodniego (bengalskiego), a także następstwa wyjątkowo silnego trzęsienia ziemi w 2005 roku w Kaszmirze (na pograniczu pakistańsko-indyjskim), w wyniku którego śmierć poniosło około 90 tys. ludzi (głównie jednak po stronie pakistańskiej). Natomiast stan Maharashtra (szczególnie Bombaj) został nawiedzony - również w 2005 roku - jedną z największych w historii tego regionu powodzią, w wyniku której m.in. śmierć poniosło około 1 tys. osób, a dobytek kilku milionów gospodarstw domowych doznał uszczerbku. 
i w dodatku rosnąca jest stopa inwestycji - w latach 2004-2007 wzrosła z 31,2 do 37,6 proc. PKB, a w okresie 2008-2012 kształtowała się na poziomie 35-37 proc. PKB. Ceną za to przyspieszenie inwestycji i wzrostu PKB jest jednak wysoka inflacja, która zwiększyła się z 4 proc. w 2004 roku do niemal 12 proc. w 2012 roku [Bombińska, 2014, s. 43-44].

Pod koniec pierwszej dekady bieżącego wieku - jak i na początku drugiej - następuje jednak osłabienie tempa indyjskiej gospodarki (do 6-8 proc.), co przypisać trzeba przede wszystkim kryzysowi gospodarczemu w USA i Europie, który pośrednio - poprzez szybko rosnące powiązania handlowe i inwestycyjne z zagranicą - dotknął także Indie. Nie bez znaczenia był tu również duży spadek tempa wzrostu produkcji rolnej w latach 2008/09-2009/10 w wyniku bardzo niekorzystnych warunków pogodowych (por. tab. 5.4). Do tych przyczyn dołożyła się też utrata zaufania zagranicznych inwestorów i znaczące zmniejszenie ich nakładów po 2008 roku, co widać w tab. 5.7. Inwestorzy ci - analizując programy nowej koalicji rządowej po wyborach w 2004 roku - spodziewali się wysokiej koniunktury w indyjskiej gospodarce oraz dalszych korzyści podatkowych i na skutek tego zwiększali inwestycje, ale sytuacja odmieniła się na początku 2008 roku, głównie na skutek światowego kryzysu gospodarczego. Wobec nagłego spadku indyjskiego eksportu i niezrównoważenia go przez popyt krajowy, inwestorzy zagraniczni zostali zmuszeni do przykręcenia przysłowiowego kurka, co w kumulacji z innymi czynnikami przełożyło się m.in. na znaczący wzrost bezrobocia. Dodatkowymi czynnikami obniżenia się tempa wzrostu gospodarczego na przełomie pierwszej i drugiej dekady XXI wieku stały się rosnące ceny ropy naftowej, zacieśnianie polityki pieniężnej oraz wspomniany wzrost inflacji (do 10-12 proc.), a także powiększenie się deficytu budżetu państwa (8-10 proc. PKB) [Bombińska, 2014, s. 43-44].

\subsection{Zmiany w strukturze gospodarki}

Dynamicznemu wzrostowi indyjskiego PKB po 1992 roku towarzyszą - jak nigdy dotąd - duże przeobrażenia struktury jego wytwarzania. Jest to efektem wysoce zróżnicowanej dynamiki rozwoju poszczególnych sektorów gospodarki. Dokładniej zjawisko to obrazują wskaźniki zestawione w tab. 5.2-5.4.

W całym badanym okresie w wytwarzaniu indyjskiego PKB systematycznie spada udział sektora I (rolnictwa i pokrewnych rodzajów działalności gospodarczej). U progu reform, tj. w roku 1990/91 dokładnie trzecia część PKB powstała $\mathrm{w}$ sektorze pierwszym. W pierwszych latach indyjskiej niepodległości (tj. 1950-1952) w sektorze I powstawało około 54 proc. PKB, a więc w 40-letnim okresie ,indyjskiego socjalizmu” wskaźnik udziału zmniejszył się o około 20 punktów procentowych [Economic Survey 2011-12, s. A-4]. W badanym 
niespełna 20-letnim okresie transformacji ustrojowej, następował jeszcze szybszy spadek udziału sektora pierwszego w tworzeniu PKB. Na początku drugiej dekady XXI wieku, w sektorze tym powstaje tylko 16-17 proc. PKB.

Tabela 5.2. Struktura wytwarzania PKB Indii według sektorów gospodarki

\begin{tabular}{|c|c|c|c|}
\hline \multirow{2}{*}{ Lata } & \multicolumn{3}{|c|}{ PKB* $=100,0$ proc., w tym: } \\
\cline { 2 - 4 } & sektor I (rolnictwo) & sektor II (przemysł) & sektor III (usługi) \\
\hline $1990 / 91$ & 33,0 & 24,2 & 42,8 \\
\hline $1993 / 94$ & 31,5 & 24,0 & 44,5 \\
\hline $1996 / 97$ & 29,3 & 25,0 & 45,7 \\
\hline $1999 / 00$ & 26,3 & 23,8 & 49,9 \\
\hline $2002 / 03$ & 23,1 & 24,4 & 52,5 \\
\hline $2005 / 06$ & 20,9 & 25,3 & 53,8 \\
\hline $2008 / 09$ & 18,1 & 25,8 & 56,1 \\
\hline $2011 / 12$ & 16,5 & 26,1 & 57,4 \\
\hline
\end{tabular}

* ceny stałe z 2004/05 roku.

Źródło: opracowanie i obliczenia własne na podstawie: [Economic Survey 2011-12, s. A-7], [Economic Survey 2013-14. Statistical Appendix, 2014, s. 5].

Innym wymiarem postępującej restrukturyzacji indyjskiej gospodarki są zmiany w zatrudnieniu według sektorów. Podstawowe wskaźniki do takiej analizy - mające jednak charakter szacunkowy - zamieszczono w tab. 5.3. Ogólny kierunek zmian struktury zatrudnienia jest taki sam, jak w przypadku sektorowego rozkładu tworzenia PKB, aczkolwiek ich dynamika oraz proporcje są odmienne. Głównym ,pracodawcą" w Indiach jest nadal, tzn. w całym badanym okresie, sektor pierwszy, czyli rolnictwo wraz z pokrewnymi działami. Zmniejsza się jednak jego udział. W okresie 16 lat (1994-2010) spadek wyniósł około 13 punktów procentowych (64,5 do 51,3 proc.), co - uwzględniając sytuację demograficzną w Indiach - należy uznać za sukces.

Tabela 5.3. Struktura zatrudnienia w Indiach według sektorów gospodarki

\begin{tabular}{|c|c|c|c|}
\hline \multirow{2}{*}{ Lata } & \multicolumn{3}{|c|}{ PKB =100,0 proc., w tym: } \\
\cline { 2 - 4 } & sektor I (rolnictwo) & sektor II (przemysł) & sektor III (usługi) \\
\hline $1993 / 94$ & 64,5 & 14,3 & 21,2 \\
\hline $1999 / 2000$ & 60,3 & 16,2 & 23,5 \\
\hline $2004 / 05$ & 57,0 & 18,2 & 24,8 \\
\hline $2007 / 08$ & 55,9 & 18,7 & 25,4 \\
\hline $2009 / 10$ & 51,3 & 22,0 & 26,7 \\
\hline
\end{tabular}

Źródło: [Garg, Walia, 2013]. 
Spadkowi udziału zatrudnienia w sektorze pierwszym towarzyszył oczywiście wzrost $\mathrm{w}$ dwóch pozostałych sektorach. Wchodzące na rynek pracy nowe roczniki Indusów coraz częściej znajdowały zatrudnienie w przemyśle lub usługach. Ponadto na zmiany sektorowej struktury zatrudnienia wpływ miała migracja ludności ze wsi, aczkolwiek była ona relatywnie niewielka. W badanym okresie udział zatrudnionych w sektorze przemysłowym wzrósł o blisko 8 punktów procentowych i był wyższy niż przyrost w sektorze usług (5,5 punktu procentowego). Można więc mówić - konkludując ten wątek - o dezagraryzacji zatrudnienia oraz stopniowej jego industrializacji i serwicyzacji. Są to zmiany właściwe, oznaczające korzystne przekształcenia struktury indyjskiej gospodarki, aczkolwiek ich tempo wydaje się niskie. Problemy zatrudnienia przedstawione są szerzej w dalszej części rozdziału.

\subsubsection{Rolnictwo}

Polityka państwa indyjskiego wobec rolnictwa w pierwszych latach po uzyskaniu niepodległości koncentrowała się na zmianach instytucjonalnych na indyjskiej wsi. Chodziło przede wszystkim o uporządkowanie stosunków własnościowych, a głównie „odfeudalizowanie” rolnictwa, zwiększenie nakładów inwestycyjnych i zapoczątkowanie jego modernizacji technicznej i społecznej [Gudowski, 1998, s. 21-29]. Jednakże wobec różnych - wcześniej opisanych trudności - postęp w tej dziedzinie był niewielki - z wyjątkiem lat ,zielonej rewolucji” w niektórych regionach kraju. Również po 1991 roku, a więc w pierwszych latach wdrażania „nowej polityki ekonomicznej” rolnictwo pozostawało nadal na drugim planie, a uwaga została skupiona na przemyśle, handlu i infrastrukturze. W rolnictwie nie nastąpiły więc poważniejsze zmiany modernizacyjne [Mohanty, 2011; Antahal, 2009]. Jego rozwój był znacznie wolniejszy niż pozostałych dwóch sektorów gospodarki, co obrazują wskaźniki dynamiki w tab. 5.4. W roku 2011/12 produkcja rolna Indii była zaledwie o 84 proc. większa niż w roku 1993/94, przy analogicznych wskaźnikach dla przemysłu - 266 proc. i usług - 357 proc. Różnice dynamiki są bardzo duże i świadczą o rozwieraniu się nożyc pomiędzy rozwojem sektora rolnego a resztą gospodarki. Jeżeli w latach 1981-1991 różnica pomiędzy przeciętnym, rocznym tempem wzrostu produkcji rolnej a PKB wynosiła 1,8 punktu procentowego (PKB - 5,7 proc., rolnictwo - 3,9 proc.), w latach 1991-2001 było to 3,9 punktu proc. (PKB - 6,7 proc., rolnictwo - 2,8 proc.), to w latach 2007-2012 dystans ten zwiększył się do 4,5 punktu proc. (PKB - 8,1 proc., rolnictwo - 3,6 proc.) [Datt, Mahajan, 2014, s. 531]. 
Tabela 5.4. Dynamika PKB Indii według sektorów jego wytwarzania

\begin{tabular}{|c|c|c|c|c|c|c|}
\hline \multirow{2}{*}{ Lata } & \multicolumn{2}{|c|}{ Sektor I* } & \multicolumn{2}{c|}{ Sektor II } & \multicolumn{2}{c|}{ Sektor III } \\
\cline { 2 - 7 } & $\begin{array}{c}\text { rok } \\
\text { poprzedni } \\
=100,0\end{array}$ & $\begin{array}{c}\text { rok } \\
1993 / 94 \\
=100,0\end{array}$ & $\begin{array}{c}\text { rok } \\
\text { poprzedni } \\
=100,0\end{array}$ & $\begin{array}{c}\text { rok } \\
1993 / 94 \\
=100,0\end{array}$ & $\begin{array}{c}\text { rok } \\
\text { poprzedni } \\
=100,0\end{array}$ & $\begin{array}{c}\text { rok } \\
1993 / 94 \\
=100,0\end{array}$ \\
\hline $1991 / 92$ & $-1,4$ & 91,5 & $-0,1$ & 91,0 & 4,7 & 88,1 \\
\hline $1992 / 93$ & 6,0 & 97,0 & 3,6 & 94,3 & 5,7 & 93,1 \\
\hline $1993 / 94$ & 3,1 & 100,0 & 6,1 & 100,0 & 7,4 & 100,0 \\
\hline $1994 / 95$ & 5,2 & 105,2 & 9,1 & 109,1 & 5,8 & 105,8 \\
\hline $1995 / 96$ & 0,0 & 105,2 & 12,0 & 122,2 & 10,1 & 116,5 \\
\hline $1996 / 97$ & 8,9 & 114,6 & 7,2 & 131,0 & 7,5 & 125,2 \\
\hline $1997 / 98$ & $-1,3$ & 113,1 & 3,3 & 135,3 & 8,9 & 136,3 \\
\hline $1998 / 99$ & 5,9 & 119,8 & 4,3 & 141,1 & 8,3 & 147,6 \\
\hline $1999 / 00$ & 2,8 & 123,2 & 6,2 & 149,8 & 11,2 & 164,1 \\
\hline $2000 / 01$ & 0,3 & 123,6 & 6,5 & 159,5 & 5,4 & 173,0 \\
\hline $2001 / 02$ & 5,5 & 130,4 & 2,7 & 163,8 & 6,9 & 184,9 \\
\hline $2002 / 03$ & $-4,9$ & 124,0 & 7,1 & 175,4 & 7,0 & 197,8 \\
\hline $2003 / 04$ & 8,2 & 134,2 & 7,9 & 189,3 & 8,1 & 213,8 \\
\hline $2004 / 05$ & 1,1 & 135,7 & 10,0 & 208,2 & 8,1 & 231,1 \\
\hline $2005 / 06$ & 4,6 & 141,9 & 10,7 & 230,5 & 10,9 & 256,3 \\
\hline $2006 / 07$ & 4,6 & 148,4 & 12,7 & 259,8 & 10,1 & 282,2 \\
\hline $2007 / 08$ & 5,5 & 156,6 & 10,3 & 286,6 & 10,3 & 311,3 \\
\hline $2008 / 09$ & 0,4 & 157,2 & 4,7 & 300,1 & 10,0 & 342,4 \\
\hline $2009 / 10$ & 1,5 & 159,6 & 9,5 & 328,6 & 10,5 & 378,4 \\
\hline $2010 / 11$ & 8,3 & 172,8 & 7,6 & 353,7 & 9,7 & 415,1 \\
\hline $2011 / 12$ & 4,4 & 180,4 & 8,5 & 383,8 & 6,6 & 442,5 \\
\hline
\end{tabular}

* w proc., ceny stałe z 2004/05 roku.

Źródło: opracowanie i część obliczeń własnych na podstawie: [Economic Survey 2011-12, s. A-5, A-7], [Economic Survey 2013-14. Statistical Appendix, 2014, s. 5].

Szybki rozwój i modernizacja przemysłu oraz usług bynajmniej nie sprzyjały indyjskiemu rolnictwu. Przestarzałe narzędzia pracy, często feudalne jeszcze stosunki własnościowe, niski - poza niektórymi regionami - poziom kultury rolnej oraz wysoki analfabetyzm na wsiach sprawiały, że większość gospodarstw rolnych nie było w stanie wykorzystywać nowoczesnych produktów przemysłu oraz usług, np. z sektora maszynowego, informatycznego, telekomunikacyjnego czy biotechnologicznego. Dobra te nie były po prostu kompatybilne z użytkowanymi dotąd przez rolników narzędziami i sposobami uprawy, a w dodatku nie byli oni w stanie ich nabywać z uwagi na wysokie ceny. Ponadto - co chyba ważniej- 
sze - te wysoce zmodernizowane gałęzie przemysłu i usług nie mogły zatrudniać zbędnych na wsi rąk do pracy z powodu ich niskich umiejętności. Nie tworzyły też nowych miejsc pracy w regionach wiejskich, czyli w pobliżu gospodarstw rolnych. Wszystko to razem wzięte nie sprzyjało przyspieszeniu rozwoju rolnictwa, likwidacji przeludnienia agrarnego i poprawie warunków życia na wsi [Müller, Rauch, 2008].

Dokładniejsza analiza struktury produkcji rolnej, a szczególnie roślinnej, wskazuje, że w okresie niemal dwóch dekad „nowej polityki ekonomicznej”, nie zanotowano istotniejszych zmian w tej dziedzinie. Praktycznie nie zmienił się obszar upraw podstawowych zbóż, tj. pszenicy i ryżu, istotnie zmalała jedynie powierzchnia zasiewów zbóż gruboziarnistych (kukurydzy, sorgo, jęczmienia). Pewne różnice dostrzec można dopiero, gdy wyrazimy produkcję roślinną w jednostkach wartościowych (pieniężnych). W latach 1991-2008 udział produkcji zbożowej w wartości całej produkcji indyjskiego rolnictwa zmniejszył się z 34,4 proc. do 31,2 proc., znacząco wzrósł natomiast udział produkcji owoców i warzyw - zwiększył się on w tym okresie z 17,9 do 24,3 proc. Udział innych produktów rolnych - zarówno żywnościowych, jak i przemysłowych (np. juta, bawełna) - nie wykazywał w badanym okresie znaczących zmian [Kannan, Sundaram, 2011, s. 3-7].

Reasumując, można stwierdzić, że transformacja gospodarcza - poza drugą połową pierwszej dekady XXI wieku - nie była pomyślna dla indyjskiego rolnictwa, pozostawało ono właściwie poza głównym nurtem przemian. Co więcej, sektor rolny był obciążeniem reform i to w różnych ich aspektach. W efekcie takiej polityki gospodarczej rolnictwo i w ogóle indyjska wieś, stawały się w coraz większym stopniu wąskim gardłem gospodarki i hamulcem przyspieszonego rozwoju kraju 6 .

${ }^{6}$ Przyczyną tego załamania były m.in. częste susze na przełomie wieków, które spowodowały spadek plonów oraz - związane z tym - ogromne zadłużenie rolników. Na początku XXI wieku rząd indyjski uruchomił różnego rodzaju programy wsparcia dla rolnictwa, np. umożliwiające dostęp małych gospodarstw rolnych do kredytów produkcyjnych. Do udzielania takich kredytów zostały zobowiązane zarówno państwowe, jak i prywatne instytucje bankowe. Dobre intencje władz nie przyniosły jednak oczekiwanych rezultatów, co gorzej - zrodziły wielką patologię. Oprócz legalnego rynku kredytowego wytworzyło się ogromne podziemie pożyczkowe, tzn. powstały prywatne instytucje udzielające rolnikom wysoko oprocentowanych (lichwiarskich) pożyczek, co było ułatwione bardzo niską świadomością ekonomiczną ludności wiejskiej (m.in. brakiem rachunków bankowych oraz analfabetyzmem). Znaczna część rolników - szczególnie w okresach nieurodzaju - nie mogła spłacić powstałych i szybko rosnących długów, co prowadziło do bankructw i rodzinnych dramatów. Znamiennym wyrazem tego ostatniego była duża - niespotykana wcześniej - liczba samobójstw na wsiach. Szacuje się, że w latach 1997-2005 corocznie odbierało sobie życie około 15 tys. rolników (12,9 na 100 tys. mieszkańców), co znacznie przewyższało przeciętną - i tak bardzo wysoką - stopę samobójstw dla całych Indii $(10,6)$ [Schöttli, Pauli, 2011; Kannan, Sundaram, 2011, s. 2]. 
Odczuwalne zmiany polityki gospodarczej w odniesieniu do sektora rolnego nastąpiły dopiero po 2000 roku, a szczególnie w drugiej połowie pierwszej dekady bieżącego wieku, a więc po kilku latach wyraźnego osłabienia wzrostu produkcji rolnej. W XI planie gospodarczym (2007-2012) rząd M. Singha znacząco zwiększył nakłady na rolnictwo oraz rozwój obszarów wiejskich [Skulska, 2013]. Oprócz tego cofnięto wiele ograniczeń w produkcji, a przede wszystkim w handlu rolnym. Korzystnie zmieniono system opodatkowania zarówno produkcji, jak i obrotu produktami rolnymi. Do przetwórstwa rolnego (żywnościowego i przemysłowego) dopuszczono zagraniczny kapitał. Przedsięwzięcia te przyniosły korzystne efekty już na przełomie pierwszej i drugiej dekady; w latach 2007/08-2011/12 produkcja rolna zwiększyła się o 15,2 proc. (por. tab. 5.4). Nie są one jednak wystarczające. Istnieje konieczność całościowego i radykalnego podejścia do problemu rolnictwa oraz warunków życia około 70 proc. obywateli Indii - mieszkańców wsi. W tym kontekście mówi się nawet o potrzebie „drugiej zielonej rewolucji" na indyjskiej wsi [Datt, Mahajan, 2014, s. 545-548] ${ }^{7}$.

\subsubsection{Przemysł}

Udział przemysłu w tworzeniu indyjskiego PKB w badanym okresie transformacji ustrojowej utrzymywał się na niemal stałym poziomie 24-26 proc., co oznacza, że jego tempo wzrostu było wysokie i podobne do zmian całego PKB (por. tab. 5.1 i 5.4). Niewątpliwie szybki wzrost produkcji przemysłowej jest dowodem na intensywną modernizację tego sektora, szczególnie w dziedzinach związanych z informatyką, automatyką, transportem i biotechnologiami. Najwyższe przyrosty produkcji przemysłowej notuje się w połowie pierwszej dekady XXI wieku (lata 2004/05-2007/08), kiedy to powiększała się ona w tempie 10-12 proc. w skali roku. U źródeł tego przyspieszenia tkwią bez wątpienia wcześniejsze reformy liberalizujące i deregulujące funkcjonowanie sektora przemysłowego oraz jego otwarcie na wymianę zagraniczną. Poważne znaczenie miał też duży zastrzyk kapitałowy w postaci znaczącego napływu do Indii bezpośrednich inwestycji zagranicznych [Mohanty, 2011]. Natomiast nieznaczny spadek tempa wzrostu produkcji przemysłowej w latach 2008/09-2011/12 należy tłumaczyć przede wszystkim pogorszeniem koniunktury na świecie w efekcie globalnego kryzysu gospodarczego.

Znamienne jest, że w historii Indii nie było takiego okresu, aby największym sektorem gospodarki był przemysł, aczkolwiek - jak wykazano w rozdziale II - w pierwszych trzech dekadach niepodległości był on przysłowiowym „oczkiem

${ }^{7} \mathrm{~W}$ celu przygotowania i wdrożenia programu reform rolnictwa oraz wsi rząd Indii powołał w listopadzie 2004 roku Państwową Komisję ds. Rolników (National Commission on Farmers) pod kierunkiem M.S. Swaminathana. W latach 2004-2006 Komisja ta przygotowała 5 raportów o kierunkach rozwoju rolnictwa w okresie realizacji XI Planu Gospodarczego (2007-2012). 
w głowie" indyjskich władz i lokomotywą rozwoju gospodarczego. Pomimo wysokiej dynamiki produkcji przemysłowej, w dalszym ciągu w strukturze tworzenia PKB dominowało rolnictwo, a od drugiej połowy lat 70. - usługi. Można więc twierdzić, że gospodarka indyjska nie przeszła w sposób klasyczny - jak w większości krajów - przez fazę industrializacji, lecz z fazy agraryzacji wkroczyła w fazę serwicyzacji.

Tego procesu nie powinno się jednak oceniać jednoznacznie korzystnie. Wiele studiów i opinii ekonomistów wskazuje na względny niedorozwój przemysłu w stosunku do potrzeb całej indyjskiej gospodarki [Förstmann, Gregosz, 2010]. Oba pozostałe sektory, tzn. rolnictwo oraz usługi, wymagają dla swego harmonijnego funkcjonowania oraz rozwoju odpowiedniego „wsparcia” ze strony przemysłu, chociażby w postaci nowoczesnych narzędzi, a tych sektor ten nie był im w stanie zapewnić w dostatecznej liczbie. Ponadto, co jest bodaj najważniejsze, bardziej rozbudowany przemysł byłby istotnym czynnikiem zwiększającym zatrudnienie. Problem wzrostu zatrudnienia, czyli tworzenia nowych miejsc pracy, staje się zaś kluczowy dla indyjskiej gospodarki i życia społeczno-politycznego w pierwszych dekadach XXI wieku. Wynika to przede wszystkim - jak już wspominano - z narastającej fali emigracyjnej ze wsi oraz nieustannie wysokiego przyrostu demograficznego. Dynamiczny rozwój sektora usług nie jest jednak w stanie wchłonąć tak dużej liczby chętnych do pracy i to osób o coraz wyższych kwalifikacjach. W tej sytuacji z ,pomocą” sektorowi usługowemu winien przyjść przemysł. Jeżeli Indie chcą efektywnie - ekonomicznie oraz społecznie - wykorzystać wspomnianą „dywidendę demograficzną", to muszą bez wątpienia zintensyfikować przede wszystkim rozwój przemysłu, czyli dokonać swoistej reindustrializacji. Dotyczy to szczególnie obszarów bardzo zaniedbanych (np. północno-wschodnich), pozostających w istocie w fazie przedindustrialnej. Naturalną koleją losu w tych właśnie regionach byłaby najpierw rozbudowa przemysłu, a dopiero później sektora usługowego, a nie - jak to się często dzieje - usług i to bynajmniej nie tych nowoczesnych; do omawianych tu spraw powrócimy w następnym rozdziale.

Renesans przemysłu miałby polegać nie tylko na budowie nowych fabryk i centrów przemysłowych, ale także na znaczącej modernizacji istniejącego potencjału, czyli rozwoju tzw. inteligentnego przemysłu, wymagającego nowoczesnych technologii, przetworzonych surowców, wysoko kwalifikowanych kadr, zaplecza badawczego itp. Dawałoby to szanse zwiększania zatrudnienia nie tylko w samych zakładach przemysłowych, ale też - a może przede wszystkim - w szerokim ich zapleczu (np. badania naukowe, szkolenia, logistyka, obsługa finansowa, marketing). Takiej reindustrializacji Indii sprzyjałby znaczący rozwój nowoczesnych usług. W tej sytuacji ujawniłyby się zapewne na większą skalę efekty komplementarności oraz synergii pomiędzy oboma sektorami.

Wskaźniki w tab. 5.4 informują, że takie oznaki intensywnej reindustrializacji już się pojawiają, o czym świadczyłoby zahamowanie procesu spadku udziału przemysłu w PKB Indii obserwowane w latach 90. ubiegłego stulecia i pierwsze 
oznaki jego wzrostu po roku 2000. W niektórych latach przyrosty produkcji przemysłowej były wyższe niż w przypadku sektora usługowego. Innym argumentem za tą tezą są zmiany w strukturze produkcji przemysłowej, co przedstawiono w tab. 5.5.

Tabela 5.5. Struktura produkcji przemysłowej (industrial production) Indii według branż (grup produktowych)

\begin{tabular}{|c|c|c|c|c|}
\hline \multirow{2}{*}{ Branże } & \multicolumn{4}{|c|}{ Lata } \\
\hline & 1993/94* & $2000 / 01$ & $2005 / 06$ & $2009 / 10$ \\
\hline Przemysł ogółem, w tym: & 100,0 & 100,0 & 100,0 & 100,0 \\
\hline I. Kopalnictwo & 10,5 & 8,4 & 7,1 & 6,4 \\
\hline $\begin{array}{l}\text { II. Przemysł wytwórczy (manufacturing), } \\
\text { w tym: }\end{array}$ & 79,4 & 81,9 & 84,5 & 85,9 \\
\hline - żywność & 9,1 & 8,6 & 6,8 & 5,1 \\
\hline - napoje, produkty tytoniowe & 2,4 & 2,9 & 4,2 & 4,3 \\
\hline - tekstylia bawełniane & 5,5 & 4,3 & 3,3 & 3,0 \\
\hline - produkty wełniane i jedwabne & 2,3 & 2,9 & 2,5 & 2,2 \\
\hline $\begin{array}{l}\text { - juta i pozostałe włókna roślinne } \\
\text { (poza bawełną) }\end{array}$ & 0,6 & 0,4 & 0,3 & 0,2 \\
\hline - produkty tekstylne i odzieżowe & 2,5 & 2,6 & 2,8 & 2,7 \\
\hline - drewno, meble i armatura & 2,7 & 1,7 & 0,8 & 1,1 \\
\hline $\begin{array}{l}\text { - papier, produkty papiernicze } \\
\text { i drukarskie }\end{array}$ & 2,7 & 2,7 & 2,7 & 2,3 \\
\hline - skóra i produkty skórzane & 1,1 & 1,0 & 0,8 & 0,6 \\
\hline - chemikalia & 14,0 & 15,2 & 16,1 & 15,9 \\
\hline $\begin{array}{l}\text { - wyroby gumowe, plastikowe, naftowe } \\
\text { i węglowe }\end{array}$ & 5,7 & 5,4 & 5,0 & 5,1 \\
\hline $\begin{array}{l}\text { - produkty mineralne- niemetalowe } \\
\text { (cement, wapno, szkło itp.) }\end{array}$ & 4,4 & 5,9 & 5,8 & 5,5 \\
\hline - metale podstawowe i stopy tych metali & 7,4 & 6,9 & 7,5 & 8,1 \\
\hline - produkty metalowe & 2,8 & 2,7 & 2,4 & 2,1 \\
\hline - urządzenia i obrabiarki nieelektryczne & 9,6 & 11,5 & 14,4 & 17,8 \\
\hline - środki i sprzęt transportowy & 4,0 & 4,7 & 6,2 & 6,9 \\
\hline $\begin{array}{l}\text { - pozostałe produkty przemysłu } \\
\text { wytwórczego }\end{array}$ & 2,6 & 2,5 & 2,9 & 3,0 \\
\hline III. Energia elektryczna & 10,1 & 9,7 & 8,4 & 7,7 \\
\hline
\end{tabular}

* wszystkie dane w cenach bieżących.

Źródło: opracowanie i część obliczeń własnych na podstawie [Economic Survey 2010-11, s. A-35]. 
Z tab. 5.5 wynika, że w okresie transformacji systematycznie zmienia się struktura produkcji sektora przemysłowego. Obniża się udział kopalnictwa oraz energetyki na rzecz rozwoju branż wytwórczych. W latach 1993/94-2009/10 przemysł wytwórczy zwiększył swój udział w łącznej produkcji sektora przemysłowego o 6,5 punktów procentowych. Także w przemyśle wytwórczym nastąpiły istotne zmiany strukturalne. Jak wskazują dane w tab. 5.5, w badanym okresie bardzo wyraźnie wzrosły udziały produkcji takich branż, jak: przemysł chemiczny, maszynowy, materiałów budowlanych oraz środków transportu. W 1993/94 roku te cztery działy dawały 35 proc. produkcji przemysłu wytwórczego, a w roku 2010/11 było to prawie 49 proc. Taka skala zmian ma już wymiar nie tylko ilościowy, ale świadczy o nowej jakości indyjskiego sektora przemysłowego. Potwierdza to sformułowaną wcześniej tezę o zapoczątkowaniu w pierwszej dekadzie XXI wieku procesu reindustrializacji Indii.

\subsubsection{Usługi}

Głównym nośnikiem indyjskiego wzrostu gospodarczego w całym niemal okresie transformacji ustrojowej, czyli po 1991 roku, był - jak już wcześniej zauważono - sektor usług. Uznaje się to wręcz za osobliwość indyjskiego rozwoju gospodarczego [Majumdar, 2012, s. 217-220]. Wyrazem tego jest bardzo szybko rosnący udział usług $\mathrm{w}$ tworzeniu PKB. W przeciągu dwóch badanych dekad udział ten zwiększył się o 16 punktów procentowych - z 43 do prawie 59 proc. (por. tab. 5.2-5.4), a więc do poziomu zbliżonego dla krajów średnio rozwiniętych.

Źródłami przyspieszonej serwicyzacji indyjskiej gospodarki są [Skulska, 2013; Wróbel, 2013]:

- liberalizacja przepływu usług i ułatwienie dostępu do indyjskiego rynku usług dla zagranicznych dostawców;

- wspomaganie dla sektora usług ze strony państwa, tj. współudział władz regionalnych i lokalnych w tworzeniu specjalnych stref dla rozwoju nowoczesnych usług (np. parki technologiczne);

- korzystne prawo dla inwestycji zagranicznych w sektorze usług i łagodna polityka podatkowa w stosunku do branż nowoczesnych usług;

- szybka liberalizacja i modernizacja sektora finansowego (banki, ubezpieczenia) oraz transportu;

- rewolucja informatyczna, tj. dynamiczny rozwój usług IT i telekomunikacji;

- szybki rozwój biotechnologii i sektora elektronicznego, które m.in. umożliwały rozwój (podaż) nowoczesnych usług;

- dynamiczny rozwój edukacji informatycznej, czyli kształcenie wysoko kwalifikowanych kadr w tej dziedzinie, ich duża mobilność oraz przystosowanie do międzynarodowych standardów biznesowych. 
Najszybszy wzrost sektora usługowego obserwuje się w okresie 2005/062009/10, kiedy wartość usług zwiększała się w tempie przekraczającym 10 proc. rocznie $^{8}$. I tu też - podobnie jak w rozwoju niektórych branż przemysłu - istotną rolę odegrał szeroki po 2005 roku strumień bezpośrednich inwestycji zagranicznych, z których znaczna część była właśnie lokowana w branżach nowoczesnych usług (por. tab. 5.7). Napływ ten był stymulowany m.in. tworzeniem na niektórych obszarach Indii specjalnych stref ekonomicznych, w których inwestorom tworzono bardzo korzystne warunki działalności poprzez lepsze przygotowanie infrastruktury, zwalnianie z podatków i ceł (lub ich obniżanie), ułatwienia prawne itp. ${ }^{9}$ Dokładniej rozwój sektora usługowego w podziale na jego bardziej jednorodne elementy obrazują wskaźniki zestawione w tab. 5.6.

Tabela 5.6. Dynamika rozwoju sektora usług w Indiach według jego segmentów (rok 1993/94 = 100,0 proc.)

\begin{tabular}{|c|c|c|c|c|}
\hline \multirow{2}{*}{$\begin{array}{r}\text { Segmenty } \\
\text { usług }\end{array}$} & \multirow{2}{*}{$\begin{array}{c}|c| \\
\text { Usługi } \\
\text { ogółem }\end{array}$} & $\begin{array}{c}\text { W tym: } \\
\text { handel, hotelarstwo, } \\
\text { transport, } \\
\text { komunikacja* }\end{array}$ & $\begin{array}{c}\text { bankowość, } \\
\text { ubezpieczenia, } \\
\text { nieruchomości, } \\
\text { obsługa biznesu }\end{array}$ & $\begin{array}{c}\text { administracja } \\
\text { publiczna, usługi } \\
\text { społeczne i osobiste, } \\
\text { obrona i in. }\end{array}$ \\
\hline $1994 / 95$ & 105,8 & 109,9 & 103,9 & 102,3 \\
\hline $1997 / 98$ & 136,3 & 144,9 & 128,2 & 128,5 \\
\hline $1999 / 00$ & 164,1 & 173,3 & 163,4 & 160,3 \\
\hline $2002 / 03$ & 184,9 & 217,3 & 188,6 & 181,4 \\
\hline $2004 / 05$ & 231,1 & 264,9 & 216,9 & 200,6 \\
\hline $2007 / 08$ & 311,3 & 367,5 & 311,6 & 235,9 \\
\hline \multirow{2}{*}{$2011 / 12$} & 457,4 & 538,7 & 460,2 & 329,2 \\
\cline { 3 - 5 } & $100,0 * *$ & 44,9 & 30,0 & 25,1 \\
\hline
\end{tabular}

* termin „komunikacja” (ang. communication) odnosi się do wytwarzania, przetwarzania oraz przekazywania informacji, ** struktura rodzajowa produkcji usług.

Źródło: opracowanie i obliczenia własne na podstawie: [Economic Survey 2011-12, A-7], [Economic Survey 2013-14. Statistical Appendix, 2014, s. 176].

${ }^{8}$ W niektórych, głównie nowoczesnych, wysoce zdigitalizowanych działach usług, jak np. w komunikacji (instalowanie i obsługa środków przekazu, przetwarzanie i przesyłanie informacji) przeciętne roczne przyrosty wartości produkcji w latach 1995-2010 przekraczały 25 proc. (w cenach stałych) [Mallik, Kathuria, 2012, s. 445].

9 Ten szybki rozwój specjalnych stref ekonomicznych - wzorowanych na specjalnych strefach w Chinach - był w głównej mierze efektem uchwalonej przez indyjski parlament w 2005 roku ustawy (The Special Economic Zones Act) [Prasad, Ray, 2010]. 
Nietrudno dostrzec, analizując dane w tab. 5.6, że zdecydowanie najwyższą dynamiką rozwojową - znacznie przewyższającą średnią dla całego sektora - legitymują się usługi zaliczane do subsektora grupującego handel, hotelarstwo, transport i komunikację. Stanowią one niemal 45 proc. całego sektora usługowego. W tej grupie - oprócz tradycyjnego, szeroko rozumianego handlu oraz transportu - mieszczą się także usługi związane z rozwojem elektroniki, informatyki, Internetu, przekazu informacji i telekomunikacji, a więc produkty o dużym wkładzie intelektualnym (oparte na wiedzy) ${ }^{10}$.

W pierwszej połowie lat 90 . Indie szeroko otworzyły swoją gospodarkę na inwestycje zagraniczne w sektorze IT. W niedługim czasie powstały przedsiębiorstwa nastawione na eksport tych usług, które przyciągnęły zagranicznych zleceniodawców. Następne miejsca - po usługach IT - zajmują usługi zaliczane do subsektora biznesowego, a więc finansowe, ubezpieczeniowe, obrót nieruchomościami, doradztwo biznesowe itp. Na tle wysokiej dynamiki tych dwóch segmentów usług, relatywnie niewielkie są przyrosty usług z zakresu administracji publicznej (w tym aparatu sprawiedliwości, szkolnictwa), bezpieczeństwa (wewnętrznego i zewnętrznego). Jeżeliby - reasumując - podzielić usługi na dwa sektory, tj. usługi tradycyjne (handel, transport i in.) oraz nowoczesne (IT, finanse, usługi biznesowe, edukacyjne i medyczne), to znacznie szybciej rozwijały się te drugie i szybko zwiększał się ich udział w łącznej produkcji sektora usługowego. Tylko w latach 1993/94-2004/05 udział ten wzrósł z 31 do 40 proc. [Bardhan, 2010, s. 28].

Jednym $\mathrm{z}$ najważniejszych rodzajów usług rozwijanych $\mathrm{w}$ Indiach po 2000 roku jest offshoring, zwany także międzynarodowym outsourcingiem. Indie urosły w tej dziedzinie do pozycji światowego lidera. Lokomotywą indyjskiego offshoringu jest bez wątpienia dobrze rozwinięty przemysł informatyczny, maszynowy, biotechnologiczny, farmaceutyczny oraz liczne, wysoko kwalifikowane, znające język angielski, kadry informatyków, finansistów, lekarzy, inżynierów czy specjalistów z zakresu telekomunikacji oraz marketingu. $\mathrm{W}$ dodatku są to zasoby pracy relatywnie tańsze niż w większości innych krajów ${ }^{11}$. W 2005 roku

${ }^{10} \mathrm{~W}$ literaturze przedmiotu zwraca się czasem uwagę na istotną różnicę pomiędzy rozwojem gospodarczym Chin a rozwojem Indii. Otóż motorem wysokiej dynamiki chińskiej gospodarki był i jest przemysł (produkcja dóbr materialnych), natomiast w przypadku Indii rolę tę pełnią nowoczesne, oparte na wiedzy, usługi. Stawiane są nawet hipotezy, że - metaforycznie ujmując - w przyszłości Chiny będą warsztatem (fabryką) świata, ale Indie przejmą nad nim intelektualne kierownictwo. Inna metafora w odniesieniu do Indii, to taka, że jest to „największe biuro świata” [Wosińska, 2008, s. 116-117].

${ }^{11}$ Głównymi czynnikami rozwoju sektora informatycznego oraz związanego z tym offshoringu są liczne i wysoko kwalifikowane kadry inżynierów i techników. Kształcenie specjalistów od przetwarzania danych ma w Indiach - jak na tę dziedzinę - długą historię, bo pierwsze uczelnie powstały już na początku lat 50. (z inicjatywy J. Nehru). Niektóre z nich uchodzą za najlepsze na świecie, ich absolwenci są poszukiwanymi pracownikami we wszystkich krajach. Jeżeli zaś chodzi o płace indyjskich inżynierów-informatyków, to w pierwszych latach XXI wieku kształtowały się one średnio na poziomie $20-40$ proc. płac inżynierów amerykańskich. Przykładowo, w latach 
65 proc. światowego rynku offshoringu usług IT i 46 proc. offshoringu usług biznesowych przypadało na Indie [Liberska, 2008, s. 246-247].

Generalnie ujmując, usługi offshoringowe wykonywane przez Indusów na rzecz zagranicznych przedsiębiorstw i osób prywatnych dotyczą w szczególności takich dziedzin, jak: usługi w zakresie finansów i rachunkowości (m.in. obliczanie podatków dla osób fizycznych), biotechnologia (m.in. testowanie leków), telekomunikacja, telemarketing, medycyna (m.in. medycyna upiększająca, analiza wyników badań), consulting, turystyka (m.in. turystka medyczna), edukacja (m.in. korepetycje przez Internet) oraz badania naukowe [Wosińska, 2008, s. 116-119]. Jest to bardzo korzystna forma współpracy dla obu stron. Dzięki offshoringowi zagraniczne przedsiębiorstwa mogą obniżać koszty swej produkcji i dystrybucji, zaś Indie pozyskują kapitał oraz nowoczesne inwestycje, a tym samym - co najważniejsze - tworzą u siebie nowe miejsca pracy dla wysoko wykwalifikowanych pracowników ${ }^{12}$.

2004-2005 indyjski analityk systemów danych w Bangalore zarobił 20,5 tys. USD w skali roku, a taki sam pracownik w USA - 58 tys. USD. Wynagrodzenie amerykańskiego inżyniera testującego programy komputerowe wynosiło 58,3 tys. USD, a inżynier indyjski za taką pracę uzyskał 11,7 tys. USD rocznie [Pleśniak, 2008, s. 200-201; Wosińska, 2008, s. 116].

${ }^{12} \mathrm{~W}$ pierwszych latach XXI wieku pojawiały się jednak w Indiach głosy kwestionujące politykę dynamicznego rozwoju sektora usługowego przy równoczesnym, względnym zaniedbaniu rozwoju rodzimego przemysłu wydobywczego i wytwórczego oraz - przede wszystkim - rolnictwa i wsi. Oparcie rozwoju gospodarczego kraju na wysokiej dynamice usług typu offshoringowego, a więc zlecanych z zagranicy, może stanowić w przyszłości poważne zagrożenie dla gospodarki i państwa. W sytuacji pogorszenia koniunktury na świecie lub w jakimś regionie (np. w Europie, USA czy Azji Wschodniej) jej pierwszą ofiarą staną się właśnie zlokalizowane w Indiach sektory usług (biznesowych, telekomunikacyjnych, informatycznych). Nadmierne preferowanie więc rozwoju sektora usług, to czynienie z indyjskiej gospodarki swoistej „gospodarki podwykonawców”, zdanych na łaskę zagranicznych zleceniodawców. Niektórym krytykom nadmiernej serwicyzacji kojarzy się to wręcz z rekolonizacją Indii. Gospodarka pozbawiona własnego przemysłu wytwarzającego dobra materialne, to gospodarka kaleka, na swój sposób „pusta”, gospodarka „na glinianych nogach" i bardzo zależna od zagranicy. Inna kwestia to przechodzący w trwałą frustrację dyskomfort psychiczny indyjskich wykonawców usług, którzy - będąc wysoko kwalifikowanymi fachowcami - mają poczucie bycia wyzyskiwanymi przez zagraniczne korporacje, gdyż są gorzej opłacani niż byliby w krajach zleceniodawców, muszą przyjmować ich standardy pracy, w tym m.in. posługiwanie się językiem angielskim. Wszystkie te problemy są coraz częściej dostrzegane w Indiach w ostatnich latach i rodzą liczne spory. One to - eksponowane przez kręgi intelektualistów oraz partie opozycyjne - miały duży wpływ na nienotowaną w historii Indii porażkę proliberalnych i reformatorskich rządów Indyjskiego Kongresu Narodowego w wyborach parlamentarnych w maju 2014 roku.

Nadmiernemu rozwojowi offshoringu sprzeciwiają się też rządy oraz - przede wszystkim - pracownicy przedsiębiorstw odbiorców tych usług (czyli ich zleceniodawców). Przenoszenie części działalności przedsiębiorstwa za granicę oznacza m.in. poważne redukcje zatrudnienia. Tego typu opory rodzą się w szczególności wówczas, gdy działalność usługowa przenoszona jest do dalekich i obcych kulturowo regionów, jak np. z USA czy Europy Zachodniej do Indii, czy innych krajów tego regionu [Klincewicz, 2008, s. 267-269]. 


\subsection{Stosunki gospodarcze z zagranicą - inwestycje i handel}

Czynnikiem mocno stymulującym rozwój indyjskiej gospodarki w całym okresie po 1991 roku są bezpośrednie inwestycje zagraniczne. Wcześniej, z uwagi na autarkiczną politykę indyjskiego rządu, nie odgrywały one praktycznie żadnej roli. W latach 80. ich udział w indyjskim PKB nie przekraczał 0,5 proc. [Burange, Yamini, 2011, s. 43]. Badania ekonometryczne, tj. analizy korelacji i regresji pomiędzy napływem bezpośrednich inwestycji zagranicznych do Indii po $1991 \mathrm{roku}$ a tempem wzrostu PKB wskazują na bardzo wysoką rolę tych inwestycji w kształtowaniu dynamiki wzrostu gospodarczego [Kumar, Jain, 2013; Chaturvedi, 2011].

Po 1991 roku - jak wykazano w rozdziale III - władze indyjskie zezwalają na inwestycje kapitału zagranicznego we wszystkich prawie dziedzinach gospodarki. Zakazy obejmują jedynie niektóre segmenty handlu detalicznego, sektor energii atomowej, loterie i zakłady sportowe. W branżach o tzw. niewielkiej skali produkcji udział kapitału zagranicznego nie może przekroczyć pewnej, wyznaczonej wielkości (np. 24 proc.). Ponadto w niektórych innych działach gospodarki obowiązują specyficzne - uwarunkowane ekonomicznie lub społecznie - regulacje inwestowania zagranicznego [Białowąs, 2013, s. 209]. Dokładniej poziom i dynamikę bezpośrednich inwestycji zagranicznych w Indiach obrazują wskaźniki zamieszczone w tab. 5.7.

Tabela 5.7. Bezpośrednie inwestycje zagraniczne w Indiach

\begin{tabular}{|c|c|c|c|c|c|}
\hline Lata & $\begin{array}{c}\text { Wartość inwe- } \\
\text { stycji, } \\
\text { w mln USD } \\
\text { (według kursu } \\
\text { wymiany)* }\end{array}$ & $\begin{array}{c}\text { Zmiana } \\
\text { w stosunku } \\
\text { do roku } \\
\text { poprzedniego, } \\
\text { w proc. }\end{array}$ & Lata & $\begin{array}{c}\text { Wartość } \\
\text { inwestycji, } \\
\text { w mln USD } \\
\text { (według kursu } \\
\text { wymiany) }\end{array}$ & $\begin{array}{c}\text { Zmiana } \\
\text { w stosunku } \\
\text { do roku } \\
\text { poprzedniego, } \\
\text { w proc. }\end{array}$ \\
\hline $1991 / 92$ & 252 & 236,0 & $2002 / 03$ & 4321 & $-23,2$ \\
\hline $1992 / 93$ & 532 & 111,1 & $2003 / 04$ & 5778 & 33,7 \\
\hline $1993 / 94$ & 974 & 83,1 & $2004 / 05$ & 7622 & 31,9 \\
\hline $1994 / 95$ & 2151 & 120,8 & $2005 / 06$ & 20328 & 166,7 \\
\hline $1995 / 96$ & 2525 & 17,4 & $2006 / 07$ & 25350 & 24,7 \\
\hline $1996 / 97$ & 3619 & 43,3 & $2007 / 08$ & 47138 & 85,6 \\
\hline $1997 / 98$ & 2633 & $-27,2$ & $2008 / 09$ & 35657 & $-24,3$ \\
\hline $1998 / 99$ & 2168 & $-17,7$ & $2009 / 10$ & 21125 & $-40,8$ \\
\hline $1999 / 00$ & 3588 & 65,5 & $2010 / 11$ & 36190 & 71,3 \\
\hline $2000 / 01$ & 5477 & 52,6 & $2011 / 12$ & 25543 & $-29,4$ \\
\hline $2001 / 02$ & 5630 & 2,8 & - & - & - \\
\hline
\end{tabular}

* wszystkie dane w cenach bieżących.

Źródło: UNCTADstat - Inward and outward foreign direct investment flows, annual, 19702012, część obliczeń własnych. 
Duży i w dodatku szybko rosnący napływ inwestycji zagranicznych obserwuje się po 2000 roku. Miarą rangi tego zjawiska jest stosunek bezpośrednich inwestycji zagranicznych do PKB Indii. W drugiej połowie pierwszej dekady bieżącego wieku wielkość ta zwiększyła się do niemal 10 proc. i to przy wysokiej dynamice PKB [Burange, Yamini, 2011, s. 43]. Takie wskaźniki należy uznać za sukces indyjskiej gospodarki, świadczący o dużej atrakcyjności inwestycyjnej tego kraju ${ }^{13}$.

$\mathrm{Na}$ zwiększenie napływu bezpośrednich inwestycji po 2003 roku zasadniczy wpływ miała - jak wcześniej stwierdzono - zmiana na scenie politycznej, tj. objęcie w 2004 roku władzy przez Indyjski Kongres Narodowy i mianowanie na stanowisko premiera rządu federalnego M. Singha. Rząd „ojca indyjskich przemian" zintensyfikował realizację programu reform, m.in. poprzez przyspieszenie liberalizacji i deregulacji gospodarki, co z natury rzeczy zachęciło kapitał zagraniczny i ułatwiło procesy inwestowania na obszarze Indii. Wyrazem tej polityki było m.in. - jak już wspomniano - uchwalenie w 2005 roku ustawy o specjalnych strefach ekonomicznych, które przyciągnęły w następnych latach dużo zagranicznych inwestycji (por. podrozdział 5.2.3, przyp. $8 \mathrm{i}$ tab. 5.7).

Spadek wielkości bezpośrednich inwestycji zagranicznych w latach 19981999 jest bez wątpienia efektem kryzysu gospodarek wschodnioazjatyckich (1997_ 1998) oraz wspomnianych sankcji amerykańskich, nałożonych na Indie w związku podjęciem przez to państwo prób z bombą atomową. Druga faza załamania się inwestycji zagranicznych przypada na lata 2008-2010, co jest skutkiem wielkiego kryzysu gospodarek zachodnich (głównie USA i Unii Europejskiej). Skala spadku strumienia inwestycji zagranicznych jest teraz bardzo wysoka, bo - przykładowo - w szczytowym roku kryzysu, tj. 2009-2010, na obszar Indii napłynęło ponaddwukrotnie mniej kapitału niż dwa lata wcześniej (tj. w roku 2007/08), czyli w okresie najlepszej koniunktury indyjskiej gospodarki (por. tab. 5.7).

Przyjmując za 100 proc. całość inwestycji bezpośrednich, jakie napłynęły na obszar Indii w latach 2000-2012, ponad jedna trzecia z nich pochodziła z Mauritiusa (38 proc.). Następne miejsca zajmowały: Singapur - 10 proc., Wielka Brytania -9 proc., USA - 6 proc., Holandia -5 proc., Cypr -4 proc. i Niemcy -3 proc.) [Datt, Mahajan, 2014, s. 375]. Nadzwyczaj wysoka pozycja w tym gronie Mauritiusa oraz Cypru wynika z faktu, że wielu inwestorów (przedsiębiorstw międzynarodowych) jest zarejestrowanych i posiada siedzibę w tych krajach. A dzieje się tak z uwagi na korzystne opodatkowanie działalności gospodarczej, w tym zawarte umowy z innymi państwami o unikaniu podwójnego opodatkowania.

${ }^{13}$ Duży napływ inwestycji do gospodarki indyjskiej jest elementem szerszego zjawiska, tj. ogromnego ożywienia przepływów kapitałowych w skali całego świata obserwowanego po 2000 roku. Jedną z ważnych przyczyn tego boomu jest zmiana nastawienia krajów rozwijających się do bezpośrednich inwestycji zagranicznych. Kraje te przestały uważać inwestycje zagraniczne za zagrożenie dla swych gospodarek i politycznej niezawisłości. Dostrzegły w nich zalety w postaci ważnego czynnika modernizującego gospodarki, a przed ewentualnymi negatywnymi skutkami dla życia politycznego i społecznego broniły się regulacjami prawnymi [Michałowski, 2013, s. 142-143]. 
Głównymi odbiorcami inwestycji zagranicznych, które napłynęły do Indii w latach 1991-2012, były następujące działy gospodarki: usługi (31 proc.), telekomunikacja (13 proc.), przemysł komputerowy (11 proc.), mieszkalnictwo i nieruchomości (11 proc.), budownictwo ( 9 proc.), przemysł farmaceutyczny ( 8 proc.) i energetyka (6 proc.) [Kumar, Jain, 2013].

Innym - obok inwestycji zagranicznych - wyrazem otwartości gospodarki indyjskiej jest rozwój handlu zagranicznego. Po 1991 roku następują w tej dziedzinie istotne zmiany. Ich skalę w całym badanym okresie obrazują dane statystyczne zamieszczone w tab. 5.8.

Tabela 5.8. Wybrane wskaźniki rozwoju handlu zagranicznego Indii

\begin{tabular}{|c|c|c|c|c|c|c|c|}
\hline \multirow[b]{2}{*}{ Lata } & \multicolumn{3}{|c|}{ Eksport towarów } & \multicolumn{2}{|c|}{ Import towarów } & \multicolumn{2}{|c|}{ Saldo handlowe } \\
\hline & $\begin{array}{l}\text { w mld } \\
\text { rupii* }\end{array}$ & $\begin{array}{c}\text { tempo } \\
\text { zmian, } \\
\text { w proc. } r / r\end{array}$ & $\begin{array}{r}\text { udział } \\
\text { w PKB, } \\
\text { w proc. }\end{array}$ & $\begin{array}{l}\text { w mld } \\
\text { rupii }\end{array}$ & $\begin{array}{c}\text { tempo } \\
\text { zmian, } \\
\text { w proc. } r / r\end{array}$ & $\begin{array}{l}\text { w mld } \\
\text { rupii }\end{array}$ & $\begin{array}{c}\text { jako proc. } \\
\text { PKB }\end{array}$ \\
\hline $1991 / 92$ & 440,0 & - & 7,5 & 478,5 & - & $-38,5$ & 2,1 \\
\hline $1992 / 93$ & 536,9 & 22,0 & 7,5 & 633,8 & 32,5 & $-96,9$ & - \\
\hline $1993 / 94$ & 695,5 & 29,5 & 8,9 & 731,0 & 15,3 & $-35,5$ & - \\
\hline $1994 / 95$ & 826,7 & 18,6 & 9,1 & 899,7 & 23,1 & $-73,0$ & - \\
\hline $1995 / 96$ & 1063,5 & 28,6 & 9,9 & 1226,8 & 36,4 & $-163,3$ & - \\
\hline $1996 / 97$ & 1188,2 & 11,7 & 9,5 & 1389,2 & 13,2 & $-201,0$ & 1,6 \\
\hline $1997 / 98$ & 1301,0 & 9,5 & 10,4 & 1541,8 & 11,0 & $-240,8$ & 1,7 \\
\hline $1998 / 99$ & 1397,5 & 7,4 & 8,7 & 1783,3 & 15,7 & $-385,8$ & 2,4 \\
\hline $1999 / 2000$ & 1595,6 & 14,2 & 9,0 & 2152,4 & 20,7 & $-556,8$ & 3,1 \\
\hline $2000 / 01$ & 2035,7 & 27,6 & 10,7 & 2308,7 & 7,3 & $-273,0$ & 1,4 \\
\hline 2001/02 & 2090,2 & 2,7 & 10,1 & 2452,0 & 6,2 & $-361,8$ & 1,7 \\
\hline $2002 / 03$ & 2551,4 & 22,1 & 11,4 & 2972,1 & 21,2 & $-420,7$ & 1,8 \\
\hline $2003 / 04$ & 2933,7 & 15,0 & 11,6 & 3591,1 & 20,8 & $-657,4$ & 2,6 \\
\hline $2004 / 05$ & 3753,4 & 27,9 & 13,1 & 5010,7 & 39,5 & $-1257,3$ & 4,4 \\
\hline $2005 / 06$ & 4564,2 & 21,3 & 14,0 & 6604,1 & 31,8 & $-2039,9$ & 6,2 \\
\hline $2006 / 07$ & 5717,8 & 25,3 & 15,3 & 8405,1 & 27,3 & $-2687,3$ & 7,1 \\
\hline 200708 & 6558,6 & 14,7 & 14,3 & 10123,1 & 20,4 & $-3564,5$ & 7,8 \\
\hline $2008 / 09$ & 8407,6 & 28,2 & 15,9 & 13744,4 & 35,8 & $-5336,8$ & 10,1 \\
\hline $2009 / 10$ & 8455,3 & 0,6 & 13,8 & 13637,4 & $-0,8$ & $-5182,1$ & 8,5 \\
\hline 2010/11 & 11429,2 & 35,2 & 15,7 & 16834,7 & 23,4 & $-5405,5$ & 12,1 \\
\hline $2011 / 12$ & 14659,6 & 28,3 & 17,4 & 23454,6 & 39,3 & $-8795,0$ & 9,6 \\
\hline
\end{tabular}

* wszystkie dane w cenach bieżących.

Źródło: opracowanie i część obliczeń własnych na podstawie: [Economic Survey 2012-13. Statistical Appendix, 2013, s. A-6, A-82], [Bhat, 2011, s. 21, 23]. 
W pierwszych czterech dekadach po uzyskaniu niepodległości handel zagraniczny odgrywał wręcz marginalną rolę w indyjskiej gospodarce. Udział eksportu w PKB kształtował się na poziomie 3-5 proc. Znacznie większy był import, a ujemne saldo obrotów handlowych nie przekraczało zazwyczaj 4 proc. PKB, zaś w niektórych latach było bliskie zera [Bhat, 2011, s. 23]. Sytuacja zmieniła się po 1991 roku. Odejście od licencjonowania importu oraz eksportu, a także obniżenie ceł oraz korzystny kurs walutowy sprawiają, że - jak wspomniano w rozdziale III - dynamicznie zaczynają rosnąć zarówno eksport, jak i import, aczkolwiek ich udział w PKB nie zmienia się istotnie do końca lat 90.

Zestawione w tab. 5.8 liczby obrazujące skalę i zmiany indyjskiego eksportu towarowego po 1991 roku wskazują na jego wysoki wzrost, aczkolwiek tempo zmian było zróżnicowane w poszczególnych latach. Niejednokrotnie po okresach, gdy wielkość eksportu zwiększała się o około 30 proc., przychodzą lata, w których wzrost ten był znacznie niższy i nie przekraczał 10 proc. Ta zróżnicowana dynamika jest przede wszystkim efektem zmienności koniunktury gospodarczej w skali Azji oraz świata. Szczególnie wyraźnie uwidacznia się tu wpływ kryzysu gospodarczego lat 1997-1998, który dotkliwie dotknął kraje bliskiego otoczenia Indii, tj. państwa Azji Południowo-Wschodniej. Do tego dołożyły się amerykańskie sankcje gospodarcze z 1998 roku jako reakcja na indyjskie doświadczenia nuklearne. Istotne są również - co wyjaśniono w rozdziale III - zmiany na indyjskiej scenie politycznej, a w ślad za tym w polityce gospodarczej.

Kryzys gospodarczy, jaki dotkliwie odczuły USA oraz Europa pod koniec pierwszej dekady bieżącego stulecia, nie wpłynął jednak znacząco na indyjski eksport towarowy. Wynika to w głównej mierze z jego struktury asortymentowej. Do Europy oraz USA Indie eksportują głównie niskoprzetworzone produkty rolne (używki, włókna, tekstylia), na które popyt nie ulega istotnym wahaniom pod wpływem zmian koniunktury. Poza tym trzeba pamiętać o polityce rządu M. Singha, silnie stymulującej eksport i szeroko otwierającej indyjską gospodarkę na świat.

Znamienną jest wewnątrzkrajowa, przestrzenna struktura ,pochodzenia” towarów eksportowanych z obszaru Indii. Jest to rozkład wysoce nierównomierny, nieodpowiadający ani geografii gospodarczej, ani rozmieszczeniu ludności. W roku 2011/12 aż 22,4 proc. krajowego eksportu pochodziło z Maharashtry, a 21,3 proc. - z Gujaratu. Dalsze trzy miejsca - ale ze znacznie mniejszymi udziałami - zajmują Tamil Nadu (9,1 proc.), Andhra Pradesh (5,2 proc.) i Karnataka (5,1 proc.) [Economic Survey 2013-14. Statistical Appendix, 2014, s. 130]. Na te pięć stanów przypada więc prawie 2/3 (63,1 proc.) wartości indyjskiego eksportu.

Jeżeli idzie o kierunki indyjskiego eksportu towarowego, to - według statystyk dla roku 2011/12 - najwięcej towarów wysyła się do krajów WANA (West Asia North Africa) - tj. 19,5 proc. całego indyjskiego wywozu. Kolejne miejsca zajmują: kraje Unii Europejskiej - 17,2 proc. (najwięcej Holandia - 3,0 proc., Niemcy - 2,8 proc., Wielka Brytania - 2,6 proc.), USA - 12,5 proc., kraje ASEANU (Association of South-East Asian Nations) - 12,0 proc. (najwięcej Sin- 
gapur $-5,5$ proc.), Chiny (z Hongkongiem) - 10,1 proc [Economic Survey 2013-14. Statistical Appendix, 2014, s. 85-90]. Po 2000 roku struktura ta nie ulegała istotniejszym zmianom.

Szybki wzrost eksportu sprawił, że systematycznie wzrastał jego udział w PKB Indii. W badanych dwóch dekadach udział ten zwiększył się z 7,5 proc. w latach 1991-1993 do 15-17 proc. PKB na początku drugiej dekady XX wie$\mathrm{ku}^{14}$. Nie jest to co prawda wskaźnik wysoki, nawet $\mathrm{w}$ porównaniu z krajami o podobnym poziomie rozwoju gospodarczego, ale podkreślić należy jego dużą dynamikę, szczególnie po 2004 roku. Świadczy to dobitnie o przyspieszonym umiędzynarodawianiu indyjskiej gospodarki.

W przekroju całego badanego okresu transformacji znacznie wyższą, niż w przypadku eksportu, dynamiką wzrostową cechuje się import towarów na indyjski rynek. Jego dynamika jest również mocno zróżnicowana w poszczególnych latach i nie pokrywa się w pełni z sekwencją zmian w eksporcie. Na rozmiary i czasowy rozkład importu wpływa przede wszystkim wewnętrzna polityka gospodarcza. Mniejsza jest natomiast rola zewnętrznej koniunktury gospodarczej. $\mathrm{Z}$ danych w tab. 5.8 wynika, że szczególnie wysokie przyrosty importu mają miejsce po 2004 roku, co jest bez wątpienia - podobnie jak w przypadku eksportu - rezultatem polityki rządu M. Singha.

Wyższa dynamika wzrostu importu niż eksportu sprawia, że powiększa się ujemne saldo indyjskiego handlu zagranicznego. Jeżeli na początku lat 90. saldo to kształtowało się na poziomie około 2 proc. PKB, to na przełomie pierwszej i drugiej dekady XXI wieku przekraczało 10 proc. PKB i stanowiło około 2/3 wartości eksportu. Zjawiska tego nie powinno się jednak oceniać negatywnie. Takie proporcje pomiędzy eksportem a importem wydają się w warunkach indyjskich racjonalne, są uzasadnione potrzebami nadrabiania wielodekadowych zaniedbań i modernizacji gospodarki oraz życia społecznego kraju.

W badanym okresie zmieniają się nie tylko globalne wielkości wymiany handlowej z zagranicą. Istotnym przekształceniom ulegają struktury zarówno eksportu, jak i importu, co obrazują wskaźniki w tab. 5.9-5.10.

Jeżeli idzie o eksport towarów, to - jak wynika z tab. 5.9 - w badanych dwóch dekadach istotnie zmniejszał się w nim udział produktów nisko przetworzonych tj. produktów rolnych (głównie żywnościowych) oraz tekstyliów. W 1990/91 roku

${ }^{14}$ Należy zaznaczyć, że wskaźniki wielkości eksportu i importu towarów oraz usług, a następnie ich udziały w PKB Indii, są w indyjskich publikacjach statystycznych oraz pracach naukowych dość często istotnie zróżnicowane. Wynika to z faktu przyjmowania do obliczeń różnych walut (głównie rupii, dolarów USA czy - po 2002 roku - euro), a także różnych cen - bieżących bądź stałych (i to $\mathrm{z}$ różnych lat). Podobnie jest z międzynarodowymi źródłami statystycznymi (takimi jak OECD, MFW, Bank Światowy, Eurostat). Różnice nie są co prawda wysokie, niemniej utrudniają analizę i porównywanie badanych zjawisk, zarówno w czasie, jak i w przestrzeni, np. w odniesieniu do wymiany z innymi krajami lub udziałami w światowym handlu. 
grupa ta stanowiła około 42 proc. globalnego woluminu eksportowego, natomiast w roku 2010/11 było to już niespełna 19 proc. Na jednakowym poziomie pozostawał eksport chemikaliów oraz kamieni szlachetnych i wyrobów z nich - wynosił w całym prawie okresie 25-27 proc. ogólnego wywozu. Zmienne były też wskaźniki struktury eksportu surowców energetycznych i energii. W latach 90. udział tych towarów nie przekraczał 10 proc. eksportu, a w drugiej połowie pierwszej dekady było to już - przeciętnie około 20 proc. Systematycznie zwiększał się eksport produktów średnio i wysoko przetworzonych, tj. wyrobów żelaznych, maszyn i urządzeń, sprzętu elektrycznego oraz środków transportowych (samochodów ciężarowych, osobowych, autobusów, taboru kolejowego). Są to więc korzystne zmiany poprawiające strukturę eksportu oraz jego efektywność ekonomiczną (m.in. terms of trade), a także pozytywnie oddziałujące na wzrost gospodarczy kraju [Jawaid, Raza, 2012]. Dodać należy, że dużą rolę w rozwoju indyjskiego eksportu odegrały licznie tworzone, szczególnie po 2004 roku, specjalne strefy ekonomiczne. Jeżeli w 2004/05 roku eksport z tych stref stanowił 4,9 proc. całego wywozu towarów z obszaru Indii, to w roku 2009/10 było to już 26,1 proc. [Datt, Mahajan, 2014, s. 822].

Tabela 5.9. Struktura eksportu towarowego Indii według grup produktów

\begin{tabular}{|l|c|c|c|c|c|}
\hline \multirow{2}{*}{ Grupy produktowe } & \multicolumn{5}{c|}{ Lata } \\
\cline { 2 - 6 } & $1990 / 91^{*}$ & $1995 / 96$ & $2000 / 01$ & $2007 / 08$ & $2010 / 11$ \\
\hline Tekstylia & 23,9 & 25,3 & 25,3 & 11,7 & 9,2 \\
\hline Żywność i inne art. rolne & 18,5 & 19,1 & 13,4 & 11,0 & 9,7 \\
\hline Chemikalia & 9,5 & 11,3 & 13,2 & 12,5 & 11,4 \\
\hline Maszyny i urządzenia & 6,0 & 5,5 & 5,8 & 9,8 & 15,6 \\
\hline Wyroby z żelaza i stali & 5,3 & 5,6 & 5,9 & 7,5 & 2,6 \\
\hline Surowce energetyczne i energia & 8,2 & 5,1 & 6,8 & 22,5 & 16,5 \\
\hline Sprzęt elektryczny & 1,3 & 2,6 & 3,6 & 5,6 & 3,5 \\
\hline Sprzęt elektroniczny & 1,3 & 2,1 & 2,4 & 2,0 & - \\
\hline Środki transportowe & 2,2 & 2,9 & 2,2 & 4,0 & 7,3 \\
\hline Metale nieżelazne & 1,2 & 1,5 & 1,4 & 1,0 & - \\
\hline $\begin{array}{l}\text { Kamienie szlachetne i półszlachetne, } \\
\text { perły oraz wyroby z nich }\end{array}$ & 16,1 & 16,6 & 16,6 & 12,0 & 16,0 \\
\hline Inne produkty & 6,5 & 2,4 & 3,4 & 0,4 & - \\
\hline
\end{tabular}

* w proc. eksportu ogółem, ceny bieżące.

Źródło: opracowanie i część obliczeń własnych na podstawie [Bhat, 2011, s. 54].

W przypadku indyjskiego importu trudniej jest dostrzec wyraźne tendencje zmian w jego strukturze, tym bardziej, że często modyfikowane są klasyfikacje i sposoby agregacji produktów w grupy towarowe. Zestawione w tab. 5.10 dane 
- poza niektórymi tylko pozycjami - nie wskazują na regularność zmian, chociaż w tym przypadku mniejszą rolę - niż w odniesieniu do eksportu - odgrywają czynniki zewnętrzne, w tym wahania koniunktury światowej.

Tabela 5.10. Struktura importu towarowego Indii według grup produktów

\begin{tabular}{|l|c|c|c|c|c|}
\hline \multirow{2}{*}{ Grupy produktowe } & \multicolumn{5}{c|}{ Lata } \\
\cline { 2 - 6 } & $1990 / 91 *$ & $1995 / 96$ & $2000 / 01$ & $2007 / 08$ & $2010 / 11$ \\
\hline Tekstylia & 1,4 & 1,6 & 1,2 & 1,0 & 0,9 \\
\hline Żywność i inne art. rolne & 1,3 & 5,9 & 2,9 & 1,6 & 2,6 \\
\hline Chemikalia & 10,1 & 16,8 & 10,7 & 5,6 & 8,8 \\
\hline Maszyny i urządzenia & 13,8 & 18,7 & 10,4 & 11,5 & 6,1 \\
\hline Wyroby z żelaza i stali & 7,1 & 5,1 & 1,6 & 3,5 & 2,9 \\
\hline Surowce energetyczne i energia & 15,3 & 23,0 & 33,2 & 34,3 & 32,8 \\
\hline Sprzęt elektryczny & 2,3 & 4,0 & 1,0 & 1,2 & 1,0 \\
\hline Sprzęt elektroniczny & - & 7,1 & 7,3 & 8,6 & 6,1 \\
\hline Środki transportowe & 3,6 & 4,5 & 2,3 & 8,0 & 3,1 \\
\hline Metale nieżelazne & 3,2 & 3,3 & 1,1 & 1,4 & 1,1 \\
\hline $\begin{array}{l}\text { Kamienie szlachetne i półszlachetne } \\
\text { perły oraz wyroby z nich }\end{array}$ & 4,9 & 5,7 & 9,5 & 3,2 & 8,9 \\
\hline Inne produkty & - & 4,3 & 18,8 & - & - \\
\hline
\end{tabular}

* w proc. importu ogółem, ceny bieżące.

Źródło: opracowanie i część obliczeń własnych na podstawie [Bhat, 2011, s. 55].

Główną pozycję w indyjskim imporcie towarowym stanowi przywóz paliw, tj. surowców energetycznych, czyli - przede wszystkim - ropy naftowej, gazu oraz produktów pochodnych. Ich udział systematycznie zwiększał się w badanym okresie. Jeśli na początku lat 90. przywóz paliw stanowił około 15 proc. wolumenu importowego Indii, to po roku 2000 przekroczył 30 proc. Drugą grupę dóbr importowych tworzą maszyny i urządzenia, których udział jest zmienny w poszczególnych latach, ale można przyjąć, że kształtuje się przeciętnie na poziomie około 10 proc. indyjskiego importu. Trzecie miejsce przypada chemikaliom - również około 10 proc. całości importu. Czwartą pozycję zajmuje sprzęt elektroniczny o udziale na poziomie 6-8 proc. łącznych przywozów. Podobne są wskaźniki udziału importu kamieni szlachetnych i wyrobów z nich (5-9 proc.). Stosunkowo pokaźną grupę stanowią inne, trudne do jednoznacznej klasyfikacji rodzajowej produkty, sprowadzane najczęściej pod wpływem doraźnych potrzeb. Niski jest natomiast przywóz tekstyliów oraz produktów rolnych (w tym żywności); nie przekraczał on w zasadzie 4 proc. ogólnej wartości importu.

Geografia indyjskiego importu towarów jest podobna do geografii eksportu, aczkolwiek różni się od niej pod względem wielkości wskaźników udziału. 
W roku 2011/12 najwięcej, bo aż 30,2 proc. przywozu (głównie paliwa) pochodziło z krajów Azji Zachodniej i Afryki Północnej (WANA). Na kolejnych miejscach lokują się: Chiny (z Hongkongiem) - 13,3 proc., Unia Europejska - 11,6 proc., kraje ASEANU - 8,6 proc. oraz Szwajcaria - 7,2 proc. Zadziwiająco niski jest udział Japonii i Korei Płd. - po około 2,5 proc. [Economic Survey 2013-14. Statistical Appendix, 2014, s. 79-84].

Analizując wymianę gospodarczą Indii z zagranicą, nie sposób nie zwrócić uwagi na jej charakterystyczną cechę, rzadką w przypadku krajów rozwijających się. Chodzi o to, że jej głównym akceleratorem stał się eksport usług. Szczególną rolę odgrywa tu - o czym wcześniej wspominano - dynamiczny rozwój offshoringu usług. Eksport usług stał się po 2000 roku wręcz specjalnością handlu zagranicznego Indii. W roku 2012/13 aż 32,8 proc. indyjskiego eksportu ogółem (towarów i usług) przypadało na usługi, podczas gdy średni światowy udział usług w eksporcie wynosił 19,8 proc. Spośród 15 największych gospodarek świata tylko Wielka Brytania legitymuje się wyższym udziałem usług w swoim eksporcie (34,9 proc.), a zbliżone wskaźniki posiadają jeszcze tylko dwa kraje, tj. USA (29,5 proc.) i Francja (28,7 proc.) [Economic Survey 2013-14. Statistical Appendix, 2014, s. 174]. W 2011 roku Indie były - według danych WTO - 8 eksporterem i 7 importerem usług na świecie [Wróbel, 2013].

Indyjski eksport usług wykazuje w pierwszej dekadzie XXI wieku jedną z najwyższych na świecie dynamik wzrostu. Przodującą rolę odgrywa w tej dziedzinie sektor IT, a dotyczy to głównie oprogramowania (IT software). Wartość jego wywozu wzrosła z 1,8 mld USD w 1997/98 roku do 75,8 mld USD w roku 2012/13, czyli ponadczterdziestokrotnie. Około 70 proc. tego wolumenu idzie do Ameryki Północnej (USA i Kanada), a blisko 20 proc. do Europy [Datt, Mahajan, 2014, s. 705]. Dokładniej skalę rozwoju eksportu usług obrazują wskaźniki zestawione w tab. 5.11.

Tabela 5.11. Podstawowe wskaźniki rozwoju eksportu indyjskich usług

\begin{tabular}{|c|c|c|c|}
\hline \multirow{2}{*}{ Lata } & \multicolumn{3}{|c|}{ Wskaźniki } \\
\cline { 2 - 4 } & $\begin{array}{c}\text { Udział eksportu } \\
\text { w produkcji usług }\end{array}$ & $\begin{array}{c}\text { Udział eksportu usług } \\
\text { w PKB }\end{array}$ & $\begin{array}{c}\text { Udział w światowym } \\
\text { eksporcie usług }\end{array}$ \\
\cline { 2 - 4 } & \multicolumn{3}{|c|}{ w proc. } \\
\hline $1990 / 91$ & 3,2 & 1,6 & 0,6 \\
\hline $1995 / 96$ & 4,5 & 2,3 & 0,6 \\
\hline $2000 / 01$ & 6,9 & 3,9 & 1,2 \\
\hline $2005 / 06$ & 12,9 & 7,8 & 2,2 \\
\hline $2008 / 09$ & 15,1 & 9,4 & 3,3 \\
\hline
\end{tabular}

Źródło: [Garg, Walia, 2013]. 
Szybko rosnące wskaźniki udziału usług w wymianie gospodarczej Indii świadczą o bardzo wysokiej dynamice rozwoju tego sektora gospodarki. Podstawową miarą tego rozwoju jest szybki wzrost udziału eksportu usług w indyjskim PKB. Udział ten - jak informuje tab. 5.11 - zwiększył się w latach 1991-2009 niemal pięciokrotnie (z 1,6 do 9,4 proc.). Blisko czterokrotnie (z 3,2 do 15,1 proc.) powiększył się udział eksportu w łącznej wartości produkcji sektora usługowego. Wypadkową tych wysokich wskaźników rozwoju jest dynamicznie rosnący udział indyjskiego eksportu usług w globalnym, tj. światowym wolumenie eksportu usług. Zwiększył się on z 0,6 proc. w 1991 roku do 3,3 proc. w 2009 roku, co jest - jak na warunki indyjskie - bardzo dobrym wynikiem. Warto zauważyć, że istotne przyspieszenie rozwoju eksportu usług nastąpiło po 2000 roku, a więc w okresie intensywnego poszerzania i pogłębiania reform gospodarczych.

$\mathrm{Na}$ zakończenie rozważań o indyjskim handlu zagranicznym zestawiono w tab. 5.12 wskaźniki udziału w światowym eksporcie grupy towarów (głównie konsumpcyjnych), kojarzonych tradycyjnie (w powszechnej niemal świadomości) z Indiami i wywożonych z tego kraju od wielu stuleci.

Tabela 5.12. Główne „tradycyjne” produkty eksportowe Indii i ich udział w światowym eksporcie

\begin{tabular}{|l|r|r|r|r|}
\hline \multirow{2}{*}{\multicolumn{1}{|c|}{ Produkty }} & \multicolumn{5}{c|}{ Lata } \\
\cline { 2 - 5 } & 1990 & 2000 & 2006 & 2011 \\
\hline Eksport ogółem* & 0,5 & 0,7 & 1,1 & 1,7 \\
\hline Herbata i pochodne & 22,1 & 14,0 & 9,1 & 14,0 \\
\hline Ryż & 6,4 & 10,2 & 14,6 & 17,9 \\
\hline Korzenie i wyroby korzenne & 7,7 & 10,3 & 13,3 & 15,3 \\
\hline Artykuły zdobnicze i akcesoria odzieżowe & 2,3 & 3,5 & 3,0 & 2,8 \\
\hline Skóra i wyroby ze skóry & 6,3 & 3,3 & 3,1 & 3,1 \\
\hline Bawełna i tkaniny bawełniane & 3,7 & 4,9 & 3,1 & 3,2 \\
\hline Perły, kamienie szlachetne i półszlachetne & 9,8 & 12,0 & 12,1 & 13,3 \\
\hline
\end{tabular}

* eksport światowy ogółem $=100,0$ proc. ceny bieżące.

Źródło: opracowanie własne na podstawie: [Economic Survey 2009-10, 2010, s. A-102-103], [Economic Survey 2012-13. Statistical Appendix, 2013, s. A-104-105].

Podstawowymi „tradycyjnymi” towarami wywożonymi z Indii są produkty o niskim stopniu przetworzenia, tj. produkty żywnościowe i surowcowe. Należą do nich herbata, korzenie, ryż, tekstylia oraz perły i kamienie szlachetne. Ich udziały w światowych obrotach kształtują się na poziomie kilkunastu proc. W przypadku innych - niewymienionych w tab. 5.12 - artykułów, udział eksportu z Indii - poza wyjątkami dla niektórych lat - nie przekracza 2 proc. światowego eksportu towarowego. 
Reasumując rozważania o indyjskiej wymianie gospodarczej z zagranicą po 1991 roku, można stwierdzić, że wykazuje ona w badanych dwóch dekadach znaczącą dynamikę rozwojową, czego syntetycznym wyrazem jest wzrost udziału indyjskiego eksportu w światowym eksporcie z 0,5 proc. w 1990 roku do 1,7 proc. w 2011 roku. Potwierdza to dobitnie opinie o stopniowym, systematycznym otwieraniu się indyjskiej gospodarki na świat i wzroście jej znaczenia w międzynarodowym podziale produkcji.

\subsection{Zatrudnienie}

O charakterze i dynamice przemian gospodarczych Indii po 1991 roku świadczą także przekształcenia w poziomie i strukturze zatrudnienia. Zatrudnienie i w ogóle sytuacja na indyjskim rynku pracy przekłada się bowiem nie tylko na dochody i warunki życia Indusów, lecz także ma dla nich szczególny wymiar społeczno-kulturowy.

W podrozdziale 5.2 scharakteryzowano zmiany struktury zatrudnienia w przekroju sektorów gospodarki (rolnictwo - przemysł - usługi). Poniżej natomiast zajmiemy się dokładniej tym zagadnieniem, ale w innej skali i odmiennych układach klasyfikacyjnych.

Analiza zatrudnienia $\mathrm{w}$ Indiach komplikuje się niestety $\mathrm{z}$ powodu braku przejrzystych i wiarygodnych danych statystycznych $\mathrm{z}$ tego zakresu dla całej gospodarki. Wynika to głównie ze słabej regulacji prawnej rynku pracy i braku odpowiednich instytucji publicznych (rządowych i stanowych), które w sposób rzetelny nadzorowałyby cały rynek pracy, a w tym także prowadziły rejestrację ruchu zatrudnionych. Dlatego też nie jest możliwa pełna, wyczerpująca analiza oraz rozpoznanie tego zagadnienia ani w skali całego kraju, ani też w poszczególnych stanach czy sektorach gospodarki.

W większości rozwijających się krajów, a w Indiach szczególnie, wyodrębnia się dwa segmenty gospodarki: nowoczesny (zorganizowany albo formalny) oraz tradycyjny (niezorganizowany albo nieformalny). Są one różnie definiowane i w dodatku granice między nimi nie są wyraźnie oznaczone, mają najczęściej charakter umowny oraz przyjmują różne wielkości w poszczególnych segmentach gospodarki i w dodatku nieustannie zmieniają się. W dalszej analizie używamy terminów: sektor zorganizowany (organised sector) oraz sektor niezorganizowany (unorganised sector). W każdym z tych sektorów można wyróżnić zatrudnienie formalne (formal employment) oraz nieformalne (informal employment). To pierwsze istnieje $\mathrm{w}$ zasadzie tylko $\mathrm{w}$ sektorze zorganizowanym. Jest to zatrudnienie regulowane - wraz z określeniem warunków pracy i wynagrodzenia - przez prawo (federalne, stanowe, branżowe, spółdzielcze itp.) lub umowy (zbiorowe, cywilnoprawne). Natomiast zatrudnienie nieformalne dominujące w sektorze nie- 
zorganizowanym nie jest objęte tego typu regulacjami i opiera się z reguły na prawie zwyczajowym oraz umowach ustnych, a najczęściej ma charakter samozatrudnienia (rolnictwo, rzemiosło, usługi itp.) [Ghose, 2011, s. 116] ${ }^{15}$.

Skala zatrudnienia nieformalnego jest w Indiach bardzo wysoka. Istniejące dane statystyczne nie są w tej dziedzinie jednolite, są to właściwie szacunki i znacząco różnią się w zależności od źródeł ${ }^{16}$. Według jednego z nich [Mehrotra, Gandhi, Sahoo, 2012, s. 6], w roku 1999/2000 łączne zatrudnienie w indyjskiej gospodarce wyniosło $396,7 \mathrm{mln}$ osób, z tego w sektorze niezorganizowanym pracowało $342,6 \mathrm{mln}$ (86,4 proc.), a w sektorze zorganizowanym $54,1 \mathrm{mln}$ (13,6 proc.). W roku 2009/10 na ogólną liczbę 460,2 mln zatrudnionych, na sektor niezorganizowany przypadło $387,3 \mathrm{mln}(84,2$ proc.), a na sektor zorganizowany - 72,9 mln osób $(15,8)$. Oznacza to, że szybciej rosło zatrudnienie w sektorze zorganizowanym i jego udział w globalnym zatrudnieniu nieznacznie zwiększył się, ale jest ogólnie bardzo niski.

Poniższa analiza dotyczy zatrudnienia formalnego w sektorze zorganizowanym i obejmuje jego obie formy własnościowe - publiczną i prywatną. Podstawą badania są dane zestawione $w$ tab. 5.13-5.15, oparte na informacjach pochodzących z oficjalnych, rządowych źródeł statystycznych.

$\mathrm{Z}$ analizy danych $\mathrm{w}$ tab. 5.13 wynika, że formalne zatrudnienie w sektorze zorganizowanym jest - jak na kilkusetmilionowe indyjskie zasoby pracy - bardzo małe, bo w badanym okresie nie przekraczało 30 mln osób. W latach 1991-2012 liczba formalnie zatrudnionych w sektorze zorganizowanym ogółem nieznacznie się zwiększyła - z 26,8 do 29,6 mln, czyli o niespełna $2,8 \mathrm{mln}$ (o 10,4 proc.).

15 Sektora nowoczesnego, czyli zorganizowanego (organised sector), nie da się jednoznacznie i precyzyjnie zdefiniować i tym samym wyznaczyć jego granic, tj. oddzielić od sektora tradycyjnego (niezorganizowanego). W Indiach zalicza się do niego wszystkie podmioty gospodarcze, które zostały urzędowo zarejestrowane i są objęte regulacjami prawa państwowego. W przybliżeniu będą to więc przedsiębiorstwa publiczne (państwowe, stanowe lub samorządu lokalnego), spółki oraz spółdzielnie. Natomiast na sektor niezorganizowany (unorganised sector) składają się podmioty o niezarejestrowanej działalności gospodarczej, czyli - z reguły - osoby fizyczne pracujące ze swoimi rodzinami. Jest to najczęściej działalność prowadzona w małych, domowych pomieszczeniach, na straganach, a nawet na ulicach czy placach. Do tego sektora zaliczani są m.in.: taksówkarze, rikszarze, uliczni rzemieślnicy, uliczna gastronomia, pośrednicy handlowi, tragarze, służba hotelowa, służba domowa, żebracy itp. Sektor niezorganizowany to także niemal całe indyjskie rolnictwo oparte na rodzinnych gospodarstwach i pracownikach najemnych. Skala tak rozumianej gospodarki niezorganizowanej jest w Indiach wyjątkowo duża.

${ }^{16} \mathrm{~W}$ badaniach wielu zjawisk gospodarczych w krajach rozwijających się często zwraca się uwagę na nieadekwatność do tamtejszej rzeczywistości wielu pojęć przyjętych w światowej ekonomii i statystyce. Dotyczy to w szczególności spraw zatrudnienia i bezrobocia. Wiele danych liczbowych z tego zakresu jest po prostu nieprawdziwych bądź stanowią ,grube” szacunki [Piasecki, 2007, s. 23]. Z tych właśnie względów zrezygnowano $\mathrm{z}$ analizy bezrobocia. W warunkach indyjskich zdefiniowanie osoby bezrobotnej, a więc także określenie skali bezrobocia, $w$ takim rozumieniu jak w ekonomii zachodniej, jest prawie niemożliwe. 
Przyrost ten jest oczywiście saldem pomiędzy napływem a odpływem do/z zatrudnienia. W dodatku dynamika tego wzrostu nie była jednakowa, w niektórych okresach, szczególnie w pierwszych latach bieżącego wieku, obserwowało się nawet bezwzględne spadki liczby zatrudnionych, czyli pracę traciło więcej osób niż ją uzyskiwało.

Tabela 5.13. Zatrudnienie formalne w gospodarce zorganizowanej (organised sector) według sektorów własnościowych

\begin{tabular}{|c|c|c|c|c|c|}
\hline \multirow{3}{*}{ Lata } & \multicolumn{3}{|c|}{ Zatrudnienie* w mln osób } & \multirow{2}{*}{\multicolumn{2}{|c|}{$\begin{array}{l}\text { W proc. zatrudnienia } \\
\text { ogółem }\end{array}$}} \\
\hline & \multirow[b]{2}{*}{ ogółem } & \multicolumn{2}{|c|}{ w tym: } & & \\
\hline & & $\begin{array}{c}\text { sektor } \\
\text { publiczny }\end{array}$ & $\begin{array}{c}\text { sektor } \\
\text { prywatny }\end{array}$ & $\begin{array}{c}\text { sektor } \\
\text { publiczny }\end{array}$ & $\begin{array}{c}\text { sektor } \\
\text { prywatny }\end{array}$ \\
\hline 1991 & 26,8 & 19,1 & 7,7 & 71,3 & 28,7 \\
\hline 1995 & 27,5 & 19,4 & 8,1 & 70,5 & 29,5 \\
\hline 1996 & 27,9 & 19,4 & 8,5 & 69,5 & 30,5 \\
\hline 1997 & 28,3 & 19,6 & 8,7 & 69,3 & 30,7 \\
\hline 1998 & 28,2 & 19,4 & 8,8 & 68,8 & 31,2 \\
\hline 1999 & 28,1 & 19,4 & 8,7 & 69,0 & 31,0 \\
\hline 2000 & 28,0 & 19,3 & 8,7 & 68,9 & 31,1 \\
\hline 2001 & 27,8 & 19,1 & 8,7 & 68,7 & 31,3 \\
\hline 2002 & 27,0 & 18,6 & 8,4 & 68,9 & 31,1 \\
\hline 2003 & 27,0 & 18,6 & 8,4 & 68,9 & 31,1 \\
\hline 2004 & 26,4 & 18,2 & 8,2 & 68,8 & 31,2 \\
\hline 2005 & 26,5 & 18,0 & 8,5 & 67,9 & 32,1 \\
\hline 2006 & 27,0 & 18,2 & 8,8 & 67,4 & 32,6 \\
\hline 2007 & 27,3 & 18,0 & 9,3 & 65,9 & 34,1 \\
\hline 2008 & 27,6 & 17,7 & 9,9 & 64,1 & 35,9 \\
\hline 2009 & 28,2 & 17,8 & 10,4 & 63,1 & 36,9 \\
\hline 2010 & 28,7 & 17,9 & 10,8 & 62,4 & 37,8 \\
\hline 2011 & 29,0 & 17,5 & 11,5 & 60,7 & 39,3 \\
\hline 2012 & 29,6 & 17,6 & 12,0 & 59,5 & 40,5 \\
\hline
\end{tabular}

* stan na dzień 31 marca każdego roku.

Źródło: opracowanie i część obliczeń własnych na podstawie: [Economic Survey 2009-10, 2010, s. A-52], [Economic Survey 2012-13. Statistical Appendix, 2013, s. A-56], [Economic Survey 2013-14. Statistical Appendix, 2014, s. 43], [Drèze, Sen, 2013, tab. A-5].

Na tak niską i w dodatku zmienną dynamikę zatrudnienia w sektorze zorganizowanym wpłynęło kilka przyczyn. Jedną z najważniejszych są przekształcenia strukturalne w indyjskiej gospodarce, a więc zmniejszanie się - bezwzględne 
i względne - zatrudnienia w tradycyjnych, zacofanych - będących pozostałością po socjalistycznej industrializacji, a nawet czasach kolonialnych - działach gospodarki, gdzie do tej pory dominowały prace proste $\mathrm{z}$ niewielkim zastosowaniem nowoczesnych technik i technologii. Dotyczyło to w zasadzie większości gałęzi przemysłu oraz usług, szczególnie w sektorze publicznym. Likwidacja, restrukturyzacja oraz modernizacja przedsiębiorstw, z reguły państwowych, sprawiały, że zapotrzebowanie na pracowników zmniejszało się. W ten sposób ograniczone zostało, jak wspomniano w rozdziale III, nadmierne, czyli tzw. socjalne zatrudnienie w sektorze zorganizowanym, aczkolwiek skala zmian była niewielka. Zrestrukturyzowane lub nowo powstające przedsiębiorstwa, szczególnie w nowoczesnych działach gospodarki, wyposażone w nowe maszyny i technologie oraz efektywniejsze systemy organizacyjne, zatrudniały znacznie mniej ludzi niż to było w okresach wcześniejszych.

Jak nietrudno dostrzec $\mathrm{w}$ tab. 5.13, w badanym dwudziestoleciu indyjskiej transformacji zatrudnienie formalne $\mathrm{w}$ sektorze zorganizowanym wzrastało jedynie w sektorze prywatnym - o 4,3 mln osób (tj. o około 55 proc.), natomiast w sektorze publicznym nastąpił spadek liczby zatrudnionych o około $1,5 \mathrm{mln}$ (o około 8 proc.). Statystyki te potwierdzają zatem zauważoną wcześniej ogólną tendencję do ograniczania się - w ramach gospodarki zorganizowanej-wielkości sektora publicznego i szybszego rozwoju sektora prywatnego, aczkolwiek różnią się co do skali tych proporcji. Na początku lat 90 . minionego wieku w sektorze prywatnym pracowało niespełna 30 proc. ogółu zatrudnionych w sektorze zorganizowanym, zaś dwadzieścia lat później, czyli na przełomie pierwszej i drugiej dekady XXI stulecia było to już 40 proc. W dalszym więc ciągu w sektorze zorganizowanym indyjskiej gospodarki dominuje sektor publiczny, ale jego rola systematycznie obniża się. Rozbieżności pomiędzy wskaźnikami udziału obu sektorów własnościowych w tworzeniu PKB a ich udziałem w globalnym zatrudnieniu wynikają po prostu z faktu odmiennej struktury produkcji w obu tych sektorach i różnej ich wydajności. W sektorze prywatnym dominują wysoko wydajne, nowoczesne branże przemysłu i usług, co z natury rzeczy przekłada się na wyższą wartość jego produkcji i tym samym wyższy udział w PKB.

$\mathrm{W}$ tab. 5.14 zestawiono dane o zmianach $\mathrm{w}$ wielkości i strukturze zatrudnienia w sektorze zorganizowanym całej indyjskiej gospodarki, to znaczy bez podziału na sektor prywatny i publiczny. Kryterium tej klasyfikacji są działy gospodarki.

Dane w tab. 5.14 wskazują, że głównym ,pracodawcą" w sektorze gospodarki zorganizowanej Indii jest segment usług publicznych określanych jako ,gospodarka komunalna, usługi społeczne oraz osobiste". Jakkolwiek w liczbach bezwzględnych w tym dziale gospodarki systematycznie wzrastało zatrudnienie, to jednak jego udział w zatrudnieniu w całej gospodarce utrzymywał w ciągu dwóch dekad transformacji na zbliżonym poziomie, tj. około 40 proc. Na drugim miejscu lokuje się przemysł, oczywiście państwowy. Jego udział w zatrudnieniu ogółem sektora zorganizowanego kształtuje się na poziomie $22-24$ proc., ze stałą, chociaż 
niewielką tendencją spadkową. Trzecią lokatę zajmuje dział określony mianem „transport, magazynowanie oraz komunikacja”, w którym udział państwa jest relatywnie wysoki. W tych wymienionych trzech segmentach gospodarki pracuje 70-75 proc. ogółu zatrudnionych w sektorze zorganizowanym.

Tabela 5.14. Zatrudnienie formalne w gospodarce zorganizowanej (organised sector) według działów (łącznie sektor publiczny i sektor prywatny)

\begin{tabular}{|c|c|c|c|c|c|c|c|}
\hline Działy gospodarki & Zatrudnienie* & 1991 & 1995 & 2000 & 2005 & 2008 & 2011 \\
\hline \multirow{2}{*}{$\begin{array}{l}\text { Rolnictwo } \\
\text { i pokrewne działy }\end{array}$} & mln osób & 1,5 & 1,4 & 1,4 & 1,5 & 1,5 & 1,4 \\
\hline & $\begin{array}{l}\text { w proc. zatrudnienia } \\
\text { ogółem }\end{array}$ & 5.6 & 5,0 & 5,0 & 5,6 & 5,4 & 4,8 \\
\hline \multirow[b]{2}{*}{ Kopalnictwo } & mln osób & 1,1 & 1,1 & 1,0 & 1,1 & 1,2 & 1,2 \\
\hline & $\begin{array}{l}\text { w proc. zatrudnienia } \\
\text { ogółem }\end{array}$ & 4,1 & 4,0 & 3,6 & 4,1 & 4,3 & 4,1 \\
\hline \multirow[b]{2}{*}{ Przemysł } & mln osób & 6,3 & 6,5 & 6,6 & 5,6 & 6,1 & 6,4 \\
\hline & $\begin{array}{l}\text { w proc. zatrudnienia } \\
\text { ogółem }\end{array}$ & 23,6 & 23,6 & 23,6 & 21,1 & 22,1 & 22,1 \\
\hline \multirow{2}{*}{$\begin{array}{l}\text { Elektryczność, } \\
\text { gaz i woda }\end{array}$} & mln osób & 0.9 & 1,0 & 1,0 & 0,9 & 0,8 & 0,9 \\
\hline & $\begin{array}{l}\text { w proc. zatrudnienia } \\
\text { ogółem }\end{array}$ & 3,7 & 3,6 & 3,6 & 3,4 & 2,9 & 3,1 \\
\hline \multirow{2}{*}{$\begin{array}{l}\text { Budownictwo } \\
\text { i projektowanie }\end{array}$} & mln osób & 1,2 & 1,2 & 1,2 & 1,0 & 0,9 & 1,0 \\
\hline & $\begin{array}{l}\text { w proc. zatrudnienia } \\
\text { ogółem }\end{array}$ & 4,5 & 4,4 & 4,3 & 3,8 & 3,3 & 3,4 \\
\hline \multirow{2}{*}{$\begin{array}{l}\text { Handel hurtowy } \\
\text { i detaliczny }\end{array}$} & mln osób & 0,5 & 0,5 & 0,5 & 0,6 & 0,6 & 0,7 \\
\hline & $\begin{array}{l}\text { w proc. zatrudnienia } \\
\text { ogółem }\end{array}$ & 1,9 & 1,8 & 1,7 & 2,3 & 2,2 & 2,4 \\
\hline \multirow{2}{*}{$\begin{array}{l}\text { Transport, } \\
\text { magazynowanie } \\
\text { i komunikacja }\end{array}$} & mln osób & 3,1 & 3,2 & 3,2 & 2,8 & 2,9 & 2,9 \\
\hline & $\begin{array}{l}\text { w proc. zatrudnienia } \\
\text { ogółem }\end{array}$ & 11,6 & 11,6 & 11,4 & 10,6 & 10,5 & 10,0 \\
\hline \multirow{2}{*}{$\begin{array}{l}\text { Finanse, } \\
\text { ubezpieczenia } \\
\text { i nieruchomości }\end{array}$} & mln osób & 1,4 & 1,6 & 1,8 & 1,9 & 2,4 & 3,1 \\
\hline & $\begin{array}{l}\text { w proc. zatrudnienia } \\
\text { ogółem }\end{array}$ & 5,2 & 5,8 & 6,4 & 7,2 & 8,7 & 10,7 \\
\hline \multirow{2}{*}{$\begin{array}{l}\text { Gospodarka } \\
\text { komunalna, usługi } \\
\text { społeczne i osobiste }\end{array}$} & mln osób & 10,7 & 11,1 & 11,3 & 11,2 & 11,2 & 11,4 \\
\hline & $\begin{array}{l}\text { w proc. zatrudnienia } \\
\text { ogółem }\end{array}$ & 39,9 & 40,2 & 40,4 & 41,9 & 40,2 & 39,4 \\
\hline
\end{tabular}

* stan na dzień 31 marca każdego roku.

Źródło: opracowanie i część obliczeń własnych na podstawie: [Economic Survey 2009-10, 2010, s. A-52], [Economic Survey 2012-13. Statistical Appendix, 2013, s. A-56]. 
Z analizy tab. 5.14 wynika, że w badanym okresie struktura indyjskiego zatrudnienia według działów gospodarki zmieniała się w niewielkim stopniu. Wyjątkiem jest tu jedynie segment usług finansowo-ubezpieczeniowych (,finanse, ubezpieczenia i nieruchomości"), którego udział w zatrudnieniu całego sektora zorganizowanego podwoił się - z 5,2 do 10,7 proc. Ponadto niewielki jest wzrost udziału zatrudnienia $w$ handlu $-\mathrm{z} 1,8-1,9$ do $2,2-2,4$ proc. Statystyka ta potwierdza zauważoną wcześniej tendencję dynamicznego rozwoju sektora usług biznesowych po reformach z pierwszych lat 90 .

Godnymi uwagi są zmiany struktury zatrudnienia według płci, co obrazują wskaźniki w tab. 5.15.

Tabela 5.15. Zatrudnienie formalne w gospodarce zorganizowanej (organised sector) według płci

\begin{tabular}{|c|c|c|c|c|c|}
\hline \multirow{3}{*}{ Lata } & \multicolumn{5}{|c|}{ Zatrudnienie* } \\
\hline & \multirow{2}{*}{$\begin{array}{l}\text { ogółem } \\
\text { w tym: }\end{array}$} & \multicolumn{2}{|c|}{ mężczyźni } & \multicolumn{2}{|c|}{ Kobiety } \\
\hline & & mln osób & $\begin{array}{l}\text { w proc. zatrud- } \\
\text { nienia ogółem }\end{array}$ & mln osób & $\begin{array}{l}\text { w proc. zatrud- } \\
\text { nienia ogółem }\end{array}$ \\
\hline 1991 & 26,8 & 23,0 & 85,8 & 3,8 & 14,2 \\
\hline 1995 & 27,5 & 23,3 & 84,7 & 4,2 & 15,3 \\
\hline 1996 & 27,9 & 23,5 & 84,2 & 4,4 & 15,8 \\
\hline 1997 & 28,3 & 23,6 & 83,6 & 4,6 & 16,4 \\
\hline 1998 & 28,2 & 23,4 & 83,4 & 4,8 & 17,0 \\
\hline 1999 & 28,1 & 23,3 & 82,9 & 4,8 & 17,1 \\
\hline 2000 & 28,0 & 23,1 & 82,5 & 4,9 & 17,5 \\
\hline 2001 & 27,8 & 22,8 & 82,0 & 5,0 & 18,0 \\
\hline 2002 & 27,0 & 22,1 & 81,9 & 4,9 & 18,1 \\
\hline 2003 & 27,0 & 22,0 & 81,5 & 5,0 & 18,5 \\
\hline 2004 & 26,4 & 21,5 & 81,4 & 4,9 & 18,6 \\
\hline 2005 & 26,5 & 21,5 & 81,1 & 5,0 & 18,9 \\
\hline 2006 & 27,0 & 21,9 & 81,1 & 5,1 & 18,9 \\
\hline 2007 & 27,3 & 22,0 & 80,6 & 5,3 & 19,4 \\
\hline 2008 & 27,6 & 22,0 & 79,7 & 5,6 & 20,3 \\
\hline 2009 & 28,2 & 22,6 & 80,1 & 5,6 & 19,9 \\
\hline 2010 & 28,7 & 22,8 & 79,4 & 5,9 & 20,6 \\
\hline 2011 & 29,0 & 23,1 & 79,7 & 5,9 & 20,3 \\
\hline 2012 & 29,6 & 23,5 & 79,4 & 6,1 & 20,6 \\
\hline
\end{tabular}

* stan na dzień 31 marca każdego roku.

Źródło: opracowanie i część obliczeń własnych na podstawie: [Economic Survey 2009-10, 2010, s. A-52], [Economic Survey 2012-13. Statistical Appendix, 2013, s. A-56], [Economic Survey 2013-14. Statistical Appendix, 2014, s. 43]. 
Jak wskazują dane w tab. 5.15, w okresie indyjskiej transformacji gospodarczej następowały zmiany struktury formalnego zatrudnienia w sektorze zorganizowanym według płci. Oczywiście wyraźnie dominował udział mężczyzn (80-86 proc.), co jest w porównaniu z większością krajów średnio rozwiniętych (nie wspominając o wysoko rozwiniętych) wskaźnikiem bardzo wysokim i wysoce nieadekwatnym do struktury globalnych zasobów pracy. Jest to w dużej mierze - jak wykazano w podrozdziałach 2.3 i 4.4 - skutkiem tradycyjnych stosunków społecznych w tym kraju, tj. dyskryminacji kobiet w życiu publicznym. Sytuacja zmienia się jednak i ta nadreprezentacja mężczyzn wśród zatrudnionych w sektorze zorganizowanym systematycznie, chociaż powoli, zmniejsza się - z niespełna 86 proc. w 1991 roku do 79-80 proc. na początku drugiej dekady XXI wieku.

W przypadku Indii rosnący udział zatrudnienia kobiet, właśnie w sektorze zorganizowanym, a więc z reguły w przedsiębiorstwach i instytucjach publicznych, ma wymiar nie tylko ekonomiczny, lecz także - a może przede wszystkim - społeczny i kulturowy. Kwestia kobiet, ich praw i miejsca w życiu publicznym - jak wyjaśniono w podrozdziałach 2.3 i 4.4 - należy do najważniejszych problemów współczesnych Indii. Stały wzrost udziału kobiet w zatrudnieniu jest dowodem na ich rosnącą aktywizację zawodową, a szerzej ujmując - emancypację. Jest to $\mathrm{w}$ istocie jeden $\mathrm{z}$ podstawowych symptomów postępu cywilizacyjnego $\mathrm{w}$ tym kraju, miara społeczno-kulturowej efektywności całej, zapoczątkowanej w 1991 roku transformacji ustrojowej gospodarki i państwa indyjskiego.

Reasumując powyższą analizę zatrudnienia, należy stwierdzić, że w okresie dwudziestolecia 1991-2012 w tej dziedzinie dokonały się w Indiach korzystne przekształcenia, aczkolwiek ich skalę oraz tempo trudno uznać za zadowalające. Wielkim problemem badań tego zagadnienia jest niedostatek wiarygodnych informacji statystycznych, szczególnie - jak wspomniano - dominującego w Indiach zatrudnienia nieformalnego $\mathrm{w}$ sektorze niezorganizowanym, włącznie z określeniem granic tego sektora. Dopóki ten niezorganizowany sektor gospodarki i życia społecznego nie zostanie objęty pełniejszą rejestracją statystyczną, jego badanie i rozpoznanie będzie bardzo utrudnione i niepełne.

\subsection{Gospodarka Indii na tle Azji i świata}

Jak wykazano w rozdziale II, w drugiej połowie lat 80 . XX wieku - w efekcie reform modernizacyjnych R. Gandhiego - został powstrzymany spadek udziału indyjskiej gospodarki w gospodarce światowej oraz kontynentu azjatyckiego, a był to proces historyczny, bo datowany od średniowiecza [Majumdar, 2012, s. 37-162, 310-312]. W ostatniej dekadzie XX stulecia rozpoczyna się proces dynamicznego wzrostu gospodarczego, w wyniku czego zwiększa się udział Indii w PKB Azji oraz świata. Dokładniej procesy ten obrazują wskaźniki zamieszczone w tab. 5.16-5.19. 
W tab. 5.16 zestawiono tempo wzrostu indyjskiego PKB ze wskaźnikami przeciętnymi dla grup krajów zagregowanych według kryterium geograficznego (dla Azji) oraz kryterium poziomu i fazy rozwoju gospodarczego ${ }^{17}$.

W pierwszych sześciu kolumnach tab. 5.16 zestawiono dynamikę wzrostu gospodarczego Indii z przeciętnymi wskaźnikami dla czterech regionów Azji, wyodrębnionymi w statystykach Konferencji Narodów Zjednoczonych ds. Handlu i Rozwoju (UNCTAD - United Nations Conference on Trade and Development). Nietrudno dostrzec, analizując je, że znacznie szybciej rozwijają się gospodarki Azji Wschodniej (głównie Chin, Korei Płd. i Tajwanu) i Południowo-Wschodniej (głównie Wietnamu, Malezji, Tajlandii, Indonezji, Singapuru) niż Azji Zachodniej (głównie Iranu, Kazachstanu, Afganistanu, Turcji i krajów arabskich) oraz Południowej (z wyłączeniem Indii, tj. Pakistanu, Sri Lanki, Bangladeszu i Nepalu), a różnice tempa wzrostu są znaczące. W tym układzie trudno wyodrębnić gospodarkę Azji Północnej, czyli w istocie Syberii, jako że jest ona częścią Rosji i nie figuruje w rocznikach statystycznych jako samodzielny obiekt statystyczny.

Tempo wzrostu indyjskiego PKB jest w całym badanym okresie najbardziej zbliżone do tempa wzrostu gospodarczego krajów Azji Wschodniej, w której dominującą rolę odgrywają Chiny. Podobna, aczkolwiek niższa, jest dynamika wzrostu gospodarczego w południowo-wschodnich krajach kontynentu.

Na podstawie danych z tab. 5.16 można sformułować tezę o podziale gospodarki Azji na dwa obszary, tj. obszar szybkiego rozwoju - Azja Wschodnia i Południowa i obszar powolnego rozwoju, czyli Azja Zachodnia. W dodatku różnice tempa wzrostu narastają, co wskazuje na pogłębianie się dystansu w poziomie rozwoju pomiędzy tymi częściami azjatyckiego kontynentu. Coraz wyraźniejszy jest podział Azji na biedny „Zachód” oraz bogaty „Wschód”, oczywiście poza wyjątkami w obu tych regionach, którymi są w Azji Zachodniej - Arabia Saudyjska, Izrael, Turcja i Emiraty nad Zatoką Perską, a w Azji Wschodniej - Laos, Birma, Kambodża i Filipiny. Indie znajdują się pośrodku tej - geograficznej i zarazem gospodarczej - konstelacji.

${ }_{17}$ Wielkim problemem w pomiarze i porównaniach międzynarodowych produktu krajowego brutto (oraz innych, pochodnych kategorii) są ceny i waluty, w jakich się go wyraża. Trudności tych nie ma w pomiarze i porównaniach PKB w jednym kraju, gdyż czyni się to zazwyczaj w walucie tego kraju. W statystyce międzynarodowej wielkości PKB wyraża się z reguły w dwóch ujęciach, tj. według kursu wymiany walut lub według parytetu siły nabywczej (PPP - Purchasing Power Parity). W tym pierwszym przypadku podstawą przeliczeń jest najczęściej bieżący kurs wymiany amerykańskich dolarów (USD) - dla porównań światowych, lub euro (€) - dla porównań europejskich. PPP jest to kurs walutowy wyliczony przez porównanie ceny (wyrażonej w walutach krajowych) sztywno ustalonego w badanych krajach koszyka towarów (czyli tych samych dóbr i usług) $\mathrm{z}$ ceną tego koszyka wyrażonego w USD (lub €). Przeważa pogląd, że teoretycznie właściwszą metodą, szczególnie w dłuższych okresach, jest wykorzystanie PPP. Z tego względu w statystykach międzynarodowych znacznie częściej stosuje się porównania PKB według PPP. W niniejszej pracy posłużono się wskaźnikami wielkości i dynamiki PKB opracowanymi według obu metod. 


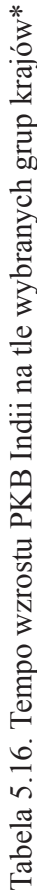

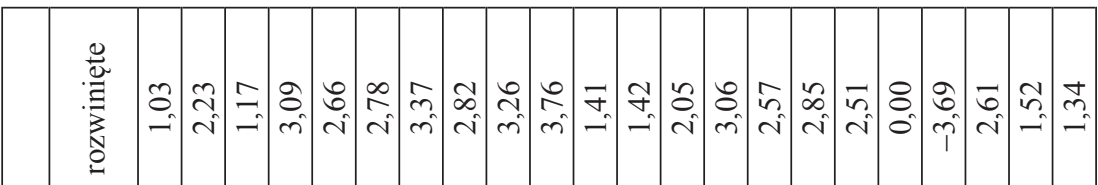

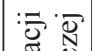

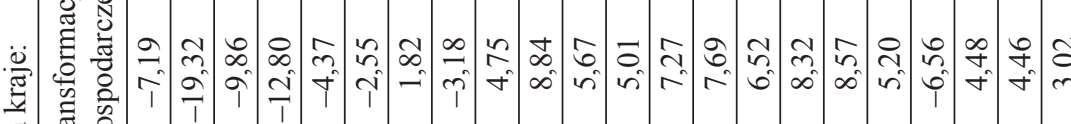
छ)

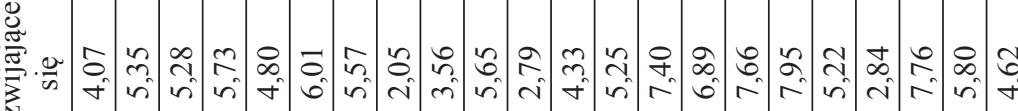
인

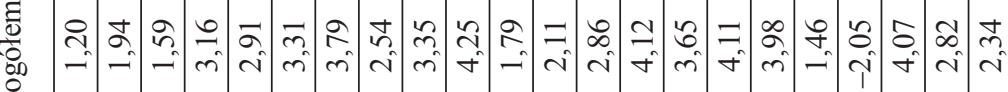

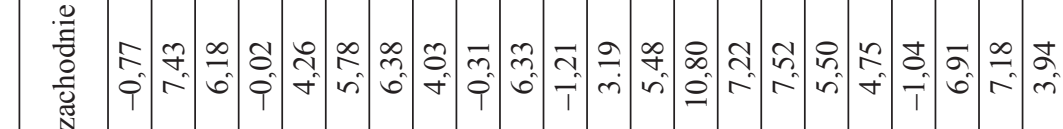

눙

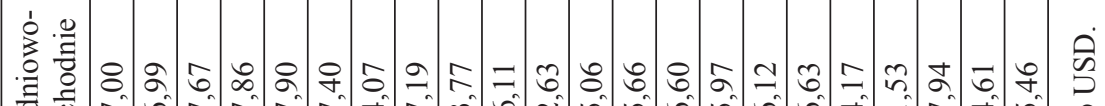

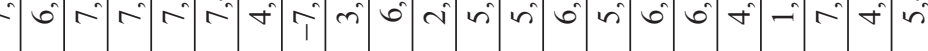

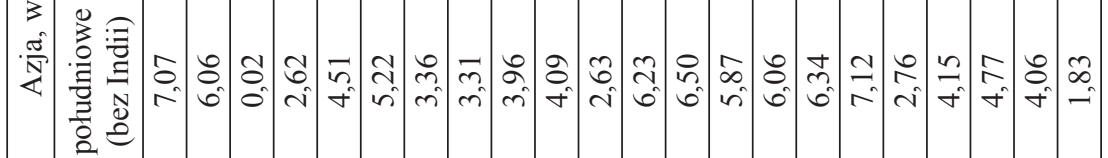

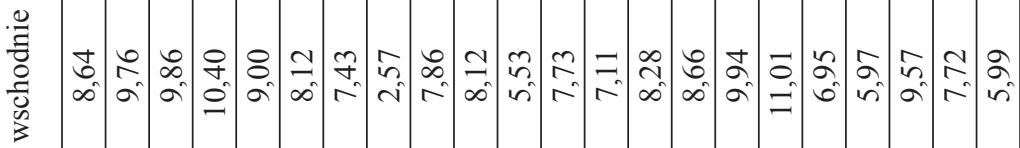

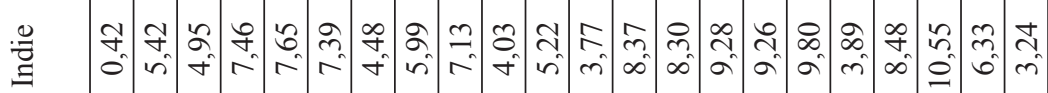


W drugiej części tab. 5.16 (ostatnie cztery kolumny) zestawiono przeciętne, roczne wskaźniki wzrostu gospodarczego dla całego świata oraz trzech typów gospodarek, tj. krajów rozwijających się (słabo rozwiniętych), krajów transformacji gospodarczej (inaczej wschodzących, tzw. emerging economies) oraz rozwiniętych ${ }^{18}$.

Porównując wskaźniki tempa wzrostu PKB Indii ze wskaźnikami dla całego świata nietrudno dostrzec, że te pierwsze były w badanym okresie (poza rokiem 1991) przeciętnie 2-3-krotnie wyższe. Oznacza to systematyczne i relatywnie szybkie odrabianie przez Indie zaległości w stosunku do gospodarki światowej. Przede wszystkim trzeba zwrócić uwagę na duże różnice tempa wzrostu, bo czasem czterokrotne (np. w latach 2005-2011), pomiędzy gospodarką indyjską a przeciętnymi wskaźnikami dla krajów rozwiniętych. Generalnie wyższym tempem wzrostu gospodarczego legitymują się Indie zarówno w porównaniu z krajami rozwijającymi się, jak i emerging econiomies, dotyczy to w szczególności ostatnich lat pierwszej dekady bieżącego stulecia. Dodać należy, że tempo wzrostu krajów rozwijających się było w okresie objętym analizą wysoce nierównomierne, cechowały je naprzemiennie głębokie spadki i wysokie przyrosty. Na te pierwsze złożyły się przede wszystkim: transformacja ustrojowa w Europie Wschodniej i wynikające $\mathrm{z}$ tego głębokie załamanie gospodarcze (lata 1991-1994), kryzys meksykański i jego skutki (1994-1995), kryzys brazylijski (1998-1999), wschodnioazjatycki (1997-1998) oraz skutki kryzysu gospodarek wysoko rozwiniętych (2008-2009).

Dokładniejszych informacji do oceny dwóch dekad transformacji gospodarczej w Indiach dostarczają porównania tempa wzrostu gospodarczego tego kraju z tempem wzrostu dużych gospodarek z bliskiego otoczenia geograficznego, tj. krajów Azji Południowej i Wschodniej oraz USA - jako największej i znacząco powiązanej z Indiami gospodarki świata. Dane statystyczne do tej analizy zestawiono w tab. 5.17.

Z porównania wskaźników tempa wzrostu PKB wyróżnionych 11 krajów w przekroju całego badanego okresu wynika, że najszybciej powiększała się gospodarka chińska, a za nią, jako druga - indyjska. Różnice tempa wzrostu były

${ }^{18}$ Podział krajów na wymienione trzy grupy nie jest jednoznaczny i rozłączny. Różni autorzy i instytucje gospodarcze przedstawiają odmienne klasyfikacje. Nie są określone np. granice pozwalające zaliczyć dany kraj do nisko rozwiniętych, ale rozwijających się czy średnio rozwiniętych i też rozwijających. Dodatkową komplikacją jest wyróżnianie tzw. emerging economies. Przyjmujemy, że emerging economies są to gospodarki (nisko lub średnio rozwinięte) znajdujące się w stadium szybkich przemian (transformacji). Cechuje je duża dynamika i potencjał rozwojowy, ale równocześnie rozwój ten jest obarczony znacznym ryzykiem finansowym (głównie walutowym) oraz politycznym. W Azji zalicza się do nich (klasyfikacja Międzynarodowego Funduszu Walutowego) m.in.: Indie, Pakistan, Turcję i większość krajów leżących w południowo-wschodniej części kontynentu. 
Tabela 5.17. Tempo wzrostu PKB Indii na tle wybranych krajów*

\begin{tabular}{|c|c|c|c|c|c|c|c|c|c|c|c|}
\hline \multirow[b]{2}{*}{ Lata } & \multicolumn{11}{|c|}{ Kraje } \\
\hline & $\stackrel{\mathscr{g}}{\stackrel{\Xi}{\Xi}}$ & 害 & 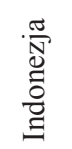 & 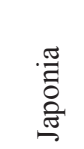 & 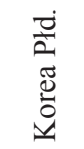 & $\frac{\frac{\pi}{N}}{\sum^{\frac{\pi}{N}}}$ & 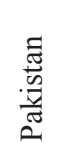 & $\begin{array}{l}\frac{\pi}{\sqrt[n]{n}} \\
\stackrel{0}{\alpha}\end{array}$ & 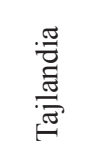 & 壹 & 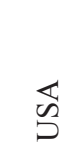 \\
\hline 1991 & 0,42 & 9,18 & - & 3,32 & 9,71 & 9,55 & 5,06 & - & 8,42 & 5,96 & $-0,04$ \\
\hline 1992 & 5,42 & 14,24 & - & 0,82 & 5,77 & 8,89 & 7,71 & - & 9,25 & 8,65 & 3,56 \\
\hline 1993 & 4,95 & 13,96 & - & 0,17 & 6,33 & 9,89 & 1,76 & $-8,70$ & 8,69 & 8,07 & 2,76 \\
\hline 1994 & 7,46 & 13,08 & - & 0,86 & 8,77 & 9,21 & 3,74 & $-12,70$ & 8,01 & 8,84 & 4,04 \\
\hline 1995 & 7,65 & 10,92 & - & 1,94 & 8,93 & 9,83 & 4,96 & $-4,10$ & 8,14 & 9,54 & 2,72 \\
\hline 1996 & 7,39 & 10,01 & - & 2,61 & 7,19 & 10,00 & 4,85 & $-3,61$ & 5,66 & 9,34 & 3,80 \\
\hline 1997 & 4,48 & 9,30 & - & 1,60 & 5,77 & 7,32 & 1,01 & 1,38 & $-2,76$ & 8,15 & 4,49 \\
\hline 1998 & 5,99 & 7,83 & - & $-2,00$ & $-5,71$ & $-7,36$ & 2,55 & $-5,34$ & $-7,65$ & 5,76 & 4,46 \\
\hline 1999 & 7,13 & 7,62 & - & $-0,20$ & 10,73 & 6,14 & 3,66 & 6,35 & 4,58 & 4,77 & 4,84 \\
\hline 2000 & 4,03 & 8,43 & - & 2,26 & 8,80 & 8,86 & 4,26 & 10,05 & 4,52 & 6,79 & 4,11 \\
\hline 2001 & 5,22 & 8,30 & - & 0,36 & 3,97 & 0,52 & 1,98 & 5,09 & 3,39 & 6,89 & 0,96 \\
\hline 2002 & 3,77 & 9,08 & - & 0,29 & 7,15 & 5,39 & 3,22 & 4,74 & 6,19 & 7,08 & 1,78 \\
\hline 2003 & 8,37 & 10,03 & - & 1,69 & 2,80 & 5,79 & 4,85 & 7,30 & 7,18 & 7,34 & 2,78 \\
\hline 2004 & 8,30 & 10,09 & 5,03 & 2,36 & 4,62 & 6,78 & 7,37 & 7,18 & 6,32 & 7,79 & 3,76 \\
\hline 2005 & 9,28 & 11,31 & 5,69 & 1,30 & 3,96 & 5,33 & 7,67 & 6,38 & 4,18 & 12,05 & 3,32 \\
\hline 2006 & 9,26 & 12,68 & 5,50 & 1,69 & 5,18 & 5,58 & 6,18 & 8,15 & 4,94 & 6,98 & 2,64 \\
\hline 2007 & 9,80 & 14,16 & 6,35 & 2.19 & 5,11 & 6,30 & 4,83 & 8,54 & 5,45 & 7,13 & 1,77 \\
\hline 2008 & 3,89 & 9,63 & 6,01 & $-1,04$ & 2,30 & 4,83 & 1,70 & 5,25 & 1,67 & 5,66 & $-0,30$ \\
\hline 2009 & 8,48 & 9,21 & 4,63 & $-5,53$ & 0,32 & $-1,51$ & 2,83 & $-7,82$ & $-0,91$ & 5,40 & $-2,79$ \\
\hline 2010 & 10,55 & 10,45 & 6,22 & 4,65 & 6,32 & 7,42 & 1,61 & 4,50 & 7,33 & 6,42 & 2,49 \\
\hline 2011 & 6,33 & 9,29 & 6,49 & $-0,58$ & 3,68 & 5,13 & 2,79 & 4,29 & 0,34 & 6,24 & 1,84 \\
\hline 2012 & 3,24 & 7,70 & 6,23 & 1,95 & 2,04 & 5,64 & 4,02 & 3,44 & 6,43 & 5,25 & 2,76 \\
\hline
\end{tabular}

* w proc. ceny stałe -2005 , według kursu walutowego USD.

Źródło: jak w tab. 5.16.

jednak dość znaczne, bo kształtowały się na poziomie $2-5$ punktów procentowych, a w pierwszych latach 90 . wynosily nawet 6-9 punktów procentowych. Oznacza to, że podobnie jak przed 1990 rokiem gospodarka chińska rozwija się szybciej niż indyjska. Indie nadal przegrywają gospodarczy wyścig i pozostają coraz bardziej w tyle za swym głównym rywalem, a niekiedy - jak w latach 60. - przeciwnikiem militarnym, na co zwraca się w tym kraju znaczną uwagę. Jest to tym bardziej istotne, że Indie doganiają Chiny pod względem demo- 
graficznym - w ciągu najbliższych dekad Indie staną się najludniejszym krajem świata. Rośnie natomiast przewaga gospodarcza Indii nad drugim, groźniejszym rywalem, jakim jest sąsiedni Pakistan. Napięcie pomiędzy Indiami a Pakistanem nie słabnie od początku istnienia obu tych państw i w każdej chwili może dojść do konfliktu zbrojnego, tak jak to było kilkakrotnie w przeszłości. Dynamika wzrostu pakistańskiej gospodarki jest - poza pierwszymi latami XX wieku - znacząco niższa od indyjskiej, co oznacza, że przewaga gospodarcza Indii nad Pakistanem systematycznie się powiększa.

Wśród badanych 10 krajów Azji, na trzecim miejscu pod względem dynamiki wzrostu PKB, lokuje się Wietnam. Znamiennym jest, że gospodarka wietnamska rozwija się wyjątkowo - na tle porównywanych krajów - równomiernie i to w wysokim tempie, wynoszącym średnio 6-9 proc. Nieznacznie tylko dotknęły ją kryzysy w latach 1997-1998 i 2008-2009, a wyraziło się to tylko zmniejszeniem tempa wzrostu do 5-6 proc. Oznacza to, że w Azji Południowo-Wschodniej - a więc na obszarze najwyższej na świecie dynamiki gospodarczej - pojawił się na początku XXI wieku nowy, duży 90-milionowy agresywny „tygrys”, który zapewne wpłynie na sytuację ekonomiczną w tym regionie Azji, a także na gospodarkę Indii.

Wysoką, w niektórych latach wyższą niż w Indiach, dynamiką wzrostu gospodarczego legitymują się: Malezja, Tajlandia oraz Korea Południowa, a w pierwszej dekadzie XX wieku do tej grupy dołączyły Indonezja oraz Rosja. Gospodarki te są jednak bardzo „wrażliwe” na kryzysy, które pochodzą albo z zewnątrz (jak w latach 2008-2009), albo też ich główne źródło tkwi w wewnątrzkrajowych zaburzeniach gospodarki (1997-1998).

Na tle wymienionych krajów słabo wypada gospodarka japońska, której roczna stopa wzrostu w badanym okresie rzadko kiedy przekraczała 2 proc., a w kilku latach następowały nawet spadki wielkości PKB.

Relatywnie wolny jest również wzrost gospodarczy USA, szczególnie po 2000 roku. Jeżeli jeszcze w latach 90. ubiegłego wieku średnie tempo wzrostu gospodarczego USA kształtowało się na poziomie 4-5 proc., to po 2000 roku tylko w dwóch latach (2004 i 2005) przekroczyło 3 proc. Lata 2008-2009 to okres poważnego kryzysu, kiedy miał miejsce spadek PKB - łącznie o około 3 proc.

Powolny wzrost dwóch czołowych gospodarek świata (USA, Japonii), przy równocześnie wysokim tempie PKB Indii oznacza, że w ciągu badanych dwóch dekad nastąpiło zmniejszenie dystansu pomiędzy nimi. Zmieniła się wskutek tego nawet kolejność największych gospodarek w światowych rankingach. Dokładniejszych danych do tej analizy dostarczają tab. 5.18-5.19.

W tab. 5.18 zestawiono wskaźniki udziału największych gospodarek w PKB całego świata; przeliczeń PKB dokonano według reguły kursu walutowego (w USD). Nietrudno dostrzec, że w okresie dwudziestolecia, tj. ostatniej dekady XX wieku i pierwszej dekady XXI stulecia, nastąpiły znaczące przesunięcia w kolejności miejsc na światowej liście czołowych gospodarek. 
Tabela 5.18. Udział Indii i wybranych krajów w PKB świata*

\begin{tabular}{|l|r|r|r|r|r|r|}
\hline \multirow{2}{*}{ Kraje } & \multicolumn{7}{c|}{ Lata } \\
\cline { 2 - 7 } & 1991 & 1995 & 2000 & 2005 & 2010 & 2012 \\
\hline Indie & 1,22 & 1,21 & 1,42 & 1,80 & 2,65 & 2,58 \\
\hline USA & 26,18 & 25,31 & 31,53 & 28,35 & 23,38 & 22,49 \\
\hline Chiny** & 1,79 & 2,49 & 3,63 & 4,92 & 9,24 & 11,50 \\
\hline Japonia & 14,92 & 17,51 & 14,40 & 9,83 & 8,53 & 8,20 \\
\hline Niemcy & 7,62 & 8,30 & 5,74 & 5,95 & 5,13 & 4,71 \\
\hline Francja & 5,26 & 5,17 & 4,04 & 4,60 & 3,99 & 3,60 \\
\hline Wielka Brytania & 4,50 & 3,88 & 4,55 & 4,99 & 3,56 & 3,40 \\
\hline Rosja & - & 1,31 & 0,79 & 1,64 & 2,94 & 2,79 \\
\hline Korea Płd. & 1,33 & 1,74 & 1,62 & 1,86 & 1,58 & 1,55 \\
\hline Tajlandia & 0,42 & 0,56 & 0,38 & 0,41 & 0,52 & 0,53 \\
\hline Pakistan & 0,24 & 0,25 & 0,23 & 0,25 & 0,27 & 0,30 \\
\hline Indonezja & - & - & 0,48 & 0,61 & 1,10 & 1,21 \\
\hline Malezja & 0,22 & 0,32 & 0,30 & 0,31 & 0,38 & 0,42 \\
\hline Australia & 1,39 & 1,29 & 1,25 & 1,63 & 2,00 & 2,15 \\
\hline
\end{tabular}

* w proc. ceny bieżące, według kursu walutowego USD, ** bez Hongkongu i Makao.

Źródło: opracowanie i obliczenia własne na podstawie [UNCTADstat (Nominal and real GDP, total and per capita, annual, 1970-2012)].

$\mathrm{Z}$ analizy wskaźników w tab. 5.18 wynika m.in., że nastąpiło obniżenie się udziału największych gospodarek w światowym produkcie brutto. Siedem największych gospodarek (pierwsze 7 krajów w tab. 5.18) wytworzyło w 1991 roku 61,5 proc. światowego PKB, a w 2012 roku było to 56,5 proc., czyli nastąpił spadek o 5 punktów procentowych. Oznacza to zmniejszanie się nierówności gospodarczych w skali świata, czyli wzrost znaczenia gospodarek średnich i małych. Uogólniając, można w świetle przytoczonych statystyk mówić o postępującej, aczkolwiek wolnej konwergencji w poziomie rozwoju gospodarczego w skali globu ziemskiego, co jest bez wątpienia zjawiskiem pozytywnym.

Znaczące, jeśli nie wręcz rewolucyjne, zmiany zaszły natomiast $\mathrm{w}$ relacjach pomiędzy wyszczególnionymi w tab. 5.18 siedmioma największymi gospodarkami świata. Szczególnie znamienny jest spadek udziału gospodarki USA w światowym PKB; z 25-30 proc. w latach 1991-2005, do 22-23 proc. na przełomie pierwszej i drugiej dekady bieżącego wieku. Najbardziej spektakularne przesunięcia w statystykach gospodarczych świata dotyczą jednak Japonii oraz Chin.

Japonia, która jeszcze na początku XXI stulecia była drugą potęgą gospodarczą świata, pod koniec pierwszej dekady ustąpiła miejsca Chinom. Jeśli w latach 
90. XX wieku gospodarka japońska wytwarzała 15-17 proc. światowego PKB, to na przełomie pierwszego i drugiego dziesięciolecia bieżącego wieku było to 8-9 proc. Jest to bez wątpienia skutek długoletniej stagnacji, a nawet okresami recesji w gospodarce tego kraju i równocześnie wysokiej dynamiki rozwoju innych gospodarek.

Odmiennie przedstawia się natomiast przypadek Chin. Wysokie i stabilne - co widać w tab. 5.17 - tempo wzrostu chińskiej gospodarki, wywindowało ją w ciągu niespełna dwóch dekad na drugą - po USA - pozycję na świecie. W 1991 roku wartość chińskiego PKB (według kursu USD) stanowiła niespełna 7 proc. PKB USA, a w 2012 roku było to już 51 proc. (por. tab. 5.18).

Systematycznie i znacząco obniżała się pozycja trzech zachodnioeuropejskich potęg gospodarczych (Niemiec, Francji i Wielkiej Brytanii), które w latach 80. i 90. XX wieku lokowały się na 3-5 miejscach w świecie, a ich łączny udział w PKB świata wyniósł 17,4 proc. Jak wskazują dane w tab. 5.18, po dwóch dekadach, tj. w 2012 roku, wskaźnik ten obniżył się do 11,7 proc.

Jednym z najbardziej zadziwiających zjawisk w światowej gospodarce pierwszych lat XXI wieku było - jak wynika z tab. 5.16-5.17 - bardzo wysokie tempo wzrostu gospodarczego Indii. Sprawiło to, że szybko zwiększał się udział indyjskiej gospodarki w światowym wolumenie produkcji dóbr materialnych i usług. W 1991 roku wynosił on zaledwie 1,2 proc. światowego PKB, a w ciągu badanych dwóch dekad wskaźnik ten podwoił się - do niemal 2,6 proc. w 2012 roku.

W dolnych wierszach tab. 5.18 zaprezentowano zmiany udziału w gospodarce świata siedmiu największych i dynamicznie rozwijających się krajów bliskich geograficznie Indiom (krajów Azji Południowej i Wschodniej oraz Australii). Wszystkie one wykazują w badanym dwóch dekadach wzrost znaczenia w gospodarce światowej, a szczególnie dotyczy to gospodarek Rosji, Australii oraz Indonezji. W latach 2000-2012 łączny udział wyróżnionych siedmiu krajów zwiększył się z 5,1 proc. do niemal 9,0 proc. PKB świata. Jest to dla gospodarki Indii bardzo korzystne, bowiem stwarza szanse kooperacji, przepływów kapitałowych oraz wymiany towarowej, tym bardziej, że są to kraje geograficznie im bliskie.

Nieco inny jest obraz roli i miejsca Indii w gospodarce światowej, gdy dokonuje się porównań gospodarek na podstawie wielkości PKB wyrażonych według reguły parytetu siły nabywczej walut (PPP). Jego zastosowanie jest - jak wcześniej zaznaczono - szczególnie wskazane z przypadku porównań PKB (globalnie lub per capita) w dłuższych okresach i w odniesieniu do krajów o bardzo zróżnicowanym poziomie rozwoju. W tego typu porównaniach otrzymujemy, dzięki zastosowaniu metody parytetu siły nabywczej walut, bardziej wiarygodne informacje niż $\mathrm{w}$ przypadku posługiwania się bieżącym kursem walutowym.

Zestawienie największych gospodarek świata wyrażonych wielkością PKB wyliczoną według reguł PPP zawiera tab. 5.19. 
Tabela 5.19. Największe gospodarki świata według wielkości PKB (PPP)*

\begin{tabular}{|l|r|r|r|r|r|}
\hline \multicolumn{1}{|c|}{ Kraj } & 1993 & 2000 & 2005 & 2010 & 2012 \\
\hline USA & 6879 & 10290 & 13095 & 14958 & 16245 \\
\hline Chiny & 1685 & 3618 & 6472 & 12110 & 14803 \\
\hline Indie & 1232 & 2150 & 3343 & 5484 & 6355 \\
\hline Japonia & 2685 & 3290 & 3890 & 4322 & 4543 \\
\hline Niemcy & 1689 & 2120 & 2566 & 3133 & 3434 \\
\hline Rosja & 953 & 1000 & 1697 & 2925 & 3386 \\
\hline Brazylia & 1109 & 1525 & 1966 & 2689 & 2891 \\
\hline Francja & 1105 & 1535 & 1861 & 2260 & 2417 \\
\hline Wielka Brytania & 1029 & 1554 & 2007 & 2150 & 2272 \\
\hline Indonezja & 674 & 921 & 1303 & 1895 & 2225 \\
\hline Włochy & 1100 & 1468 & 1657 & 1898 & 2079 \\
\hline Meksyk & 778 & 1074 & 1331 & 1729 & 1985 \\
\hline Hiszpania & 573 & 859 & 1189 & 1458 & 1503 \\
\hline Korea Płd. & 456 & 809 & 1097 & 1394 & 1501 \\
\hline
\end{tabular}

* w tys. mld USD, ceny bieżące.

Źródło: [GDP, PPP (current international \$), 2014].

Zestaw największych gospodarek świata w tab. 5.19 jest podobny do wcześniejszych (tab. 5.16-5.18). Różna jest jednak ich kolejność oraz dystanse między nimi. Największa różnica dotyczy usytuowania Indii. Według tab. 5.19 gospodarka Indii znalazła się na przełomie pierwszej i drugiej dekady XXI wieku na trzeciej pozycji w świecie - po USA i Chinach, a według tab. 5.18 była dopiero na ósmym miejscu.

W 1993 roku, a więc na początku realizacji „nowej polityki ekonomicznej”, PKB Indii (według PPP) lokował ten kraj na piątym miejscu w świecie po USA, Japonii, Niemczech i Chinach, a przed Brazylią, Francją, Wielką Brytanią oraz Włochami, przy czym różnice pomiędzy tymi krajami nie były duże (np. PKB Chin przewyższał PKB Indii o około 37 proc.). Zróżnicowana dynamika rozwojowa poszczególnych gospodarek w latach 90. sprawiła, że w 2000 roku Indie były już przed Niemcami, czyli na czwartym miejscu w świecie. Systematycznie zmniejszała się różnica pomiędzy wielkością gospodarki Indii a gospodarkami USA oraz Japonii, natomiast powiększała w stosunku do Chin. Z danych w tab. 5.19 można obliczyć, że w 1993 roku PKB Indii stanowił 18 proc. PKB USA, a w 2012 było to 39 proc. W odniesieniu zaś do Chin indyjski PKB wynosił odpowiednio 73 proc. i 43 proc., co oznacza, że w dalszym ciągu Chiny „uciekają" Indiom. 
Przesunięcie się gospodarki Indii w badanych latach 1991-2012 z piątego na trzecie miejsce w świecie i powiększanie dystansu w stosunku do tak wielkich gospodarek, jak japońska, niemiecka, francuska i brytyjska dowodzi trafności założeń „nowej polityki ekonomicznej” zapoczątkowanej w 1991 roku i - generalnie - pomyślnej jej realizacji. Indie stały się na początku XXI stulecia jednym z najważniejszych na świecie centrów wzrostu gospodarczego, wpływających istotnie na rozwój i kształt gospodarki światowej [Liberska, 2013].

W świetle teorii i praktyki współczesnego, szczególnie tzw. nowego regionalizmu (jako kategorii międzynarodowych stosunków gospodarczych), można pokusić się o uznanie Indii niemal za odrębny, samoistny region ekonomiczny i to nie tylko w odniesieniu do procesów regionalizacji w Azji, ale w ogóle podziału świata. Przemawiają za tym takie argumenty, jak wielkość kraju (powierzchnia i ludność), odrębność geograficzna (półwysep odgrodzony od Azji wysokimi górami), specyfika polityczna (największe federalne, głęboko zdecentralizowane i demokratyczne państwo świata) oraz - co najważniejsze - wielkość gospodarki, jej potencjał wytwórczy i dynamika rozwojowa ${ }^{19}$.

Rangę dokonań gospodarczych Indii po reformach z lat 1991-1992 podnosi dodatkowo to, że odbywały się one w niezwykle trudnych warunkach demograficznych, społecznych, politycznych. Przy tak ogromnej liczbie ludności i jej szybkim wzroście, zróżnicowaniu ekonomicznym i społecznym oraz konfliktach etnicznych i religijnych utrzymanie średniego, a tym bardziej - jak w ostatnich dwóch dekadach - bardzo wysokiego tempa rozwoju gospodarczego, jest nie lada fenomenem, niemającym odniesienia w najnowszej historii gospodarki światowej ${ }^{20}$.

19 Formalnie rzecz traktując, Indie są członkiem powstałego w 1985 roku Południowoazjatyckiego Stowarzyszenia Współpracy Regionalnej (South Asian Association for Regional Cooperation - SAARC). Oprócz Indii do Stowarzyszenia należą: Pakistan, Bangladesz, Sri Lanka, Nepal, Malediwy, Bhutan oraz Afganistan (od 2007 roku). Nietrudno jednak dostrzec, że pod względem ludnościowym oraz gospodarczym jest to organizacja zdominowana przez Indie. Ludność Indii stanowi 75 proc. ludności Stowarzyszenia, natomiast jeśli idzie o potencjał gospodarczy, to 82 proc. PKB SAARC przypada na Indie (według PPP - dane za 2012 rok). Szerzej na temat istoty i problemów współczesnego regionalizmu ekonomicznego (szczególnie w Azji) pisze B. Skulska [2012, s. 21-40].

${ }^{20}$ Niestety po 2011 roku obserwuje się wyraźne gaśnięcie wysokiego tempa wzrostu gospodarczego (por. tab. 5.1). W roku gospodarczym 2011/12 PKB Indii zwiększył się o 6,7 proc. w roku 2012/13 o 4,5 proc., a w roku 2013/14 o 4,7 proc. [szacunki według Economic Survey 2013-14. Statistical Appendix, 2014, s. 7]. Słabnąca koniunktura gospodarcza legła u podstaw gruntownej przebudowy indyjskiej sceny politycznej i największej w historii Indii klęski Indyjskiego Kongresu Narodowego, który zapoczątkował w 1991 roku radykalne reformy gospodarki oraz państwa i zdynamizował je w okresie swoich dwukadencyjnych rządów (2004-2014). W wyborach parlamentarnych w kwietniu i maju 2014 IKN uzyskał samodzielnie zaledwie 44 miejsca w 545-osobowej izbie niższej (543 posłów z bezpośrednich wyborów oraz 2 tzw. Anglo-Indusów mianowanych przez prezydenta republiki). IKN stracił aż 162 mandaty. Zaskakująco wysokie zwycięstwo odniosła Indyjska Partia Ludowa (BJP), zdobywając 282 mandaty, czyli o 166 więcej niż w 2009 roku. Władzę 
Dodać trzeba, że rozwój Indii nie tylko w ostatnich dwóch dekadach, ale w całym okresie ich niepodległości, odbywał się w warunkach demokracji i - generalnie - gospodarki rynkowej ${ }^{21}$. W dodatku oba te składniki ustrojowe, tj. demokracja i rynek, nie były nigdy poważnie zagrożone ani tym bardziej obalone, jak to miało miejsce w większości nowych, postkolonialnych państw Azji i Afryki, a nawet krajów Ameryki Łacińskiej, które z systemu kolonialnego wyszły jeszcze w XIX wieku.

przejęła koalicja partii prawicowych i nacjonalistycznych pod nazwą Narodowy Sojusz Demokratyczny (zdominowana przez BJP), dysponująca łącznie 336 miejscami w parlamencie. Na klęskę IKN - pomimo ewidentnych sukcesów makroekonomicznych w przekroju całych dwóch kadencji jego rządów - złożyło się skumulowanie następujących zjawisk: a) wspomniane osłabienie tempa wzrostu gospodarczego i nikłe szanse na jego przywrócenie; b) wysoka, z reguły towarzysząca dużej dynamice wzrostu, inflacja - bardzo dokuczliwa dla warstw biednych, szczególnie ludności wiejskiej; c) zaniedbanie rolnictwa i obszarów wiejskich; d) deprecjacja rupii; e) restytucja biurokracji oraz szerzące się skandale korupcyjne na wszystkich szczeblach organizacji gospodarki i państwa; f) liczne konflikty na linii kapitał krajowy-kapitał zagraniczny (BIZ); g) narastająca przestępczość; h) kłopoty z napływającymi imigrantami (głównie z Bangladeszu). W wyniku wyborów parlamentarnych w 2014 roku na czele rządu federalnego stanął przewodniczący BJP, od 2001 roku gubernator Gujaratu - najszybciej rozwijającego się stanu Indii (por. tab. 6.1) - Narendra Modi [Bonikowska, 2014].

${ }^{21}$ Indusi z dumą podkreślają, że Indie są od zarania niepodległości „największą demokracją świata”. Słowo „największa” wywodzi się oczywiście od liczby ludności kraju i wynikającej z tego liczby wyborców. Potwierdziły to wybory w 2014 roku, gdy spośród $815 \mathrm{mln}$ uprawnionych do głosowania, do lokali wyborczych przybyło około 67 proc. z nich, czyli prawie $550 \mathrm{mln}$ osób. 


\section{ROZDZIAL VI}

\section{REGIONALNY I SPOLECZNY WYMIAR ROZWOJU GOSPODARCZEGO PO 1991 ROKU}

\subsection{Regionalne zróżnicowanie wzrostu gospodarczego}

Reformy ekonomiczne oraz decentralizacja państwa indyjskiego po 1991 roku wpłynęły - jak wykazano w poprzednim rozdziale - na dynamikę i strukturę gospodarki rozumianej jako całość. Wraz z upływem lat zmieniały się nie tylko wielkości makroekonomiczne, ale przeobrażeniom ulegała także struktura przestrzenna gospodarki. Łącząc te dwa wątki - gospodarczy i geograficzny - można mówić o regionalnych następstwach indyjskiej transformacji, które są przedmiotem analizy w niniejszym rozdziale ${ }^{1}$.

\subsubsection{Dynamika wzrostu gospodarczego stanów}

W rozdziale III stwierdzono, na podstawie analizy rosnącego udziału przedstawicieli partii regionalnych w składzie parlamentu Indii, że po 1991 roku szybko postępuje proces regionalizacji życia politycznego i społecznego. Potwierdzają to także inne badania i obserwacje [Förstmann, Gregosz, 2010]. Wśród przyczyn tego zjawiska na czołowym miejscu wymienia się decentralizację władzy publicznej, której wyrazem jest utworzenie w 1992 roku samorządowego szczebla lokalnego i nadanie mu znacznych kompetencji. W tym kontekście pojawia się pytanie, czy w ślad za regionalizacją polityczno-społeczną następują zmiany w przestrzeni gospodarczej Indii, to znaczy m.in., czy zachodzą w niej procesy dywergencji czy konwergencji?

Empirycznym wyrazem tego zjawiska będą zmiany regionalnego zróżnicowania tempa wzrostu oraz poziomu rozwoju gospodarczego. Analiza taka przeprowadzona zostanie - podobnie jak w rozdziale II - w oparciu o podział kraju na stany, ale $\mathrm{z}$ uwzględnieniem zmian $\mathrm{w}$ ich liczbie i granicach dokonanych w 2000 roku. Pominięto osiem małych stanów leżących w północno-wschod-

${ }^{1}$ Podrozdziały 6.1 i 6.2 są zmienioną i szeroko rozbudowaną wersją artykułu autora niniejszej monografii opublikowanego w „Studiach Ekonomicznych” [Bywalec, 2013]. 
niej części kraju, lub też - podobnie jak poprzednio - ujęto je jako całość pod nazwą Trójkąta Assamskiego. Z uwagi na znikome znaczenie dla gospodarki indyjskiej, z analizy wyłączono także terytoria unijne, natomiast uwzględniono - z uwagi na dużą i rosnącą rangę gospodarczą - utworzone w 1991 roku Delhi Narodowe Terytorium Stołeczne (Delhi NCT - Delhi National Capital Territory).

Za początkową, wyjściową datę do analizy zmian w geografii gospodarczej Indii przyjęto - podobnie jak w rozdziale V - rok 1993/94, gdyż wtedy rozpoczynało się wdrażanie większości reform zarówno na poziomie federalnym, jak i stanowym oraz lokalnym. Oznacza to, że badany okres wynosi zazwyczaj 18-20 lat. Jest to więc dostatecznie długi przedział czasu, aby można było zmierzyć, zdiagnozować oraz próbować ocenić skutki reform gospodarki i ustroju terytorialnego dla rozwoju przestrzennego Indii.

W tab. 6.1 zestawiono wskaźniki dynamiki produktu społecznego netto poszczególnych stanów Indii (Net State Domestic Product) dla całego badanego okresu 1993/94-2011/12². Wskaźniki te wyrażono w dwóch postaciach: jako indeksy jednopodstawowe (rok 1993/94 = 100,0) oraz jako indeksy łańcuchowe (rok poprzedni $=100,0)$ Te pierwsze będą ułatwiać analizę trendów wzrostu gospodarczego stanów, czyli wyrażać trajektorię „oddalania się” wielkości produktu społecznego stanów netto od jego wielkości początkowej (czyli z roku 1993/94), natomiast te drugie (łańcuchowe) dostarczają informacji o rocznych zmianach (tempie wzrostu) tegoż produktu w poszczególnych stanach.

Analiza tab. 6.1 wskazuje na - generalnie - wysoką dynamikę wzrostu gospodarczego indyjskich stanów. Jest ona jednak zróżnicowana w poszczególnych stanach, a także zmienna w czasie.

Jeżeliby porównać wzrost produktu społecznego netto poszczególnych stanów ze wzrostem produktu krajowego netto Indii, który w latach 1993/94-2011/12 wyniósł 337,5 proc., to w 9 stanach wskaźniki wzrostu były wyższe niż średnie krajowe. Do tych stanów zaliczają się: Andhra Pradesh, Bihar, Delhi NCT, Goa, Gujarat, Haryana, Himachal Pradesh, Maharashtra i Tamil Nadu.

Zbliżonym do średniego krajowego wzrostem gospodarczym w latach 1993/94-2011/12, tzn. zamykającym się w granicach 317,5-337,5 proc., legitymują się: Karnataka, Kerala, Rajasthan i Bengal Zachodni. Wyraźnie słabszy od średniego krajowego, tzn. poniżej 317,5 proc., jest natomiast wzrost gospodarczy takich stanów, jak: Chhattisgarh, Jharkhand, Jammu \& Kashmir, Madhya Pradesh, Punjab, Orissa i - przede wszystkim - Uttar Pradesh - największy ludnościowo stan Indii.

2 Termin Net State Domestic Product tłumaczymy jako produkt stanowy netto lub produkt społeczny stanu netto, zaś Net Domestic Product to produkt krajowy netto (PKN) i jest on sumą produktu społecznego netto całego kraju, czyli stanów, Delhi NCT oraz terytoriów unijnych. 


\begin{tabular}{|c|c|c|c|c|c|c|c|c|c|c|c|c|c|c|}
\hline & $\bar{a}=$ & กิ & $\begin{array}{l}0 \\
\stackrel{0}{\circ}\end{array}$ & $\begin{array}{l}0 \\
\dot{y} \\
d\end{array}$ & $\stackrel{m}{\stackrel{m}{g}}$ & कृ & $\stackrel{M}{\Xi}$ & है & $\stackrel{+}{\exists}$ & 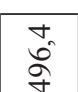 & $\begin{array}{l}\dot{I} \\
\stackrel{I}{I}\end{array}$ & $\begin{array}{l}0 \\
\text { ì }\end{array}$ & $\begin{array}{l}n \\
0 \\
0 \\
0\end{array}$ & $\begin{array}{l}0 \\
\vec{\exists} \\
\vec{\exists}\end{array}$ \\
\hline & $\stackrel{\partial}{\grave{d}}=$ & 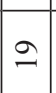 & बे & $\begin{array}{l}{ }_{i}^{\infty} \\
\vec{d}\end{array}$ & $\overrightarrow{\underline{n}}$ & $\stackrel{m}{m}$ & İ & 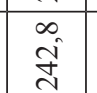 & 仓े & $\begin{array}{l}0 \\
\text { in } \\
\text { sat }\end{array}$ & $\begin{array}{l}\infty \\
\stackrel{0}{0} \\
\stackrel{0}{a}\end{array}$ & 를 & $\vec{\varrho}$ & d্ \\
\hline & ఫ్రిऽ & $\stackrel{\infty}{\oplus}$ & $\overrightarrow{8}$ & $\begin{array}{l}\infty \\
\text { î } \\
\text { ते }\end{array}$ & 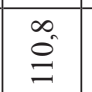 & $\begin{array}{l}0 \\
\text { on } \\
\text { o. } \\
\text { ind }\end{array}$ & बे & $\begin{array}{l}\text { tr } \\
\stackrel{d}{\text { th }}\end{array}$ & $\stackrel{\circ}{\Xi}$ & $\begin{array}{l}\infty \\
\stackrel{+}{+} \\
\vec{a}\end{array}$ & $\stackrel{m}{\Xi}$ & $\overrightarrow{0}$ & $\begin{array}{l}\text { U. } \\
\text { I }\end{array}$ & 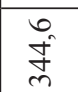 \\
\hline & के & $=$ & 气̂ & $\begin{array}{l}0 \\
0 \\
0\end{array}$ & $\begin{array}{l}\text { ñ } \\
\stackrel{2}{\Rightarrow}\end{array}$ & ठे & $\begin{array}{l}0 \\
\overbrace{}^{\circ}\end{array}$ & है & $\begin{array}{l}\stackrel{n}{\Xi} \\
\cong\end{array}$ & $\begin{array}{l}\text { id } \\
\text { id }\end{array}$ & $\begin{array}{l}{ }_{0}^{\infty} \\
\stackrel{0}{\sigma}\end{array}$ & हो & $\begin{array}{l}m \\
\dot{0}\end{array}$ & $\begin{array}{l}0 \\
8 \\
0\end{array}$ \\
\hline & $\overrightarrow{\sigma_{0}} \infty$ & $\because$ & $\stackrel{n}{\Xi}$ & $\begin{array}{l}n \\
n \\
n\end{array}$ & $\begin{array}{l}n \\
\tilde{a} \\
0\end{array}$ & $\begin{array}{l}0 \\
\text { aे } \\
\text { ad }\end{array}$ & $\overrightarrow{\stackrel{0}{\circ}}$ & ${ }_{0}^{m}$ & $\stackrel{m}{\exists}$ & $\begin{array}{l}\infty \\
\vec{j}\end{array}$ & 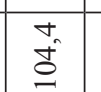 & $\begin{array}{l}\text { हे } \\
\text { हे }\end{array}$ & $\begin{array}{l}{ }^{\infty} \\
\stackrel{\equiv}{\Xi}\end{array}$ & बू. \\
\hline & ఫั่ & $\because$ & $\hat{\varrho}$ & बें & $\begin{array}{l}\stackrel{\circ}{\Rightarrow} \\
\Rightarrow\end{array}$ & ठे & $\begin{array}{l}\ddot{\theta} \\
\Rightarrow\end{array}$ & 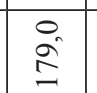 & $\stackrel{+}{\mathfrak{I}}$ & $\overrightarrow{\vec{\alpha}}$ & $\begin{array}{l}\infty \\
\dot{g}^{\circ}\end{array}$ & $\overrightarrow{\mathrm{g}}$ & 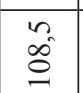 & $\begin{array}{l}\text { I } \\
\text { d̂d }\end{array}$ \\
\hline & ટ્વેః & \pm & $\hat{\mathrm{g}}$ & 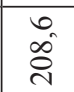 & $\begin{array}{l}\stackrel{+}{8} \\
\stackrel{8}{8}\end{array}$ & 苞 & 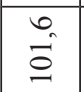 & $\begin{array}{l}\text { ta } \\
\text { 音 }\end{array}$ & $\stackrel{?}{\varrho}$ & $\begin{array}{l}\text { ỹ } \\
\text { ñ }\end{array}$ & $\stackrel{m}{\stackrel{m}{a}}$ & $\begin{array}{l}\text { तె } \\
\tilde{N}\end{array}$ & $\begin{array}{l}\text { 年 } \\
\stackrel{J}{=}\end{array}$ & $\begin{array}{l}\infty \\
\vec{d} \\
\vec{d}\end{array}$ \\
\hline & 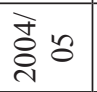 & 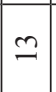 & $\begin{array}{l}0 \\
\stackrel{8}{0}\end{array}$ & $\begin{array}{l}n \\
\stackrel{2}{\Omega}\end{array}$ & $\stackrel{\partial}{\Xi}$ & ह̂े & 㖪 & 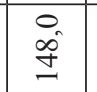 & 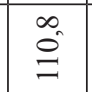 & 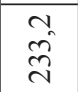 & $\hat{\stackrel{\theta}{g}}$ & $\overrightarrow{\mathrm{d}}$ & $\begin{array}{l}{ }_{0}^{\infty} \\
\stackrel{0}{\varrho}\end{array}$ & $\stackrel{\cong}{\bar{N}}$ \\
\hline & 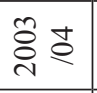 & $\simeq$ & $\widehat{\vec{g}}$ & Iे & 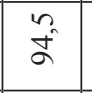 & $\begin{array}{l}\dot{0} \\
\dot{n} \\
\end{array}$ & 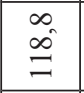 & 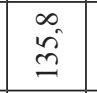 & $\begin{array}{l}0 \\
\stackrel{0}{0}\end{array}$ & $\begin{array}{l}\tilde{n}_{0} \\
\tilde{s}_{0}\end{array}$ & $\begin{array}{l}\text { 京 } \\
\stackrel{8}{\circ}\end{array}$ & 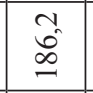 & $\hat{\widehat{\sigma}}$ & बे \\
\hline ป & ఫ્రે & $=$ & बें & $\begin{array}{l}n \\
\hat{s} \\
\underline{6}\end{array}$ & $\begin{array}{l}0 \\
\stackrel{I}{\Xi}\end{array}$ & $\bar{~}$ & $\vec{a}$ & $\stackrel{\text { m }}{\stackrel{\text { f }}{J}}$ & $\begin{array}{l}n \\
\hat{n}^{2} \\
\stackrel{2}{2}\end{array}$ & $\begin{array}{l}0 \\
\stackrel{\circ}{\Omega} \\
\Omega\end{array}$ & \begin{tabular}{l|}
$\vec{\circ}$ \\
$\stackrel{8}{\circ}$
\end{tabular} & $\begin{array}{l}m \\
\stackrel{n}{I}\end{array}$ & $\begin{array}{l}\overrightarrow{0} \\
\stackrel{\Delta}{a}\end{array}$ & 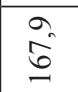 \\
\hline & 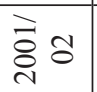 & $\cong$ & 管 & $\begin{array}{l}\vec{\infty} \\
\stackrel{2}{n}\end{array}$ & fo & $\begin{array}{l}n \\
n \\
\dot{q}\end{array}$ & छे & $\stackrel{\stackrel{m}{2}^{2}}{\Rightarrow}$ & 商 & 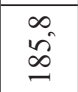 & बे & \begin{tabular}{l}
$m$ \\
m \\
\multirow{6}{*}{}
\end{tabular} & $\overrightarrow{\stackrel{0}{g}}$ & 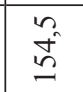 \\
\hline & ఫ্ণ ప & $a$ & $\overrightarrow{\stackrel{0}{\circ}}$ & $\overrightarrow{\tilde{n}}$ & $\begin{array}{l}n \\
\stackrel{n}{0} \\
=\end{array}$ & 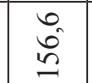 & $\begin{array}{l}\infty \\
\dot{\alpha}\end{array}$ & $\stackrel{0}{\stackrel{0}{8}}$ & 气̆ & $\vec{E}$ & dे & $\overrightarrow{\bar{\infty}}$ & बू & $\begin{array}{l}\overrightarrow{\mathrm{I}} \\
\text { (1) }\end{array}$ \\
\hline & 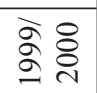 & $\infty$ & I & $\hat{\bar{q}}$ & $\begin{array}{l}\stackrel{0}{\circ} \\
\stackrel{\leftrightarrow}{a}\end{array}$ & $\begin{array}{l}+t \\
\text { f }\end{array}$ & $\begin{array}{l}\infty \\
\infty \\
\infty \\
\infty\end{array}$ & $\begin{array}{l} \\
\stackrel{0}{\circ} \\
\stackrel{8}{a}\end{array}$ & $\begin{array}{l}0 \\
\stackrel{0}{0}\end{array}$ & 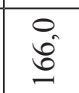 & \begin{tabular}{l|} 
\\
\\
$\vdots$ \\
$\vdots$ \\
$\vdots$
\end{tabular} & $\begin{array}{l}0 \\
0 \\
0\end{array}$ & $\begin{array}{l}\text { tr. } \\
\stackrel{8}{8}\end{array}$ & 官 \\
\hline & ळু & $r$ & $\begin{array}{l} \pm \\
\stackrel{J}{\Xi}\end{array}$ & $\begin{array}{l}0 \\
\text { sin } \\
\Leftrightarrow\end{array}$ & $\begin{array}{l}m \\
\stackrel{2}{0} \\
\stackrel{0}{0}\end{array}$ & 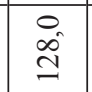 & 离 & $\stackrel{\circ}{\Xi}$ & $\begin{array}{l}0 \\
\stackrel{u}{\varrho}\end{array}$ & $\begin{array}{l}\hat{\infty} \\
\stackrel{\infty}{n} \\
\stackrel{n}{n}\end{array}$ & 窇 & 胥 & 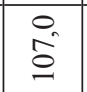 & $\begin{array}{l}+ \\
\\
\end{array}$ \\
\hline & 奈文 & 6 & $\stackrel{t}{a}$ & $\begin{array}{l}0 \\
\stackrel{\infty}{=} \\
=\end{array}$ & $\alpha^{2}$ & $\begin{array}{l}\text { t. } \\
\text { đิ }\end{array}$ & $\hat{\varrho}$ & $\begin{array}{l}m \\
\stackrel{m}{a} \\
\stackrel{a}{a}\end{array}$ & 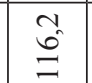 & $\overline{\vec{n}}$ & $\begin{array}{l} \\
\stackrel{+}{\Phi}\end{array}$ & $\frac{m}{m}$ & $\begin{array}{l}0 \\
\dot{8}\end{array}$ & 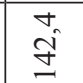 \\
\hline & よั & in & ठे & $\stackrel{\vec{\partial}}{=}$ & $\begin{array}{l}n \\
\text { aे } \\
\text { and }\end{array}$ & 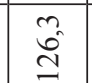 & 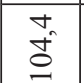 & 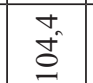 & 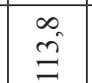 & $\begin{array}{l}0 . \\
\text { di }\end{array}$ & فे & $\begin{array}{l}0 \\
0 \\
0\end{array}$ & $\begin{array}{l}n \\
\triangleq \\
\Rightarrow\end{array}$ & 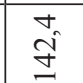 \\
\hline & گूँ̊ & 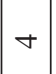 & 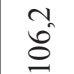 & $\overrightarrow{\mathfrak{I}}$ & तें & $\begin{array}{l}0 \\
\stackrel{0}{\circ}\end{array}$ & $\begin{array}{l}\stackrel{0}{0} \\
\stackrel{0}{0}\end{array}$ & $\stackrel{0}{\circ}$ & $\begin{array}{l}\stackrel{n}{0} \\
\stackrel{0}{0}\end{array}$ & $\stackrel{N}{ \pm}$ & $\stackrel{0}{\stackrel{0}{a}}$ & $\stackrel{\cong}{\Xi}$ & $\stackrel{0}{\stackrel{8}{g}}$ & $\begin{array}{l}0 \\
\tilde{\jmath} \\
\tilde{\jmath}\end{array}$ \\
\hline & 吾え & $m$ & $\begin{array}{ll}0 \\
\stackrel{0}{0}\end{array}$ & $\begin{array}{l}0 \\
\ddot{8} \\
\stackrel{0}{0}\end{array}$ & $\begin{array}{ll}m \\
0_{0}^{2} \\
0\end{array}$ & ma & & 1 & $\begin{array}{l}n \\
\mathfrak{I} \\
\exists\end{array}$ & $\stackrel{n}{\tilde{I}}$ & 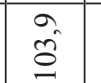 & $\vec{\rho}$ & ¿े & Oे \\
\hline & 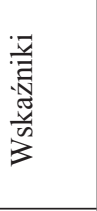 & 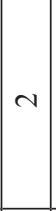 & 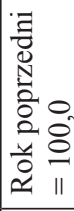 & 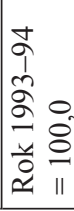 & 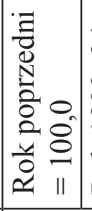 & 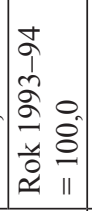 & 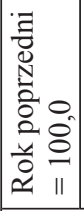 & 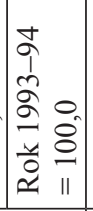 & 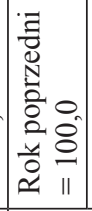 & 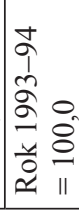 & 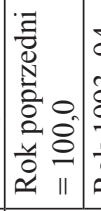 & 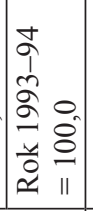 & 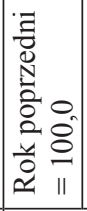 & 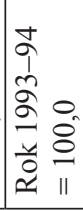 \\
\hline & 善 & - & & & & 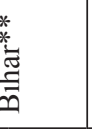 & & & & & 气ू & & & \\
\hline
\end{tabular}




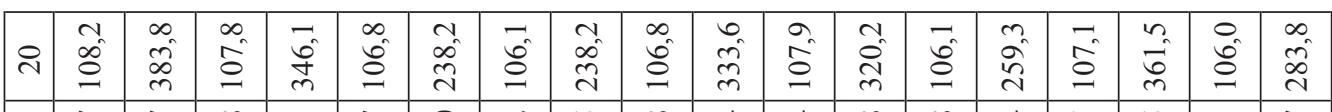

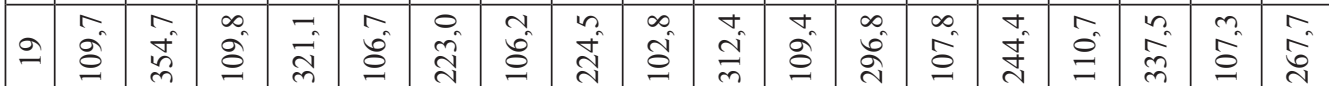

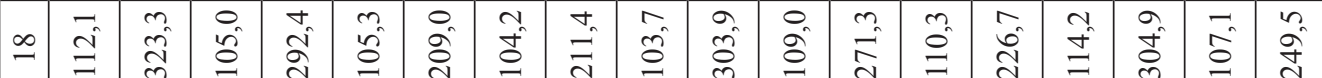

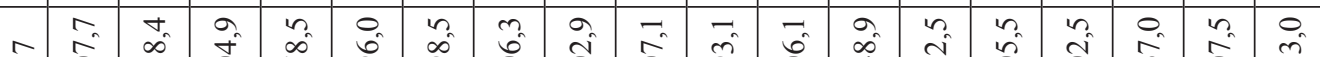

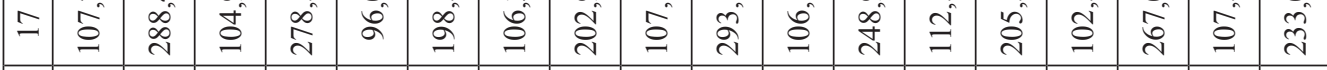

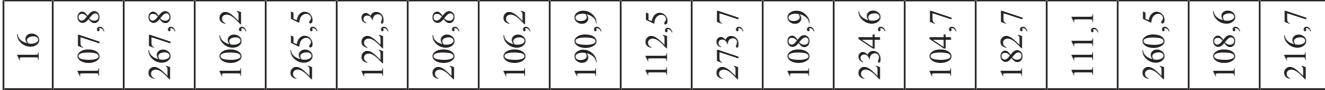

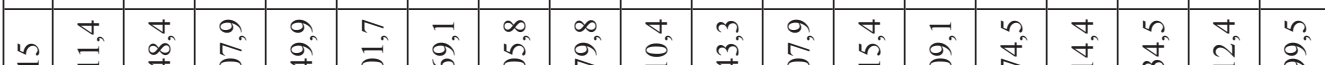

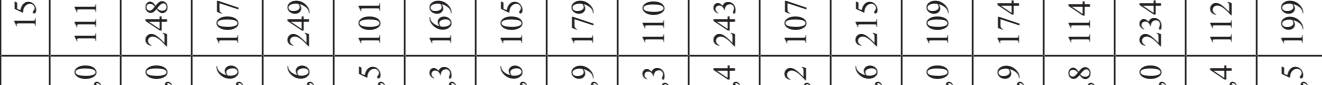

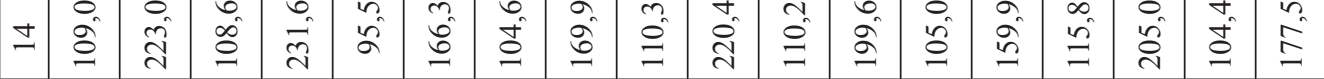

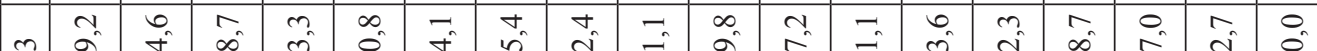

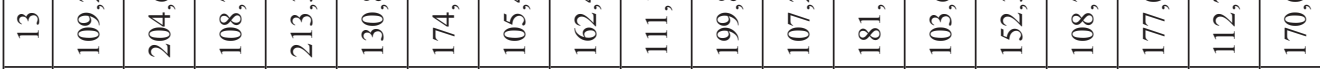

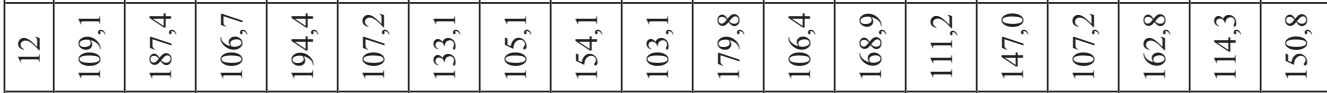

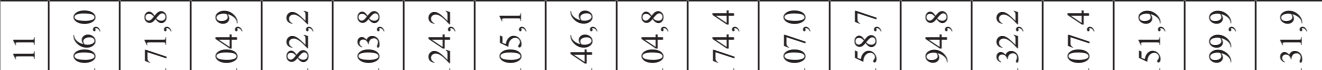

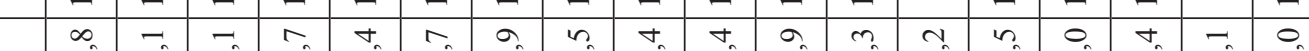

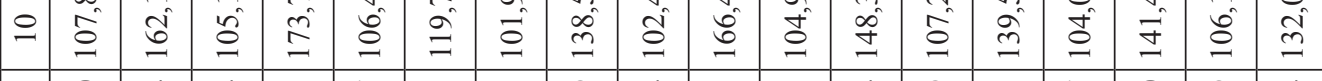
क्र

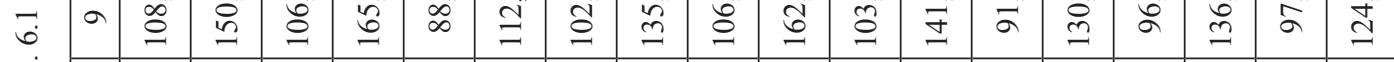

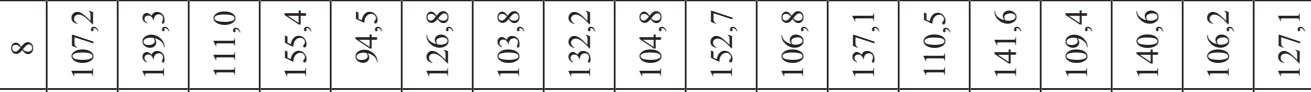

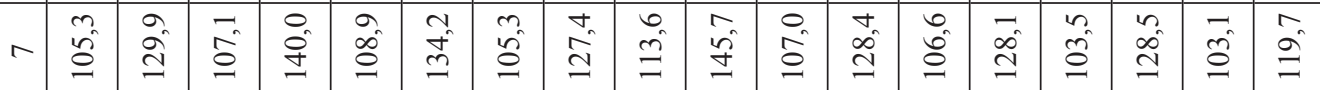

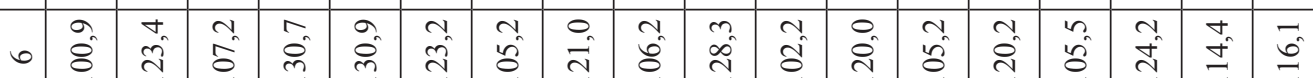

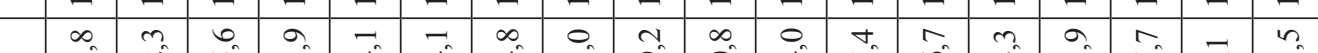

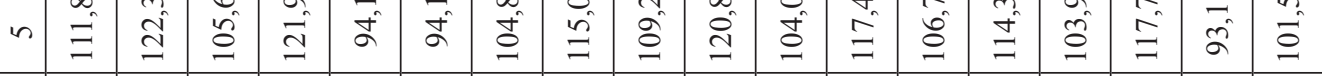

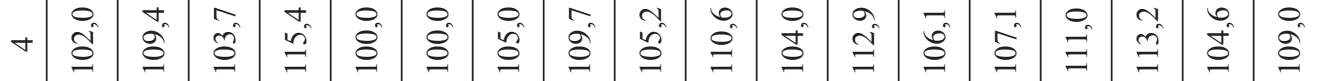

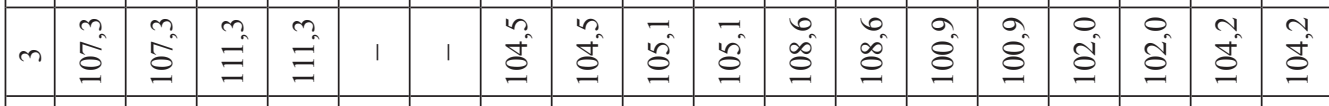

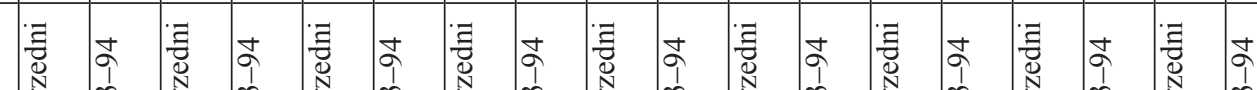
v है 긍

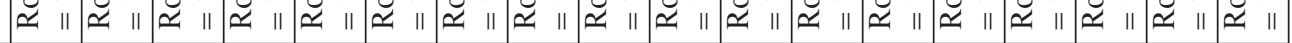

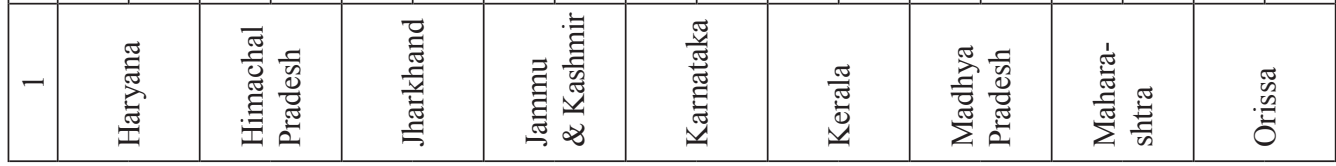


Dlaczego w jednych stanach miał miejsce wysoki wzrost gospodarczy, a w innych był znacznie niższy? Do pierwszej grupy stanów, a więc tych o najwyższej dynamice wzrostowej, zaliczają się bowiem wysoko rozwinięte - Delhi NCT, Goa, Gujarat, Haryana i stan najbiedniejszy - Bihar. Są w tej grupie zarazem stany bardzo duże, Maharashtra czy Tamil Nadu, jak i jeden z najmniejszych stanów - Goa. Podobnie wygląda sytuacja w grupie stanów najwolniej rozwijających się, do których należy wielki Uttar Pradesh, stany średnie - Himachal Pradesh, Jammu \& Kashmir oraz bogaty Punjab, nie wspominając już o bardzo małych stanach Trójkąta Assamskiego.

Jedną z ważnych determinant wzrostu gospodarczego indyjskich stanów po reformie lat 1991-1992 była zapewne ich ówczesna pozycja startowa, tj. wielkość i struktura gospodarki oraz poziom jej rozwoju na początku lat 90 . Aby zweryfikować tę tezę, wyliczono współczynnik korelacji liniowej pomiędzy wartością wytworzonego w poszczególnych stanach produktu społecznego netto w roku 1993/94 a wskaźnikami dynamiki jego wzrostu w latach 1993/94-2010/11 (tzn. wielkością wskaźników dynamiki w każdym stanie w roku 2010/11, przy przyjęciu za 100,0 wartości produktu społecznego netto w roku 1993/94). Wyjściowe dane do obliczeń współczynnika korelacji oraz jego wartość podano w tab. 6.2.

Wartość współczynnika korelacji $\left(r_{x v}\right)$ pomiędzy wielkością produktu społecznego netto stanów w 1993/94 roku a jego dynamiką w latach 1993/94-2010/11 wyniosła 0,643 , co oznacza, że pomiędzy badanymi zmiennymi występuje umiarkowanie silna zależność liniowa. Poprawność oszacowania została potwierdzona testem istotności dla tej wartości współczynnika³. Obliczony na podstawie uzyskanej wartości współczynnika korelacji współczynnik determinacji $\left(W_{d}\right)$ wyniósł 41,3 proc., co oznacza, że zmienność dynamiki produktu stanowego netto w latach 1993/94-2010/11 była w 41,3 proc. określana przez jego wartość wyjściową (czyli z roku 1993/94) ${ }^{4}$.

Przeprowadzona analiza korelacyjna pozwala twierdzić, że ważną rolę w rozwoju regionalnym Indii po 1991 roku odegrał ,czynnik historyczny (dziedziczny)", czyli nagromadzony we wcześniejszych okresach potencjał gospodarczy rozumiany szeroko, czyli jako kapitał rzeczowy, a także społeczno-kulturowy. Poza tym stany duże mają większe - niż stany małe - możliwości różnego manewrowania czynnikami produkcyjnymi, ponieważ posiadają ich więcej i są one bardziej

${ }^{3}$ Dla obu wyliczonych współczynników korelacji (tzn. w ujęciu globalnym i per capita) przeprowadzono weryfikację hipotezy $H_{0}$, która wykazała, że przy 16 stopniach swobody (n-2) i poziomie istotności 0,05 wartość statystki $|t|>t_{\alpha}(3,356$ i 3,828 > 3,252). Oznacza to, że pomiędzy badanymi zmiennymi istnieje związek przyczynowo-skutkowy.

${ }^{4}$ Analiza korelacji pomiędzy wielkością produktu stanowego netto per capita (jako miarą poziomu rozwoju gospodarczego) w 1993/94 roku a jego dynamiką w latach 1993/94-2010/11 będzie przeprowadzona w podrozdziale 6.2. Dane wyjściowe do tej analizy - ze względów praktycznych - zestawiono w tab. 6.2. 
Tabela 6.2. Korelacja pomiędzy wielkością produktu społecznego netto stanów - globalnie i per capita (NSDP i NSDP per capita) w roku 1993/94 roku a wskaźnikami dynamiki ich wzrostu w latach 1993/94-2010/11

\begin{tabular}{|c|c|c|c|c|}
\hline \multirow{3}{*}{ Stany } & \multicolumn{2}{|c|}{ Produkt stanowy netto globalnie } & \multicolumn{2}{|c|}{ Produkt stanowy netto per capita } \\
\hline & $\begin{array}{c}\text { 1993/94 } \\
\text { w mld rupii* }\end{array}$ & $\begin{array}{c}\text { dynamika } \\
\text { w latach } \\
\text { 1993/94-2010/11, } \\
\text { 1993/94 = 100,0 }\end{array}$ & $\begin{array}{c}1993 / 94 \\
\text { w rupiach* }\end{array}$ & $\begin{array}{c}\text { dynamika } \\
\text { W latach } \\
\text { 1993/94-2010/11, } \\
\text { 1993/94 = 100,0 }\end{array}$ \\
\hline & $\mathrm{X}$ & $\mathrm{Y}$ & $\mathrm{X}$ & $\mathrm{Y}$ \\
\hline Andhra Pradesh & 517 & 322 & 7447 & 259 \\
\hline Bihar & 342 & 332 & 3810 & 238 \\
\hline Delhi NCT & 188 & 446 & 18023 & 280 \\
\hline Goa & 20 & 337 & 15602 & 211 \\
\hline Gujarat & 426 & 379 & 9796 & 281 \\
\hline Haryana & 194 & 355 & 11090 & 248 \\
\hline Himachal Pradesh & 42 & 321 & 7364 & 247 \\
\hline Jammu \& Kashmir & 55 & 224 & 6543 & 155 \\
\hline Karnataka & 370 & 312 & 7835 & 249 \\
\hline Kerala & 239 & 297 & 7938 & 251 \\
\hline Madhya Pradesh & 459 & 244 & 6537 & 175 \\
\hline Maharashtra & 1018 & 338 & 12290 & 253 \\
\hline Orisa & 159 & 268 & 4797 & 211 \\
\hline Punjab & 271 & 233 & 12714 & 171 \\
\hline Rajasthan & 290 & 307 & 6192 & 213 \\
\hline Tamil Nadu & 516 & 324 & 8952 & 278 \\
\hline Uttar Pradesh & 778 & 217 & 5256 & 166 \\
\hline West Bengal & 484 & 296 & 6781 & 238 \\
\hline $\begin{array}{l}\text { Współczynniki } \\
\text { korelacji }\end{array}$ & \multicolumn{2}{|c|}{$r_{x y}=0,643$} & \multicolumn{2}{|c|}{$r_{x y}^{1}=0,691$} \\
\hline $\begin{array}{l}\text { Współczynniki } \\
\text { determinacji } \\
\left(r^{2} \times 100\right)\end{array}$ & \multicolumn{2}{|c|}{$W_{d}=41,3$ proc } & \multicolumn{2}{|c|}{$W_{d}^{1}=47,8$ proc. } \\
\hline
\end{tabular}

* wielkości produktu stanowego oraz wskaźniki dynamiki zaokrąglano do pełnych liczb, ceny stałe - jak w tab. 6.1.

Źródło: opracowanie i obliczenia własne na podstawie danych w tab. 6.1 oraz 6.8. Procedura wyliczeń współczynników korelacji według [Domański (red.), 2001, s. 171, 185-186]. 
zróżnicowane. Znacznie większe są też możliwości pozyskiwania kapitału zewnętrznego przez duże stany, który zazwyczaj lokuje się tam, gdzie ma sprzyjające otoczenie gospodarcze (m.in. klimat społeczny, mniejszą biurokrację), lepszą infrastrukturę, korzystniejsze perspektywy rozwoju (m.in. podaż pracy, rynki zbytu itp.). Nie bez znaczenia są również regionalne tradycje i wynikające z nich stosunki polityczne, co wpływa na preferencje gospodarcze władz i sposób zarządzania stanami. Dokładniejsza analiza gospodarki oraz systemów politycznych w poszczególnych stanach dowodzi, że tak się właśnie dzieje [Kohli, 2012, s. 153-156; Antahal, 2009].

Duży wpływ na rozwój gospodarek stanowych ma także ich struktura, czyli udział poszczególnych sektorów w tworzeniu produktu społecznego. Chodzi tu przede wszystkim o relacje pomiędzy sektorem I (rolnictwo i pokrewne działy), sektorem II (przemysł, budownictwo i rzemiosło) oraz sektorem III (usługi). Różne proporcje tych sektorów w tworzeniu produktu społecznego stanów oraz zróżnicowane tempo ich zmian będą silnie oddziaływać na dynamiką całej gospodarki stanowej, a ostatecznie na kształtowanie się jej miejsca na mapie gospodarczej Indii. Zmieniająca się struktura produktu społecznego stanu świadczy o zróżnicowanej dynamice rozwojowej tych sektorów. Wzrost udziału któregoś z sektorów dowodzi wysokiego tempa jego rozwoju, znacznie wyższego niż w przypadku pozostałych sektorów. Kształtowanie się sektorowych proporcji gospodarki w poszczególnych stanach przedstawiają wskaźniki zestawione w tab. 6.3.

Jak wynika $\mathrm{z}$ tab. 6.3, we wszystkich stanach $\mathrm{w}$ obu badanych latach (1999/2000 i 2011/12) najwyższy udział w tworzeniu produktu społecznego ma sektor III (usługi). Udziały te są jednak różne w poszczególnych stanach i trudno jest dostrzec jakąś prawidłowość w tym względzie. Wysokim odsetkiem usług w tworzeniu produktu społecznego legitymują się zarówno stany wysoko rozwinięte gospodarczo (np. Karnataka - 73,2 proc., Tamil Nadu - 77,6 proc., Kerala - 82,5 proc., Delhi NCT - 93,4 proc.), jak i stany gospodarczo zacofane (np. Bihar $-77,4$ proc. czy West Bengal - 70,8). Wynika to zapewne z wielu przyczyn, wśród których główną rolę odgrywa także poziom rozwoju pozostałych dwóch sektorów - rolniczego i przemysłowego. W tych stanach, gdzie jest bardziej rozwinięte rolnictwo (np. Punjab, Haryana, Madhya Pradesh), a szczególnie przemysł (Maharashtra, Jharkhand, Gujarat, Chhattisgarh, Goa), tam z natury rzeczy udział usług jest niższy.

Analizę dynamiki gospodarczej indyjskich stanów znacząco ułatwi zestawienie ich najwyższych i najniższych wskaźników wzrostu zamieszczone w tab. 6.4, będące pochodną obliczeń przedstawionych w tab. 6.1. Tabela 6.4 umożliwia zorientowanie się w zmianach tempa wzrostu gospodarczego stanów nie tylko w całym badanym okresie, ale także w dwóch krótszych podokresach: pierwszym - charakteryzującym lata 90. i zamykającym się datą 2000/01 oraz drugim - obejmującym pierwsze dziesięciolecie XXI wieku. 
Tabela 6.3. Struktura wytwarzania produktu stanowego netto (NSDP) według sektorów gospodarki*

\begin{tabular}{|l|c|c|c|c|c|c|}
\hline \multirow{2}{*}{ Stany } & \multicolumn{3}{|c|}{$1999 / 2000$} & \multicolumn{3}{c|}{$2011 / 2012$} \\
\cline { 2 - 7 } & sektor I & sektor II & sektor III & sektor I & sektor II & sektor III \\
\hline Andhra Pradesh & 30,5 & 14,9 & 54,6 & 20,2 & 13,5 & 66,3 \\
\hline Assam & 37,4 & 12,2 & 50,4 & 23,7 & 10,4 & 65,9 \\
\hline Bihar & 34,4 & 7,9 & 57,7 & 17,6 & 5,0 & 77,4 \\
\hline Chhattisgarh & 27,1 & 27,1 & 45,8 & 19,9 & 27,0 & 53,1 \\
\hline Delhi NCT & 1,7 & 11,4 & 86,9 & 0,7 & 5,9 & 93,4 \\
\hline Goa & 11,8 & 30,3 & 57,9 & 4,2 & 31,6 & 64,2 \\
\hline Gujarat & 17,7 & 30,9 & 51,4 & 13,3 & 28,0 & 58,7 \\
\hline Haryana & 33,6 & 19,4 & 47,0 & 17,1 & 17,3 & 65,6 \\
\hline Himachal Pradesh & 25,0 & 14,7 & 60,3 & 15,6 & 18,3 & 66,1 \\
\hline Jharkhand & 18,1 & 37,4 & 44,5 & 19,5 & 23,6 & 56,9 \\
\hline Jammu \& Kashmir & 33,7 & 8,5 & 57,8 & 20,6 & 10,3 & 69,1 \\
\hline Karnataka & 29,4 & 14,2 & 56,4 & 16,1 & 10,7 & 73,2 \\
\hline Kerala & 20,8 & 10,4 & 68,8 & 9,4 & 8,1 & 82,5 \\
\hline Madhya Pradesh & 31,5 & 15,3 & 53,2 & 24,2 & 16,6 & 59,2 \\
\hline Maharashtra & 16,8 & 21,0 & 62,2 & 8,7 & 25,6 & 65,7 \\
\hline Orissa & 32,5 & 14,5 & 53,0 & 18,4 & 17,3 & 64,3 \\
\hline Punjab & 40,0 & 15,6 & 44,4 & 24,1 & 22,3 & 53,5 \\
\hline Rajasthan & 31,7 & 15,6 & 52,7 & 24,0 & 16,6 & 59,4 \\
\hline Tamil Nadu & 17,9 & 25,6 & 56,5 & 7,9 & 14,5 & 77,6 \\
\hline Uttar Pradesh & 36,9 & 14,4 & 48,7 & 23,4 & 12,6 & 64,0 \\
\hline Uttarakhand & 31,5 & 10,9 & 57,6 & 11,6 & 21,4 & 67,0 \\
\hline West Bengal & 31,8 & 10,6 & 57,6 & 18,8 & 10,5 & 70,7 \\
\hline
\end{tabular}

* w proc., produkt stanowy netto $(\mathrm{NSDP})=100,0$, ceny stałe.

Źródło: opracowanie i obliczenia własne na podstawie: [Handbook of Statistics on the Indian Economy 2007-08, 2008, tab. 7], [Handbook of Statistics on the Indian Economy 2012-13, 2013, tab. 7].

Analizując tab. 6.4, nietrudno dostrzec, że najwyższą dynamikę rozwojową wykazywały stany północno-zachodnie. Wśród sześciu najszybciej rozwijających się stanów Indii, aż pięć znajduje się w tym właśnie regionie i są to stany bardzo różniące się wielkością powierzchni oraz gospodarki. Do grupy tej należy m.in. największy gospodarczy stan Indii (Maharashtra) oraz jeden z najmniejszych (Goa). Stan szósty - Bihar leży w północno-wschodnich Indiach. Z wyłączeniem Biharu - najbiedniejszego stanu - pozostałe pięć stanów należy do najbardziej rozwiniętych regionów Indii, aczkolwiek różna jest ich struktura gospodarcza i inne czynniki rozwoju. Generalnie o ich wysokiej pozycji ekonomicznej i dynamice zadecydował szybki rozwój przemysłu i/lub sektora usługowego, 
aczkolwiek proporcje udziału tych sektorów w rozwoju były różne w poszczególnych stanach. W każdym z tych najszybciej rozwijających się stanów znacząco obniżył się w badanym okresie udział rolnictwa, co było po części - jak wykazano w rozdziale V - efektem zaniedbań tego sektora. Dotyczy to także Haryany, traktowanej - wraz z sąsiednim Punjabem - jako spichlerz Indii - w roku 1999/2000 rolnictwo tworzyło niemal 34 proc. produktu społecznego tego stanu, a w roku 2011/12 wskaźnik ten wyniósł 17 proc. Nieznacznie obniżył się w pierwszej dekadzie bieżącego wieku udział przemysłu, natomiast znacząco wzrósł udział usług - do prawie 66 proc. produktu społecznego netto Haryany. Na tak szybkie przemiany, i to w niedługim czasie (10 lat), w znaczącym stopniu wpłynęła wyjątkowo wysoka dynamika rozwoju sąsiadującego z Haryaną okręgu stołecznego (Delhi NCT), w którym ponad 90 proc. produktu społecznego wytwarza sektor trzeci. W największym gospodarczo stanie Indii - Maharashtrze - lokomotywą rozwojową były również usługi, których udział w produkcie społecznym przekroczył na początku drugiej dekady XXI wieku 70 proc. Nie zmienił się praktycznie udział przemysłu, który wytwarza prawie 21 proc. produktu stanowego. Podobnie jak w przypadku Harayny, znacząco obniżył się w produkcie społecznym Maharashtry udział rolnictwa - spadł poniżej 10 proc.

Tabela 6.4. Najszybciej i najwolniej rozwijające się gospodarczo stany Indii

\begin{tabular}{|l|l|l|l|}
\hline \multirow{2}{*}{ Lp. } & \multicolumn{3}{|c|}{ Dynamika wzrostu produktu stanowego netto* } \\
\cline { 2 - 4 } & \multicolumn{3}{|c|}{ Stany najszybciej rozwijające się } \\
\hline \multicolumn{4}{|c|}{ 2000/01-2011/12 } \\
\hline 1 & Delhi (496) & Delhi (177) & Uttarakhand (287) \\
\hline 2 & Gujarat (412) & Himachal Pradesh (165) & Delhi (281) \\
\hline 3 & Haryana (384) & Karnataka (163) & Maharashtra (266) \\
\hline 4 & Goa (379) & Haryana (162) & Gujarat (266) \\
\hline 5 & Bihar (376) & Goa (158) & Chhattisgarh (263) \\
\hline 6 & Maharashtra (362) & Bihar (157) & Haryana (255) \\
\hline \multicolumn{4}{|c|}{ Stany najwolniej rozwijające się } \\
\hline 1 & Trójkąt Assamski (252) & Madhya Pradesh (136) & West Bengal (202) \\
\hline 2 & Punjab (248) & Uttar Pradesh (127) & Trójkąt Assamski (199) \\
\hline 3 & Madhya Pradesh (244) & Trójkąt Assamski (127) & Madhya Pradesh (188) \\
\hline 4 & Jharkhand (238) & Orissa (124) & Punjab (184) \\
\hline 5 & Jammu \& Kashmir (238) & Jharkhand (113) & Uttar Pradesh (182) \\
\hline 6 & Uttar Pradesh (230) & Chhattisgarh (103) & Jammu \& Kashmir (175) \\
\hline
\end{tabular}

* w nawiasach wskaźniki wzrostu zaokrąglone do pełnych liczb, w proc.

Źródło: opracowanie i obliczenia własne na podstawie tab. 6.1. 
Nietypowo przedstawiają się zmiany w gospodarce szybko rozwijającego się Biharu, zaliczanego - oprócz większości stanów Trójkąta Assamskiego - do najbiedniejszych w Indiach. Dzięki wysokiej stopie wzrostu stan ten zmniejszył dystans do pozostałych regionów Indii. Jest to stan niemal pozbawiony przemysłu - legitymuje się zaledwie 5-procentowaym udziałem sektora przemysłowego $\mathrm{w}$ tworzeniu produktu stanowego. O jego wysokiej dynamice przesądza szybki wzrost sektora usługowego, którego udział w tworzeniu produktu społecznego przekroczył na przełomie pierwszej i drugiej dekady bieżącego stulecia 77 proc., co lokuje ten stan w gronie pięciu najbardziej „zserwicyzowanych” stanów Indii (o udziale usług w produkcie stanowym powyżej 70 proc.). Bardzo wysokiego udziału usług $\mathrm{w}$ tworzeniu produktu społecznego Biharu - przy równocześnie nikłym udziale przemysłu - nie można bynajmniej oceniać pozytywnie i traktować jako przejaw szybkiej modernizacji. Usługi te mają zazwyczaj mało walorów nowoczesności, bowiem dominują w nich tzw. usługi niskiego rzędu, jak nad wyraz rozbudowane instytucje służby domowej, sprzedaży obnośnej, handlu i gastronomii ulicznej, ulicznych usług osobistych (fryzjerstwo, naprawy), prostych usług transportowych itp.

Czynnikiem pobudzającym rozwój dużych, dobrze rozwiniętych i w miarę sprawnie zarządzanych stanów, jest możliwość pozyskiwania inwestycji zagranicznych, które - jak wykazano w rozdziale $\mathrm{V}$ - znacząco zwiększyły się po 2004 roku. Napływowi bezpośrednich inwestycji zagranicznych (BIZ) sprzyja tworzenie po 2005 roku znacznej liczby specjalnych stref ekonomicznych (SSE). Duża część BIZ jest właśnie lokowana w obrębie tych stref. Analiza przestrzennego rozmieszczenia SSE oraz napływu BIZ wskazuje, że kapitał - zarówno krajowy jak i zagraniczny - lokuje się przede wszystkim na obszarach uprzemysłowionych, z dobrą infrastrukturą oraz wykwalifikowanymi zasobami pracy. Wykazano wysoką korelację $\left(r_{x y}>0,8\right)$ pomiędzy wielkością produkcji przemysłowej oraz - szerzej - produktem społecznym stanów a liczbą zlokalizowanych na ich terenie specjalnych stref ekonomicznych [za: Chari, Pandit, 2010]. Ścisłą czołówkę pod względem wielkości napływających BIZ stanowią kolejno: Maharashtra, Gujarat, Karnataka, Tamil Nadu oraz Delhi NCT. Cechą tych obszarów jest względnie dobrze rozwinięty przemysł oraz komplementarne do niego usługi informatyczne, telekomunikacyjne i finansowe oraz duża podaż wykwalifikowanych kadr. Na drugim końcu listy stanów pod względem napływu inwestycji zagranicznych znajdują się natomiast: stany Trójkąta Assamskiego, Bihar, Orissa, Madhya Pradesh, Uttar Pradesh, Jammu \& Kashmir i Rajasthan. Jak nietrudno dostrzec, są to stany północne, zachodnie oraz północno-wschodnie, a więc tereny słabo rozwinięte gospodarczo, niekorzystnie zlokalizowane (trudne warunki klimatyczne - pustynie, góry, częste klęski żywiołowe, słaba infrastruktura oraz bliskość granicy z Pakistanem - narażone na działania zbrojne, liczne konflikty etniczne i religijne) [Mallick, 2011; Mukim, Nunnenkamp, 2012]. 
Z kolei do stanów o najniższej dynamice wzrostu produktu społecznego w obu wyróżnionych podokresach zalicza się jeden z najbardziej rozwiniętych - Punjab oraz większość stanów leżących w centralnej oraz północno-wschodniej części Indii, czyli stanów biednych - wchodzących w skład Trójkąta Assamskiego, Uttar Pradesh, Madhya Pradesh, a także leżący na północno-zachodnich kresach Indii - Jammu \& Kashmir. Cechą wspólną tej grupy stanów jest - pomimo różnego poziomu rozwoju - duży, znacznie przekraczający średnie krajowe (20-25 proc. w roku 2011/12) udział rolnictwa w tworzeniu stanowych produktów społecznych, przy równocześnie niskim (z wyjątkiem Punjabu) - wyraźnie poniżej średniego poziomu dla kraju - udziale sektora przemysłowego (10-17 proc.).

Ważnym elementem badań rozwoju regionalnego jest analiza jego cykliczności. Chodzi o uzyskanie wiedzy o naturze tej zmienności, czyli - konkretnie ujmując - stwierdzenie, czy poszczególne regiony rozwijają się w rytmie jakichś swoich, im właściwych cyklów, czy cykle te są do siebie zbliżone, jakie są ich amplitudy, jaka jest relacja cykli regionów do cykliczności rozwoju całej gospodarki itp. [Domański, 2012, s. 31-33].

Analiza tab. 6.1 wskazuje na znaczną cykliczność (fazowość) rozwoju gospodarczego indyjskich stanów. Jej wypadkową jest oczywiście rozwój gospodarczy kraju - przedstawiony w podrozdziale 5.1. W rozwoju tym wyróżniono - przypomnijmy - trzy fazy: 1) lata 1993/94-1996/97, 2) 1997/98-2003/04, 3) 2004/052011/12. W jakim stopniu ta właśnie cykliczność całej gospodarki jest związana $\mathrm{z}$ fazami rozwojowymi stanów?

Z tab. 6.1 wynika, że wzrost gospodarczy stanów miał na ogół niejednakowe sekwencje faz, a w odniesieniu do niektórych stanów różnice były znaczące. Generalnie jednak cykliczność rozwoju gospodarczego większości stanów była podobna do cykliczności całej indyjskiej gospodarki. Różne było oczywiście nasilenie zmian w poszczególnych latach czy okresach, ale na ogół zjawiska miały zbliżony przebieg. Wyjątek mogą stanowić gospodarki dwóch sąsiadujących ze sobą północno-wschodnich stanów, tj. Biharu i Jharkhandu (wydzielonego w 2000 roku z Biharu) oraz Rajasthanu - położonego w północno-zachodniej części kraju. W Biharze roczne przyrosty produktu społecznego netto cechowały się, głównie do połowy pierwszej dekady XXI wieku, dużymi, niemal corocznymi skokami, a były to naprzemiennie bardzo wysokie przyrosty - sięgające 15-25 proc. (lata: 1996/97, 2000/01, 2006/07) oraz jego 4-7-procentowe spadki (lata: 1995/96, 2001/02, 2003/04). Po 2006 roku wzrost ten stabilizuje się na wysokim poziomie (10-19 proc.), co generalnie sprawiło (por. tab. 6.1), że w całym badanym okresie, przyrost produktu społecznego netto Biharu należał do najwyższych w skali kraju. Natomiast w Jharkhandzie latami wyjątkowo wysokich przyrostów (20-30 proc.) były: 1997/98, 2004/05 oraz 2007/08, zaś spadki (4-12 proc.) wystąpiły w latach 1996/97, 1990/2000, 2005/06 i 2008/09. Zjawisko to tłumaczyć należy dużą - bodaj największą w Indiach - rolą czynników klimatycznych, czyli szczególnie dużymi, niemal corocznymi powodziami, będącymi efektem monsunów i ogromnej 
ilości wód niesionych w tym czasie na równinne tereny obu stanów przez rzeki spływające z Himalajów. Czynią one wielką szkodę w rolnictwie odgrywającym dużą rolę w obu tych stanach (por. tab. 6.3). W przypadku Rajasthanu, którego większość powierzchni zajmują pustynie i półpustynie, uciążliwością są z kolei susze, co negatywnie wpływa na tamtejsze rolnictwo, mające - podobnie jak w Biharze i Jharkhandzie - duże znaczenie dla gospodarki tego stanu.

Do stabilnie rozwijających się stanów, to znaczy wykazujących podobne tempo rozwoju w całym analizowanym okresie, zaliczyć należy: Andhra Pradesh, Delhi NCT, Himachal Pradesh, Jammu \& Kashmir, Keralę, Punjab i West Bengal.

Bardziej nierównym i niższym tempem wzrostu gospodarczego stanów cechowały się lata 90. ubiegłego wieku. Natomiast po 2000 roku tempo to wyraźnie wzrasta i stabilizuje się na wyższym poziomie niż w poprzedniej dekadzie, co wpływa na przyspieszenie wzrostu gospodarczego niemal wszystkich stanów i - kumulując się - daje - jak wykazano w podrozdziale 5.1 - wysokie wskaźniki wzrostu całej indyjskiej gospodarki. Trzeba jednak podkreślić, że - jak wynika z tab. 6.1 - tempo wzrostu gospodarczego jest różne w poszczególnych stanach, co powoduje najprawdopodobniej narastanie dywergencji przestrzennej indyjskiej gospodarki; hipoteza ta będzie weryfikowana w następnych fragmentach rozdziału.

Analiza porównawcza wzrostu gospodarczego stanów za pomocą wskaźników dynamiki produktu społecznego netto nie daje jednak pełnego obrazu zmian przestrzennych indyjskiej gospodarki. Postawienie tezy o wzroście dywergencji rozwoju przestrzennego Indii tylko na podstawie stwierdzenia różnic tempa wzrostu produktu społecznego w poszczególnych stanach byłoby przedwczesne. Zróżnicowane tempo nie zawsze oznacza narastanie regionalnej dywergencji, czasem może ją zmniejszać, to znaczy wyrównywać różnice powstałe w okresach wcześniejszych, jak to ma miejsce w przypadku Biharu, Chhattisgarhu czy Uttarakhandu.

W świetle powyższego, aby pogłębić analizę regionalnych aspektów wzrostu gospodarczego, badaniu poddane zostaną zmiany struktury wytwarzania produktu społecznego Indii według stanów.

\subsubsection{Struktura wytwarzania produktu społecznego według stanów}

Jak już wykazano, produkt społeczny netto zwiększał się nierównomiernie w poszczególnych stanach Indii. Zróżnicowana dynamika wzrostu winna w dłuższym okresie doprowadzić do zmian struktury przestrzennej (według stanów) wytwarzania produktu krajowego netto (PKN) Indii. Te właśnie kwestie są przedmiotem rozważań w niniejszym podrozdziale. Podstawą analizy są wskaźniki zamieszczone w tab. 6.5.

Analizując tab. 6.5 można zauważyć, że udział poszczególnych stanów w tworzeniu produktu krajowego Indii jest bardzo zróżnicowany, a różnice w krańcowych przypadkach są aż ponadtrzydziestokrotne (pomiędzy Maharashtrą a Goa). 
Zróżnicowana dynamika wzrostu produktu społecznego netto poszczególnych stanów Indii w latach 1993/94-2010/11 zmieniła jego przestrzenny rozkład w skali kraju. Klasyfikując pod tym względem indyjskie stany, można wyróżnić sześć ich grup.

Do grupy pierwszej zaliczają się te stany, których udział w produkcie krajowym netto Indii wykazywał niemal stałą i wyraźną tendencję wzrostową, co oznacza zwiększanie się ich znaczenia gospodarczego ${ }^{5}$. Są to: gospodarczo najbardziej zacofany Bihar oraz stany dobrze rozwinięte, takie jak: Delhi NCT oraz Goa i Haryana. Mamy tu więc do czynienia z równoczesnymi zjawiskami - „doganiania” (Bihar) oraz „uciekania” (Delhi NCT, Goa i Haryana).

Grupę drugą tworzą stany, których udział w produkcie krajowym netto Indii w całym badanym okresie wykazywał tendencję umiarkowanie wzrostową i był w ostatnich latach tego okresu (przełom pierwszej i drugiej dekady XXI wieku) wyższy niż w pierwszych (1992-1995). Do tej grupy należą sąsiadujące ze sobą stany Karnataka, Andhra Pradesh oraz Chhattisgarh. Pomimo geograficznej bliskości są to jednak stany o różnym poziomie rozwoju gospodarki i różnej jej strukturze (por. tab. 6.3).

Trzecią grupę stanowią stany, których dynamika rozwojowa była wysoka do - mniej więcej - połowy pierwszej dekady XXI wieku, a później obniżyła się, co sprawiło, że ich udział w tworzeniu produktu krajowego najpierw zwiększał się, a później - to znaczy w ostatnich latach dekady - wykazywał spadek. Do tych stanów zalicza się Himachal Pradesh, West Bengal, Jammu \& Kashmir, Punjab oraz stany Trójkąta Assamskiego. Są to również stany bardzo zróżnicowane gospodarczo, a Jammu \& Kashmir i stany Trójkąta Assamskiego zaliczane są - obok Biharu i Uttar Pradesh - do najbiedniejszych w Indiach. Malejący udział Punjabu - jednego z najbardziej rozwiniętych gospodarczo stanów Indii - w tworzeniu produktu krajowego wynika - paradoksalnie - z bardzo wysokiego rozwoju rolnictwa w tym regionie. Punjab legitymuje się - jak pokazano w tab. 6.3 - najwyższym spośród wszystkich badanych stanów udziałem rolnictwa w tworzeniu produktu stanowego netto. Rolnictwo cechowało się jednak - jak wykazano w rozdziale $\mathrm{V}$ - stosunkowo niską dynamiką rozwojową, co ostatecznie zaważyło na tempie rozwoju całej gospodarki Punjabu.

Na czwartą grupę składają się stany, w których wystąpiły odwrotne tendencje niż w grupie trzeciej, to znaczy najpierw miał miejsce spadek udziału w tworzeniu produktu krajowego netto Indii, a później jego wzrost. Tworzą ją: Gujarat, Maharashtra, Orissa i Uttarakhand, a więc stany leżące w różnych regionach kraju, ale relatywnie mało zróżnicowane pod względem poziomu i struktury gospodarczej (por. tab. 6.3).

5 Wyrażenie ,wzrost (czy spadek)” udziału nie oznacza, że tak się działo w każdym z badanych lat, lecz, że jest to po prostu tendencja dominująca w jakimś przedziale badanego okresu. Z uwagi na różną skalę przyrostów (spadków) produktu społecznego netto w poszczególnych stanach i latach nierzadkie są sytuacje, że - przykładowo - po kilku latach wzrostu nastąpił w jakimś roku spadek lub na odwrót, ale ogólny, wieloletni trend zmian był wzrostowy (lub spadkowy). 


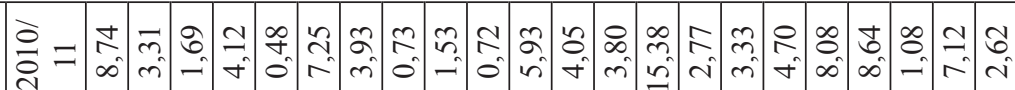

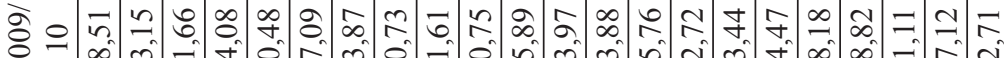

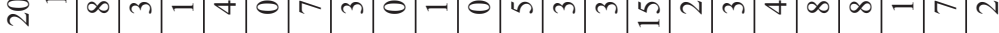

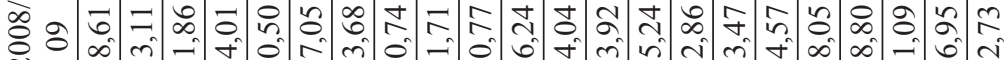

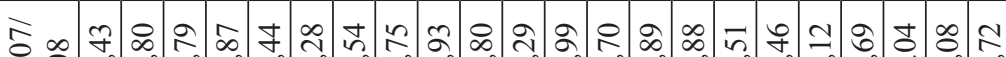

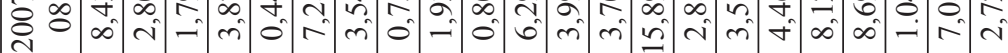

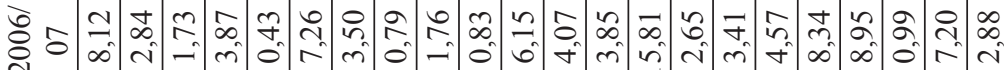
官

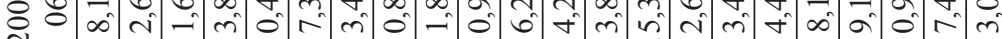
焉 ले 苞

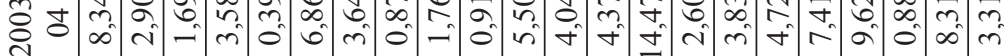

సิ

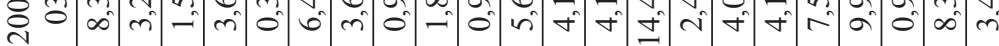

خ

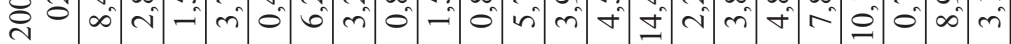
○े

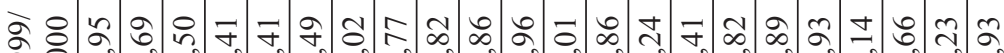
مे है ती क

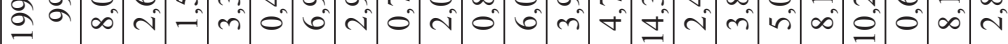

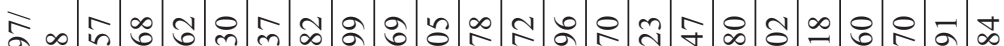

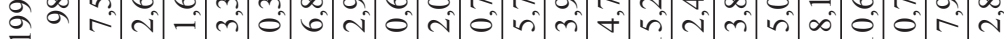
ڤ

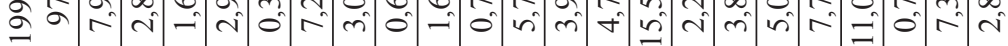

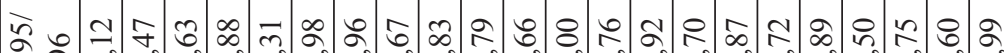

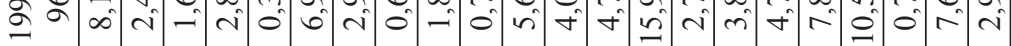

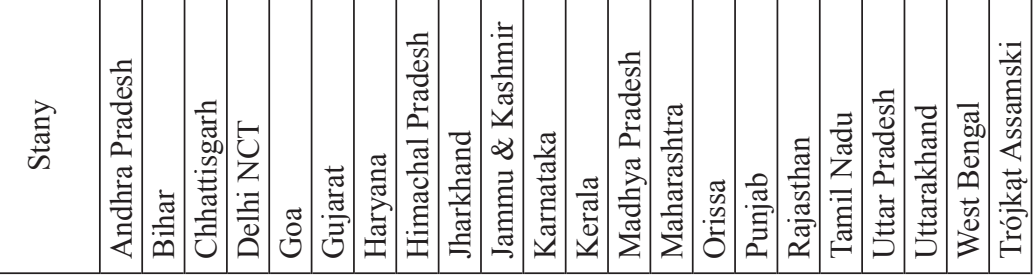


Do piątej grupy kwalifikują się te stany, których udział w produkcie krajowym netto Indii pod koniec pierwszej dekady XXI stulecia był zbliżony do pozio$\mathrm{mu} \mathrm{z}$ połowy lat 90 . minionego wieku, a pojawiające się $\mathrm{w}$ międzyczasie zmiany wskaźników struktury miały charakter nietrwały, skokowy. Są to dwa południowe i sąsiadujące ze sobą stany Kerala i Tamil Nadu oraz środkowo-zachodni stan Rajasthan. Te dwa pierwsze stany są zbliżone do siebie pod względem poziomu rozwoju oraz struktury gospodarczej. Natomiast znacznie - in minus - różni się od nich Rajasthan.

Szóstą grupę tworzą trzy stany, których udział w tworzeniu produktu krajowego netto ma tendencję spadkową w całym badanym okresie. Są to: dwa, zaliczane do największych ludnościowo i/lub obszarowo, stany Indii - Uttar Pradesh i Madhya Pradesh oraz trzeci - Jharkhand. Leżą one w północno-środkowych Indiach i należą do najuboższych, a zamieszkuje w nich niemal jedna czwarta mieszkańców kraju (ok. $300 \mathrm{mln}$ ). Mają podobną strukturę gospodarczą, cechującą się dużym udziałem rolnictwa w gospodarce, którego dynamika rozwojowa była niska w całym badanym okresie.

$\mathrm{Z}$ analizy danych $\mathrm{w}$ tab. 6.5 wynika, że nastąpiło nieznaczne spłaszczenie przestrzennego (według stanów) rozkładu wytwarzania produktu krajowego netto Indii w badanym okresie. W 1995/96 roku różnica (rozstęp) pomiędzy najwyższym a najmniejszym wskaźnikiem udziału (Maharashtrą a Goa) wynosiła 15,6 punktu procentowego, a w roku 2010/11 zmniejszyła się do 14,9 punktu procentowego.

W celu dokładniejszego wyrażenia zmian w strukturze przestrzennej gospodarki indyjskiej w badanym okresie, wyliczono dla niektórych lat wartości współczynnika lokalizacji P.S. Florence'a, stosowanego zazwyczaj do badania przekształceń strukturalnych danego zjawiska w czasie. W naszym przypadku współczynnik ten obrazuje skalę zmian w strukturze wytwarzania produktu społecznego netto Indii według stanów. Datą odniesienia dla dwóch wybranych lat (2001/02 i 2010/11) jest struktura wytwarzania produktu społecznego netto Indii według stanów w roku 1995/966. Wyniki obliczeń zawarto w tab. 6.6.

Przedstawione w tab. 6.6 wartości współczynnika Florence’a wskazują, że w badanym okresie nastąpił wzrost regionalnego zróżnicowania (według stanów) wytwarzania produktu krajowego netto Indii. Można więc sformułować tezę o narastaniu dywergencji przestrzennej w indyjskiej gospodarce.

${ }^{6}$ Współczynnik lokalizacji Florence'a ma matematyczną postać $F_{p}=\Sigma\left(S_{1 n}-S_{t n}\right) / 100$, gdzie $S_{1 n}=$ udział danego stanu $(n) \mathrm{w}$ wytwarzaniu produktu krajowego netto w roku bazowym 1995/96, $S_{t n}=$ udział danego stanu $(n)$ w wytwarzaniu produktu krajowego netto w latach 2000/2001 oraz 2010/11, $n=$ poszczególne stany Indii. Przy obliczaniu bierze się pod uwagę sumę różnic dodatnich lub ujemnych (są one w wyrażeniu bezwzględnym identyczne). Wzór i procedurę wyliczeń przyjęto za: [Isard, 1965, s. 123-125]. 
Tabela 6.6. Współczynniki lokalizacji Florence’a produktu społecznego netto stanów w latach 1995/96-2010/11

\begin{tabular}{|c|c|}
\hline Lata & Wartości współczynnika Florence'a \\
\hline $2000-2001$ & 0,0479 \\
\hline $2010-2011$ & 0,0514 \\
\hline
\end{tabular}

Źródło: opracowanie i obliczenia własne na podstawie tab. 6.5.

Bardziej syntetyczny obraz zmian przestrzennego zróżnicowania indyjskiej gospodarki pozwala uzyskać przeprowadzenie analizy uwzględniającej podział terytorium Indii na 5 makroregionów wyodrębnionych według kryteriów geograficzno-administracyjnych. Są to następujące makroregiony [Bywalec, 2013]:

1. Północno-zachodni (stany: Jammu \& Kashmir, Punjab, Rajasthan, Himachal Pradesh, Haryana, Gujarat, Delhi NCT).

2. Północno-środkowy (stany: Madhya Pradesh, Uttar Pradesh, Bihar, Uttarakhand, Jharkhand).

3. Północno-wschodni (stany: West Bengal, Trójkąt Assamski - Arrunachal Pradesh, Assam, Manipur, Meghalaya, Mizoram, Nagaland, Sikkim, Tripura).

4. Południowo-zachodni (stany: Goa, Maharashtra, Karnataka, Kerala).

5. Południowo-wschodni (stany: Tamil Nadu, Andhra Pradesh, Orissa, Chhattisgarh).

W tab. 6.7 przedstawiono kształtowanie się udziału wyróżnionych makroregionów w wytwarzaniu produktu krajowego netto Indii w okresie 1995/962010/11. Wskaźniki te skonfrontowano z powierzchnią oraz liczbą ludności makroregionów, co uzupełnia charakterystykę i daje pogląd na ich miejsce i znaczenie w życiu społecznym i gospodarczym Indii.

$\mathrm{Z}$ tab. 6.7 wynika, że potencjał gospodarczy Indii wyrażony wielkością wytwarzanego produktu społecznego netto jest - wyłączając peryferyjny Makroregion Północno-wschodni - dość równomiernie rozmieszczony na terytorium kraju i to pomimo znaczących różnic w powierzchni i liczbie ludności makroregionów. Te właśnie istotne dysproporcje w powierzchni i ludności - przy podobnym wolumenie wytwarzanego produktu społecznego - świadczą jednak o zróżnicowanej intensywności (efektywności) rozwoju gospodarczego makroregionów; szerzej sprawy te zostaną przedstawione w podrozdziale 6.2. Cztery makroregiony - poza Północno-wschodnim - wytwarzają po 20-25 proc. krajowego produktu społecznego i wielkości te tylko nieznacznie zmieniały się. W krańcowych latach badanego okresu udział największego makroregionu - Południowo-zachodniego - w tworzeniu produktu społecznego Indii nie uleg1 zmianie, zaś drugiego z kolei, tj. Makroregionu Północno-zachodniego, zwiększył się o blisko 2 punkty procentowe. 
Tabela 6.7. Powierzchnia, ludność oraz produkt krajowy netto Indii według makroregionów

\begin{tabular}{|c|c|c|c|c|c|c|}
\hline$\times$ & Makroregiony & 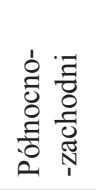 & 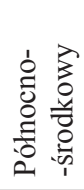 & 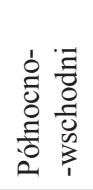 & 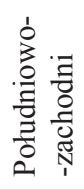 & 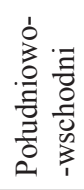 \\
\hline Рowiarzhnia* & w tys. $\mathrm{km}^{2}$ & 912,2 & 776,2 & 350,7 & 542,1 & 695,8 \\
\hline 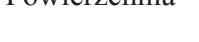 & w proc. powierzchni kraju & 27,8 & 23,6 & 10,7 & 16,5 & 21,2 \\
\hline Ludność* & $\mathrm{w}$ mln & 218,2 & 419,1 & 137,0 & 208,3 & 224,3 \\
\hline$(2011)$ & w proc. ludności kraju & 18,0 & 34,6 & 11,3 & 17,2 & 18,5 \\
\hline & $1995 / 96$ & 22,87 & 20,31 & 10,59 & 25,89 & 20,34 \\
\hline Udział & $1997 / 98$ & 23,40 & 20,73 & 10,75 & 25,28 & 19,84 \\
\hline w produkcie & $2001 / 01$ & 23,32 & 19,57 & 11,70 & 24,94 & 20,47 \\
\hline netto. & $2003 / 04$ & 24,41 & 19,53 & 11,62 & 24,40 & 20,04 \\
\hline $\mathrm{w}$ proc.** & $2007 / 08$ & 24,21 & 18,16 & 9,80 & 26,61 & 21,22 \\
\hline & 2010/11 & 24,78 & 18,36 & 9,74 & 25,84 & 21,28 \\
\hline
\end{tabular}

* udziały nie sumują się do 100,0 z powodu nieuwzględnienia terytoriów związkowych, ** suma produktu społecznego netto stanów oraz Delhi NCT $=100,0$ proc. (bez terytoriów związkowych), ceny bieżące.

Źródło: opracowanie i obliczenia własne na podstawie tab. 6.5 i 6.14 .

Nieznaczny wzrost udziału (o niespełna 1 punkt procentowy) obserwuje się w przypadku Makroregionu Południowo-wschodniego. Te wysokie udziały wymienionych trzech makroregionów są - jak wcześniej stwierdzono - przede wszystkim wynikiem rozwoju na ich obszarach nowoczesnego przemysłu i usług - szczególnie informatycznych, telekomunikacyjnych i finansowych opartych w dużej mierze na bezpośrednich inwestycjach zagranicznych skupionych w takich stanach, jak: Andhra Pradesh, Tamil Nadu, Karnataka, Maharashtra, Gujarat czy Haryana [Banerjee-Guha, 2008]. W analizowanym okresie obniżył się natomiast udział w tworzeniu produktu społecznego netto pozostałych dwóch makroregionów, tj. Północno-wschodniego i Północno-środkowego (z 31 do 27 proc.). Oznacza to pogłębianie się zróżnicowania potencjału gospodarczego pomiędzy północno-wschodnią a pozostałą częścią Indii. Sprawy te zostaną dokładniej przedstawione w podrozdziale 6.2 .

\subsection{Regionalne zróżnicowanie poziomu rozwoju gospodarczego}

Analizy dynamiki wzrostu gospodarczego stanów oraz zmiany ich udziału w produkcie krajowym netto Indii umożliwiają poznanie miejsca i znaczenia danego stanu w gospodarce kraju. Niewiele jednak można się dowiedzieć 
o samym poziomie rozwoju gospodarczego stanów oraz relacjach między nimi w tym względzie. Chcąc dokonać takich porównań, konieczne jest wykorzystanie - podobnie jak uczyniono w odniesieniu do pierwszych dekad niepodległych Indii (podrozdział 2.4.3) - innej agregatowej miary, tj. wielkości produktu społecznego stanów przeliczonej na 1 mieszkańca. Dysponując takimi wskaźnikami, możliwe staje się ustalenie hierarchii stanów pod względem poziomu rozwoju gospodarczego, pomierzenie dystansów między nimi oraz przeprowadzenie analizy zmian.

Dynamikę wskaźników produktu społecznego netto per capita dla indyjskich stanów zestawiono w tab. 6.8. Analizując tę tab. i porównując ją z tab. 6.1, łatwo dostrzec pewne różnice w kolejności stanów pod względem tempa wzrostu gospodarczego wyrażonego wskaźnikami dynamiki produktu społecznego netto stanów a wskaźnikami dynamiki tegoż produktu przeliczonego na 1 mieszkańca. Sprawiła to zróżnicowana dynamika procesów demograficznych w poszczególnych stanach. Nie są to jednak różnice duże i kolejność wielu stanów w obu przypadkach jest podobna. Można to wyraźniej dostrzec, porównując tab. 6.4 i 6.9. W obu tych tabelach na czołowych miejscach utrzymują się takie stany, jak: Delhi NCT, Gujarat, Maharashtra i Bihar, a więc trzy stany - jak na warunki indyjskie - wysoko rozwinięte i jeden stan (Bihar) zaliczany do najbardziej gospodarczo zacofanych. Oznacza to, że poziom rozwoju gospodarczego, a tym samym warunków życia ludności, podniósł się najwyraźniej w tych właśnie regionach. Geograficznie ujmując, są to stany odległe od siebie, położone niemal na przeciwległych kresach Indii.

Dynamika poziomu rozwoju gospodarczego stanów, wyrażonego wielkością produktu społecznego netto stanów per capita, jest jednak zróżnicowana nie tylko w ujęciu przestrzennym, lecz także czasowym.

Jak wynika z tab. 6.8 i 6.9, większość stanów szybciej rozwijała swą gospodarkę po 2000 roku, co można tłumaczyć w głównej mierze zaawansowaniem - po pierwszych, trudnych latach reform - procesów liberalizacyjnych i deregulacyjnych. Przyspieszenie gospodarcze nastąpiło bardzo wyraźnie po 2004 roku, gdy - jak wspomniano - do władzy ponownie doszli twórcy i zwolennicy gruntownych zmian na czele z M. Singhem - premierem rządu federalnego.

Najniższymi wskaźnikami dynamiki rozwoju gospodarczego w badanym okresie legitymują się stany północno-środkowe (Madhya Pradesh, Jharkhand, Uttar Pradesh, Chhattisgarh) oraz północno-wschodniej części Indii (stany Trójkąta Assamskiego), a także dwa stany z kresów północno-zachodnich, tj. Jammu \& Kashmir oraz Punjab. Z wyjątkiem Punjabu, pozostałe wymienione stany tej części kraju są słabo lub bardzo słabo rozwinięte gospodarczo, z reguły o dużym udziale rolnictwa, które pomimo ,nowej polityki ekonomicznej” przeżywało - jak wykazano w rozdziale V - stagnację i od czasów „zielonej rewolucji” niewiele się zmieniło. 


\begin{tabular}{|c|c|c|c|c|c|c|c|c|c|c|c|}
\hline$\overline{\bar{z}}$ 工 & $=\stackrel{\infty}{\stackrel{\infty}{B}}$ & $\stackrel{m}{\stackrel{7}{d}}$ & 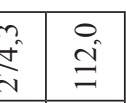 & & & & & & & & \\
\hline 高= & $=\left[\begin{array}{l}\stackrel{\infty}{\otimes} \\
\stackrel{\infty}{8}\end{array}\right.$ & $\begin{array}{c}3 \\
\dot{2}\end{array}$ & $\begin{array}{c}\hat{c}^{\prime} \\
\end{array}$ & 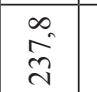 & $\stackrel{\circ}{\stackrel{\Xi}{\Xi}}$ & $\overrightarrow{\bar{\alpha}}$ & \begin{tabular}{l|}
$\infty$ \\
$\stackrel{\infty}{g}$ \\
$\stackrel{8}{*}$
\end{tabular} & 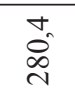 & ठُ & $\begin{array}{l}\overrightarrow{\mathrm{d}} \\
\text { के }\end{array}$ & 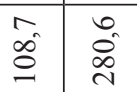 \\
\hline 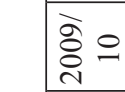 & $\simeq \bar{s}$ & 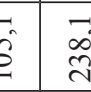 & 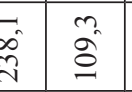 & $\begin{array}{l}n \\
\text { aे } \\
\text { aे }\end{array}$ & $\stackrel{8}{8}$ & $\vec{E}$ & 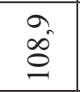 & हैं & 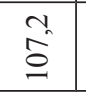 & $\begin{array}{l}\text { 吕 } \\
\stackrel{0}{\sigma}\end{array}$ & $\stackrel{8}{\Xi}$ \\
\hline 离商 & $=\bar{g}$ & 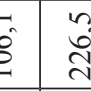 & 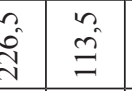 & $\stackrel{2}{g}$ & $\mathrm{e}_{0}^{2}$ & 递 & $\stackrel{m}{=}$ & 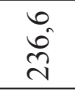 & $\stackrel{\infty}{\stackrel{\infty}{8}}$ & $\hat{\infty}_{\infty}^{2}$ & 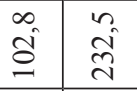 \\
\hline 害品 & 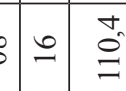 & $\frac{m}{n}$ & 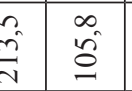 & 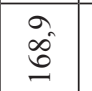 & है & مे & $\begin{array}{ll} \\
g \\
g\end{array}$ & $\frac{n}{\frac{n}{d}}$ & $\stackrel{\circ}{\stackrel{0}{ \pm}}$ & $\begin{array}{l}n \\
\stackrel{\infty}{\infty} \\
\stackrel{0}{=}\end{array}$ & $\stackrel{\text { Ŝ }}{\cong}$ \\
\hline : & $=$ & $\begin{array}{c}9 \\
0\end{array}$ & \begin{tabular}{l|l}
$\overrightarrow{0}$ & $\bar{E}$ \\
$\hat{2}$
\end{tabular} & $\begin{array}{ll}\circ \\
\stackrel{\circ}{\circ}\end{array}$ & 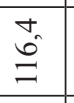 & 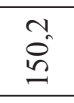 & $\stackrel{\mathrm{m}}{\Xi}$ & 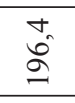 & 它 & $\begin{array}{l}\tilde{b} \\
\stackrel{-0}{\Xi}\end{array}$ & 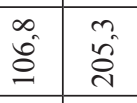 \\
\hline 总: & $\pm \stackrel{\infty}{g}$ & 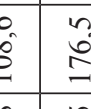 & \begin{tabular}{c|c}
0 \\
0 \\
0
\end{tabular} & 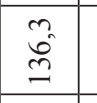 & $\begin{array}{l}\infty \\
0^{\circ} \\
\end{array}$ & $\begin{array}{l}0.0 \\
\text { à }\end{array}$ & 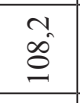 & $\overrightarrow{\underline{\infty}}$ & 葛 & \begin{tabular}{|l|} 
\\
$\ddot{B}$ \\
\end{tabular} & $\hat{\Xi}$ \\
\hline 害旅 & 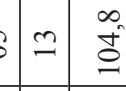 & 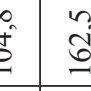 & 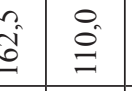 & $\begin{array}{l}\vec{\infty} \\
\stackrel{\rightarrow}{\rightarrow}\end{array}$ & 告 & $\stackrel{a}{a}$ & 誉 & 苦 & $\begin{array}{l}\stackrel{0}{\circ} \\
\stackrel{0}{\Xi}\end{array}$ & \begin{tabular}{|l}
$\tilde{E}$ \\
$\underline{n}$
\end{tabular} & $\vec{\circ}$ \\
\hline 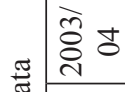 & $\cong \stackrel{+}{\stackrel{\infty}{\leftrightarrows}}$ & 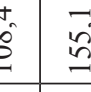 & $\hat{n}$ & $\begin{array}{l}n \\
\text { and } \\
\text { and }\end{array}$ & $\stackrel{\circ}{\stackrel{6}{\leftrightarrows}}$ & $\stackrel{ \pm}{\vec{I}}$ & 赾 & $\overline{8}$ & 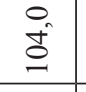 & \begin{tabular}{|l}
0 \\
6 \\
10 \\
\end{tabular} & 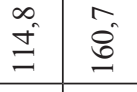 \\
\hline "s & $=\stackrel{2}{\Xi}$ & 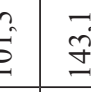 & $\overline{\mathrm{g}}$ & 童 & ถू & 过 & $\begin{array}{l}\tilde{U} \\
\tilde{\Xi}\end{array}$ & $\begin{array}{l}\stackrel{0}{0} \\
\stackrel{0}{+}\end{array}$ & 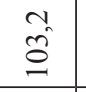 & \begin{tabular}{|l|} 
\\
$\dot{ \pm}$ \\
\end{tabular} & $\frac{\tilde{a}}{\tilde{2}}$ \\
\hline हृㅝㄹ & $=0 \begin{array}{l}\infty \\
\varrho\end{array}$ & 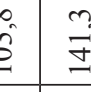 & $\frac{a}{a}$ & 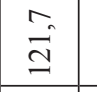 & @̊ & $\stackrel{n}{\stackrel{n}{g}}$ & 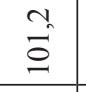 & $\begin{array}{l}+ \\
\text { 委 } \\
\dot{q}\end{array}$ & $\stackrel{\vec{े}}{\mathrm{~g}}$ & $\begin{array}{l}0 \\
\stackrel{0}{0} \\
\end{array}$ & $\stackrel{0}{\stackrel{0}{8}}$ \\
\hline 高 & $=0$ 局 & 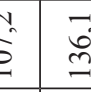 & $\stackrel{3}{\cong}$ & $\vec{m}$ & बे & $\stackrel{\circ}{\circ}$ & 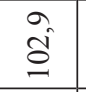 & 䇥 & స̃ & 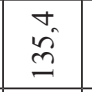 & $\frac{3}{2}$ \\
\hline 㟢言 & 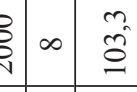 & 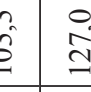 & 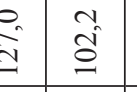 & $\begin{array}{l}n \\
\stackrel{n}{\Xi} \\
=\end{array}$ & $\stackrel{+}{\stackrel{+}{a}}$ & $\stackrel{m}{s}$ & 思 & $\begin{array}{l}\overrightarrow{\hat{m}} \\
\stackrel{9}{m}\end{array}$ & $\begin{array}{l}\circ \\
\stackrel{0}{8}\end{array}$ & $\begin{array}{l}a \\
\dot{b} \\
\dot{c}\end{array}$ & 宓 \\
\hline 営 8 & $-\stackrel{0}{\Xi}$ & $\begin{array}{l}0 \\
\dot{E}\end{array}$ & बू. & $\begin{array}{l}0 \\
\stackrel{0}{3}\end{array}$ & छे & $\overrightarrow{\underline{8}}$ & $\stackrel{2}{\underline{E}}$ & \begin{tabular}{|l|}
0 \\
0 \\
\hdashline \\
\end{tabular} & 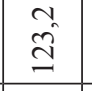 & $\begin{array}{l}9 \\
\dot{j} \\
\end{array}$ & 管 \\
\hline 䙲 & 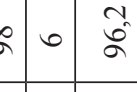 & $\stackrel{0}{g}$ & हो สू & $\bar{\Xi}$ & है & 羿 & $\stackrel{9}{\Xi}$ & $\overrightarrow{\bar{a}}$ & $\begin{array}{l}0 \\
\circ\end{array}$ & $\underline{\partial}$ & $\infty$ \\
\hline 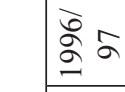 & $=n \frac{n}{\stackrel{n}{3}}$ & 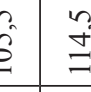 & 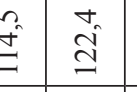 & $\begin{array}{l}0 \\
\stackrel{0}{\Xi}\end{array}$ & $\begin{array}{l}\text { i } \\
\stackrel{\mathrm{I}}{\Xi}\end{array}$ & 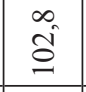 & $\begin{array}{l}m \\
\stackrel{n}{g} \\
g\end{array}$ & 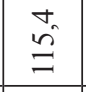 & $\begin{array}{l}\overrightarrow{+} \\
\stackrel{2}{\cong} \\
=\end{array}$ & $\overrightarrow{\hat{g}}$ & $\begin{array}{l}\stackrel{+}{3} \\
\stackrel{3}{\Xi}\end{array}$ \\
\hline $\begin{array}{l}5 \\
20 \\
2\end{array}$ & 8 度 & 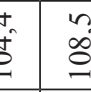 & 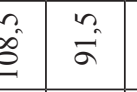 & $\bar{a}$ & $\begin{array}{l}0 \\
\dot{8}\end{array}$ & \begin{tabular}{|l|}
$\dot{8}$ \\
$\dot{8}$
\end{tabular} & $\hat{\sigma}$ & \begin{tabular}{|l|}
\multirow{r}{*}{} \\
$\stackrel{0}{g}$
\end{tabular} & $\begin{array}{l}m \\
\stackrel{m}{g}\end{array}$ & \begin{tabular}{|l|}
$\tilde{\theta}$ \\
$\underline{\theta}$
\end{tabular} & $\stackrel{\square}{\Xi}$ \\
\hline 票々 & $m=\frac{8}{9}$ & 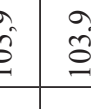 & $\hat{b}$ & $\begin{array}{l}\text { 足 } \\
\stackrel{-}{=}\end{array}$ & & & & 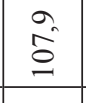 & & & 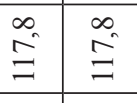 \\
\hline 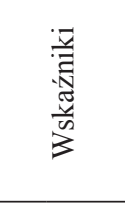 & & & & & & & & & & & \\
\hline 言 & & & & & & & & & 气̊ & & \\
\hline
\end{tabular}




\begin{tabular}{|c|c|c|c|c|c|c|c|c|c|c|c|c|c|c|c|}
\hline & $\begin{array}{l}0 \\
\stackrel{0}{0}\end{array}$ & 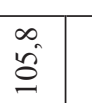 & & $\stackrel{m}{\stackrel{m}{a}}$ & త్రీ & $\begin{array}{l}\infty \\
\dot{0} \\
\dot{0}\end{array}$ & di & $\hat{\mathrm{s}}$ & $\overrightarrow{\mathrm{s}}$ & $\overrightarrow{\vec{\Xi}}$ & $\begin{array}{l}\text { aे } \\
\text { do }\end{array}$ & & & & \\
\hline & $\begin{array}{ll}n \\
\substack{n \\
d \\
d}\end{array}$ & 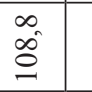 & $\begin{array}{l}3 \\
y \\
d\end{array}$ & $\stackrel{m}{\underline{0}}$ & s & \begin{tabular}{|l|} 
\\
京 \\
\end{tabular} & 产 & 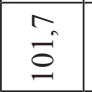 & $\begin{array}{l}\vec{a} \\
\text { do } \\
d\end{array}$ & $\begin{array}{l}\text { 吕 } \\
\stackrel{8}{9}\end{array}$ & $\overline{\vec{a}}$ & $\overrightarrow{\mathrm{g}}$ & İ & g. & \\
\hline & $\begin{array}{l}+ \\
\text { aे }\end{array}$ & 仓े & ते & $\stackrel{\text { ले }}{=}$ & 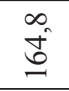 & $\overrightarrow{\tilde{d}}$ & \begin{tabular}{l}
$\infty$ \\
\multirow{1}{*}{} \\
$\dot{I}$
\end{tabular} & 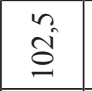 & 等 & 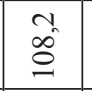 & $\underset{\tilde{d}}{\tilde{d}}$ & $\begin{array}{l}n \\
\stackrel{n}{o b} \\
\stackrel{8}{a}\end{array}$ & है. & $\begin{array}{l}n \\
\stackrel{n}{I}\end{array}$ & \\
\hline 8 & 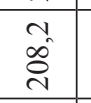 & $\begin{array}{l}\infty \\
\stackrel{8}{8} \\
\stackrel{8}{2}\end{array}$ & $\begin{array}{l}\infty \\
\stackrel{\infty}{c} \\
\end{array}$ & $\frac{6}{j}$ & 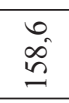 & 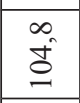 & के & \begin{tabular}{|l}
$\hat{o}$ \\
$\stackrel{g}{g}$
\end{tabular} & 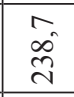 & $\stackrel{n^{2}}{a}$ & $\overrightarrow{\vec{d}}$ & $\begin{array}{l} \\
\stackrel{\circ}{\leftrightarrows}\end{array}$ & $\begin{array}{l}\overrightarrow{\tilde{N}} \\
\underline{2}\end{array}$ & $\stackrel{8}{\Phi}$ & \\
\hline e & $\begin{array}{l}\underbrace{\infty}_{0} \\
\stackrel{0}{\circ}\end{array}$ & ڤे & 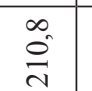 & בิ & $\begin{array}{l}\tilde{\Xi} \\
\underline{\Xi}\end{array}$ & 安 & $\stackrel{m}{m}$ & $\stackrel{\rho}{\exists}$ & 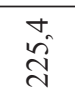 & $\overrightarrow{\mathrm{og}}$ & $\begin{array}{l}\text { तें } \\
\text { ते }\end{array}$ & बे & $\begin{array}{l}\frac{m}{2} \\
\stackrel{m}{m}\end{array}$ & $\begin{array}{ll}n \\
g \\
g\end{array}$ & \\
\hline 8 & 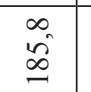 & $\frac{m}{g_{0}^{2}}$ & $\vec{g}$ & 8 & 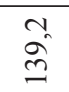 & $\frac{m}{d}$ & $\overrightarrow{\bar{m}}$ & $\overline{\mathrm{g}}$ & त्ते & 苞 & $\begin{array}{l}\tilde{\infty} \\
\stackrel{\infty}{\infty}\end{array}$ & $\stackrel{\tilde{g}}{\tilde{g}}$ & 党 & 㯊 & $\infty$ \\
\hline 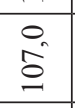 & $\dot{B}$ & $\stackrel{8}{\stackrel{8}{g}}$ & $\underset{\widetilde{d}}{2}$ & fo & $\stackrel{2}{9}$ & $\overrightarrow{\underline{g}}$ & తิ & \begin{tabular}{|l|}
0 \\
$\dot{g}$
\end{tabular} & 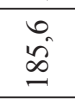 & $\frac{2}{g}$ & 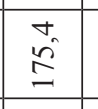 & $\overrightarrow{\underline{B}}$ & 总 & $\stackrel{\circ}{ \pm}$ & \\
\hline & 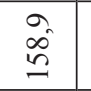 & 宛 & $\hat{\Omega}_{\underline{\Omega}}^{m}$ & 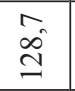 & 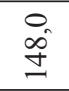 & \begin{tabular}{|c}
$\tilde{d}$ \\
$\underline{d}$
\end{tabular} & $\begin{array}{l}\vec{g} \\
\vec{I}\end{array}$ & \begin{tabular}{|l|} 
\\
$\vdots$ \\
$\dot{g}$
\end{tabular} & 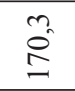 & $\begin{array}{l}0 \\
\stackrel{0}{0}\end{array}$ & $\begin{array}{ll}n \\
0 \\
0\end{array}$ & $\stackrel{\circ}{\stackrel{0}{ \pm}}$ & ঐे & 苛 & f \\
\hline$\delta$ & 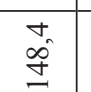 & 产 & $\begin{array}{l}m^{2} \\
\vdots \\
a\end{array}$ & 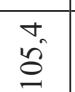 & $\begin{array}{l}\stackrel{\rho}{\text { gi }} \\
=\end{array}$ & 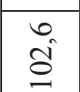 & $\stackrel{\Gamma}{\stackrel{\infty}{\prime}}$ & \begin{tabular}{|l|}
$\infty$ \\
$\stackrel{0}{ \pm}$
\end{tabular} & $\overrightarrow{\vec{b}}$ & $\begin{array}{l}m_{2}^{2} \\
\stackrel{3}{0}\end{array}$ & 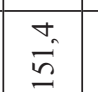 & $\overrightarrow{\underline{g}}$ & $\stackrel{\circ}{\stackrel{\circ}{\prime}}$ & $\begin{array}{ll}n \\
\stackrel{n}{o} \\
o\end{array}$ & $=$ \\
\hline 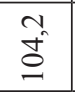 & 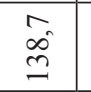 & $\overrightarrow{\mathrm{g}}$ & $\overrightarrow{\vec{v}}$ & 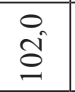 & $\overrightarrow{\mathrm{g}}$ & है & $\begin{array}{l}\tilde{y} \\
\hat{g}\end{array}$ & \begin{tabular}{|l|}
$\stackrel{0}{0}$ \\
$\stackrel{8}{8}$
\end{tabular} & 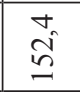 & 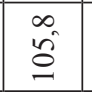 & \begin{tabular}{|l}
$\infty$ \\
$\mathfrak{f}$ \\
\end{tabular} & ఫे & $\overline{\vec{g}}$ & $\begin{array}{l}\infty \\
\stackrel{\infty}{0} \\
\stackrel{0}{0}\end{array}$ & ه্] \\
\hline$\underline{\varrho}$ & $\overrightarrow{\mathrm{m}}$ & $\stackrel{m}{\Xi}$ & $\begin{array}{l}m \\
+2\end{array}$ & 管 & $\begin{array}{l}0 \\
\stackrel{0}{\Xi}\end{array}$ & $a^{2}$ & 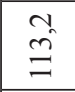 & \begin{tabular}{|l|}
$\overrightarrow{\mathrm{g}}$ \\
$\mathrm{g}$
\end{tabular} & 正 & $\begin{array}{l}0 \\
\dot{0} \\
\stackrel{0}{*}\end{array}$ & 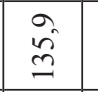 & $\overrightarrow{\mathrm{s}}$ & 葛 & $\overrightarrow{\mathrm{g}}$ & \\
\hline$\stackrel{b}{\underline{x}}$ & 品 & 产 & 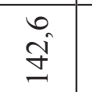 & बे. & $\hat{\tilde{g}}$ & $\overline{\vec{\Xi}}$ & $\begin{array}{l}\stackrel{0}{ \pm} \\
\pm\end{array}$ & 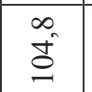 & 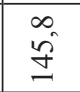 & בี & \begin{tabular}{|l|}
$\dot{0}$ \\
$\dot{a}$
\end{tabular} & $\stackrel{\circ}{\circ}$ & 吾 & वे & \\
\hline 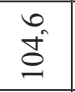 & 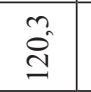 & $\overrightarrow{\mathrm{g}}$ & $\begin{array}{l}\vec{g} \\
\hat{g}\end{array}$ & i. & $\begin{array}{l}\alpha^{\alpha} \\
\stackrel{\infty}{=}\end{array}$ & $\frac{\sigma}{0}$ & $\begin{array}{l}\text { 品 } \\
\stackrel{J}{\Xi}\end{array}$ & $\begin{array}{l}+\dot{0} \\
\stackrel{\leftrightarrow}{g}\end{array}$ & $\vec{\sigma}$ & $\begin{array}{l}\infty \\
\stackrel{\infty}{o b} \\
\varrho\end{array}$ & \begin{tabular}{|l|}
$\vec{\jmath}$ \\
$\Xi$
\end{tabular} & \begin{tabular}{l}
\multicolumn{1}{c}{} \\
$\stackrel{0}{\triangle}$
\end{tabular} & $\bar{\Xi}$ & 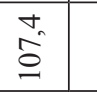 & \\
\hline 8 & $\begin{array}{l}0 \\
\stackrel{n}{=}\end{array}$ & $\begin{array}{l}3 \\
\stackrel{3}{s}\end{array}$ & 足 & ठे & $\overrightarrow{\underline{I}}$ & 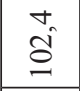 & $\stackrel{n}{\exists}$ & $\begin{array}{l}0 \\
\stackrel{j}{\Xi}\end{array}$ & 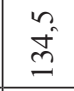 & $\begin{array}{l}a \\
\stackrel{a b}{a}\end{array}$ & \begin{tabular}{|l|}
$\mid \overrightarrow{\hat{\theta}}$ \\
\multirow{q}{*}{$\mid$}
\end{tabular} & $\begin{array}{l}+ \\
\stackrel{+}{ \pm}\end{array}$ & 兲 & $\stackrel{n}{s}$ & \\
\hline 8 & 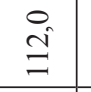 & $\stackrel{2}{s}$ & $\stackrel{\infty}{\stackrel{\infty}{=}}$ & 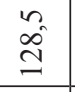 & $\stackrel{\infty^{\infty}}{=}$ & $\overline{\mathrm{g}}$ & 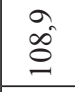 & 守 & 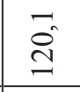 & \begin{tabular}{|l|}
$\dot{\vec{\Xi}}$ \\
$\dot{\Xi}$
\end{tabular} & \begin{tabular}{|c|c|}
\multirow{J}{*}{} \\
\end{tabular} & 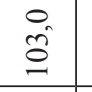 & gे & 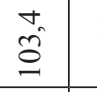 & \\
\hline & 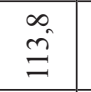 & बे & $\overrightarrow{\mathrm{j}}$ & na & $\begin{array}{l}n \\
n \\
n\end{array}$ & $\hat{\mathrm{s}}$ & 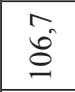 & 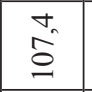 & 等 & \begin{tabular}{|c|}
$\hat{i}$ \\
$\underline{S}$
\end{tabular} & $\overrightarrow{9}$ & 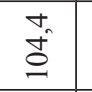 & 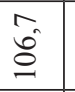 & $\begin{array}{l}\infty \\
\stackrel{0}{\Xi}\end{array}$ & \\
\hline & 商 & 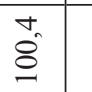 & $\overrightarrow{\overline{0}}$ & : & : & $\vec{\partial}$ & $\begin{array}{l}\text { बे } \\
\text { gे }\end{array}$ & 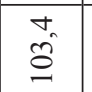 & \begin{tabular}{|l|l|}
$\infty$ \\
$\stackrel{0}{o}$
\end{tabular} & \begin{tabular}{|c|}
$\hat{s}$ \\
$\underline{s}$
\end{tabular} & \begin{tabular}{|l|}
$\overrightarrow{9}$ \\
\end{tabular} & 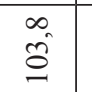 & 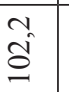 & $\begin{array}{l}0 \\
\dot{8}\end{array}$ & \\
\hline & 守 & $\hat{\mathscr{E}}$ & s. & & T & 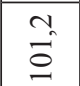 & 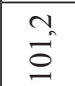 & \begin{tabular}{|c|}
$m^{2}$ \\
9
\end{tabular} & $\stackrel{m}{a} \stackrel{m}{a}$ & 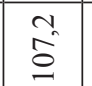 & 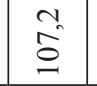 & $\infty_{\infty}^{\infty}$ & 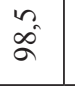 & $\overrightarrow{\mathrm{g}}$ & \\
\hline & 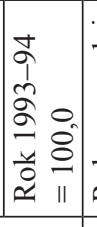 & & & & & & & & & & & & & & \\
\hline & & & & & & & & & & & & & & & \\
\hline
\end{tabular}




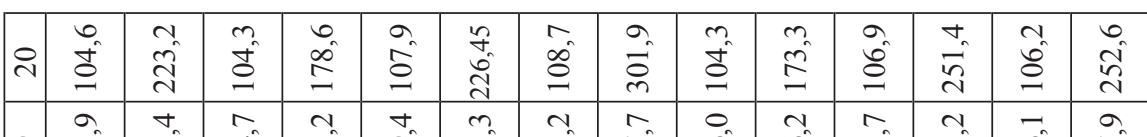

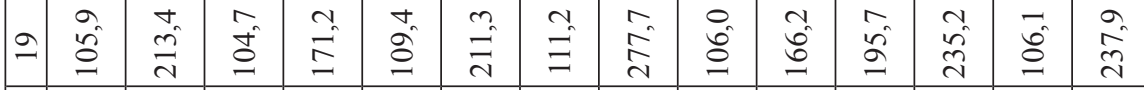

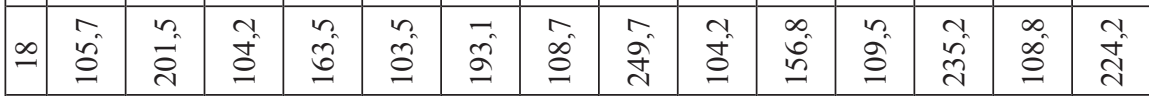

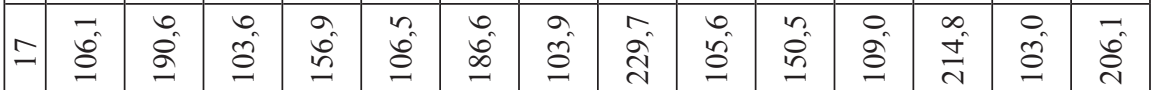

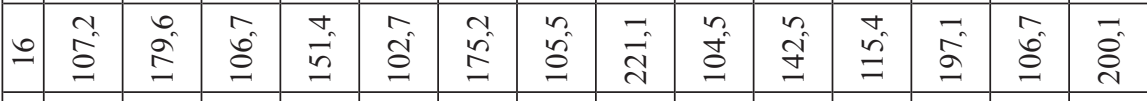

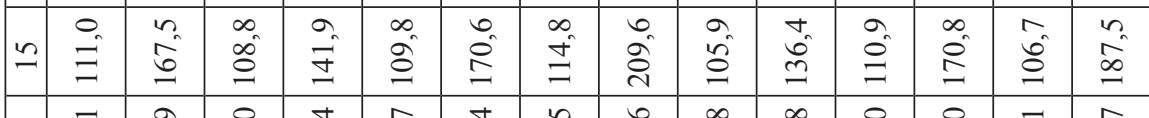

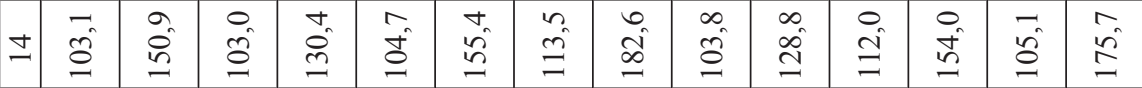

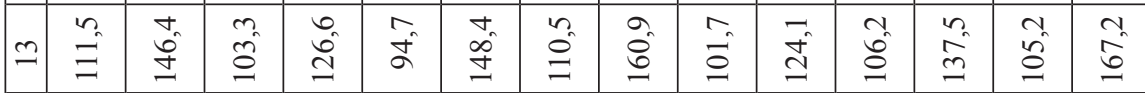

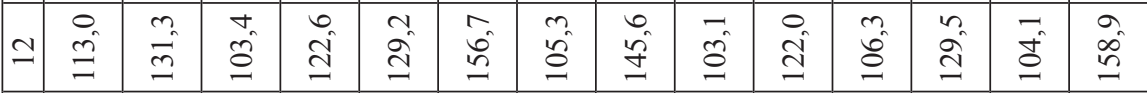

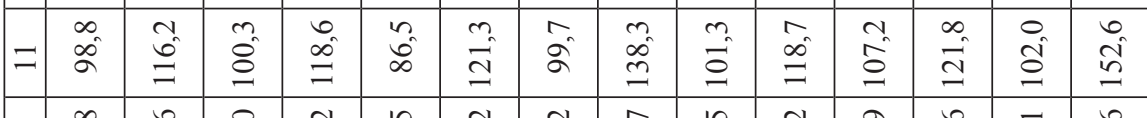

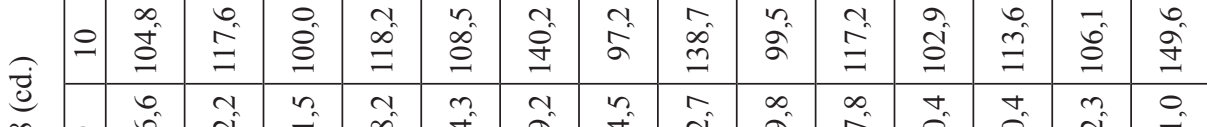

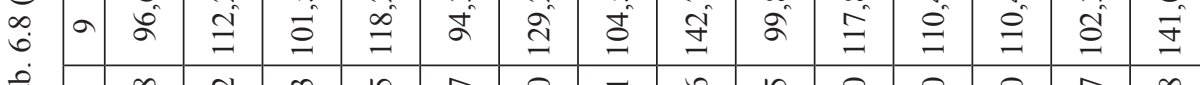

\begin{tabular}{|c|c|c|c|c|c|c|c|c|c|}
\hline 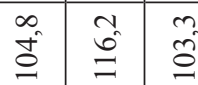 & $\stackrel{b}{\stackrel{b}{=}}$ & & . & & & & & & \\
\hline$\stackrel{\circ}{\stackrel{\Xi}{\Xi}}$ & & $\stackrel{\infty}{\Xi}$ & 9 & & & $=$ & & & $\dot{f}$ \\
\hline 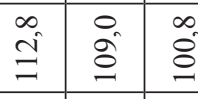 & 它 & 它 & & & & & & & $\stackrel{\check{g}}{x}$ \\
\hline$\frac{5}{\sigma}$ & 品 & $\stackrel{\circ}{g}$ & & 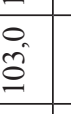 & & $\cong$ & & & \\
\hline
\end{tabular}

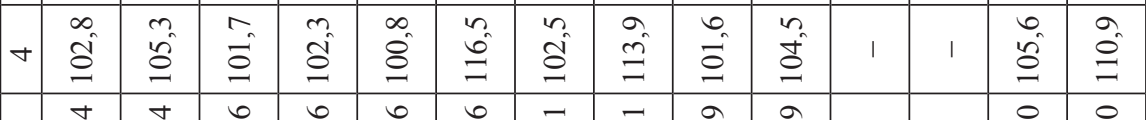

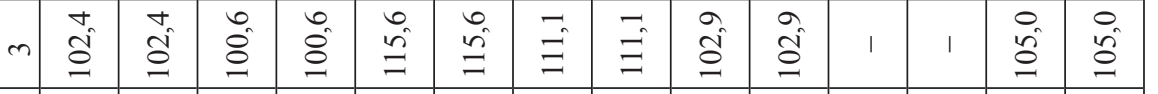

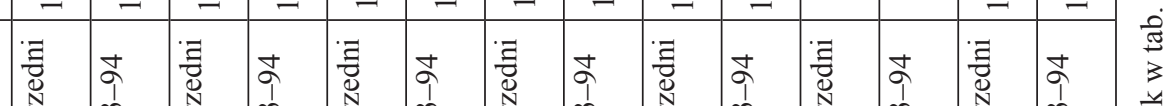

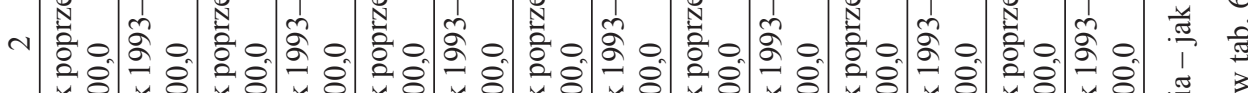

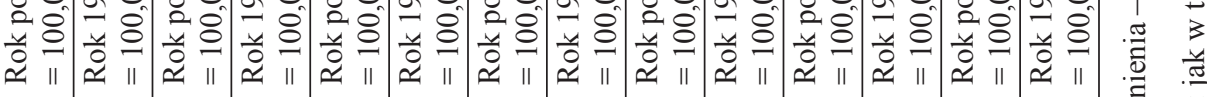

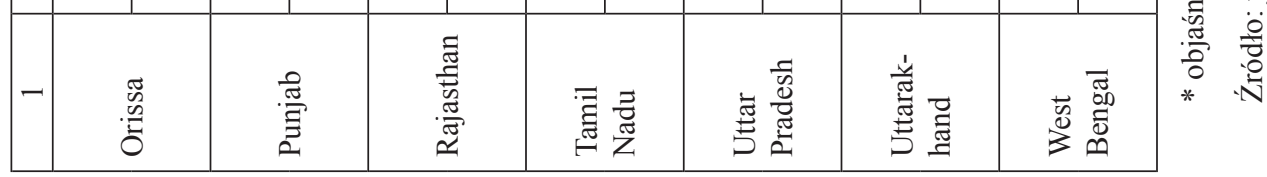


Przeprowadzone w poprzednim podrozdziale badania korelacji pomiędzy wielkością gospodarki na początku transformacji a jej późniejszą dynamiką rozwojową wykazały, że wyższym tempem wzrostu cechują się stany duże (por. tab. 6.2). Im większy był produkt społeczny netto danego stanu w roku bazowym (1934/94), tym - na ogół - wyższe jest też jego tempo wzrostu w okresie późniejszym.

Podobną sytuację obserwujemy w odniesieniu do badań tempa wzrostu poziomu rozwoju gospodarczego indyjskich stanów. Podany w tab. 6.2 współczynnik korelacji $\left(r_{x y}^{1}\right)$ pomiędzy wielkością produktu społecznego netto per capita badanych stanów w roku 1993/94 a wskaźnikami ich dynamiki w latach 1993/94-2010/11 wyniósł $=0,691$, a więc jest to korelacja umiarkowana i statystycznie istotna ${ }^{7}$. Wyliczony współczynnik determinacji $\left(W_{d}^{1}\right)=47,8$ proc. oznacza, że zmienność wskaźnika dynamiki produktu społecznego netto per capita stanów była w 47,8 proc. określana przez jego poziom w roku wyjściowym. Wynika z tego, że początkowa wielkość produktu stanowego per capita ma znaczny, dodatni wpływ na dynamikę jego zmian. Konkludując, w badanym okresie wyższe tempo wzrostu poziomu rozwoju gospodarczego uzyskiwały na ogół stany bardziej rozwinięte, czyli legitymujące się wyższym poziomem produktu społecznego netto na 1 mieszkańca, co musiało z natury rzeczy sprzyjać narastaniu dywergencji w indyjskiej przestrzeni gospodarczej.

Tabela 6.9. Stany o najwyższej i najniższej dynamice wzrostu produktu stanowego netto per capita

\begin{tabular}{|c|c|c|c|}
\hline \multirow{2}{*}{ Lp. } & \multicolumn{3}{|c|}{ Lata } \\
\hline & 1993/94-2011/12 & $1993 / 94-2000 / 01$ & $2000 / 01-2011 / 12$ \\
\hline \multicolumn{4}{|c|}{ Stany o najwyższej dynamice wzrostu* } \\
\hline 1 & Delhi (307) & Karnataka (146) & Gujarat (243) \\
\hline 2 & Tamil Nadu (302) & Tamil Nadu (143) & Uttarakhand (228) \\
\hline 3 & Gujarat (301) & Himachal Pradesh (143) & Maharashtra (225) \\
\hline 4 & Andra Pradesh (274) & Delhi (142) & Delhi (216) \\
\hline 5 & Maharashtra (268) & West Bengal (141) & Tamil Nadu (212) \\
\hline 6 & $\operatorname{Bihar}(266)$ & Andhra Pradesh (136) & Haryana (208) \\
\hline \multicolumn{4}{|c|}{ Stany o najniższej dynamice wzrostu } \\
\hline 1 & Chhattisgarh (206) & Punjab (118) & Rajasthan (175) \\
\hline 2 & Madhya Pradesh (184) & Jammu \& Kashmir (114) & Goa (171) \\
\hline 3 & Jharkhand (183) & Orissa (112) & Madhya Pradesh (164) \\
\hline 4 & Punjab (179) & Madhya Pradesh (112) & Punjab (151) \\
\hline 5 & Uttar Pradesh (173) & Uttarakhand (110) & Utrat Pradesh (147) \\
\hline 6 & Jammu/Kashmir (162) & Jharkhand (103) & Jammu/Kashmir (142) \\
\hline
\end{tabular}

* w nawiasach wskaźniki wzrostu, w proc.

Źródło: opracowanie i obliczenia własne na podstawie tab. 6.8 .

${ }^{7}$ Weryfikację istotności wyliczonych współczynników przedstawiono w podrozdziale 6.1.1 (przyp. 3). 
Zróżnicowana dynamika rozwoju gospodarczego indyjskich stanów w badanym okresie zmieniła relacje pomiędzy nimi. Przeprowadzona w podrozdziale 6.1.2 analiza wskazuje, że na skutek nierównomiernego tempa wzrostu gospodarczego stanów powiększyło się przestrzenne zróżnicowanie indyjskiej gospodarki. $\mathrm{Z}$ tego powodu zmianom uległa też hierarchia stanów pod względem poziomu rozwoju gospodarczego.

Skalę zróżnicowania poziomu rozwoju gospodarczego indyjskich stanów (mierzonego produktem społecznym netto stanu per capita) w okresie przemian transformacyjnych przedstawiają dane liczbowe zestawione w tab. 6.10.

Wskaźniki w tab. 6.10 nie mają charakteru bezwzględnego, lecz względny, tzn. wielkość produktu społecznego netto per capita nie jest wyrażona bezpośrednio w jednostkach pieniężnych, lecz w odniesieniu do jednego z najbardziej rozwiniętych i szybko rozwijających się regionów, tj. Delhi NCT. Takie ujęcie nie zmienia istoty merytorycznej zagadnienia, natomiast znacznie ułatwia jego prezentację i analizę porównawczą.

$\mathrm{Z}$ tab. 6.10 nietrudno odczytać usytuowanie poszczególnych stanów w hierarchii ich poziomu rozwoju gospodarczego w każdym roku badanego okresu. Można też określić dystans dzielący dany stan od innych stanów i na tej podstawie oceniać jego dynamikę rozwojową. Szczególnie istotne jest porównanie kolejności stanów pod względem poziomu rozwoju na początku lat 90 . ze stanem z przełomu pierwszej i drugiej dekady XXI wieku.

Aby ułatwić taką analizę, w tab. 6.11 zestawiono - podobnie jak w przypadku analizy tempa wzrostu globalnych wielkości produktów społecznych stanów - kolejno 6 najwyżej i 6 najsłabiej rozwiniętych gospodarczo stanów w trzech najważniejszych dla analizy latach.

Tabela 6.11 przedstawia rozkład przestrzenny poziomu rozwoju gospodarczego Indii. Jakkolwiek zmieniły się w badanym okresie, na skutek różnego tempa rozwoju, dystanse pomiędzy poszczególnymi stanami, to jednak nie można mówić o jakichś istotnych przekształceniach w indyjskiej przestrzeni gospodarczej. Potwierdza to wcześniejsze ustalenia poczynione na gruncie badania dynamiki i struktury wzrostu gospodarczego stanów.

Obszary i bieguny wysokiego oraz niskiego poziomu rozwoju gospodarczego pozostały w zasadzie te same, zmieniła się jedynie odległość między nimi, przy czym w niektórych przypadkach mamy do czynienia ze wzrostem rozpiętości, a kiedy indziej z ich zmniejszeniem. Nietrudno dostrzec, że obszarami najbardziej rozwiniętymi gospodarczo są północno-zachodnie stany Indii (Delhi NCT, Haryana, Punjab, Himachal Pradesh) oraz zachodniej (Goa, Maharashtra i Gujarat). Znamienny jest przypadek Punjabu, który na skutek niskiego tempa rozwoju w pierwszych latach bieżącego wieku „wypad’” z grona stanów najbardziej rozwiniętych. Obszarami najgorzej rozwiniętymi są z kolei stany leżące w północno-środkowej (Bihar, Uttar Pradesh, Jharkhand, Chhattisgarh, Madhya Pradesh) i północno-wschodniej (Assam i pozostałe stany Trójkta Assamskiego) części kraju. 


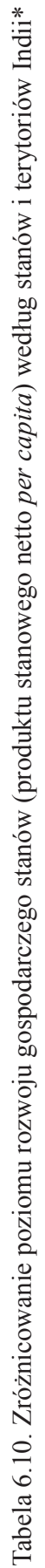

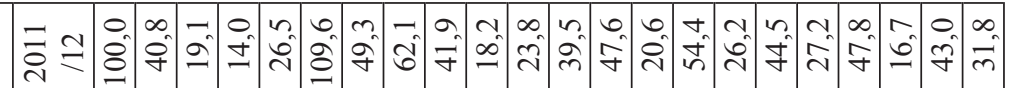
(4)

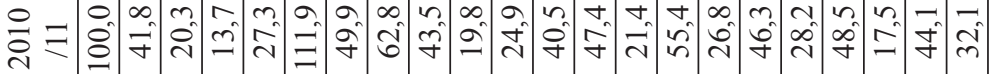
I 0 o ठำㅇำ

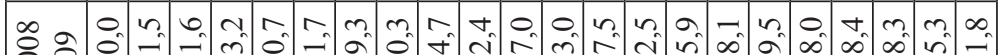
ह่

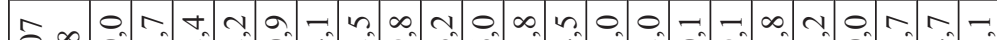

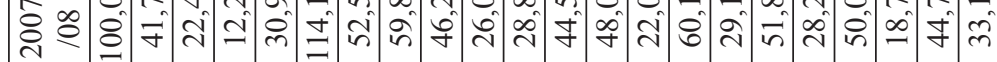

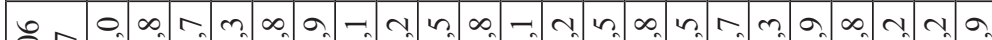
ठํㅇㅇำ

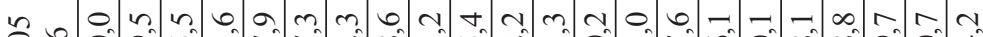

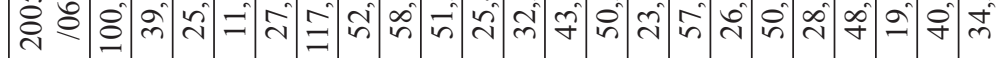
I n

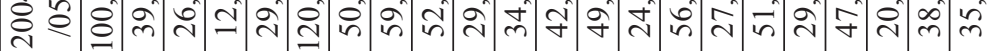

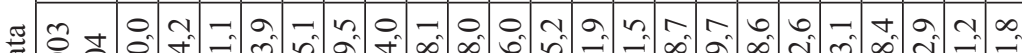

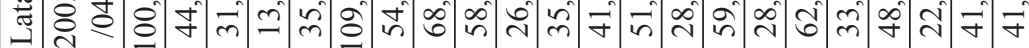

ป⿰

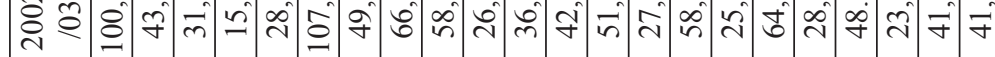

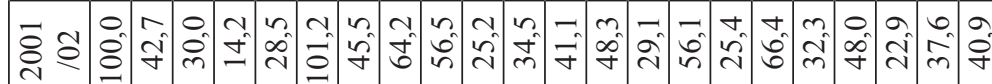
\&

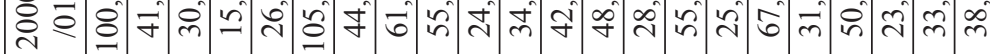
2 8

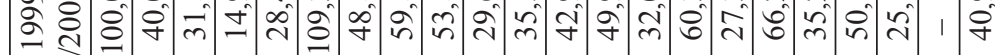

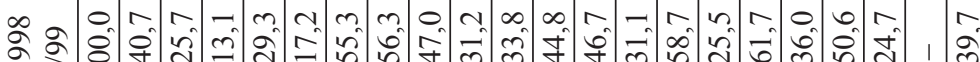
- -1 च

$\hat{\sigma} \infty$ O

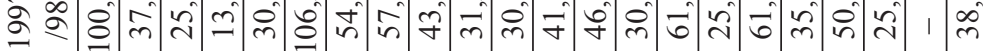

$\circ \wedge$ 이

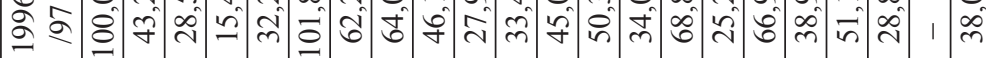

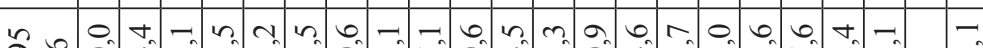

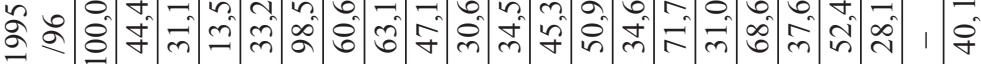

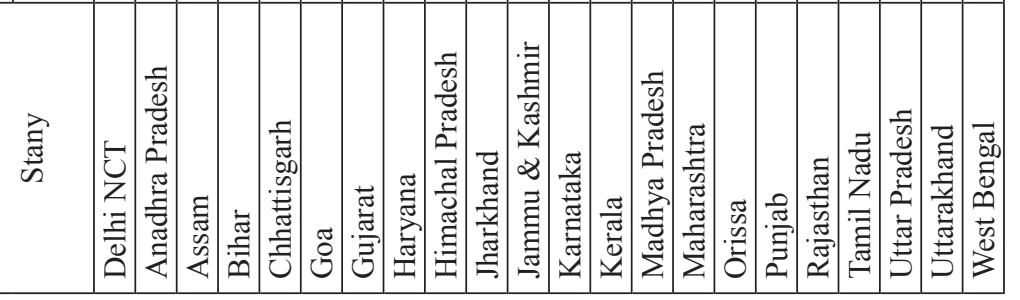


Tabela 6.11. Stany o najwyższym i najniższym poziomie rozwoju gospodarczego

\begin{tabular}{|c|l|l|l|}
\hline \multirow{2}{*}{ Lp. } & \multicolumn{3}{|c|}{ Lata } \\
\cline { 2 - 4 } \multicolumn{2}{|c|}{ Stany o najwyższym produkcie społecznym netto per capita } \\
\hline 1 & Delhi NCT & Goa & Goa \\
\hline 2 & Goa & Delhi NCT & Delhi NCT \\
\hline 3 & Maharashtra & Punjab & Haryana \\
\hline 4 & Punjab & Haryana & Maharashtra \\
\hline 5 & Haryana & Maharashtra & Gujarat \\
\hline 6 & Gujarat & Himachal Pradesh & Tamil Nadu \\
\hline \multicolumn{4}{|c|}{ Stany o najniższym produkcie społecznym netto per capita } \\
\hline 1 & Chhattisgarh & Madhya Pradesh & Jammu/Kaszmir \\
\hline 2 & Assam & Chhattisgarh & Madhya Pradesh \\
\hline 3 & Orissa & Orisa & Assam \\
\hline 4 & Jharkhand & Jharkhand & Jharkhand \\
\hline 5 & Uttar Pradesh & Uttar Pradesh & Uttar Pradesh \\
\hline 6 & Bihar & Bihar & Bihar \\
\hline
\end{tabular}

Źródło: opracowanie własne na podstawie tab. 6.10.

Z tab. 6.10 i 6.11 wynika, że do trzeciej grupy stanów, czyli średnio rozwiniętych gospodarczo, zaliczają się (z wyjątkiem Jammu \& Kashmir, West Bengal i Rajasthan) stany zachodniej i południowej części kraju (Karnataka, Kerala, Andhra Pradesh i Tamil Nadu), których dystans w stosunku do stanów najwyżej rozwiniętych tylko nieznacznie się zmieniał.

W celu dokładniejszego pomiaru zmian przestrzennego zróżnicowania rozwoju gospodarczego Indii wykorzystano - podobnie jak w rozdziale II - statystyczne miary rozproszenia, tj. rozstęp oraz współczynnik zmienności ${ }^{8}$. Podstawą obliczeń są wskaźniki przestrzennego zróżnicowania produktu stanowego netto per capita w poszczególnych latach badanego okresu zawarte w tab. 6.10. Jakkolwiek wartości produktu stanowego per capita $\mathrm{w}$ tej tabeli są wyrażone w wielkościach względnych ( $\mathrm{tj}$. w stosunku do wielkości produktu społecznego netto per capita w Delhi NCT), to fakt ten - jak wspomniano - nie zmienia merytorycznej istoty wskaźników zmienności, a ułatwia ich prezentację oraz interpretację. Wyniki wyliczeń obu wskaźników przedstawiono w tab. 6.12.

\footnotetext{
${ }^{8}$ Metodykę wyliczeń obu wskaźników przedstawiono w podrozdziale 2.4.3 (przypis 42).
} 
Tabela 6.12. Wskaźniki zmienności przestrzennej poziomu rozwoju gospodarczego stanów (produktu stanowego netto per capita)

\begin{tabular}{|c|c|c|}
\hline \multirow{2}{*}{ Lata } & \multicolumn{2}{|c|}{ Wskaźnik } \\
\cline { 2 - 3 } & $\begin{array}{c}\text { Rozstęp }\left(R_{x}\right) \\
\text { - różnica punktów w tab. 6.10 }\end{array}$ & $\begin{array}{c}\text { Współczynnik zmienności }\left(V_{d x}\right), \\
\text { w proc. }\end{array}$ \\
\hline $1995-96$ & 86,5 & 35,1 \\
\hline $1996-97$ & 86,4 & 36,7 \\
\hline $1997-98$ & 93,1 & 37,0 \\
\hline $1998-99$ & 104,1 & 36,9 \\
\hline $1999-00$ & 94,4 & 36,4 \\
\hline $2000-01$ & 90,1 & 38,1 \\
\hline $2001-02$ & 87,0 & 36,5 \\
\hline $2002-03$ & 92,2 & 37,2 \\
\hline $2003-04$ & 95,6 & 36,3 \\
\hline $2004-05$ & 108,1 & 38,6 \\
\hline $2005-06$ & 105,7 & 39,9 \\
\hline $2006-07$ & 101,6 & 39,7 \\
\hline $2007-08$ & 101,9 & 39,2 \\
\hline $2008-09$ & 108,5 & 40,0 \\
\hline $2009-10$ & 101,0 & 41,4 \\
\hline $2010-11$ & 98,2 & 41,2 \\
\hline $2011-12$ & 95,6 & 41,8 \\
\hline
\end{tabular}

Źródło: obliczenia własne na podstawie tab. 6.10 oraz wzorów podanych w pracy [Domański (red.), 2001, s. 48-50].

Pierwsza miara zmienności - rozstęp $\left(R_{x}\right)$ - jest różnicą pomiędzy stanem o najwyższej a stanem o najniższej wielkości produktu stanowego netto per capita. Jak wynika z tab. 6.10, są to konkretnie rozpiętości pomiędzy poziomem rozwoju ekonomicznego stanu Goa a stanu Bihar. Wielkości produktu społecznego na 1 mieszkańca Goa przekraczały w badanym okresie 8-10-krotnie analogiczny wskaźnik dla stanu Bihar. Gdyby jeszcze porównać drugi stan pod względem poziomu rozwoju gospodarczego, tj. Delhi NCT (formalnie - terytorium związkowe) z przedostatnim stanem (w tab. 6.10. i 6.11), czyli Uttar Pradesh (sąsiadującym z Delhi NCT), to w analogicznym czasie wielokrotności w produkcie społecznym netto per capita zwiększyły się z 3,6 do 6,0. Różnice są więc ogromne jak na jeden kraj, a w dodatku regiony sąsiadujące ze sobą.

Dokładniej skalę zmian poziomu rozwoju gospodarczego indyjskich stanów w całej ich populacji wyrażają zestawione w tab. 6.12 wartości współczynnika 
zmienności $\left(V_{d x}\right)$. Są one dość wysokie (35-42 proc.) i wykazują stały wzrost. Taka tendencja zmian tego współczynnika oznacza, że zróżnicowanie poziomu rozwoju ekonomicznego stanów jest dość duże i w badanym okresie powiększało się, czyli - można teraz jednoznacznie stwierdzić - po 1991 roku narastała przestrzenna dywergencja indyjskiej gospodarki.

Na zakończenie analizy warto przyglądnąć się problemowi zróżnicowania wyróżnionych makroregionów pod względem wydajności ich gospodarek. Miarą tej wydajności są wielkości produktu społecznego netto przypadające na 1 mieszkańca w badanych makroregionach (inaczej - produktu makroregionalnego netto per capita) ${ }^{9}$. W naszym ujęciu nie podajemy tych wielkości wprost, lecz pośrednio - jako stosunek udziału danego makroregionu w tworzeniu produktu krajowego netto do udziału tegoż makroregionu w liczbie ludności kraju. Wyliczone wskaźniki dla lat 2001/02 i 2010/11 zawarto w tab. 6.13.

Tabela 6.13. Wskaźniki wydajności gospodarczej makroregionów Indii

\begin{tabular}{|c|c|c|c|c|c|c|}
\hline \multirow[b]{3}{*}{ Makroregiony } & \multicolumn{6}{|c|}{ Lata } \\
\hline & \multicolumn{3}{|c|}{$2000 / 2001$} & \multicolumn{3}{|c|}{$2010 / 2011$} \\
\hline & 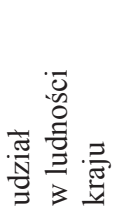 & 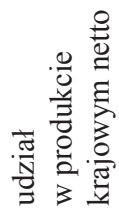 & 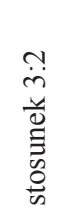 & 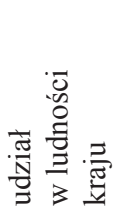 & 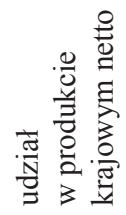 & 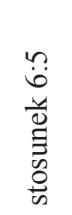 \\
\hline Północno-zachodni & 17,8 & 23,32 & 1,31 & 18,0 & 24,78 & 1,38 \\
\hline Północno-środkowy & 33,6 & 19,57 & 0,58 & 34,6 & 18,36 & 0,53 \\
\hline Północno-wschodni & 11,6 & 11,70 & 1,01 & 11,3 & 9,74 & 0,83 \\
\hline Południowo-zachodni & 17,8 & 24,94 & 1,40 & 17,2 & 25,84 & 1,44 \\
\hline Południowo-wschodni & 19,1 & 20,47 & 1,07 & 18,5 & 21,28 & 1,15 \\
\hline
\end{tabular}

Źródło: opracowanie i obliczenia własne na podstawie danych z tab. 6.7 i 6.10.

Analizując dane w tab. 6.13, nietrudno dostrzec znaczące różnice w poziomie wydajności gospodarek wyróżnionych makroregionów. Otóż najbardziej wydajną - to znaczy legitymującą się najwyższymi wielkościami produktu społecznego netto na 1 mieszkańca - jest gospodarka w Makroregionie Południowo-zachodnim (stany: Goa, Maharashtra, Karnataka i Kerala). Drugie miejsce zajmuje Makroregion Północno-zachodni (Punjab, Rajastthan, Hima-

${ }^{9}$ Produkt makroregionalny (brutto/netto) jest sumą produktu społecznego (brutto/netto) stanów wchodzących w skład danego makroregionu. 
chal Pradesh, Haryana, Gujarat, Delhi NCT i Jammu \& Kashmir). Na ostatnich dwóch miejscach w tab. 6.13 znajdują się: Makroregion Północno-wschodni (stany: West Bengal i stany Trójkąta Assamskiego) oraz Północno-środkowy (Madhya Pradesh, Uttar Pradesh, Bihar, Uttarkhand i Jharkhand). Wydajność gospodarki tego ostatniego makroregionu jest ponaddwuipółkrotnie niższa niż W wiodącym Makroregionie Południowo-zachodnim. W dodatku różnice te wzrosły w pierwszej dekadzie XXI wieku, co świadczy pogłębianiu się dysproporcji regionalnych w poziomie rozwoju gospodarczego Indii. Dobitnie potwierdza się więc teza o narastającej dywergencji w gospodarce przestrzennej tego kraju. Jej najbardziej znamienną cechą jest pogłębianie się podziału kraju pod względem poziomu rozwoju gospodarczego na Indie dwóch prędkości: pierwszej - wyższej, tj. Indii zachodnich i południowych oraz drugiej - niższej, tj. Indii północnych i wschodnich. Inaczej ujmując, można mówić nie tylko o istnieniu Indii A i Indii B, ale - co gorsze - o oddalaniu się od siebie obu tych obszarów.

\subsection{Społeczne aspekty rozwoju gospodarczego - ujęcie regionalne}

Dokonujące się po reformach lat 1991-1992 zmiany w gospodarce Indii wyraziły się wysoką dynamiką podstawowych parametrów makroekonomicznych, tj. głównie wzrostem produktu społecznego (brutto oraz netto), produkcji rolnej, przemysłowej, wymiany handlowej, napływu kapitału zagranicznego, a także intensywnym rozwojem sektora nowoczesnych usług.

Rozwój gospodarczy nie jest jednak celem samym w sobie, jest przede wszystkim środkiem do osiągnięcia nadrzędnego, finalnego celu gospodarowania, jakim jest poprawa materialnych i społecznych warunków życia ludności. Ostatecznym kryterium i weryfikatorem przemian gospodarczych są zmiany w poziomie oraz jakości życia ludzi na badanym terytorium. W praktyce badawczej skalę tych zmian wyraża się z reguły przy pomocy analizy i oceny wskaźników z zakresu takich dziedzin życia społecznego, jak: żywienie oraz użytkowanie ważniejszych artykułów gospodarstwa domowego, transport osobowy, edukacja, zdrowie, kultura, przyrost naturalny, umieralność oraz trwanie życia ludzkiego [Das, 1999]. Tak też postąpiono w niniejszym podrozdziale.

Analiza empiryczna wybranych, ważniejszych wskaźników społecznych posłuży do dopełnienia oceny indyjskich przemian gospodarczych po 1991 roku. Wskaże na wpływ, jaki wywarły zapoczątkowane w latach 1991-1992 reformy gospodarki i państwa na poprawę warunków życia ludności, i jak się te warunki zmieniały w poszczególnych regionach kraju oraz w różnych grupach indyjskiego społeczeństwa. 


\subsubsection{Przemiany demograficzne}

Jak już wspominano, na efekty ekonomiczne reform indyjskiej gospodarki i państwa istotny wpływ wywierała wysoka dynamika rozwoju demograficznego. Skala i kierunki tego oddziaływania były różne, na ogół miały charakter sprzężeń zwrotnych.

Z jednej strony wysoki przyrost naturalny pomniejszał społeczne efekty wzrostu gospodarczego Indii. Przyrosty globalnego PKB ,rozkładały się” bowiem na coraz większą liczbę mieszkańców, co sprawiało, że faktyczny, czyli realny - bo przeliczony na 1 osobę - wzrost gospodarczy był znacznie wolniejszy i słabiej odczuwany przez społeczeństwo.

Z drugiej jednak strony wysoka dynamika demograficzna w okresie 19912012 była ważnym akceleratorem wzrostu gospodarczego i to zarówno w sensie ilościowym, jak i jakościowym. Zwiększanie się liczby ludności, szczególnie tej w wieku produkcyjnym, a więc ludzi młodych, na ogół lepiej wykształconych niż wcześniejsze roczniki, podnosiło wartość kapitału ludzkiego, co sprzyjało wzrostowi wydajności pracy i ostatecznie wzrostowi gospodarczemu, tym bardziej, że odbywało się to w coraz nowocześniejszych segmentach gospodarki. Ponadto wzrost liczby ludności i jej wykształcenia stymulował popyt konsumpcyjny, a ten z kolei - w warunkach gospodarki rynkowej - stawał się lokomotywą produkcji towarów oraz rozwoju sfery usług (szczególnie handlowych i finansowych).

Celem niniejszego podrozdziału jest wskazanie podstawowych zjawisk i procesów, jakie pojawiły się w krajobrazie demograficznym Indii po 1991 roku, a które są równocześnie efektem i determinantą rozwoju gospodarczego.

W tab. 6.14 zestawiono wielkości przedstawiające dynamikę rozwoju demograficznego Indii w podziale na stany. Nietrudno dostrzec, że zróżnicowanie stanów pod względem powierzchni oraz liczby ludności i jej zmian w badanych dwóch dekadach, wyznaczonych datami narodowych spisów powszechnych (1991, 2001 i 2011), jest znaczące ${ }^{10}$.

Jak informuje tab. 6.14, w okresie 1991-2011 nastąpił znaczący wzrost liczby ludności Indii, bo o blisko $364 \mathrm{mln}$, czyli o 43 proc. Jest to wyższy przyrost względny niż w przypadku pozostałej (tj. z wyłączeniem Indii) ludności świata, który w tym okresie wyniósł 35 proc. Z kolei liczba mieszkańców Azji (też z wyłączeniem Indii) zwiększyła się o 38 proc. [Rocznik Statystyczny RP 2012, 2012, s. 746]. Wskaźniki te dają pogląd na skalę trudności, a zarazem szans rozwojowych Indii. Należy jednakże zwrócić uwagę na słabnące (degresywne) tempo powiększania się ludności Indii. Jeżeli w latach 1981-1991 liczba mieszkańców tego kraju powiększyła się o 23,9 proc., to w dekadzie 1991-2001 stopa wzrostu wyniosła 21,5 proc., a w latach 2001-2011 było to już 17,6 proc. [Census of India 2011, 2011, s. 45].

${ }^{10} \mathrm{~W}$ dniu 2 czerwca 2014 roku powstał nowy, 29. stan Indii - Telangana. Jego powierzchnia wynosi 114,8 tys. km² i jest zamieszkały przez 35 mln ludzi. Wydzielono go z Andhra Pradesh. 
Tabela 6.14. Powierzchnia oraz ludność stanów i terytoriów unijnych

\begin{tabular}{|c|c|c|c|c|c|}
\hline \multirow{2}{*}{$\begin{array}{c}\text { Stany } \\
\text { i terytoria unijne }\end{array}$} & \multirow{2}{*}{$\begin{array}{c}\begin{array}{c}\text { Powierzchnia* } \\
\text { w tys. } \mathrm{km}^{2}\end{array} \\
2001\end{array}$} & \multicolumn{4}{|c|}{$\begin{array}{c}\text { Ludność, } \\
\text { w tys. }\end{array}$} \\
\hline & & 1991 & 2001 & 2011 & $\begin{array}{l}\text { 2011/1991 } \\
\text { w proc.** }\end{array}$ \\
\hline Andhra Pradesh & 275,0 & 66508 & 75728 & 84666 & 127,3 \\
\hline Arunachal Pradesh & 83,7 & 865 & 1091 & 1383 & 159,9 \\
\hline Assam & 78,4 & 22414 & 26638 & 31170 & 139,1 \\
\hline Bihar & 94,2 & 86374 & 82879 & 103805 & 158,4 \\
\hline Chhattisgarh & 135,0 & - & 20796 & 25540 & - \\
\hline Goa & 3,7 & 1170 & 1344 & 1457 & 124,4 \\
\hline Gujarat & 196,0 & 41310 & 50597 & 60384 & 146,2 \\
\hline Haryana & 44,2 & 16464 & 21083 & 25353 & 154,0 \\
\hline Himachal Pradesh & 55,7 & 5171 & 6077 & 6857 & 132,6 \\
\hline Jammu/Kashmir & 222,2 & 7719 & 10070 & 12549 & 162,3 \\
\hline Jharkhand & 79,6 & - & 26909 & 32966 & - \\
\hline Karnataka & 191,8 & 44977 & 52734 & 61131 & 135,9 \\
\hline Kerala & 38,9 & 29099 & 31839 & 33388 & 114,7 \\
\hline Madhya Pradesh & 308,1 & 66181 & 60385 & 72598 & 148,3 \\
\hline Maharshtra & 307,7 & 78937 & 96752 & 112373 & 142,4 \\
\hline Manipur & 22,3 & 1837 & 2389 & 2722 & 150,9 \\
\hline Meghalaya & 22,2 & 1775 & 2306 & 2964 & 167,0 \\
\hline Mizoram & 21,1 & 690 & 891 & 1091 & 158,1 \\
\hline Nagaland & 16,6 & 1210 & 1989 & 1981 & 163,7 \\
\hline Orissa & 155,7 & 31660 & 36707 & 41947 & 132,5 \\
\hline Punjab & 50,4 & 20282 & 24289 & 27704 & 136,6 \\
\hline Rajasthan & 342,2 & 44006 & 56473 & 68621 & 155,9 \\
\hline Sikkim & 7,1 & 406 & 540 & 608 & 149,8 \\
\hline Tamil Nadu & 130,1 & 55859 & 62111 & 72139 & 129,1 \\
\hline Tripura & 10,5 & 2757 & 3191 & 3671 & 133,2 \\
\hline Uttar Pradesh & 241,0 & 139112 & 166053 & 199581 & 150,7 \\
\hline Uttarakhand & 53,3 & - & 8480 & 10117 & - \\
\hline West Bengal & 88,8 & 68078 & 80221 & 91348 & 134,2 \\
\hline Terytoria unijne razem & 9,4 & 2023 & 2670 & 3228 & 159,6 \\
\hline Delhi NCT & 1,5 & 9421 & 13783 & 16753 & 177,8 \\
\hline Ogółem - Indie $* * *$ & 3286,4 & 846305 & 1027015 & 1210193 & 143,0 \\
\hline
\end{tabular}

* w latach 90. ub. wieku powierzchnia poszczególnych stanów, z wyjątkiem Uttar Pradesh, Biharu i Madhya Pradesh (z których wyodrębniono trzy stany), nie uległa zmianie, ${ }^{* *}$ dla obliczania wskaźników dynamiki 2011/1991, w przypadku stanów Bihar, Madhya Pradesh oraz Uttar Pradesh, dla 2011 roku przyjęto liczbę ludności powiększoną o ludność wyłonionych z nich w 2000 roku stanów Jharkhand, Chhattisgarh oraz Uttarakhand, *** dane łączne dla Indii nie są - z uwagi na zaokrąglenia dla stanów - dokładną sumą ludności w stanach i terytoriach unijnych oraz NCT Delhi.

Źródło: opracowanie i część obliczeń własnych na podstawie: [Statistical Outline of India 1999-2000, 1999, s. 43], [India 2003. Observer Statistical Handbook, 2003, s. A-02, D-03], [Bose, 2001, s. 26], [Census of India 2011, 2011, s. 36-47]. 
Analizując dynamikę demograficzną Indii w kontekście zmian warunków życia ludności, warto odnieść ją do dynamiki PKB oraz globalnej produkcji zbóż. Otóż jeżeli w pierwszych trzech dekadach niepodległości tempo wzrostu wszystkich trzech wielkości było podobne (nieznacznie wolniejsze tempo wzrostu liczby ludności), to od lat 80. różnice szybko się zwiększają. Najwyższą dynamikę wykazuje wzrost PKB, następnie jest produkcja zbóż, a znacznie niższy od nich jest wzrost demograficzny [Census of India 2011, 2011, s. 60].

W badanych dwóch dekadach we wszystkich stanach miał miejsce przyrost liczby ludności, aczkolwiek stopa tego wzrostu była znacząco zróżnicowana. Najwyższymi przyrostami legitymują się NCT Delhi - o 77 proc., a następnie - kolejno: Meghalaya, Nagaland, Jammu \& Kashmir oraz Bihar; w tych stanach liczba ludności zwiększyła się o ponad 55 proc. Jak nietrudno zauważyć, najszybciej powiększa się demograficznie region stołeczny, a decyduje o tym przede wszystkim wysoka migracja. Kolejne terytoria o wysokich przyrostach, to osiem stanów gospodarczo zacofanych, położonych na kresach Indii - północno-zachodnich (Jammu \& Kashmir i Rajasthan), oraz północno-wschodnich (Maghalaya, Nagaland, Mizoram, Bihar, Arunachal i terytoria unijne). W tych stanach głównym źródłem rozwoju demograficznego był przyrost naturalny.

Średni, bo w granicach 40-55 proc., przyrost demograficzny obserwuje się w stanach środkowo-zachodnich (Haryana, Madhya Pradesh, Maharashtra, Uttar Pradesh, Gujarat) oraz małych stanach północno-wschodnich (Manipur, Sikkim). Generalnie stany zaliczane do tej grupy cechuje - jak wiadomo z wcześniejszej analizy - średni lub niski poziom rozwoju gospodarczego.

Mniejszy niż 40-procentowy przyrost ludności w latach 1991-2011 miał miejsce w pozostałych stanach, zlokalizowanych w południowo-zachodniej lub wschodniej części Indii (Karnataka, Kerala, Orissa, Tamil Nadu, West Bengal, Assam i Tripura). Są to na ogół obszary o średnim lub wyższym - jak na warunki indyjskie - poziomie rozwoju gospodarczego.

Powyższa analiza nie pozwala dostrzec jakichś wyraźnie charakterystycznych cech w rozmieszczeniu przestrzennym ludności Indii, ani też sformułować prawidłowości zmian. Jedyne, co dałoby się zauważyć - chociaż ze znaczącymi wyjątkami - to fakt, że w badanym okresie w stanach biedniejszych występowały wyższe przyrosty liczby ludności niż w stanach zamożniejszych i bardziej zurbanizowanych. To też odbijało się - jak wykazała analiza w podrozdziale 6.2 - na skali przestrzennego zróżnicowania poziomu rozwoju ekonomicznego stanów. Wpłynęło także na kształtowanie się wielkości niektórych wskaźników społecznych, przedstawionych w dalszej części rozdziału.

Istotnym elementem krajobrazu demograficznego Indii są międzystanowe przepływy ludności. Ich skala jest bardzo duża. Według powszechnego spisu ludności w 2001 roku liczba emigrantów wynosiła $315 \mathrm{mln}$, tj. 31 proc. ogółu ludności. W 2011 roku, na skutek przyspieszonej urbanizacji w pierwszych latach XXI wieku, już $400 \mathrm{mln}$ osób na obecne (w 2011 roku) miejsce pobytu przybyło 
z innego obszaru (33 proc. wszystkich Indusów) [Rajan, 2013, s. 1]. Są to z reguły migracje motywowane ekonomicznie, czyli pracą i edukacją lub związkami małżeńskimi. Stanami, do których płynęły główne strumienie migrantów, to Maharashtra, Gujarat, NCT Delhi, Karnataka, Punjab oraz Haryana. Natomiast stanami, z których emigruje najwięcej osób, są stany biedne, a więc przede wszystkim stany północne oraz wschodnie, a w szczególności Uttar Pradesh, Bihar, Madhya Pradesh, Andhra Pradesh, Orissa, West Bengal i Tamil Nadu [Social Inclusion of Internal Migrants in India, 2013, s. 2-4].

Do podstawowych wskaźników demograficznych należą proporcje pomiędzy liczbą kobiet a liczbą mężczyzn zamieszkujących dane terytorium. Otóż w skali świata liczba kobiet równoważy się z liczbą mężczyzn. W krajach średnio i wysoko rozwiniętych populacja kobiet jest na ogół liczniejsza od populacji mężczyzn, np. w Unii Europejskiej (2010) na 100 mężczyzn przypadało 105 kobiet, a w Polsce - 107 [Rocznik Statystyczny RP 2012, 2012, s. 742]. Odwrotnie wygląda natomiast sytuacja w Indiach. Jak wskazują wyniki spisów ludności w tym kraju, przez cały niemal wiek XX liczba kobiet była niższa od liczby mężczyzn i w dodatku współczynnik ten systematycznie obniżał się z 972 kobiet na 1000 mężczyzn w 1901 roku do 927 w 1991 roku - najmniej w całym stuleciu. Dopiero w latach 90. obserwuje się ponowny wzrost i w 2001 roku na 1000 mężczyzn przypadały już 933 kobiety, a w 2011 - 940 kobiet $^{11}$. Jedynym stanem, w którym liczba kobiet przewyższa liczbę mężczyzn jest Kerala (w 2011 roku - 1084) [Census of India 2011, 2011, s. 80-81, 87]. Nie jest chyba przypadkiem, że ta cezura zmiany trendu (1991 rok) jest związana z zapoczątkowaniem reform gospodarki i państwa.

Głównym źródłem rozwoju demograficznego Indii jest przyrost naturalny. Jego wielkość obrazują wskaźniki w tab. 6.15. Jeżeli chodzi o ruchy migracyjne (tj. wyjazdy za granicę i przyjazdy na stałe), to ich skala jest relatywnie niewielka. Saldo migracji jest dla całych Indii niemal zawsze ujemne, ale nie odgrywa ono poważniejszej roli w kształtowaniu sytuacji demograficznej kraju.

Przyrost naturalny jest - jak widać w tab. 6.15 - bardzo wysoki. Pod koniec pierwszej dekady bieżącego wieku przekraczał średnią światową (łącznie $\mathrm{z}$ Indiami) o ponad 30 proc., a w porównaniu z krajami europejskimi jest

${ }^{11}$ Przyczyny tego zjawiska mają charakter ekonomiczno-kulturowy, opisano je w rozdziale II i IV. Jednym ze skutków deficytu kobiet jest to, że nie wszyscy mężczyźni mogą znaleźć żony i zakładać rodziny. Dodatkowo problem ten pogłębia widoczna po 1991 roku emancypacja kobiet, szczególnie tych wykształconych i ekonomicznie niezależnych. Nie chcą się one podporządkować tradycyjnym regułom indyjskiego życia rodzinnego i wolą pozostawać w stanie wolnym albo wyjść za mąż za obcokrajowca i wyjechać za granicę. Wyrazem tego jest systematycznie obniżający się odsetek mężatek w ogólnej liczbie indyjskich kobiet w wieku 15-44 lat. W 1961 roku zamężnych kobiet było 85,8 proc., a w 2001 roku - 73,6 proc. [Datt, Mahajan, 2014, s. 62]. 
kilkunastokrotnie większy [Rocznik Statystyczny RP 2012, 2012, s. 762-763]. Takie wskaźniki przyrostu naturalnego są typowe dla krajów zacofanych, o niskim poziomie rozwoju społecznego, a zwłaszcza kultury zdrowotnej.

Tabela 6.15. Ruch naturalny ludności Indii

\begin{tabular}{|c|c|c|c|c|c|c|c|c|c|}
\hline \multirow{3}{*}{ Lata } & \multicolumn{3}{|c|}{ Urodzenia żywe } & \multicolumn{3}{|c|}{ Zgony } & \multicolumn{3}{|c|}{ Przyrost naturalny } \\
\hline & \multicolumn{9}{|c|}{ na 1 tys. mieszkańców } \\
\hline & ogółem & wsie & miasta & ogółem & wsie & miasta & ogółem & wsie & miasta \\
\hline 1991 & 29,5 & 30,9 & 24,3 & 9,8 & 10,6 & 7,1 & 19,7 & 20,3 & 17,2 \\
\hline 1994 & 28,7 & 30,5 & 23,1 & 9,3 & 10,1 & 6,7 & 19,4 & 20,4 & 16,4 \\
\hline 1997 & 27,2 & 28,9 & 21,5 & 8,9 & 9,6 & 6,5 & 18,3 & 19,2 & 15,0 \\
\hline 2000 & 25,8 & 27,6 & 20,7 & 8,5 & 9,3 & 6,3 & 17,3 & 18,3 & 14,4 \\
\hline 2003 & 24,8 & 26,4 & 19,8 & 8,0 & 8,7 & 6,0 & 16,8 & 17,8 & 13,8 \\
\hline 2006 & 23,5 & 25,2 & 18,8 & 7,5 & 8,1 & 6,0 & 16,0 & 17,2 & 12,8 \\
\hline 2009 & 22,5 & 24,1 & 18,3 & 7,3 & 7,8 & 5,8 & 15,2 & 16,3 & 12,5 \\
\hline 2012 & 20,6 & - & - & 7,4 & - & - & 13,2 & - & - \\
\hline
\end{tabular}

Źródło: [Selected Socio-Economic Statistics India, 2011, s. 32, tab. 1.21].

W badanym dwudziestoleciu następuje jednakże wyraźny spadek stopy urodzeń. Jak wynika z tab. 6.15, w 2012 roku jest ona o ok. 30 proc. niższa niż w 1991 roku. Na taki obraz zjawiska wpłynęło wiele równocześnie występujących czynników, do których zaliczyć można w szczególności znaczące zmniejszenie stopy dzietności kobiet w najmłodszych grupach wiekowych. W 1988 roku współczynnik dzietności kobiet (ilość urodzeń na 1 tys. kobiet) wyniósł w najmłodszej grupie wiekowej (15-19 lat) - 259, a w 2011 roku było to już tylko 31 urodzeń. Ogólna wartość tego współczynnika (Total Fertility Rate - TFR) dla całych Indii zmniejszyła się w tym czasie z 5,4 do 2,4 dziecka na 1 kobietę w wieku 15-44 lat. Podniósł się także przeciętny wiek zawierania małżeństw. W 1961 roku przeciętny Indus zawierał związek małżeński w wieku 21,6 lat, Induska w wieku 15,8 lat, w 2001 roku liczby te wyniosły odpowiednio - 22,6 i 18,3 lat [Datt, Mahajan, 2014, s. 44]. Zmiany te były - generalnie - efektem poprawy poziomu życia, a szczególnie usług medycznych, wzrostu ogólnego poziomu edukacji społeczeństwa, a w tym także edukacji seksualnej ${ }^{12}$.

${ }^{12}$ Nie bez wpływu na malejącą stopę urodzeń w Indiach ma też sterylizacja kobiet, a także - ale w mniejszym zakresie - mężczyzn. Formalnie rzecz biorąc, odbywa się ona dobrowolnie, ale jest intensywnie zalecana przez władze (szczególnie stanowe), które wyznaczają tzw. kwoty sterylizacyjne oraz wynagrodzenia zarówno dla osób wysterylizowanych, jak i wykonujących te zabiegi. Nie zawsze jednak zabiegi te odbywają się we właściwych warunkach sanitarnych i są przeprowadzane przez kwalifikowanych lekarzy, co prowadzi do skomplikowanych powikłań zdrowotnych i zgonów. Skala zjawiska jest dość duża. Według informacji podawanych przez indyjską prasę, rocznie sterylizuje się w Indiach 3-4 mln kobiet. 
Zmienia się również stopa ogólnej umieralności, przy czym - co znamienne - jej poziom jest zbliżony do wielkości średnich dla świata i niższy nawet niż w wielu rozwiniętych krajach [Rocznik Statystyczny RP 2012, 2012, s. 762]. Stopa zgonów też wykazuje tendencje spadkowe, aczkolwiek dynamika tego procesu jest niższa niż w przypadku urodzeń. Relatywnie niewysoka umieralność i jej stałe obniżanie się jest - ogólnie ujmując - rezultatem wzrostu poziomu życia ludności, w tym także poprawy higieny oraz opieki medycznej.

Wypadkową zmian częstotliwości urodzeń oraz zgonów jest przyrost naturalny. Zmniejszył się on w ciągu dwóch dekad o ok. 30 proc., co jest istotnym spadkiem i zjawiskiem korzystnym dla gospodarki, szczególnie w okresie jej szybkiego rozwoju i dynamicznych przemian kulturowych.

Wszystkie trzy analizowane parametry demograficzne (stopa urodzeń, zgonów oraz przyrostu naturalnego) różnicują się w przekroju wieś-miasto. Znacząco wyższymi wartościami legitymują się obszary wiejskie, ale w badanym okresie różnice nie zmieniają się istotnie.

Zróżnicowany jest przestrzenny rozkład zarówno urodzeń, jak i umieralności. Stanami o najwyższych współczynnikach urodzeń, bo przekraczającymi 25 urodzeń na 1 tys. mieszkańców, są (dane dla 2011 roku): Bihar (27,7), Uttar Pradesh (27,8), Madhya Pradesh $(26,9)$, Rajasthan $(26,2)$ oraz Jharkhand $(25,0)$. Natomiast najniższymi stopami urodzeń (poniżej 18,0) legitymują się: Goa $(13,3)$, Kerala $(15,2)$, Tamil Nadu $(15,9)$, West Bengal $(16,3)$, Himachal Pradesh $(16,5)$, Maharashtra (16,7), NCT Delhi $(17,5)$ i większość stanów Trójkąta Assamskiego (14,0-18,0) [Economic Survey of Maharashtra 2012-13, 2013, s. 238]. Rozkład ten pokrywa się w dużej mierze z geografią poziomu rozwoju gospodarczego, to znaczy wyższe stopy urodzeń występują w stanach biednych, a niższe w stanach zamożnych. Podobnie jest z przestrzennym rozkładem wielkości współczynników zgonów; są one na ogół wyższe w stanach zacofanych gospodarczo i słabo zurbanizowanych.

W badaniach poziomu rozwoju demograficznego oraz społecznego, dużą wartość diagnostyczną mają współczynniki (stopy) umieralności niemowląt. Są one odzwierciedleniem warunków życia, zdrowia, higieny i poziomu edukacyjnego badanych społeczności. Kształtowanie się wartości tych współczynników w latach 1991-2010 w układzie przestrzennym Indii przedstawia tab. 6.16.

Umieralność niemowląt była w Indiach w latach 90. minionego wieku o ok. 25 proc. wyższa od średniej światowej (łącznie z Indiami). Pod koniec pierwszej dekady bieżącego stulecia różnica ta zmniejszyła się do 15 proc. [Rocznik Statystyczny RP 2012, 2012, s. 762]. W badanym okresie nastąpił jednak znaczący postęp w dziedzinie higieny i opieki medycznej nad matkami i niemowlętami, co wyraziło się właśnie szybkim spadkiem stopy umieralności niemowląt. 
Tabela 6.16. Współczynnik umieralności niemowląt według stanów (na 1000 urodzeń żywych)

\begin{tabular}{|c|c|c|c|c|c|c|}
\hline \multirow{3}{*}{ Stany } & \multirow{3}{*}{1991} & \multirow{3}{*}{2001} & \multirow{3}{*}{2010} & \multicolumn{3}{|c|}{2012} \\
\hline & & & & \multirow{2}{*}{ ogółem } & \multicolumn{2}{|c|}{ w tym: } \\
\hline & & & & & chłopcy & dziewczynki \\
\hline Indie - ogółem & 77 & 71 & 47 & 42 & 41 & 43 \\
\hline Delhi-NCT & 54 & 51 & 28 & 25 & 24 & 26 \\
\hline Andhra Pradesh & 55 & 66 & 45 & 41 & 40 & 43 \\
\hline Assam & 92 & 78 & 55 & 55 & 54 & 57 \\
\hline Bihar & 75 & 67 & 48 & 43 & 42 & 45 \\
\hline Chhattisgarh & - & - & 51 & 47 & 46 & 47 \\
\hline Goa & 51 & 36 & 10 & 10 & 8 & 12 \\
\hline Gujarat & 78 & 64 & 44 & 38 & 36 & 39 \\
\hline Haryana & 52 & 69 & 48 & 42 & 41 & 44 \\
\hline Himachal Pradesh & 82 & 64 & 40 & 36 & 35 & 38 \\
\hline Jharkhand & - & - & 42 & 38 & 36 & 39 \\
\hline Jammu \& Kashmir & - & 45 & 43 & 39 & 38 & 40 \\
\hline Karnataka & 74 & 58 & 38 & 32 & 30 & 34 \\
\hline Kerala & 42 & 16 & 13 & 12 & 10 & 13 \\
\hline Madhya Pradesh & 133 & 97 & 62 & 56 & 54 & 56 \\
\hline Maharashtra & 74 & 49 & 28 & 25 & 24 & 26 \\
\hline Orissa & 125 & 98 & 61 & 53 & 52 & 54 \\
\hline Punjab & 74 & 54 & 34 & 28 & 27 & 29 \\
\hline Rajasthan & 87 & 83 & 55 & 49 & 47 & 51 \\
\hline Tamil Nadu & 54 & 53 & 24 & 21 & 21 & 22 \\
\hline Uttar Pradesh & 99 & 85 & 61 & 53 & 52 & 55 \\
\hline Uttarakhand & - & - & 38 & 34 & 33 & 35 \\
\hline West Bengal & 62 & 53 & 31 & 32 & 31 & 33 \\
\hline
\end{tabular}

Źródło: [Dev (ed.), 2013, s. 404-405], [Economic Survey 2013-14. Statistical Appendix, 2014, s. 114].

W skali całych Indii śmiertelność niemowląt zmniejszyła się w latach 1991-2012 z 77 do 42 zgonów na 1 tys. żywych urodzeń, co jest - podkreślmy - dużym osiągnięciem społecznym. Szczególnie wysokie spadki wskaźnika niemowlęcej umieralności notuje się w po 2000 roku. Zjawisko to rozkłada się jednak bardzo nierównomiernie na obszarze kraju i różnice pomiędzy niektórymi stanami są nawet ponaddwukrotne. Najwyższa umieralność niemowląt cechuje 
- podobnie jak umieralność ogółem - stany najbiedniejsze, leżące w środkowej i północno-wschodniej części Indii, tj. w Uttar Pradesh, Madhya Pradesh, Orissie, Chhattisgarh i Trójkącie Assamskim, a także w leżącym na zachodzie kraju - Rajasthanie. Z kolei najniższą stopą zgonów niemowląt charakteryzują się najbardziej rozwinięte ekonomicznie i socjalnie stany, tj. Goa, Kerala, Maharashtra, Tamil Nadu, NCT Delhi oraz West Bengal. W dwóch pierwszych stanach (Goa oraz Kerala) poziom śmiertelności niemowląt jest nawet zbliżony do europejskiego, co świadczy nadzwyczaj dobrze o polityce ekonomicznej oraz społecznej na tym obszarze. Znamienne jest, że - jak widać w tab. 6.16 - we wszystkich stanach znacznie wyższa jest umieralność niemowląt-dziewcząt niż chłopców ${ }^{13}$.

Przeprowadzona analiza przemian ludnościowych w Indiach pozwala stwierdzić, że w okresie badanych dwóch dekad dokonał się w tej dziedzinie znaczący postęp. Dane statystyczne pozwalają na sformułowanie opinii o zatrzymaniu lub regresie niekorzystnych zjawisk i zapoczątkowaniu modernizacji demograficznej Indii. Trendy te są bez wątpienia - aczkolwiek pośrednio - efektem rozpoczętych po 1991 roku reform gospodarki i państwa.

\subsubsection{Warunki życia w świetle wybranych wskaźników społecznych}

Podstawowym kryterium oceny rozwoju gospodarczego Indii są jego efekty społeczne, rozumiane - jak wspomniano w rozdziale II - jako warunki życia (bytu), albo inaczej - poziom życia społeczeństwa. Dlatego też podjęto w niniejszym rozdziale próbę ich identyfikacji i analizy.

Do pomiaru i oceny warunków życia ludności stosuje się różnorakie wskaźniki społeczne wyrażające bezpośrednio lub pośrednio jakiś wymiar ludzkiego bytowania. Nie ma jednak obiektywnych i jednoznacznych kryteriów ani procedur doboru tych miar, istnieją co najwyżej ogólne przesłanki i zalecenia. Skala arbitralności jest więc w tej dziedzinie dość znaczna. Dobór wskaźników oraz sposób ich interpretacji są w dużym stopniu uzależnione od konkretnego przypad$\mathrm{ku}$, czasu, miejsca analizy oraz posiadanego materiału empirycznego ${ }^{14}$.

Pomiar i analizę warunków życia społeczeństwa indyjskiego oraz ich przemian w latach 1991-2012 oparto na wybranych wskaźnikach charakteryzujących

13 Pojawia się w tym miejscu pytanie, czy jest to jakaś biomedyczna prawidłowość, przypadek czy też może efekt opisanych wcześniej (rozdział II) praktyk dyskryminacji indyjskich kobiet wyrażających się m.in. w biernej lub nawet czynnej eutanazji niemowląt płci żeńskiej. W Europie sytuacja jest odwrotna - chłopcy umierają częściej. W Polsce też rejestruje się wyższą umieralność niemowląt-chłopców [por. Rocznik Demograficzny 2013, 2013, s. 344].

${ }^{14}$ Przy doborze miar warunków życia społeczeństwa indyjskiego oparto się na zasadach doboru wskaźników do badań społecznych zalecanych przez S. Nowaka w pracy Metodologia badań spolecznych [Nowak, 2012]. 
infrastrukturę techniczną oraz społeczną. Jakkolwiek wskaźniki te nie odzwierciedlają bezpośrednio stopnia zaspokojenia potrzeb bytowych ludności, to jednak są $\mathrm{z}$ nimi tak silnie skorelowane, że na podstawie ich kształtowania się możemy wnioskować z niewielką dozą błędu o tym, jaki jest w istocie ten poziom życia i jak się zmienia w badanym okresie. Poziom rozwoju indyjskiej infrastruktury technicznej wyrażony jest długością sieci drogowej, dostępem gospodarstw domowych do wody pitnej oraz zużyciem prądu elektrycznego w gospodarstwach domowych. Natomiast dla analizy i oceny infrastruktury społecznej użyto wskaźników charakteryzujących wydatki konsumpcyjne gospodarstw domowych, poziom analfabetyzmu, szkolnictwo wyższe oraz stan zdrowia wyrażony długością życia Indusów ${ }^{15}$.

Jak wskazuje tab. 6.17, w badanym okresie znacząco poprawiły się w Indiach warunki transportu osobowego, co jest bardzo ważne dla tak wielkiego i ludnego kraju. Wyraża się to wzrostem długości i gęstości dróg. Ogólnie ujmując, tj. uwzględniając wszystkie rodzaje dróg, ich długość wzrosła w latach 1991-2011 półtorakrotnie. Najszybszy (ok. 220 proc.) był przyrost dróg lokalnych - miejskich i wiejskich. Ocenić to należy wysoce pozytywnie. Dzięki temu poprawiają się warunki życia społeczności lokalnych. Podwojenie się długości autostrad krajowych (210 proc.) oznacza duże usprawnienie transportu dalekiego zasięgu, a szczególnie szybsze połączenia samochodowe między największymi aglomeracjami. Znakomicie zwiększa to atrakcyjność inwestycyjną i turystyczną kraju, a także jego poszczególnych obszarów, ułatwia codzienne funkcjonowanie gospodarki i państwa oraz życie obywateli. Podwojenie długości sieci transportu drogowego, i to na ogół w stosunkowo niekorzystnych warunkach geograficznych (wysokie góry, gęsta sieć rzek, pustynie, częste powodzie), uznać należy za duży sukces polityki gospodarczej zarówno na szczeblu federalnym, jak i na poziomie stanów, tym bardziej, że dokonało się to w relatywnie krótkim czasie, bo zaledwie w ciągu dwóch dekad.

W warunkach indyjskich, szczególnie na obszarach wiejskich, które zamieszkuje ponad 70 proc. ludności, ważnym kryterium oceny warunków życia jest dostęp do wody pitnej i sposób jej pozyskiwania przez gospodarstwa domowe. Warunki geograficzne oraz klimatyczne sprawiają, że na wielu obszarach kraju występują stałe albo okresowe niedobory tego dobra. Stopień dostępności wody wyraża się najczęściej wskaźnikami udziału gospodarstw domowych mających bezpośredni dostęp do wody pitnej w ogólnej liczbie gospodarstw na danym obszarze. W tab. 6.18 zestawiono takie wskaźniki dla indyjskich gospodarstw domowych w okresie 1991-2011.

15 Podobne miary i sposoby analizy stosuje wielu autorów badających indyjskie przemiany ostatnich dziesięcioleci, jak m.in. wielokrotnie cytowani J. Dreze i A. Sen [2013], A. Kohli [2012] oraz S.K. Majumdar [2012]. Podobne są miary oraz procedury metodyczne w większości innych badań warunków życia. 
Tabela 6.17. Długość dróg według kategorii

\begin{tabular}{|c|c|c|c|c|}
\hline \multirow{2}{*}{\multicolumn{2}{|c|}{ Rodzaj dróg }} & \multicolumn{3}{|c|}{ Lata* } \\
\hline & & \multirow{2}{*}{$\frac{1991}{33650}$} & \multirow{2}{*}{\begin{tabular}{|c|}
2001 \\
57737
\end{tabular}} & \multirow{2}{*}{$\frac{2011}{70934}$} \\
\hline \multirow[b]{2}{*}{ Autostrady krajowe } & kilometry & & & \\
\hline & $\begin{array}{l}\text { zmiany w stosunku do } \\
1991 \mathrm{r} \text {. (w proc.) }\end{array}$ & 100,0 & 171,6 & 210,8 \\
\hline \multirow[b]{2}{*}{ Autostrady stanowe } & kilometry & 127311 & 132100 & 163898 \\
\hline & $\begin{array}{l}\text { zmiany w stosunku do } \\
1991 \mathrm{r} \text {. (w proc.) }\end{array}$ & 100,0 & 103,8 & 128,7 \\
\hline \multirow{2}{*}{$\begin{array}{l}\text { Pozostałe } \\
\text { drogi publiczne** }\end{array}$} & kilometry & 509435 & 736001 & 1005327 \\
\hline & $\begin{array}{l}\text { zmiany w stosunku do } \\
1991 \mathrm{r} \text {. (w proc.) }\end{array}$ & 100,0 & 144,5 & 197,3 \\
\hline \multirow[b]{2}{*}{ Drogi wiejskie } & kilometry & 1260430 & 1972016 & 2749805 \\
\hline & $\begin{array}{l}\text { zmiany w stosunku do } \\
1991 \mathrm{r} \text {. (w proc.) }\end{array}$ & 100,0 & 156,5 & 218,2 \\
\hline \multirow[b]{2}{*}{ Drogi miejskie } & kilometry & 186799 & 252001 & 411840 \\
\hline & $\begin{array}{l}\text { zmiany w stosunku do } \\
1991 \mathrm{r} \text {. (w proc.) }\end{array}$ & 100,0 & 134,9 & 220,5 \\
\hline \multirow[b]{2}{*}{ Ogółem } & kilometry & 2117625 & 3149855 & 4401804 \\
\hline & $\begin{array}{l}\text { zmiany w stosunku do } \\
1991 \mathrm{r} \text {. (w proc.) }\end{array}$ & 100,0 & 148,7 & 207,8 \\
\hline
\end{tabular}

* stan na 31 marca każdego roku, ** pozostałe drogi publiczne (krajowe i stanowe) podległe Urzędom Robót Publicznych (figurujące w statystykach transportu jako other PWD Roads).

Źródło: opracowanie i część obliczeń własnych na podstawie [India Country Report 2013. Statistical Appraisal, 2013, s. 42, tab. 8].

Z tab. 6.18 wynika, że w okresie dwóch dekad indyjskiej transformacji zwiększył się odsetek gospodarstw domowych posiadających źródło wody pitnej w obrębie swego gospodarstwa. W 1991 roku - w skali całego kraju - bezpośredni dostęp do wody miało mniej niż dwie trzecie gospodarstw (62,3 proc.), a w 2011 było to już 85,5 proc. Istnieją jednak różnice pomiędzy wsią a miastem, oczywiście na niekorzyść wsi. Dystanse te jednak szybko się zmniejszają. O ile bowiem w 1991 roku różnica wynosiła 26 punktów procentowych, to w 2011 roku było to już niespełna 9 punktów. Wskaźniki te świadczą o dużym postępie w gospodarce wodnej, aczkolwiek nadal istnieją znaczące dysproporcje między poszczególnymi stanami, zaś na ich terytorium pomiędzy miastami a wsiami. Różnice te jednak nie zależą w prostej linii od poziomu rozwoju gospodarczego stanów, lecz w dużej mierze - a często przede wszystkim - od stosunków wodnych na ich obszarze, sposobów gospodarowania ziemią oraz typu sieci osiedleńczej. Tym w głównej mierze należy tłumaczyć niskie wskaźniki dostępności do wody gospodarstw domowych (poniżej 80 proc. w 2011 roku) w takich stanach, jak: Kerala, Jammu \& Kashmir, Madhya Pradesh, Orissa, Jharkhand, Assam czy Rajasthan. 
Tabela 6.18. Odsetek gospodarstw domowych mających bezpośredni dostęp do wody pitnej*

\begin{tabular}{|c|c|c|c|c|c|c|c|c|c|}
\hline \multirow{3}{*}{ Stany } & \multicolumn{9}{|c|}{ Lata } \\
\hline & \multicolumn{3}{|c|}{1991} & \multicolumn{3}{|c|}{2001} & \multicolumn{3}{|c|}{2011} \\
\hline & ogółem & wsie & miasta & ogółem & wsie & miasta & ogółem & wsie & Miasta \\
\hline Ogółem - Indie & 62,3 & 55,5 & 81,4 & 77,9 & 73,2 & 90,0 & 85,5 & 82,7 & 91,4 \\
\hline Delhi NCT & 95,8 & 91,0 & 96,2 & 97,2 & 90,1 & 97,7 & 95,0 & 87,9 & 95,2 \\
\hline Andhra Pradesh & 55,1 & 49,0 & 73,8 & 80,1 & 76,9 & 90,2 & 90,5 & 88,6 & 94,5 \\
\hline Assam & 45,9 & 43,3 & 64,1 & 58,8 & 56,8 & 70,4 & 69,9 & 68,3 & 78,3 \\
\hline Bihar & 58,8 & 56,5 & 64,1 & 86,6 & 86,1 & 91,2 & 94,0 & 93,9 & 94,7 \\
\hline Chhattisgarh & - & - & - & 70,5 & 66,2 & 88,8 & 86,3 & 84,1 & 93,9 \\
\hline Goa & 43,4 & 30,5 & 61,7 & 70,1 & 58,3 & 82,1 & 85,7 & 78,4 & 90,4 \\
\hline Gujarat & 69,8 & 60,0 & 87,2 & 84,1 & 76,9 & 95,4 & 90,3 & 84,9 & 97,0 \\
\hline Haryana & 74,3 & 67,1 & 93,2 & 86,1 & 81,1 & 97,3 & 93,8 & 92,0 & 96,7 \\
\hline Himachal Pradesh & 77,3 & 75,5 & 91,9 & 88,6 & 87,5 & 97,0 & 93,7 & 93,2 & 97,8 \\
\hline Jharkhand & - & - & - & 42,6 & 35,5 & 68,2 & 60,1 & 54,3 & 78,4 \\
\hline Jammu \& Kashmir & - & - & - & 65,2 & 54,9 & 95,7 & 76,8 & 70,1 & 96,1 \\
\hline Karnataka & 71,7 & 67,3 & 81,4 & 84,6 & 80,5 & 92,1 & 87,5 & 84,4 & 92,4 \\
\hline Kerala & 18,9 & 12,2 & 38,7 & 23,4 & 16,9 & 42,8 & 33,5 & 28,3 & 39,4 \\
\hline Madhya Pradesh & 53,4 & 45,6 & 79,4 & 68,4 & 61,5 & 88,6 & 78,0 & 73,1 & 92,1 \\
\hline Maharashtra & 68,5 & 54,0 & 90,5 & 79,8 & 68,4 & 95,4 & 83,4 & 73,2 & 95,7 \\
\hline Orissa & 39,1 & 35,3 & 62,8 & 64,2 & 62,9 & 72,3 & 75,3 & 74,4 & 79,8 \\
\hline Punjab & 92,7 & 92,1 & 94,2 & 97,6 & 96,9 & 98,9 & 97,6 & 96,7 & 98,9 \\
\hline Rajasthan & 59,0 & 50,6 & 86,5 & 68,2 & 60,4 & 93,5 & 78,1 & 72,8 & 94,3 \\
\hline Tamil Nadu & 67,4 & 64,3 & 74,2 & 85,6 & 85,3 & 85,9 & 92,5 & 92,2 & 92,9 \\
\hline Uttar Pradesh & 62,2 & 56,6 & 85,8 & 87,8 & 85,5 & 97,2 & 95,1 & 94,3 & 97,9 \\
\hline Uttarakhand & - & - & - & 86,7 & 83,0 & 97,8 & 92,2 & 89,5 & 98,7 \\
\hline West Bengal & 82,0 & 80,3 & 86,2 & 88,5 & 87,0 & 92,3 & 92,2 & 91,4 & 93,9 \\
\hline
\end{tabular}

* źródło wody (kran, pompa ręczna, studnia rurowa) znajduje się w obrębie gospodarstwa domowego (mieszkania, domu, zagrody wiejskiej).

Źródło: [Economic Survey 2013-14. Statistical Appendix, 2014, s. 115].

Oceniając jednak zmiany w dostępności ludności do wody pitnej, zauważyć można, że w badanym okresie dokonał się w tej dziedzinie znaczący postęp. Istotnie zmniejszyły się różnice międzystanowe oraz dystanse pomiędzy wsią a miastem. Posiadanie źródła wody w obrębie własnego gospodarstwa staje się zjawiskiem niemal powszechnym, co w warunkach indyjskich jest dużym, wręcz historycznym osiągnięciem i jednym z podstawowych wyznaczników postępu społecznego. 
Inną, adekwatną dla warunków indyjskich, miarą poprawy materialnych warunków życia jest wzrost stopnia elektryfikacji gospodarstw domowych oraz zużycia w nich elektryczności. Dane statystyczne obrazujące te procesy zestawiono w tab. 6.19-6.20.

Dane w tab. 6.19 wskazują, że w latach 80. dokonał się wielki, wręcz skokowy, postęp w dziedzinie elektryfikacji, szczególnie dotyczy to obszarów wiejskich. W ciągu dekady liczba zelektryfikowanych wsi zwiększyła się z 2,77 do $4,75 \mathrm{mln}$, tj. o 73 proc. W 1991 roku prąd elektryczny docierał do 88 proc. wsi; było to więc o 37 punktów procentowych więcej niż 10 lat wcześniej [Reddy, 2013, s. 171] ${ }^{16}$. W następnych dwóch dekadach przyrosty były już niewielkie.

Tabela 6.19. Stopień elektryfikacji gospodarstw domowych

\begin{tabular}{|c|c|c|c|c|}
\hline \multirow{2}{*}{ Lata } & \multirow{2}{*}{$\begin{array}{c}\text { Odsetek } \\
\text { zelektryfikowanych wsi }\end{array}$} & \multicolumn{3}{|c|}{$\begin{array}{c}\text { Odsetek zelektryfikowanych } \\
\text { gospodarstw domowych }\end{array}$} \\
\cline { 3 - 5 } & & ogółem & wsie & miasta \\
\hline 1981 & 50,8 & 26,2 & 14,7 & 62,5 \\
\hline 1991 & 88,0 & 42,4 & 30,5 & 75,8 \\
\hline 2001 & 89,1 & 55,8 & 43,5 & 87,6 \\
\hline 2011 & 91,4 & 65,0 & 55,0 & 92,7 \\
\hline
\end{tabular}

Źródło: [Reddy, 2013, s. 171, tab. 12.4].

Inaczej jednak wygląda sytuacja, gdy uwzględnimy bezpośredni dostęp indywidualnych gospodarstw domowych do prądu elektrycznego, czyli posiadanie jego instalacji w obrębie domu (mieszkania). W 1991 roku - jak widać w tab. 6.19 - liczba gospodarstw domowych korzystających z energii elektrycznej wynosiła 42,4 proc., a w następnych dwóch dekadach wskaźnik ten podniósł się do 65 proc. Oznacza to, że co trzecie indyjskie gospodarstwo nie miało dostępu do prądu elektrycznego, a tym samym nie mogło korzystać z większości nowoczesnych artykułów gospodarstwa domowego (lodówki, pralki, telewizora czy komputera).

Duże jest zróżnicowanie gospodarstw domowych w dostępie do energii elektrycznej w przekroju miasto-wieś. W 1981 roku prąd elektryczny posiadało niespełna 15 proc. gospodarstw wiejskich oraz 63 proc. gospodarstw miejskich. Wyposażenie wiejskiej zagrody $\mathrm{w}$ instalację elektryczną było więc rzadkością. W następnych trzech dekadach sytuacja poprawia się, ale i tak w 2011 roku z „dobrodziejstw" prądu elektrycznego korzystało niewiele ponad połowa wiejskich gospodarstw (55 proc.).

16 Termin ,zelektryfikowana wieś” rozumieć należy w ten sposób, że dana miejscowość ma dostęp do sieci elektrycznej. Nie oznacza to jednak, że z prądu elektrycznego korzystają wszystkie gospodarstwa ją zamieszkujące, najczęściej jest to tylko jakiś ich odsetek. 
Znaczące jest zróżnicowanie dostępu do energii elektrycznej oraz zużycia prądu elektrycznego w gospodarstwach domowych w ujęciu regionalnym, czyli w poszczególnych stanach Indii. Danych do takiej analizy dostarcza tab. 6.20.

Tabela 6.20. Zużycie prądu elektrycznego oraz stopień elektryfikacji gospodarstw domowych w 2010 roku według stanów

\begin{tabular}{|c|c|c|c|c|}
\hline \multirow{2}{*}{ Stany } & \multirow{2}{*}{$\begin{array}{l}\text { Roczne zużycie prądu } \\
\text { - KWh/gospodarstwo }\end{array}$} & \multicolumn{3}{|c|}{ Odsetek gospodarstw zelektryfikowanych } \\
\hline & & ogółem & wsie & miasta \\
\hline Indie - ogółem & 700 & 65,0 & 55,3 & 92,7 \\
\hline Andhra Pradesh & 920 & 70,9 & 60,0 & 95,0 \\
\hline Assam & 250 & 36,4 & 16,5 & 80,6 \\
\hline Bihar & 120 & 26,5 & 5,1 & 74,1 \\
\hline Chhattisgarh & 650 & 60,3 & 46,0 & 92,2 \\
\hline NCT Delhi & 1650 & 89,8 & 85,5 & 99,4 \\
\hline Goa & 2263 & 94,2 & 92,4 & 98,3 \\
\hline Gujarat & 1500 & 80,0 & 72,1 & 97,5 \\
\hline Haryana & 1320 & 84,4 & 78,5 & 97,5 \\
\hline Himachal Pradesh & 970 & 96,0 & 94,5 & 99,4 \\
\hline Jammu/Kashmir & 850 & 82,2 & 74,5 & 99,4 \\
\hline Jharkhand & 800 & 35,0 & 10,0 & 90,8 \\
\hline Karnataka & 900 & 79,7 & 72,2 & 96,5 \\
\hline Kerala & 500 & 74,5 & 65,5 & 94,5 \\
\hline Madhya Pradesh & 680 & 72,5 & 62,3 & 95,1 \\
\hline Maharashtra & 1000 & 85,3 & 65,2 & 97,4 \\
\hline Orissa & 800 & 53,6 & 19,3 & 83,9 \\
\hline Punjab & 1600 & 92,1 & 89,5 & 98,2 \\
\hline Rajasthan & 750 & 70,7 & 44,0 & 95,7 \\
\hline Tamil Nadu & 1080 & 78,2 & 71,2 & 93,8 \\
\hline Uttar Pradesh & 1112 & 40,1 & 19,8 & 85,4 \\
\hline Uttarakhand & 400 & 64,2 & 50,3 & 95,0 \\
\hline West Bengal & 500 & 41,8 & 20,3 & 89,6 \\
\hline
\end{tabular}

Źródło: [Reddy, 2013, s. 172, tab. 12.5].

Analizując pierwszą kolumnę tab. 6.20, nietrudno dostrzec ogromne zróżnicowanie przestrzenne w zużyciu prądu elektrycznego przez gospodarstwa domowe. W stanie Bihar wyniosło ono w 2010 roku zaledwie $120 \mathrm{KWh}$ /gospodarstwo, 
czyli 5,5-krotnie mniej od średniej dla całych Indii i niemal 19-krotnie mniej od zużycia w stanie Goa, który jest w tej dziedzinie krajowym liderem.

Jeżeli chodzi o wyposażenie gospodarstw domowych w instalacje elektryczne, to pod tym względem najgorszymi wskaźnikami legitymują się stany północno-wschodnie (Bihar, Assam, Jharkhand, Uttar Pradesh oraz West Bengal). Wskaźniki te są niemal o połowę mniejsze (26-42 proc.) od średniej krajowej (65 proc.). W tym regionie Indii prąd elektryczny dopływa zaledwie do co trzeciego gospodarstwa domowego. Najwyższy odsetek zelektryfikowanych gospodarstw jest w północno-zachodniej i południowo-zachodniej części kraju i kształtuje się na poziomie 70-95 proc. Wysoki i na ogół nieznacznie zróżnicowany przestrzennie jest wskaźnik wyposażenia w źródła energii elektrycznej gospodarstw miejskich. W 2010 roku wynosił on - poza niektórymi stanami - przeciętnie ponad 90 proc., a tylko w jednym stanie (Bihar) był niższy niż 80 proc.

Znacznie większe jest przestrzenne zróżnicowanie dostępu gospodarstw domowych do instalacji elektrycznych w przypadku obszarów wiejskich. Jak widać w tab. $6.20, \mathrm{w}$ jednym z największych stanów - Biharze - z prądu elektrycznego korzystało w 2010 roku zaledwie co dwudzieste gospodarstwo wiejskie (5,1 proc.), a w sąsiednim Jharkhandzie - co dziesiąte. Ponadto w stanach Assam, Orissa, Uttar Pradesh oraz West Bengal odsetek zelektryfikowanych gospodarstw wiejskich nie przekraczał 25 proc. Są to wskaźniki bardzo niskie. Brak prądu w gospodarstwach wiejskich to nie tylko kwestia gorszych warunków życia, ale - a czasem przede wszystkim - także niemożność mechanizacji wielu czynności produkcyjnych, a więc - uogólniając - modernizacji rolnictwa. Reasumując analizę elektryfikacji na indyjskiej wsi, potwierdzenie znajduje sformułowana w rozdziale V opinia o względnym zaniedbaniu w okresie transformacji rozbudowy infrastruktury technicznej na obszarach wiejskich, co hamowało ich modernizację i poprawę warunków życia mieszkańców wsi.

Przejdziemy teraz do analizy budżetów indyjskich gospodarstw domowych, a szczególnie ich strony wydatkowej. Taka analiza pozwoli dokładniej poznać ich poziom życia oraz zróżnicowanie społeczne i regionalne w tym względzie.

$\mathrm{W}$ tab. 6.21 podano wyniki reprezentacyjnych badań indyjskich gospodarstw domowych dotyczących ich wydatków konsumpcyjnych ogółem oraz wydatków na najważniejszą grupę przedmiotów spożycia, tj. żywność ${ }^{17}$. Badania te wskazują, że w okresie 1991-2008 rosły nominalne wydatki konsumpcyjne zarówno w gospodarstwach miejskich, jak i wiejskich ${ }^{18}$. Wyższą dynamikę

${ }^{17}$ Wyniki pochodzą z badań Narodowego Biura Badań Reprezentacyjnych (National Sample Survey Office) będącego instytucją działającą w ramach Ministerstwa Statystyki i Wdrażania Programów (Ministry of Statistics and Programme Implementation). NSSO jest największą indyjską instytucją prowadzącą regularne badania społeczno-ekonomiczne, działa od 1950 roku.

${ }^{18}$ Wyniki badań deformuje nieco inflacja, sprawiająca że wzrost wydatków nie jest tylko efektem zwiększania się konsumpcji, lecz także wzrostu cen. Przy przyjęciu cen stałych wielkości 
wzrostu obserwuje się w gospodarstwach miejskich (395 proc.) niż wiejskich (314 proc.). Znamienne jest, że tempo wzrostu wydatków ma w badanym okresie tendencję malejącą - po 2000 roku przyrosty wydatków zarówno ogółem, jak i żywnościowych, są coraz mniejsze. Uwidacznia się natomiast wyraźnie prawo Engla, czyli spadek udziału wydatków na żywność wraz ze wzrostem dochodów i wydatków ogółem gospodarstw domowych ${ }^{19}$. Taką tendencję można interpretować jako poprawę poziomu życia indyjskiego społeczeństwa. Większy spadek udziału wydatków żywnościowych w wydatkach ogółem gospodarstw miejskich (o ok. 17 punktów proc.) świadczy o szybszym postępie poprawy poziomu życia w mieście niż na wsi, gdzie udział ten obniżył się o 11 punktów proc. Niemniej jednak udziały wydatków na żywność w wydatkach ogółem, zwane współczynnikami Engla, na poziomie 40 proc. - jak w gospodarstwach miejskich, a w gospodarstwach wiejskich nawet powyżej 50 proc. - uznać trzeba za bardzo wysokie, czyli niekorzystne. Takie wielkości współczynników Engla są charakterystyczne dla społeczeństw (grup społecznych) biednych. Pozytywnym zjawiskiem jest natomiast to, że następuje systematyczna poprawa, czyli obniżanie się udziału wydatków na żywienie w wydatkach ogółem indyjskich gospodarstw domowych.

Dokładniej zmiany w strukturze wydatków konsumpcyjnych indyjskich gospodarstw domowych pokazują wskaźniki w tab. 6.22. Wyrazem tego jest - oprócz spadku udziału wydatków na żywienie - zwiększanie się udziału wydatków na utrzymanie mieszkania i na dobra trwałe oraz udziału wydatków na cały agregat „pozostałe dobra i usługi”, a wśród nich wydatków na edukację, lecznictwo, kulturę i turystykę. Są to - ogólnie ujmując - korzystne zmiany, świadczące o poprawie i unowocześnianiu się poziomu życia społeczeństwa indyjskiego. Dotyczy to jednak przede wszystkim ludności miejskiej. Na wsi sytuacja jest natomiast wyraźnie gorsza.

wydatków gospodarstw byłyby mniejsze. Uwzględnianie jednak stopy inflacji konsumenckiej, przeciętnej dla całych Indii, niewiele by dawało w odniesieniu do przyjętych do badań gospodarstw domowych w konkretnym regionie i porze roku; wyniki mogłyby być nawet bardziej zdeformowane. Dlatego też - podobnie jak indyjskie źródła statystyczne - pozostajemy przy wielkościach wydatków w cenach bieżących, zdając sobie oczywiście sprawę z ich ułomności.

19 Niemiecki statystyk Ernst Engel (1821-1896), analizując wyniki badań budżetów gospodarstw domowych stwierdził, że wzrost ich dochodów powoduje zwiększanie się wydatków, a wraz z tym wzrostem obniża się odsetek wydatków na żywność. Niski udział wydatków na żywność w wydatkach ogółem gospodarstwa domowego oznacza, że jest to zazwyczaj gospodarstwo zamożne. Obniżanie się tego wskaźnika świadczy o poprawie sytuacji ekonomicznej gospodarstwa, a w skali makro - społeczeństwa. W ekonomii prawidłowość ta przyjęła nazwę prawa Engla, a wskaźniki udziału wydatków na żywność w wydatkach ogółem (współczynniki Engla) są jedną z podstawowych miar poziomu rozwoju ekonomicznego (dobrobytu) gospodarstwa domowego i całego społeczeństwa [Stankiewicz, 1998, s. 212]. 
Tabela 6.21. Wydatki konsumpcyjne gospodarstw domowych

\begin{tabular}{|l|c|c|c|c|c|c|}
\hline \multirow{2}{*}{ Lata } & \multicolumn{4}{|c|}{ Wsie } & \multicolumn{3}{c|}{ Miasta } \\
\cline { 2 - 7 } & \multicolumn{4}{|c|}{ przeciętne miesięczne wydatki na 1 osobę, w rupiach } \\
\cline { 2 - 7 } & $\begin{array}{c}\text { ogółem } \\
(1)\end{array}$ & $\begin{array}{c}\text { żywność } \\
(2)\end{array}$ & $\begin{array}{c}\text { relacja w proc. } \\
(2 / 1)\end{array}$ & $\begin{array}{c}\text { ogółem } \\
(1)\end{array}$ & $\begin{array}{c}\text { żywność } \\
(2)\end{array}$ & $\begin{array}{c}\text { relacja w proc. } \\
(2 / 1)\end{array}$ \\
\hline 1991 & 243,5 & 153,6 & 63,1 & 370,3 & 207,8 & 56,1 \\
\hline $1993 / 94$ & 281,4 & 177,8 & 63,2 & 458,0 & 250,3 & 54,7 \\
\hline 1997 & 395,0 & 231,9 & 58,7 & 645,4 & 320,2 & 49,6 \\
\hline $1999 / 2000$ & 486,1 & 288,8 & 59,4 & 971,6 & 443,2 & 45,6 \\
\hline $2001 / 02$ & 498,3 & 276,4 & 55,5 & 932,8 & 402,3 & 43,1 \\
\hline 2003 & 554,0 & 298,6 & 53,9 & 1022.0 & 429,0 & 42,0 \\
\hline $2004 / 05$ & 558,8 & 307,6 & 55,0 & 1052,3 & 447,4 & 42,5 \\
\hline $2006 / 07$ & 763,0 & 363,0 & 47,6 & 1312,0 & 517,0 & 39,4 \\
\hline $2007 / 08$ & 763,0 & 395,0 & 51,8 & 1464,0 & 575,0 & 39,3 \\
\hline
\end{tabular}

Źródło: opracowanie i część obliczeń własnych na podstawie [Selected Socio-Economic Statistics India, 2011, s. 156, tab. 10.1].

Tabela 6.22. Struktura rzeczowa wydatków konsumpcyjnych gospodarstw domowych

\begin{tabular}{|c|c|c|c|c|c|c|c|c|}
\hline \multirow[b]{2}{*}{ Dobra konsumpcyjne } & \multicolumn{4}{|c|}{ Wsie } & \multicolumn{4}{|c|}{ Miasta } \\
\hline & $\begin{array}{l}1993 \\
/ 94\end{array}$ & $\begin{array}{l}1999 \\
/ 2000\end{array}$ & $\begin{array}{c}2004 \\
/ 05\end{array}$ & $\begin{array}{c}2007 \\
/ 08\end{array}$ & $\begin{array}{c}1993 \\
194\end{array}$ & $\begin{array}{l}1999 \\
/ 2000\end{array}$ & $\begin{array}{c}2004 \\
/ 05\end{array}$ & $\begin{array}{c}2007 \\
/ 08\end{array}$ \\
\hline $\begin{array}{l}\text { Wydatki - razem*, } \\
\text { w tym: }\end{array}$ & 100,0 & 100,0 & 100,0 & 100,0 & 100,0 & 100,0 & 100,0 & 100,0 \\
\hline - żywność & 63,2 & 59,4 & 55,0 & 52,4 & 54,7 & 48,1 & 42,5 & 39,6 \\
\hline $\begin{array}{l}\text { Dobra nieżywnościowe } \\
\text { - razem, w tym: }\end{array}$ & 36,8 & 40,6 & 45,0 & 47,6 & 45,3 & 51,9 & 57,5 & 60,4 \\
\hline - używki, tytoń & 3,2 & 2,9 & 2,7 & 2,5 & 2,3 & 1,9 & 1,6 & 1,3 \\
\hline - ogrzewanie i światło & 7,4 & 7,5 & 10,2 & 9,7 & 6,6 & 7,8 & 9,9 & 8,5 \\
\hline - odzież & 5,4 & 6,9 & 4,5 & \multirow{2}{*}{7,3} & 4,7 & 6,1 & 4,0 & \multirow{2}{*}{6,8} \\
\hline - obuwie & 0,9 & 1,1 & 0,8 & & 0,9 & 1,2 & 0,7 & \\
\hline Pozostałe dobra i usługi & 17,2 & 19,6 & 23,4 & 24,5 & 27,5 & 31,3 & 37,2 & 39,6 \\
\hline Artykuły trwałego użytku & 2,7 & 2,6 & 3,4 & 3,6 & 3,3 & 3,6 & 4,1 & 4,2 \\
\hline
\end{tabular}

* wydatki miesięczne.

Źródło: opracowanie i część obliczeń własnych na podstawie [Selected Socio-Economic Statistics India, 2011, s. 158, tab. 10.3]. 
W tab. 6.23 zestawiono kwoty przeciętnych wydatków konsumpcyjnych indyjskich gospodarstw domowych (na 1 osobę) w ujęciu regionalnym, czyli według stanów. Można przyjąć, że wydatki te wyrażają - jak to się zazwyczaj czyni w badaniach warunków bytu - poziom faktycznej konsumpcji i traktować te pojęcia jako zamienne. Dodatkowo w tab. 6.24 przedstawiono zróżnicowanie społeczne tych wydatków w poszczególnych stanach wyrażone współczynnikiem Giniego ${ }^{20}$.

Tabela 6.23. Przeciętne wydatki gospodarstw domowych oraz próg ubóstwa w 2009/10 roku

\begin{tabular}{|l|c|c|c|c|}
\hline \multirow{2}{*}{ Stany } & \multicolumn{2}{c|}{$\begin{array}{c}\text { Wydatki, w rupiach na osobę/ } \\
\text { miesięcznie w gospodarstwie }\end{array}$} & \multicolumn{2}{c|}{$\begin{array}{c}\text { Próg ubóstwa, w rupiach na osobę/ } \\
\text { miesięcznie w gospodarstwie* }\end{array}$} \\
\cline { 2 - 5 } & wiejskim & Miejskim & wiejskim & miejskim \\
\hline Indie - ogółem & 1054 & 1984 & 673 & 860 \\
\hline Andhra Pradesh & 1234 & 2238 & 694 & 926 \\
\hline Assam & 1003 & 1755 & 692 & 871 \\
\hline Bihar & 780 & 1238 & 656 & 775 \\
\hline Chhattisgarh & 784 & 1647 & 617 & 807 \\
\hline Gujarat & 1110 & 1909 & 726 & 951 \\
\hline Haryana & 1510 & 2321 & 792 & 975 \\
\hline Himachal Pradesh & 1536 & 2654 & 708 & 888 \\
\hline Jammu \& Kashmir & 1344 & 1759 & 723 & 845 \\
\hline Jharkhand & 825 & 1584 & 616 & 831 \\
\hline Karnataka & 1020 & 2053 & 629 & 908 \\
\hline Kerala & 1835 & 2413 & 775 & 831 \\
\hline Madhya Pradesh & 903 & 1666 & 632 & 772 \\
\hline Maharashtra & 1153 & 2427 & 744 & 961 \\
\hline Orissa & 818 & 1548 & 567 & 736 \\
\hline Punjab & 1649 & 2109 & 830 & 961 \\
\hline Rajasthan & 1179 & 1663 & 755 & 846 \\
\hline Tamil Nadu & 1160 & 1948 & 639 & 801 \\
\hline Uttar Pradesh & 899 & 1574 & 664 & 800 \\
\hline West Bengal & 952 & 1965 & 643 & 831 \\
\hline
\end{tabular}

* obliczenia według metody Komitetu S. Tendulkara (por. uwagi w podrozdziale 6.3.3).

Źródło: [Dreze, Sen, 2013, Statistical Appendix, tab. A-3, Part I], [Press Note on Poverty Estimates, 2009-10, tab. 1, s. 5], [Datt, Mahajan, 2014, s. 407].

${ }^{20}$ Współczynnik (indeks) Giniego wyraża stopień nierównomierności rozkładu jakiejś cechy w badanej zbiorowości, w tym przypadku dochodów (wydatków) lub progu ubóstwa. Przybiera wartości od 0 do 1 (lub 0-100 proc.). Im wyższe są wartości tego współczynnika, tym dana zbiorowość jest bardziej zróżnicowana. Corrado Gini (1884-1965) był włoskim statystykiem i demografem. 
Zróżnicowanie wydatków konsumpcyjnych gospodarstw domowych w poszczególnych stanach jest dość znaczne. W odniesieniu do gospodarstw wiejskich wydatki per capita były najniższe w Biharze i stanowiły 42,5 proc. wydatków przeciętnego mieszkańca Kerali. W odniesieniu do mieszkańców miast dystanse były nieco mniejsze; wydatki najniższe (Bihar) to 46,6 proc. wydatków w stanie najzamożniejszym (Himachal Pradesh). Należy dodać, że wydatki gospodarstw miejskich znacznie przekraczały, bo średnio niemal dwukrotnie, wydatki mieszkańców obszarów wiejskich. Takie różnice świadczą o - generalnie - wyższym poziomie życia w mieście niż na wsi. Porównując budżety gospodarstw wiejskich z miejskimi, pamiętać jednak trzeba, że po pierwsze - ludność wiejska nie nabywa wielu produktów, lecz wytwarza je we własnym gospodarstwie, a po drugie - gospodarstwa (rodziny) wiejskie są na ogół większe i z natury dochody (wydatki) muszą być dzielone na większą liczbę osób, co w przeliczeniu na 1 osobę czyni je mniejszymi. Rozkład geograficzny wydatków konsumpcyjnych per capita jest podobny do innych poprzednio badanych ujęć wskaźników poziomu życia, to znaczy, że są one niższe w północno-wschodnich stanach, a wyższe, często znacząco, w stanach północno- i południowo-zachodnich.

$\mathrm{W}$ ostatnich dwóch kolumnach tab. 6.23 zaprezentowano, za obliczeniami indyjskich statystyków, wielkości progów ubóstwa dla mieszkańców poszczególnych stanów. Pozwalają one na określenie dystansów pomiędzy faktycznym poziomem życia (wyrażonym wielkością wydatków konsumpcyjnych - kolumny 2 i $3 \mathrm{w}$ tab. 6.23) a progiem ubóstwa (kolumny 4 i $5 \mathrm{w}$ tab. 6.23), czyli - inaczej ujmując - jak daleko przeciętne gospodarstwo jest oddalone od stanu, który można uznać za - przyjmując indyjskie standardy - ubóstwo (biedę).

Jak wynika z porównania wydatków konsumpcyjnych per capita $\mathrm{z}$ wielkością progów ubóstwa, różnice pomiędzy stanami są w tym względzie znaczące. W stanach uznanych, na podstawie wcześniejszych analiz, za słabo rozwinięte gospodarczo, dystanse te są niewielkie i inne na wsi niż w mieście. Znacznie mniejsze są one w odniesieniu do ludności wiejskiej. Jak można wyliczyć z danych w tab. 6.23, w roku gospodarczym 2009/10, w skali całych Indii przeciętne wydatki konsumpcyjne per capita na wsi były wyższe od wielkości progu ubóstwa zaledwie o 57 proc., zaś w przypadku miast - o 128 proc. I znów do obszarów o najgorszych wskaźnikach zaliczają się stany północo-wschodnich Indii: Bihar, Assam, Chhattisgarh, Jharkhand, Orissa, Uttar Pradesh i West Bengal. Najkorzystniejszymi zaś relacjami wydatków konsumpcyjnych do wielkości progów ubóstwa legitymują się: Kerala, Punjab, Haryana, Himachal Pradesh i Tamil Nadu.

Przedstawioną wyżej statystykę zróżnicowania regionalnego wydatków konsumpcyjnych indyjskich gospodarstw domowych uzupełniają oszacowane dla wybranych stanów współczynniki nierównomierności Giniego. Ich wielkości dla lat 1993-2010 zestawiono w tab. 6.24. 
Tabela 6.24. Współczynnik Giniego wydatków konsumpcyjnych, miesięcznie na 1 osobę (w ujęciu procentowym)

\begin{tabular}{|l|l|l|l|l|}
\hline \multirow{2}{*}{\multicolumn{1}{|c|}{ Stany }} & \multicolumn{4}{c|}{ Lata } \\
\cline { 2 - 5 } & 1994 & 2000 & 2005 & 2010 \\
\hline Andhra Pradesh & 31,0 & 29,8 & 34,3 & 32,3 \\
\hline Assam & 24,6 & 24,5 & 27,2 & 28,0 \\
\hline Bihar & 25,8 & 24,1 & 28,3 & 27,5 \\
\hline Gujarat & 27,1 & 28,6 & 29,5 & 28,7 \\
\hline Haryana & 29,6 & 36,9 & 35,5 & 33,7 \\
\hline Himachal Pradesh & 39,1 & 27,1 & 33,1 & 33,0 \\
\hline Karnataka & 29,9 & 31,3 & 32,7 & 27,8 \\
\hline Kerala & 32,6 & 33,4 & 39,9 & 45,5 \\
\hline Madhya Pradesh & 32,2 & 29,3 & 31,5 & 32,3 \\
\hline Maharashtra & 33,7 & 35,3 & 35,2 & 32,9 \\
\hline Orissa & 28,3 & 27,8 & 32,6 & 31,5 \\
\hline Punjab & 28,1 & 27,1 & 36,0 & 35,9 \\
\hline Rajasthan & 28,2 & 24,6 & 32,4 & 29,6 \\
\hline Tamil Nadu & 33,4 & 36,6 & 34,5 & 29,5 \\
\hline Uttar Pradesh & 30,9 & 28,2 & 33,7 & 30,7 \\
\hline West Bengal & 30,5 & 29,8 & 33,9 & 29,9 \\
\hline
\end{tabular}

Źródło: opracowanie własne na podstawie [Ghosal, 2012, s. 16].

Dane w tab. 6.24 wskazują, że stopień nierówności wydatków konsumpcyjnych gospodarstw domowych nie jest wysoki i współczynnik Giniego kształtuje się w poszczególnych stanach oraz latach - poza wyjątkami - na poziomie $25-35$ proc. $(0,25-0,35)$. Różnice pomiędzy stanami jakkolwiek występują, to generalnie nie są znaczące. Nieco wyższymi wielkościami współczynnika Giniego, przekraczającymi zazwyczaj 33 proc., legitymują się najbardziej rozwinięte gospodarczo stany (por. tab. 6.10), jak: Haryana, Himachal Pradesh, Kerala, Maharashtra, Punjab i Tamil Nadu. Natomiast współczynnik ten najniższe wartości (poniżej 31 proc.) przyjmuje najczęściej w stanach biednych, tj. Bihar, Assam, Andhra Pradesh, Orissa, Rajasthan i West Bengal. Wyjątek stanowi tu Gujarat, gdzie - pomimo względnie wysokiego poziomu rozwoju gospodarczego - współczynniki Giniego wydatków konsumpcyjnych gospodarstw domowych należą do najniższych w skali całego kraju. Generalnie, na podstawie analizy tab. 6.24, trudno jest sformułować jakąś jednoznaczną konkluzję w kwestii zmian stopnia nierównomierności rozkładu konsumpcji społeczeństwa indyjskiego i jego zróżnicowania przestrzennego. Wydaje się jednak, bez obaw popełnienia większego 
błędu, że nierównomierność ta jest większa na obszarach gospodarczo bardziej rozwiniętych i zwiększa się w miarę poprawy sytuacji ekonomicznej danego stanu. Na to ostatnie wskazują rosnące wielkości współczynnika Giniego w takich zapóźnionych gospodarczo, a względnie szybko odrabiających straty, stanach, jak: Bihar, Assam, Orissa, czy Andhra Pradesh. Podobną wzrostową tendencję nierównomierności rozkładu konsumpcji obserwuje się w badanym okresie 1994-2010 w stanach o wyższym poziomie gospodarczym jak - przede wszystkim - Kerala, Haryana czy Punjab.

Jak wspomniano w rozdziale II, podstawowymi miarami postępu gospodarczego i społecznego w krajach zacofanych a jednocześnie rozwijających się, są zmiany współczynników alfabetyzacji oraz trwania życia ludzkiego. Traktuje się je często jako wskaźniki jakości demograficznej kraju (regionu) (quality of population) [Datt, Mahajan, 2014, s. 56].

Skalę alfabetyzacji - przypomnijmy - wyraża odsetek dorosłej ludności umiejącej się posługiwać pismem (czytać i pisać). Miarę tę zastosujemy także do analizy i oceny regionalnych przeobrażeń ekonomiczno-społecznych w Indiach po reformach gospodarki i państwa z lat 1991-1992. Dane liczbowe zestawiono w tab. 6.25.

Zamieszczone w tab. 6.25 wskaźniki alfabetyzacji informują, że w okresie 1991-2011 w Indiach nastąpił znaczący wzrost odsetka ludności umiejącej czytać i pisać - z 52,2 proc. do 74,0 proc., a więc o ponad 20 punktów procentowych. Jest to bez wątpienia duże osiągnięcie systemu edukacji, mające wpływ na wszystkie dziedziny życia gospodarczego, społecznego i kulturowego. Oznacza ono istotną zmianę jakościową indyjskiego społeczeństwa.

Znacząco zróżnicowana jest jednak stopa alfabetyzacji według płci. Wyraźnie wyższe są odsetki mężczyzn umiejących czytać i pisać, aczkolwiek różnice te zmniejszały się w badanym dwudziestoleciu. W 1991 roku 36 proc. mężczyzn (powyżej 7 roku życia) było analfabetami, a wśród kobiet wskaźnik ten przekraczał 60 proc., a więc różnica wynosiła prawie 24 punkty procentowe. W 2011 roku wielkości te kształtowały się odpowiednio: 18 proc. i 34,5 proc., czyli różnica zmalała do 16,5 punktu procentowego. Na tę wielce pozytywną zmianę wpłynęły nie tylko proliberalne reformy ekonomiczne, ale w większym stopniu proces decentralizacji państwa i utworzenie samorządu lokalnego, w którym - jak opisano w rozdziale IV - zagwarantowano jedną trzecią miejsc dla kobiet. Jednym z warunków tego wejścia kobiet do sfery publicznej i aktywne w niej uczestniczenie jest właśnie podnoszenie poziomu wykształcenia.

Zróżnicowana jest jednak sytuacja pod względem stopnia alfabetyzacji pomiędzy stanami. Według spisu ludności w 2011 roku, najlepiej wygląda ona w takich stanach, jak: Kerala (niemal 94 proc. umiejących czytać i pisać), a następnie Goa (87 proc.), Delhi NCT (86 proc.), Himachal Pradesh (84 proc.), Maharashtra ( 83 proc.) oraz Tamil Nadu ( 80 proc.). Oznacza to, że w tych stanach, zamieszkałych przez blisko 240 mln Indusów (20 proc. ludności kraju) odsetek analfabetów waha 
się w granicach 6-20 proc., co jest, jak na regiony kraju nisko rozwiniętego, wskaźnikiem bardzo korzystnym. Na końcu tab. 6.25 znajdują się natomiast stany, w których odsetek umiejących czytać i pisać w 2011 roku nie przekraczał 70 proc. Są to: Bihar (63,8 proc.), Rajasthan (67,1 proc.), Jharkhand (67,4 proc.), Andhra Pradesh (67,7 proc.), Jammu \& Kashmir (68,7 proc.) i Uttar Pradesh (69,7 proc.). W badanym okresie istotnie zmniejszyła się różnica pod względem stopnia alfabetyzacji pomiędzy stanem najlepszym (Keralą) a stanem najgorszym (Biharem). W 1991 roku wynosiła ona 51,4 punktu procentowego, a w 2011 roku 30,1 punktu procentowego.

Tabela 6.25. Współczynnik alfabetyzacji społeczeństwa według stanów i płci

\begin{tabular}{|c|c|c|c|c|c|c|c|c|c|}
\hline \multirow{3}{*}{ Stany } & \multicolumn{3}{|c|}{1991} & \multicolumn{3}{|c|}{2001} & \multicolumn{3}{|c|}{2011} \\
\hline & \multirow{2}{*}{ ogółem* } & \multicolumn{2}{|c|}{ w tym: } & \multirow{2}{*}{ ogółem } & \multicolumn{2}{|c|}{ w tym: } & \multirow{2}{*}{ ogółem } & \multicolumn{2}{|c|}{ w tym: } \\
\hline & & $\mathrm{M}$ & $\mathrm{K}$ & & $M$ & $\mathrm{~K}$ & & $\mathrm{M}$ & $\mathrm{K}$ \\
\hline Ogółem - Indie & 52,2 & 64,1 & 39,3 & 64,8 & 75,3 & 53,7 & 74,0 & 82,1 & 65,5 \\
\hline Delhi NCT & 75,3 & 82,0 & 67,0 & 81,7 & 87,3 & 74,7 & 86,3 & 91,0 & 80,9 \\
\hline Andora Pradesh & 44,1 & 55,1 & 32,7 & 60,5 & 70,3 & 50,4 & 67,7 & 75,6 & 59.7 \\
\hline Assam & 52,9 & 61,9 & 43,0 & 63,3 & 71,3 & 54,6 & 73,2 & 78,8 & 67,3 \\
\hline Bihar & 38,5 & 52,5 & 22,9 & 47,0 & 59,7 & 33,1 & 63,8 & 73,4 & 53,3 \\
\hline Chattisgarh & - & - & - & 64,7 & 77,4 & 51,9 & 71,0 & 81,5 & 60,6 \\
\hline Goa & 75,5 & 83,6 & 67,1 & 82,0 & 88,4 & 75,4 & 87,4 & 92,8 & 81,8 \\
\hline Gujarat & 61,3 & 73,1 & 48,6 & 69,1 & 79,7 & 57,8 & 79,3 & 87,2 & 70,7 \\
\hline Haryana & 55,9 & 69,1 & 40,5 & 67,9 & 78,5 & 55,7 & 76,6 & 85,4 & 66,8 \\
\hline Himachal Pradesh & 63,9 & 75,4 & 52,1 & 76,5 & 85,3 & 67,4 & 83,8 & 90,8 & 76,6 \\
\hline Jharkhand & - & - & - & 53,6 & 67,3 & 38,9 & 67,4 & 78,5 & 56,2 \\
\hline Jammu \& Kashmir & - & - & - & 55,5 & 66,6 & 43,0 & 68,7 & 78,3 & 58,0 \\
\hline Karnataka & 56,0 & 67,3 & 44,3 & 66,6 & 76,1 & 56,9 & 75,6 & 82,9 & 68,1 \\
\hline Kerala & 89,8 & 93,6 & 86,2 & 90,9 & 94,2 & 87,7 & 93,9 & 96,0 & 92,0 \\
\hline Madhya Pradesh & 44,2 & 58,4 & 28,9 & 63,7 & 76,1 & 50,3 & 70,6 & 80,5 & 60,0 \\
\hline Maharashtra & 64,9 & 76,6 & 52,3 & 79,9 & 86,0 & 67,0 & 82,9 & 89,8 & 75,5 \\
\hline Orissa & 49,1 & 63,1 & 34,7 & 63,1 & 75,3 & 50,5 & 73,5 & 82,4 & 64,4 \\
\hline Punjab & 58,5 & 65,7 & 50,4 & 69,7 & 75,2 & 63,4 & 76,7 & 81,5 & 71,3 \\
\hline Rajasthan & 38,6 & 55,0 & 20,4 & 60,4 & 75,7 & 43,9 & 67,1 & 80,5 & 52,7 \\
\hline Tamil Nadu & 62,7 & 73,8 & 51,3 & 73,5 & 82,4 & 64,4 & 80,3 & 86,8 & 73,9 \\
\hline Utrat Pradesh & 41,6 & 55,7 & 25,3 & 56,3 & 68,8 & 42,2 & 69,7 & 79,2 & 59,3 \\
\hline Uttarakhand & - & - & - & 71,6 & 83,3 & 59,6 & 79,6 & 88,3 & 70,7 \\
\hline West Bengal & 57,7 & 67,8 & 46,6 & 68,6 & 77,0 & 59,6 & 77,1 & 82,7 & 71,2 \\
\hline
\end{tabular}

* odsetek ludności umiejącej czytać i pisać w wieku powyżej 7 lat; $\mathrm{M}$ - mężczyźni, $\mathrm{K}$ - kobiety.

Źródło: [Dev (ed.), 2013, s. 402-403]. 
Jeżeli chodzi o zróżnicowanie stopnia alfabetyzacji pomiędzy mężczyznami a kobietami, to najlepiej pod tym względem wypada Kerala (tylko 4 punkty proc.), natomiast najgorzej sytuacja przedstawia się w: Assamie, Biharze, Chhattisgarh, Jharkhandzie, Madhya Pradesh i Uttar Pradesh - wszędzie po ok. 20 punktów procentowych. Podkreślić jednak trzeba, że w okresie 1991-2011 w każdym stanie te rozpiętości w poziomie alfabetyzacji mężczyzn i kobiet istotnie się zmniejszyły.

Przeprowadzona analiza poziomu alfabetyzacji wskazuje na postępującą konwergencję regionalną w tak ważnej dziedzinie życia społecznego, jakim jest podstawowa edukacja. Nietrudno stwierdzić, że proces ten w dużym stopniu przyczynia się - i tak będzie też w przyszłości - do zmniejszania przestrzennego zróżnicowania poziomu rozwoju gospodarczego stanów i tym samym wyrównywania warunków życia ludności.

Jeżeli najniższym - aczkolwiek społecznie najważniejszym - poziomem systemu indyjskiej oświaty jest nauczanie ludzi czytania i pisania, to na najwyższym szczeblu drabiny edukacyjnej lokuje się szkolnictwo wyższe. Jego podstawową miarą jest liczba studentów ogółem oraz w przeliczeniu na 1 tys. mieszkańców. Dane do analizy zmian tego zjawiska przedstawiono w tab. 6.26.

Tabela 6.26. Liczba studentów w Indiach - globalnie i na 1 tys. mieszkańców

\begin{tabular}{|c|c|c|}
\hline Lata & $\begin{array}{c}\text { Liczba studentów } \\
(\mathrm{w} \text { mln })\end{array}$ & $\begin{array}{c}\text { Liczba studentów } \\
\text { na 1 tys. mieszkańców }\end{array}$ \\
\hline $1990 / 91$ & 4,92 & 4,8 \\
\hline $2000 / 01$ & 8,40 & 8,2 \\
\hline $2005 / 06$ & 11,03 & - \\
\hline $2009 / 10^{*}$ & 14,62 & 12,1 \\
\hline
\end{tabular}

* do obliczeń wskaźnika dla roku 2009/10 przyjęto liczbę ludności z narodowego spisu powszechnego w 2011 roku.

Źródło: opracowanie i obliczenia własne na podstawie [Datt, Mahajan, 2014, s. 42, 168].

Jak wynika z tab. 6.26, w okresie 1991/92-2009/10 liczba studiujących na indyjskich uczelniach wzrosła niemal trzykrotnie - z niespełna $4,9 \mathrm{mln}$ do 14,6 mln. Znacząco, bo dwuipółkrotnie zwiększył się wskaźnik skolaryzacji na poziomie wyższym. Takie tempo zmian uznać należy za wysokie i świadczące o szybkim rozwoju wyższej edukacji i wzroście wykształcenia Indusów po reformach z lat 1991-1992. Dynamiczny przyrost liczby studiujących i absolwentów szkół wyższych wpływa istotnie na poprawę jakości indyjskiego społeczeństwa i podnoszenie jego konkurencyjności na międzynarodowych rynkach pracy, szczególnie - jak wykazano w rozdziale V - w kontekście przyciągania zagranicznych inwestycji oraz usług offshoringowych. Należy dodać, że w populacji indyjskich studentów systematycznie wzrasta odsetek kobiet. W drugiej połowie pierwszej dekady XXI stulecia przekroczył on 40 proc., co jest jednym 
z ważnych dowodów postępującej emancypacji ekonomicznej i społecznej indyjskich kobiet [Datt, Mahajan, 2014, s. 168].

$\mathrm{Na}$ zakończenie analizy społecznych efektów reform gospodarki i państwa przedstawione zostanie zróżnicowanie warunków życia ludności Indii w świetle wartości wskaźnika przeciętnego dalszego trwania życia - wyrażonego w latach i liczonego od momentu urodzenia człowieka $\left(\mathrm{e}^{\circ}\right)$. Wskaźnik ten jest oczywiście kategorią demograficzną i służy z reguły do charakterystyki przemian ludnościowych. Można go jednak także wykorzystać - jak to już uczyniono w rozdziale II - do opisu i oceny przemian poziomu i jakości życia ludności. Wynika to z faktu - przypomnijmy - że trwanie życia jest funkcją warunków, w jakich ludzie żyją i jak się zachowują, tj. sytuacji mieszkaniowej, poziomu i jakości odżywiania się, higieny i opieki medycznej, edukacji, jakości pracy oraz walorów otoczenia przyrodniczego i społecznego. Merytorycznie zasadne jest więc posługiwanie się wskaźnikami długości życia w analizie przemian poziomu i jakości życia ludności.

W tab. 6.27 zestawiono wskaźniki przeciętnej długości życia Indusów i jego zmiany w okresie 1993-2010 w podziale na stany oraz płeć.

Tabela 6.27. Przeciętne trwanie życia ludności ( $\mathrm{e}^{\mathrm{o}}-\mathrm{w}$ latach $)$ - wielkości średnie dla podanych okresów

\begin{tabular}{|l|c|c|c|c|c|c|c|c|c|c|}
\hline \multirow{2}{*}{ Stany } & \multirow{2}{*}{\begin{tabular}{c}
$1993-1997$ \\
\cline { 3 - 10 }
\end{tabular}} & \multicolumn{3}{|c|}{$1999-2003$} & \multicolumn{3}{c|}{$2000-2004$} & \multicolumn{3}{|c|}{$2006-2010$} \\
\cline { 3 - 11 } & O* & $\mathrm{M}$ & $\mathrm{K}$ & $\mathrm{O}$ & $\mathrm{M}$ & $\mathrm{K}$ & $\mathrm{O}$ & $\mathrm{M}$ & $\mathrm{K}$ \\
\hline Indie- ogółem & 61,1 & 62,7 & 61,5 & 63,5 & 63,0 & 62,1 & 63,7 & 66,1 & 64,6 & 67,7 \\
\hline Andhra Pradesh & 62,4 & 63,7 & 62,2 & 64,8 & 63,9 & 62,4 & 65,0 & 65,8 & 63,5 & 68,2 \\
\hline Assam & 56,7 & 58,0 & 57,8 & 58,3 & 58,3 & 58,0 & 58,6 & 61,9 & 61,0 & 63,2 \\
\hline Bihar & 59,6 & 61,0 & 61,6 & 59,7 & 61,2 & 61,8 & 59,9 & 65,8 & 65,5 & 66,2 \\
\hline Gujarat & 61,9 & 63,5 & 62,5 & 64,6 & 63,7 & 62,7 & 64,8 & 66,8 & 64,9 & 69,0 \\
\hline Haryana & 64,1 & 65,4 & 65,0 & 65,6 & 65,6 & 65,3 & 65,8 & 67,0 & 66,0 & 69,5 \\
\hline Karnataka & 63,3 & 64,6 & 62,9 & 66,4 & 64,9 & 63,1 & 66,7 & 67,2 & 64,9 & 69,7 \\
\hline Kerala & 73,3 & 73,6 & 70,9 & 76,0 & 73,7 & 71,0 & 76,1 & 74,2 & 71,5 & 76,9 \\
\hline Madhya Pradesh & 55,5 & 57,1 & 57,2 & 56,9 & 57,4 & 57,5 & 57,2 & 62,4 & 61,1 & 63,8 \\
\hline Maharashtra & 65,5 & 66,4 & 65,2 & 67,6 & 66,8 & 65,5 & 67,8 & 69,9 & 67,9 & 71,9 \\
\hline Orissa & 57,2 & 58,7 & 58,6 & 58,7 & 58,9 & 58,9 & 58,9 & 63,0 & 62,2 & 63,9 \\
\hline Punjab & 67,7 & 68,6 & 67,6 & 69,6 & 68,9 & 67,8 & 69,8 & 69,3 & 67,4 & 71,6 \\
\hline Rajasthan & 60,0 & 61,3 & 60,7 & 61,8 & 61,5 & 60,9 & 62,0 & 66,5 & 64,7 & 68,3 \\
\hline Tamil Nadu & 64,1 & 65,4 & 64,3 & 66,5 & 65,7 & 64,6 & 66,8 & 68,9 & 67,1 & 70,9 \\
\hline Uttar Pradesh & 57,6 & 59,3 & 59,6 & 58,7 & 59,6 & 59,9 & 59,0 & 62,7 & 61,8 & 63,7 \\
\hline West Bengal & 62,8 & 64,1 & 63,5 & 65,0 & 64,4 & 63,7 & 65,2 & 69,0 & 67,4 & 71,0 \\
\hline
\end{tabular}

* O - ogółem, M - mężczyźni, $\mathrm{K}$ - kobiety.

Źródło: [Selected Socio-Economic Statistics India, 2011, s. 45, tab. 1.32], [Economic Survey 2012-2013. Statistical Appendix, 2013, s. A-121, tab. 9.1]. 
Z analizy wskaźników zestawionych w tab. 6.27 wynika, że w badanym okresie życie mieszkańców Indii systematycznie się wydłużało. W pierwszej połowie lat 90. statystyczny obywatel tego kraju żył 61,1 lat, a w drugiej połowie pierwszej dekady XX stulecia było to już 66,1 lat, a więc jego życie wydłużyło się o 5 lat. Wartości tego wskaźnika były jednak znacznie zróżnicowane regionalnie.

W latach 2006-2010 najwyższe wskaźniki trwania życia obserwuje się w stanach (dane w latach): Kerala (74,2), Maharashtra $(69,9)$, Punjab $(69,0)$, West Bengal $(69,0)$, Tamil Nadu $(68,9)$, Karnataka $(67,2)$ i Haryana $(67,0)$. Natomiast najwcześniej umierają mieszkańcy stanów: Assam $(61,9)$, Madhya Pradseh $(62,4)$, Uttar Pradesh $(62,7)$ i Orissa $(63,0)$.

Niejednakowe były też przyrosty wskaźnika przeciętnego trwania życia w poszczególnych stanach. $\mathrm{Z}$ danych w tab. 6.27 wynika, że w badanym, blisko dwudziestoletnim okresie, najbardziej wydłużyło się życie ludzkie w stanach o niskim - jak na warunki indyjskie - poziomie rozwoju ekonomicznego i społecznego, tj. w: Madhya Pradesh (6,9 lat), Rajasthanie (6,5 lat), Biharze (6,4 lat) i Bengalu Zachodnim (6,2 lat). Najniższe zaś przyrosty miały miejsce w Kerali (0,9 lat), Punjabie (1,6 lat), Haryanie (2,9 lat), czyli w stanach najbardziej gospodarczo rozwiniętych. Statystyki te potwierdzają sformułowaną przez demografów kilka dekad wcześniej tezę o malejących przyrostach trwania życia ludzkiego w miarę rozwoju ekonomicznego i postępu społecznego oraz jego wyrównywaniu się [Rosset, 1979].

Znamienne są porównania zmian długości trwania życia kobiet i mężczyzn. Generalnie - tj. w przekroju całego kraju - kobiety żyją dłużej niż mężczyźni. Niemniej jednak na przełomie wieków (1999-2004) w kilku, i to największych - a zarazem najbiedniejszych - stanach (Uttar Pradesh, Madhya Pradesh i Bihar), przeciętne trwanie życia mężczyzn było dłuższe niż kobiet. Sytuacja zmieniła się pod koniec pierwszej dekady obecnego stulecia, i - jak pokazuje tab. 6.27 - we wszystkich stanach kobiety żyją już dłużej niż mężczyźni przeciętnie o 1-4 lat, a w Kerali różnica wynosi ponad 5 lat. Takie zjawisko można uznać już za normalne, zgodne z regułami demografii, czyli świadczące o poprawie warunków życia ludności, a w tym szczególnie poprawy sytuacji kobiet, co było do niedawna jedną z największych bolączek społecznych Indii.

Na podstawie powyższej analizy nietrudno dostrzec, że rozkład przestrzenny długości życia mieszkańców Indii pokrywa się z geografią poziomu rozwoju gospodarczego, a następnie z rozkładem infrastruktury i konsumpcji. Potwierdza to hipotezę o korelacji tych zjawisk i opinię o wysokiej wartości diagnostycznej wskaźnika przeciętnego trwania życia w badaniach poziomu życia ludności.

Reasumując przeprowadzoną analizę warunków życia indyjskiego społeczeństwa, można stwierdzić, że po 1991 roku następowała systematyczna poprawa w tej dziedzinie. Świadczą o tym nie tylko poprawiające się wskaźniki infrastruktury techniczno-ekonomicznej oraz materialnej konsumpcji, ale także korzystne tendencje wielu zjawisk społecznych, takich jak: malejący analfabetyzm, 
rosnąca skolaryzacja na poziomie wyższym, obniżająca się umieralność niemowląt, wydłużające się trwanie życia ludzkiego itp. Bezwzględne wielkości większości wskaźników są jednak nadal niekorzystne - albo za wysokie, albo za niskie i generalnie odpowiadają jedynie standardom krajów opóźnionych w rozwoju. Tak więc pomimo ogromnego postępu w badanych dwóch dekadach, długi jest jeszcze czas, by pod względem dobrobytu społeczeństwo indyjskie - przynajmniej w swej większości - zbliżyło się do standardu krajów średnio rozwiniętych, nie wspominając już o krajach wysoko rozwiniętych.

\subsubsection{Dynamika i struktura ubóstwa}

Jak stwierdzono w rozdziale II, w przypadku Indii najważniejszą miarą postępu ekonomicznego jest odczuwalna redukcja ubóstwa oraz zmniejszanie się dystansów w zakresie zróżnicowania materialnych warunków życia Indusów ${ }^{21}$. Wszelkie reformy i zmiany w gospodarce oraz życiu społecznym są zasadne, jeśli przełożą się ostatecznie na ograniczenie zasięgu i głębokości biedy, czyli spadek odsetka ludności żyjącej poniżej progu ubóstwa. Jak te kwestie wyglądają w Indiach po rozpoczęciu wielkich reform gospodarki i państwa w 1991 roku? Poniższa analiza będzie próbą odpowiedzi na to pytanie.

Kwestie definicyjne oraz metodyczne badania ubóstwa w Indiach przedstawiono w rozdziale II. Na użytek niniejszego podrozdziału przyjęto dla pomiaru i analizy ubóstwa wskaźniki obliczone - na zlecenie indyjskiego rządu - przez zespół badaczy pod kierunkiem wybitnego ekonomisty i statystyka Suresha Tendulkara, byłego szefa Narodowej Komisji Statystycznej. Metoda ta stała się podstawą oficjalnego dokumentu rządowego - raportu Komisji Tendulkara opublikowanego w grudniu 2009 roku (Report on Methodology of Estimation of Poverty 2009). Zastąiła ona wcześniejsze miary ubóstwa obliczane najczęściej na podstawie kaloryczności żywienia $^{22}$. Dlatego też w indyjskich statystykach oraz literaturze ekonomicznej można spotkać dane dotyczące ubóstwa istotnie różniące się od podanych w tab. 6.23 i 6.28.

${ }^{21}$ Premier rządu federalnego M. Singh w swym wystąpieniu z okazji 60. rocznicy uzyskania niepodległości przez Indie (sierpień 2007) mówił m.in.: „Indie nie mogą być krajem wysp nowoczesnego rozwoju pośród bezkresnych obszarów nietkniętych rozwojem. [...] Marzenie Mahatmy Gandhiego o wolnych Indiach może się ziścić tylko wtedy, gdy z naszego podwórka wypędzimy biedę" [za: Wolpert, 2010, s. 561-562].

${ }^{22}$ Problem oszacowania rozmiarów ubóstwa w skali całych Indii i w podziale na różne segmenty (regionalne, społeczne) był od lat 50. przedmiotem licznych studiów oraz badań empirycznych. Powstało wiele zespołów badawczych, które opracowały odpowiednie raporty. Wyniki tych badań różniły się jednak znacząco z uwagi na odmienne podejście metodyczne oraz materiał empiryczny. W badaniach indyjskiego ubóstwa po 1991 roku statystycy oraz ekonomiści tego kraju posługują się najczęściej wyliczeniami Komisji Tendulkara. Dokładniej na ten temat piszą Datt, Mahajan [2014, s. 388-416]. 
W tab. 2.12 (podrozdział 2.4.2) przedstawiono zmiany ubóstwa w pierwszych czterech dekadach niepodległych Indii. Jak wynika z tych danych, redukcja ubóstwa w tym kraju rozpoczęła się w drugiej połowie lat 70., a znaczący postęp obserwuje się dopiero w latach 80 ., co było rezultatem ożywienia gospodarczego w tym okresie i równoczesnego obniżania się stopy przyrostu naturalnego. Proces ten miał miejsce także po 1991 roku, aczkolwiek jego dynamika w ostatniej dekadzie XX wieku nieco osłabła, o czym informują wskaźniki w tab. 6.28.

Istotne przyspieszenie spadku ubóstwa nastąpiło po 2003 roku. W latach 2003/04-2009/10 stopa ubóstwa w odniesieniu do całego społeczeństwa obniżyła się o 7,3 punktu procentowego. W roku gospodarczym 2003/04 poniżej linii ubóstwa żyło 37 proc. mieszkańców Indii, a w 2009/10 roku wskaźnik ten zmniejszył się do niespełna 30 proc. Poprawa była znacznie większa w społecznościach wiejskich. Odsetek ludności wiejskiej żyjącej poniżej progu ubóstwa zmalał w tym czasie o 8 punktów procentowych (z 41,8 do 33,8 proc.), natomiast w przypadku ludności miejskiej spadek wyniósł 4,6 punktu procentowego (z 25,5 do 20,9 proc.).

Analiza tab. 6.28 wskazuje, że ubóstwo nie obniżało się jednakowo we wszystkich stanach. W okresie 1993/94-2003/04 w trzech stanach (Uttarakhand, Madhya Pradesh, Goa) nastąpił nawet wzrost stopy ubóstwa, a w kilku innych (Chhattisgarh, Orissa, Punjab) wskaźnik ten zmalał nieznacznie - o mniej niż 2,5 punktu procentowego. Natomiast po 2003 roku tylko w zamożnym Delhi NCT i biednym Assamie miał miejsce nieznaczny wzrost stopy ubóstwa, aczkolwiek ich poziomy wyraźnie się różniły (Delhi NCT - 14,2, Assam - 37,9 proc.). W pozostałych 20 stanach mamy do czynienia ze zmniejszeniem się obszarów biedy i to w niektórych bardzo znaczącym (Goa, Himachal Pradesh, Kerala, Karnataka, Madhya Pradesh, Maharasthra, Orissa, Rajasthan, Tamil Nadu i Uttarakhand) - rzędu kilkunastu punktów procentowych. Większość tych ostatnich stanów - jak wiadomo z wcześniejszej analizy - jest relatywnie dobrze rozwinięta gospodarczo i wykazuje $\mathrm{w}$ tej dziedzinie wysoką dynamikę. Nie bez znaczenia w tym kontekście jest także istotne obniżanie się przyrostu naturalnego, wyraźna poprawa zdrowia oraz edukacji ludności na wszystkich jej poziomach.

Dane w tab. 6.28 wskazują na duże różnice w poziomie ubóstwa pomiędzy miastem a wsią. W latach 1993/94-2003/04 stopa ubóstwa była we wszystkich stanach znacząco wyższa na terenach wiejskich, o 16-19 proc. w skali całego kraju. W drugiej połowie pierwszej dekady XXI wieku sytuacja istotnie się zmieniła i w roku 2009/10 w niektórych stanach wskaźnik ubóstwa w miastach był nawet wyższy niż na wsi. Do tej grupy należą stany leżące w północno-zachodniej części kraju: Haryana, Punjab, Himachal Pradesh, Uttarakhand, Jammu \& Kashmir oraz Delhi NCT. „Konwersję” tę należy tłumaczyć odmiennie w poszczególnych stanach. Cztery pierwsze stany, tj. Haryana, Punjab, Himachal Pradesh oraz Uttarakhand, są - jak wiemy z wcześniejszej analizy - stanami dobrze rozwiniętymi gospodarczo. Ważnym - bardziej niż w większości innych stanów - sektorem 
Tabela 6.28. Stopa ubóstwa - odsetek ludności żyjącej poniżej progu (linii) ubóstwa

\begin{tabular}{|c|c|c|c|c|c|c|c|c|c|}
\hline \multirow{4}{*}{ Stany } & \multicolumn{9}{|c|}{ Lata } \\
\hline & \multicolumn{3}{|c|}{ 1993-94 } & \multicolumn{3}{|c|}{ 2003-04 } & \multicolumn{3}{|c|}{ 2009-10 } \\
\hline & \multirow{2}{*}{ ogółem } & \multicolumn{2}{|c|}{ w tym: } & \multirow{2}{*}{ ogółem } & \multicolumn{2}{|c|}{ w tym } & \multirow{2}{*}{ ogółem } & \multicolumn{2}{|c|}{ w tym: } \\
\hline & & miasta & wsie & & miasta & Wsie & & miasta & wsie \\
\hline Ogółem - Indie & 45,1 & 31,4 & 50,1 & 37,1 & 25,5 & 41,8 & 29,8 & 20,9 & 33,8 \\
\hline Delhi NCT & 15,7 & 15,6 & 16,2 & 13,0 & 12,9 & 15,6 & 14,2 & 14,4 & 7,7 \\
\hline Andhra Pradesh & 44,6 & 35,2 & 48,1 & 29,8 & 24,4 & 32,3 & 21,1 & 17,7 & 22,8 \\
\hline Assam & 51,8 & 27,7 & 55,0 & 34,4 & 21,8 & 36,4 & 37,9 & 26,1 & 39,9 \\
\hline Bihar & 60,5 & 44,6 & 62,3 & 54,5 & 43,7 & 55,7 & 53,5 & 39,4 & 55,3 \\
\hline Chhattisgarh & 50,9 & 28,1 & 55,9 & 49,4 & 28,4 & 55,1 & 48,7 & 23,8 & 56,1 \\
\hline Goa & 20,7 & 14,5 & 25,4 & 25,0 & 22,2 & 28,1 & 8,7 & 6,9 & 11,5 \\
\hline Gujarat & 37,8 & 28,0 & 43,1 & 31,8 & 20,1 & 39,1 & 23,0 & 17,9 & 26,7 \\
\hline Haryana & 35,9 & 24,2 & 40,0 & 24,1 & 22,4 & 24,8 & 20,1 & 23,0 & 18,6 \\
\hline Himachal Pradesh & 34,7 & 13,6 & 36,8 & 22,9 & 4,6 & 25,0 & 9,5 & 12,6 & 9,1 \\
\hline Jharkhand & 60,7 & 41,8 & 65,9 & 45,3 & 23,8 & 51,6 & 39,1 & 31,1 & 41,6 \\
\hline Jammu \& Kashmir & 26,3 & 6,9 & 32,5 & 13,1 & 10,4 & 14,1 & 9,4 & 12,8 & 8,1 \\
\hline Karnataka & 49,5 & 34,3 & 56,6 & 33,4 & 25,9 & 37,5 & 23,6 & 19,6 & 26,1 \\
\hline Kerala & 31,3 & 23,9 & 33,9 & 19,7 & 18,4 & 20,2 & 12,0 & 12,1 & 12,0 \\
\hline Madhya Pradesh & 44,0 & 31,8 & 48,9 & 48,6 & 35,1 & 53,6 & 36,7 & 22,9 & 42,0 \\
\hline Maharashtra & 47,7 & 30,3 & 59,3 & 38,1 & 25,6 & 47,9 & 24,5 & 18,3 & 29,5 \\
\hline Orissa & 59,2 & 34,6 & 63,1 & 57,1 & 37,6 & 60,8 & 37,0 & 25,9 & 39,2 \\
\hline Punjab & 22,4 & 27,2 & 20,3 & 20,9 & 18,7 & 22,1 & 15,9 & 18,1 & 14,6 \\
\hline Rajasthan & 38,3 & 29,8 & 40,8 & 34,4 & 29,7 & 35,8 & 24,8 & 19,9 & 26,4 \\
\hline Tamil Nadu & 44,5 & 33,3 & 51,0 & 29,0 & 19,7 & 37,5 & 17,1 & 12,8 & 21,2 \\
\hline Uttar Pradesh & 48,4 & 38,2 & 50,9 & 40,9 & 34,1 & 42,7 & 37,7 & 31,7 & 39,4 \\
\hline Uttarakhand & 32,1 & 18,7 & 36,7 & 32,7 & 26,2 & 35,1 & 18,0 & 25,2 & 14,9 \\
\hline West Bengal & 39,4 & 31,2 & 42,5 & 34,3 & 24,4 & 38,2 & 26,7 & 22,0 & 28,8 \\
\hline
\end{tabular}

Źródło: opracowanie własne na podstawie: [Mohanty (ed.), 2011, s. 22], [Press Note on Poverty Estimates 2009-10, tab. 2], [Datt, Mahajan, 2014, s. 407].

ich gospodarki jest rolnictwo. Niską stopę ubóstwa na tych obszarach można więc wyjaśnić względnie wysokimi dochodami z pracy na roli i wynikającym z tego samozaopatrzeniem w żywność - główny składnik koszyka zakupowego ludności ubogiej. Przypomnieć trzeba, że ludność wiejska stanowi ponad połowę mieszkańców tych stanów - od 60-65 proc. w Punjabie, Uttarkhandzie i Haryanie do 90 proc. w Himachal Pradesh (najsłabiej zurbanizowany stan Indii). Znaczną rolę w kształtowaniu zamożności mieszkańców tych stanów odgrywa również turystyka, głównie pielgrzymkowa i rekreacyjna. Podobna jest struktura demogra- 
ficzna (ponad 60 proc. osób mieszka na wsi) oraz gospodarcza - aczkolwiek na niższym poziomie - w stanie Jammu \& Kashmir; tu również ważną rolę odgrywa rolnictwo i turystyka. Ponadto we wszystkich tych pięciu stanach słabo rozwinięta jest sieć miast, a w dodatku są one pozbawione większych centrów przemysłowych bądź usługowych.

Z natury rzeczy odmienna jest sytuacja na obszarze Delhi NCT. Jest to jednostka administracyjna wysoce zurbanizowana (tylko 3 proc. ludności zamieszkuje tereny wiejskie), ze znacznymi odsetkami ludności biednej (m.in. znane delhijskie slumsy). Podstołeczne wsie zamieszkuje zaś duży odsetek ludzi średnio i wysoko zamożnych - wysokich urzędników i przedsiębiorców - dojeżdżających do pracy w stolicy.

Zróżnicowana - jak wyżej wykazano - dynamika ubóstwa ludności w poszczególnych stanach wpłynęła na zmianę jego przestrzennego rozkładu. O skali tego zjawiska informują wielkości wskaźników zmienności zestawione w tab. 6.29, tj. rozstęp oraz współczynnik zmienności ${ }^{23}$.

Tabela 6.29. Wskaźniki zmienności przestrzennej stopy ubóstwa w latach 1993/94-2009/10 według stanów

\begin{tabular}{|c|c|c|c|c|c|c|}
\hline \multirow{2}{*}{ Lata } & \multicolumn{3}{|c|}{ Rozstęp $\left(R_{x}\right)$} & \multicolumn{2}{c|}{$\begin{array}{c}\text { Współczynnik zmienności }\left(V_{d x}\right), \\
\text { w proc. }\end{array}$} \\
\cline { 3 - 4 } & \multirow{2}{*}{ ogółem } & \multicolumn{2}{|c|}{ w tym: } & \multirow{2}{*}{ Ogółem } & \multicolumn{2}{c|}{ w tym: } \\
\cline { 3 - 4 } \cline { 6 - 7 } & & Miasta & wsie & & miasta & wsie \\
\hline $1993 / 94$ & 45,0 & 37,7 & 49,7 & 25,3 & 25,6 & 25,2 \\
\hline $2003 / 04$ & 44,1 & 39,1 & 41,6 & 28,4 & 26,4 & 28,5 \\
\hline $2009 / 10$ & 44,8 & 32,5 & 48,0 & 40,7 & 28,3 & 43,9 \\
\hline
\end{tabular}

Źródło: obliczenia własne na podstawie danych z tab. 6.28.

Analiza wskaźników w tab. 6.29 pozwala na sformułowanie tezy o narastających dysproporcjach w przestrzennym rozkładzie ubóstwa w Indiach po reformach z lat 1991-1992. Ubóstwo oczywiście istotnie maleje, ale nierównomiernie w poszczególnych regionach kraju. W badanym okresie w odniesieniu do całych Indii nie nastąpiło co prawda - jak wskazują wartości rozstępu $\left(R_{x}\right)$ - zwiększenie obszaru zróżnicowania ubóstwa, czyli nie powiększyły się rozpiętości pomiędzy stanami o najwyższej i najniższej stopie ubóstwa. Gdy jednak uwzględnimy podział badanej zbiorowości na miejską i wiejską, to obraz zjawiska zmienia się. Otóż w populacji wiejskiej odległości (wartości wskaźnika $R_{x}$ ) pomiędzy stanami o największej i najmniejszej wielkości stopy ubóstwa zmieniły się w okresie 2003/04-2009/10 nieznacznie - zamykały się w granicach 48-50 punktów

${ }^{23}$ Por. wyjaśnienia metodyczne w podrozdziale 2.4.3 (przypis 42). 
procentowych. Istotny był natomiast spadek rozpiętości w przypadku ludności miejskiej - z 37,7 punktu procentowego (pomiędzy Biharem a Jammu \& Kashmirem) w roku 1993/94 do 32,5 punktu procentowego (pomiędzy Biharem a Goa) w roku 2009/10 (por. tab. 6.28).

Jak wcześniej zaznaczono, wielkości rozstępu informując o różnicach pomiędzy dwoma krańcowymi wartościami stopy ubóstwa (stanem o najwyższej i najmniejszej stopie), nie dają jednak obrazu tego, co dzieje się wewnątrz badanego obszaru, czyli o rozkładzie odległości pomiędzy pozostałymi stanami. Takiej wiedzy dostarczają dopiero współczynniki zmienności przestrzennej stopy ubóstwa $\left(V_{d x}\right)$ wyliczone dla całej zbiorowości badanych stanów i zamieszczone w tab. 6.29.

Jak wynika z tab. 6.29, współczynniki zmienności przestrzennej ubóstwa w badanych latach są dość wysokie, co potwierdza opinię o dużych dysproporcjach w tym względzie. Ich zmiany wskazują natomiast, że w okresie 1993-2010 - przy generalnej tendencji spadkowej stopy ubóstwa - narastało jednak jej przestrzenne zróżnicowanie na obszarze Indii. Oznacza to, że społeczne efekty dynamicznego rozwoju gospodarczego (w postaci redukcji ubóstwa) nie rozkładały się równomiernie na obszarze kraju. Dowodzi to, że w badanym okresie zwiększała się terytorialna dywergencja w zakresie ubóstwa. Proces ten jest szczególnie widoczny na obszarach wiejskich.

Na podstawie danych z tab. 6.28 można sporządzić „,mapę biedy” w Indiach. Podstawą delimitacji jest wielkość stopy ubóstwa w poszczególnych stanach w roku 2009/10. Przyjęto następujący podział stanów:

1) stany bardzo biedne, w których poniżej progu ubóstwa żyje ponad 30 proc. mieszkańców;

2) stany o średnim poziomie biedy, w których poniżej progu ubóstwa żyje 15-30 proc. mieszkańców;

3) stany o niskim poziomie biedy, w których poniżej progu ubóstwa żyje mniej niż 15 proc. mieszkańców.

Do pierwszej, najuboższej, grupy stanów zaliczają się (w nawiasie stopa ubóstwa w roku 2009/10): Bihar (53,5), Chhattisgarh (48,7), Jharkhand (39,1), Assam $(37,9)$, Uttar Pradesh $(37,7)$, Orissa $(37,0)$ i Madhya Pradesh $(36,7)$.

Drugą grupę stanów, o średnim poziomie ubóstwa, tworzą: West Bengal $(26,7)$, Rajasthan $(24,8)$, Maharashtra $(24,5)$, Karnataka $(23,6)$, Gujarat $(23,0)$, Andhra Pradesh $(21,1)$, Haryana $(20,1)$, Uttarakhand $(18,0)$, Tamil Nadu $(17,1)$ oraz Punjab $(15,9)$.

Do trzeciej grupy stanów, o najniższej stopie ubóstwa, czyli o najlepszych warunkach życia, zaliczają się: Delhi NCT $(14,2)$, Kerala, $(12,0)$, Himachal Pradesh $(9,5)$, Jammu \& Kashmir $(9,4)$ i Goa $(8,7)$.

$\mathrm{Z}$ powyższego zestawienia wynika, że największa skala biedy występuje w północno-środkowych oraz wschodnich regionach Indii. Najzamożniejszymi, czyli o niewielkiej skali ubóstwa, są zaś małe stany zlokalizowane - oprócz Kerali - w północno-zachodniej części kraju. 
Kończąc, nietrudno skonstatować - porównując analizę w podrozdziałach 6.1-6.2 z analizą w niniejszym podrozdziale - że skala ubóstwa w poszczególnych stanach jest ujemnie skorelowana $\mathrm{z}$ ich poziomem rozwoju gospodarczego. Im jest on wyższy, tym na ogół niższe są rozmiary biedy. Zaobserwowane rosnące dysproporcje w przestrzennym rozkładzie ubóstwa są następstwem zwiększania się wcześniej opisanych nierównomierności w terytorialnym rozwoju gospodarczym Indii. Jest to oczywiście logiczne, zgodne z elementarnymi prawami rozwoju gospodarczego i społecznego. Trudno bowiem wyobrazić sobie sytuację, aby zróżnicowany poziom i dynamika gospodarcza indyjskich stanów nie przynosiły podobnych efektów w odniesieniu do warunków życia społeczeństwa.

Zauważone tendencje przestrzennego różnicowania się poziomu rozwoju gospodarczego oraz poziomu życia ludności Indii są - jak już wcześniej sygnalizowano - naturalne w okresach szybkich zmian gospodarczych i polityczno-społecznych. Trzeba jednak pamiętać, że tempo narastania tych dysproporcji nie może być duże, a czas tego procesu - zbyt długi. Jest to nad wyraz ważne w warunkach indyjskich, gdzie mamy do czynienia z ogromnym, wręcz unikalnym w skali świata, zróżnicowaniem społeczeństwa pod względem etnicznym, kulturowym, religijnym itp. Gdyby na te, mocno utrwalone przez historię, różnice nałożyły się szybko rosnące dysproporcje ekonomiczne, to - po przekroczeniu pewnej skali tych procesów - mogłoby dojść do nadmiernej polaryzacji indyjskiej przestrzeni społeczno-politycznej, a w ślad za tym konfliktów międzyregionalnych. Niewątpliwie w takich sytuacjach rodziłyby się dążenia separatystyczne, które mogłyby prowadzić nawet do rozpadu państwa. 



\section{PODSUMOWANIE I UWAGI KOŃCOWE}

W historii gospodarczej niepodległych Indii wyróżnia się dwa okresy. Ich cezurą jest 1991 rok. Są to lata 1947-1991 oraz 1992-2012.

Pierwszym zadaniem nowo powstałego w 1947 roku państwa indyjskiego stało się stworzenie i wprowadzenie w życie podstawowych struktur politycznych, społecznych oraz gospodarczych. Było to wielkie wyzwanie, zważywszy na niezwykłą, nieznaną dotąd, skomplikowaną naturę tworzącego się bytu politycznego. Na mapie świata pojawiło się nowe państwo obejmujące ogromny obszar, zamieszkały przez blisko $350 \mathrm{mln}$ ludzi różnej proweniencji etnicznej i religijnej, mocno zhierarchizowanych ekonomicznie oraz kulturowo, dla których termin ,demokracja” miał wymiar abstrakcyjny. Z tej masy ludzi należało w krótkim okresie utworzyć jeden organizm społeczny, ukształtować jego świadomość państwową, czyli poczucie przynależności obywateli do nowego państwa, a następnie skonstruować system organizacyjny, w ramach którego społeczeństwo to miałoby funkcjonować.

Obecnie, w połowie drugiej dekady XXI wieku, a więc z perspektywy niemal siedemdziesięciu lat, można twierdzić, że zadanie zostało pomyślnie zrealizowane. Rzeczywiście powstało nowe, wielkie państwo o ogromnej, nieznanej gdzie indziej mozaice kulturowej swych obywateli. Co najważniejsze - społeczeństwo tego państwa systematycznie się rozwija, czyniąc swój kraj jednym z najważniejszych na świecie i to w wielu wymiarach - demograficznym, kulturowym, politycznym oraz ekonomicznym.

$\mathrm{Na}$ podstawie przeprowadzonej analizy kształtowania się podstawowych wskaźników ekonomicznych oraz społecznych nietrudno się zorientować, że - jakiekolwiek by przykładać miary i kryteria - to w badanym okresie dokonał się w Indiach wielki skok gospodarczy i chyba nienotowany w historii tej części świata postęp społeczny. Na początku drugiej dekady XXI wieku indyjska gospodarka - mierzona produktem krajowym brutto - stała się, jak niemal 5-6 wieków temu, jedną z trzech największych na świecie.

Wysokie wskaźniki rozwoju całej gospodarki nie rozkładają się jednak proporcjonalnie na obszarze Indii. Na podstawie analizy przestrzennego zróżnicowania zmian gospodarczych, nietrudno dostrzec $\mathrm{w}$ tej dziedzinie narastającą nierównomierność. Zarysowuje się podział Indii na obszary dwóch prędkości rozwojowych. Szybciej rozwija się generalnie zachodnia (zarówno południowo-zachodnia, jak i północno-zachodnia) część Indii. Natomiast wolniejsze tempo rozwoju cechuje wschodnie obszary kraju, a szczególnie zapóźniona pozostaje część środkowa subkontynentu. Tego procesu rozdwajania się Indii nie można 
ocenić pozytywnie. Narastające przez dłuższy czas dysproporcje w poziomie rozwoju ekonomicznego pomiędzy poszczególnymi regionami mogą okazać się bardzo niekorzystane dla kraju. Jest to szczególnie niebezpieczne w sytuacji kumulowania się, czyli nakładania na zróżnicowanie ekonomiczne różnic etnicznych i/lub religijnych. W ten sposób może wytworzyć się swoista „synergia różnic”, co będzie potęgować konflikty społeczne.

Jeżeli chodzi o społeczny wymiar szybkiego rozwoju gospodarczego Indii po $1991 \mathrm{roku}$, to przeprowadzona analiza wskazuje, że systematycznie poprawiała się materialna egzystencja indyjskiego społeczeństwa, a przynajmniej jego znaczącej większości. Poprawa ta wyraża się w korzystnych tendencjach tak ważnych dla indyjskiego społeczeństwa wskaźników społecznych, jak: dostępność do wody pitnej, zużycie prądu elektrycznego w gospodarstwach domowych, umieralność niemowląt, stopa alfabetyzacji, i - przede wszystkim - przeciętna długość życia Indusów. Ponadto z badań wynika, że następowało powolne, ale systematyczne niwelowanie się niektórych różnic w zakresie warunków życia, czego wyrazem jest m.in. zmiana na korzyść kobiet oraz mieszkańców wsi takich wskaźników, jak stopa alfabetyzacji, długość życia, umieralność niemowląt czy obniżanie rozmiarów skrajnego ubóstwa zarówno na wsiach, jak i w miastach.

Za zjawiska negatywne w dziedzinie społecznej należy uznać niestety utrzymywanie się, lub nawet - poza wyjątkami - wzrost zróżnicowania poziomu życia w przekroju przestrzennym, co jest bez wątpienia efektem znacznych, regionalnych dysproporcji ekonomicznych. Jakkolwiek wskaźniki społeczne poprawiają się we wszystkich stanach, to $\mathrm{w}$ jednych odbywa się to znacznie szybciej niż w innych.

Głównym impulsem szybkiego rozwoju gospodarczego Indii, a następnie czynnikiem jego kontynuacji były oczywiście wielkie i radykalne reformy ekonomiczne oraz decentralizacja państwa. Rola tych reform w pobudzaniu rozwoju gospodarczego jest jednak różna. Niewątpliwie ważniejszą i dającą szybkie, bo niemal natychmiastowe, rezultaty była reforma ekonomiczna polegająca na daleko idącej - w stosunku do systemu sprzed 1991 roku - liberalizacji i deregulacji gospodarki. Uwolnienie gospodarki z uciążliwych pęt państwowej biurokracji i zwiększenie wolności gospodarczej wyzwoliło ogromną energię społeczną, otworzyło gospodarkę na świat, spowodowało napływ zagranicznego kapitału oraz towarów, zmotywowało indyjskie przedsiębiorstwa do eksportu i podejmowania międzynarodowych wyzwań konkurencyjnych. Wszystko to w makroskali zaowocowało wysokimi, jednymi z najwyższych na świecie, wskaźnikami wzrostu gospodarczego.

Nieco inną rolę w rozwoju Indii po 1991 roku spełniała reforma decentralizacyjna. Jej wpływ na dotychczasowe wskaźniki rozwoju gospodarczego i społecznego nie był jeszcze wyraźny, ponieważ nie dotyczyła ona bezpośrednio gospodarki. Nie można jednak w żaden sposób negować jej znaczenia w dynamizowaniu „indyjskiego cudu gospodarczego". Studia teoretyczne oraz doświadczenia in- 
nych krajów i okresów dowodzą, że decentralizacja, oddziałując na funkcjonowanie państwa i społeczeństwa, wpływa także na dynamikę i kształt gospodarki. W przypadku Indii szczególną rolę odgrywa przełamanie wielowiekowego status quo, czyli odejście od wysoce zhierarchizowanego, wręcz niehumanitarnego systemu relacji międzyludzkich oraz kształtowanie demokratycznych, aktywnych postaw i zachowań ludzi w miejscu zamieszkania, zmianę ich systemów wartości, wzrost lokalnego patriotyzmu itp. Wszystko to istotnie - aczkolwiek z opóźnieniem - wpływa na rozwój gospodarki lokalnej, a ten - skumulowany w skali kraju - przekłada się na wyższe wartości makrowskaźników gospodarczych. Nie ulega wątpliwości, że w indyjskich warunkach ustrojowych liberalizacja i deregulacja gospodarki bez decentralizacji państwa byłyby modernizacją niekompletną, może nawet nieudaną. Pomiędzy liberalizacją i deregulacją a decentralizacją zachodzą przecież silne relacje synergii.

Reasumując, możemy stwierdzić, że sformułowany we Wstępie cel badań został zrealizowany. Lektura pracy umożliwia poznanie i ocenę tego, co działo się w indyjskiej gospodarce i życiu społecznym zarówno przed reformami z lat 1991-1992, jak i - przede wszystkim - po tej dacie, czyli w okresie dwudziestolecia 1993-2012. Przyjęte hipotezy badawcze - główna oraz cząstkowe - znalazły potwierdzenie w wynikach analiz empirycznych. 



\title{
ECONOMIC AND POLITICAL REFORMS AND THE ECONOMIC DEVELOPMENT OF INDIA (1991-2012)
}

\author{
(SUMMARY)
}

The aim of the monograph is to present the economic changes that took place in India after the implementation of economic and political reforms in the early 1990s. The analysis covers the period spanning from 1991 to 2012.

The essence of the economic reforms was the liberalization and deregulation of the Indian economy, which until the end of the 1980s was very similar to the economies of socialist countries (so-called Indian socialism), that is, it was managed centrally by the state. With the reform of the economy other significant modifications to the political system were carried out, meaning the decentralization of the state and thus creating a democratic local government.

The research is focused on the description and analysis of the dynamics and structure of India's most important economic values, such as GDP, agricultural and industrial production, services, employment, international trade and foreign investment. The transformation of the living conditions of the population, including in particular the problem of poverty, an element that garners a lot of attention in India, was also analysed. This latter approach allows for the most important analysis, the social verification of Indian economic development.

The research was conducted in three dimensions:

1) macroeconomic, that is, in relation to the whole Indian economy;

2) spatial - national and international, i.e. according to regional divisions and in comparison to other countries;

3) social, i.e. taking into account the demographic and social divisions of the Indian society.

Due to substantive, methodological and editorial reasons, the monograph is divided into six chapters.

Chapter I contains a theoretical introduction to the subsequent empirical analyses of the economic and political changes in India. The area of study falls into an economic sub-discipline newly created after World War II, i.e. economic development - which deals with issues involving the beginnings and development of underdeveloped countries, mostly former colonies. It shows the genesis and evolution of the theory and the ensuing dilemmas of choice in regards to the developmental paths available for underdeveloped countries. In this context special attention was given to the theoretical aspects and circumstances for independent India's choice of economic model. 
Chapter II presents the political, social and economic problems of India in the period 1947-1991. In the first part of the chapter the genesis, organization and problems in the realisation of the state's choice of political model at the dawn of independence is highlighted. The second part of the chapter focuses on characterising the dynamics and structural transformation of social and economic life. In order to objectify the assessment of these changes, comparisons are made between India and the economic development of other large Asian countries during the same time period.

An attempt at a more accurate characterization of the economic reforms launched in 1991 in India is made in chapter III. Their immediate circumstances and causesare pointed out, as well as the main elements of the "new economic policy" - as the reforms were named. In the last fragment of the chapter attention is drawn to the practical problems, dilemmas and the initial effects after the implementation of new rules of management, not only in the economic aspect, but also in the political and social ones as well.

Chapter IV presents the second part of the Indian reforms, that is, the transformation of the state's political system. The essence of these reforms was the creation in 1992 of an obligatory democratic local government at the lowest level of territorial organisation of public administration. In India, there was a local government, however, it did not have a democratic nature, and was a part of an extremely hierarchical organisation of society, based on inequality. The second part of the chapter is devoted to a detailed presentation of the decentralization reform, its legal bases, new structures and institutions, their competences, as well as the practical problems and dilemmas arising from the implementation of democratic governments in Indian villages and towns.

Chapter $\mathrm{V}$ analyses the macroeconomic effects of the Indian economic and state reforms from the early 1990s till 2012. The analysed period spans 20 years, thus a long enough amount of time enabling to identify, measure and evaluate the entire process of modernising the Indian economy. The analysis primarily focuses on the dynamics of basic economic indicators as well as transformations in the structure of the economy. In order to objectify and relativise the Indian economic changes, within the last fragment of the chapter comparisons are made with other large and rapidly growing economies in the world.

In chapter VI the spatial changes in the Indian economy are characterized. Rapid economic development of a country usually carries with it an increase in territorial differences. The scale of these processes is shown in the analysis within the first two subchapters. The third subchapter, on the other hand, attempts to examine the regional disparities in the shaping of the living conditions of the population, treated as a social outcome of the economic and state reforms.

The analyses carried out showed that in the period 1991-2012 a giant leap in economic and social development occurred in India. The source of these successes were the economic and state reforms conducted in 1991-1992. At the beginning 
of the second decade of the $21^{\text {st }}$ century, the Indian economy became - in terms of GDP (according to PPP) - the third largest economy in the world.

The high rates of development of the Indian economy, however, are not distributed evenly across the country. The analyses indicate that western India is developing significantly faster. In contrast, a slower pace of development is seen in the eastern areas of the country, whilst the central part of the subcontinent brings up the rear. This process of splitting up in India cannot be assessed as being a positive attribute. In the long term it will lead to the division of India into two parts: India - A (highly developed) and India - B (underdeveloped).

The result of the rapid development of the Indian economy is the systematic improvement of living conditions for the Indian society, or at least a substantial majority. It is expressed primarily in the positive changes in such important social indicators as: improving the nourishment of the population, decline in infant mortality, increased schooling rate of children and adolescents, and - above all, a significant increase in the life expectancy of the Indian people and a substantial reduction in poverty. 



\section{BIBLIOGRAFIA}

Acharya S., Ahluwalia I.J., Krishna K.L., Patnaik I. [2006], Economic Growth in India, 19502000, [w:] K.S. Parikh (ed.), Explaining Growth in South Asia, Oxford University Press, Delhi.

Adams J. [2001], Culture and Economic Development in South Asia, "The Annals of the American Academy of Political and Social Science", vol. 573, no. 1.

Antahal P.C. [2009], Growing Regional Disparities in Economic Development in India: Implication for Infrastructure Investments, "Madhya Pradesh Journal of Social Sciences", vol. 14, no. 1, www.questia.com (dostęp: 12.03.2012).

Baba K.S. [2009], Articles in Indian Constitution, "The Hindu”, Sunday, March 15, www.hindu. com/op/2009/03/15/stories/2009031550091200.htm (dostęp: 21.07.2014).

Banerjee-Guha S. [2008], Space Relations of Capital and Significance of New Economic Enclaves: SEZs in India, "Economic \& Political Weekly", November 22.

Baran P.A. [1963], Ekonomia polityczna wzrostu, PWE, Warszawa.

Bardhan P. [1997], The Role of Governance in Economic Development. A Political Economy Approach, Development Centre of the Organisation for Economic Co-operation and Development, Paris.

Bardhan P. [2002], Decentralization of Governance and Development, "Journal of Economic Perspectives", vol. 16, no. 4.

Bardhan P. [2010], Awakening Giants. Feet of Clay. Assessing the Economic Rise of China and India, Princeton University Press, Princetown and Oxford.

Bartkowiak R. [2003], Historia myśli ekonomicznej, PWE, Warszawa.

Bartkowiak R. [2013], Ekonomia rozwoju, PWE, Warszawa.

Bąkiewicz A., Żuławska U. [2010], Od teorii wzrostu do ekonomii rozwoju, [w:] A. Bąkiewicz, U. Żuławska (red.), Rozwój w dobie globalizacji, PWE, Warszawa.

Bhagwati J., Panagariya A. [2013], Why Growth Matters. How Economic Growth in India Reduced Poverty and the Lessons for Other Developing Countries, Public Affairs, New York.

Bhat T.P. [2011], Structural Changes in India's Foreign Trade, Institute for Studies in Industrial Development, New Delhi, http://isidev.nic.in/pdf/icssr_tpb.pdf (dostęp: 20.05.2014).

Bhatia H.L. [1999], Public Finance, Vikas Publishing House Pvt. Ltd., New Delhi.

Bhattacharya B.B., Sakthivel S. [2004], Regional Growth and Disparity in India: A Comparison of the Pre- and Post-Reform Decades, "Economic and Political Weekly", vol. 39, no. 10, March 6.

Bhutani S. [2006], Indie, rosnace supermocarstwo?, „Homo Politicus. Rocznik Politologiczny”, t. 1.

Białowąs T. [2013], Zagraniczne inwestycje bezpośrednie jako czynnik wzrostu znaczenia Indii w gospodarce światowej, [w:] G. Wolska (red.), Wspótczesne problemy ekonomiczne. Polityka państwa a proces globalizacji, Uniwersytet Ekonomiczny w Katowicach.

Bijapurkar R. [2012], Consuming classes, [w:] Reforms 2020. Last 20 years, next 20 years, The Express Group, Delhi.

Boivin M. [2011], Indie. Zarys historii, Wydawnictwo Akademickie Dialog, Warszawa.

Bombińska E. [2014], Sytuacja gospodarcza krajów pozaunijnych w latach 2004-2012 a możliwości rozwoju polskiego eksportu, [w:] S. Wydymus, B. Pera (red.), Perspektywy rozwoju polskiego eksportu do krajów unijnych, Difin, Warszawa. 
Bonikowska M. [2014], Indie: krajobraz po wyborach. Inspiracje dla Europy, Centrum Stosunków Międzynarodowych, Raporty i analizy, nr 2, http://csm.org.pl/pl/publikacje1/category/53-2014?download=488:indie-krajobraz-po-wyborach (dostęp: 20.07.2014).

Bose A. [2001], Population of India. 2001 Census Results and Methodology, B.R. Publishing Corporation, New Delhi.

Bossak J.W. [2008], Instytucje, rynki i konkurencja we współczesnym świecie, Oficyna Wydawnicza Szkoła Główna Handlowa, Warszawa.

Brass P.R. [1999], Regionalism, Hindu Nationalism and Party Politics in India's Federal System, [w:] I. Copland, J. Rickard (eds.), Federalism - Comparative Perspectives from India and Australia, Manohar, New Delhi.

Budnikowski A. [2003], Międzynarodowe stosunki gospodarcze, wyd. 2, PWE, Warszawa.

Burange L.G., Yamini S. [2011], A Review of India's Industrial Policy and Performance, University of Mumbai, Department of Economics, Working Paper UDE 34/1, http://archive.mu.ac. in/arts/social_science/eco/pdfs/depart/dwp56.pdf (dostęp: 15.03.2013).

Bywalec G. [2003], Nowa polityka ekonomiczna a wzrost gospodarczy Indii po roku 1991, „Gospodarka Narodowa", nr 7-8.

Bywalec G. [2004], Uwarunkowania rozwoju samorządności wiejskiej w Indiach, „Wieś i Rolnictwo", $\mathrm{nr} 1$.

Bywalec G. [2005], System finansów publicznych Indii na tle reform państwa i gospodarki, „Ekonomista", nr 6.

Bywalec G. [2007], Problemy pomiaru decentralizacji finansów publicznych, „Samorząd Terytorialny", $\mathrm{nr} 12$.

Bywalec G. [2008], Decentralizacja a funkcje finansów publicznych, „Samorząd Terytorialny”, nr 6.

Bywalec G. [2010], Dynamika i determinanty rozwoju gospodarczego Indii, „Ekonomista”, nr 3.

Bywalec G. [2012], Dylematy decentralizacji we wspótczesnym świecie, „Gospodarka Narodowa", nr 11-12.

Bywalec G. [2013], Rozwój regionalny Indii po reformach z lat 1991-1992, „Studia Ekonomiczne", $\mathrm{nr} 4$.

Cauvery R., Sudha Nayak U.K., Girija M., Kruparani N., Meenakshi R. [2000], Public Finance (Fiscal Policy), S. Chand \& Company Ltd., New Delhi.

Census of India 2011. Provisional Population Totals [2011], Paper 1 of 2011. India Series 1, Office of the Register General \& Census Commissioner, India, New Delhi.

Chand S., Sen K. [2002]: Trade Liberalization and Productivity Growth: Evidence from Indian Manufacturing, "Review of Development Economics", vol. 6, no. 1.

Chandra B., Mukherjee A., Mukherjee M. [1999], India after Independence, Viking Penguin India, New Delhi.

Chari V., Pandit N. [2010], Localization Rationale of Special Economic Zones and Its Units in India, "European Journal of Management", vol. 10 (1).

Chaturvedi I. [2011], Role of FDI in Economic Development of India: Sectoral Analysis, International Conference on Technology and Business Management, Jaipuria Institute of Management Studies, Ghaziabad.

Clunies-Ross A., Forsyth D., Huq M. [2009], Development Economics, McGraw-Hill, Higher Education, London.

Crook R.C., Sverrisson A.S. [2001], Decentralisation and Poverty-Alleviation in Developing Countries: A Comparative Analysis or, is West Bengal Unique?, "IDS Working Paper 130", Institute of Development Studies, Brighton.

Das A. [1999], Socio-Economic Development in India: A Regional Analysis, "Development and Society", vol. 28, no. 2, December. 
Das D. [2009], Indie - od Curzona do Nehru i później, Wydawnictwo TRIO, Warszawa.

Datt G., Mahajan A. [2014], Datt \& Sundharan Indian Economy, S. Chand \& Company Pvt. Ltd., New Delhi.

De Ruijter A. [1998], The Purse and Power. Aspects of Centre - State Relations in India, B.R. Publishing Corporation, Delhi.

Decentralisation in India. Challenges \& Opportunities [2000], United Nations Development Programme, New Delhi.

Desai A.R. [1960], Problemy socjologiczne Indii, [w:] Społeczno-ekonomiczne problemy Indii, PWG, Warszawa.

Dev S.M. (ed.), [2013], India Development Report 2012-13, Indira Gandhi Institute of Development Research, Oxford University Press, New Delhi.

Dębnicki K. [2000], Konflikt i przemoc w systemie politycznym niepodległych Indii, Wydawnictwo Akademickie Dialog, Warszawa.

Dobrska Z. [1963], Wybór technik produkcji w krajach gospodarczo zacofanych, PWE, Warszawa.

Domański Cz. (red.), [2001], Metody statystyczne. Teoria i badania, Wydawnictwo Uniwersytetu Łódzkiego, Łódź.

Domański R. [2012], Ewolucyjna gospodarka przestrzenna, Wydawnictwo Uniwersytetu Ekonomicznego w Poznaniu, Poznań.

Drèze J., Sen A. [2013], An Uncertain Glory.India and Its Contradictions, Princeton University Press, Princeton-Oxford.

Dumont L. [2009], Homo hierarchicus. System kastowy i jego implikacje, Zakład Wydawniczy NOMOS, Kraków.

Durth R., Körner H., Michaelowa K. [2002], Neue Entwicklungsökonomik, Lucius \& Lucius UTB, Stuttgart.

Economic Survey 2002-2003 [2003], Government of India. Ministry of Finance, Oxford University Press, New Delhi.

Economic Survey 2009-10 [2010], Government of India. Ministry of Finance, Oxford University Press, New Delhi.

Economic Survey 2010-11 [2011], Government of India. Ministry of Finance, Oxford University Press, New Delhi.

Economic Survey 2011-12 [2012], Government of India. Ministry of Finance, Oxford University Press, New Delhi.

Economic Survey 2013-14 [2014], Government of India. Ministry of Finance, Oxford University Press, New Delhi.

Economic Survey 2012-13. Statistical Appendix [2013], Government of India. Ministry of Finance, Oxford University Press, New Delhi.

Economic Survey 2013-14. Statistical Appendix [2014], Government of India. Ministry of Finance, Oxford University Press, New Delhi.

Economic Survey of Maharashtra 2012-13 [2013], Directorate of Economics \& Statistics, Planning Department, Government of Maharashtra, Mumbai.

Ellinger H. [1997], Hinduizm, Wydawnictwo Znak, Kraków.

Förstmann R., Gregosz D. [2010], Indiens Wirtschaftspolitik und die Notwendigkeiteines ökonomischen Leitbildes, ,KAS-Auslandsinformationen“, Nr 26, www.kas.de/wf/doc/kas_19449544-1-30.pdf?121126083307 (dostęp: 12.02.2014).

Friedman M. [1993], Polityka i tyrania, Heuros, Warszawa.

Gaikwad S.L. [1999], Protective Discrimination Polity and Social Change. An Analytical Study of State Action on Scheduled Castes in Aurangabad City, Rawat Publications, Jaipur and New Delhi. 
Galbraith J.K. [1987], Istota masowego ubóstwa, PWN, Warszawa.

Gandhi M.K. [1958], Autobiografia. Dzieje moich poszukiwań prawdy, Książka i Wiedza, Warszawa.

Garg I., Walia S. [2013], An Analysis of Services Sector in Indian Economy, "International Journal of Research in Economics \& Social Sciences", vol. 3, no. 3.

Gaudemet P.M., Molinier J. [2000], Finanse publiczne, PWE, Warszawa.

Gedam R. [1999], Statistical Profile of India 1999, Deep \& Deep Publication PVT Ltd., New Delhi.

GDP, PPP (current international \$), The World Bank [2014], http://data.worldbank.org/indicator/ NY.GDP.MKTP.PP.CD?page=2 (dostęp: 16.06.2014).

Gerlach T. [1988], Indie w świadomości Indusów, Zakład Narodowy im. Ossolińskich - Wydawnictwo PAN, Wrocław $i$ in.

Ghosal R. [2012], Growth, Poverty and Inequality Paradox in India: A Panel Data Approach, Paper prepared for the 32nd General Conference of The International Association for Research in Income and Wealth, Boston (USA) (wersja pdf: www.iariw.org, dostęp: 23.06.2014).

Ghose A.K. [2011], Informal Employment in India, [w:] M. Mohanty (ed.), India. Social Development Report 2010. The Land Question and the Marginalized, Oxford University Press, New Delhi.

Gleason S. [2001], Female Political Participation and Health in India, "The Annals of the American Academy of Political and Social Science", January, vol. 573, no. 1.

Gosh H.A. [2004], Chattels of Society. Domestic Violence in India, "Violence Against Women", vol. 10, no. 1, January.

Gross Domestic Product 2012, PPP, [w:] World Development Indicators Database, World Bank, 7 May 2014, http://databank.worldbank.org/data/download/GDP_PPP.pdf (dostęp: 16.06.2014).

Gudowski J. [1990], Polityka kształtowania dochodów ludności wiejskiej a wzrost produkcji rolnej w krajach rozwijajacych się (na przyktadzie Indii), Wydawnictwa Uniwersytetu Warszawskiego, Warszawa.

Gudowski J. [1998], Rolnictwo w krajach przechodzacych etap liberalizacji gospodarczej, [w:] J. Gudowski, U. Żuławska (red.), Nowa polityka gospodarczych w krajach przechodzacych proces liberalizacji gospodarczej, Wydawnictwo Akademickie Dialog.

Gutowski A. [2002], Standortqualitäten und ausländische Direktinvestitionen - Ein Vergleich zwischen der VR China und India, Universität Bremen (dysertacja doktorska, wersja pdf, dostęp: 12.05.2014).

Gupta A.R. [1984], Caste Hierarchy and Social Change. A Study of Myth and Reality, Jyotsna Prakashan, New Delhi.

Handbook of Statistics on the Indian Economy 2007-08 [2008], Reserve Bank of India, Mumbai, https://rbidocs.rbi.org.in/rdocs/Publications/PDFs/87380.pdf (dostęp: 24.11.2012).

Handbook of Statistics on the Indian Economy 2012-13 [2013], Reserve Bank of India, Mumbai, https://rbidocs.rbi.org.in/rdocs/Publications/PDFs/FHB160913FLS.pdf (dostęp: 27.02.2014).

Hasan Z. [1999], Region and Nation in India's Political Transition, [w:] I. Copland, J. Rickard (eds.), Federalism - Comparative Perspectives from India and Australia, Manohar, New Delhi.

Iimi A. [2005], Decentralization and Economic Growth Revisited: an Empirical Note, "Journal of Urban Economics", vol. 57, no. 3.

India Country Report 2013. Statistical Appraisal [2013], Central Statistics Office. Ministry of Statistics and Programme Implementation. Government of India, New Delhi (wersja pdf, dostęp: 10.05.2014). 
India 2003. Observer Statistical Handbook [2003], Rupa and Co., New Delhi.

Indian Public Finance Statistics 1999-2000 [2000], Ministry of Finance-Department of Economic Affairs-Economic Division, Delhi.

Indian Public Finance Statistics 2001-2002 [2002], Ministry of Finance-Department of Economic Affairs-Economic Division, Delhi.

Indian Public Finance Statistics 2004-2005 [2005], Ministry of Finance-Department of Economic Affairs-Economic Division, Delhi.

Indian Public Finance Statistics 2007-2008 [2008], Ministry of Finance-Department of Economic Affairs-Economic Division, Delhi.

Indian Public Finance Statistics 2011-2012 [2012], Ministry of Finance-Department of Economic Affairs-Economic Division, Delhi.

Iwanek K., Burakowski A. [2013], Indie. Od kolonii do mocarstwa 1857-2013, Wydawnictwo Naukowe PWN, Warszawa.

Jawaid S.T., Raza S.A. [2012], Effects of Terms of Trade and its Volatility on Economic Growth in India, http://mpra.ub.uni-muenchen.de/38998/, MPRA Paper no. 38998 (dostęp: 26.05.2014).

Isard W. [1965], Metody analizy regionalnej. Wprowadzenie do nauki o regionach, PWN, Warszawa.

Jabłoński Ł. [2008], Ewolucja poglądów na temat konwergencji w ekonomii rozwoju, „Gospodarka Narodowa", nr 5-6.

Jabłoński Ł. [2011], Modernizacja ekonomiczna w ekonomii rozwoju, „Zeszyty Naukowe Uniwersytetu Ekonomicznego w Krakowie", nr 859.

Joshi R.P., Narwani G.S. [2002], Panchayat Raj in India. Emerging Trends Across the States, Rawat Publications, Jaipur and New Delhi.

Jütting J., Kauffmann C., McDonnell I., Osterrieder H., Pinaud N., Wegner L. [2004], Decentralisation and Poverty Reduction in Developing Countries: Exploring the Impact, OECD, Development Centre Working Paper, no. 236, OECD, Paris.

Kalecki M. [1960], Uwagi o problemach finansowych trzeciego planu pięcioletniego $w$ Indiach, „Ekonomista”, nr 6.

Kalmar G. [1989], Indira Gandhi, KiW, Warszawa.

Kannan E., Sundaram S. [2011], Analysis of Trends in India's Agricultural Growth, "Working Paper 276", The Institute for Social and Economic Change, Bangalore.

Kapila U. [2005], Indian Economy. Issues in Development \& Planning and SectoralAspects, $4^{\text {th }}$ ed., Academic Foundation, New Delhi.

Kapp K.W. [1963], Hindu Culture, Economic Development and Economic Planning in India. A Collection of Essays, Asia Publishing House, Bombay.

Kar S., Sakthivel S. [2006], Regional Divergence in India during the Era of Liberalization: A Sectoral Decomposition, "The Journal of Developing Areas", vol. 40, no. 1, www.questia.com (dostęp: 24.08.2013).

Kashyap S.C. [2008], Our Political System, National Book Trust, India, New Delhi.

Khan A. [1998], Regional Political Parties - Federal Experiences in Indian Polity, [w:] A.P. Vijapur (ed.), Dimensions of Federal Nation Building, CFS JHU - Manak Publications (P) Ltd., New Delhi.

Kinnvall C. [2002], Nationalism, Religion and the Search for Chosen Traumas. Comparing Sikh and Hindu Identity Constructions, "Ethnicities", vol. 2, no. 1.

Klamut M. [2006], Wzrost i rozwój gospodarczy. Czynniki wzrostu, [w:] B. Winiarski (red.), Polityka gospodarcza, wyd. 3, Wydawnictwo Naukowe PWN, Warszawa.

Kleer J. [1962], Zapoczątkowanie rozwoju ekonomicznego we współczesnych krajach słabo rozwiniętych, PWN, Warszawa. 
Klincewicz K. [2008], Indyjski model offshoringu. Wnioski dla Polski, [w:] A. Szymaniak (red.), Globalizacja ustug. Outsourcing, offshoring i shared services centers, Wydawnictwa Akademickie i Profesjonalne, Warszawa.

Kohli A. [2012], Poverty Amid Plenty in the New India, Cambridge University Press India Pvt. Ltd., New Delhi.

Kohli A., Mullen R.D. [2003], Democracy, Growth and Poverty in India, [w:] A. Kohli, R.D. Mullen, G. Sørensen (eds.), States, Markets and just Growth: Development in the Twenty-First Century, United Nations University Press, New York, www.questia.com (dostęp: 23.09.2013).

Konstytucja Republiki Indii [1976], Zakład Narodowy im Ossolińskich - Wydawnictwo PAN, Wrocław-Warszawa-Kraków-Gdańsk.

Kozak Z. [2001], Ekonomia zacofania i rozwoju, Oficyna Wydawnicza Szkoły Głównej Handlowej, Warszawa.

Krugman P.R., Obstfeld M. [2007], Ekonomia międzynarodowa. Teoria i polityka, Wydawnictwo Naukowe PWN, Warszawa.

Kumar D., Jain V. [2013], Impact of Foreign Direct Investment on India's GDP, "International Journal of Research in Economics \& Social Sciences", December, vol. 3, no. 12.

Kurien C.T. [1969], Indian Economic Crisis. A Diagnostic Study, Asia Publishing House, London.

Kwiatkowski E. [2005], Wzrost gospodarczy, [w:] R. Milewski, E. Kwiatkowski (red.), Podstawy ekonomii, Wydawnictwo Naukowe PWN, Warszawa.

Lange O. [1961], Uwagi o drugim planie pięcioletnim Indii, [w:] O. Lange, Pisma ekonomiczne i społeczne, PWN, Warszawa.

Levien M. [2011], Special Economic Zones and Accumulation by Dispossession in India, "Journal of Agrarian Change", October, vol. 11, no. 4.

Liberska B. [2008], Globalizacja a offshoring ustug sektora IT, [w:] A. Szymaniak (red.), Globalizacja ustug. Outsourcing, offshoring i shared services centers, Wydawnictwa Akademickie i Profesjonalne, Warszawa.

Liberska B. [2013], Nowe centra wzrostu światowej gospodarki, „Studia Ekonomiczne”, nr 2.

Maheshwari S.R. [2003], Administration of India, Macmillan India Ltd., Delhi-Visakhapatnam.

Majumdar S.K. [2012], India's Late, Late Industrial Revolution. Democratizing Entrepreneurship, Cambridge University Press, Cambridge-New York.

Malaviya H.D. [1956], Village Panchayats in India, Economic and Political Research Department, All India Congress Committee, New Delhi.

Mallick J. [2011], Determinants of Private Investment in Indian States: An Applicationof Panel Fixed Effect Model, "Political Journal of Economics and Business", vol. 10, no. 1, www. questia.com.

Mallik J.K., Kathuria M. [2012], Issues in Services Sector. A Case Study of Delhi, [w:] D. Mohanty (ed.), Regional Economy of India. Growth and Finance, Academic Foundation in Association with Reserve Bank of India, Delhi-Mumbai.

Mallikarjun B. [2001], Languages of India According to the 1991 Census, www.languageinindia. com/nov2001/1991Languages.html (dostęp: 2.05.2004).

Manor J. [2006], Renewing the Debate on Decentralisation, "Commonwealth and Comparative Politics", vol. 44, no. 3.

Manpower Profile India Yearbook [2008], Institute of Applied Manpower Research, New Delhi.

Matera R. [2014], Studia nad bogactwem i ubóstwem narodów na przełomie mileniów - wkład Darona Acemoglu i Jamesa A. Robinsona, „Ruch Prawniczy, Ekonomiczny i Socjologiczny", nr 1. 
Mathew G. [2000], Panchayati Raj in India - An Overview, [w:] G. Mathew \& N. Buch (eds.), Status of Panchayati Raj in the States and Union Territories of India, Institute of Social Sciences, Concept Publishing Company, New Delhi.

Mathur O.P. [2000], State-Local Fiscal Relations, [w:] D.K. Srivastava (ed.), Fiscal Federalism in India. Contemporary Challenges, Har - Anand Publications Pvt. Ltd., New Delhi.

Mehrotra S., Gandhi A., Sahoo B.K. [2012], Organised and Unorganised Employment in the Nonagriculture Sectors in the 2000s, Institute of Applied Manpower Research, Planning Commission, Government of India, Occasional Paper, no. 6, New Delhi.

Meier G.M. [1971], Leading Issues in Economic Development. Studies in International Poverty, $2^{\text {nd }}$ ed., Oxford University Press, Singapore.

Meier G.M. [2001], The Old Generation of Development Economists and the New, [w:] G.M. Meier, J.E. Stiglitz (eds.), Frontiers of Development Economics. The Future in Perspective, The World Bank and Oxford University Press, New York-Washington, D.C.

Meredith R. [2009], Chiny i Indie. Supermocarstwa XXI wieku, Media Lazar-Nadir, Warszawa.

Michałowski T. [2013], Międzynarodowe przepływy kapitałowe we współczesnej gospodarce światowej, [w:] E. Oziewicz, T. Michałowski (red.), Międzynarodowe stosunki gospodarcze, PWE, Warszawa.

Minkner K. (współpraca Czywilis D.) [2010], Rozwój czy niedorozwój demokracji w Indiach? Rozwiąania instytucjonalne a otoczenie spoteczno-kulturowe, [w:] K. Górak-Sosnowska, J. Jurewicz (red.), Kulturowe uwarunkowania rozwoju w Azji i Afryce, Ibidem, Łódź.

Mishan E.J. [1986], Spór o wzrost gospodarczy, PIW, Warszawa.

Mishra S. [2001], Institutional Mechanism for People's Participation at the Local Level, [w:] R.K. Arora (ed.), People - Centered Governance, Essays in Honour of Professor K. D. Trivedi, Aalekh Publishers, Jaipur.

Mohanty M. (ed.), [2011], India Social Development Report 2010. The Land Questions and the Marginalized, Oxford University Press, New Delhi.

Mohanty S.D. [2011], Indian Economy: Progress and Prospects, www.rbi.org.in/scripts/BS SpeechesView.aspx?Id=603 (dostęp: 15.08.2013).

Mrozek B. [1971], Indie wspótczesne, Wiedza Powszechna, Warszawa.

Mrozek B. [1974], Nehru, Książka i Wiedza, Warszawa.

Mrozek B. [1976], Indie - Pakistan - Bangladesz, PWN, Warszawa.

Mukherjee A. [2001], Resource Mobilisation: Dependency of the Panchayats, [w:] A. Pinto, H. Reifeld (eds.), Women in Panchayati Raj, Indian Social Institute, New Delhi.

Mukherjee R. (ed.), [2007], Great Speeches of Modern India, Random House India, New Delhi.

Mukim M., Nunnenkamp P. [2012], The Location of Foreign Investors: A District-levelAnalysis in India, "The World Economy", July, vol. 35, no. 7.

Müller H., Rauch C. [2008], Indiens Weg zur Wirtschaftsmacht, Bundeszentrale für politische Bildung/Aus Politik und Zeitgeschichte (APUZ 22/2008), www.bpb.de/apuz/31199/indiens-weg-zur-wirtschaftsmacht (dostęp: 23.01.2014).

Myrdal G. [1958], Teoria ekonomii a kraje gospodarczo nierozwinięte, PWG, Warszawa.

Myrdal G. [1968], Asian Drama. An Inquiry into the Poverty of Nations, vol. 2, Panteon. A Division of Random House, New York.

Myrdal G. [1975], Przeciw nędzy na świecie, PIW, Warszawa.

Nawrot K.A. [2014], Kraje rozwijające się we współczesnej gospodarce światowej, Wydawnictwo Naukowe Scholar, Warszawa.

Nehru J. [1957], Odkrycie Indii, Czytelnik, Warszawa.

Nowak S. [2012], Metodologia badań społecznych, Wydawnictwo Naukowe PWN, Warszawa. 
Nurkse R. [1962], Problemy tworzenia kapitału w krajach gospodarczo słabo rozwiniętych, PWN, Warszawa.

Oommen M.A., Datta A. [1995], Panchayats and their Finance, Institute of Social Sciences \& Concept Publishing Company, New Delhi.

Panda M. [2013], Macroeconomic Overview. The Growth Story, [w:] S.M. Dev (ed.), India Development Report 2012-13, Indira Gandhi Institute of Development Research, Oxford University Press, New Delhi.

Payne A., Phillips N. [2011], Rozwój, Wydawnictwo Sic!, Warszawa.

Paz O. [1997], Podpatrywanie Indii, Wydawnictwo Literackie, Kraków.

Panikkar K.M. [1967], Dzieje Indii, PWN, Warszawa.

Pęciak R. [2013], Korupcja jak przejaw crony capitalism na przykładzie wybranych gospodarek azjatyckich, [w:] G. Wolska (red.), Wspótczesne problemy ekonomiczne. Polityka państwa a proces globalizacji, Uniwersytet Ekonomiczny w Katowicach.

Piasecki R. [2003a], Rozwój gospodarczy a globalizacja. Ekonomia rozwoju w zderzeniu z rzeczywistościa, PWE, Warszawa.

Piasecki R. [2003b], Ewolucja ekonomii rozwoju a globalizacja, „Ekonomista”, nr 2.

Piasecki R. [2007], Ewolucja teorii rozwoju gospodarczego krajów biednych, [w:] R. Piasecki (red.), Ekonomia rozwoju, PWE, Warszawa.

Pleśniak E. [2008], Ustugi outsourcingowe w Indiach, [w:] B. Drelich-Skulska (red.), Procesy integracyjne w regionie Azji i Pacyfiku, Wydawnictwo Uniwersytetu Ekonomicznego we Wrocławiu, Wrocław.

Prasad K.N. [1993], Indian Economy since 1951: Growth with Imbalances, Intellectual Publishing House, New Delhi.

Prasad R., Ray R.S. [2010], Special Economic Zones in India: Following Well Trodden Paths, "Indian Journal of Economics and Business", vol. 9, no. 3, www.questia.com (dostęp: 16.01.2014).

Press Note on Poverty Estimates, 2009-10, Government of India, Planning Commission, March 2012, http://planningcommission.nic.in/news (dostęp: 13.01.2013).

Prud'homme R. [1994], On the Dangers of Decentralization, Policy Research Working Paper 1252, The World Bank, Washington, D.C.

Rai M., Nambiar M., Paul S., Singh S.U., Sahni S.S. [2001], The State of Panchayats. A Participatory Perspective, Samskriti, New Delhi.

Rajan S.I. [2013], Internal Migration and Youth in India: Main Features, Trends and Emerging Challenges, Discussion Paper, UNESCO, New Delhi, http://unesdoc.unesco.org/images/0022/002214/221487e.pdf (dostęp: 26.06.2014).

Ramachandran P. [2013], Public Administration in India, National Book Trust, India, New Delhi.

Rao Ch.A.K., Sarojini M. [1998], State - Local Transfers: A Suggested Approach, [w:] State Local Fiscal Relations in India, Manohar Publishers, New Delhi.

Reddy B.S. [2013], Access to Modern Energy Services. The Road Not Taken, [w:] S.M. Dev (ed.), India Development Report 2012-13, Indira Gandhi Institute of Development Research, Oxford University Press, New Delhi.

Report of the Eleventh Finance Commission for 2000-2005 [2000], Akalank Publications, New Delhi.

Rocznik Demograficzny 2013 [2013], Główny Urząd Statystyczny, Warszawa

Rocznik Statystyczny Rzeczypospolitej Polskiej 1999 [1999], Główny Urząd Statystyczny, Warszawa. Rocznik Statystyczny Rzeczypospolitej Polskiej 2000 [2000], Główny Urząd Statystyczny, Warszawa. Rocznik Statystyczny Rzeczypospolitej Polskiej 2012 [2012], Główny Urząd Statystyczny, Warszawa. Rothermund D. [2008], Indie. Nowa azjatycka potęga, Dialog, Warszawa. 
Rosenstein-Rodan P.N. [1943], Problems of Industrialisation of Eastern and South-Eastern Europea, "The Economic Journal", vol. 53, no. 210/211, www.nyu.edu/econ/user/debraj/Courses/Readings/RosensteinRodan.pdf (dostęp: 5.04.2015).

Rosenstein-Rodan P.N. [1959], Uwagi o teorii wielkiego pchnięcia, „Ekonomista”, nr 2.

Rosset E. [1979], Granice starzenia się społeczeństw, „Kultura i Społeczeństwo”, nr 3.

Rostow W.W. [1959], The Stages of Economic Growth, "The Economic History Review”, vol. 12, no. 1 www.ufjf.br/oliveira_junior/files/2009/06/rostow.pdf (dostęp: 7.04.2015].

Rozłucki W. [1980], „Zielona rewolucja” w Indiach; bilans dziesięciolecia, [w:] E. Szymański (red.), Problemy spoleczno-gospodarcze i kulturowe krajów pozaeuropejskich, t. 1, PWN, Warszawa.

Rudowicz B. [1973], Kapitalizm państwowy w krajach gospodarczo mniej rozwiniętych - ze szczególnym uwzględnieniem Indii, PWN, Warszawa.

Rürup L.B. [1999], Fallbeispiel: Indien, [w:] P. Hengstenberg (Red.), Dezentralisierung und kommunale Selbstverwaltung: zur kommunalpolitischen Projektarbeit der Friedrich Ebert-Stiftung in Afrika, Asien, Lateinamerika, Friedrich Ebert-Stiftung, Bonn, www.fes.de/fulltext/ iez/00650006a.htm (dostęp: 15.12.2013).

Rybarski A. [1968], Kryteria wyboru technik w krajach słabo rozwiniętych, PWE, Warszawa.

Rynarzewski T. [2003], Cto wychowawcze $i$ clo optymalne $w$ teorii i praktyce polityki handlu międzynarodowego, „Ruch Prawniczy, Ekonomiczny i Socjologiczny”, z. 1.

Rynarzewski. T. [2006], Teoria polityki handlu międzynarodowego, [w:] T. Rynarzewski, A. Zielińska-Głębocka, Międzynarodowe stosunki gospodarcze. Teoria wymiany i polityki handlu międzynarodowego, Wydawnictwo Naukowe PWN, Warszawa.

Sachdeva P. [2011], Local Government in India, Dorling Kindersley (India) Pvt. Ltd., Licensees of Pearson Education in South Asia, Delhi.

Sachs I. [1959], Problemy rozwoju gospodarczego krajów słabo rozwiniętych, „Ekonomista”, nr 2.

Sachs I. [1961], Sektor państwowy a rozwój gospodarczy, PWE, Warszawa.

Sachs I. [1964], Drogi i manowce Świata „B”, PWN, Warszawa.

Satyanarayanan S. [2004], Muslims Register Higher Growth Rate, "The Tribune - Online Edition", September 7.

Schneider B. [1989], Rewolucja bosych. Raport dla Klubu Rzymskiego, PWE, Warszawa.

Schöttli J., Pauli M. [2011], Indien zwischen Subsistenzwirtschaft und Weltmarktführung, www. sai.uni-heidelberg.de/sapol/forschung/jm.pdf (dostęp: 14.04.2014).

Schumacher E.F. [1981], Małe jest piękne. Spojrzenie na gospodarkę świata z założeniem, że człowiek coś znaczy, PIW, Warszawa.

Selected Socio-Economic Statistics India [2011], Government of India. Ministry of Statistics and Programme Implementation Central Statistics Office. Social Statistics Division, New Delhi.

Sharma S. [1994], Grass Root Politics and Panchayati Raj, Deep \& Deep Publications, New Delhi.

Sen A. [2000], Nierówności. Dalsze rozważania, Społeczny Instytut Wydawniczy Znak - Kraków, Fundacja im. Stefana Batorego - Warszawa.

Sen A. [2008], The Concept of Development, [w:] Ch.B. Barret (ed.), Development Economics. Critical Concepts in Development Studies, vol. 1, Routlegde. Taylor and Francis Group, London-New York.

Singh D.B. [1966], Economics of Development. With Special Reference to India, Asia Publishing House, London.

Skulska B. [2012], Regionalizm ekonomiczny Azji Wschodniej. Jedno spojrzenie - różne wymiary, Wydawnictwo Uniwersytetu Ekonomicznego we Wrocławiu, Wrocław.

Skulska B. [2013], Narodowy system innowacji w Indiach na tle rozwoju gospodarczego kraju na przełomie XX i XXI wieku, „Zeszyty Naukowe Uniwersytetu Szczecińskiego”, nr 756. 
Social Inclusion of Internal Migrants in India [2013], UNESCO, New Delhi, http://unesdoc.unesco.org/images/0022/002237/223702e.pdf (dostęp: 22.06.2014).

Solarz M.W. [2009], Trzeci Świat. Zarys biografii pojęcia, Wydawnictwo Uniwersytetu Warszawskiego, Warszawa.

Solski R. [1989], Niepokoje pod Himalajami, KAW, Warszawa.

Stankiewicz W. [1998], Historia myśli ekonomicznej, PWE, Warszawa.

Stańczyk Z.J. [2004], Konsensus waszyngtoński a reformy w krajach postkomunistycznych, „Zeszyty Naukowe", nr 2, PTE, Kraków.

States Census 2011 [2011], www.census2011.co.in/states.php (dostęp: 14.10.2013).

Statistical Outline of India 1999-2000 [1999], Tata Services Limited - Department of Economics and Statistics, Mumbai.

Stiglitz J.E. [2004], Globalizacja, Wydawnictwo Naukowe PWN, Warszawa.

Sury M.M. (ed.), [2003], India: Central Government Budgets 1947/48-2003/2004, New Century Publications, New Delhi.

Świerkocki J. [2004], Zarys międzynarodowych stosunków gospodarczych, PWE, Warszawa.

Tandon S. [2012], Economic reform, voting, and local political intervention: Evidence from India, "Journal of Development Economics", March, vol. 97, no. 2.

Telep J. [2010], Elementy ekonomii rozwoju, Wydawnictwo Wyższej Szkoły Cła i Logistyki, Warszawa.

Tendulkar S.D., Bhavani T.A. [2007], Understanding Reforms. Post 1991 India, Oxford University Press, New Delhi.

The Constitution of India [2000], Akalank Publications, New Delhi.

The Constitution of India [2007], http://lawmin.nic.in/coi/coiason29july08.pdf (dostęp: 23.07.2014).

The Constitution (Amendment) Acts [2013], http://indiacode.nic.in/coiweb/coifiles/amendment. htm (dostęp: 21.07.2014).

The Local Government System in India [2004], [w:] The Commonwealth Local Government Handbook 2004, Commonwealth Business Publications Ltd., London.

Tokarski S. [2006], Nowoczesne Indie. Wyzwania XXI wieku, „Homo Politicus. Rocznik Politologiczny", t. 1.

Tokarski S. [2011], Grupy etniczne i mniejszości religijne w Indiach. Jedność wielości w konflikcie $i$ wspótpracy, „Krakowskie Studia Międzynarodowe”, nr 1.

Tokarski S., Bhutani S. [2007], Nowoczesne Indie. Wyzwania rozwoju, Prace Monograficzne Zakładu Krajów Pozaeuropejskich Polskiej Akademii Nauk, Wydawnictwo Naukowe ASKON, Warszawa.

UNCTADstat (Inward and outward foreign direct investment flows, annual, 1970-2012), http:// unctadstat.unctad.org/TableViewer/tableView.aspx?ReportId (dostęp: 30.03.2014).

UNCTADstat (Nominal and real GDP, total and per capita, annual, 1970-2012), http://unctadstat. unctad.org/TableViewer/tableView.aspx (dostęp: 9.06.2014).

UNCTADstat (Real GDP growth rates, total and per capita, annual, 1970-2012), http://unctadstat.unctad.org/TableViewer/tableView.aspx?ReportId=109 (dostęp: 28.05.2014).

Williamson J. [1990], What Washington Means by Policy Reform, [w:] J. Williamson (ed.), Latin American Adjustment: How Much Has Happened?, Institute for International Economics, Washington.

Wolpert S. [2010], Nowa historia Indii, Książka i Wiedza, Warszawa.

Wosińska W. [2008], Oblicza globalizacji, Smak Słowa, Sopot.

Wróbel A. [2013], Rola sektora ustug w tworzeniu gospodarki opartej na wiedzy w Indiach, „Prace Komisji Geografii Przemysłu Polskiego Towarzystwa Geograficznego”, nr 21. 
Zadroga A. [2012], Wspótczesna ekonomia w poszukiwaniu paradygmatu rozwoju gospodarczo-spolecznego, „Roczniki Ekonomii i Zarządzania”, t. 4 (40).

Zajączkowski J. [2007], Wewnętrzne i międzynarodowe uwarunkowania polityki zagranicznej i bezpieczeństwa wspótczesnych Indii, „Homo Politicus. Rocznik Politologiczny”, t. 1 (2).

Zajączkowski J. [2012], Indie - studium przypadku geoekonomicznego działania mocarstwa wschodzacego, [w:] E. Haliżak (red.), Geoekonomia, Wydawnictwo Naukowe Scholar, Warszawa. 



\section{SPIS TABEL I RYSUNKÓW}

\section{Tabele}

2.1. Liczba oraz dynamika i struktura ludności Indii w latach 1971-1991 według spisów

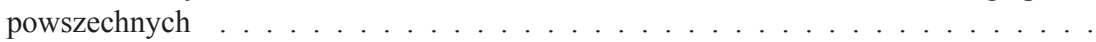

2.2. Stopa urodzeń i zgonów oraz przyrost naturalny w latach 1951-1991, na 1 tys. mieszkańców (rocznie) . . . . . . . . . . . . . . . . . . . . . 62

2.3. Przeciętne dalsze trwanie życia ludności $\left(\mathrm{e}^{\mathrm{o}}-\mathrm{w}\right.$ latach) w okresie 1951-1991 . . . . . 62

2.4. Zróżnicowanie przeciętnego dalszego trwania życia ludności (e $\mathrm{e}^{\mathrm{o}} \mathrm{w}$ latach) pomiędzy miastem a wsią w okresie $1981-1991 \ldots \ldots$. . . . . . . . . . . . .

2.5. Stopa alfabetyzacji społeczeństwa w latach $1951-1991 \ldots$. . . . . . . . . . . . .

2.6. Przestrzenne zróżnicowanie wybranych wskaźników rozwoju społeczno-kulturowego na początku lat $90 . \mathrm{XX}$ wieku . . . . . . . . . . . . . . . . . . . .

2.7. Struktura ludności według języków wyszczególnionych w VIII załączniku do konstytucji w 1991 roku . . . . . . . . . . . . . . . . . . . . . . . . . .

2.8. Struktura ludności według wyznań religijnych według spisów powszechnych . . . . .

2.9. Tempo wzrostu produktu krajowego netto (PKN) Indii w latach 1951-1990 . . . . . .

2.10. Tempo wzrostu PKB Indii w podziale na sektory . . . . . . . . . . . . . . . . .

2.11. Struktura wytwarzania PKB Indii według sektorów . . . . . . . . . . . . . . . . . . 86

2.12. Wskaźniki ubóstwa ludności Indii _ . . . . . . . . . . . . . . . . . . . 88

2.13. Wybrane wskaźniki zróżnicowania regionalnego indyjskiej gospodarki . . . . . . . . 91

2.14. Dynamika PKB Indii na tle innych krajów Azji, rok $1950=100,0 \ldots \ldots$. . . . . . . . . 94

4.1. Struktura kompetencji administracji publicznej w Indiach . . . . . . . . . . . . . . 152

4.2. Kompetencje do nakładania i pobierania podatków lokalnych przez samorządy wiejskie po przyjęciu Conformity Acts (zgodnie z poprawką do konstytucji nr 73) . . . . . . . . 158

5.1. Wzrost gospodarczy Indii - przyrosty produktu krajowego brutto/netto (PKB/PKN) . . 171

5.2. Struktura wytwarzania PKB Indii według sektorów gospodarki . . . . . . . . . . . . 174

5.3. Struktura zatrudnienia w Indiach według sektorów gospodarki . . . . . . . . . . . . . 174

5.4. Dynamika PKB Indii według sektorów jego wytwarzania . . . . . . . . . . . . . 176

5.5. Struktura produkcji przemysłowej (industrial production) Indii według branż (grup produktowych) . . . . . . . . . . . . . . . . . . . .

5.6. Dynamika rozwoju sektora usług w Indiach według jego segmentów (rok 1993/94

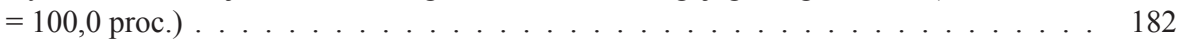

5.7. Bezpośrednie inwestycje zagraniczne w Indiach . . . . . . . . . . . . . . . . 185

5.8. Wybrane wskaźniki rozwoju handlu zagranicznego Indii ． . . . . . . . . . . . . 187

5.9. Struktura eksportu towarowego Indii według grup produktów . . . . . . . . . . . . 190

5.10. Struktura importu towarowego Indii według grup produktów . . . . . . . . . . . . . . 191

5.11. Podstawowe wskaźniki rozwoju eksportu indyjskich usług . . . . . . . . . . . . . . 192

5.12. Główne „tradycyjne” produkty eksportowe Indii i ich udział w światowym eksporcie . 193

5.13. Zatrudnienie formalne w gospodarce zorganizowanej (organised sector) według sektorów własnościowych . . . . . . . . . . . . . . . . . . . . . 196

5.14. Zatrudnienie formalne w gospodarce zorganizowanej (organised sector) według działów (łącznie sektor publiczny i sektor prywatny) . . . . . . . . . . . . . 
5.15. Zatrudnienie formalne w gospodarce zorganizowanej (organised sector) według płci . . 199

5.16. Tempo wzrostu PKB Indii na tle wybranych grup krajów . . . . . . . . . . . . . . . 202

5.17. Tempo wzrostu PKB Indii na tle wybranych krajów . . . . . . . . . . . . . . . . . 204

5.18. Udział Indii i wybranych krajów w PKB świata . . . . . . . . . . . . . . . . 206

5.19. Największe gospodarki świata według wielkości PKB (PPP) . . . . . . . . . . . . . 208

6.1. Dynamika produktu społecznego netto stanów (Net State Domestic Product - NSDP) w latach 1993/94-2011/12 . . . . . . . . . . . . . . . . . . . . . . . . . .

6.2. Korelacja pomiędzy wielkością produktu społecznego netto stanów - globalnie i per capita (NSDP i NSDP per capita) w roku 1993/94 roku a wskaźnikami dynamiki ich wzrostu w latach 1993/94-2010/11 . . . . . . . . . . . . . . . . . . . . . . . 217

6.3. Struktura wytwarzania produktu stanowego netto (NSDP) według sektorów gospodarki . . 219

6.4. Najszybciej i najwolniej rozwijające się gospodarczo stany Indii . . . . . . . . . . . . 220

6.5. Struktura wytwarzania produktu krajowego netto według stanów . . . . . . . . . . . . 225

6.6. Współczynniki lokalizacji Florence’a produktu społecznego netto stanów w latach 1995/96-2010/11 . . . . . . . . . . . . . . . . . . 227

6.7. Powierzchnia, ludność oraz produkt krajowy netto Indii według makroregionów _ . . 228

6.8. Dynamika produktu społecznego netto per capita stanów (Per Capita Net State Domestic Product) w latach 1993/94-2011/2012 (ceny stałe) . . . . . . . . . . . . . . . . 230

6.9. Stany o najwyższej i najniższej dynamice wzrostu produktu stanowego netto per capita . . 233

6.10. Zróżnicowanie poziomu rozwoju gospodarczego stanów (produktu stanowego netto per capita) według stanów i terytoriów Indii . . . . . . . . . . . . . . . . . . . 235

6.11. Stany o najwyższym i najniższym poziomie rozwoju gospodarczego . . . . . . . . . 236

6.12. Wskaźniki zmienności przestrzennej poziomu rozwoju gospodarczego stanów (produktu stanowego netto per capita $) \ldots \ldots \ldots$. . . . . . . . . . . . 237

6.13. Wskaźniki wydajności gospodarczej makroregionów Indii ． . . . . . . . . . . . . 238

6.14. Powierzchnia oraz ludność stanów i terytoriów unijnych . . . . . . . . . . . . . 241

6.15. Ruch naturalny ludności Indii . . . . . . . . . . . . . . . . . . . . . . 244

6.16. Współczynnik umieralności niemowląt według stanów (na 1000 urodzeń żywych) . . 246

6.17. Długość dróg według kategorii . . . . . . . . . . . . . . . . . . . . . . . . . 249

6.18. Odsetek gospodarstw domowych mających bezpośredni dostęp do wody pitnej . . . . 250

6.19. Stopień elektryfikacji gospodarstw domowych . . . . . . . . . . . . . . . . . 251

6.20.Zużycie prądu elektrycznego oraz stopień elektryfikacji gospodarstw domowych w 2010 roku według stanów . . . . . . . . . . . . . . . . . . . . . . 252

6.21. Wydatki konsumpcyjne gospodarstw domowych . . . . . . . . . . . . . . . 255

6.22. Struktura rzeczowa wydatków konsumpcyjnych gospodarstw domowych . . . . . . . 255

6.23. Przeciętne wydatki gospodarstw domowych oraz próg ubóstwa w 2009/10 roku . . . . 256

6.24. Współczynnik Giniego wydatków konsumpcyjnych, miesięcznie na 1 osobę (w ujęciu

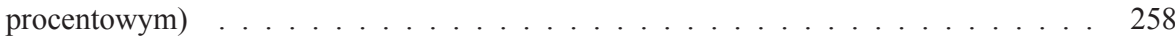

6.25. Współczynnik alfabetyzacji społeczeństwa według stanów i płci . . . . . . . . . . . 260

6.26. Liczba studentów w Indiach - globalnie i na 1 tys. mieszkańców . . . . . . . . . . . . 261

6.27. Przeciętne trwanie życia ludności $\left(\mathrm{e}^{\circ}-\mathrm{w}\right.$ latach $)$ - wielkości średnie dla podanych okresów . . . . . . . . . . . . . . . . . . . . . . 262

6.28. Stopa ubóstwa - odsetek ludności żyjącej poniżej progu (linii) ubóstwa . . . . . . . . 266

6.29. Wskaźniki zmienności przestrzennej stopy ubóstwa w latach 1993/94-2009/10 według

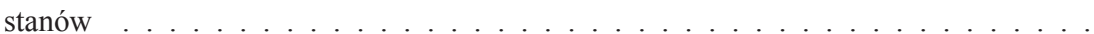




\section{Rysunki}

1.1. Schemat błędnego koła ubóstwa R. Nurksego . . . . . . . . . . . . . . . . . . . . . 21

2.1. Organizacja władzy publicznej w Indiach na szczeblu federalnym i stanowym . . . . . 45

4.1. Organizacja lokalnego szczebla administracji publicznej w Indiach . . . . . . . . . . . 146 



\section{OD REDAKCJI}

Grzegorz Bywalec studiował w latach 1994-2000 finanse i bankowość na Wydziale Ekonomiczno-Socjologicznym Uniwersytetu Łódzkiego. Następnie na tym samym Wydziale odbył studia doktoranckie z zakresu finansów. W marcu 2007 roku uzyskał stopień doktora nauk ekonomicznych na podstawie pracy Determinanty decentralizacji finansów publicznych Indii (promotor prof. dr hab. Krystyna Kietlińska). W roku akademickim 2007/2008 pracował w Społecznej Wyższej Szkole Przedsiębiorczości i Zarządzania w Lodzi (od 2011 roku - Akademia Nauk Społecznych). Od października 2008 roku jest zatrudniony na stanowisku adiunkta w Zakładzie Azji Wschodniej na Wydziale Studiów Międzynarodowych i Politologicznych Uniwersytetu Łódzkiego.

Zainteresowania badawcze autora koncentrują się na zagadnieniach gospodarki Indii, ze szczególnym uwzględnieniem przemian w tej dziedzinie po wielkich reformach w latach 1991-1992. Efektem pracy badawczej jest kilkanaście artykułów naukowych i rozdziałów w pracach zbiorowych. Dotyczą one ustroju terytorialnego i rozwoju gospodarczo-społecznego Indii. Publikował je m.in. w „Ekonomiście”, „Gospodarce Narodowej”, „Samorządzie Terytorialnym”, „Studiach Ekonomicznych”, „Wsi i Rolnictwie” oraz - jako rozdziały - w monografiach wydanych przez Uniwersytet Szczeciński i Uniwersytet Ekonomiczny we Wrocławiu. Jest także autorem około 30 reportaży społeczno-kulturowych z obszaru Azji, Ameryki Południowej i Afryki zamieszczonych m.in. w: „Gazecie Wyborczej”, „Rzeczpospolitej”, „Przeglądzie”, „Poznaj Świat” i „Dzienniku”. Są one pokłosiem jego licznych podróży po tych kontynentach - prywatnych, studyjnych oraz wyjazdów dydaktycznych ze studentami Uniwersytetu Łódzkiego. 